IAN ALISTAIR NAIRN

SOVE STUDIES OF THE GEOLOGY, VOLCANIC HISTORY, AND GEOTHERMAL RESOURCES OF THE OKATAINA VOLCANIC CENTRE, TAUPO VOLCANIC ZONE, NEW ZEALAND

Thesis submitted for the degree of Doctor of Philosophy in Geology

Victoria University of Wellington June 1981 
ABSTRACT

$\underline{\text { Page }}$

ACKNOWLEDGEIMENTS

GENERAL INTRODUCTION

xiii

PREVIOUS WORK AT O.V.C.

\section{PART I}

GENERAL GEOLOGY OF OKATAINA VOLCANIC CENTRE

A: STRATIGRAPHY AND CHRONOLOGY OF OKATAINA VOLCANIC CENTRE

1) Pre-Rotoiti Breccia Ignimbrite Chronology

2) Stratigraphy of Mapped Formations

3) Stratigraphy and Chronology of Post-Rotoiti Breccia Pyroclastic Deposits

B: STRUCTURE

1) Regional Structure

2) Age of Regional Faulting

3) Okataina Volcanic Centre Structures

Okataina Ring structure

Haroharo Caldera

Haroharo Ring Fault and Dike

Rotoma Caldera(?)

Puhipuhi Basin

Okareka Embayment

West Rerewhakaaitu Fissures

Rotokawau-Rotoatua Fissure

Earth Deformation Data

C: INTRACALDERA VOLCANOES

Haroharo Volcanic Complex

1) General morphology and history of the complex: 70

2) Haroharo vent lineation:

3) Descriptions and ages of Haroharo eruptives:

Tarawera Volcanic Complex

1) General morphology and history of the complex:

2) Tarawera vent lineation:

3) Tarawera Emuptives:

a) North-eastern Area:

b) South-western Eruptives:

c) Kaharoa and 1886 Eruptives: 
Rotomahana Eruptives

Rotoma Volcanic Complex

Tikitapu Rhyolite Complex (Note)

D: VOLUIVES OF ERUPTIVES

Caldera Forming Eruptives (pre-20,000 years B.P.)

Intracaldera Eruptives (post-20,000 years B.P.)

Eruption Rates

PART II

ERUPTIVE HISTORY OF OKATAINA VOLCANIC CENTRE AND EFFECTS ON REGIONAL DRAINAGE

A: SYNTHESIS OF ERUPTIVE HISTORY

Introduction

Eruptive Episodes

Early Volcanism

Rotoiti Eruptive Episode

"Source, age, and eruptive mechanisms of the

Rotoehu Ash, Okataina Volcanic Centre, North

Island, New Zealand" - (manuscript)

Later Volcanism

Mangaone Sub-group Eruptive Sequence

Te Rere Eruptive Episode

Okareka Eruptive Episode

Rerewhakaaitu Eruptive Episode

Rotorua Eruptive Episode

"Source, age, and emuptive mechanisms of Rotorua Ash"

Waiohau Eruptive Episode

Rotoma Eruptive Episode

205

Mamaku Eruptive Episode

Whakatane Eruptive Episode

Rotokawau Emuptive Episode

Kaharoa Eruptive Episode

"Age and duration of the Kaharoa Eruptive Episode" - (manuscript)

1886 A.D. Tarawera-Rotomahana-Waimangu Eruptive Episode

"Rotomahana-Waimangu eruption, 1886: base surge and basalt magma"

"Basalt dikes in the 1886 Tarawera Rift" (manuscript) 
B: EFFECTS OF O.V.C. ERUPTIONS ON REGIONAL DRAINAGE

Introduction

Ancient Lakes

Lake Rotoma Drainage

Climatic versus Geological Controls on Lake Rotorua Levels

262

Lake Rotoiti

264

Lake Rotoehu

265

Lake Rotoma

Lake Okataina

Lakes Okareka, Tikitapu, and Rotokakahi

Lake Rotomahana

Lake Rerewhakaaitu

268

Lake Tarawera and the Tarawera River

268

Puhipuhi Basin Outflow Channel

270

PART III

GEOTHERIML RESOURCES

273

A: REGIONAL RESOURCES

274

Introduction

274

Hydrothermal fields associated with the O.V.C.

Lake Okataina hydrothermal activity

276

Lake Tarawera hydrothermal activity

276

Lake Rotoiti hydrothermal activity

277

Lake Rotoehu hydrothermal activity

279

Rotoma Geothermal Field

279

Tikitere Geothermal Field

282

Warm Springs (Waiaute and Mangakotukutuku)

284

Mt. Tarawera Fumaroles

Lake Rotomahana hydrothermal field

288

Waimangu hydrothermal field

289

Haumi Springs

290

Waiotapu and Reporoa hydrothermal field

290

Waikite-Paukohurea field

293

Kawerau hydrothermal field

294

"Late Quaternary Hydrothermal Explosion

Breccias at Kawerau"

Lake Water Chemistry 
B: DISCUSSION OF OKATAINA GEOTHERIMAL RESOURCES

Page

Assessment of total heat flow at O.V.C.

306

Comparison with volcanic heat flow

306

Location of the surface fields

311

311

Assessment of O.V.C. fields

312

PART IV

COMPARISONS OF OKATAINA VOLCANIC CENTRE WITH OTHER CALDERA STRUCTURES

318

Valles Caldera

319

Long Valley Caldera

321

Yellowstone Caldera

325

Calderas of Okataina Volcanic Centre 329

Caldera structures

329

Eruption cycles

331

Evidence for magma at Okataina

335

PART V

REFERENCES

338

PART VI

APPENDICES

359

Appendix 1: New chemical analyses of Okataina Eruptives

Appendix 2: Size data for Rotoehu Ash and Rotoiti Breccia samples

Appendix 3: Estimate of volcanic heat flow at O.V.C. 
1. Radiometric ages available for the major ignimbrite deposits at Okataina, and the ages accepted in this study

2. New radiocarbon dates at Okataina Volcanic Centre

3. Summary of stratigraphy and chronology of postRotoiti Breccia pyroclastic deposits at Okataina

4. Stratigraphy and chronology of Haroharo Volcanic Complex lavas and pyroclastics

5. Stratigraphy and chronology of Tarawera Volcanic Complex lavas and pyroclastics

6. Estimated volumes of caldera-forming eruptives at Okataina (pre 20,000 years B.P.)

7. Estimated volumes of intracaldera eruptives at Okataina (post 20,000 years B.P.)

Manuscript Table.

1. Radiocarbon ages for Kaharoa pyroclastics and possible correlatives

8. Catchment and lake data for lakes associated with Okataina Volcanic Centre

9. Catchment areas above Puhipuhi Basin outlet at present day and at 20,000 yrs B.P.

10. Chemical analyses of Waiaute and Mangakotukutuku springs

11. Chemical analyses of waters from lakes associated with Okataina Volcanic Centre

12. Chloride contents of lakes sampled in September 1972

13. Tarawera River chloride fluxes

14. Measured, estimated, and inferred natural surface heat flows (MW) at Okataina Volcanic Centre

15. Summary of reasonable hydrothermal heat flow estimates from Okataina Volcanic Centre

16. Summary of the resurgent-cauldron cycle at Okataina Volcanic Centre 
1. Map of Taupo Volcanic Zone

2. Landsat photo of Okataina Volcanic Centre

3. Bouguer gravity anomaly map of Okataina Volcanic Centre

4. Photo showing Puhipuhi Dacite lavas forming pseudo-pillows

5. Photo showing Tumunui and Paeroa Faults

6. Photo of fault displacing Rotoma Ash at Rendall Road.

7. Stereo-aerial photos of Haroharo Caldera margin at Lake Okataina

8. Map of West Rerewhakaaitu fissures

9. Rates of vertical deformation during 1950-1977 inferred from relevelling in the Bay of PlentyTaupo area

10. Photo of southern lavas of Haroharo Volcanic Complex 71

11. Photo of north-western lavas of Haroharo Volcanic Complex

12. Map of Haroharo Volcanic Complex lavas and major pyroclastic deposits, with ages

13. Stereo-air photo of Pukerimu Tuff Cone

14. Photo of Mamaku Ash overlying Rotoma Ash and Pukerimu Pyroclastics

15. Photo of Mamaku Ash overlying Waiti Lava Flow

16. Stereo-air photos of Te Horoa lava extrusion and Te Whekau explosion crater

17. Map of Tarawera Volcanic Complex lavas and pyroclastics, with ages

18. Photo of Waikakareao Lavas with interbedded and mantling Waiohau Pyroclastics

19. Photo of airfall Waiohau Ash and interbedded pyroclastic surge deposits 
20. Photo of Kaharoa Pyroclastics overlying Waiohau Pyroclastics in gullies eroded at the contact of Southern Dome with Rerewhakaaitu Tuff Cone

21. Photo of Kaharoa and Waiohau Pyroclastics overlying Southern Dome lavas

22. Photo showing detail of Fig. 21. Waiohau Pyroclastics overlie brecciated and flow banded Southern Dome Lavas

23. Photo of Rotomahana Tuff and Scoria Cone

24. Photo showing detail of the rhyolite ash and lapilli surge beds shown in Fig. 23

25. Photo showing Rotoma Ash overlying Rotoma Lava Flow

26. Photo showing Rotoma Pyroclastics in tuff ridge near the Matutu Basin eruptive vent

27. Map of present Matahina Ignimbrite outcrop, and estimate of original extent

The following Figures are included in a paper on the Rotoehu Ash, included here in manuscript form (see p. 143-182).

1. Map showing distribution of Rotoiti Breccia pyroclastic flows, and locations of Rotoehu Ash sections.

2. Schematic section through Rotoehu Ash and Rotoiti Breccia

3. Rotoehu Ash at Omataroa, with histograms

4. Rotoehu Ash at Ohope, with histograms

5. Rotoehu Ash and Rotoiti Breccia at Otamarakau with histograms

6. Rotoehu Ash transect line between Lake Rotoiti, Te Puke, and the Bay of Plenty coast 154

7a. Rotoehu Ash transect between Lake Rotoma and Ohope, with histograms

7b. Comparative histograms of individual fall units correlated between sections at Lake Rotoma and Ohope

8. Rotoehu Ash sections on transect between Lake Rotoma and Pikowai 
9. Rotoehu Ash sections on transect line between Waimangu Forest and Ngamotu Road

10. Photo showing block beds overlying Rotoiti Breccia at Lake Rotoehu

11. Rotoehu Ash isopachs from Pullar (1973) 162

12. Size, sorting, and skewness parameters for correlated Rotoehu Ash fall units on transects between Lake Rotoma and (A) Ohope,

(B) Pikowai.

13. Rotoehu Ash (Re3) transects between (A) Otamarakau and Papamoa, and (B) between Lake Rotoiti and Maketu

14. Size, sorting, and skewness parameters for correlated Re3 fall units on transects between

(A) Lake Rotoiti and Maketu, and (B) Papamoa and Otamarakau

28. Locations of sampled sites from the Mangaone Subgroup Pyroclastics

29. Histograms of Mangaone Sub-group Pyroclastics

30. Photo showing Mangaone Pyroclastics at Kawerau

31. Photo showing cross-bedded surge deposits in the Mangaone Pyroclastics at Lake Rotoehu

32. Isopach map of Te Rere Ash, and locations of sampled sites

33. Stratigraphic correlation and size data for Te Rere Ash sections

34. Histograms of Te Rere Ash samples

35. Photo showing Te Rere Ash at Puhipuhi Road

36. Sampled sites and measured thicknesses of Okareka Ash

37. Stratigraphy and size data for Okareka Ash sections 198

38. Histograms of Okareka Ash samples

39. Photo of Okareka Ash at Trunk Road

40. Map of Rotoma Eruptive Episode lavas and pyroclastics with vent locations

41. Map of Mamaku Eruptive Episode lavas and pyroclastics, with vent locations 
42. Photo showing interbedded pyroclastic flow and fall units of the Mamaku Eruptive Episode

43. Photo showing plane surge beds of Mamaku Eruptive Episode age

44. Map of Whakatane Emuptive Episode lavas and pyroclastics, with vent locations

45. Photo of plane surge beds and airfall deposits of proximal Whakatane Pyroclastics

46. Photo of pyroclastic deposits associated with

Tikorangi Dome

The following figures are included in a paper on the age of the Kaharoa Eruptive Episode, included here in manuscript form (see p. 219-232)

1. Distribution of Kaharoa Tephra, locations of sections and stratigraphic correlations

2. Photo showing pyroclastic fall sequence in Kaharoa Tephra

3. Age ranges of ${ }^{14} \mathrm{C}$ samples collected from Kaharoa pyroclastics

The following figures are included in a paper on "Basalt dikes in the 1886 Tarawera Rift", included here in manuscript form (see p. 235-252)

1. Map of Tarawera Volcanic Complex showing Tarawera Rift

2. Map showing dike outcrops, inferred dike locations and emptive fissure strikes

3. Photo of basalt dike intruding Crater Dome

4. Aerial photo of Waimangu explosion craters

47. Map showing catchment boundaries for Lake Rotorua, Haroharo Caldera, and Puhipuhi Basin

48. Inferred variations in the water level of Lake Rotorua from before 42,000 yrs B.P. to present

49. Inferred drainage paths from Lake Rotoma and Haroharo Caldera during the period $\geqslant 42,000$ yrs B.P. to present 
50. Photo of Lake Rotoehu

51. Location map for Mangakotukutuku and Waiaute Springs

52. Location map of sampling sites for Tarawera River chloride flux, with flux values

53. Conceptual model for location of geothermal fields at Okataina

54. Interpretation of sub-caldera structures developed at Okataina Volcanic Centre

\section{MAPS}

(in map. pocket)

MAP 1: Geological Map of the Okataina Volcanic Centre $(1: 50,000)$

MAP 2: Regional Tectonic Map of the Okataina Volcanic Centre $(1: 50,000)$

MAP 3: Geothermal Fields associated with the Okataina Volcanic Centre $(1: 50,000)$. 
Okataina Volcanic Centre is the most recently active of the four major rhyolite eruptive centres in the Taupo Volcanic Zone of New Zealand. Within the Centre lies Haroharo Caldera, a complex of overlapping collapse structures resulting from successive voluminous pyroclastic eruptions from the same general source area. At least four main and possibly two minor caldera-forming eruptions have occurred during the last 250,000 years, although poor exposure means that attempts to interpret the early structural history are highly speculative.

Although there is no compelling evidence of structural updoming within Haroharo Caldera, magma resurgence has followed the last major caldera-forming emption of the Rotoiti Breccia at $\geqslant 42,000$ years B.P. Eruption of this magma within the caldera has formed the two large rhyolite lava and pyroclastic piles of the Haroharo Volcanic Complex and Tarawera Volcanic Complex, plus two subsidiary adjacent complexes at Okareka and Rotoma. All these intracaldera eruptives are younger than 20,000 years B.P., with the most recent eruptions from Tarawera; of rhyolite at c. 700 years B.P., and of basalt in 1886 A.D.

A considerable amount of earlier work carried out at Okataina was directed mainly at petrology and chemistry of the rhyolites forming the Tarawera and Haroharo Volcanic Complexes. The present study has arisen from a 1:50,000 mapping programme at Okataina and has sought to examine structures and volcanic history in greater detail, and to consider the resulting geological implications for geothermal resources. Caldera boundaries have been mapped, and two major vent lineations are defined, apparently related to fundamental basement fractures which have controlled location of the Tarawera and Haroharo Volcanic Complexes. An intracaldera ring fault is also suggested by the sub-circular arrangement of some young volcanic vents. The Haroharo and Tarawera Complexes are mapped, with locations of source vents, and dating of the major lavas and pyroclastic deposits. All the post-20,000 year eruptives are placed in 
four main eruptive episodes at Haroharo, and five at Tarawera. The near-source pyroclastic surge and flow deposits are ${ }^{14} \mathrm{C}$ dated, and with their associated widespread plinian fall deposits they provide time planes for dating the associated lavas. The eruptive episodes generally appear to have been of much shorter duration than the intervening quiescent periods which lasted for thousands of years. All the eruptive episodes at Haroharo involved multiple eruptions from vents spread out over several kilometres along the vent lineations. Similar multiple vent eruptions can be demonstrated for some of the Tarawera eruptive episodes.

More than $500 \mathrm{~km}^{3}$ of magma has been erupted from Haroharo Caldera during the last 250,000 years, $80 \mathrm{~km}^{3}$ of which was erupted in the last 20,000 years. This history suggests that a large magmatic heat source should continue to underlie the Okataina Volcanic Centre. However, very little surface hydrothermal activity occurs within Haroharo Caldera. It is suggested that the large external hydrothermal fields at Tikitere, Waimangu-Waiotapu-Waikite, and possibly Kawerau, are related to Haroharo Caldera heat sources. Presently available data are summarized for hydrothermal fields in and adjacent to Haroharo Caldera, and new analyses are presented for some warm springs discovered within the caldera. Estimates and measurements of chloride fluxes in lakes and rivers are reported. The chloride flux values suggest the occurrence of larger hydrothermal heat flows into lakes and rivers than are apparent at the surface. Measurements of chloride flux in the Tarawera River showed that $280 \mathrm{~g} \mathrm{~s}^{-1}$ of chloride is added to the river within Haroharo Caldera below the Lake Tarawera outlet. Only $80 \mathrm{~g} \mathrm{~s}^{-1}$ of this chloride comes from known geothermal sources. A total chloride flux of $760 \mathrm{~g} \mathrm{~s}^{-1}$ in the Tarawera River passing out of the Okataina Volcanic Centre indicates a minimum geothermal heat flow of 600 MW. Estimates of heat flows in other drainage paths from Haroharo Caldera suggest that minimum total heat flow from the caldera may exceed 1500 MW. A large heat flow from the caldera would appear consistent with the volcanic history. Some suggestions are made for further investigation of the geothermal resources at Okataina. 


\section{ACKNOWLEDGEMENTS}

This study could not have been completed without assistance from a great many people.

Prof. R.H. Clark and Dr J.W. Cole of Victoria University supervised the project, guided its direction, and provided moral support and encouragement. Valuable discussions with C.G. Vucetich, Dr R. Howorth, and P.C. Froggatt were also held at the University and in the field. The late M. Schafer instructed and assisted the writer in XRF analytical techniques.

At Rotorua, the writer has received invaluable assistance and support from his colleagues, who gracefully tolerated the dismuption caused by this study. This work follows in the footsteps of $\mathrm{J}$. Healy, who supplied the inspiration for volcanological and geothermal studies at Okataina. J. Healy, Dr B.F. Houghton, E.F. Lloyd, and B.J. Scott provided critical reviews of various aspects of this study. B.J. Scott and P. van der Werff assisted in the field and laboratory. Many valuable discussions were held with Dr W.A. Pullar whose work, together with C.G. Vucetich, contributes the stratigraphic and chronological framework within which much of this study is based. R.E. Murray provided considerable hydrological data and assistance with river flow measurements and sampling.

W.A.J. Mahon, Drs R.B. Glover, R.W. Henley and J.B. Finlayson at the Wairakei Geothermal Laboratory provided analyses of geothermal waters, advised on geothermal aspects of this study, and critically read parts of the thesis. G.B. Dawson and H. Rayner provided provisional resistivity data, and P.M. Otway, earth deformation data.

Drs P.R.L. Browne and C.P. Wood assisted with petrological aspects of geothermal studies; ${ }^{14} \mathrm{C}$ data and advice was received from T.L. Grant Taylor and H.S. Jansen; paleoclimatic data and advice was generously provided by M. McGlone. D.L. Homer provided many of the photographs used in this thesis, and much darkroom assistance. The study was greatly assisted by 
excellent service from the N.Z. Geological Survey Library staff at Lower Hutt.

The writer wishes to thank Dr R.P. Suggate, Director N.Z. Geological Survey, and the Department of Scientific and Industrial Research, for permission to carry out this study, and for granting of the study leave which made it possible. The Tasman Pulp and Paper Co. Ltd. are thanked for allowing access to their forests at Okataina, and particularly Forestry staff members J. Mitchell and J. Gleed for their assistance and interest in this work. The writer is especially appreciative of the dramatic and continuing improvement in exposure provided by new forestry roads at Okataina.

During the course of this study, new insights and valuable advice have been provided by many overseas visitors to Okataina, including Drs R.L. Christiansen, W.E. Elston, J. Donnelly-Nolan, S. Self, H.U. Schmincke, G.P.L. Walker, and L. Wilson,

This thesis has been painstakingly typed by Audrey Riddell, to whom the writer expresses his considerable gratitude.

Finally, the writer wishes to thank his wife for her tolerance and support during this study, and his parents for providing accommodation and assistance in Wellington. 


\section{GENERAL INTRODUCTION}

Okataina Volcanic Centre is the most north-eastern and the most recently active of the four major rhyolitic eruptive centres (Fig. 1) in the Taupo Volcanic Zone of the central North Island, New Zealand.

The $300 \mathrm{~km}$ long Taupo Volcanic Zone (T.V.Z.) occupies a volcano-tectonic depression in which gravity data indicate that basement greywacke (Mesozoic) has been downfaulted to more than $3600 \mathrm{~m}$ below sea level (Modriniak and Studt 1959). The T.V.Z. has been the major focus of late Quaternary rhyolitic volcanism in New Zealand (Healy 1962, 1963, 1964), with Holocene activity concentrated in areas of caldera collapse at Taupo and Okataina. No Holocene eruptive activity is recorded at the two other rhyolite centres of Maroa and Rotorua (Cole and Nairn 1975).

The Okataina Volcanic Centre (O.V.C.) was first defined (Healy 1962) to include the young rhyolite massifs of Haroharo and Tarawera, lying to east of Rotorua, in a sunken area partly occupied by several lakes (Fig. 2). Okataina is regarded as an "active volcanic centre" (Healy 1963), with both a historic eruption (of Tarawera in 1886) and an extended history of repeated volcanic eruptions, separated by long periods of quiescence. Future eruptions can be expected from the centre.

Considerable scientific investigations have been carried out at Okataina, and are summarised in the next section. In general, previous workers have concentrated on specific aspects of Okataina geology. Structure has been briefly described by Healy, petrology, chemistry and petrogenesis of Haroharo eruptives have been intensively studied by Ewart and co-workers, and the widespread distribution of Okataina pyroclastics has been mapped by Vucetich, Pullar, and Howorth. Structure and petrology of the Tarawera Volcanic Complex has been described in detail by Cole. Results of much of this previous work are briefly summarised by Cole and Nairm (1975) and Cole (1979). The present study originated as a programme to map the entire O.V.C. at relatively large scale $(1: 50,000)$, to provide a basis 


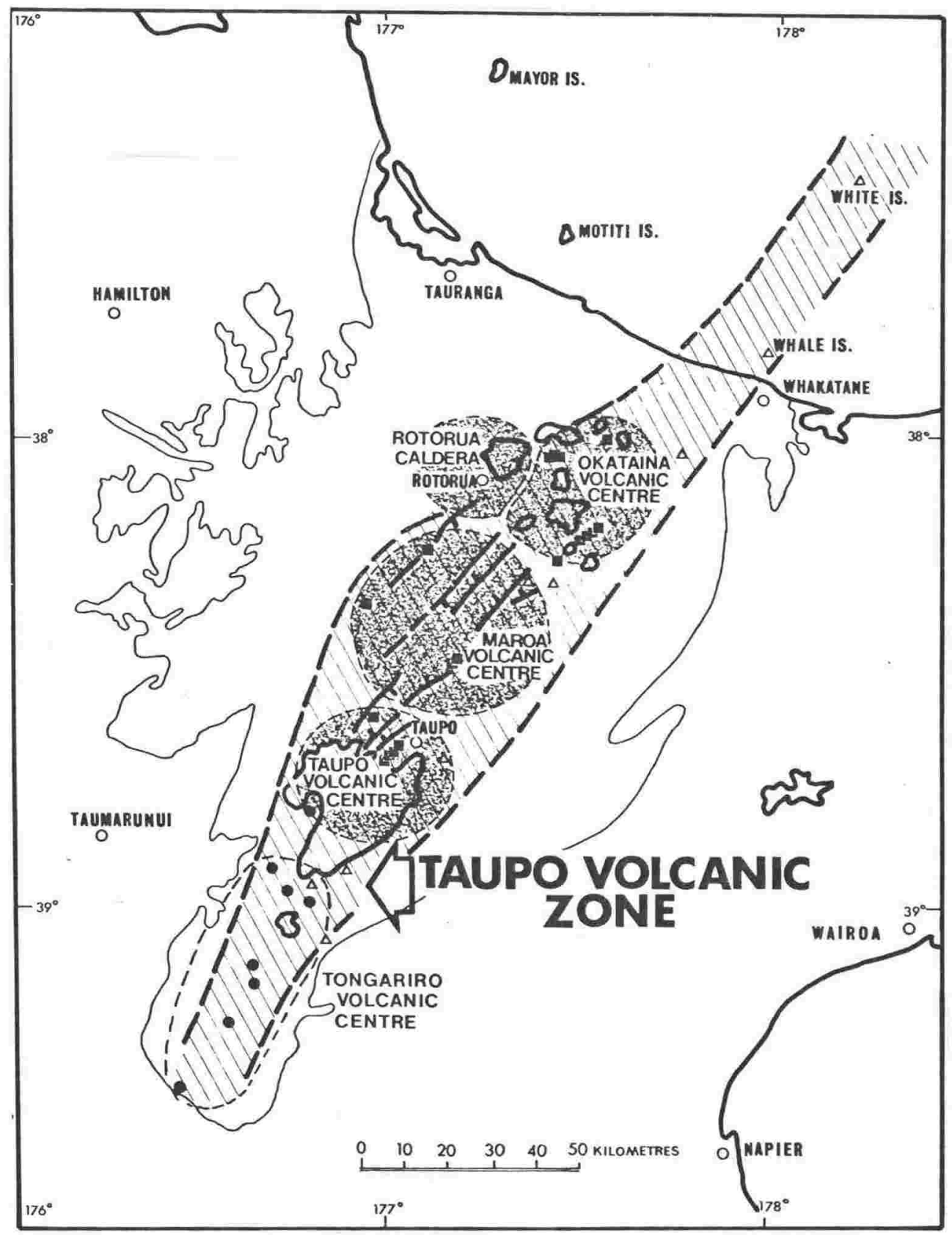

FIG. 1 - Taupo Volcanic Zone (T.V.Z.) showing Tongariro, Taupo, Maroa, and Okataina Volcanic Centres; Rotorua Caldera, and major faults. Areas of rhyolitic volcanism are shaded; $\Delta$ dacite volcanoes;

- andesite volcanoes; basalt volcanoes. Extent of the Quaternary ignimbrites erupted from T.V.Z. is also shown. (Figure from Cole and Nairn 1975). 
for synthesis of stratigraphy, structure, and volcanic history of the Centre. Ideally it would be preferable to have carried out this mapping prior to the earlier petrological and chemical studies of Okataina eruptives; however the present work has been aimed at complementing the previous studies.

The more detailed understanding of structure and volcanic history resulting from this study has two main implications. The emptive history provides data for estimates of future volcanic risk at O.V.C.; it is also significant in investigations of the geothermal energy resources which are associated with the O.V.C. The structure and history of the Centre suggest that it should be associated with a large magmatic heat source, although there is only minor surface expression of convective heat flow within the Centre. Geothermal investigations are discussed in the third part of this thesis.

When mapping for this study commenced in 1974, little exposure was available within much of the O.V.C., which was largely covered by native forest vegetation over a thick pyroclastic mantle. Concurrent with the mapping has been an extensive land clearance and forestry roading programme which has greatly increased exposure of the pyroclastic mantle on the northern parts of both the Haroharo and Tarawera Volcanic Complexes. In these areas, exposure has been improved from effectively nil $(<1 \mathrm{~m})$ to road-cut sections up to $30 \mathrm{~m}$ deep. Almost continuous remapping has been required as the roading programme has progressed. Available data has improved from initial photogeological interpretation of volcanic landforms, to abundant exposure of the stratigraphic relationships between ${ }^{14} \mathrm{C}$-dated pyroclastic deposits and the interbedded lavas which make up the rhyolite complexes. However, large parts of the southerm Haroharo and Tarawera Volcanic Complexes do not form part of the forestry operations, and new road exposures are not available in these areas. A considerable contrast exists between the amounts of stratigraphic and lithological data available from the roaded and non-roaded areas of the O.V.C. and the interpretations of stratigraphic relationships and eruption mechanisms are less firmly based in the non-roaded areas. 
FIG. 2 - (Over page). False colour satellite photo of Okataina Volcanic Centre (Landsat 2334 - 2112322 Dec. 1975 PEL 18 Bands 4, 5, 7 POS enhanced; supplied by Remote Sensing Section, PEL, D.S.I.R.). Overlay shows positions of caldera boundaries, major faults and grabens, and young volcanic complexes and vents $(\star)$. Basaltic fissure(?) zones are cross hatched. Lakes are numbered:

1 - Rotorua, 2 - Rotoiti, 3 - Okataina, 4 - Okareka, 5 - Tikitapu, 6 - Rotokakahi, 7 - Tarawera, 8 - Rotomahana, 9 - Rerewhakaaitu, 10 - Rotoehu, 11 - Rotoma, 12 - Rotokawau. See text and Map 2 for further interpretation. 


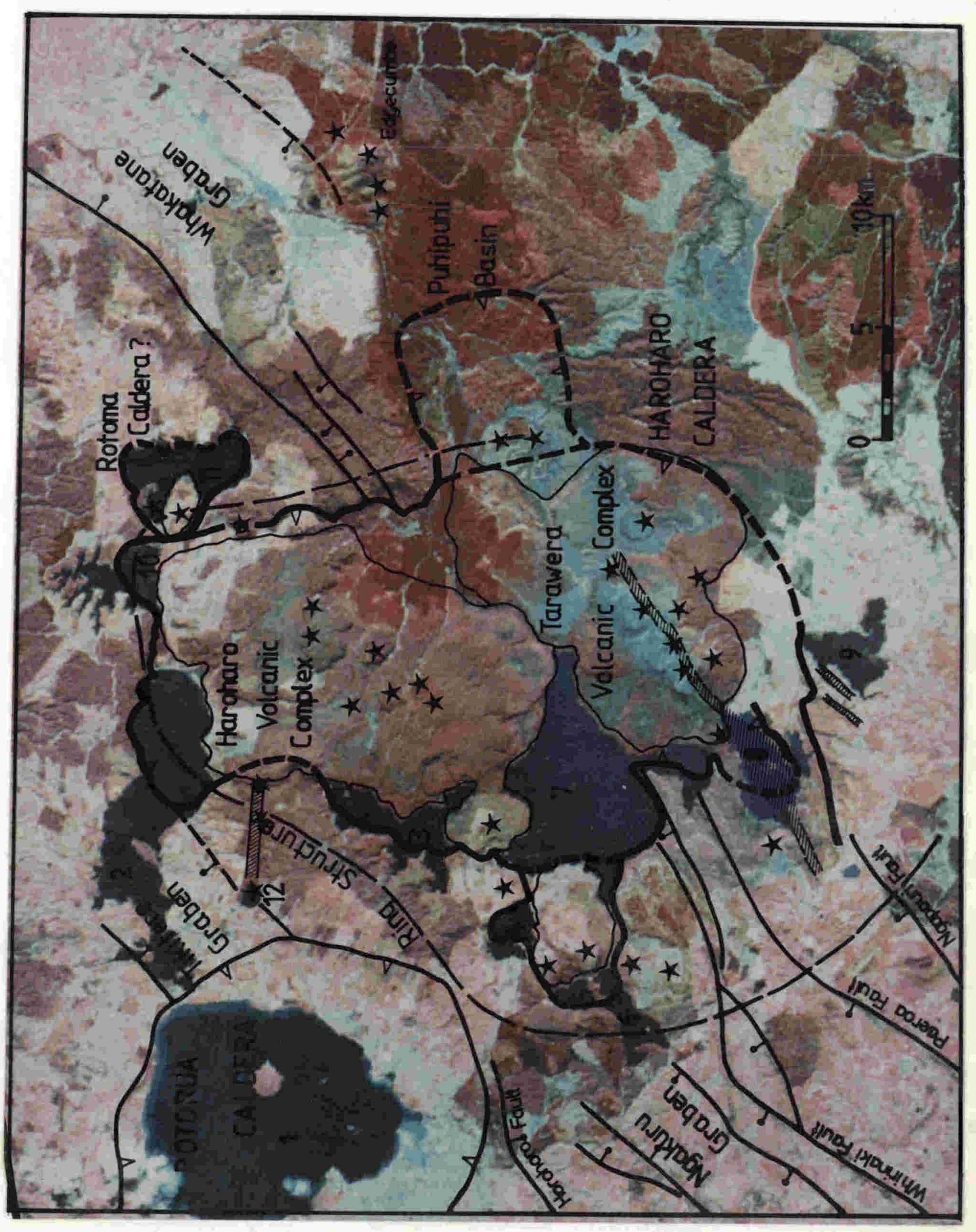


The regional study of T.V.Z. ignimbrites by Martin (1961) has described the basic stratigraphy and lithology of early eruptives from O.V.C. Healy (1962) first defined the Okataina Volcanic Centre and surrounding structures, and suggested that the Centre lay within a large ring complex in which cauldron subsidence had occurred. Extrusion of the large rhyolite massifs of Haroharo and Tarawera had been preceded by ignimbrite eruptions associated with collapse to form Haroharo Caldera. The O.V.C. was regarded as an "active eruptive centre" of the T.V.Z., with a long history of repeated large-scale pyroclastic eruptions separated by long periods of quiescence (Healy 1963). The Rotorua district (including the O.V.C.) was mapped at 1:250,000 scale by Healy et al (1964). The O.V.C. was described as the probable source for the Matahina and Kaingaroa Ignimbrites, with later collapse following eruption of the Rotoiti Breccia. Rough boundaries for Haroharo Caldera and a surrounding "Ring Structure?" were sketched by Healy (1964) based on a study of smoothed topographic contours.

Structure and petrography of the O.V.C. were described in more detail by Ewart and Healy (1965), who included in the O.V.C., not only the Tarawera and Haroharo rhyolite massifs, but also older rhyolites to north, west, and east, and a rhyolite complex centred on Lake Tikitapu. Rhyolites of the Centre were classified on physiography into outer-older, and inner-younger divisions, and further subdivided on the basis of location and mineralogy into 4 complexes. Chemical (major element) and modal analyses of several of the O.V.C. rhyolites and some pyroclastic deposits were presented, together with maps of total crystal content and ferromagnesian assemblages in the lavas. Bailey (1965) described stratigraphy and petrography of the Matahina Ignimbrite, which he concluded was probably erupted from the O.V.C., possibly in the Haroharo Caldera.

Vucetich and Pullar (1964, 1969) mapped the widespread distribution of the Late Quaternary and Holocene pyroclastic fall deposits in the Rotorua district, and showed that many 
had their eruptive sources in the O.V.C. area. Pullar and Birrell (1973) presented updated isopach maps of O.V.C. pyroclastics and Pullar et al (1973) included a summary of the ${ }^{14} \mathrm{C}$ dates available for Okataina eruptives. Kohn (1973) provided fission-track dates (on glass) for Matahina and Kaingaroa Ignimbrites (and also dated stratigraphicallyimportant ignimbrites from other sources). The fission track dates confirmed paleomagnetic ages earlier obtained on ignimbrites by Cox $(1969,1971)$. Kohn also defined the dominant ferromagnesian mineralogy of O.V.C. pyroclastic deposits, for which bulk chemical analyses were also presented. Pyroclastic fall deposits were "finger printed" by their titanomagnetite trace element compositions. Howorth (1975) re-examined the distribution and lithology of the O.V.C. Late Pleistocene pyroclastic deposits previously termed the "Mangaone Lapilli Formation" (Vucetich and Pullar 1969). Nairn (1971, 1972), Pullar and Nairn (1972), and Nairn and Kohn (1973), described the Earthquake Flat Breccia, Rotoehu Ash, and Matahi Basalt pyroclastic deposits, and their sequential and coeval relationships with the Rotoiti Breccia eruptions. Briggs (1973) provided a useful summary of T.V.Z. pyroclastic stratigraphy and lithology, including O.V.C. eruptives.

The history, petrography, and chemistry of Tarawera Volcanic Complex lavas and pyroclastics were described in a series of papers by Cole (1970a,b,c,d), who demonstrated a series of volcanic episodes extending back to eruption of the Rerewhakaaitu Ash (c. 15,000 yrs B.P.). Cole (1973) also briefly described the small basaltic eruptions of Rotokawau Ash from the north-east O.V.C. Duncan (1970) described the andesites and dacites of the Bay of Plenty, including Edgecumbe volcano on the eastern margin of the O.V.C. The other intensive work at O.V.C. has been that of Ewart and co-authors who have carried out detailed studies of Haroharo rhyolite petrography, and major and trace element chemistry. Ewart (1966, 1967, 1968) described petrology of the Haroharo rhyolites in increasing detail, and showed them to have certain unique characteristics (c.f. other rhyolites of the T.V.Z.) which suggested crystallization under relatively higher water 
pressures. The pumice and ash flow deposits of the Rotoiti Breccia were also described, and together with Matahina Ignimbrite, shown to have mineralogical similarities to the Haroharo rhyolites.

[However, Ewart's (1968) analysed samples of "Rotoiti Breccia" from both the "Rotoiti-Rotoma-Kawerau region" and the Bay of Plenty coast, include brecciated Haroharo rhyolite, Matahina Ignimbrite, and probable Kaingaroa Ignimbrite, so that the reported similarity is not altogether surprising.]

Lavas in the south-western O.V.C. were grouped into the Tikitapu Rhyolite complex, although of variable mineralogy. The lavas were interpreted as resulting from an extended phase of extrusion from a large underlying magma reservoir, with the various units being erupted from smaller and more localized cupolas or apophyses, resulting in localized variations in crystallization history. In contrast all the Haroharo complex lavas were characterized by a persistent hypersthene-hornblende ferromagnesian assemblage irrespective of their plagioclase/quartz ratios, and total crystal contents, suggesting different physical conditions during crystallization of a magma chemically similar to the other rhyolites of the T.V.Z. The rhyolites of the 4 complexes within the O.V.C. were considered to represent the eruptive products from separate magma sources or reservoirs, and therefore indicated the positions and extents of the higher-level magma bodies.

Later work by Ewart and co-authors examined petrogenesis of O.V.C. (and T.V.Z.) eruptives, through studies of $\mathrm{Sr}$ isotopes (Ewart and Stipp 1968), trace and minor element geochemistry of total rock residual liquids (Ewart et al 1968), and phenocryst phases (Ewart and Taylor 1969). It was generally concluded that partial melting of the TriassicJurassic "greywacke" sediments of the central North Island could provide a possible parent source for the rhyolitic magmas. 
The most recent data on O.V.C. rhyolites is summarized and extensively discussed by Ewart et al (1975), with heavy emphasis on the cummingtonite-bearing eruptives from Haroharo Complex earlier discussed by Ewart et al (1971), Nichols et al (1971), and Wood and Carmichael (1973). Ferromagnesian assemblages were correlated with Fe-Ti oxide equilibration temperature ranges to produce the following subdivision of the O.V.C. rhyolites.

(1) Cummingtonite (c) + calcic hornblende ( $\mathrm{hb}) \pm$ orthopyroxene (opx); $725-755^{\circ} \mathrm{C}$

(2) $\mathrm{Hb} \pm \mathrm{opx} ; 750-825^{\circ} \mathrm{C}$

(3) Biotite $+\mathrm{hb} \pm \mathrm{C} \pm \mathrm{opx} ; 720-765^{\circ} \mathrm{C}$

(4) Opx \pm clinopyroxene (cpx); $860-915^{\circ} \mathrm{C}$

These ferromagnesian assemblages showed statistically significant correlations with the total crystal contents, plagioclase/quartz ratios, and co-existing ground mass compositions within the rocks in which they occurred (Ewart 1967, 1969). The biotite-bearing assemblages were correlated with low plagioclase/quartz ratios, highest phenocryst contents, and most potash-rich groundmass compositions. The opx-cpx assemblages were correlated with lowest phenocryst contents, highest plagioclase/quartz ratios, and less potassic groundmass compositions. The amphibole-opx assemblages were intermediate in all respects. Plagioclase is predominantly andesine; quartz is typically resorbed.

The Fe-Ti oxide equilibration temperatures showed that $755^{\circ} \mathrm{C}$ is the maximum temperature for the cummingtonite-bearing Haroharo eruptives, and the $\mathrm{C} / \mathrm{hb}$ ratio increased with lower temperatures. The biotite-bearing rhyolites ( $\pm \mathrm{C}, \mathrm{hb}, \mathrm{opx}$ ) equilibrated at temperatures between $720-765^{\circ} \mathrm{C}$.

Estimates of $\mathrm{P}_{\text {total }}$ were made for Okataina lavas and pumices from calculated equilibration pressures. All pressures were relatively low (average $2.2 \mathrm{~kb}$ ), indicating that the rhyolites had equilibrated in the upper crust $(\approx 7-8 \mathrm{~km}$ depth). No consistent differences between lavas and pumice deposits 
were noted in either $\mathrm{P}_{\text {total }}$ or ferromagnesian assemblage. Complete overlap existed between the equilibration pressures of the various ferromagnesian assemblages, but with decreasing $T$ and $P_{\text {total }}$ the rhyolites became more crystalline. Both the cummingtonite and biotite-bearing rhyolite magmas must have been water saturated ( 6 wt\%), and the cummingtonitebearing rhyolites probably equilibrated under conditions of $\mathrm{P}_{\mathrm{H}_{2} \mathrm{O}} \approx \mathrm{P}_{\text {total }}$, although in this case the pumice may have been slightly less water-saturated than the lavas. Three hornblendebearing rhyolites (no cummingtonite) also appear to have equilibrated at $\mathrm{P}_{\mathrm{H}_{2} \mathrm{O}} \approx \mathrm{P}_{\text {total }}$ (as did the biotite-bearing rhyolites) indicating that the controlling parameter for the occurrence of cummingtonite was temperature. The pyroxene rhyolites (lacking amphibole or biotite) equilibrated under relatively high $\mathrm{P}_{\mathrm{H}_{2}} \mathrm{O}^{\circ}$

Speculations on eruptive mechanisms based on evidence from the Haroharo Volcanic Complex hinged on the similarity of chemical and mineralogical properties of the cummingtonitebearing pumices and rhyolite lavas. The different emption mechanisms for these contrasting deposits were considered controlled by the fluid dynamic behaviour of the magma; fully turbulent convection being expected in a magma chamber of $5 \mathrm{~km}$ radius. The extensive pumice deposits of the Rotoiti Breccia were considered to represent the eruption of magma in a state of intense vesiculation within the uppermost zone of the magma chamber. In contrast the younger lavas represented eruption of smaller, disconnected, and relatively poorly vesiculated magma bodies, in which convection was greatly reduced.

Cole (1979) has recently summarized structural, petrological, and chemical data on the T.V.Z., particularly usefully for the more basic eruptives at O.V.C. Basalts are considered mantle-derived; origin of the andesites is ascribed to the underlying subduction zone; and the Bay of Plenty dacites probably formed by assimilation of minor crustal material or rhyolitic magma by an andesitic magma. 
The geology of Rotorua Caldera, to west of O.V.C., has been mapped at 1:63,360 scale by Thompson (1974), and the T.V.Z. to south-west of O.V.C. by Grindley (1959) and Nairn (1973). Bathymetry of all the lakes associated with the O.V.C. has been mapped by Irwin (multiple citations - see References).

Geophysics of the O.V.C. has only recently been studied in any detail. Malahoff (1968) compiled a residual total force magnetic map and discussed the origin of magnetic anomalies in the T.V.Z. He found the highest and lowest amplitude magnetic anomalies observed in the T.V.Z. to both occur at O.V.C., above the Haroharo lava pile, and immediately to south of Tarawera, respectively. A 1:250,000 total force anomaly magnetic map of the Rotorua district has recently been published (Hunt and Whiteford 1979), as have Bouguer and Isostatic gravity maps (Woodward and Ferry 1973). The gravity maps show a major negative gravity anomaly of amplitude 25 mGals and wavelength c. $30 \mathrm{~km}$ is associated with the O.V.C., centred to east of Lake Tarawera (Fig. 3).

Calhaem (1973) carried out heat flow studies in some of the O.V.C. lakes, discovering a major hot water inflow on the floor of Lake Rotoiti.

Very little seismic data is available for the O.V.C. A swarm of small earthquakes which occurred in the Waimangu area (on south-west margin of the O.V.C.) in 1972 has been analysed (Latter et al 1974). S-wave attenuation, and delay of P-waves occurred along paths passing under the O.V.C. and were tentatively attributed to the possible existence of partially molten material in the lower part of the crust beneath the Tarawera-Lake Rotomahana area. 


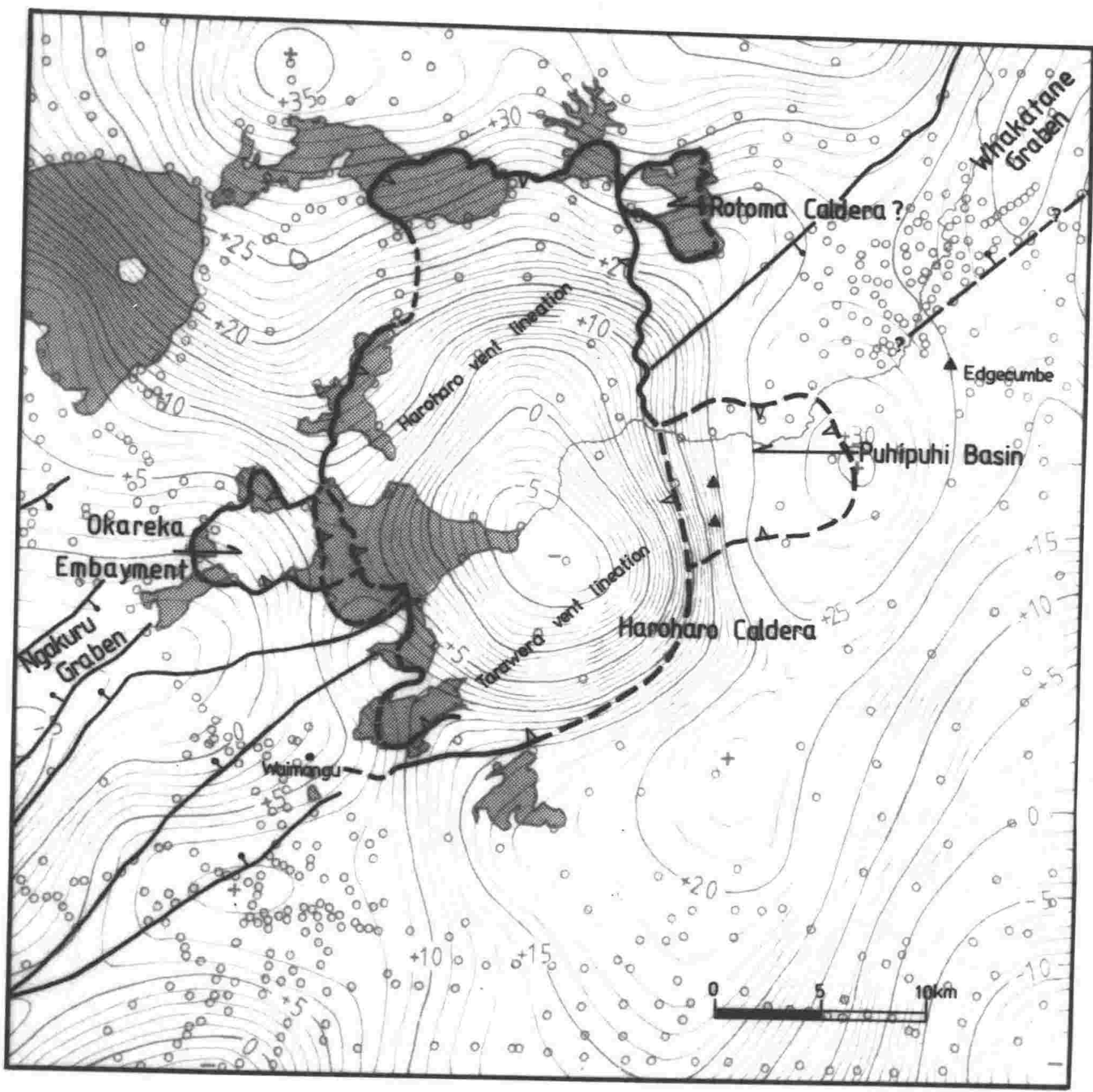

FIG. 3 - Bouguer gravity anomalies map (taken from Woodward and Ferry 1973) of Okataina Volcanic Centre and surrounding region. Circles mark gravity station locations. The few stations within Haroharo Caldera define a major gravity low in the southern caldera. See Fig. 2 and Map 2 for structural data. 
PART 1

GENERAL GEOLOGY OF OKATAINA VOLCANIC CENTRE 
A: STRATIGRAPHY AND CHRONOLOGY OF OKATAINA VOLCANIC CENTRE

1) Pre-Rotoiti Breccia Ignimbrite Chronology

Major time planes at Okataina are defined by widespread ignimbrite deposits of the Rotoiti Breccia and the Kaingaroa, Mamaku, Matahina, and Rangitaiki Ignimbrites. The radiometric ages available for these deposits are summarised in Table 1. All these ages are provisional. The age for Rotoiti Breccia is at the limit of radiocarbon dating techniques used in New Zealand, and its validity has been questioned (Nathan 1975). Further large charcoal samples from the Rotoiti Breccia have been sent to the University of Washington for isotope enrichment dating ( see $\mathrm{p} .167$ ) but results are not yet available. Most of the other ignimbrites have been fission track dated on glass shards (Kohn 1973), with revised, younger ages more recently obtained (Kohn, pers. comm.). The Mamaku Ignimbrite fission track age was obtained from zircons (Murphy and Seward in press). While the glass fission track ages cannot be regarded as reliable due to annealing (Seward 1979), they are in correct sequence and in agreement with paleomagnetic data, all these ignimbrites being normally magnetised and thus less than $0.72 \times 10^{6}$ yr B.P. (Cox 1969, 1971; MacDougall 1979). The "accepted" ages in Table 1 are used throughout this study.

\section{2) Stratigraphy of Mapped Formations}

Geology of the O.V.C. is shown at 1:50,000 scale on Map 1 (in back pocket). The deposits which underlie Rotoiti Breccia are relatively poorly exposed in the Okataina area, and only a basic stratigraphy has been established. Rangitaiki Ignimbrites comprise the oldest formation mapped adjacent to the O.V.C. The closely related Whakamaru Ignimbrite which appears to form part of the same eruptive episode from Lake Taupo Volcanic Centre (Briggs 1973) has been fission track dated at c. 230,000 yrs B.P. (Table 1). Older volcanics have been penetrated by geothermal wells at Waiotapu, and at Kawerau where they overlie Mesozoic Torlesse greywacke basement. The main stratigraphic units at O.V.C. are described below, from oldest to youngest. Chemical analyses of some emptives and previously undescribed 


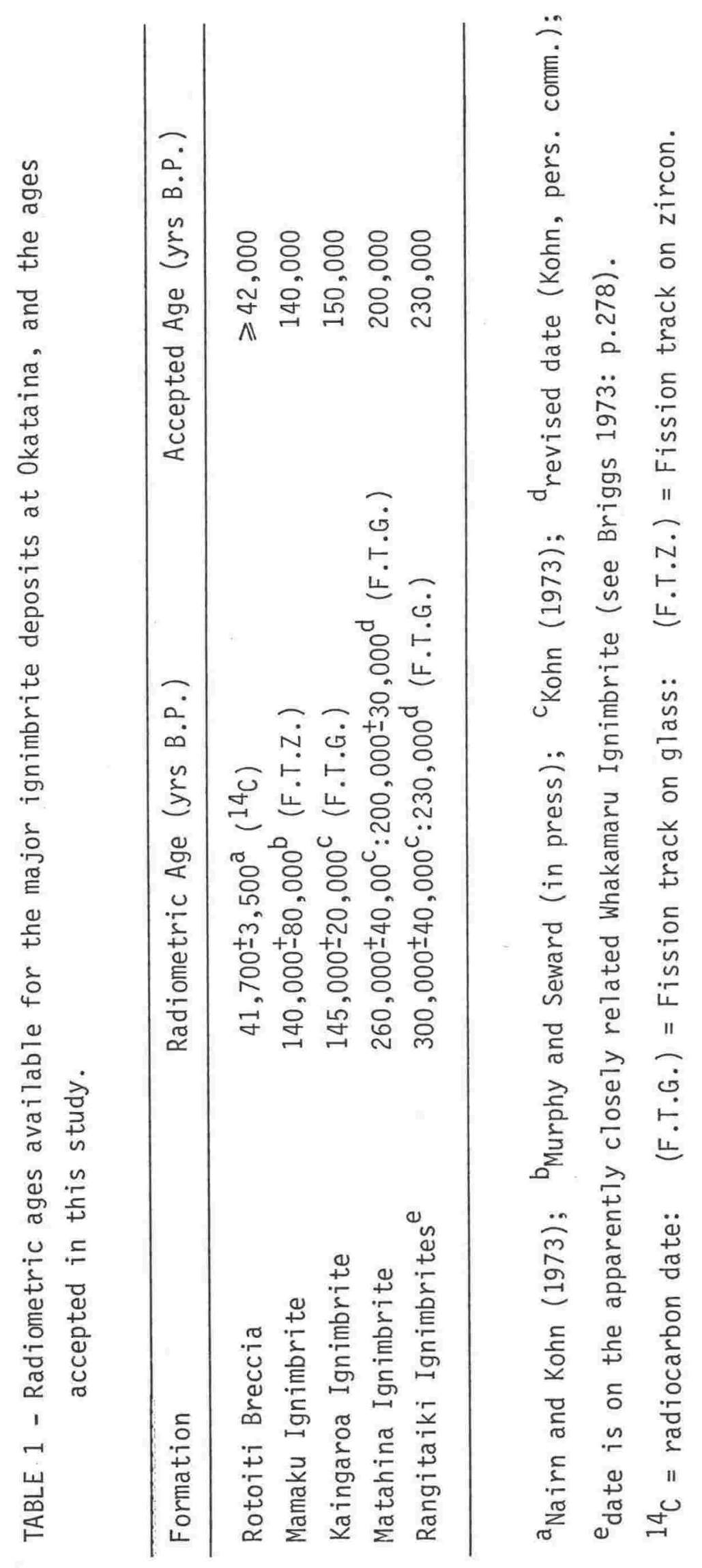


formations are presented in Appendix 1. Stratigraphy is summarized in the Legend for Map 1.

\section{Rangitaiki Ignimbrites}

Rangitaiki Ignimbrites were mapped at O.V.C. by Healy et al (1964), extending between Lakes Rotomahana and Rerewhakaaitu, and north-east of Rerewhakaaitu towards Matahina. Confusion has existed as to the relationship between the Rangitaiki Ignimbrites and Te Whaiti Ignimbrite (see Briggs 1973, p. 274-287 for summary). The present study follows Martin (1961) who considered the Te Whaiti Ignimbrites to form a fine-grained distal facies of the Rangitaiki Ignimbrites, rather than a separate formation (cf. Grindley 1960). A close relationship between the two ignimbrites is also suggested by similar directions of remanent magnetization (Cox 1971).

The Rangitaiki Ignimbrites are moderately welded, dark grey, crystal-rich quartzose-hypersthene tuffs (Martin 1961) which outcrop on the southern margin of O.V.C. Here their mapped distribution differs little from that of Healy et al (1964), and the ignimbrites form a major structural surface, cut off by the caldera-bounding faults. Rangitaiki Ignimbrites extend $110 \mathrm{~km}$ south of O.V.C. to the Lake Taupo area (Healy et al 1964, Grindley 1960), from where Martin (1961) considered them to have been empted, based on lateral variations in phenocryst size and abundance, and degree of welding. Rangitaiki Ignimbrites do not outcrop within central Haroharo Caldera, or in the Puhipuhi Basin. A minimum thickness of about $100 \mathrm{~m}$ is exposed on the caldera margin at Rotomahana.

Included in the area mapped as Rangitaiki Ignimbrites (Healy et al 1964, and this study), are coarse tuffs which contain abundant biotite in contrast to the trace amounts present within the "type" Rangitaiki Ignimbrites (Martin 1961). This "quartz-biotite ignimbrite" outcrops to south and east of Puhipuhi Basin, and is characterized by large quartz phenocrysts (to $4 \mathrm{~mm}$ diameter), and large devitrified pumice lapilli which commonly reach $50 \mathrm{~mm}$ across. The tuffs are typically unwelded 
or weakly-welded, coarse, crystal-rich pumice breccias, with occasional intercalated airfall beds which are very crystal-rich and include some large fibrous pumice blocks up to $80 \mathrm{~mm}$ across, and rarely reaching $250 \mathrm{~mm}$. No single section exposes the entire thickness of the "quartz-biotite ignimbrites", but a type area located in the vicinity of the Mangawhio Stream (N77/100940) [V16/295251]* encompasses several deep valley sections where interbedded coarse flow and fall units are exposed.

Unpublished descriptions (Healy 1959) of sections to south of O.V.C. in northern Kaingaroa Forest, suggest that these "quartzbiotite ignimbrites" underlie the fine-grained Murupara Ignimbrite of Healy et al (1964) (equivalent to the Murupara Member of the Te Whaiti Ignimbrites - Martin 1961). They probably also correlate with unnamed, non-welded massive biotite tuffs which underlie the Te Whaiti Ignimbrites of northern Kaingaroa Plateau, and with the "quartz-biotite ignimbrites" (Martin 1961) drilled in Waiotapu Geothermal Field (Martin 1961, Grindley 1963, Steiner 1963). Rather similar quartz-biotite bearing tuffs outcrop at Hereperu Road on the Matata coast, and have also been drilled in the Kawerau Geothermal Field (Browne 1978).

The "quartz-biotite ignimbrites" appear to be interbedded with the type Rangitaiki Ignimbrites emupted from Taupo. However, the known distribution and coarse lithology of the "quartz-biotite ignimbrites" suggest that they were erupted from an Okataina source, and they probably represent the first major pyroclastic eruptives from this volcanic centre. A chemical analysis of this ignimbrite is included in Appendix 1.

\section{Onuku Breccia}

The Onuku Breccia consists of moderately compacted pumiceous pyroclastics containing obsidian xenoliths, plus interbedded fine ash layers some of which are pisolitic. The formation outcrops over a wide area, and ranges in elevation from 300-340 m a.s.I.

*Grid references are based on the national thousand-yard grid of the 1:63 360 topographical map series (NZMS I). These are followed (in square brackets) by the equivalent grid references from the metric 1:50 000 map series (NZMS 260). 
at Waiotapu (where it is crossbedded, contains flow structures, and appears to have been deposited subaqueously) to 490-520 m a.s.I. on the Kaingaroa Plateau at Onuku (N86/909801) [V16/117129], and Plateau Road (N95/905590) [V17/108936]. In the more elevated sections, Onuku Breccia is well showerbedded and consists of soft, slightly weathered pumice fragments, plus minor obsidian and rhyolite xenoliths. The pumice is crystal-poor, with plagioclase, pyroxene and amphibole phenocrysts. The Onuku Breccia is in part a correlative of the Huka Group - hu1 "sediments" of Grindley (1959) but is here regarded as a primary volcanic deposit only locally deposited in water. The type locality is taken as the exposures in road cuttings from the Highway 38 culvert across the Waikokomuku Stream, at the formation base (N85/892824) [V16/102151], eastward to the Bretts Road intersection (N86/909801) [V16/117129], where the apparent thickness is about $60 \mathrm{~m}$.

The Onuku Breccia overlies the eroded surface of the Rangitaiki Ignimbrites, appears to underlie the Matahina Ignimbrite, and definitely underlies the Kaingaroa Ignimbrites with considerable erosional unconformity. Conical hills in the Onuku-Rerewhakaaitu area are formed in soft Onuku Breccia capped by a thin layer of welded Kaingaroa Ignimbrites.

Similar, quartz-poor, obsidian-bearing pumiceous pyroclastics outcrop overlying the "quartz-biotite ignimbrites" in a section on the eastern margin of Puhipuhi Basin where they appear to lie under Matahina Ignimbrite forming the basin walls. Remnants of Onuku Breccia also overlie the "quartz-biotite ignimbrites" to south of the Puhipuhi Basin, and underlie Matahina Ignimbrite in sections on the eastern shore of Lake Rotomahana. Onuku Breccia outcrops above ha1 rhyolite and beneath Matahina Ignimbrite at Lake Rotoma. At Murupara, $5 \mathrm{~m}$ thick showerbedded, obsidian-bearing pyroclastics correlated with the Onuku Breccia, are interbedded between Matahina Ignimbrite and the Rangitaiki Ignimbrites and contain an intervening paleosol. This weathering break is not seen elsewhere but indicates that products of multiple eruptions are included 
in the mapped Onuku Breccia deposits. The distribution, and greatest mapped thickness of the Onuku Breccia indicates that it was erupted from Okataina Volcanic Centre.

\section{Pokopoko Breccia}

This formation has been named and described by Thompson (1974). Pokopoko Breccia is mapped on the western shore of Lake Okataina (type area) and to west and south of Lake Okareka where it consists of $120 \mathrm{~m}$ of moderately compacted to slightly welded, poorly stratified pumiceous ash, lapilli, and block beds, with interbedded pumice lapilli fall beds containing obsidian xenoliths. Pokopoko Breccia unconformably underlies Mamaku Ignimbrite, the contact being exposed on the Haroharo Caldera rim between Lakes Okareka and Okataina (N76/855020) [U16/073330]. The Pokopoko Breccia at Okataina appears to be a near-source correlative of the Onuku Breccia as it has similar lithology and apparent stratigraphic position. Similar breccias have been drilled beneath Mamaku Ignimbrite in investigation wells at Tikitere (see Part III) and the Kaituna River (Thompson 1974), and are correlated with Pokopoko Breccias.

Terrace Road Basalt (not mapped)

Stratified, thin beds $(5-15 \mathrm{~cm})$ of generally flat-lying vesicular black scoria and coarse ash are exposed in a small area of dissected terrain at Terrace Road (type area) of Waiotapu Forest (N85/877785) [U16/087115]. The outcrops occur just south of the mapped area. The scoria beds are interbedded with thin rhyolitic sediments which are probably correlated with Onuku Breccia. The plagioclase-pyroxene-olivine bearing lava contains a little xenocrystic(?) quartz - apparently derived from fused rhyolite inclusions. Interspersed through the deposits are essential blocks of vesicular basalt, and rare ignimbrite and rhyolite lithics. The beds commoniy display inverse grading, and appear to be base surge and fall deposits resulting from a small phreatomagmatic eruption at a nearby but non-preserved vent. A chemical analysis is presented in Appendix 1. 


\section{Waikokomuka Andesite/Dacite}

Outcrops of hard, vesicular, pyroxene-plagioclase bearing lavas are exposed on forested domes and associated lava flows to east of Maungakakaramea dacite dome (to south-west of O.V.C.). Two analyses of these lavas (Appendix 1) have given silica contents of 62 and $63 \%$ silica. The Waikokomuka lavas appear to span the gradational andesite/dacite boundary (taken here at $63 \% \mathrm{SiO}_{2}$ - Taylor 1969).

\section{Matahina Ignimbrite}

Matahina Ignimbrite outcrops mainly to east of O.V.C., where it overlies Onuku Breccia and the Rangitaiki Ignimbrites on the northern Kaingaroa Plateau, and is overlain by the Kaingaroa Ignimbrites. To north of O.V.C. the Matahina Ignimbrite laps over ha1 rhyolites at Rotoma, and is overlain by remnants of Kaingaroa Ignimbrites, thin weathered pyroclastic fall deposits, and Rotoiti Breccia. To north-east of O.V.C. the Matahina Ignimbrite is downfaulted into the Whakatane Graben where it underlies Kaingaroa Ignimbrites and Rotoiti Breccia, and has been drilled at shallow depths (100-200 m) in Kawerau Geothermal Field. Matahina Ignimbrite does not outcrop within Haroharo Caldera apart from a single outcrop overlying a back-tilted subsided block lying just within the caldera rim on the south-east shore of Lake Rotomahana. Isolated remnants also outcrop to south-east of O.V.C., on the Paeroa Fault scarp and in the Ngakuru Graben (Nairn 1973).

Matahina Ignimbrite has been studied in detail by Bailey (1965) who divided it into basal pyroclastic fall and lower and upper welded pyroclastic flow deposits. The thickest deposits occur in the Rangitaiki River valley to east of O.V.C. where the ignimbrite filled a pre-existing fault angle depression. Here the ignimbrite is densely welded, but adjacent to O.V.C. the ignimbrite is most commonly a compacted to moderately welded light-brown tuff, characteristically containing large lithic rhyolite and vesiculated obsidian inclusions, and large 
devitrified pumice fragments. Quartz is present as small phenocrysts $(1-2 \mathrm{~mm})$, and pyroxene and hormblende are the main mafic minerals. The basal airfall beds are about $1 \mathrm{~m}$ thick on the south shore of Lake Rotoma (N77/038126) [V15/243423], where the ignimbrite overlies c. $5 \mathrm{~m}$ thick Onuku Breccia and brecciated ha1 rhyolites.

Distribution of the Matahina Ignimbrite and the size gradation of lithic inclusions has suggested a source in the O.V.C. "possibly in the Haroharo Caldera" (Bailey 1965). The upper part of Matahina Ignimbrite is now exposed in a new quarry on Tarawera Road (N77/111053) [V16/308354], at the outlet of the Tarawera River from Puhipuhi Basin. Here lithic rhyolite inclusions commonly reach $50 \mathrm{~mm}$ in diameter, and occasionally reach $150 \mathrm{~mm}$ across. Pumice inclusions also reach $150 \mathrm{~mm}$ dimensions. No detailed study has been made of variation of clast size with distance, but the quarry section contains some of the largest clasts seen in Matahina Ignimbrite.

Matahina Ignimbrite does not outcrop in Puhipuhi Basin, and its distribution to east of the O.V.C., together with the coarseness of lithic inclusions at the Tarawera River quarry suggest that it may have been erupted from vicinity of the basin. Puhipuhi Basin is infilled by Kaingaroa Ignimbrite and was apparently formed during or shortly after emption of the Matahina Ignimbrite. The basin has little geophysical expression but may represent a collapse structure formed during the Matahina Ignimbrite eruption.

\section{Puhipuhi Dacite}

Dacite lavas and breccias are intruded into and overlie lacustrine sediments and pyroclastic deposits in the Puhipuhi Basin. The lavas form a small dissected cone and strongly dissected flows on the western margin of the basin. Only the cone is mapped separately, the other lavas to south are mapped as part of the Puhipuhi Beds. The cone was previously mapped (Healy et al 1964) as (?Miocene) Beeson's Island Andesite, the lavas to south were not mapped. The lava locally forms pseudo- 
pillows (Fig. 4) where intruded into wet lacustrine sediments at the type locality (N77/043002) [V16/245309]. Both the sediments and lavas are hydrothermally altered, and the sediments often baked at contacts. Quartz, pyrite, and marcasite are reported present in mineralized veins, with very small amounts of gold and silver (N.Z. Geological Survey 1928; A.J. Ellis pers. comm. 1976). Plagioclase is the major phenocryst in the lava, with hypersthene and minor augite.

Puhipuhi Dacite postdates the post-Matahina Ignimbrite formation of Puhipuhi Basin, but stratigraphic relations with the Kaingaroa Ignimbrites are uncertain, as no contacts are exposed. From degree of dissection the Puhipuhi Dacite is inferred to underlie the Kaingaroa Ignimbrites.

\section{Puhipuhi Beds}

The area within Puhipuhi Basin mapped as Puhipuhi Beds consists of lacustrine sediments and Puhipuhi Dacite mantled by thick Mangaone Sub-group pyroclastics and Rotoiti Breccia. Exposures are rare, and large erosional unconformities at each contact preclude separate mapping of the individual formations. The lacustrine beds are stratified, with pumiceous pyroclastics, coarse sands, and thin interbedded mudstones, all commonly silicified or baked by the intruding dacite.

\section{Maungakakaramea Dacite}

Two dacite volcanoes - Maungakakaramea and Maungaongaonga and associated plagioclase-pyroxene lava flows - were erupted to south-west of O.V.C. Maungaongaonga is K-Ar dated at $159,000 \pm 7000$ years B.P. (Stipp 1968). This age dates the main cone; a little-eroded tholoid occupies the breached crater of Maungaongaonga, and is probably younger. The domes overlie Waiora Formation and Rangitaiki Ignimbrites, and the Earthquake Flat Breccia flowed around them. Maungakakaramea 


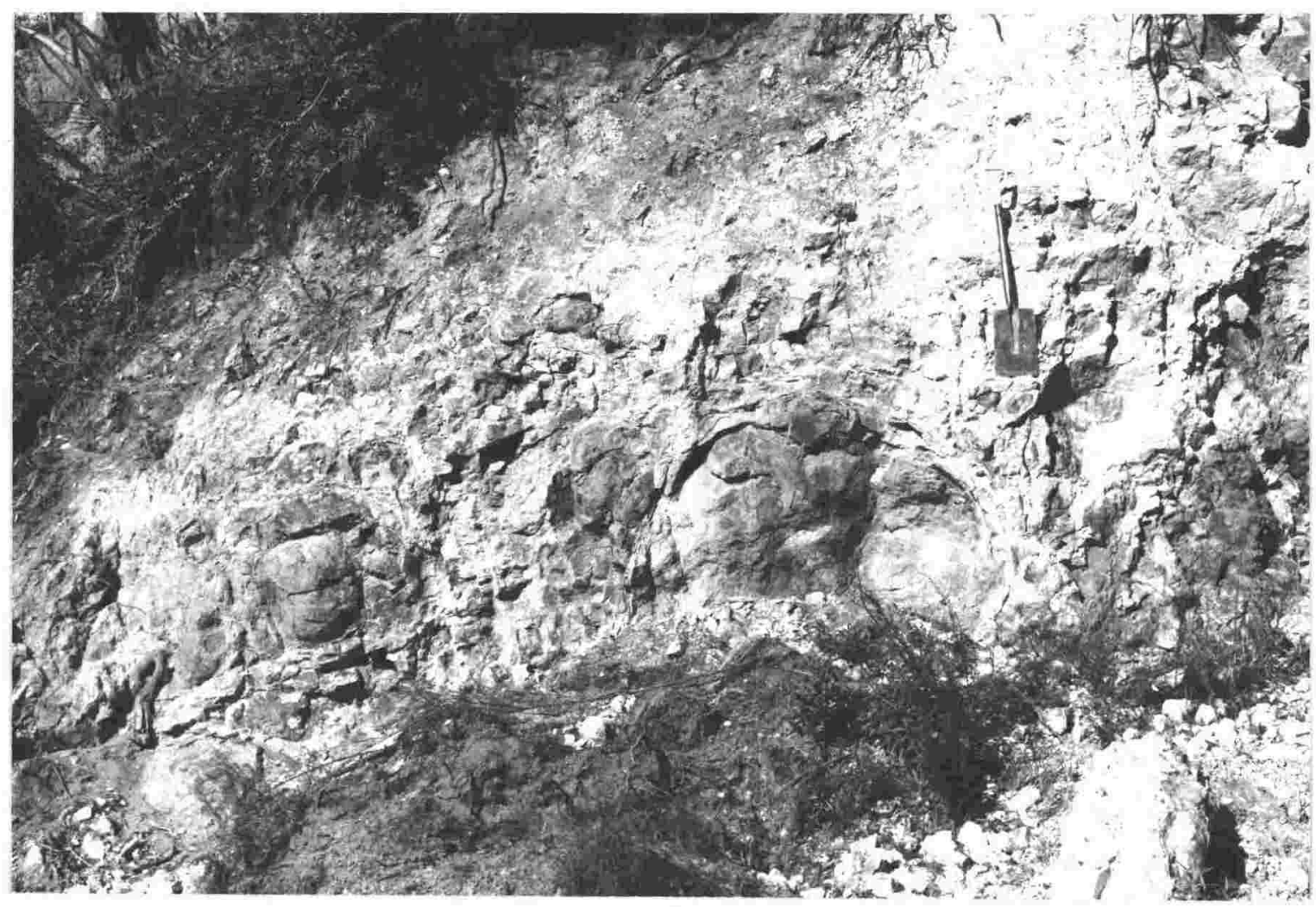

FIG. 4 - Puhipuhi Dacite lavas forming rounded pseudo-pillows intruded into weakly stratified lacustrine sediments. Section exposed in abandoned quarry at V16/245310. Spade is $1 \mathrm{~m}$ long. 
is considerably altered by hydrothermal activity associated with the Ngapouri Fault, and is pitted by recent explosion craters. Aeromagnetic surveys show little anomaly, the domes appearing to be largely superficial. Topographic thickness is about $300 \mathrm{~m}$ on both domes.

\section{Kaingaroa Ignimbrites}

Although previously mapped only to south and south-east of the O.V.C. (Healy et al 1964), Kaingaroa Ignimbrites also largely fill the Puhipuhi Basin on the eastern boundary of Haroharo Caldera, outcrop extensively in the Kawerau area, and a remnant has been found $8 \mathrm{~km}$ to north of Lake Rotoma. Other isolated outcrops occur near Waikite on both upthrown and downthrown sides of the Paeroa Fault, on the west flank of Tumunui rhyolite dome, and on the east flank of Waikorapa rhyolite dome (Nairn 1973). This distribution pattern is consistent with a source in southern O.V.C., probably in the area now occupied by Tarawera Volcanic Complex, as suggested from the previously mapped distribution by earlier workers (i.e. Grindley 1965).

Kaingaroa Ignimbrites overlie Onuku Breccia at higher elevations to south of the O.V.C., overlie lacustrine sediments in Puhipuhi Basin, and Matahina Ignimbrite to north of Rotoma and in the Kawerau area.

Previous workers (Martin 1961, Healy et al 1964) described Kaingaroa Ignimbrite as consisting of two quartz-poor and lenticulitic welded members $\mathrm{kg} 1$ and $\mathrm{kg} 2$, the "lower member ( $\mathrm{kg} 1$ ) consists of lightly welded, dark grey to black pumice tuff, containing light grey pumice fragments," (Martin 1961). However, at Martin's type locality for the lower member - "three miles south-east of Lake Rotowhero on the Rotorua-Murupara Road" (to south of the mapped area), this "sandy black" member grades down into a non-welded grey-brown ash and pumice breccia containing abundant andesite xenoliths. The base of this breccia 
unit is not exposed, but it appears to be at least $50 \mathrm{~m}$ thick at the type locality. The unwelded breccia also outcrops to south in the Kaingaroa scarp and the valleys eroded headward into it (Nairn 1973). In the Waiotapu area, the unwelded breccia is found only where Onuku Breccia is absent, i.e. it appears to fill buried valleys eroded into the Onuku Breccia. Where Onuku Breccia is present it is overlain by welded "sandy black" Kaingaroa Ignimbrite; this relationship is exposed in Waiotapu Forest at N85/880788 [U16/090118]. The basal unwelded breccia unit of the Kaingaroa Ignimbrites was mapped by Grindley (1959) as part of an underlying Huka Group sedimentary deposit (hu1) containing andesite gravels. The unwelded breccia unit has since been mapped as kg1a (Nairn 1973), while the overlying welded or partly welded sheets are designated $\mathrm{kg} 1 \mathrm{~b}$. These sheets form the kg1 sheet of Healy et al (1964). The welded sheet is about $30 \mathrm{~m}$ thick in the eastern Waiotapu area.

Both the upper units (kg1a, kg2) of the Kaingaroa Ignimbrites are crystal poor ( $<10 \%$ phenocrysts), have a distinctive vitroclastic texture where not strongly welded, and are mineralogically similar in containing only rare quartz. Pyroxene is the dominant mafic mineral (Martin 1961, see also summary by Briggs 1973). The Kaingaroa Ignimbrites are further characterised by plagioclasepyroxene andesite xenoliths which occur throughout the deposit, but most abundantly in the basal breccia. Petrography and a chemical analysis of this andesite are presented in Appendix 1. The xenoliths are presumed to have originated from an earlier andesite extrusion in the ignimbrite source vent area, but no similar low-silica andesite now outcrops within the O.V.C. Possibly similar (but hydrothermally altered) andesites(?) have been cored in geothermal wells at Kawerau and Waiotapu, close to opposite ends of the Tarawera vent lineation.

\section{Mamaku Ignimbrite}

Mamaku Ignimbrite outcrops on the western margin of the O.V.C., extending south from Lake Rotoiti to Lakes Okareka and Tarawera. In this area the ignimbrite overlies Pokopoko Breccia 
and laps around the ha1 rhyolite domes of Whakapoungakau, Pukepoto, and at Okareka. Between Lakes Okataina and Okareka the Mamaku Ignimbrite is step-faulted down into the caldera (see p. 51). An isolated outcrop occurs between Lake Okareka and Lake Tarawera, and the Moura peninsula extending into southern Lake Tarawera is largely composed of Mamaku Ignimbrite.

Mamaku Ignimbrite is generally considered erupted from, and to have caused the subsidence of, Rotorua Caldera (see Briggs 1973 for summary). The stratigraphic relationships with Kaingaroa and Matahina ignimbrites are nowhere exposed, but relative erosion and different magnetization directions suggest that Mamaku Ignimbrite may be the youngest of the three ignimbrites (Cox 1971, Briggs 1973). The structural and volcanic history of $\mathrm{O} . \mathrm{V} . \mathrm{C}$. is most readily interpreted if this stratigraphic order is assumed. The available radiometric dates suggest that the ignimbrites become older in sequence - Mamaku, Kaingaroa, Matahina (Table 1), although the age differences are not statistically significant ( they overlap at the one standard deviation level). Kaingaroa Ignimbrite fission track dated on glass has given an age of $145,000 \pm 20,000$ yrs B.P. (Kohn 1973) while Mamaku Ignimbrite is fission track dated on zircons at $140,000 \pm 80,000$ yrs B.P. (Murphy \& Seward in press).

Te Wairoa Breccia

A new formation defined by Thompson (1974), to comprise a weakly compacted primary pyroclastic breccia containing pumiceous rhyolite in an ash matrix, and considered to overlie the Mamaku Ignimbrite. Te Wairoa Breccia occupies a small area north of Lake Tikitapu. It may represent the soft top to the Mamaku Ignimbrite, or be a younger pyroclastic flow deposit erupted from the northern Moerangi rhyolite domes to west of Tikitapu. Age and thickness are uncertain.

\section{Onepu Dacite}

Two dacite domes on the western margin of the Kawerau Geothermal Field rise above Kaingaroa and Matahina Ignimbrites 
which they postdate, and are overlain by Rotoiti Breccia and Mangaone Sub-group pyroclastics. The lavas are crystal-rich and contain large quartz and plagioclase phenocrysts, together with abundant amphibole. Most outcrops are hydrothermally altered. A chemical analysis is included in Appendix 1.

\section{Haparangi Rhyolites}

Lava domes and flows are mapped as Haparangi Rhyolite after Healy et al (1964), where rhyolites predating the youngest widespread ignimbrite sheets (Mamaku and Kaingaroa) are denoted ha1, and those younger than the ignimbrites as ha2. Rhyolites mapped as ha3 postdate the Rotoiti Breccia, and occur only within Haroharo Caldera and the subsidiary Rotoma Caldera(?) and Okareka Embayment. Individual rhyolite lava domes and flows are named and described in later sections which discuss histories and structures of the various rhyolite complexes.

\section{Haparangi Rhyolitic Pumice (hap)}

Undifferentiated deposits of small pyroclastic flow eruptions associated with rhyolite dome-building are mapped as hap. Several pyroclastic flow deposits are individually named and described in sections on the Haroharo and Tarawera Volcanic Complexes.

\section{Huka Group}

Late Pleistocene volcanic sandstones and siltstones, plus minor diatomite and interbedded primary pyroclastic deposits, occupy the Ngakuru Graben and outcrop in the lowest areas within O.V.C. Huka Group sediments (hu2) underlie Rotoiti Breccia outside the O.V.C., and some younger lavas and pyroclastics within Haroharo caldera. The sediments record intervals of lacustrine sedimentation in subsidence-formed basins of the O.V.C.

Similar, but older sediments and interbedded pyroclastics deposited in Puhipuhi Basin are intruded and altered by Puhipuhi 
Dacite lavas, and are mapped within the Puhipuhi Beds and elsewhere as hu1.

\section{Rotoiti Breccia}

Rotoiti Breccia Formation consists of multiple unwelded pyroclastic flow deposits with underlying, intercalated, and mantling pyroclastic fall beds (Nairn 1972), erupted from northern Haroharo Caldera at $\geqslant 42,000$ yrs B.P. ${ }^{14} \mathrm{C}$ date (Nairn and Kohn 1973, see also p.164). The rhyolitic pyroclastic flows form a large $\left(>850 \mathrm{~km}^{2}\right)$ fan, commonly $50-100 \mathrm{~m}$ thick, extending north from Haroharo Caldera to the Bay of Plenty coast. Smaller flow lobes spread through valleys in the Maungawhakamana ha1 rhyolites, and the Puhipuhi Basin, to partially occupy the Whakatane Graben near Kawerau. Minor deposits are now found overlying older deposits in Puhipuhi Basin, and thin $(<10 \mathrm{~m}$ ) fine grained distal deposits occur at Rotomahana-Waimangu, and in the Waipa area south of Rotorua Caldera (Nairn 1973). The interbedded pyroclastic fall deposits collectively comprise the Rotoehu Ash and are separately described on p.143. The Rotoiti Breccia is immediately underlain by basaltic scoria of the Matahi Basalt Tephra (Pullar and Nairn 1972).

Rotoiti Breccia overlies older weathered tuffs mantling the weathered surface of Mamaku Ignimbrite to north-west of O.V.C., and similarly overlies Matahina Ignimbrite to north-west. The breccia overlies Kaingaroa Ignimbrites and Puhipuhi Group lavas and sediments in Puhipuhi Basin, rhyolite lavas and pyroclastics at Rotomahana, Kaingaroa Ignimbrites at Waimangu, and lacustrine Huka Group sediments in the Waipa area. Rotoiti Breccia conformably underlies the Earthquake Flat Breccia to south without weathering or erosional break at the contact (Nairn and Kohn 1973). To north and east, the weathered surface of Rotoiti Breccia is overlain by pyroclastic deposits of the Mangaone Sub-group. 
Earthquake Flat Breccia Formation

Weakly compacted rhyolite ash and pumice lapilli pyroclastic flow units and interbedded airfall units, form low angle ash-flow fans extending radially from a $5 \mathrm{~km}$ fissure source at Earthquake Flat and adjacent craters on the Taupo-Rotorua Highway (Nairn 1971). The flow units are unstratified and commonly range between 0.5 and $7 \mathrm{~m}$ in thickness. An ash-sized matrix of glass and pumice, plagioclase, quartz, biotite, hornblende, and hypersthene phenocrysts, surrounds lapilli and blocks of pumice and slightly vesiculated rhyolite, plus rare lithic rhyolite fragments. Shower-bedded airfall units are intercalated between and mantle the flow units. Beyond the pyroclastic flow deposits the fall units coalesce to form the widespread tephra component named Rifle Range ash (Nairn and Kohn 1973). The Earthquake Flat Breccia flow deposits cover an area of $110 \mathrm{~km}^{2}$; maximum thickness approaches $120 \mathrm{~m}$, with thicknesses commonly in the 50-80 m range. The Earthquake Flat Breccia was erupted immediately following eruption of Rotoiti Breccia from northern Haroharo Caldera, $25 \mathrm{~km}$ to the north-east (Nairn and Kohn 1973). No weathering or erosion breaks occur within the Earthquake Flat Breccia which is inferred to have been erupted as a single cooling unit.

\section{Mangaone Sub-group Pyroclastics}

Overlying the weathered surface of the Rotoiti Breccia Formation are eight pyroclastic deposits separated by paleosols. Originally grouped as five informal members of the "Mangaoni Lapilli Formation" (Vucetich and Pullar 1969), these pyroclastics were redefined as eight separate formations by Howorth (1975). From oldest to youngest the formations are Ngamotu Tephra, Tahuna Tephra, Maketu Tephra, Te Mahoe Tephra, Hauparu Tephra, Mangaone Tephra, Awakeri Tephra, and Omataroa Tephra. The formations commonly form a conformable stack and for general mapping purposes the detailed subdivision is not essential. In this study the eight pyroclastic formations are defined as forming the "Mangaone Sub-group pyroclastics". In the Okataina area this Sub-group lies above Rotoiti Breccia 
and below the Okaia Tephra erupted from Taupo Volcanic Centre at some time prior to 20,000 yrs B.P. (Vucetich and Howorth 1976).

\section{Tapuaeharuru Breccia}

A massive pyroclastic flow deposit containing large fibrous pumice lapilli and blocks and lithic and glassy rhyolite inclusions, outcrops only at the eastern end of Lake Rotoiti, where it is well exposed in a large quarry pit. The deposit is strongly dissected but rare weathered surfaces appear to be overlain by Kawakawa Tephra. Mangaone Sub-group pyroclastics are not identified. Although previously regarded as Rotoiti Breccia (see table 8 in Ewart 1968, sample P30402) the low crystal content, absence of phenocrystic quartz and only rare amphibole precludes this correlation. The Tapuaeharuru Breccia is here regarded as a pre-20,000 yr B.P. pyroclastic flow deposit, probably related to the Mangaone Sub-group pyroclastics, but present data are inadequate to confirm its stratigraphic position more precisely, and it is mapped as a separate formation.

\section{Edgecumbe Dacite/Andesite}

Lavas forming Edgecumbe cone and associated dome and flows are porphyritic, plagioclase-pyroxene andesites and dacites, some quartz-bearing (Duncan 1970).

All the Edgecumbe lavas are overlain by Taupo Pumice (c. 1800 yrs B.P.); the Main Cone is also mantled by Waimihia Ash; Whakatane Ash is not found on any of the exposed lavas. However an andesite boulder found resting beneath Whakatane Ash at foot of Edgecumbe (Duncan 1970) indicates that eruptions may have commenced prior to 5000 yrs B.P.

\section{3) Stratigraphy and Chronology of Post-Rotoiti Breccia Pyroclastic Deposits}

Pyroclastic deposits erupted from O.V.C. following the Rotoiti Breccia are mapped separately only where thick and comprising land-form units. 
widespread stratigraphic horizons from which the younger volcanic events in O.V.C. have been dated.

During this study, 22 new radiocarbon dates from O.V.C. eruptives were obtained on samples submitted by the writer. These new dates are summarized in Table 2, together with two additional dates earlier reported for Rotoiti Breccia and Kawakawa Tephra. Special dating studies were made on the Kaharoa and Whakatane Eruptive Episodes, for which abundant charcoal was available. Only four samples could be obtained from near-source Mamaku pyroclastics, and two samples from a pyroclastic flow and a lava flow of the Rotoma Eruptive Episode. Single charcoal samples were obtained for each of Rotomahana pyroclastics, Rotoma pyroclastics, Te Rere pyroclastics, Mangaone Tephra Formation, and Rotoiti Breccia.

The new dates obtained are in rough agreement with those reported by earlier workers, (as summarixed by Pullar et al 1973) except for the Kaharoa and Rotoma dates which are considerably revised (Table 3). The Whakatane and Mamaku dates are refined and the Rotorua and Te Rere Eruptive Episodes have been positively dated for the first time. Most of the new dates reported here are from charcoal enclosed in thick, proximal pyroclastic deposits and are considered optimum for dating the individual eruptive episodes. In each case, the charcoal originated by catastrophic overwhelming of vegetation by near source pyroclastic flows or surges. Many samples had only recently been exposed in new road cuts or erosion gullies, with little possibility of contamination by younger carbon. The charcoal-bearing surge deposits are interbedded within the previously mapped widespread pyroclastic fall deposits, with unequivocal stratigraphic control. Many of the earlier published dates on these pyroclastic deposits came from distal areas where wood or carbon was found associated with relatively thin airfall deposits which presumably fell cool or cold, so that some uncertainty exists as to relationship of the carbon sample to the pyroclastic deposit. 
The ages assumed here for the post-Rotoiti eruptive deposits of O.V.C. are listed in Table 3, together with dates for those pyroclastic fall deposits from Taupo Volcanic Centre which are also present at Okataina. The accepted ages are based on averages, of either the new half life ages, or the secularly corrected ages (where applicable), listed in Table 2, together with the ages obtained by other workers for the Waiohau and Rerewhakaaitu eruptive episodes. The undated Rotokawau Ash and Okareka Ash are assigned ages intermediate between the enclosing dated pyroclastic deposits. Because of the various uncertainties involved, all the pre-Kaharoa Ash accepted ages are assessed in hundred- or thousand-year units. The available ages provide an excellent chronological framework for the post-Rotoiti Breccia emptive history of Okataina Volcanic Centre. All the ages are stratigraphically consistent, except those for the Te Rere pyroclastics and Kawakawa Tephra. Five ${ }^{14} \mathrm{C}$ dates from Kawakawa Tephra at widely separated sites, all to south of Lake Taupo (including NZ1056 - Table 2), have given ages (old T T $\frac{1}{2}$ ) between 19,850 and 21,900 yrs B.P., and an age of c. 20,000 yrs B.P. is generally accepted (see Vucetich and Howorth 1976). The Te Rere pyroclastics at Lakes Rotoiti and Rotoehu have given two dates (old T T) of 20,700 \pm 450 and $21,500 \pm 450$ (Table 2 and 3). Kawakawa Tephra underlies the dated Te Rere pyroclastics at Lake Rotoehu. The c. 20,000 yr B.P. date is accepted here for Kawakawa Tephra. Te Rere Ash must be younger, and an age of 19,000 yrs B.P. is accepted. 


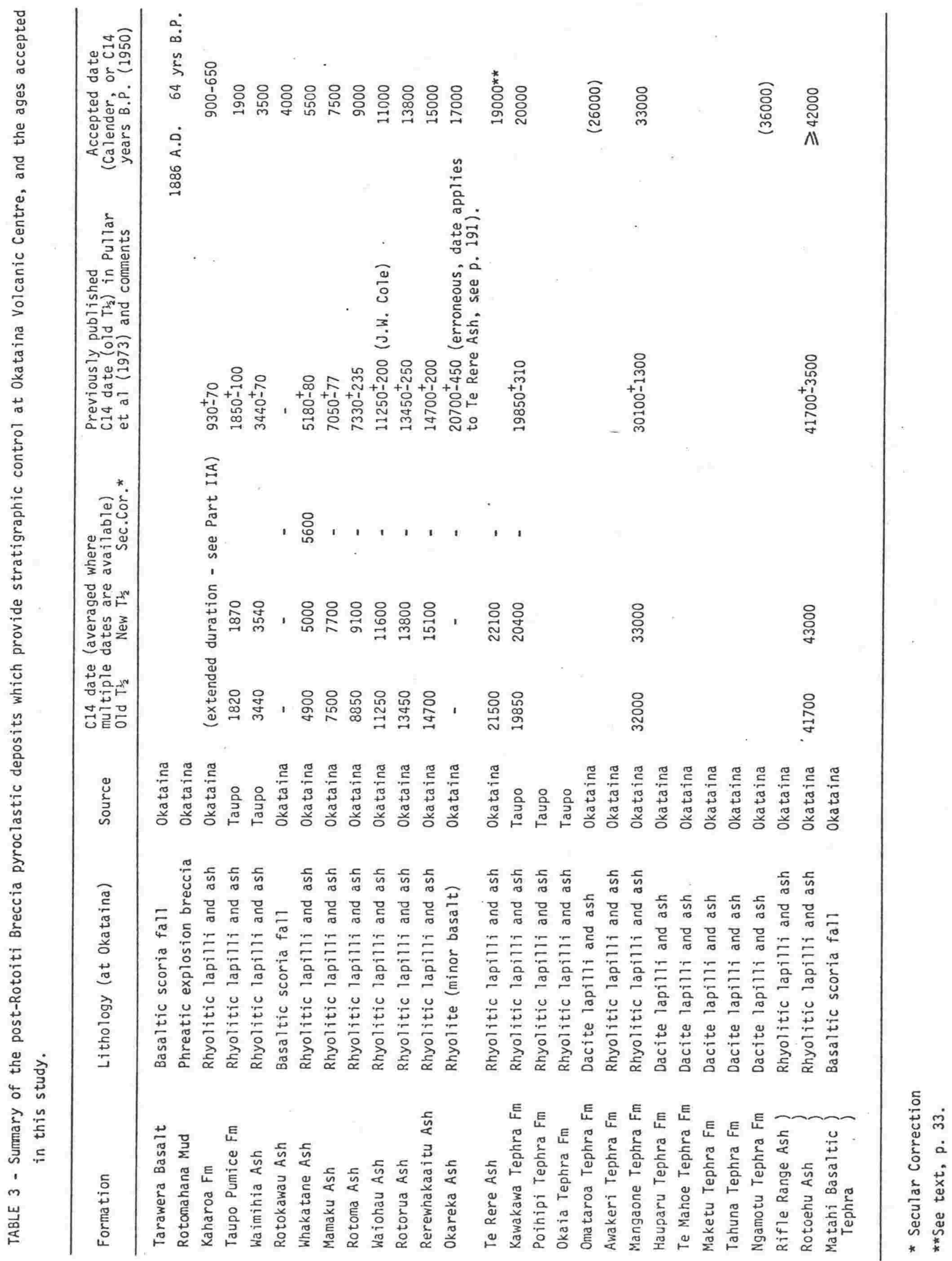


B: STRUCTURE

\section{1) Regional Structure}

The O.V.C. occurs within the linear volcano-tectonic depression of the Taupo Volcanic Zone, and is sited immediately east of Rotorua Caldera, in an area where the T.V.Z. is narrowing north-eastward from its greatest width of $40-50 \mathrm{~km}$ between Mangakino and Broadlands on opposite sides of the Maroa Volcanic Centre (see Fig. 1). North-east of the O.V.C. the T.V.Z. narrows into the $10-15 \mathrm{~km}$ wide Whakatane Graben which is largely infilled by volcanic products erupted from the O.V.C.

The margins of the T.V.Z. closely coincide with the bounding faults of the Taupo Fault Belt (Grindley 1960) - a late Pleistocene zone of numerous north-north-east trending, subparallel, dominantly vertical fault traces which outline the major T.V.Z. structural units. South-west of the O.V.C. these structural units are the Te Weta, and Paeroa Blocks (Grindley 1959), together with the major Horohoro, Ngakuru, Whirinaki, Tumunui, Paeroa, and Ngapouri Faults (Map 2 and Fig. 5 (Nairn 1973, 1976), which define the "Taupo-White Island Depression" (Modriniak and Studt 1959). North-east of the O.V.C., surface faulting is less intense. Little surface faulting is apparent within Haroharo Caldera (Map 2), although several unmappable small displacements $(<1 \mathrm{~m})$ have been observed in young pyroclastic deposits near eruptive vents.

The "Taupo-White Island Depression" was recognised from gravity evidence as a basement depression c. $4000 \mathrm{~m}$ deep near Ngakuru (Modriniak and Studt 1959). To south-west of O.V.C., the Depression is represented at the surface by the coalescing Ngakuru and Guthrie Grabens (Map 2). The axis of maximum subsidence of the Depression is indicated by opposing downthrow of recent fault traces and lies immediately to south of the Ngakuru Fault. The axis intersects the O.V.C. near Lake Rotokakahi, where its north-eastward continuation as a fundamental basement fracture beneath Haroharo Caldera is marked by strong alignment of rhyolite eruptive vents between Lakes Tikitapu and Rotoma (Map 2). 


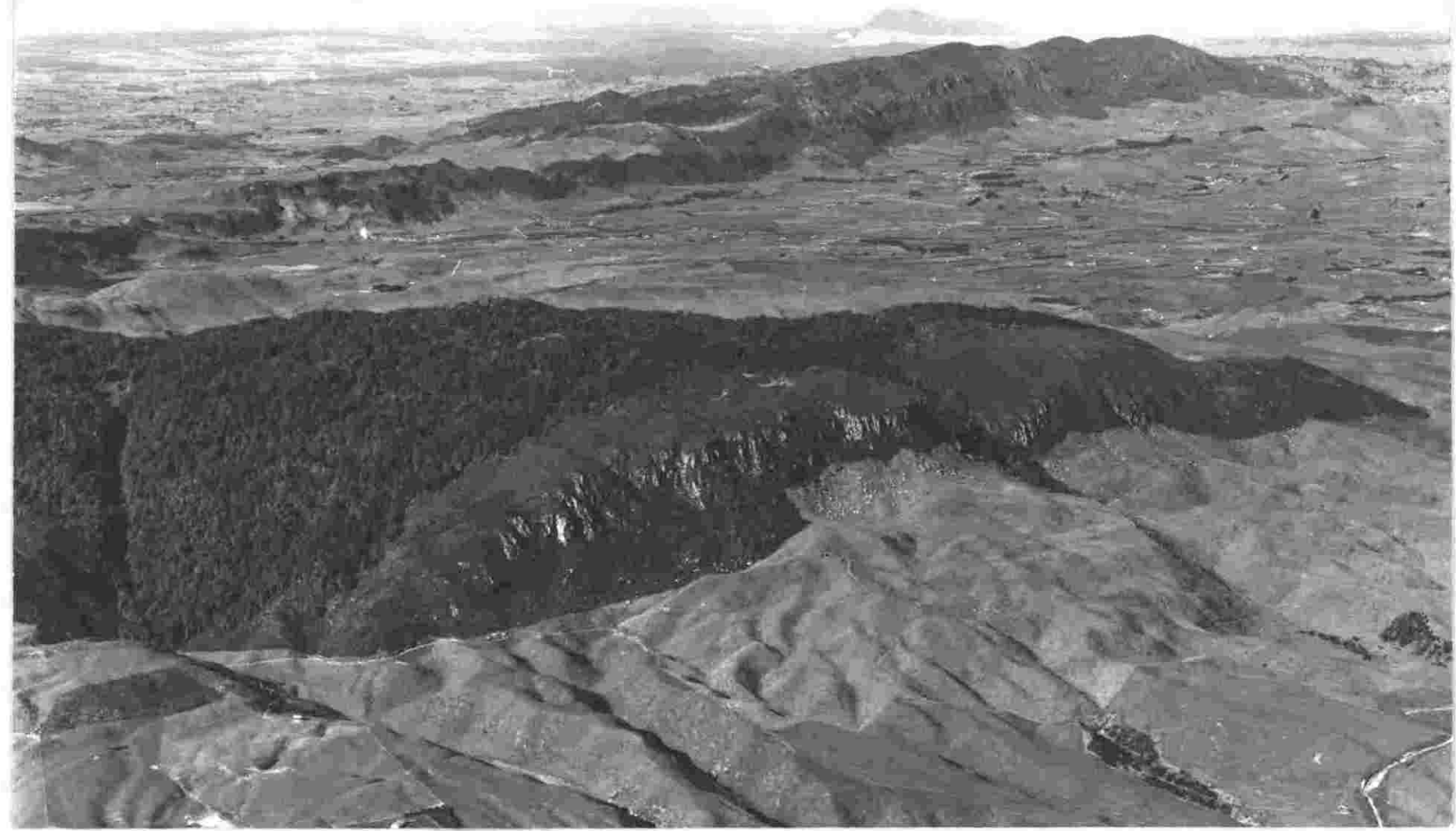

FIG. 5 - Tumunui Fault displacing Tumunui hal rhyolite dome in foreground; sub-parallel Paeroa Fault displacing back-tilted Quaternary ignimbrites in background. Photo looking south-east by D.L. Homer. 
The tilted Paeroa Block at Waiotapu is bounded by the spectacular Paeroa Fault scarp displacing Kaingaroa and older (>150,000 yrs B.P.) ignimbrites (Nairn 1973). North-east along the $040^{\circ}$ strike the Paeroa Fault is represented by many discontinuous arcuate traces which define a graben in the $\geqslant 42,000$ yr B.P. Earthquake Flat Breccia deposits (Nairn 1976). Further north-east the young traces die out but the Paeroa Fault reappears on the south-west caldera margin as an eroded scarp in ha1 rhyolite forming the south wall of the Waima Stream valley (Maps 1 \& 2). Although the Paeroa Fault is a major structural feature of the T.V.Z., its inferred north-eastward extension has no surface expression within Haroharo Caldera, and no eruptive vents are located on it.

The Ngapouri Fault is the southernmost major displacement in the Taupo Fault Belt. It branches from the Paeroa Fault eastward across the Paeroa Block, passing through the Waiotapu hydrothermal field as a semi-continuous trace, before terminating in the Okaro area south-west of Lake Rotomahana (Map 2). Here the Ngapouri Fault lies immediately north of the major north-east striking Rotomahana Fault which controls the south-western extension of the Haroharo Caldera margin, and the two faults probably intersect at depth.

Te Weta Block is bounded by the Whirinaki Fault which parallels the Paeroa Fault in the Ngakuru area, but splits north-eastward into a zone of several arcuate traces which maintain the $040^{\circ}$ strike before swinging abruptly east to strike at $085^{\circ}$ south of Lake Rotokakahi. The discontinuous fault trace continues east-north-east at $060-070^{\circ}$ strike across the ha2 Tutaeheka rhyolites to south-west of Lake Tarawera, where it enters the caldera as a major scarp controlling the re-entrant Moura Block peninsula in Lake Tarawera. As with the Paeroa Fault, the Whirinaki Fault has no surface expression within Haroharo Caldera, and no eruptive vents are aligned along it.

The Horohoro Fault forms the western boundary of the T.V.Z. immediately to south of Rotorua Caldera, where it displaces 
Mamaku Ignimbrite but its north-eastward continuation is uncertain The fault (or a branch) may pass into Rotoma Caldera to east of Pohaturoa Rhyolite Dome (Maps 1 \& 2). Alternatively, the main fault may bend to the south, where a poorly-defined inferred fault strikes east-north-east, subparallel to the opposite downthrown Rotorua Caldera fault, before entering the O.V.C. to north of Lake Okareka (Map 2). It also appears to be related to the older, apparently fundamental, Whakapoungakau Fault which displaces the ha1 rhyolite extrusions of Pukepoto and Whakapoungakau to west of Lake Okataina. However, the Whakapoungakau Fault does not displace the Mamaku Ignimbrite which partially buries the rhyolite extmusions, and therefore its most recent movement predates that of the Horohoro Fault to south-west of Pohaturoa. The inferred north-eastward continuation of the Whakapoungakau Fault intersects Haroharo Caldera close to Lake Rotoatua, $2 \mathrm{~km}$ south of Lake Rotoiti (Map 2).

Other faults to west of Whakapoungakau are related either to the Rotorua Caldera, or to a graben which extends northeast from Rotorua Caldera into the Tikitere area. These faults do not appear related to the O.V.C. and are not considered further here.

To north of O.V.C., recent faulting is re-established to east of Lake Rotoehu, and becomes well defined to north and east of Lake Rotoma (Map 2). The western margin of this fault zone lies approximately along strike from the HorohoroWhakapoungakau Fault, suggesting its north-eastward continuation under the O.V.C.

Faults to north and east of Rotoma have a more easterly trend, commonly striking at about $080^{\circ}$ (in contrast to the general Taupo Fault Belt strike at about 040-050) before intersecting and merging with north-north-east trending regional faults controlling the western topographic margin of the Whakatane Graben. These north-north-east faults extend from the eastern Haroharo Caldera boundary at Maungawhakamana, where 
large displacements of pre-caldera ha1 rhyolites form a graben with axis occupied by the Waikanapiti Stream. The Waikanapiti Fault forms the western margin of the Maungawhakamana Graben, and extends north-east towards the western margin of the Whakatane Graben (Map 2). Here, ha1 rhyolite lavas overlain by Matahina Ignimbrite are progressively block faulted down south-west into the Whakatane Graben. Much of this faulting postdates the Matahina Ignimbrite. The Maungawhakamana Graben lies approximately along strike from the Whirinaki Fault to south-west of the O.V.C., and might represent continuation of this regional structure across the O.V.C. into the Whakatane Graben.

\section{Younger surface fault traces displace the Kaingaroa} Ignimbrites and Rotoiti Breccia surface within Whakatane Graben to north of Kawerau. These fault traces again define a graben, with axis in the Lake Rotoitipaku area (Map 2). No major surface faults are mapped to east of Kawerau Geothermal Field, but the presence of north-west-downthrown faults buried beneath young volcanics and sediments has been inferred from drillhole stratigraphy in the geothermal field (Map 2). Greywacke basement rises $300 \mathrm{~m}$ to south between wells KA25 and KA26 on the eastern margin of the field, while Matahina Ignimbrite encountered at c. $-60 \mathrm{~m}$ (below sea level) in KA26 outcrops at c. $+60 \mathrm{~m}, 800 \mathrm{~m}$ to south of KA26. These displacoments are interpreted as buried faults which may form part of the eastern boundary of the Whakatane Graben at Kawerau. No post-Matahina Ignimbrite displacements appear to have occurred to east of these buried faults. Subaerially deposited ignimbrites, lavas, and non-marine sediments, overlying weathered greywacke, have been drilled to $1 \mathrm{~km}$ below present sea level within the Kawerau Geothermal Field, demonstrating that subsidence of the Whakatane Graben has continued throughout the Quaternary.

Volcanic structures near Kawerau comprise the two small Onepu dacite domes to west of the Tarawera River, and the Holocene andesite/dacite Edgecumbe Volcanic Complex to east of the river (Maps 1 \& 2). The western dacite domes lie on a north-east alignment parallel to the regional fault trend. However, the 
numerous vents on the Edgecumbe complex may be unrelated to the regional trend. Duncan (1970) considered that most Edgecumbe vents fell inside a $300 \mathrm{~m}$ wide band, $3 \mathrm{~km}$ long, trending at $085^{\circ}$, (although the three summit vents on Edgecumbe Main Cone are aligned at $120^{\circ}$ over $250 \mathrm{~m}$ ). An alternative suggestion is that most Edgecumbe vents fall on two north-east trending lineations, with the Main Cone summit vents lying roughly normal to this trend.

The Whakatane Graben has been regarded as forming part of a continuous "Taupo- White Island Depression" (Modriniak and Studt 1959). However, its south-west extension passes through the Puhipuhi Basin towards Tarawera and Waiotapu, where it appears to terminate. The surface structures thus suggest that two main structural units may occur within the "TaupoWhite Island Depression". A Taupo-Rotoma depression is represented in the Okataina vicinity by the coalescing Ngakum-Guthrie grabens which extend under the O.V.C. marked by lineation of vents of the Okareka, Haroharo, and Rotoma rhyolites. A Waiotapu-Whakatane Graben depression is marked by lineation of basic vents at Waimangu, Tarawera, Puhipuhi, and Edgecumbe, and merges into the eastern margin of the Whakatane Graben. The O.V.C. Iies between these two overlapping, offset segments which probably represent major basement fractures.

\section{2) Age of Regional Faulting}

Ages of recent fault movements in the Taupo Fault Belt have been obtained from displacements of dated pyroclastic deposits. Results from the Taupo Fault Belt to south-west of the O.V.C. have been previously summarized (Nairn 1976). Nearly all major faults in this area displace the Earthquake Flat Breccia ${ }^{14} \mathrm{C}$ dated at $\geqslant 42,000$ yrs B.P. The most recent displacements cut the floors of valleys eroded into the Earthquake Flat Breccia fan surface. Erosion of this surface continued until stabilized by deposition of thick Rotorua Ash (c. 13,800 yrs B.P.), during a period of improving climate. The valley floor displacements thus largely postdate the Rotoma Ash. Several fault planes exposed in road cuttings also dis- 
place Rotorua Ash, and in one case a weathered fault scarp is mantled by Waiohau Ash (c. 11,000 yrs B.P.) which is not displaced Extrapolation to the many other surface fault traces of similar appearance suggests that a major tectonic pulse occurred in the Earthquake Flat area shortly after eruption of Rotorua Ash from near Lake Tikitapu, when movement appears to have been renewed on earlier displacements. Similar post-Rotorua Ash displacements also occur to west of Lake Okareka, and on the young rhyolite extrusions between Lakes Tikitapu and Tarawera.

Evidence has been presented for repeated episodic movement of the major faults, older rocks consistently exhibiting greater fault throws than younger rocks along the same fault strike (Nairn 1973, 1976). For example, the Tumunui Fault has a throw approaching $100 \mathrm{~m}$ where it displaces the ha1 Tumunui rhyolite dome ( $>150,000$ yrs B.P.), but throw is only $15 \mathrm{~m}$ on the adjacent Earthquake Flat Breccia, and less than $1 \mathrm{~m}$ across lacustrine sediments ( $<20,000$ yrs B.P.) filling crateral depressions along the fault strike.

Only the Horohoro Fault does not intersect the Earthquake Flat Breccia to south-west of the O.V.C., so that its most recent movement cannot be accurately determined. Makaku Ignimbrite (c. 140,000 yrs B.P.) is considerably displaced by the fault to south of Rotorua Caldera, but the apparently related Whakapoungakau Fault on the western margin of the O.V.C. is buried by undisplaced Mamaku Ignimbrite, so that movement on this sector is somewhat older.

To north-east of the O.V.C., the faults north and east of Lake Rotoma displace the eroded surface of the Rotoiti Breccia ( $\geqslant 42,000$ yrs B.P.), commonly forming small basins of internal drainage. Fault scarps here are usually more subdued than those displacing the similar age Earthquake Flat Breccia (to south of the O.V.C.), and thus appear older. Many of the Rotoma faults appear to predate the thick cover of Rotoma Ash which mantles the area. However, some fault traces have very fresh scarps, (i.e. the North Rotoma Fault, Map 2) and fault 
planes exposed in road cuts at several locations north-east of Lake Rotoma displace Rotoma Ash (c. 9000 yrs B.P.). Normal fault planes exposed on Matahi Road (at N77/087179) [V15/289470] and Rendall Road (N77/068196) [V15/272486] - Fig. 6 displace Rotoma Ash, but the mantling Mamaku Ash (c. 7500 yrs B.P.) appears to mantle the fault scarp. These faults thus last moved between 9000 and 7500 years B.P., possibly immediately following the Rotoma Ash eruptions. Hydrothermal explosions occurred at Kawerau at c. 9000 yrs B.P., shortly following deposition of the Rotoma Ash (see Part III), and may have been triggered by the same tectonic events recorded at Rotoma. Low angle $\left(45^{\circ}\right)$ faults commonly displace Rotoma Ash at Kawerau, beneath the 9000 yr B.P. hydrothermal explosion breccia, but at least some of these faults appear to record slumping of steep slopes probably resulting from ground vibration induced by the hydrothermal explosions.

Other normal faults displace Kaingaroa Ignimbrite (c. 150,000 yrs B.P.) to north of Kawerau (Maps 1 \& 2). Mangaone Sub-group pyroclastics (26,000-36,000 yrs B.P.) exposed in road cuts near Lake Rotoroa (north of Kawerau) are also displaced by this fault zone. Overlying tephras had been removed by excavation and these faults could be as young as the c. 9000 yr B.P. displacements at Rotoma.

\section{3) Okataina Volcanic Centre Structures}

Definition of structures associated with the O.V.C. varies from those which are clearly evident from surface geology supported by the available geophysical data, to those for which geological evidence is tenuous and detailed geophysical data is not yet available. Structures which appear well defined by surface geology are the Okataina Ring Structure and the northern margins of Haroharo Caldera (Map 2). Less well defined structures discussed here include the Rotoma Caldera(?), the Okareka Embayment, and the Puhipuhi Basin, all adjacent and subsidiary to Haroharo Caldera. Presently available data is insufficient to confirm the nature of these structures. 


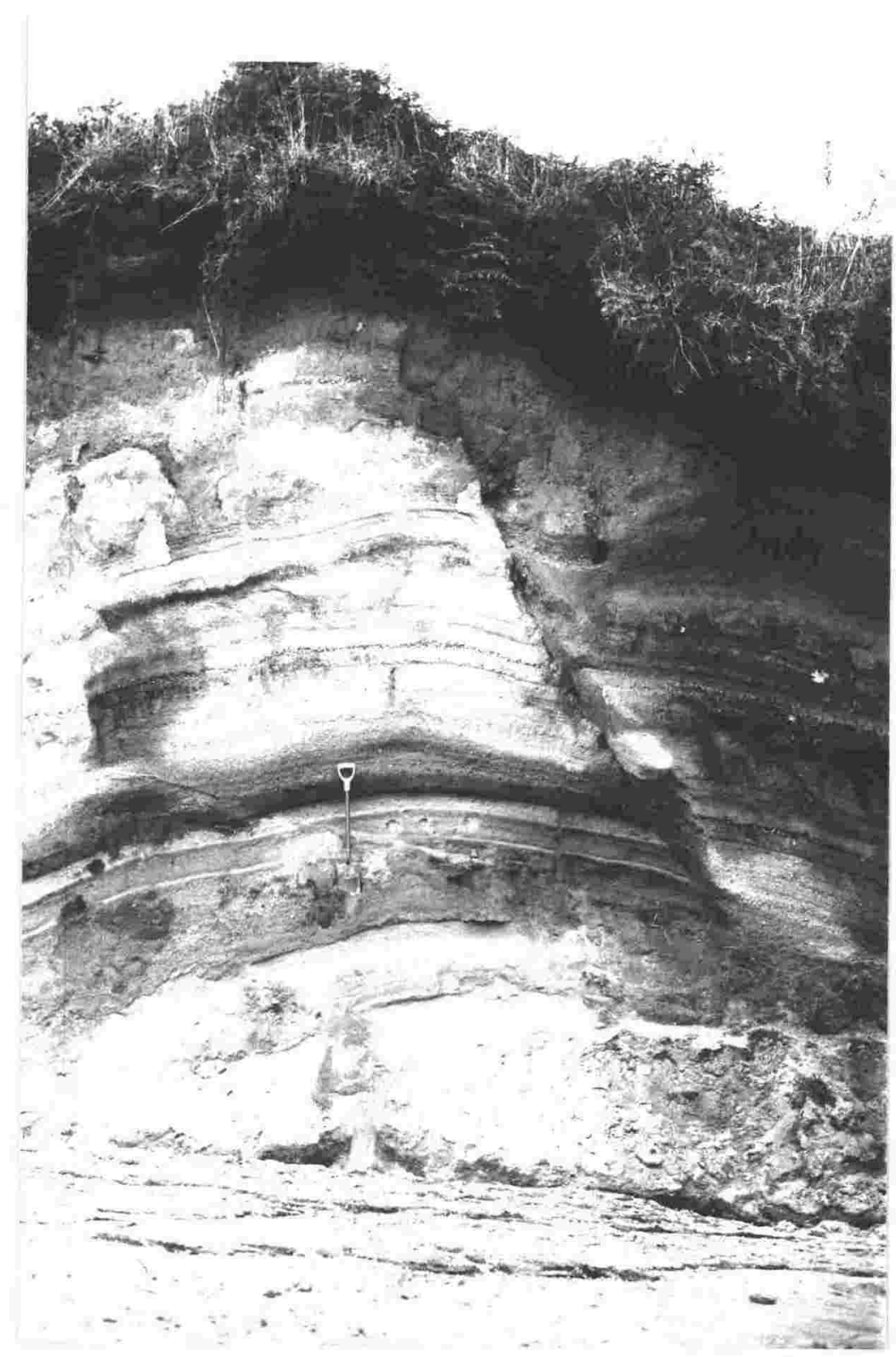

FIG. 6 - Showerbedded Rotoma Ash at Renda11 Road (V15/273487) displaced by normal fault. Displacement does not extend into overlying tephras. Spade is $1 \mathrm{~m}$ long. 
Okataina Ring Structure

Rhyolite domes and flows mapped as ha1 outcrop around the margins of the O.V.C. as dissected peaks, often partly buried under younger ignimbrites. The inferred positions of emuptive vents (Map 2) for these rhyolites are considered to mark location of underlying ring fractures up which magma was extruded early in the Okataina eruptive sequence. Stratigraphic positions of the Ring Structure rhyolites are well known only in the northern O.V.C.. Pukepoto and Whakapoungakau domes to west of Lake Okataina, the Matawhaura massif remnant to north of Lake Rotoiti, the Waitangi ridge between Lakes Rotoehu and Rotoma, the Rere massif immediately to south of Rotoma, and the Maungawhakamana massif to north of the Tarawera River valley all comprise rhyolite extrusives which underlie either Mamaku or Matahina Ignimbrites and Pokopoko Breccia (Maps 1 \& 2).

No ha1 rhyolites outcrop to south of Maungawhakamana so that there is no evidence for existence of the Okataina Ring Structure in the south-east sector of the O.V.C., although the two vents of the Puhipuhi dacite massif may lie on the ring structure extended to south. Conversely, many rhyolites outcrop south of Pukepoto in the south-west sector of the O.V.C., but most appear to postdate the ignimbrites (they are mapped as ha2, although contacts with ignimbrites are nowhere exposed), and location of the Ring Structure is uncertain. However, the apparent alignments of emptive vents may again reflect the location of an underlying outer ring fracture extending from Pukepoto south-south-west to the Moerangi rhyolites on the west shore of Lake Tikitapu. From there the ring fracture curves to the south-east, passing through the Earthquake Flat Breccia vents, which have been suggested (Nairn 1971) to lie on the Okataina Ring Structure. The Earthquake Flat Breccia was erupted from a north-west trending fissure immediately following the Rotoiti Breccia eruptions (Nairn and Kohn 1973). Rotoiti Breccia was erupted from the northern Haroharo Caldera, apparently triggering the Earthquake Flat eruptions on the margins of the O.V.C. Alternatively, the ring structure may pass from Pukepoto south through the Tutaeheka vent to the Waima and 
Hapeotoroa rhyolites and an unnamed rhyolite on the south shore of Lake Rotomahana.

The positions of the two postulated outer ring structures in the south-west O.V.C. are shown on Map 2.

Haroharo Caldera

Haroharo Caldera lies largely within the Okataina Ring Structure and is essentially defined by an elongated (28 x 16 $\mathrm{km}$ ) area of subsidence between surrounding pre-caldera ignimbrite/ rhyolite plateaus (Maps 1 \& 2). Major subsidence of the northern caldera floor accompanied eruption of the Rotoiti Breccia. Subsidence of the southern caldera floor is inferred to have accompanied eruption of the Kaingaroa and Matahina Ignimbrites (at 150,000 and 200,000 yrs B.P.), the Onuku and Pokopoko Breccias and probably part of the Rangitaiki Ignimbrites (c. 230,000 yrs B.P.). Since the Rotoiti Breccia eruptions, the Haroharo and Tarawera Volcanic Complexes have grown on the caldera floor, to largely fill the overlapping collapse structures, and impound Lakes Rotoiti, Rotoehu, Okataina, and Tarawera on the outer margins. A clear age distinction exists between the younger eruptives which outcrop within the caldera (nearly all less than 20,000 yrs B.P.), and the rocks forming the caldera margins which are all older than 140,000 yrs B.P.

In this section, Haroharo Caldera is described as a single topographic unit. In Part IV of this thesis, the caldera is divided into a series of sub-calderas, with eruptive origins and structural histories largely inferred by analogy with apparently similar calderas well-described from the western United States.

Margins of Haroharo Caldera are clearly defined to the north of Lake Tarawera and the Tarawera River (Map 2), but are much less obvious to the south where collapse is considerably older. At Lakes Rotoiti and Okataina, the caldera rim has clear topographic expression, but position of the rim in other areas is obscured either by regional faulting (e.g. at Lake Tarawera) 
or burial beneath young eruptives (between Lakes Rotoiti and Okataina; and to north-east of Lake Rerewhakaaitu). Where well-expressed, the topographic caldera rim is often strongly scalloped, indicating rim slumping of oversteepened caldera ring fault scarps following catastrophic collapse of the caldera floor during large ignimbrite eruptions. At Lakes Rotoiti and Rotoehu, the collapsed margin extends up to $1.5 \mathrm{~km}$ beyond the inferred position of the outer Okataina Ring Structure, due either to outward growth of underlying magma bodies prior to the caldera-forming eruptions or to extension of post-collapse slumping well beyond the structural margin defined at depth by the inner caldera ring fault. The latter alternative would require rapid and deep collapse of the caldera floor prior to rim slumping.

Considerable variation occurs in geomorphic expression of the caldera rim which is described below in sectors. Geographic locations are shown on Map 1, and the structural interpretation on Map 2.

(1) Northern sector - Lakes Rotoiti-Rotoehu: The northern caldera margin is well expressed on the north shore of Lake Rotoiti where massive rhyolite lavas of Matawhaura dome and its flows to west are sharply cut off by strongly scalloped steep slump scarps which continue to at least $30 \mathrm{~m}$ below lake level*. Only a northward sloping remnant of the original large

* This structural interpretation has relied heavily on the bathymetric maps of O.V.C. lakes (Irwin 1966; 1967a, b; 1969a, b; 1970a, b; 1973; 1974, and in press). On these maps both the echosounding traverse lines and the bathymetric contours are shown. The density of traverses varies, so that bathymetric contours drawn between the traverse lines are not always well controlled. More detailed bathymetric surveys of some areas have resulted in modification of the depth contours. An example is the resurvey of Centre Basin in Lake Rotoiti by Calhaem (1973) who found maximum depth to be $120 \mathrm{~m}, \mathrm{c} .26 \mathrm{~m}$ deeper than that shown by Irwin (1969). However, in lieu of more detailed data, the structural interpretations presented here are based on the published depth contours, with greater confidence where traverse lines actually covered areas of critical interest. 
Matawhaura dome is present on the caldera rim. The caldera margin scarp extends eastward to Lake Rotoehu where a large northward embayment cuts off hal rhyolites of both Matawhaura, and the Waitangi rhyolite on the easterm shore. Lake Rotoehu is now shallow due to infilling by young sediments, and caldera structures are not apparent in the bathymetry. Following the caldera collapse, deep erosion of thick Rotoiti Breccia deposits occurred, forming a gullied terrain to north of the caldera margin and contributing much sediment onto the caldera floor. Later extmusion of the caldera-filling rhyolites blocked southward drainage from Rotoehu to create the extremely digitate drowned northern shoreline, and the lake has since largely infilled with young sediments contributed from the rhyolites to south. Less sedimentation has occurred in the northern part of the lake, partly due to the small surface catchment areas. The lack of deeper erosion in the northern catchments suggests that base level at the upthrown caldera rim was controlled by resistant rock, possibly ha1 rhyolite lava extending between outcrops at Matawhaura Bay and Waipuia Points, which prevented deep incision into the steep caldera scarp. Intracaldera rhyolites (c. 9000 yrs B.P.) to south of Lake Rotoehu are displaced by arcuate faults, apparently due to local collapse. The main collapse fault appears to be a southward continuation of the large caldera-bounding fault of the Rotoehu embayment (Map 2), forming a sub-circular shape suggestive of increased collapse perhaps above a local magma cupola. The collapse faults do not displace the c. 7500 yr B.P. lava flows to south, indicating that the most recent displacements occurred between 9000 and 7500 yrs B.P.

Bathymetry of Lake Rotoiti suggests that the caldera margin extends west from the Puketapu Point ha1 rhyolite across a $65 \mathrm{~m}-$ deep erosional valley before curving back to the east in Mamaku Ignimbrite on the southern shore of Lake Rotoiti, so that an embayment was formed into the pre-existing Tikitere Graben. Headward erosion from this embayment following the Rotoiti Breccia eruptions captured northward drainage from the $505 \mathrm{~km}^{2}$ Rotorua basin, so that a large river flowed down the western 
section of Lake Rotoiti, and into the Haroharo Caldera (see Part II.B).

Depressions in the Centre Basin area reach $120 \mathrm{~m}$ below lake level (190 m a.s.l.) and appear to be young craters formed close to the caldera margin. Locations of these craters and associated areas of high heat flow (Calhaem 1973) are consistent with a possible location on a caldera ring fault, within the topographic caldera rim.

2) Eastern sector - Lakes Rotoiti-Okataina-Tarawera: Apart from a short section immediately south of Lake Rotoiti (Map 2) the caldera margin between Lakes Rotoiti and Okataina is buried beneath late Pleistocene rhyolite lavas and Holocene sediments. Mamaku Ignimbrite defines the caldera rim on the south shore of Lake Rotoiti but is overlain to south by 19,000 yr B.P. Haroharo lavas which overtopped the caldera rim in the Lake Rotoatua area (Map 2) and flowed back into the caldera to form the south shore of Lake Rotoiti in the Gisborne Point area. The ignimbrite surface is buried under volcanic sediments further south, but was drilled between Lakes Rotoiti and Okataina in a series of investigation bores (Map 1) for the Kaituna hydro scheme. Well logs (Ministry of Works 1965) show that the upper surface of the ignimbrite dips steadily to the south, without any major displacement which could be correlated with either the Haroharo Caldera-bounding fault or the older Whakapoungakau Fault. The caldera rim must therefore lie to the east of these boreholes, buried under the Haroharo rhyolites. The young (c. $4000 \mathrm{yr}$ B.P.) east-west aligned Rotokawau-Rotoatua basaltic explosion craters thus also lie totally outside Haroharo Caldera.

The caldera margin is again clearly defined at Lake Okataina, where a strongly-scalloped scarp is developed in Mamaku Ignimbrite overlying soft pumiceous pyroclastics of the Pokopoko Breccia. Less slumping occurred of the underlying Whakapoungakau ha1 rhyolites. Deep, narrow, valleys with steep walls were eroded headwards into the ignimbrite/breccia sequence behind the major scallops, even though these have small surface catchments (Fig.7) 
FIG. 7 - (Over page). Stereo aerial photos of the Haroharo Caldera margin forming the deeply eroded, scalloped western shore of Lake Okataina. Haroharo lavas form eastern shore. Note the small catchments above the major valleys eroded into Mamaku Ignimbrite of the caldera rim. Te Horoa rhyolite extrusion forms the southern shore of Lake Okataina. Photos SN3837: L3,4,5, reproduced by permission of the Department of Lands and Survey, New Zealand. 

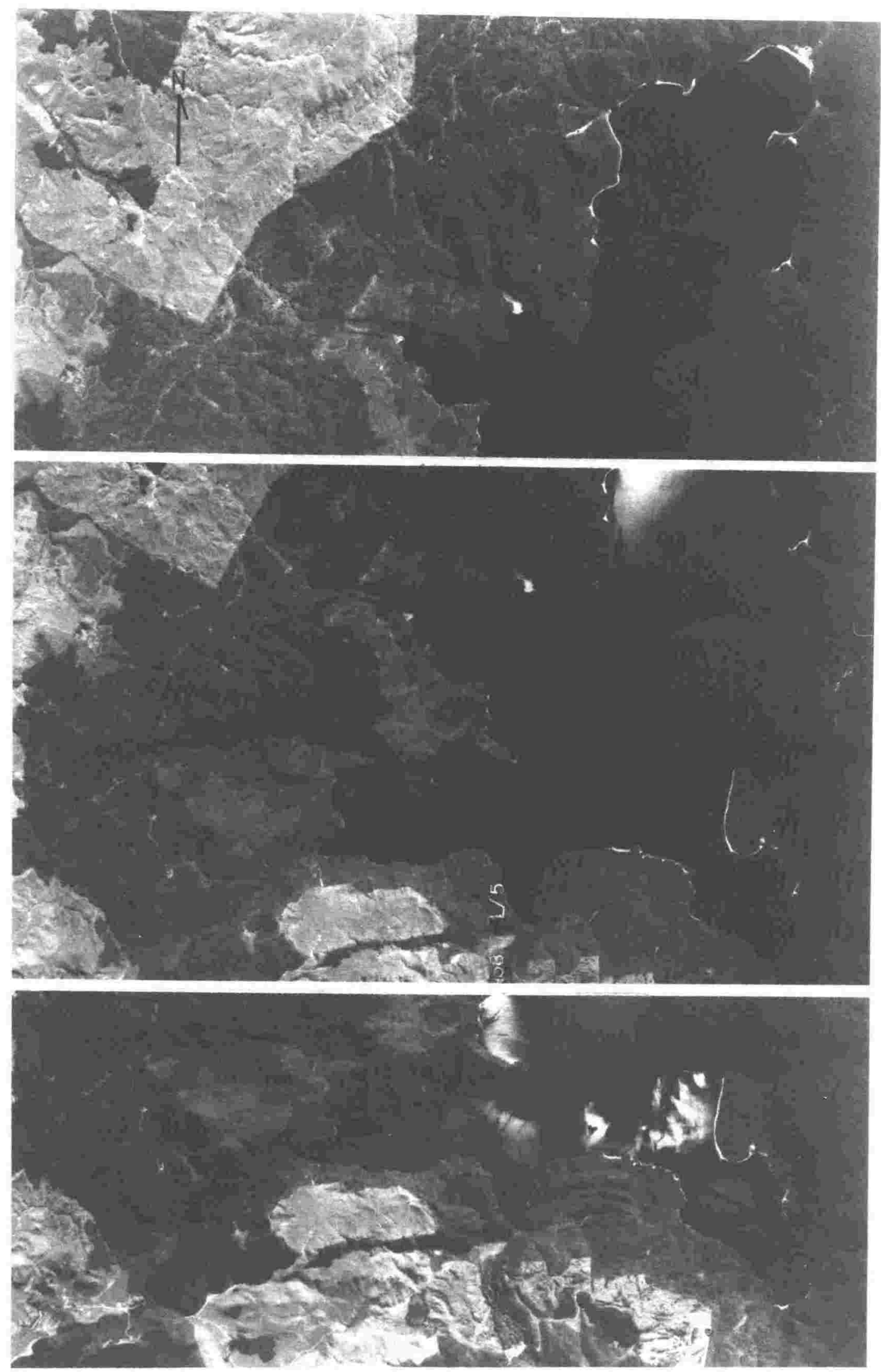
extending only a few kilometres from the caldera margin. The depth of erosion evidenced by topographic and bathymetric contours suggests that the caldera floor was very deep in this area, producing very steep stream gradients between caldera rim and floor. Present bathymetry defines a near-flat lake floor at $75 \mathrm{~m}$ below 1965 lake level (floor at $236 \mathrm{~m} \mathrm{a.s.1.),} \mathrm{showing}$ that the Mamaku Ignimbrite surface was downthrown at least $280 \mathrm{~m}$ into the caldera (and probably very much more).

To south of Lake Okataina the caldera margin continues as an arcuate scarp, separating a strongly step-faulted Mamaku Ignimbrite surface to west, from the Holocene (c. 7500 yr B.P.) pyroclastics and lavas of Te Horoa rhyolite dome, between Lakes Okataina and Tarawera.

South of Te Horoa Dome, the caldera margin becomes complex and much less clearly defined, with structure complicated by both intersecting north-east trending regional faulting, and the Okareka Embayment to west, together with burial under young lava flows from the Okareka eruptive centre. Between Lakes Okataina and Okareka, subsidence has occurred on several subparallel faults which downthrow the Mamaku Ignimbrite and underlying ha1 rhyolite towards Lake Tarawera. These faults have a regional, north-east trend. The largest fault extends to the south-east corner of Lake Okareka, but displaces the upper surface of the Mamaku Ignimbrite by less than $100 \mathrm{~m}$, in contrast to the $>280 \mathrm{~m}$ displacement on the caldera-bounding fault at Lake Okataina. The downfaulted ignimbrite surface on the western shore of Lake Tarawera is covered by late Pleistocene rhyolite lavas and pyroclastics from the Okareka eruptive centre. Bathymetry of the western Lake Tarawera floor (Map 2) suggests that somewhat older lavas also extend into the lake from this source. These lavas and/or the underlying ignimbrite surface, form a gently sloping, irregular shelf extending c. $1 \mathrm{~km}$ from the western lake shore, before a steeper slope falls to the $80 \mathrm{~m}$ deep Central Basin of Lake Tarawera (at $210 \mathrm{~m}$ a.s.l.), possibly reflecting the deeply sediment-infilled floor of Haroharo Caldera. The caldera margin structure in the western Lake Tarawera area is 
thus interpreted to comprise at least two step-faulted subcircular scarps, one roughly in position of the present lake shore between Te Miro and Te Toroa where it is partly buried beneath younger lavas, and another offshore with position roughly defined by the relatively steep gradient onto the floor of Central Basin (Maps 1 \& 2). More detailed bathymetry would help in definition of the submerged structures. Drowned valleys extending from Central Basin towards Waitangi and Karikaria (Map 1) represent deeply eroded channels which carried drainage from the large Okareka $\left(20 \mathrm{~km}^{2}\right.$ ) and Rotokakahi $\left(25 \mathrm{~km}^{2}\right)$ catchments, during a period of low lake level following the caldera collapse.

A similar structural relationship appears to hold for southwest Lake Tarawera where the arcuate shore line of eroded ha2 rhyolite cliffs may be controlled by a concentric caldera fault scarp, with the main caldera-boundary again roughly defined by the $80 \mathrm{~m}$ bathymetric contour, apparently terminating the northeastward extension of drowned ha2 rhyolite lavas (Map 2). A deeply eroded drowned valley extending back from this caldera rim lies to north of Te Poroku, with its location apparently controlled by north-east extension of the regional fault mapped on land.

The apparent caldera boundary again becomes well defined off the eastern shore of Moura Block, where the Block and the regional fault mapped on land to south-west are sharply cut off in the lake by a north-south trending scarp which drops steeply toward the $80 \mathrm{~m}$ depth contour (Map 2). This scarp extends southward towards a large arcuate scallop forming the southern extremity of Lake Tarawera, from which a drowned valley extends back towards the large Wairua Stream catchment $\left(20 \mathrm{~km}^{2}\right)$, again marking the site of deep erosion following caldera collapse.

3) Southern sector - Lake Rotomahana-Lake Rerewhakaaitu: The location of complex boundaries to Haroharo Caldera becomes more uncertain in the western Rotomahana area, where bathymetry and landforms were strongly modified by the 1886 eruption (see Part 
II.A). The structural interpretation shown in Map 2 is based on surface geology which suggests that Lake Rotomahana may occupy a deep embayment between pre-caldera rocks to north and south. North-east trending faults cut Patiti (Banded) Island and form the lake shore to east of the island, where a slightly scalloped scarp to a south-east tilted block suggests formation by calderal collapse, perhaps accompanying the Kaingaroa Ignimbrite eruptions. A roughly concentric, arcuate scarp to south of Rotomahana marks block subsidence towards the inferred caldera rim, and extends from Hapeotoroa Dome towards the large regional Rotomahana Fault marking the south-eastern boundary of the Taupo Fault Belt. The Rotomahana Fault meroes eastwand into a scalloned scam formed 
Tarawera River, where a generally north-south trending, stronglyscalloped single scarp marks collapse of the Maungawhakamana and Rere ha1 rhyolite massifs. The caldera margin in this sector is a direct continuation of that forming the eastern shore of Lake Rotoehu. The margin is also marked by the vent for a 4800 yrs B.P. rhyolite pyroclastic and lava dome eruption. The Tarawera River flows out of the caldera through the Te Haehaenga basin, lying just inside the eastern caldera rim. At $130 \mathrm{~m} \mathrm{a.s.1.} \mathrm{this} \mathrm{basin} \mathrm{is} \mathrm{at} \mathrm{lower} \mathrm{elevation} \mathrm{than} \mathrm{any} \mathrm{other}$ surface within the caldera, including the deep basins in Lakes Rotoiti and Tarawera.

Haroharo inner ring fault and dike

Much of the Haroharo Caldera topographic margin is interpreted (following Smith and Bailey 1968, Lipman 1976, Christiansen et al 1977), as a series of coalescing slump scars marking the limit of erosional damage to an oversteepened ring fault scarp following catastrophic collapses of the caldera floor. Position of the true caldera-bounding fault(s) at depth will lie inside the present topographic scarp, and may not be expressed at the surface. In Valles-type calderas (Williams and McBirney 1979) position of the internal ring fault may be marked by a sub-circular alignment of vents for post-caldera rhyolites, extruded from dikes which rose up the ring fracture zone (Smith and Bailey 1968). Some evidence exists for a possible ring dike in Haroharo Caldera. The outermost vents of the Tarawera Volcanic Complex lie on a sub-circular arc located a few kilometres inside the inferred caldera margin (Map 2). This arc may define a "ring dike" which merges with the steep caldera scarp in the Moura area and then passes north across Lake Tarawera onto the Haroharo Volcanic Complex, where eruptive vents again form a sub-circular arc (Map 2). However, most of the numerous vents of the Haroharo and Tarawera complexes lie within this possible ring dike. The dominant controls on vent locations, including those vents outside the ring dike at Okareka, Tikorangi, Rotoma, and Rotomahana, appear to have been north-east trending lineations which extend beyond the Haroharo Caldera margins. 
Rotoma Caldera(?)

Lake Rotoma occupies a $5 \mathrm{~km}$ diameter basin of subsidence which coalesces with the north-east corner of Haroharo Caldera (Map 2). The lake has no natural surface overflow, although an artificial high-level overflow has recently been constructed. The basin is formed in ha1 rhyolites, overlain by Matahina Ignimbrite (c. 200,000 yrs B.P.) and Rotoiti Breccia. Basin formation is considered to postdate the Matahina Ignimbrite, which would otherwise have filled an earlier depression. Kaingaroa Ignimbrites (c. 150,000 yrs B.P.) overlie Matahina Ignimbrite $8 \mathrm{~km}$ to north of Lake Rotoma but do not outcrop in the Rotoma basin suggesting that the subsidence also postdates eruption of the Kaingaroa Ignimbrites.

The northern margins of Rotoma basin are fault controlled, with most recent ( $<9000 \mathrm{yr}$ B.P.) movement on the North Rotoma Fault (Map 2), displacing ha1 rhyolite, Matahina Ignimbrite, Rotoiti Breccia, and Mangaone Sub-group pyroclastics. The south margin of the basin appears controlled by an arcuate ring fault, cutting ha1 rhyolite and overlying Matahina Ignimbrite (Maps 1 \& 2). Development of slight scalloping suggests that rim slumping has occurred. The eastern basin margin is less well defined, with older structures in ha1 rhyolite obscured by overlying Rotoiti Breccia. A poorly developed sub-circular drainage pattern to east of Lake Rotoma is roughly concentric with the inferred basin margin, and possibly suggests terraced slumping towards the centre of the basin.

General bathymetry of the Rotoma basin is dominated by the north-south trending North and South Basins (Map 2), which undoubtedly formed part of a continuous larger basin now infilled to west by the Rotoma lava flow and associated pyroclastics. Floor of this basin at $235 \mathrm{~m}$ a.s.1. provides a minimum (100 $\mathrm{m+}$ ) depth for basin subsidence below Matahina Ignimbrite outcropping on the south lake shore. Gently sloping sediment(?) fans extend into the lake from the southern and eastern shores, where considerable erosion of Rotoiti Breccia and underlying rhyolites 
occurred in adjacent catchments, which are the largest surrounding the lake.

The most recent major event in Rotoma basin was the plinian eruption of a large part of the Rotoma Ash at c. 9000 yrs B.P. from Matutu Basin crater in the north-west arm of the present lake. This pyroclastic eruption accompanied and followed extrusion of the coeval Rotoma lava flow which blocked westward drainage from the basin and formed the present Lake Rotoma. Another explosion vent may occupy the north-eastern arm of the lake, where bathymetric contours suggest the existence of a crater (Map 2). However no ejecta from a source in this area have yet been identified.

The existence of other young rhyolite extrusions within the Rotoma basin is indicated by bathymetry. Otangiwai Bank rises $60 \mathrm{~m}$ above South Basin floor and has a geomorphic form suggesting a small steep-sided rhyolite extrusion. A smaller dome to north-north-east of Otangiwai Bank rises $30 \mathrm{~m}$ above the South Basin floor, and probably has a similar origin. The flat top to Otangiwai Bank at $10 \mathrm{~m}$ below 1965 lake level may have been cut at a time of slightly lower lake level. The bank was reportedly emergent and supported a Maori village until about 200 yr B.P. (Stafford pers. comm., quoted by Healy 1975b).

Origin of Rotoma basin is not clearly understood. Grange (1937) considered Rotoma to occupy double or composite explosion craters (see also Healy 1975a). This explanation is clearly valid for the Rotoma Ash vent in Matutu Basin, but is unlikely to apply to the older, much larger ( $5 \mathrm{~km}$ across) and deeper main basin floor, particularly as near-source ejecta from pre-9000 yr B.P. eruptions has not been identified at Rotoma. Lack of local ejecta is more consistent with a basin origin by subsidence. Subsidence may have occurred during or following both the Rotoiti Breccia and Mangaone Sub-group eruptions. Lack of proximalfacies ejecta in lake shore exposures of both these deposits suggests that no major eruptions occurred from the Rotoma basin. Collapse may have been due to withdrawal of underlying magma migrating towards Haroharo Caldera vents during the voluminous 
Rotoiti and Mangaone eruptions. That magma has since underlain the Rotoma basin is demonstrated by the Holocene eruption of Rotoma Ash, the Rotoma lava flow, and the probable young dome extrusions within the lake. The known and inferred vent positions delineate a roughly triangular area which includes most of the main basin, and could indicate location of ring faults within the caldera(?), on which most collapse has occurred (Map 2).

Little geophysical data is available for assessment of Rotoma structures. The basin falls in an area of steadily northward increasing gravity values (Woodward and Ferry 1973). However, all gravity measurements in the Rotoma area were made on the margins of the proposed structure, and none were made within the area of apparent major subsidence (see Fig. 3).

Puhipuhi Basin

An $8 \mathrm{~km}$ diameter basin adjoins the eastern margin of Haroharo Caldera, located between the northern toe of the eastern lavas from Tarawera Volcanic Complex, and the Maungawhakamana ha1 rhyolite massif to north of the Tarawera River (Maps 1 \& 2). The basin is rimmed by Rangitaiki Ignimbrites to south, Matahina Ignimbrite to east and north-east, and ha1 rhyolite to north. The western margin is open into Haroharo Caldera. Matahina and Rangitaiki Ignimbrites do not outcrop within the basin which has little topographic expression as it has since been infilled with younger deposits of the Kaingaroa Ignimbrites and the pyroclastics, lacustrine sediments, and intruding dacite lavas forming the Puhipuhi massif (Map 2). Exposure within the basin is generally restricted to isolated outcrops, and contacts are not exposed so that stratigraphic relationships are imperfectly known. The basin is thought to have a complex stmuctural rather than an erosional origin, but its history is not clearly understood.

Matahina Ignimbrite is about $80 \mathrm{~m}$ thick on the eastern basin rim where it overlies Onuku Breccia pyroclastics and Rangitaiki Ignimbrites. The lower, dark grey, vitric kg1 member 
of the Kaingaroa Ignimbrites occupies the centre of the basin, with an unwelded pink-grey vitric tuff (kg2?) outcropping in eastern and northern sections. The western basin is occupied by the Puhipuhi massif. Small remnants of Rotoiti Breccia occupy valleys eroded into both the Kaingaroa Ignimbrites and the Puhipuhi massif.

The eastern margin of the basin comprises a scalloped steep scarp in Matahina Ignimbrite. Steep-walled, wide valleys with sediment-infilled gently sloping lower floors, have been eroded headwards into the north-eastern basin rim. Many of these valleys have relatively small catchment areas which extend back less than 1-2 $\mathrm{km}$ from the basin rim. This erosion pattern is similar to that on the western shore of Lake Okataina, and suggests that floor of the north-eastern Puhipuhi Basin may have been much lower than present at time of the valley erosion, to produce the required steep stream gradients.

The Puhipuhi Basin discharges from its north-east corner where a $0.5 \mathrm{~km}$ wide canyon has been cut by the Tarawera River through Matahina Ignimbrite (Map 1). The canyon is floored with alluvium and depth to underlying bed rock is unknown. However, a tributary valley (occupied by Pokohu Road) which extends back more than $2 \mathrm{~km}$ from the river valley to the Puhipuhi Basin rim has a narrow $v$-shaped cross section almost to its mouth, suggesting that here the Tarawera River valley has not been greatly deeper than at present. This tributary valley cross section is in contrast to the adjacent valleys draining into the Puhipuhi Basin which have been more strongly eroded, although having much smaller catchments.

This contrast suggests that erosional base level was lower in the north-eastern Puhipuhi Basin than in its outflow channel, a situation that could only be produced by subsidence of the basin floor.

The north-western basin rim forms a sub-circular arc in ha1 rhyolite of the Whakapoungakau massif, with south-east slopes which appear to have been oversteepened by faulting and block 
slumping into the Puhipuhi Basin. Lacustrine sediments and pyroclastic breccias lap onto the rhyolite flanks, and outcrop up to an elevation of about $300 \mathrm{~m} \mathrm{a.s.1.} \mathrm{The} \mathrm{lacustrine} \mathrm{beds}$ consist of finely laminated silts, unbedded sands, and rhyolite pebble and cobble beds, commonly regularly bedded with plane parallel contacts, and with dips which vary from $0^{\circ}$ to $21^{\circ}$. These beds appear to have been deposited by streams flowing off the steep rhyolite slopes into a temporary lake. With present day topography there is no way to retain a lake in Puhipuhi Basin at more than about $150 \mathrm{~m} \mathrm{a.s.1.} \mathrm{-} \mathrm{the} \mathrm{elevation}$ of the Matahina Ignimbrite surface at the lowest (north-east) basin rim in the Tarawera River outlet area.

East of the Maungawhakamana rhyolite, the Puhipuhi Basin is rimmed by Matahina Ignimbrite (Map 1) without overlying high level lacustrine beds.

The southern basin rim is developed in Matahina Ignimbrite overlying Rangitaiki Ignimbrites to the east, and largely in Rangitaiki Ignimbrites overlain by lake sediments to the west. Streams draining the Rangitaiki Ignimbrites to south of the basin have large catchments, but have $v$-shaped cross sections where they debouch onto the sediment-infilled floor of the basin, suggesting that no deep collapse of the basin floor has occurred in this region.

Much of the eastern Puhipuhi Basin is occupied by the Kaingaroa Ignimbrites which form a moderately dissected plateau remnant between the Mangawhio and Waiwhakapa tributaries to the Tarawera River. The upper surface of this ignimbrite plateau at c. $200 \mathrm{~m} \mathrm{a.s.1.} \mathrm{is} \mathrm{rather} \mathrm{higher} \mathrm{than} \mathrm{the} 150 \mathrm{~m} \mathrm{a.s.l.}$ Matahina Ignimbrite surface forming the north-eastern basin rim, suggesting that the Kaingaroa Ignimbrites filled the basin to above rim level. Steep-walled valleys cut into the plateau occupy most of their small catchments, and have sedimentinfilled planar floors, again suggesting that erosional base level was lower than the present Basin floor. 
The south-western Puhipuhi Basin is largely infilled with lacustrine sediments and intruding dacite lavas of the Puhipuhi massif. Lacustrine sediments outcrop up to at least $230 \mathrm{~m}$ elevation, are deeply dissected, and thickly mantled by Rotoiti Breccia and Mangaone Sub-group pyroclastics. Although Kaingaroa Ignimbrites have not been found overlying the Puhipuhi Group, the sediments are inferred to predate the ignimbrites, based on relative degrees of dissection.

Origin of the Puhipuhi Basin is clearly complex. The lacustrine sediments at $300 \mathrm{~m}$ elevation on the flanks of Maungawhakamana, together with those of the Puhipuhi Group at $230 \mathrm{~m} \mathrm{a.s.l.} \mathrm{indicate} \mathrm{lake} \mathrm{levels} \mathrm{which} \mathrm{cannot} \mathrm{be} \mathrm{contained}$ within the present Puhipuhi Basin. An overflow level of c. $150 \mathrm{~m}$ a.s.l. is controlled by the Matahina Ignimbrite surface above the present Tarawera River outlet to the basin. Assuming that no major uplift of the Maungawhakamana or Puhipuhi massifs has occurred, the high indicated lake levels require a topographic high to east of Puhipuhi, perhaps consisting of the Rangitaiki Ignimbrites. Removal of such a high could only be reasonably accomplished by subsidence.

Puhipuhi massif and the Maungawhakamana-flank sediments might then occupy an embayment extending east from Haroharo Caldera, and possibly related to emption of either the Matahina Ignimbrite or the Rangitaiki Ignimbrites. Eastward enlargement of the basin would have followed, either due to erosion by the proto-Tarawera River draining the caldera, together with its major tributaries draining from the ignimbrite plateau to south, or to further collapse occurring within the Matahina Ignimbrite, perhaps following that eruption from a nearby source. Lakes occupied the enlarged basin before it was largely infilled by the Kaingaroa Ignimbrites, which were eroded and partially submerged in a lake prior to the Rotoiti Breccia emptions.

Okareka Embayment

Lakes Okareka, Tikitapu, and the north-eastern part of Rotokakahi occupy a basin formed in ha1 and ha2 rhyolites, 
Mamaku Ignimbrite, and underlying Pokopoko Breccia. The individual lakes have been dammed against the margins of this basin by extrusion of $<20,000 \mathrm{yr}$ B.P. ha3 Okareka rhyolites (Maps 1 \& 2). The north-east basin margin is strongly downfaulted along the shore of Lake Okareka where ha1 rhyolite is displaced more than $240 \mathrm{~m}$. This north-west-trending fault is normal to the regional trend, and also displaces Mamaku Ignimbrite with less throw $(\mathrm{c} .100 \mathrm{~m}$ ) before branching to the west. Other boundaries to the basin are less certain. The ha2 Moerangi Rhyolite domes have over-steepened slopes to west of Lake Tikitapu, suggesting slumping of these lavas. Collapse also appears to have occurred on the northern face of the ha2 dome to south of Lake Rotokakahi, suggesting a possible basin margin in that area (Maps 1 \& 2). The southern margin of the basin is mapped against the ha2 Tutaeheka Rhyolites to south.

Bathymetry of Lake Okareka provides little information on the basin structure, the lake having a large area of near-flat floor at $320 \mathrm{~m}$ a.s.l., with gently sloping sediment fans developed from the ha3 Okareka rhyolites on the south shore, and from the dissected northern and north-western catchments. The lake basin drained east towards Tarawera, before the outlet was blocked by the 19,000 yr B.P. Okareka lava flows (see Part II)

Lake Tikitapu also has a near-flat floor, at $393 \mathrm{~m} \mathrm{a.s.1.,}$ although considerable infilling by Rotorua Ash pyroclastics associated with the Okareka rhyolites will have occurred.

Lake Rotokakahi occupies a depression between the ha2 rhyolite complexes of Moerangi and Tutaeheka, with outlet to south blocked by the younger Earthquake Flat Breccia, and to north by the ha3 Okareka rhyolites. This lake is also largely flat floored at c. $365 \mathrm{~m}$ a.s.l., deepest at the closed southwest corner, indicating infilling of the north-east outlet end by pyroclastics, which presumably bury any structures beneath the lake floor.

The geological history and structure of the Okareka basin suggest that it may comprise a subsidiary embayment of Haroharo 
Caldera in which the pre-caldera surface has been downfaulted at some time after deposition of the Mamaku Ignimbrite. Subsidence of the basin may have been caused by withdrawal of magma associated with the Rotoiti Breccia emptions, and appears to have been partly controlled by pre-existing regional faults, particularly the north-west trending cross fault forming the north-east shore of Lake Okareka. The well-defined north-west alignment of vents for the Okareka rhyolites (Map 2) parallels this cross fault, indicating location of a dike at depth. Magma has clearly been present beneath the embayment during the last 20,000 years, as evidenced by eruption of the Okareka rhyolites and Rotorua Ash pyroclastics at c. 19,000 and 13,800 yrs B.P. Detailed gravity measurements are required in the Okareka embayment to provide a check on the postulated structure inferred from the surface geology.

West Rerewhakaaitu Fissures

Two alignments of coalescing and individual explosion craters occur to west of Lake Rerewhakaitu, extending southwest from the Haroharo Caldera margin (Maps 1 \& 2 , and Fig. 8). The eastern and western lineations strike at $042^{\circ}$ and $048^{\circ}$ and extend over $2.5 \mathrm{~km}$ and $4 \mathrm{~km}$ respectively. They are located about $0.9 \mathrm{~km}$ apart in an en-echelon pattern. Awaatua Basin in Lake Rerewhakaaitu occupies the largest ( $600 \times 180 \times 30 \mathrm{~m}$ ) individual crater in the eastern lineation, but the longest $(1500 \mathrm{~m})$ continuous fissure of coalescing craters occurs near the middle of the western lineation (Fig. 8). All the craters are formed in welded Rangitaiki Ignimbrites overlain by eroded Onuku Breccia. The craters are up to $60 \mathrm{~m}$ deep, have steep walls, and flat, sediment-infilled floors. Only low (c. $10 \mathrm{~m}$ ) crater rims are preserved, suggesting wide dispersal of ejecta (or a partial origin by subsidence?). The crater lineations cut obliquely across the earlier formed north-north-east trending drainage pattern incised into the ignimbrite surface, and craters are located independently of topography, both in pre-existing valleys and on ridge tops. The craters are little-eroded and all appear of recent origin and contemporaneous age. 
FIG. 8 - (Over page). Map of West Rerewhakaaitu fissures showing en echelon alignments of explosion craters $(x)$ and outlines of major craters. Steep scarp to north is Haroharo Caldera rim. Contours are at $50 \mathrm{ft}(15.25 \mathrm{~m})$ intervals; Grid is the NZMS 1 Yard Grid and is not the metric grid as on Maps 1 and 2. "Tarawera Road" is now named Bretts Road. 


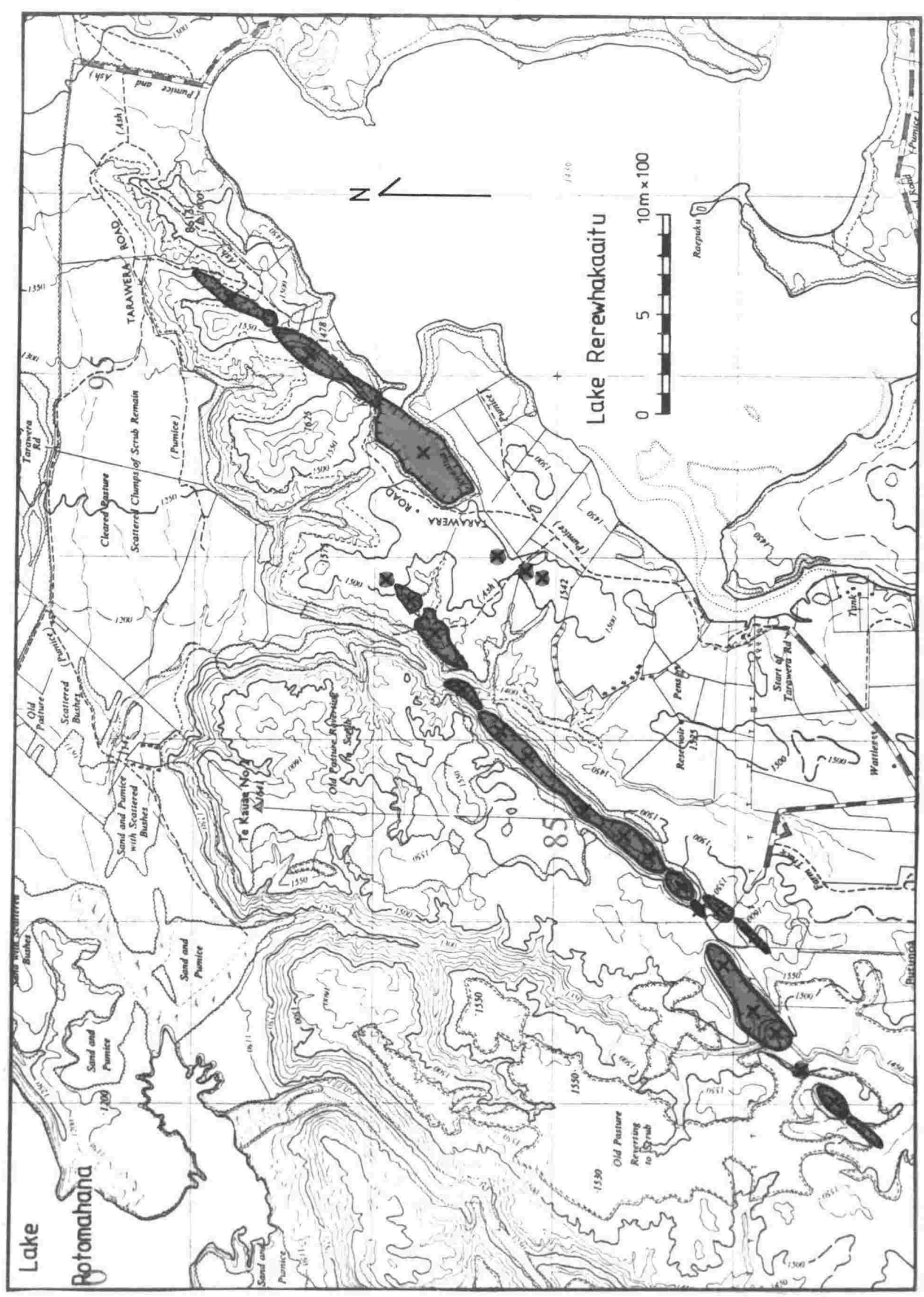


Ejecta from both lineations is poorly exposed, the eastern ejecta outcropping only in sections along Bretts Road north-east of Awaatua Basin (see also Cole 1970a - fig. 2). Angular blocks up to $3 \mathrm{~m}$ across of fresh Rangitaiki Ignimbrites are perched on crater walls in the western lineation, and a distal exposure of thin explosion breccia occurs $500 \mathrm{~m}$ south-east of the western lineation at N86/916833 [V16/124158]. Ejecta from both lineations is similar and very poorly sorted, with a lithic coarse fraction ( $>2 \mathrm{~mm}$ ) dominantly comprising angular blocks of Rangitaiki Ignimbrites with minor pumice, rhyolite, greywacke, and rare basalt/andesite lapilli, in a weathered vitric ash matrix. The fine fraction $(<2 \mathrm{~mm})$ includes pumice, rhyolite, ignimbrite, and greywacke, with abundant free crystals of quartz, plagioclase, biotite, hornblende, hypersthene, and magnetite. All clasts are relatively fresh and are not strongly hydrothermally altered. The explosion breccias from both lineations occupy identical stratigraphic positions, overlying a weakly developed paleosol on Waiohau Ash (c. 11,000 yrs B.P.), and with a weakly weathered upper contact beneath Rotoma Ash (c. 9000 yrs B.P.). An age of 10,000 yrs B.P. is assumed for the crater-forming explosions.

Origin of the explosion craters is not readily apparent. Although the crater lineations subparallel the bounding faults of the Taupo Fault Belt located $1.5 \mathrm{~km}$ to north-west, no surface fault displacements appear on the lineations. An origin by hydrothermal explosion appears excluded by the lack of alteration of ejected clasts and crystals, in contrast to the intenselyaltered ejecta in known hydrothermal explosion deposits (e.g. at Kawerau; see Part III.A). The nearest surface hydrothermal activity occurs at Lake Rotomahana $3 \mathrm{~km}$ to north-west of the western lineation, and no present-day activity (or indication of fossil hydrothermal activity) is present in the Rerewhakaitu craters. A volcanic origin is not supported by the general lack of ejecta which can be identified as magmatic, unless it is represented by the rare small basalt/andesite clasts. However, sub-rounded greywacke pebbles occur more abundantly in the explosion breccias, and are presumably derived from sedimentary 
beds beneath the Rangitaiki Ignimbrite. The basic clasts might also have come from sediments caught up in the craterforming explosions.

A preferred explanation suggests that the craters are of phreatic eruptive origin. If strike of the eastern lineation is extended $9 \mathrm{~km}$ south-west it passes close to outcrops of the Terrace Road Basalt in Waiotapu Forest (Nairn 1973). This late Pleistocene scoria deposit outcrops in dissected terrain, where it is interbedded between Onuku Breccia and Kaingaroa Ignimbrites. The Terrace Road Basalt and the West Rerewhakaaitu fissures may both be related to north-east trending subparallel basaltic dikes which erupted at Waiotapu in the late Pleistocene (c. 150,000 yr B.P.?) to form the Terrace Road Basalt. Further dike intrusions at Rerewhakaaitu followed the 11,000 yr B.P. Waiohau Eruptive Episode at Tarawera. These shallow intrusions did not reach the surface but encountered cold groundwater at or beneath base of the Rangitaiki Ignimbrites. The resulting phreatic explosions along the narrow dike lineations formed the existing craters but ejected very little (if any) basalt magma. A detailed magnetic survey might detect the presence of buried basalt dikes beneath the crater lineations, as has been found at Tarawera (Cole and Hunt 1968). However, the small size of the Rerewhakaaitu craters of. those on Tarawera, suggest.s that dike widths at Rerewhakaaitu could be very narrow (the 1886 Tarawera basalt dike has widths of order $0.5-2 \mathrm{~m}$ where presently exposed cutting solid rhyolite of the lava domes).

If the phreatic origin inferred for the Rerewhakaaitu fissures is correct, then together with the Terrace Road Basalt, they represent the most south-eastern eruptive activity in the Taupo Volcanic Zone between the O.V.C. and the Reporoa Basin, and thus, together with Edgecumbe volcano, they define position of the "volcanic front" (Sameshima 1975) in the O.V.C. area. However, the silica index $\left[\theta=\mathrm{SiO}_{2}(\right.$ wt $\%)-47\left(\mathrm{Na}_{2} \mathrm{O}+\mathrm{K}_{2} \mathrm{O}\right) /$ $\mathrm{Al}_{2} \mathrm{O}_{3}$ (mol. propns.)] calculated from the single analysis (Appendix 1) of Terrace Road Basalt is 39.2, similar to that of. the 1886. Tarawera Basalt, and rather less than the regional average of $41.4 \pm 0.3$ for the North Island volcanic front (Sameshima 1975). 
Rotokawau-Rotoatua Fissure

A series of six small explosion craters form an east-west lineation on the western margin of the O.V.C. (Maps 1 \& 2). Five craters, including Lake Rotoatua, form a coalescing chain adjacent to the Haroharo Volcanic Complex, but Lake Rotokawau occupies the largest crater ( $1 \mathrm{~km}$ across) separated by $2.5 \mathrm{~km}$ to the west. The craters mark source vents for the basaltic Rotokawau Ash, erupted c. 4000 yrs B.P. Cole (1972) considers that most of the $0.7 \mathrm{~km}^{3}$ basalt was erupted from Lake Rotoatua, but all craters are surrounded by thick and coarse proximal basaltic ejecta. The explosions were of phreatomagmatic and strombolian type with near-vent deposits containing abundant lithic rhyolite and ignimbrite clasts in surge and fall-bedded dense basalt lapilli and blocks.

Lake Rotokawau lies on the regional fault forming the eastern boundary of Tikitere Graben, but the other craters cannot be related to any apparent structural feature. The crater lineation is considered to mark location of an underlying basalt dike similar to those which erupted at Tarawera (see Part II.A) and postulated at Rerewhakaitu. The east-west orientation of this dike is unexplained.

Earth Deformation Data

Very little data is available on present day earth deformation within Okataina Volcanic Centre. Preliminary results from an experimental tilt detection network using three water level recorders on Lake Tarawera have shown no significant long term tilt across the lake during 1976-1978 (Scott 1978, 1979). Tilt levelling patterns installed to south of Mt. Tarawera and to west of Puhipuhi (Otway 1979, and pers. comm.) have also shown no significant tilt during the interval 1976-1980 (Otway pers. comm.).

Precise level surveys since the early 1950s have been extended in loops from a tide gauge at Moturiki Island (Mt. Maunganui), to south of Lake Taupo (Fig. 9).

Recent re- 


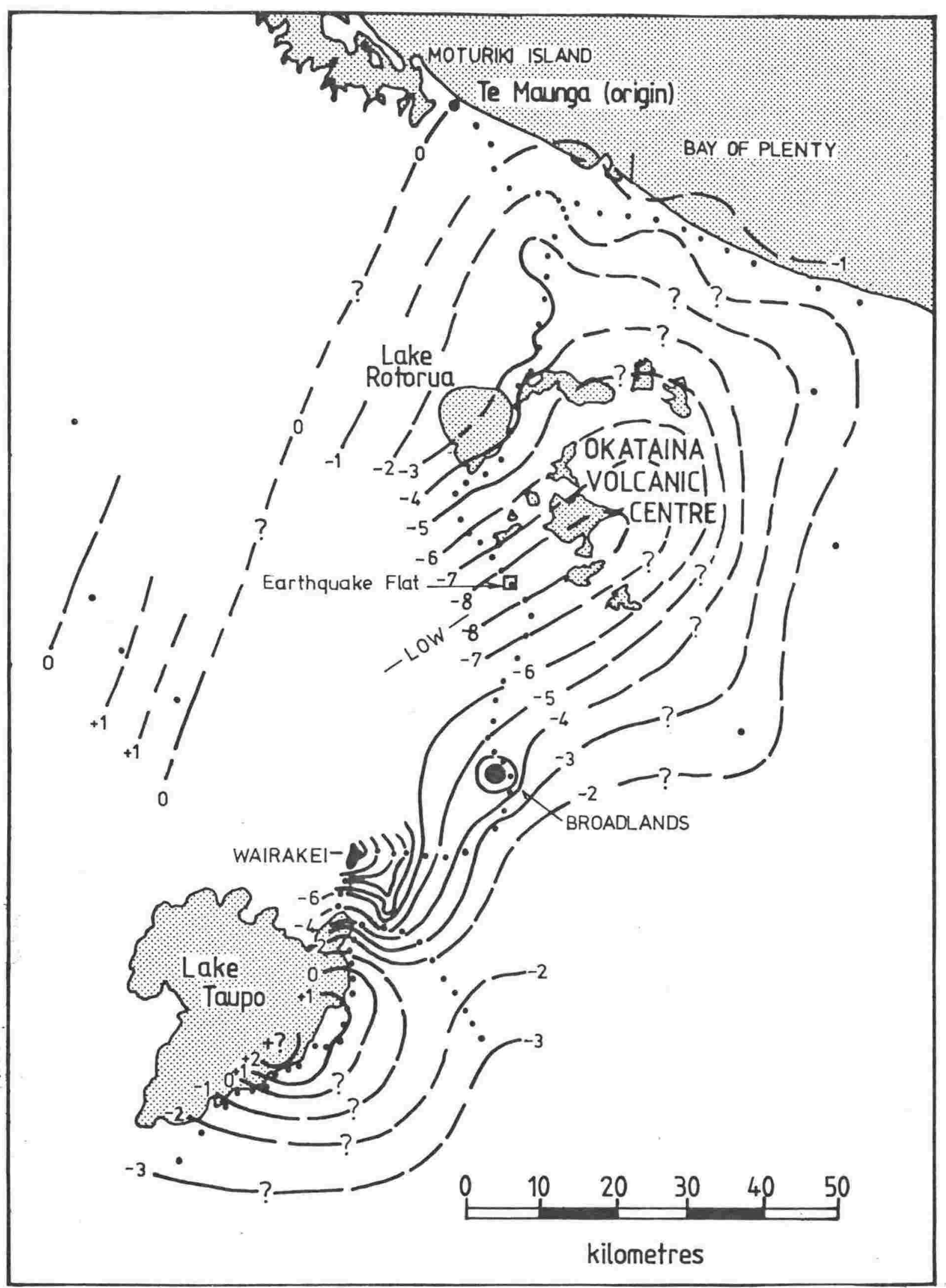

FIG. 9 - A provisional interpretation by P.M. Otway of rates of vertical deformation (in mm year-1) of the area between Bay of Plenty and Lake Taupo for period 1950 to 1977. Contours are speculative where dashed. Based on relevelling data from Locke (1978). Dots are benchmark sites Major subsidence occurs at Wairakei and Broadlands Geothermal Fields, and in the vicinity of Earthquake Flat. Compare with Map 2 for structures at Okataina Volcanic Centre. 
levelling of these loops has detected significant vertical ground movements (Locke 1978); unfortunately although the relevelled loops enclose the Okataina Volcanic Centre, they do not yet extend into it. The maximum measured tectonic (i.e. not due to withdrawal of geothermal fluids) subsidence rate of $-8 \mathrm{~mm}$ $\mathrm{yr}^{-1}$ occurs in the Earthquake Flat area, closely associated with position of the Paeroa Fault (Fig. 9). This axis of present day subsidence is displaced slightly south-east of the zone of maximum late Pleistocene subsidence, which is shown by the surface fault traces to be centred on the Ngakuru Graben.

The relevelling results demonstrate that non-seismic subsidence is still continuing in the T.V.Z., and as most faults within the zone are apparently of normal type, the subsidence indicates crustal extension across the Taupo Fault Belt. Sissons (1979) presents retriangulation data which indicates that the T.V.Z. at the Bay of Plenty coast is widening at $7 \pm$ $3 \mathrm{~mm} \mathrm{yr}^{-1}$, measured normal to the north-north-east trending faults. Extension rates may be higher in the much wider central T.V.Z., but complete retriangulation data is not yet available for this area. 


\section{C: INTRACALDERA VOLCANOES}

Haroharo Volcanic Complex

1) General morphology and history of the complex: Haroharo Volcanic Complex consists of overlapping rhyolite lava domes and flows with minor pyroclastic flow and fall deposits, forming a broad $14 \times 10 \mathrm{~km}$ low-angle pile which largely fills the northern half of Haroharo Caldera (Maps 1 \& 2, Figs. 10,11). The Haroharo pile rises $800 \mathrm{~m}$ above the lowest area of the caldera floor (represented by the sediment- and pyroclasticinfilled Te Haehaenga basin) to the summit of Makatiti Dome at $914 \mathrm{~m}$ a.s.1. A very large positive $(+725 \gamma$ ) residual total force magnetic anomaly (Malahoff 1968) associated with the Haroharo pile suggests that it extends to considerable depth. All the presently exposed lavas are younger than 20,000 yrs B.P., and postdate the voluminous pyroclastic eruptions of the Rotoiti Breccia Formation ( $\geqslant 42,000$ yrs B.P.) and the Mangaone Sub-group (36-26,000 yrs B.P.), which last caused caldera modification. Minor basalt is also represented, both as pyroclastics erupted from the site of Haroharo Complex (Matahi Basaltic Tephra - Pullar and Nairn 1972) and as younger intrusions - identified as source of basaltic accessory lithics in the pyroclastic surge deposits erupted from Pukerimu Cone during the 9000 yrs B.P. Rotoma Eruptive Episode.

The exposed lavas and pyroclastics demonstrate that the Haroharo pile was built up in at least four major eruptive episodes at c. 19,000, 9000, 7500, and 5500 yrs B.P. (Table 3). other older lavas are undoubtedly buried beneath the exposed extrusives. Eruptions occurred from multiple vents, nine of which still have surface expression (Fig. 12). All the known vents are younger than the 9000 yrs B.P., but the morphology and distribution of the exposed older lavas indicates that their sources are buried close to the younger vents.

2) Haroharo vent lineation: All the post-20,000 yr B.P. eruptive vents of the Haroharo Complex, plus those of the adjacent Okareka and Rotoma eruptive centres, lie within a $4 \mathrm{~km}$ wide $050^{\circ} \mathrm{N}$ trending zone (Map 2). This zone extends 


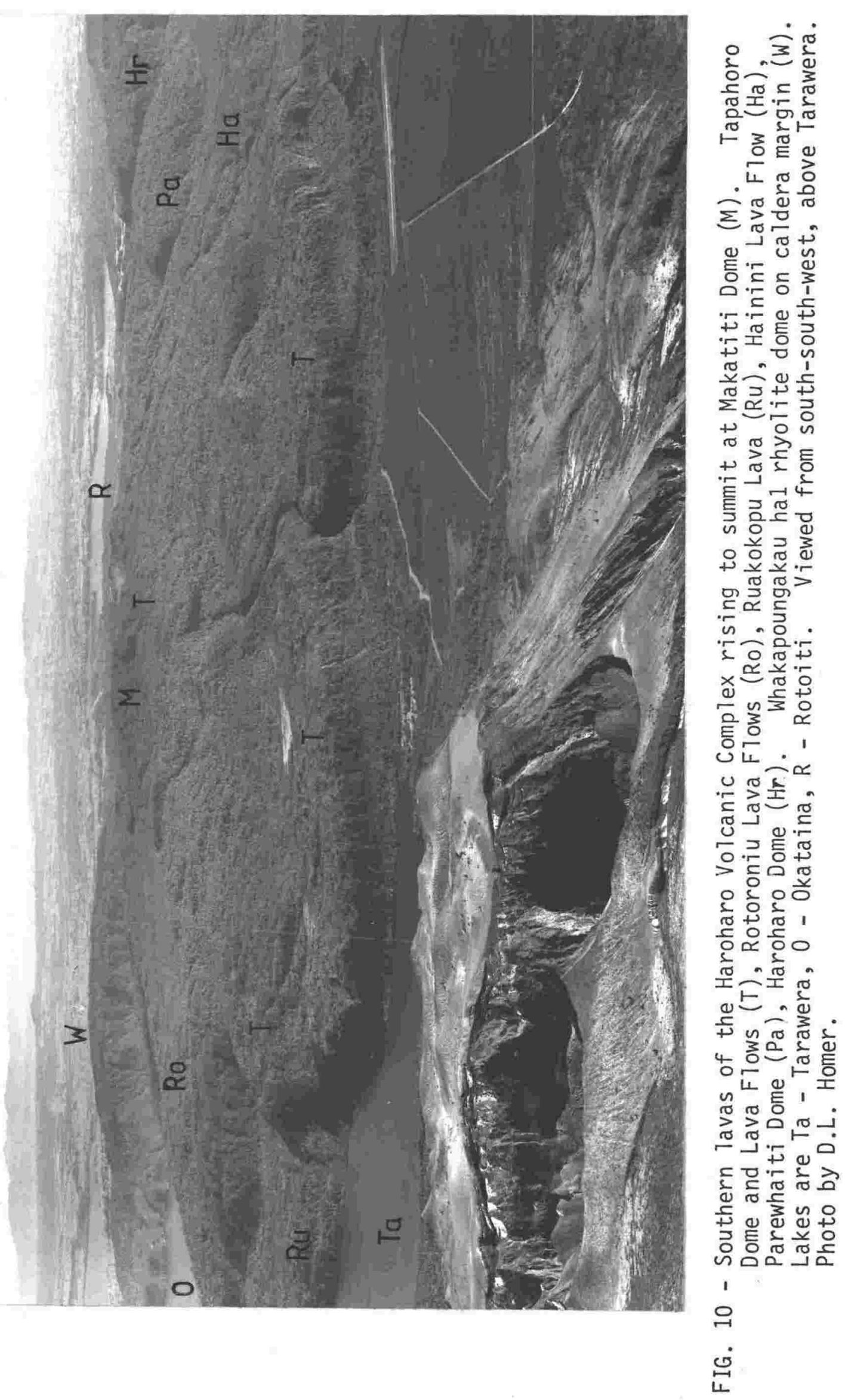




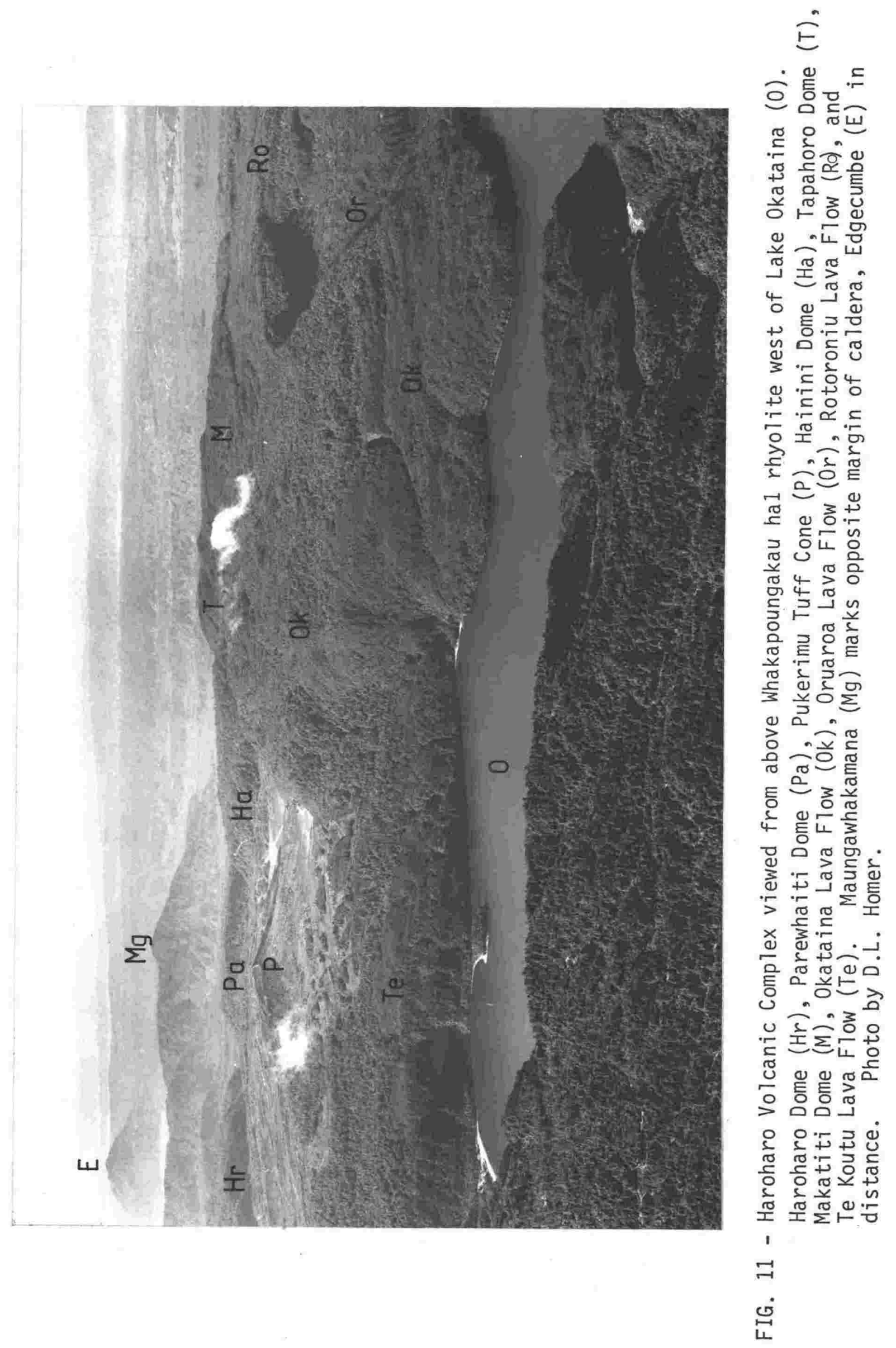




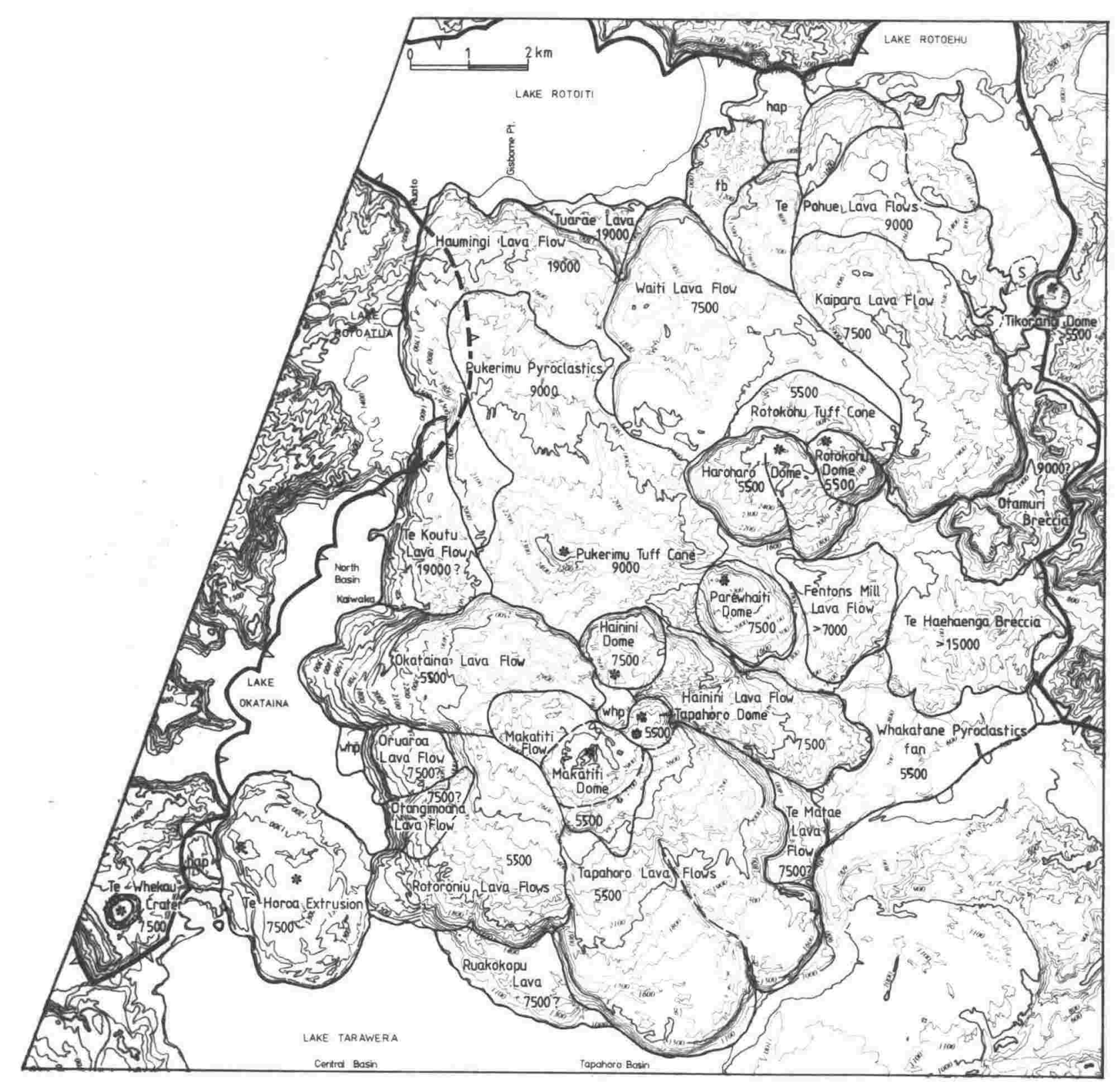

FIG. 12 - Map of Haroharo Volcanic Complex lavas and major pyroclastic deposits, with ages. Haroharo Caldera boundary shown by thick line; *-eruptive vent; hap - Haparangi Rhyolite Pumice; whp - Whakatane Pyroclastics; tb - Tapuaeharuru Breccia; contours at $100 \mathrm{ft}(30.5 \mathrm{~m})$ intervals. S marks areas of solfataric activity at Tikorangi. 
for $28 \mathrm{~km}$ between the Okareka Embayment and Rotoma Caldera(?), and represents a deep-seated basement fracture (Malahoff 1968). A similar broad vent lineation occurs at Tarawera (see p. 102). The basement fractures associated with these lineations form the two fundamental structures which have controlled location and activity of the O.V.C. The Haroharo vent lineation is a direct north-eastward continuation of the Ngakuru Graben delineating the axis of maximum subsidence of the "TaupoWhite Island Depression". North-east of Lake Rotoma this subsidence axis appears to terminate, although the much older Beeson's Island andesites at Otuhepo and Awakaponga (near Matata) may also fall on the alignment.

As suggested earlier, location of the outermost vents of the Haroharo complex at Te Horoa, Pukerimu, Haroharo, and Rotokohu may also be controlled by an underlying, sub-circular ring dike. However, influence of a linear fracture controlling Haroharo vent locations is clearly dominant because the lineation extends beyond the caldera margins to Rotoma and Okareka.

3) Descriptions and ages of Haroharo eruptives: The major exposed lavas and pyroclastic flows making up the Haroharo pile are described below, together with their established and inferred ages. Ages of the northern and eastern flows are well established from forestry road exposures through the overlying pyroclastic mantle, but little exposure is available on the heavily forested southern flows, so that some ages here can only be inferred from flow superposition, and by comparison of dissection with the well dated northern flows. A rather similar but less detailed map of Haroharo lavas is shown by Ewart (1968) but without any age control and with several differences in interpretation of the boundaries of individual flow units. Stratigraphy of the Haroharo lavas and interbedded pyroclastics is summarized in Table 4.

The relatively well exposed northern Haroharo extrusives are described first, followed by the poorly exposed, denselyforested southern lavas. 


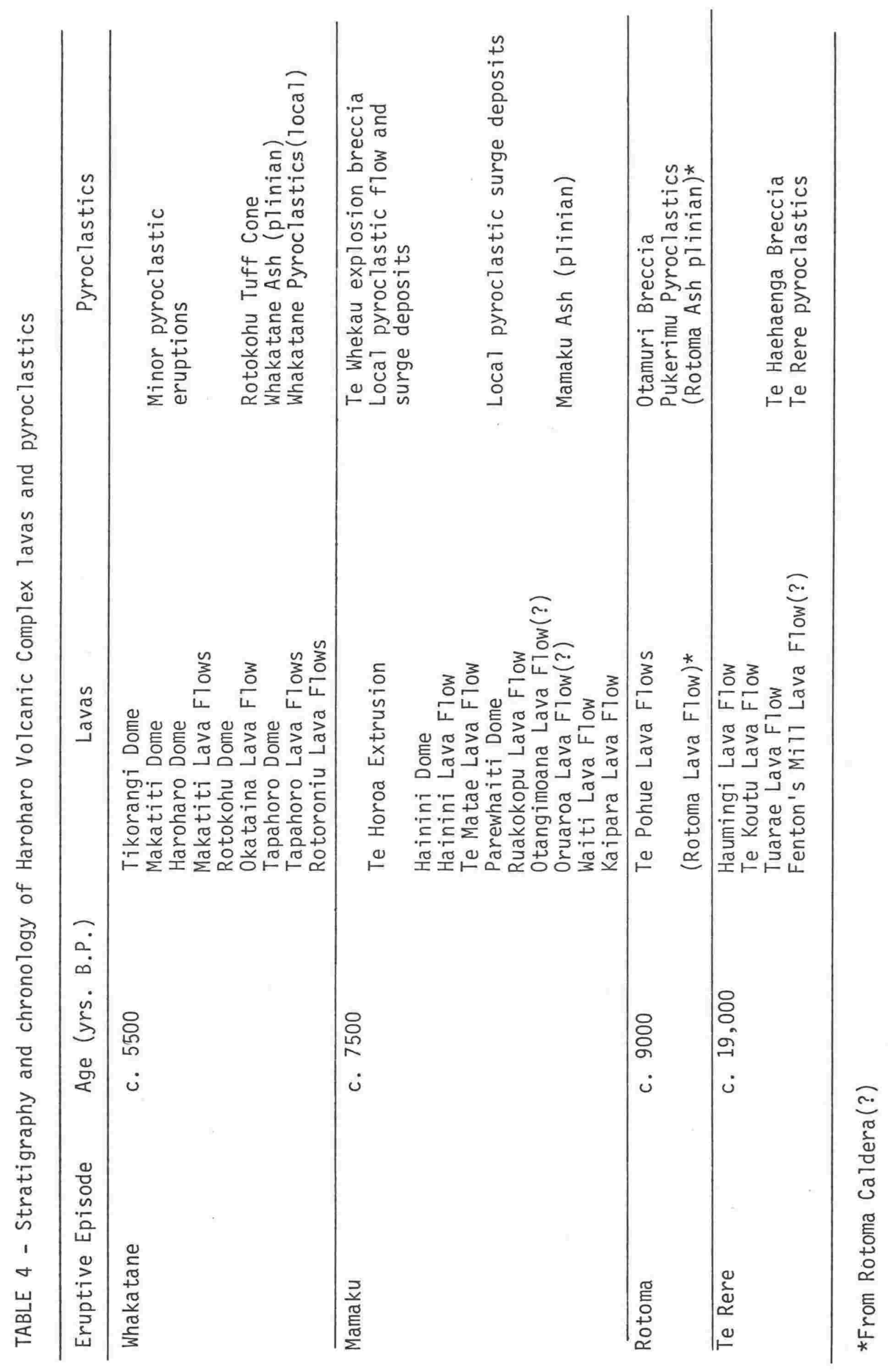


Te Koutu Lava Flow: The oldest exposed flow of the Haroharo pile, the Te Koutu lava forms the north-east shore of Lake Okataina, to north of Kaiwaka Bay (Fig.11). The steep flow front falls $310 \mathrm{~m}$ into the North Basin of Lake Okataina. Lake bathymetry provides no evidence of underlying older flows. Exposures through the tephra mantle on the Te Koutu flow are not available so that its age is uncertain, but it is overlain by the younger Haumingi Lava Flow (c. 19,000 yrs B.P.). Thedegree of dissection of the Te Koutu and Haumingi flows is similar, and they are assumed to form part of the same eruptive episode. The Te Koutu Flow is displaced by a small fault downthrown into the caldera. Because much of the flow is buried under younger eruptives location of its source is uncertain but the vent probably lies beneath the Pukerimu area (Fig.12).

The Te Koutu Lava Flow overrides the caldera rim to north of Lake Okataina.

Haumingi Lava Flow: This lava flow was erupted from a source vent apparently buried under the Pukerimu area of the Haroharo massif and extends $8 \mathrm{~km}$ north to Lake Rotoiti.

Bathymetric contours (Map 1) indicate the underwater continuation of underlying, possibly older, lava flows to north-west of Gisborne Point. The Haumingi Flow has steep margins $140 \mathrm{~m}$ high above Lake Rotoatua, and well developed transverse arcuate flow ribs on the surface, convex downstream and best developed on the northern extremity of the flow. Longitudinal ridges resembling narrow levees subparallel the eastern and western flow margins, but are largely obscured by mantling Pukerimu Pyroclastics. The Haumingi Flow laps over the Haroharo Caldera rim between Lake Okataina and Lake Rotoiti, but reenters the caldera by draping down over the buried caldera rim east of Ruato ( see Map 1). Lithologies exposed on the flow margins range from autobrecciated (glassy and lithic rhyolite blocks in a crushed glassy ash matrix), to massive lithic rhyolites.

The Haumingi Lava Flow is overlain by weakly weathered tephric loess immediately underlying Okareka Ash (c. 17,000 yrs 
B.P.) at sites on the flow front (N77/927132) [V15/142431] and on the upper surface of the flow (N77/908133) [V15/125432]. Te Rere Ash and Kawakawa Tephra (c. 20,000 yrs B.P.) are absent so that an age of c. 19,000 yrs B.P. is inferred for the Haumingi Lava Flow, as part of the Te Rere Eruptive Episode.

\section{Tuarae Lava Flow: The Haumingi Lava Flow overlies a} moderately eroded, brecciated obsidian flow exposed in sections along S.H. 30 to south of Lake Rotoiti. A paleosol on tephric loess overlying this brecciated flow is overlain by Okareka Ash, but Te Rere Ash and older tephras are absent. The Tuarae Flow appears to have immediately preceded the Haumingi Flow as part of the Te Rere Eruptive Episode at c. 19,000 yrs B.P.

\section{Pukerimu Breached Tuff Cone and Pyroclastic Deposits:}

Pukerimu (Fig.13) rises $150 \mathrm{~m}$ above the underlying Haumingi Lava Flow surface, as a steeply sloping (c. $20^{\circ}$ ) cone remnant with crater breached to north-east. Pyroclastic surge and flow deposits interbedded within fall deposits of the Rotoma Ash (Fig. 14) are apparently associated with the cone, and extend $4.5 \mathrm{~km}$ to north and at least $3 \mathrm{~km}$ east of the breached vent. The eastern margins of the Pukerimu deposits are buried under the younger Waiti and Haroharo lavas, and alluvium. The breached cone and its associated outflow deposits are strongly dissected, the dissection having largely occurred prior to the Mamaku Eruptive Episode when thick pyroclastics were deposited over the area, so that exposures of the cone-forming material are not available. (A $10 \mathrm{~m}$ deep auger hole bored on the flanks of the cone did not penetrate the cover of Mamaku pyroclastics). Distal exposures of the pyroclastic surge deposits are located on forestry roads to north and east of the cone. The near-flat lying surge deposits consist of strongly crossbedded, poorly sorted rhyolitic ash and pumice, plus rare basaltic accessory lithics. The Pukerimu deposits are conformably interbedded within airfall Rotoma Ash without weathering or erosional breaks, and underlie a weathered, often strongly unconformable, contact beneath Mamaku Ash. Charcoal from within the surge deposits has been dated at $8860 \pm 120$ yrs 


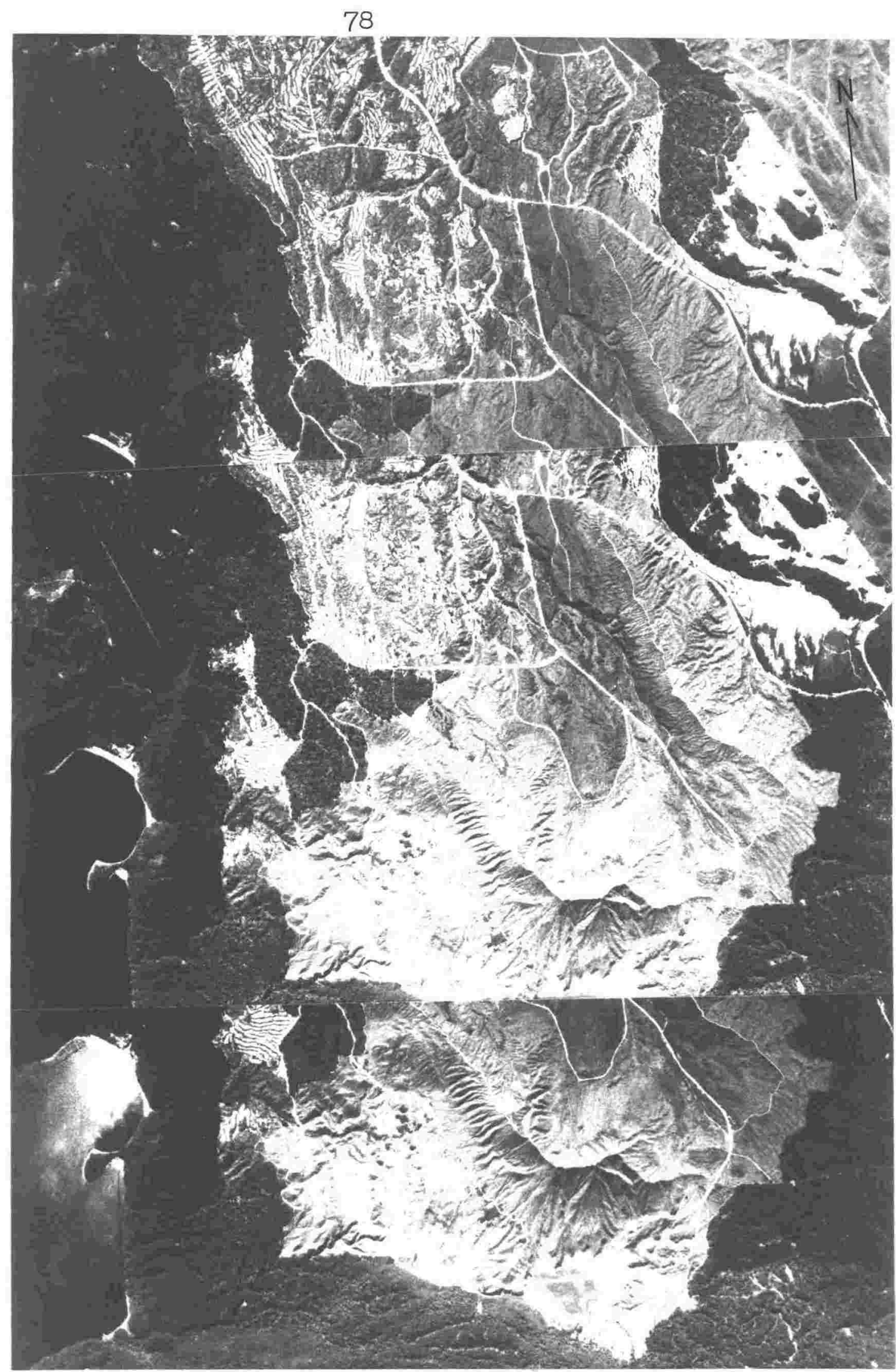

FIG. 13 - Stereo air photo of Pukerimu breached tuff cone and pyroclastic deposits, overlying Haumingi Lava Flow. Considerable vertical exaggeration.

Photos 152443, 152444, $152445(25.4 .80)$ reproduced by permission of Airmaps Tauranga and Tasman Pulp and Paper Co., Kawerau. 


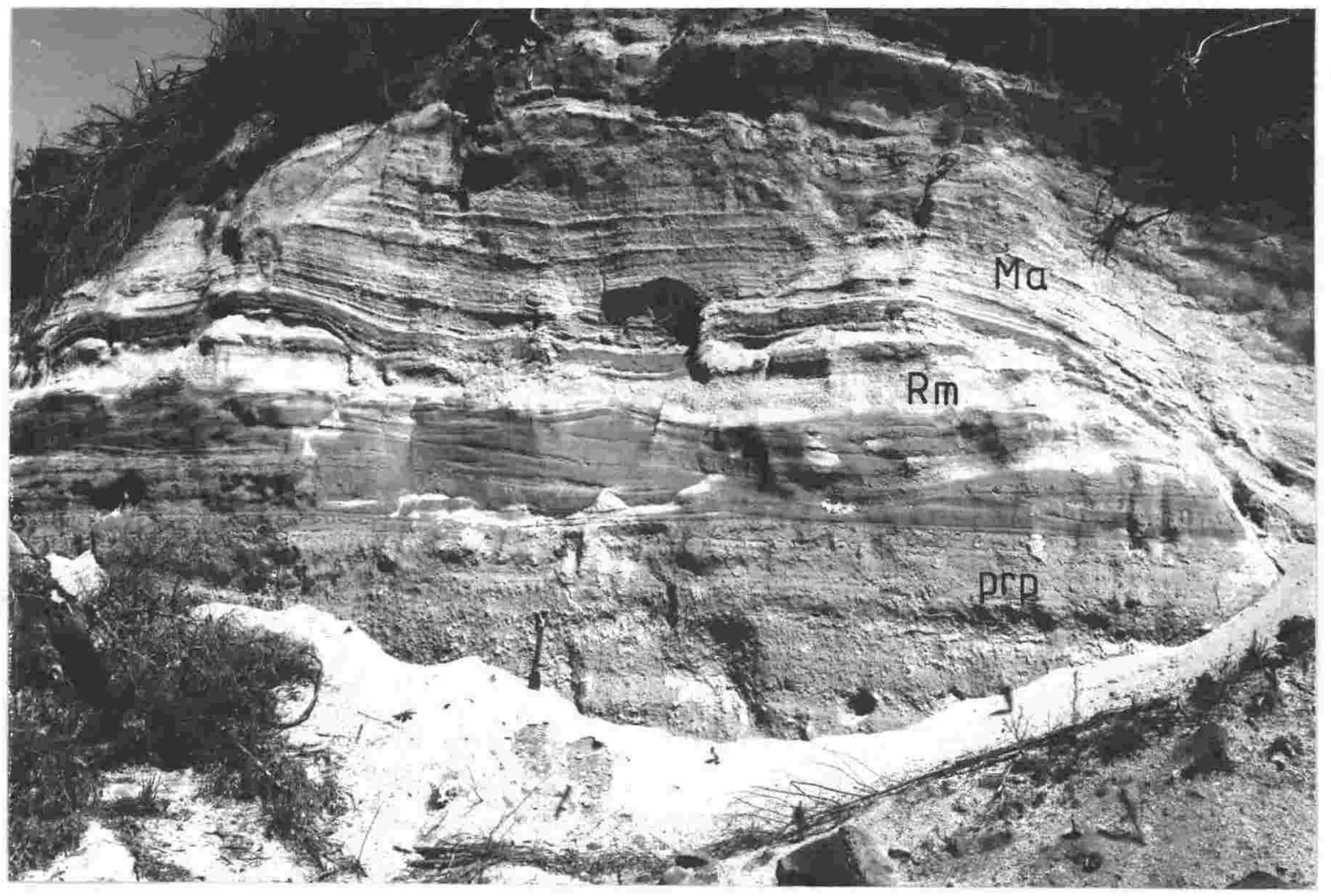

FIG. 14 - Showerbedded Mamaku Ash (Ma) unconformably overlying showerbedded Rotoma Ash $(\mathrm{Rm})$, over crossbedded surge deposits and massive pyroclastic flow deposits of the Pukerimu Pyroclastics (prp). Section at N77/920105 [V15/135407], 2.6 km north of Pukerimu Tuff Cone. Spade is $1 \mathrm{~m}$ long. 
B.P. (See Table 2). The Pukerimu Pyroclastics are inferred to have been erupted during and immediately following the widespread Rotoma Ash pyroclastic fall eruptions from vents at Lake Rotoma (see $\mathrm{p}$.

Although no exposures are available on Pukerimu Cone, its morphology suggests construction by fallback of dense ejecta, so that the outer slopes of the cone approached the angle of rest for coarse pyroclasts. If this interpretation is correct, then Pukerimu Cone forms the largest preserved pyroclastic structure within the Haroharo complex and its emption is unique in not having been followed by lava extrusion.

The Pukerimu pyroclastic emptions appear to have resulted in explosive breaching of the crater, giving rise to turbulent pyroclastic flows, directed to north and east. The northeastern margins of the pyroclastic deposits are sharply defined and steeply sloping (Fig. 13), suggesting that the surges may have come to a sudden halt. Alternatively, the steep marginal slopes may reflect the buried edge of the underlying Haumingi Lava Flow, so that the pyroclastic surges avalanched down the flow margin to lower elevations. Position of the Haumingi Lava Flow margin (and any lower surge deposits) is not known as the area was later overridden from the east by the c. 7500 and c. 5500 yr B.P. lavas of the Waiti Flow and Haroharo Dome which effectively reversed the 9000 yr B.P. topography. The southern margin of the Pukerimu Pyroclastics appears also to have been controlled by the southern margin of Haumingi Flow, now buried under the post-7500 yr B.P. lava from Makatiti and Hainini Domes, so that here also the topography has been reversed.

Waiti Lava Flow: A little-eroded lava flow extends 4.5 $\mathrm{km}$ north-north-west from beneath Haroharo Dome to approach the southern shore of Lake Rotoiti. The western margin of the Waiti Flow laps over the older Haumingi Lava Flow and dissected Púkerimu Pyroclastics, except close to Lake Rotoiti where the Waiti Flow occupies a valley between the Haumingi Lava Flow and 
dissected Tapuaeharuru Breccia deposits to east (Fig. 12). In this area, the Waiti Lava Flow has a maximum exposed thickness of c. $150 \mathrm{~m}$. Flow margins are steep, typically consisting of glassy, often autobrecciated rhyolite. The upper surface of the flow displays well-developed downstream convex arcuate ribs, often composed of brecciated, highly vesicular pumiceous lava and partly buried by a thick pyroclastic mantle near Haroharo Dome. The lava flow distribution and topography, together with the pattern of surface ribbing defines a source vent position underlying the Haroharo-Rotokohu Domes. The unweathered upper surface of the Waiti Flow is directly overlain by Mamaku Ash at many sites (Fig. 15), while Rotoma Ash is nowhere present. The flow is thus positively dated at between c. 9000 and 7500 years B.P. Dissection of the Pukerimu surge deposits indicates a time interval prior to burial of the eroded surface by the Waiti Lava Flow. The lack of a paleosol, or fine ash drift derived from the eroding pyroclastics, on the lava surface suggests that the flow was extmuded shortly before the Mamaku Ash was deposited, but the airfall ash is nowhere baked nor altered by gases from the underlying flow suggesting an intervening cooling period elapsed. At one site, small fragments of carbonised organic matter have been found at the contact between the lava and the overlying Mamaku Ash, suggesting the rare re-establishment of vegetation on the lava flow prior to eruption of the Mamaku Ash. A lava age of c. 7500 years B.P. is inferred, shortly prior to the Mamaku Ash emuption.

Kaipara Lava Flow: The Kaipara Flow merges with the eastern boundary of the Waiti Flow and probably comprises an early, eastward lobe of that extrusion. It has a strongly flow-ribbed upper surface, only slightly eroded, and with very steep flow margins to east and south where it flowed over deeply dissected terrain, and is locally more than $150 \mathrm{~m}$ thick. The Kaipara Flow is also overlain by Mamaku Ash, but not Rotoma Ash. In the only good exposure through the tephra mantle on the flow (at N77/965130) [V15/177428], a layer of massive to weakly stratified fine-medium ash is interbedded between the Kaipara Lava Flow and the overlying Mamaku Ash. In places 


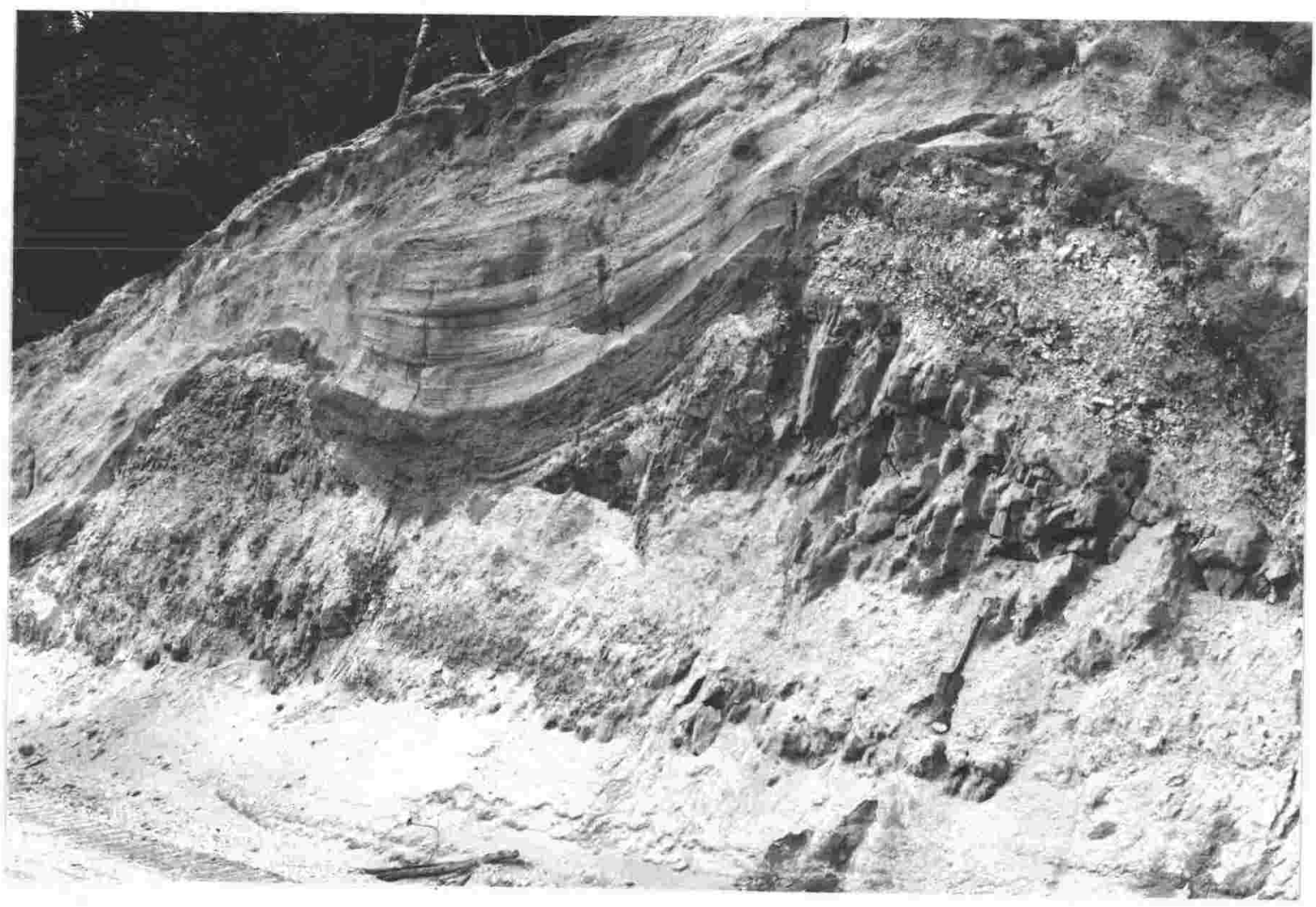

FIG. 15 - Showerbedded Mamaku Ash overlying basal fine ash (dark coloured) on the flow brecciated, pressure ribbed upper surface of the Waiti Lava Flow at V15/169425. Spade is $1 \mathrm{~m}$ long. 
the interbedded fine ash is pneumatolytically altered by heat from the underlying lava flow. This intervening fine ash layer is not found on the Waiti Flow, and its presence suggests that the Kaipara Flow may be slightly older; deposition of the fine ash layer possibly accompanying later extrusion of the Waiti Lava Flow. An age close to 7500 yrs B.P. is inferred for the Kaipara Lava, shortly before extrusion of the Waiti Flow.

The Kaipara Flow probably originated from the same source vent as the Waiti Flow - i.e. close to that for Haroharo or Rotokohu Domes.

Te Pohue Lava Flow and Pyroclastic Deposits: The strongly dissected $\mathrm{Te}$ Pohue Lava Flow extends $2 \mathrm{~km}$ north towards Lake Rotoehu from beneath the younger Waiti and Kaipara Lava Flows. Few good exposures are available of the flow interior, but two main lithologies outcrop within the area mapped as the Te Pohue Flow. These lithologies are: (1) strongly autobrecciated lavas, commonly with angular blocks of glassy rhyolite in a brecciated pink-red ash and lapilli matrix. The blocks often contain abundant xenoliths of lithic rhyolite and vesiculated obsidian. (2) Pyroclastic flow deposits containing pumice and lithic rhyolite, with interbedded weakly shower-bedded airfall layers. Outcrops of both lithologies are commonly closely associated and the lava and pyroclastic flows apparently form interbedded deposits of the same emptive episode. The upper surface of the lava flow is finely dissected, presumably related to brecciation patterns in the underlying lava, with more resistant (less brecciated) lava ribs standing above strongly brecciated areas.

In the Taupo Stream area (N77/965148) [V15/177445] the Te Pohue Lava overlies an ash and block pyroclastic flow which is directly mantled by thick airfall Rotoma Ash without weathering break at the contact. The pyroclastic deposits appear to have immediately preceded eruption of both the Rotoma Ash and the $\mathrm{Te}$ Pohue Lava Flow. A thin $(0.5 \mathrm{~m})$ layer of pneumatolytically altered Rotoma Ash has been found in one locality 
(N77/982157) [V15/193452] on the Te Pohue Lava Flow. Commonly the Te Pohue Flow is overlain by Mamaku Ash with a strong paleosol or erosional unconformity at the contact. The Te Pohue Lava Flow is also overlain by the 7500 yr B.P. Waiti and Kaipara Lava Flows and is thus considered to have been extruded during the Rotoma Ash pyroclastic fall eruptions, and to form part of the Rotoma Eruptive Episode. This stratigraphic inference is confirmed by a ${ }^{14} \mathrm{C}$ date of $8830 \pm 90$ yrs B.P. obtained from "coalified" charcoal found incorporated in the flow front of the western lobe of the Te Pohue Lava (at N77/963147) [U15/175444] equivalent to the date of $8860 \pm 120$ yrs B.P. obtained for the Pukerimu Pyroclastics interbedded within the Rotoma Ash (see p. 205). Mamaku Ash also mantles an aggradational fan sited below an erosional gully at the northern toe of the $\mathrm{Te}$ Pohue Lava Flow, showing that the lava considerably preceded the Mamaku Ash pyroclastic fall.

Surface flow rib patterns and topographic form indicate that the Te Pohue Flow was probably extruded from a buried source vent in the vicinity of Rotokohu Dome. Flow margins are up to $100 \mathrm{~m}$ thick.

Rotokohu Dome and Tuff Cone: A small (1 km diameter) dome on the south margin of the Waiti Lava Flow, Rotokohu Dome was extruded adjacent to Haroharo Dome which overlies it to west. Rotokohu Dome is craterless, but a vent location is inferred close to the highest point near its northern margin. Most lava flowed to south, off the buried margin of the Waiti Flow. Rotokohu Dome is thickest $(150 \mathrm{~m}$ ) on its south-eastern margin. Sampled exposures comprise glassy rhyolite in an autobrecciated pink ash matrix. Lava extrusion was preceded by construction of a tuff cone, probably breached to south. Part of the cone is now preserved on the north and east margins of the dome (Fig. 12), which grew within the cone before lava flowed out to the south-east. A moat is present between the dome and tuff cone on the north and east margins. Summit of the tuff cone is adjacent to the inferred lava vent suggesting that the pyroclastic were erupted from the same vent as the lava. Few exposures 
of the material comprising the tuff cone are available. Six metres of massive, poorly sorted pyroclastic flow material is exposed in a gully on edge of the cone at N77/984099 [V16/193399]. Angular lapilli and blocks range up to $1 \mathrm{~m}$ diameter, in a greybrown ash matrix. The blocks are lithic and glassy rhyolite, some with breadcrust outer surfaces. The weathered pyroclastic flow deposit is immediately overlain by Rotokawau Ash and is therefore coeval with Whakatane Ash. Base of the pyroclastic deposit is not exposed. In roadcut sections on the northern slopes of the tuff cone, coarse pyroclastic flow deposits are interbedded with fall units of the Whakatane Ash and appear to comprise the cone building material. Thickness of the Whakataneage pyroclastics falls off rapidly to the north.

A moderately well sorted coarse pyroclastic fall deposit comprising pneumatolytically-altered rhyolite ash, lapilli, and blocks, exceeds $2 \mathrm{~m}$ thickness in a single exposure on Rotokohu Dome (N77/972097) [V16/182398]. The fall deposit is overlain by Rotokawau Ash and was probably erupted from the Haroharo vent prior to the extrusion of Haroharo Dome. Although base of the fall deposit is not exposed, the pneumatolytic alteration indicates that the underlying dome was still hot when the pyroclastics were deposited. Rotokohu Dome is therefore inferred to have been extruded during the Whakatane Eruptive Episode pyroclastic eruptions at ${ }^{14} \mathrm{C}$ date c. 5500 years B.P. and immediately prior to extmusion of Haroharo Dome.

Haroharo Dome and Lava Flow: Haroharo is a $2 \mathrm{~km}$ diameter dome sited on the south margin of Waiti Lava Flow, and partly overlying the slightly older Rotokohu Dome to east. Haroharo Dome is also craterless, but a vent location is inferred close to the summit. Lava flowed initially to south-west off the margin of Waiti Lava Flow, and later to south-east where the youngest flow extends into the Te Haehaenga Basin. This flow shows moderately well developed ribbing of the upper surface, transverse to the flow direction. Both the dome and the flow have steep margins up to $130 \mathrm{~m}$ thick, which override the Rotokohu Tuff Cone to east, and the dissected margin of the Pukerimu 
Pyroclastics to west. The western flow margin is exposed in a forest track as strongly flow brecciated, angular blocky lava in a pink ashy matrix. The Haroharo lava extrusion was preceded by explosive pyroclastic eruptions which produced cross-bedded coarse surge deposits and ballistic blocks interbedded within Whakatane Ash on Otamuri Road to west of the dome, and the coarse pyroclastics overlying Rotokohu Dome. Angular blocks of lava fallen from the adjacent Haroharo Dome flow front sit in the uppermost Whakatane Ash on Otamuri Road at N77/948086 [V16/160388]. The pyroclastic eruptions at Haroharo form part of the Whakatane Eruptive Episode.

Whakatane Ash is not present on the upper surface of Haroharo Dome, although thick ash outcrops immediately adjacent to the dome. The coarse pyroclastic deposit found on Rotokohu Dome is also absent. Instead, Rotokawau Ash overlies $450 \mathrm{~mm}$ of yellow-brown rhyolitic medium ash containing occasional small pumice lapilli which overlies the dome rhyolite. Haroharo Dome was therefore extruded after the main Whakatane Ash eruptions, but prior to deposition of the overlying tephra, here informally named "Bed 1". Bed 1 is not identified elsewhere, but is considered to represent the final phase of the Whakatane Eruptive Episode, possibly associated with the extrusion of Tikorangi Dome. Bed 1 is not baked or pneumatolytically altered, consistent with cooling of Haroharo Dome prior to its deposition.

Parewhaiti Dome: Parewhaeti Dome is situated on the southern margin of Haumingi Lava Flow where it overlies dissected Pukerimu Pyroclastics. The dome surface is craterless and slopes south-eastward from an inferred vent location beneath the northern summit. The weathered dome surface is mantled by $6-7 \mathrm{~m}$ of thick Whakatane pyroclastic deposits which subdue any lava-surface topography. Mamaku Ash does not mantle the dome. Maximum apparent lava thickness is about $120 \mathrm{~m}$ on the southern dome margin, where glassy and autobrecciated rhyolites outcrop. Due to lack of good exposures, structure and history of Parewhaiti Dome are only poorly known. The dome is partly surrounded by coarse pyroclastic surge and flow deposits of Mamaku Eruptive 
Episode age, which are best exposed and coarsest between Parewhaiti Dome and Haroharo Dome. These proximal-facies surge beds dip away from Parewhaiti Dome and are considered to comprise a remnant of a pre-dome tuff ring, since largely overwhelmed by the dome extrusion. Other shallow outcrops of the uppermost Mamaku Ash occur in stream beds between Parewhaiti Dome and Hainini Dome to west, and on a forestry road north-west of Parewhaiti Dome, but these exposures are not deep enough to provide further information. From the limited exposure, Parewhaiti Dome appears to have been extruded following pyroclastic surge and flow eruptions which form a component of the Mamaku Eruptive Episode, and is therefore c. 7500 yrs B.P. in age.

Hainini Dome and Lava Flow: Hainini Dome is also sited close to the southern margin of Haumingi Lava Flow, to southeast of Pukerimu Cone. It is a small ( $1.5 \mathrm{~km}$ diameter) pyroclastic-mantled dome, with preceding lava flow which extends 4.5 $\mathrm{km}$ to east-south-east, into the Te Haehaenga Basin. The dome has steep northern and eastern flow margins reaching $150 \mathrm{~m}$ thickness above the Mangakotukutuku Stream, but is overridden by younger lavas to west and south, where it is also deeply buried under whakatane Pyroclastics. The dome is craterless but a buried vent location is inferred close to the summit. The upper dome lava is exposed as glassy rhyolite showing strongly developed sub-horizontal arcuate platy jointing, on the forestry track up the northern side. Exposures of the lava flow toe include brecciated pumiceous rhyolite, and grey lithic rhyolite containing obsidian inclusions.

Mamaku Ash is not present on Hainini Dome. The dome lava surface at the northern edge (N77/938065) [V15/150369] is overlain by a thin veneer of slightly weathered fine ash (tephric loess?) which is directly overlain by charcoal-bearing pyroclastic surge and fall deposits of the Whakatane Eruptive Episode. These pyroclastics were probably erupted from the site of Makatiti Dome, to the south. The basal surge beds contain abundant blocks of glassy rhyolite picked up from the brecciated lava surface of 
Hainini Dome. The presence of abundant small carbonised branches and twigs indicates that vegetation had become established on Hainini Dome prior to the Whakatane Episode eruptions. Together with the absence of Mamaku Ash, this is consistent with extrusion of Hainini Dome immediately after the Mamaku Ash eruptions at c. 7500 yrs B.P. A similar age is demonstrated for the associated lava flow where horizontally flow banded and vertically jointed lava at N77/958053 [V16/168358] is overlain by autobrecciated blocky lava with a mantle of Whakatane Ash. The contact here is inaccessible, but a talus fan of lava blocks fallen from the flow edge is also overlain by Whakatane Ash with a strong paleosol beneath the contact. Mamaku Ash is not present.

Te Matae Lava Flow: Te Matae Lava Flow lies to south of the adjacent Hainini Lava Flow, where it underlies the Tapahoro Lavas. Only the toe of the Te Matae Flow is exposed. Stratigraphic position and degree of dissection are similar to the Hainini Flow and the Te Matae Flow is therefore inferred to be of similar, Mamaku Emuptive Episode, age. It was probably extruded from a vent in the vicinity of Tapahoro Dome but cannot be traced back to this area due to burial beneath the Tapahoro Lava Flow.

Oruaroa Lava Flow: The densely-forested Oruaroa Lava Flow on the east shore of Lake Okataina is overlain by the very young Okataina Lava Flow, and the moderately eroded Otangimoana Lava Flow so that only a small part of the flow is not buried. It has steep, little-eroded $150 \mathrm{~m}$ high flow margins above the lake. The Oruarua Flow appears to be deeply mantled by pyroclastics but no sections through the mantle have been found by ground or helicopter searches. The pyroclastic mantle obscures flow structure on the lava surface, which slopes gently away from a presumed source vent underlying Makatiti Dome. Bathymetric contours below the Oruaroa Flow in Lake Okataina are much less steep (Map 1) than those below the younger Okataina Flow which is not thickly mantled. This suggests existence of a thick pyroclastic fan extending into the South Basin of the lake, below the Oruaroa Flow. The thick pyroclastic cover on the Oruaroa Flow shows it to predate at least the Whakatane Eruptive 
Episode; however the lack of much lava erosion indicates the flow is younger than the more severely eroded Te Koutu and Haumingi Flows of the Te Rere Eruptive Episode (c. 19,000 yrs B.P.). Morphological comparison with the well-dated northern lava flows of the Haroharo Complex suggests the Oruaroa Flow may form part of the Mamaku Eruptive Episode (c. 7500 yrs B.P.). It is less likely to form part of the Rotoma Eruptive Episode (c. 9000 yrs B.P.).

Otangimoana Lava Flow: The small exposure of the Otangimoana Flow overlies the Omaroa Flow, and is overlain by the Okataina and Rotoroniu Lava Flows. The Otangimoana Flow appears to be thickly covered with a (Whakatane?) pyroclastic mantle, which obscures flow structures. The steep flow margins are moderately eroded. The Otangimoana Flow appears to have been extruded following the adjacent Oruaroa and Haumingi Flows, as part of the Mamaku Eruptive Episode.

Ruakokopu Lava Flow: The Ruakokopu Flow on the north shore of Lake Tarawera underlies the Rotoroniu and Tapahoro Lava Flows, and has well-developed flow-ribbing on its upper surface. The lava flow is partly buried by a thick pyroclastic mantle of Whakatane Ash age, which outcrops in a gully at eastern end of the flow (N77/930990) [V16/141301]. The lava itself is slightly eroded. The Ruakokopu Lava Flow clearly predates the Whakatane Eruptive Episode but its maximum age is not clearly defined. The degree of lava erosion suggests it forms part of the Mamaku Eruptive Episode. Bathymetry shows the Ruakokopu Flow to have an offshore fan gently sloping into the Central Basin of Lake Tarawera (Map 1). The fan presumably consists of Whakatane age pyroclastic flows which passed over the lava surfaces to enter the lake.

Rotoroniu Lava Flows: The densely forested Rotoroniu Lavas overlie the Oruaroa, Otangimoana, Te Horoa, and Ruakokopu Lava Flows, and appear to form a slightly earlier south-west lobe of the Okataina Lava Flow (Fig.12). They are overlain by the Makatiti and Tapohoro Flows. Structure of the Rotoroniu Lavas is poorly defined, but 3 main lobes extend from a source 
area in the vicinity of Makatiti Dome. Some surface flow structures are apparent in the lava, except near source where shallow exposures reveal a mantle of pyroclastic flow material associated with the terminating extrusion of Makatiti Dome. No good exposures through the tephra mantle have been found. Although the distal Rotoroniu Lavas are somewhat dissected, the lava surface lacks thick pyroclastic deposits of Whakatane Ash age. The Rotoroniu Lavas are therefore somewhat uncertainly interpreted as forming an early phase of lava extrusion during the Whakatane Eruptive Episode.

Tapahoro Lava Flows: The multi-lobate Tapahoro Lava Flows extend $6 \mathrm{~km}$ south-east from presumed source vents under Makatiti Dome and Tapahoro Dome, to form the north-eastern shore of Lake Tarawera and control location of the lake outlet into the Tarawera River. Tapahoro Dome is a multiple extrusion (Fig.12), situated to south of Hainini Dome, and partly overlain by Makatiti Dome. A thick (>10 m) mantle of late-phase Whakatane age pyroclastics completely obscures detailed structure of the extrusion, but two vents aligned north-east are suggested by the topography.

The densely-forested Tapahoro Flows have moderately well developed surface arcuate ribbing; overlie the Rotoroniu, $\mathrm{Te}$ Matae and Ruakokopu Flows; and have steep, $150 \mathrm{~m}$ high flow fronts into the Tapahoro Basin of Lake Tarawera, and above the Tarawera River between the lake outlet and the Tarawera Falls. The Tapahoro Flows are overlain by Makatiti Dome and Flows. The lavas are poorly exposed apart from a few cliff sections on the flow fronts, but Kaharoa Ash is found overlying thin Whakatane age pyroclastics on the flow surface in distal sections. However, the eastern margin of the Tapahoro Dome and Flow overlies very thick $(>60 \mathrm{~m}$ ) Whakatane Pyroclastics in the Te Matae stream valley, with only a thin pyroclastic mantle on the lavas which were therefore extruded following the main Whakatane pyroclastic eruptions and prior to the terminating extrusion of Makatiti Dome. Support for this conclusion comes from the $5090 \pm$ 100 (old T T) years B.P. ${ }^{14} \mathrm{C}$ age of a tree found in growth 
position at $30 \mathrm{~m}$ depth in Lake Tarawera (see Part II. B). This date indicates a $30 \mathrm{~m}$ rise in lake level drowning the tree, presumably caused by advance of the Tapahoro Flows to block an earlier and lower outlet from the Lake Tarawera Basin.

Okataina Lava Flow: The Okataina Lava Flow (Figs. 11,12) extends $5 \mathrm{~km}$ north-west from a source vent under Makatiti Dome, and falls through $620 \mathrm{~m}$ onto the floor of Lake Okataina as a bilobate flow. Bathymetric contours indicate the flow extends west only 200-300 $\mathrm{m}$ under the lake and there is no evidence for earlier lava flows (Map 1). The Okataina Lava Flow has only a thin pyroclastic cover, and is very little eroded. The flow surface shows well developed arcuate flow ribbing, convex downstream and aligned transverse to flow direction. The flow overlies Te Koutu Lava and Pukerimu Pyroclastics to north, where it is up to $210 \mathrm{~m}$ thick, and overlies the thickly ash-covered Oruaroa and Rotoroniu Lava Flows to south. Okataina Flow overrides Hainini Dome to east, but is separated from Tapahoro Dome by a Whakatane Pyroclastics-filled depression.

Surface outcrops of Okataina Flow consist of autobrecciated, glassy pumiceous rhyolite, with a weak paleosol, overlain by thin Rotokawau Ash and Taupo Pumice, under Kaharoa Ash. The widespread airfall components of the Whakatane. Ash are not present, but a relatively thin (1-2 m) pyroclastic flow deposit has patchy distribution on the flow. This massive pyroclastic flow has a weathered upper surface under Rotokawau Ash, and consists of an ash and pumice breccia containing angular black glassy rhyolite lapilli and blocks up to $45 \mathrm{~cm}$ across, some with breadcrust expansion cracks. It is considered to have been deposited during extrusion of the overlying Makatiti Dome, which immediately followed the Okataina Lava extrusion. The pyroclastic flow material is not found on Makatiti Dome and may have originated from small explosive emptions during the dome extrusion.

Makatiti Dome and Flows: Makatiti Dome (Figs. 11,12) occupies the summit of the Haroharo Volcanic Complex and together with 
Haroharo and Tikorangi Domes is one of the three youngest extrusions on the complex.

Small, ribbed, lava flows extend north-west and south-east from Makatiti Dome, and both the flows and the dome have sharply defined, steep flow margins commonly reaching about $50 \mathrm{~m}$ height, and which overlie the Okataina and Rotoroniu Flows and the tephra mantled Tapahoro Dome and Flows. The northern flow is pocked with 3 deep $(>30 \mathrm{~m}$ ) flat floored pits. A track cutting adjacent to the northern pit exposes $6 \mathrm{~m}$ of massive, monolithologic ash, lapilli, and block breccia, overlying the brecciated lava dome. Blocks consist of pumiceous and glassy rhyolite, up to $1 \mathrm{~m}$ across. The breccia appears likely to have originated from pit-forming explosions, in the same manner as the pits on the Te Horoa extrusion (see p. 93). All the Makatiti pits are located on valleys between the flow ridges, suggesting that the pit-forming explosions originated by concentration of infiltrating surface water onto underlying hot lava. The weathered upper surface of the explosion breccia is directly mantled by patchy Rotokawau Ash. Elsehwere on the Makatiti Dome and Lava Flows, Rotokawau Ash directly overlies the weathered upper surface of the brecciated lava flow, which is thus regarded as the terminating phase of the Whakatane Eruptive Episode.

Tikorangi Dome: A little-eroded, small (700 m basal diameter) rhyolite lava dome with a weakly developed summit crater, rises $150 \mathrm{~m}$ above the Holocene alluvium and pyroclastic-infilled valley floor to west (Fig. 12). Tikorangi Dome is sited on the Haroharo Caldera rim and laps onto the dissected ha1 rhyolite of the pre-caldera Rere rhyolite massif to east and south, where it appears to occupy a small cirque-like embayment in the caldera wall. The dome lava is overlain by Kaharoa Ash in poorly exposed sections, but Whakatane Ash is not present. Pyroclastic flow deposits which preceded the dome extmusion outcrop in track cuttings west of the dome, are interbedded within fall units of the Whakatane Ash, and contain charcoal ${ }^{14} \mathrm{C}$ dated at $5420 \pm 100$ yrs B.P. Tikorangi Dome is one of the youngest rhyolite extrusions of the Haroharo Complex, and is the only known eruptive 
vent to have associated solfataric activity. Areas of warm sinter pans occur on the north-west foot of the dome (Fig.12), with slight emission of $\mathrm{H}_{2} \mathrm{~S}$ gas and a few small patches of active sulphur deposition (see Part III. A). The association of the dome and solfataric activity may be fortuitous because more intense solfataras occur $1.2 \mathrm{~km}$ south-west of Tikorangi Dome on the margins of the Kaipara Lava Flow (Fig.12). The Tikorangi activity is thought to be part of a larger field with heat source to south-west related to the Haroharo massif.

No young lava flows are associated with Tikorangi Dome, a nearby sulphur investigation well passing through tuffs and alluvium to $39 \mathrm{~m}$ depth.

Te Horoa Extrusion: Te Horoa lavas and a small area of associated pyroclastic flow deposits, have been extruded into the moat between the Haroharo caldera rim to east of Lake Okareka, and the main Haroharo rhyolite pile (Fig.12). The lava separates Lakes Okataina and Tarawera, and has a deeply (c. $20 \mathrm{~m}$ ) ribbed upper surface, forming arcuate transverse ridges and valleys, convex downflow and roughly concentric on the near central, lava-filled, main vent (Fig. 16). Coulkes extend c. $2.2 \mathrm{~km}$ to north and south of the vent, and have steep flow margins both above and below the lake surfaces. The dome rises $240 \mathrm{~m}$ above the floor of Lake Tarawera, with about $30 \%$ of its total thickness below lake level. No older lava flows are apparent in the bathymetry. A secondary vent may be present at Trig point 7662 (Map 1) where surface topography suggests the existence of a small dome.

Several small ( $<100 \mathrm{~m}$ diameter) steep-sided pits in the lava flow surface intersect the convex ridges. The pits do not appear to represent features formed at the extrusive vent and rafted out in the flowing lava, as such features would be modified during flow by folding and curving of the transverse ridges (Fink 1980). Rather similar craters in basaltic lava flows of the Columbia Plateau have been interpreted as resulting from interaction of rising groundwater with the hot interior of 

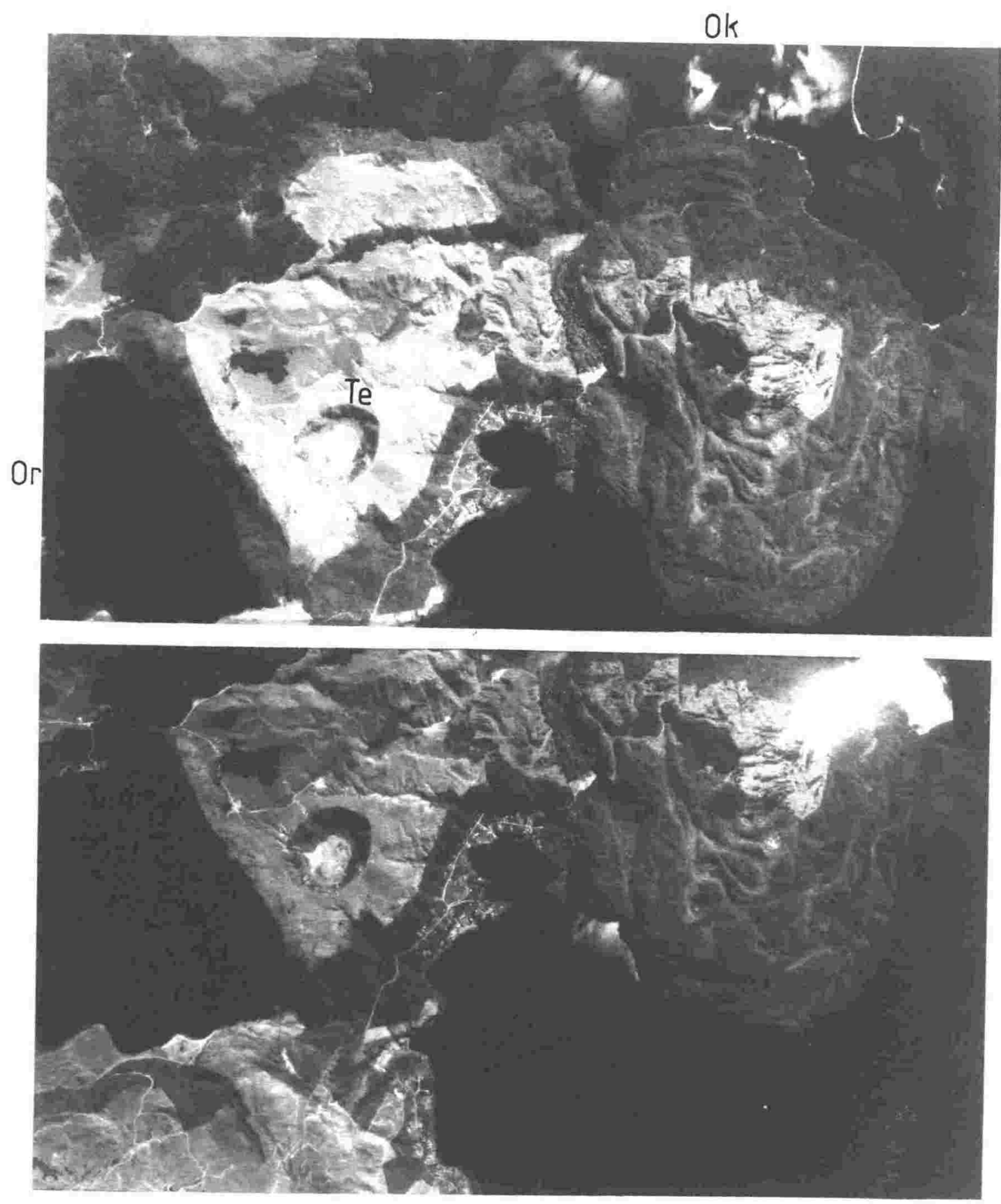

T

FIG. 16 - Stereo-pair air photos of Te Horoa Lava extrusion separating Lake Okataina (OK) and Tarawera (T). Te Whekau explosion crater (Te) lies between Te Horoa and Lake Okareka (Or).

Compare with Fig. 12 and Map 2 for structural interpretation. See Fig. 7 for stereo view of northern Te Horoa extrusion. Photos SN3837: L5, 6 reproduced by permission of Department of Lands and Survey, New Zealand. 
the ponded lava, causing explosive venting through the cooling crust (Hodges 1978). An analogous explanation seems likely for the Te Horoa pits, although the tephra and vegetation-covered lava flow surface provides no verifying exposures of ejecta. The pits are commonly located on valleys between the ridges suggesting that surface concentration of downward percolating rainwater may have caused the explosions.

The pumiceous and autobrecciated upper lava surface in access track exposures on the western side of the Te Horoa extrusion is overlain by thin Whakatane Ash, which is not baked by the underlying lava flow. Mamaku Ash is not present in the few exposures through the tephra cover on the extrusion. However, thin (1-2 m) pyroclastic fall and surge beds ${ }^{14} \mathrm{C}$ dated at $7660 \pm 80$ yrs B.P. occur with weathered upper contact beneath Whakatane Ash on Miller Road, $4 \mathrm{~km}$ to west of the Te Horoa vent (N76/835016) [U16/055327]. These pyroclastics are correlated with a remnant pyroclastic flow deposit which lies to west of the Te Horoa Lava extrusion, abutting faulted Mamaku Ignimbrite of the caldera rim. $\quad A{ }^{14} \mathrm{C}$ date of $7560 \pm 150 \mathrm{yrs}$ B.P. has been obtained for this deposit (Table 2). The lithic (rhyolite and ignimbrite) and pumice-rich pyroclastic flow deposit is moderately dissected and appears to have been erupted from the same vent as the overlying Te Horoa Lava extmusions. The slightly weathered upper surface of the pyroclastic flow deposit is overlain by thin Whakatane Ash.

From the sparse available data, the Te Horoa eruptive sequence is interpreted as commencing with a relatively small pyroclastic fall and surge eruption which produced the distal deposits exposed at Miller Road. Pyroclastic flow eruptions followed to partly fill the caldera rim scallop between Lakes Okataina and Tarawera, before extrusion of the Te Horoa Lavas terminated the eruption. The Te Horoa events, together with the Te Whekau explosions, form part of the Mamaku Eruptive Episode. 
Te Whekau Explosion Crater: A $600 \mathrm{~m}$ diameter and c. $80 \mathrm{~m}$ deep, steep-walled explosion crater is located in Mamaku Ignimbrite terrain between Lakes Okareka and Tarawera, $3.2 \mathrm{~km}$ west-south-west of the Te Horoa vent (Fig. 16). The crater lies outside the Haroharo Caldera rim, but within the Haroharo vent lineation (Maps 1 \& 2). Although of youthful appearance the crater surprisingly lacks the prominent ejecta rim which could be expected from the large crater dimensions. Explosion breccia deposits are poorly exposed in rare shallow track cuttings to north of the crater, and on the eastern crater wall, where ejected blocks of lithic rhyolite and Mamaku Ignimbrite reach 2-3 $\mathrm{m}$ in size, contained in a poorly sorted ash matrix. The explosion breccia is not hydrothermally altered and no magmatic component has been identified. In general, the volume of explosion ejecta appears minimal compared to volume of the explosion crater.

In rare exposures to north of the crater, the explosion breccia overlies without weathering break the c. 7500 yr B.P. dated pyroclastic fall and surge deposits associated with the Te Horoa extrusion. The weathered upper surface of the breccia is overlain by Whakatane Ash. The Te Whekau explosions thus appear to have been coeval with the Te Horoa Lava extrusion, and occurred immediately after the associated pyroclastic eruptions. However, other evidence suggests that the explosion crater was not formed by a single eruption. Explosion breccia is found unconformably overlying the local tephra sequence (Rotorua Ash to Okareka Ash) in a track cutting half-way down the eastern wall of the crater (older ashes are not found). The tephra section does not appear to have slumped into position, and if in situ, demonstrates that the crater existed prior to $c$. 17,000 yrs B.P. - the age of the Okareka Ash. Further, the crater walls (but not the flat, sediment-infilled floor) are displaced by an east-north-east trending regional fault, which from degree of scarp erosion probably last moved prior to $c$. 13,000 yrs B.P.

These structural and stratigraphic relations suggest that formation of the $\mathrm{Te}$ Whekau crater largely occurred before 17,000 
yrs B.P., but that a smaller phreatic explosion occurred about 7500 yrs B.P., associated with the Te Horoa rhyolitic eruptions. No ejecta from the early crater-forming events has yet been recognised and the crater may have formed largely by subsidence. Subsidence may have been related to the c. 19,000 yr B.P. northern dome lava extrusion in the Okareka eruptive centre (see p.203), from a source vent sited $4 \mathrm{~km}$ to south-west of Te Whekau crater along the Haroharo vent lineation.

Otamuri Breccia: A strongly eroded, pumiceous breccia deposit occupies the moat between the eastern rim of Haroharo Caldera and the Kaipara Lava Flow, to north of Otamuri Road. The moderately compacted breccia contains abundant angular lithic and glassy rhyolite lapilli and is apparently of pyroclastic flow origin, but its stratigraphic position is uncertain. Although the breccia was deeply dissected $(>200 \mathrm{~m}$ ) prior to extrusion of the overlying Kaipara Lava Flow at c. 7500 yrs B.P., suggesting a considerable intervening erosional interval, the preserved upper surface of the breccia is mantled only by Mamaku Ash. An intervening paleosol at the contact (and the time needed for dissection) indicate that the breccia must be at least of Rotoma Ash age ( c. 9000 yrs B.P.) although its topographic form would suggest a much greater age. A possible explanation for the anomalous dissection may lie in the steep stream gradients between the eastern caldera rim and the Tarawera River on the floor of Te Haehaenga Basin $300 \mathrm{~m}$ below.

Fentons Mill Flow: A moderately dissected lava flow is conspicuous on aerial photographs as a roughly triangular shape with apex between Parewhaiti and Haroharo Domes. The only exposures of the lava flow occur on the eastern toe where blocks of glassy rhyolite occur in a matrix of autobrecciated ash. The lava flow is overlain and surrounded by thick Whakatane pyroclastic fall and flow material so that its age predates 5500 yrs B.P.

The degree of dissection suggests a rather older date, but maximum age is uncertain. The lava flow appears to underlie 
the c. 7500 yrs B.P. Parewhaiti Dome, and it may be a southeastward extension into the Te Haehaenga Basin of the c. 19,000 yr B.P. Haumingi Lava Flow.

Te Haehaenga Breccia: A moderately dissected, obsidianbearing, massive pyroclastic flow deposit on the floor of the Te Haehaenga Basin is exposed overlying lacustrine silts and clays in the entrenched Mangakotukutuku Stream (at N77/986053) [V16/194357]. The lacustrine beds dip at $35^{\circ}$ upstream $\left(330^{\circ} \mathrm{N}\right)$, probably related to the adjacent fault (Map 1). The pyroclastic flow deposit is overlain by Rerewhakaaitu Ash with an intervening paleosol and is therefore $>15,000$ yrs B.P. in age. 
Tarawera Volcanic Complex

1) General morphology and history of the complex: Structure, chronology and petrology of the Tarawera Volcanic Complex has previously been described by Cole (1966, 1970a, b, c, d). Eleven rhyolite domes ( 3 with accompanying flows) and their associated pyroclastic deposits were grouped in three main "volcanic formations" produced during separate eruptive episodes. Cole (1970) also divided the Tarawera rhyolites into "Early" and "Late" extrusives, comprising eruptives of preKaharoa, and Kaharoa-age (taken as c. 930 yr B.P.) respectively. This convention is followed here. However, the recent detailed mapping, improved exposure, and availability of high altitude aerial photography, has allowed the identification of two further early lava flows (plus additional pyroclastic flows) from the complex, and the reinterpretation of other early Tarawera volcanic structures (Fig.17). Structural and stratigraphic relationships of the early extrusives are considerably obscured by burial under younger emptives and the interpretations presented here rely heavily on photo-geology, assisted by the relatively few exposures through the pyroclastic mantles.

Five main eruptive episodes are now recognised at Tarawera, comprising the 1886 A.D. basaltic scoria eruption, and the rhyolitic lava and pyroclastic eruptions of the Kaharoa episode, the c. 11,000 yr B.P. Waiohau episode, the c. 15,000 yr B.P. Rerewhakaaitu episode, and an c. 17,000 yr B.P. episode related to the Okareka Ash. Most of the exposed extrusives can be placed within this sequence (Table 5), with varying degrees of certainty. As at Haroharo, the lavas are dated by their relationships to enclosing ${ }^{14} \mathrm{C}$-dated pyroclastic beds.

The new interpretations of early Tarawera structures and chronology are discussed below. Some aspects of the Kaharoa and 1886 eruptions are also described in Part II.A.

The Tarawera Volcanic Complex is separated from the Haroharo Complex by Lake Tarawera and the Tarawera River which conveniently divide eruptives from these two sources. 


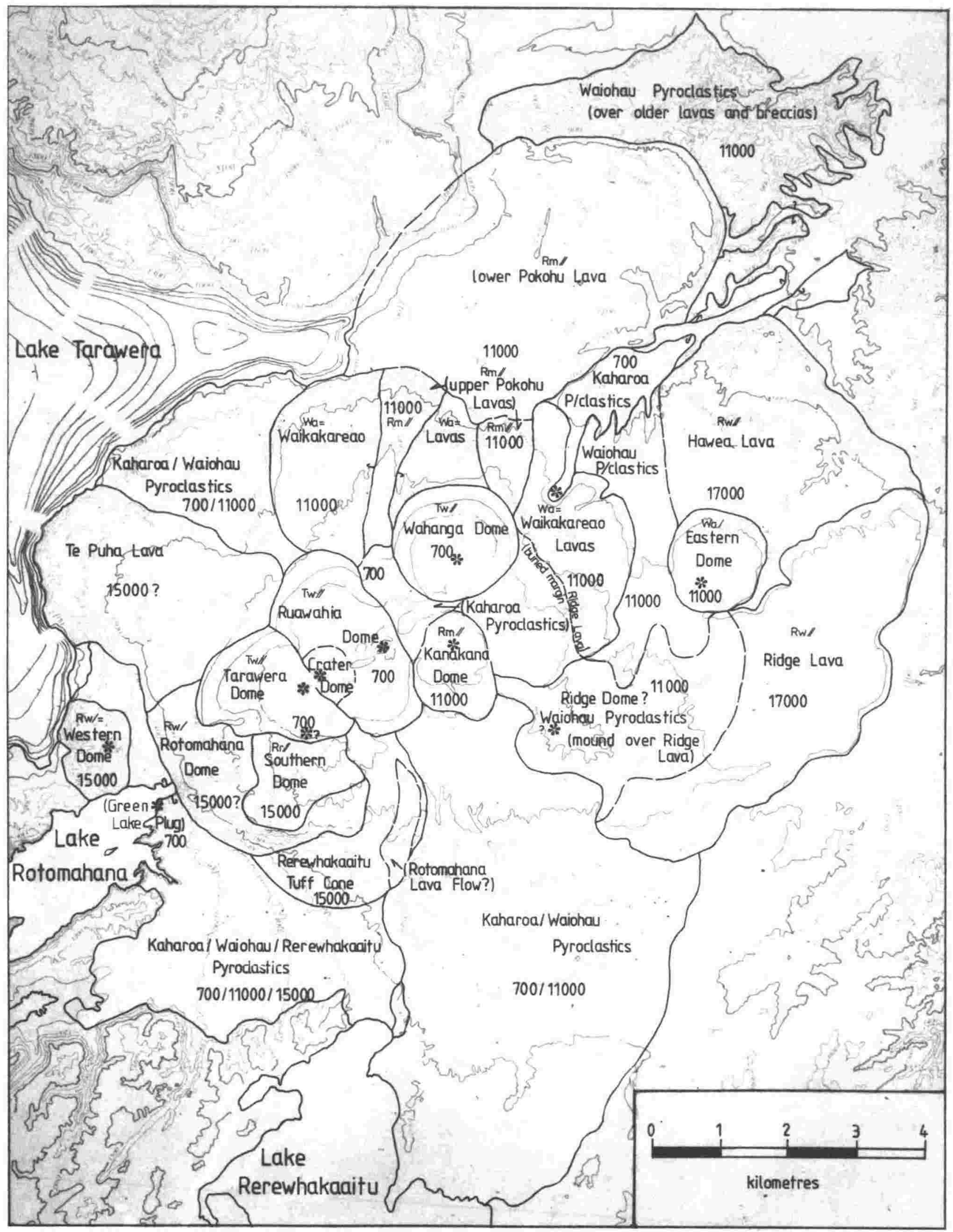

FIG. 17 - Map of Tarawera Volcanic Complex rhyolite lavas and major pyroclastic deposits, with ages. * - eruptive vent. 1886 Rift not shown. Mantling tephras (where exposed) shown as on Map 1. Tw - Tarawera Ash and Lapilli, Rm - Rotoma Ash, Wa - Waiohau Pyroclastics, Rr - Rotorua Ash, Rw - Rerewhakaaitu Pyroclastics. Contours at $100 \mathrm{ft}(30.5 \mathrm{~m})$ intervals. 


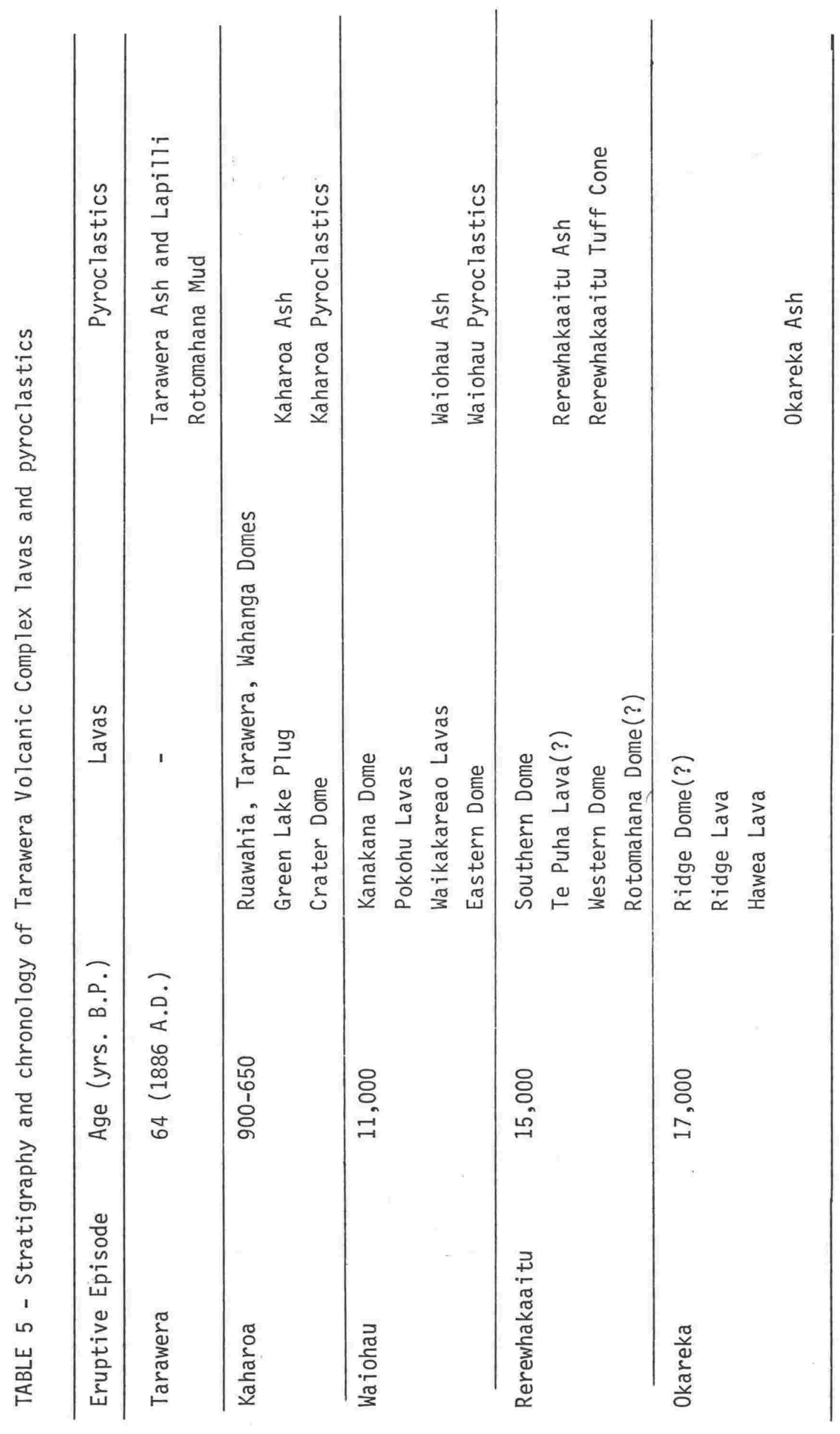


2) Tarawera vent lineation: As at Haroharo, the Tarawera vents appear likely to lie above a deep seated fundamental fracture (Malahoff 1968). All the known (rhyolitic and basaltic) vent locations on the complex lie within a $5 \mathrm{~km}$ wide, $057^{\circ} \mathrm{N}$ striking zone (Map 2), which can be extended from the basaltic/ phreatic 1886 craters at Waimangu, through Rotomahana and Tarawera, to the andesite-dacite cones of Puhipuhi and Edgecumbe to the north-east (see Map 2). Older andesites have been drilled in the Kawerau Geothermal Field at the foot of Mt. Edgecumbe. This $38 \mathrm{~km}$ lineation is inferred to overlie basic intrusions (i.e. Cole 1973), which have given rise to the basaltic eruptives at Waimangu, Rotomahana, and Tarawera, and may also be associated with the north-eastern andesites/dacites which are considered to represent rocks of hybrid origin (Cole 1979). The dacite cones of Maungakakaramea and Maungaongaonga lie at the south-western end of this major zone, which may also extend east to include the inferred basaltic dikes at west Rerewhakaaitu (see p. 66), and is a regional feature present both within and outside the Haroharo Caldera. The Tarawera vent lineation is not a direct continuation of any of the major faults or structures to southwest, as indicated by the surface traces of the Taupo Fault Belt. These commonly strike at about $040^{\circ} \mathrm{N}$.

All the known basaltic vents (and the Puhipuhi and Edgecumbe andesites/dacites) lie within $500 \mathrm{~m}$ of the axis of the Tarawera vent lineation, but some of the rhyolite vents lie at greater distances. The most distant - those of Ridge Dome(?) and Eastern Dome may be located on a ring fault of the Haroharo Caldera, possibly accounting for their greater divergence from the basement fracture.

\section{3) Tarawera Eruptives: The "early" Tarawera eruptives are} divided for descriptive convenience into north-eastern and southwestern areas, in which the deposits are described from oldest to youngest. 
3a) North-eastern Area:

Hawea Lava Flow: The previously undescribed Hawea Flow is the oldest exposed lava from northem Tarawera Volcanic Complex and extends $6 \mathrm{~km}$ to north of a possible source under the Eastern Dome - Ridge Dome(?) - Kanaka Dome area (Fig. 17). The northeastern toe of the lava flow overlies lacustrine sediments and breccias of the Puhipuhi Group. The eastern and southern margins of the flow underlie Ridge Lava Flow and Eastern Dome respectively and the western margin is deeply buried under Waiohau Pyroclastics. Margins of the Hawea Lava Flow are moderately dissected, exposing both autobrecciated and massive glassy and spherulitic flow banded lavas. Outcrops on the upper flow surface also include soft pumiceous lavas. A moderately-developed paleosol is present in several sections on the flow surface, beneath Rerewhakaaitu Ash. Okareka Ash is not present unless it is represented by some rare pockets of pumice lapilli apparently caught up in the uppermost lava. Hawea Lava Flow is considered to form part of the Okareka Eruptive Episode (c. 17,000 yrs B.P.), as is the immediately overlying Ridge Lava Flow.

Location of the Hawea source vent is uncertain. The lava could have been erupted from the site of Eastern Dome; alternatively it may have come from vents under Ridge or Kanakana Domes, but burial by Ridge Lavas and the younger pyroclastics precludes confirmation of these sources.

Ridge Lavas ("Ridge Dome and Waiwhakapa Lavas"): Cole (1970b: p. 882-883, p. 888) described a "poorly defined Ridge Dome" as the earliest Tarawera lava extrusion, regarded as preceding the Rerewhakaaitu Eruptive Episode, and distinguished from an adjacent younger Waiwhakapa Dome and Lava Flow to east. The Waiwhakapa extrusives were considered to postdate the Rerewhakaaitu Eruptive Episode, and were possibly of Waiohau age. However, interpretation of high-altitude aerial photographs now suggests that the "Waiwhakapa" extrusives form a simple $7 \mathrm{~km}$ north-eastward outflow from the "Ridge Dome" area. 
This concept is supported by the pre-Rerewhakaaitu age of the "Waiwhakapa flow" now definitely established in several sections on the north-western margin of the flow, to east of Eastern Dome. Here Rerewhakaaitu Ash mantles a strong paleosol on thin tephric loess over the autobrecciated lava. Okareka Ash is not present. The "Waiwhakapa" lava flow is thus considered part of the Okareka Eruptive Episode and is here mapped as the Ridge Lava Flow (Fig. 17).

No good exposures for independently dating "Ridge Dome" have been found. The lava appears to be strongly dissected but is very deeply mantled by a mound of Waiohau Pyroclastics erupted from the adjacent site of Kanakana Dome, (and perhaps older pyroclastics?), so that only one lava outcrop of "Ridge Dome" occurs, at N77/996928 [V16/200243]. The southern margin of "Ridge Dome" is buried under thick Waiohau and Kaharoa pyroclastic flow deposits. "Ridge Dome" is considered likely to be the same age as the dated Ridge Lava Flow but vent site is uncertain. "Ridge Dome" may have been extruded from an arcuate fracture trending south-east under the present ridge summit (Fig. 17). An alternative hypothesis is that "Ridge Dome" forms only a part of Ridge Lava Flow, with the summit ridge formed in thick remnant Waiohau pyroclastic flow deposits erupted from the adjacent Kanakana Dome site. Location of the ridge is largely controlled by form of the underlying lava flow, but ridge shape results from morphology of the pyroclastic deposits. In this case, the eruptive vent for Ridge Lava Flow may lie under or close to the site of Kanakana Dome. The concept is supported by a steep break in slope of the overlying Waikakareao Lava Flow between Wahanga Dome and the northern margin of Ridge Lava Flow (Fig. 17). This slope break occurs where the Waikakareao Lava Flow appears to have flowed over the Ridge Flow margin. From either inferred vent (Ridge Dome or Kanakana Dome), Ridge Lava flowed south-east into the caldera moat below the Haroharo Caldera rim, and was then turned north-east to follow and override the dissected ignimbrite of the eastern caldera rim. To north the Ridge Lava Flow overlies the immediately preceding Hawea Lava Flow. 
Eastern Dome: A $1.5 \mathrm{~km}$ diameter, little eroded, circular dome standing $100 \mathrm{~m}$ above the Hawea Lava Flow, Eastern Dome is directly overlain by coarse airfall Waiohau Ash at N77/011943 [V16/214256]. No paleosol occurs at the contact of the blocky dome lava with the overlying ash, so that the dome is considered to form an early phase of the Waiohau Eruptive Episode. Waiohau Pyroclastics flow deposits appear to lap around the south and west margins of the dome.

"Plateau Dome and Lava Flow": These extrusives were defined by Cole (1970b) to form part of the Waiohau Eruptive Episode, and to comprise most of the north-eastern Tarawera massif. However a more complex structural interpretation is presented here, with subdivision of the "Plateau" lavas into the Waikakareao Lava Flows which preceded and accompanied the Waiohau pyroclastic eruptions, and the Pokohu Lava Flows, and Kanakana Dome which followed them (Fig. 17). Position of the eruptive vent is also redefined as underlying Kanakana Dome, and the associated pyroclastic deposits are described in more detail.

\section{Waikakareao Lava Flows (Plateau lavas of Cole 1970b):}

Lavas forming the north and north-eastern slopes of the Tarawera massif overlie Ridge and Hawea lavas, and are overlain by Kanakana Dome and at least part of the Waiohau Pyroclastics, plus the two upper lobes of the Pokohu Lavas. The Waikakareao Lavas were extruded during the Waiohau pyroclastic eruptions as only a relatively thin $(\mathrm{c} .10-30 \mathrm{~m}$ ) pyroclastic mantle is present in exposures on the eastern flow, cf. the very thick (>50 m) and deeply dissected pyroclastic mound which buries Ridge Lavas to east. Waiohau Pyroclastics which overlie the Waikakareao Lava in an erosion gully at N77/985942 [V16/190256] are pneumatolytically altered (Cole 1970a, b) indicating the lava was still hot when the pyroclastics were deposited. In the 1886 explosion crater immediately north of Wahanga Dome (N77/986948) [V16/191261 5-10 m of baked Waiohau Pyroclastic flow deposits are interbedded between glassy lavas of the Waikakareao Lava Flows, and about $5 \mathrm{~m}$ of pyroclastic flow deposits (with eroded top) overlie the uppermost lava (Fig. 18). Up to $30 \mathrm{~m}$ of Waiohau Pyro- 


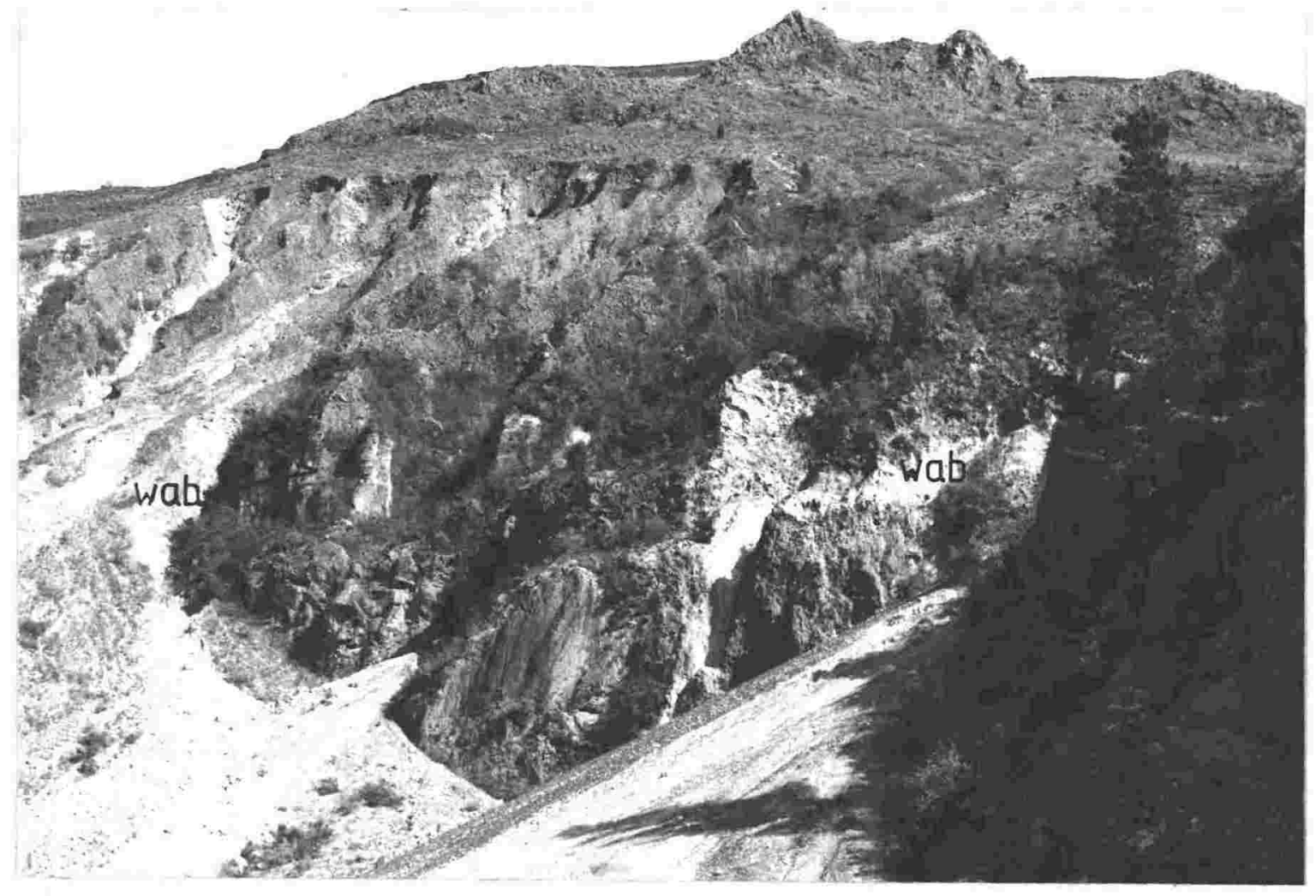

FIG. 18 - Waikakareao Lavas with interbedded and mantling Waiohau Pyroclastics (wab) exposed in the 1886 explosion crater to north of Wahanga Dome (at top). Stratified upper Waiohau Pyroclastics are overlain by blocky scree deposits from Wahanga Dome. 
clastic flow and fall deposits, including crumble breccia from the upper flow, directly overlie the lower part of the eastern Waikakareao Flow, below the prominent break in slope where this flow passed over the edge of the buried Ridge Lava Flow. Airfall Waiohau Ash sits directly on the distal toe of the Waikakareao Lava Flow in cuttings on Edwards Road at N77/989969 [V16/196280]. Waikakareao Lava Flow is therefore coeval with the Waiohau pyroclastic eruptions, and is everywhere mantled by at least the upper part of these pyroclastic deposits. Outcrops of the flow range from spherulitic, massive flow-banded and jointed lavas exposed deep in the walls of the north-easternmost 1886 and Kaharoa explosion craters, to glassy, autobrecciated, pumiceous upper lava surfaces exposed immediately beneath, and interbedded with, the Waiohau Pyroclastics.

A moderately dissected lava flow which extends north to the shore of Lake Tarawera comprises the "Plateau Lava Flow" of Cole $(1970 \mathrm{~b})$. Depth of dissection of the tephra mantle indicates it is also overlain by Waiohau Pyroclastics (although no exposures through the mantle are available). The north-eastern margin of the lava flow is buried beneath the two upper lobes of the Pokohu Lava Flows which separate it from the Waikakareao Lava to east. The "Plateau Lava Flow" is considered to be a western lobe of the Waikakareao Lava Flow, and both lava flow surfaces slope up toward, and appear likely to have been erupted from, the site of Kanakana Dome.

A similarly dissected, thickly pyroclastic-mantled lava surface lies between the two upper lobes of the Pokohu Lava Flows. No exposures through the pyroclastic mantle are available, but the morphology suggests that this area also forms part of the Waikakareao Lava surface.

Waiohau Pyroclastics: Thick deposits of Waiohau-age pyroclastic falls, surges, flows, and apparent debris avalanche deposits, outcrop to north and north-east of the Tarawera massif, and overlie Ridge Lavas to east of Kanakana Dome. The pyroclastic flow deposits also outcrop on the Tarawera access track 
in the valley to south of Kanakana Dome (The "Flow Breccia Member" of Cole 1970a), and fine-grained surge deposits underlie and are interbedded with thick (up to $20 \mathrm{~m}$ ) airfall Waiohau Ash at higher elevations on Southern Dome (Fig. 19), and the Rerewhakaaitu Tuff Cone to east. The Waiohau Pyroclastics have yet to be intensively studied, and are not well exposed close to source, but comprise an early to intermediate phase of the Waiohau Eruptive Episode, as they are interbedded within and overlie the Waikakareao Lavas, and underlie the Pokohu and Kanakana Lavas. The pyroclastic flows also form a fan with distinct topographic expression between the Waikakareao and Hawea Lavas, and extend $7 \mathrm{~km}$ north to the Tarawera River, underlying the Pokohu Lavas. Very thick Waiohau pyroclastic flow deposits must also occupy the caldera moat to south of Kanakana Dome, between the earlier Southern Dome and Ridge Lavas, but only two shallow exposures of multiple flows containing vesiculated obsidian blocks (Cole 1970a). occur on the Tarawera access track in this area. Waiohau Pyroclastic flows also outcrop in the 1886 explosion craters below the "Chasm" on the south-west end of Tarawera, and at Moura Point on the west shore of Lake Tarawera. Although unexposed, they are inferred to also overlie the Te Puha Lava Flow and to occupy the large pyroclastic fan between this lava flow and the Waikakareao Lava to north. Distribution of the northern pyroclastic flow deposits was partly controlled by the Hawea Lava Flow and Eastern Dome to east, which directed the flows north-east towards the Tarawera River, where they overlie brecciated rhyolite and older, preOkareka Ash lacustrine sediments. The flow deposits are at least $50 \mathrm{~m}$ thick in the fan between the Waikakareao and Hawea Lavas. No complete exposure of the pyroclastic sequence is available in this densely forested area, but a lower coarse pyroclastic flow breccia is over $20 \mathrm{~m}$ thick and controls the fan topography. It consists of poorly sorted pink-red, pumice and obsidian-rich, ash, lapilli, and blocks, in places showing incipient welding. Thin $(0.3 \mathrm{~m})$ shower-bedded airfall ash and lapilli beds are intercalated in some sections. Base of the coarse flow deposit is not exposed. It is overlain by $2-3 \mathrm{~m}$ of poorly sorted massive ash flows interbedded with thin rainflush(?) beds of vesiculated fine ash, and thin finely-stratified 


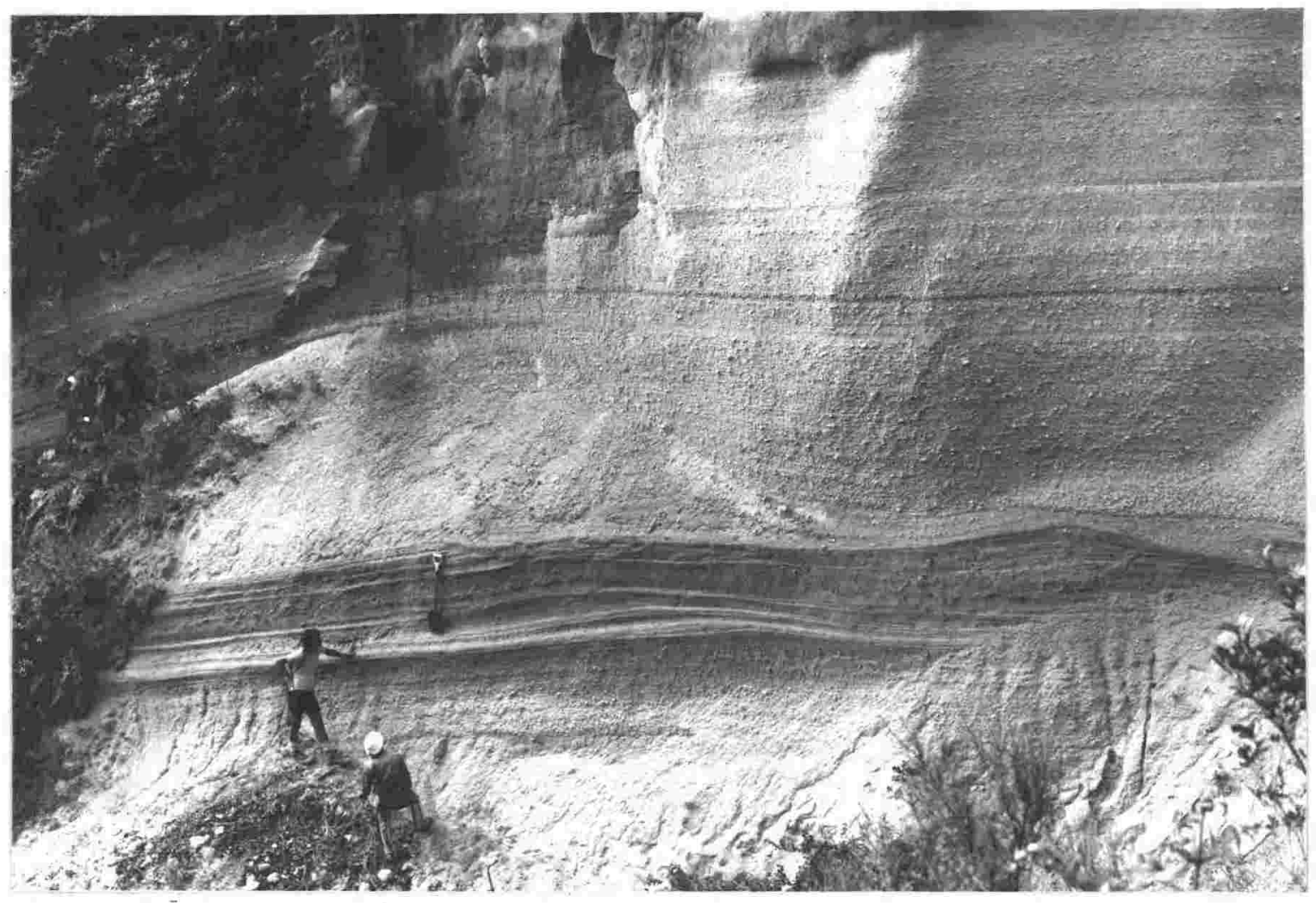

FIG. 19 - Showerbedded airfall Waiohau Ash with interbedded fine-grained pyroclastic surge deposits displaying low angle crossbedding and dune forms. Section is sited $3 \mathrm{~km}$ south-west of Kanakana vent, overlying Southern Dome. 
plane ash beds, some with slight pinch and swell stratification. The uppermost unit exposed is $2 \mathrm{~m}$ of showerbedded (airfall) ash and lapilli. In some sections, i.e. beneath Wahanga Dome, up to $10 \mathrm{~m}$ of normally-graded rhyolite lapilli and blocks are included within the sequence above the basal coarse breccia. These block beds appear to represent a debris avalanche deposit formed by collapse of an advancing adjacent Waikakareao Lava flow front. The upper pyroclastic deposits are also interbedded with Waikakareao Lavas in exposures in the 1886 explosion crater walls, to north-east of Wahanga and are overlain by the Pokohu and Kanakana Lavas.

The Waiohau Pyroclastics north and east of the lower Pokohu Lava are anomalously strongly dissected considering their relatively young age. The degree of dissection appears caused by (a) eruption over a previously irregular terrain of eroded brecciated lavas and lacustrine sediments, and (b) continuing erosion due to undercutting by sapping at the saturated contact between the pyroclastics and the lacustrine sediments of low permeability.

Pokohu Lava Flows: Poorly exposed, little-dissected lava flows form two lobes which appear to overlie the Waikakareao Lavas north of Wahanga Dome (Fig. 17). Two exposures near the toe of the eastern lobe show the lava to be mantled only by Rotoma Ash, overlying a well-developed paleosol. Waiohau Ash is not present. The lobes are inferred to mark upper flow paths for lavas feeding the previously undescribed lower Pokohu Lava flow, which is of identical age to the upper flows, and younger than the underlying, Waiohau Ash-mantled Waikakareao Lavas. The pronounced slope break between the upper and lower Pokohu Lavas marks the margin of the buried Waikakareao Lava Flow. Flow structure on the lower Pokohu flow below the margin is obscured beneath thick Kaharoa Pyroclastics, but it appears likely that the two upper lobes converged in this area. A prominent, north-striking ridge on the western upper Pokohu lobe is interpreted as a marginal levee. Both the upper lobes of the Pokohu Lavas appear to have been erupted from a vent near the site of Kanakana Dome. 
The lower Pokohu Lava Flow extends $5 \mathrm{~km}$ north-east from the upper Pokohu lobes, to overlie earlier Waiohau Pyroclastics and lacustrine deposits in the Te Haehaenga Basin. Although parts of this flow were considered by Ewart and Healy (1965) and Cole (1970b) to have a Haroharo origin, the flow morphology and age clearly demonstrate a Tarawera source. The Tarawera River flows across the north-western margin of the flow and over (and through) the flow front at the Tarawera Falls. Much of the flow is thickly mantled by Kaharoa Pyroclastics but many lava exposures occur on the eastern flow margin and on the north-eastern toe. Arcuate flow ribs outcrop beneath a thinning Kaharoa pyroclastic mantle towards the distal end of the flow, and are convex away from Tarawera. A variety of glassy lavas outcrop, from massive and flow banded solid lavas to highly vesiculated (1 $\mathrm{cm}$ diameter vesicles) pumiceous lava. Much of the lava is autobrecciated, with some solid lava spines protruding through preferentiallyeroded brecciated areas. The western part of the flow is moderately eroded, apparently by overflow during a high stand (c. $320 \mathrm{~m} \mathrm{a.s.1.)} \mathrm{of} \mathrm{Lake} \mathrm{Tarawera} \mathrm{at} \mathrm{about} \mathrm{time} \mathrm{of} \mathrm{the} \mathrm{Whakatane}$ Eruptive Episode.

Stratigraphic position of the lower Pokohu Flow is well established in many sections near the eastern flow margin, where thick Rotoma Ash overlies well-developed paleosols on the lava surface. Waiohau Ash is not present on the lava. The upper and lower Pokohu Lava Flows thus appear to have formed the penultimate phase of the Waiohau Eruptive Episode, following the Waiohau pyroclastic eruptions, and preceding the terminating extrusion of Kanakana Dome in the main Waiohau emuptive vent.

Kanakana Dome: Previously undescribed, Kanakana Dome is the youngest eruptive of the Waiohau Eruptive Episode, extruded within the probable vent for the Waikakareao and Pokohu lava flows and the Waiohau Pyroclastics. The dome is c. $1 \mathrm{~km}$ in diameter, $150 \mathrm{~m}$ thick on its southern flow margin, overlies the Waikakareao Lava Flow, Ridge Lava and thick Waiohau and older pyroclastics to south. It is overlain by Ruawahia Dome to west and thick Kaharoa-age pyroclastics to north, plus 1886 
ejecta. A shallow moat separates Kanakana Dome from the Waikakareao Lava Flow to east. The dome lavas do not outcrop in the 1886 Ruawahia-Wahanga explosion crater, which thus limits its mapped extension to west.

Unlike the Waikakareao Lava Flows, Kanakana Dome is not mantled by Waiohau Pyroclastics. Instead, in a gully section at N77/973923 [V16/179239], Rotoma Ash lies unconformably on slightly eroded, soft autobrecciated glassy lava of the dome, which is thus considered to form the final phase of the Waiohau Eruptive Episode.

3b) South-western Eruptives:

The early south-western Tarawera extrusives are largely concealed under Kaharoa domes, thick pyroclastic cover, and dense vegetation, so that least is known about this area. Cole (1970b) has described "Koa Dome and Lava Flow" overlying "Rotomahana Dome", distinguished mainly on petrographic evidence from isolated sampled outcrops. These lavas were respectively considered to be coeval with, and to underlie the Rerewhakaaitu Tephra (Cole 1970a, b). A somewhat extended structural interpretation is presented here, resulting from the detailed interpretation of new aerial photographs, and re-examination of the rare pyroclastic sections. The only good exposures of the relationships between the early lavas and their pyroclastic mantles occur in a shallow gully eroded onto the upper lava surface to south of Tarawera Dome, and in three precipitous gullies on the eastern margin of the early extrusions. Unfortunately, where best exposed in the largest of the eastern gullies, the section is inaccessible although it can be viewed from a distance (Fig. 20).

\section{Rotomahana Dome (and Lava Flow?): Although mapped} boundaries differ, the Rotomahana Dome of this study is stratigraphically equivalent to that of Cole (1970b). Rotomahana Dome is characterised by crystal-rich biotite-hornblende lava (Cole 1970c) which outcrops on the steep flow margins between Lake Rotomahana and the most southern of the three deep erosion 


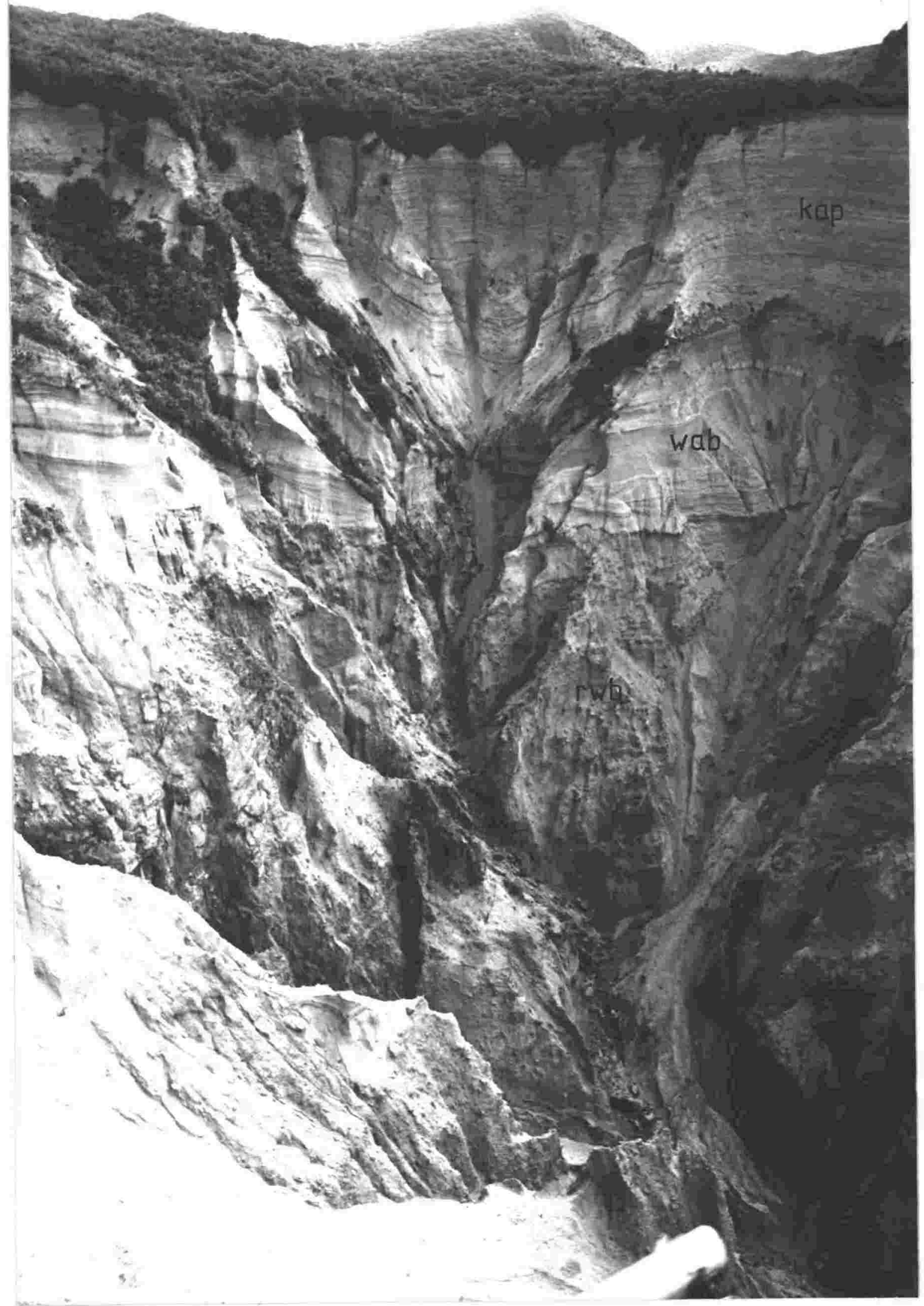

FIG. 20 - Kaharoa Pyroclastics (kap) overlying Waiohau Pyroclastics (wab) in gullies eroded at the contact of Southern Dome with the Rerewhakaaitu Tuff Cone. To right wab directly overlies Rerewhakaaitu Pyroclastics (rwb) of the tuff cone, to left, wab overlies Southern Dome lavas above the Rerewhakaaitu Pyroclastics. Photo by B.J. Scott. 
gullies on the east margin of the dome. The lava also outcrops in an 1886 explosion crater through the flow surface above Lake Rotomahana (N77/933911) [V16/142229]. The north-western boundary of Rotomahana Dome is obscured beneath thick 1886 and Kaharoa pyroclastics, but it appears to underlie the Te Puha Lava Flow, to east of Tarawera Dome (Fig. 17). A low arcuate ridge to east of Rotomahana Dome is little-dissected and may comprise a lava core, of similar age to the dome, beneath a thick pyroclastic mantle. It is tentatively mapped as the Rotomahana Lava Flow although no exposures are available.

Rotomahana Dome underlies the Rerewhakaaitu Pyroclastics, which form a thick ( $>60 \mathrm{~m}$ ) tuff cone on the eastern margin of the dome, and were apparently erupted from the same vent. However, no contact between the pyroclastics and the underlying lava has yet been found, so that whether the lava was erupted as an initial phase of the Rerewhakaaitu Eruptive Episode, or an earlier (Okareka?) episode, is uncertain. Similar mineralogy of the dome lava and the Rerewhakaaitu Pyroclastics (Cole 1970c) support a Rerewhakaaitu correlation, but do not preclude an Okareka, or earlier, age.

Rerewhakaaitu Tuff Cone: Very thick and coarse deposits of both crystal-poor and crystal-rich (Cole 1970a) pyroclastic fall, surge, and flow deposits outcrop in the middle and northern gullies to east of Rotomahana Dome, where they underlie a paleosol beneath Rotorua Ash and thick Waiohau Pyroclastics, and Southern Dome lavas. These Rerewhakaaitu-age pyroclastics form part of a tuff cone, location of which is controlled by the eastern margin of Rotomahana Dome. Particularly coarse, massive, pyroclastic flow deposits up to $50 \mathrm{~m}$ thick are well exposed (Fig. 20) in inaccessible sections at head of the middle erosion gully (N77/960911) [V16/167229], where the gully floor is presumed cut down onto Rotomahana Dome Lava. The uppermost $20 \mathrm{~m}$ of these deposits are accessible in gully sections to south-

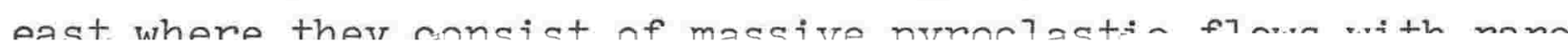


clastics are also well exposed at the head of the northern erosion gully (N77/961916) [V16/168233], where more than $60 \mathrm{~m}$ of coarse pyroclastic fall, surge, and flow deposits outcrop in downward sequence, but the base is not exposed. The beds dip at c. $10^{\circ}$ to north, beneath Waiohau Pyroclastics underlying the crumble-breccia margin of Ruawahia Dome, and become generally coarser and more obsidian-rich downwards. Rare lithic blocks up to $1 \mathrm{~m}$ diameter in the upper fall deposits indicate proximity to source.

The very thick and coarse nature of the Rerewhakaaitu Pyroclastics on the easterm margin of Rotomahana Dome together with the surge bed forms, indicate proximity to source. The pyroclastics were probably erupted from the same vent as Rotomahana Dome (Cole 1970b) and are here considered to form a tuff cone with vent now occupied by Southern Dome.

\section{Southern Dome (Koa Dome of Cole 1970b): Rotomahana Dome} is overlain by the younger crystal-poor Southern Dome lavas which are not mantled by Rerewhakaaitu Ash. Although stratigraphically equivalent to "Koa Dome" of Cole (1970b), the name "Southern Dome" is preferred for these younger lavas. (Koa Trig is sited on the adjacent margin of Tarawera Dome and not on the lavas discussed here). Exposures through the pyroclastic mantle on Southern Dome occur in a gully to south of Tarawera Dome, (N77/947914) [V16/155231] where $12 \mathrm{~m}$ thick Waiohau Pyroclastics and thin Rotorua Ash overlie a weak paleosol on pumice breccia and brecciated rhyolite of the Southern Dome surface. The lava is thus of Rerewhakaaitu age. The same lava is exposed in the southern wall at head of the inaccessible middle erosion gully on the eastern margin of Rotomahana Dome (N77/959912) [V16/166229], and in the smaller gully to south (Fig. 21). Here the dissected upper surface of the brecciated lava underlies a paleosol beneath Waiohau Ash (Fig. 22). Underlying this contact, the lava in places is interbedded with Rerewhakaaitu pyroclastic flow deposits (Fig. 20), which form the northern gully wall where up to $50 \mathrm{~m}$ is exposed. The Southern Dome lava appears to have been extruded within the 


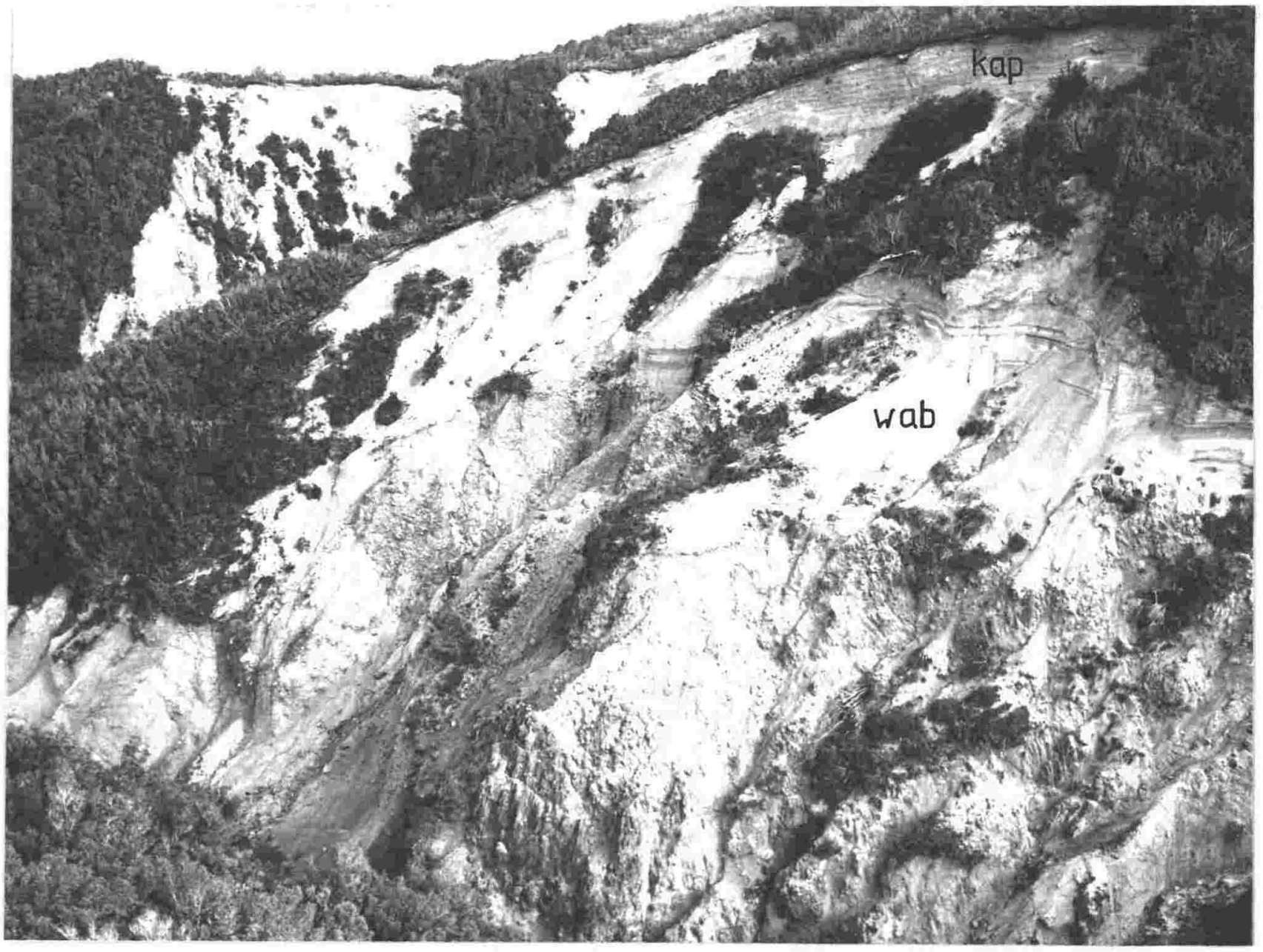

FIG. 21 - Kaharoa (kap) and Waiohau (wab) Pyroclastics overlying Southern Dome lavas in erosion gully at N77/958909 [V16/166227]. Photo B.J. Scott. 


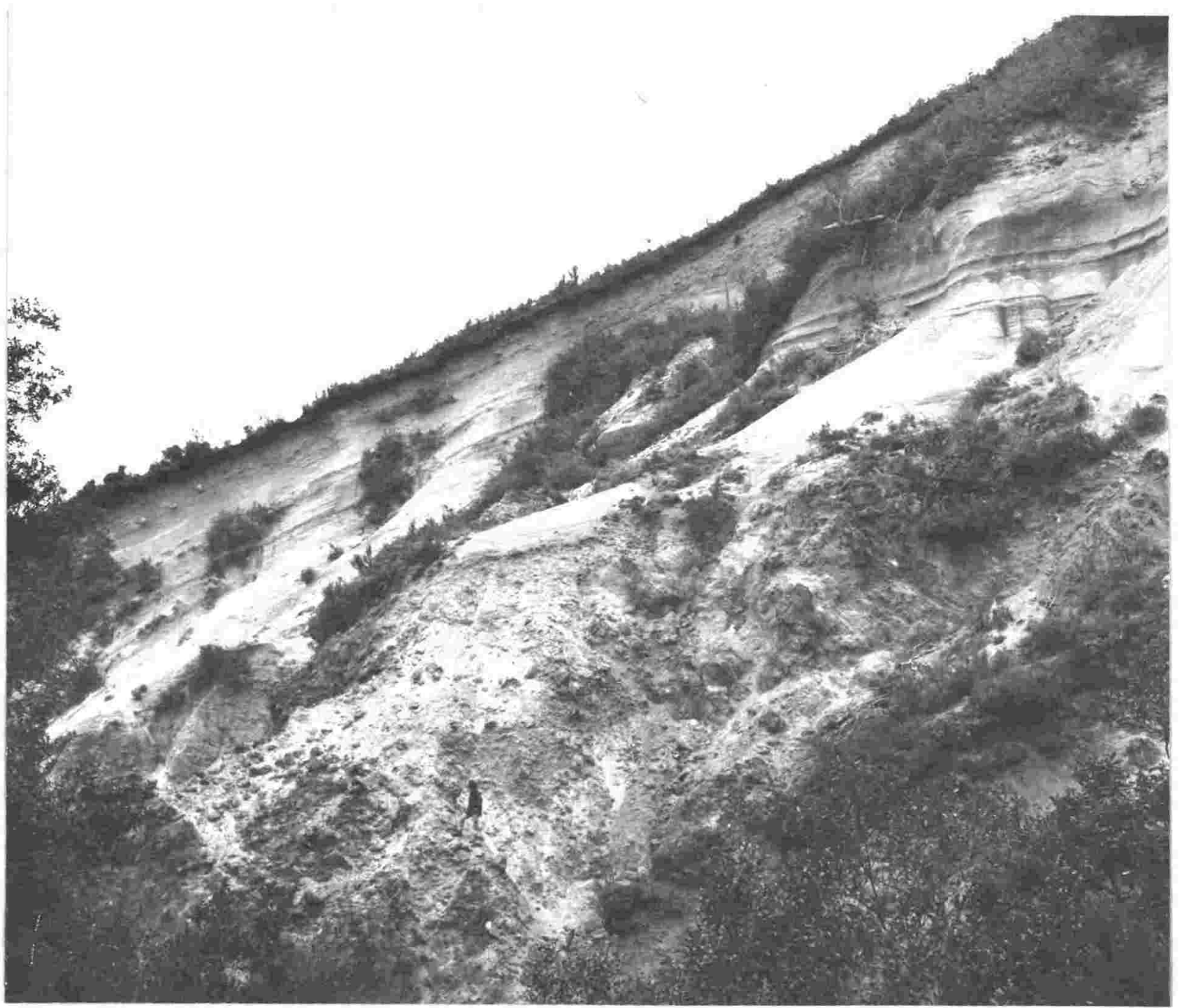

FIG. 22 - Close-up of centre of Fig. 21. Brecciated and flow banded (steeply-dipping) lavas of Southern Dome, unconformably overlain by showerbedded airfall and pyroclastic surge deposits of Waiohau Pyroclastics. Note geologist for scale. Photo by D.L. Homer. 
tuff cone formed by eruption of the Rerewhakaaitu Pyroclastics, with location of the erosion gully controlled by position of . the Southern Dome margin. Southern Dome therefore represents a crystal-poor lava (Cole 1970c) extruded in the pyroclastic vent as the final phase of the Rerewhakaaitu Emuptive Episode.

Te Puha Lava Flow: This lava flow ("Koa Lava Flow" of Cole 1970b) extends north-west from an apparent source in the vicinity of Tarawera Dome or Southern Dome. Cole (1970b) considered it to represent an outflow from the vent of "Koa Dome" (Southern Dome). This appears the most reasonable interpretation but as $2 \mathrm{~km}$ of intervening area is buried beneath Tarawera and Ruawahia Domes, the interpretation cannot be certain and a separate name is preferred here. Outcrops of Te Puha Lava on the shore of Lake Tarawera are of low-crystal content, hypersthene-hornblende rhyolite (Cole 1970c). No stratigraphic control is available on the lava flow, apart from a relatively shallow depth of surface dissection indicating a moderate thickness of pyroclastic cover. The presence of Waiohau Pyroclastics flow deposits on Moura Pt., to west of the Te Puha Lava Flow, suggests the lava predates the pyroclastic flows for which it provided a path to the western shore of Lake Tarawera. Bathymetry indicates the lava flow extends only a short distance into Lake Tarawera, with no indication of underlying older lavas. The lava flow almost certainly postdates the Rerewhakaaitu Ash and appears likely to be the same age as the Southern Dome lavas, i.e., a late phase of the Rerewhakaaitu Eruptive Episode.

Western Dome: This $1.3 \mathrm{~km}$ diameter, thickly pyroclastic mantled, eroded dome rises $100 \mathrm{~m}$ between Lakes Rotomahana and Tarawera. The dome overlies the Rotomahana tuff and scoria cone (20-26,000 yrs B.P.) and is partly buried to north-east by a fan of Kaharoa pyroclastic flow deposits. Rotorua Ash overlies a thin remnant of Rerewhakaaitu Ash on the hornblendehypersthene-biotite lava of the dome in sections on the shore of Lake Rotomahana (N77/922905) [v16/132224]. Western Dome appears to have been extruded during a late stage of the Rerewhakaaitu Eruptive Episode, confirming the age suggested on geomorphic evidence by Cole (1970b) 
3c) Kaharoa and 1886 Eruptives:

The Kaharoa eruptives have been described by Cole (1970a, b). During this episode, the widespread Kaharoa Ash pyroclastic fall deposits were erupted, interbedded with near-source pyroclastic flow, surge, and avalanche deposits. Crater Dome (Fig. 17) was extruded during the pyroclastic eruptions. The episode terminated with extrusion of Wahanga, Ruawahia and Tarawera Domes (Fig. 17), forming the summit of Tarawera massif. Green Lake Plug was extruded at the south-west foot of the massif, and a phreatic explosion crater formed through the north-eastern Waikakareao Lavas during an initial phase of the episode. A detailed investigation of the Kaharoa pyroclastics is in progress (Nairn and Self, in prepn.), but does not form part of this thesis. Chronology of the Kaharoa Eruptive Episode is discussed in Part II.A (p.219). Some aspects of the 1886 A.D. eruption are also described ( $p .235)$. 
Rotomahana Eruptives

Geology of the area around Lake Rotomahana is obscured by thick deposits of the 1886 Rotomahana Mud. However, two postcaldera eruptive centres are exposed within the lake basin, and the products of other local eruptions outcrop on the lake shores (see also $\mathrm{p}$.

Rotomahana Tuff and Scoria Cone: A small rhyolite/basalt pyroclastic cone (Fig. 23) is cut by the north shore of Lake Rotomahana (N86/910897) [V16/121217]. The cone has little topographic expression apart from gentle slopes away from a thickly mud-covered summit, $60 \mathrm{~m}$ above the lake; the eruptive vent probably lay within the present lake. The cone is exposed as c. $20 \mathrm{~m}$ of north-east outward dipping (15\%) pumiceous hornblende-biotite rhyolite lapilli and ash, in weakly-stratified plane surge beds (Fig. 24), of alternating, poorly-sorted finecoarse ash and lapilli layers. Lapilli beds are commonly inversely graded, with weakly developed imbricate texture. Some thickening and thinning of the pyroclastic beds is also evident. Occasional angular large rhyolite blocks (to $20 \mathrm{~cm}$ ) are present, but impact sags do not occur, and the blocks are not mantled by overlying beds. Some blocks have breadcrust outer surfaces. The outward dipping beds are overlain with strong unconformity by 3-8 $\mathrm{m}$ of inward thickening and dipping (at $30^{\circ}$ to south-west) rhyolite ash and lapilli beds, including occasional large blocks to $0.4 \mathrm{~m}$. Rare basalt lapilli up to $10 \mathrm{~mm}$ diameter are also found in these beds. The unconformity is thought to represent the floor and rim of a cratered tuff ring, partly infilled with younger rhyolite pyroclastics.

The inward dipping rhyolite beds are conformably overlain and baked by 5-8 $\mathrm{m}$ of basic scoriaceous ash, lapilli, and bombs with abundant rhyolite inclusions, apparently deposited immediately following the rhyolite eruptions. The scoria beds contain a middle horizon of rhyolite blocks in a cross-bedded basaltic ash and lapilli matrix. The basic bombs commonly contain many rhyolite inclusions, assimilation sometimes proceeding to produce thoroughly mixed quartz-olivine "andesite" hybrids indicating the mixing of magmas rather than simple 


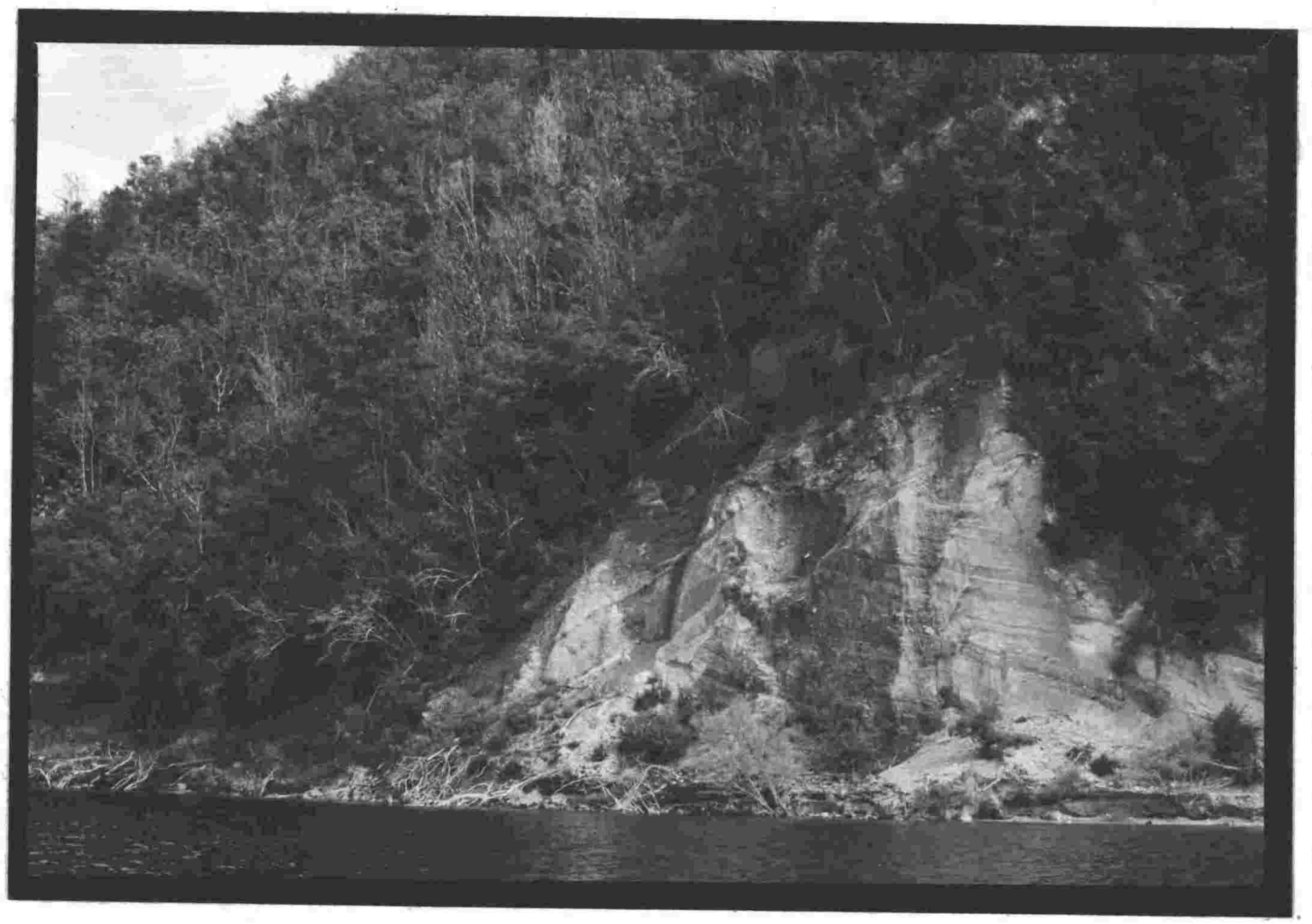

FIG. 23 - The only exposure of Rotomahana Tuff and Scoria Cone, located on the north shore of Lake Rotomahana (N86/910897) [V16/121217]. Black scoria beds overlie heat-reddened rhyolite ash and lapilli, passing unconformably downwards into outward dipping, planebedded ash and lapilli (white). 


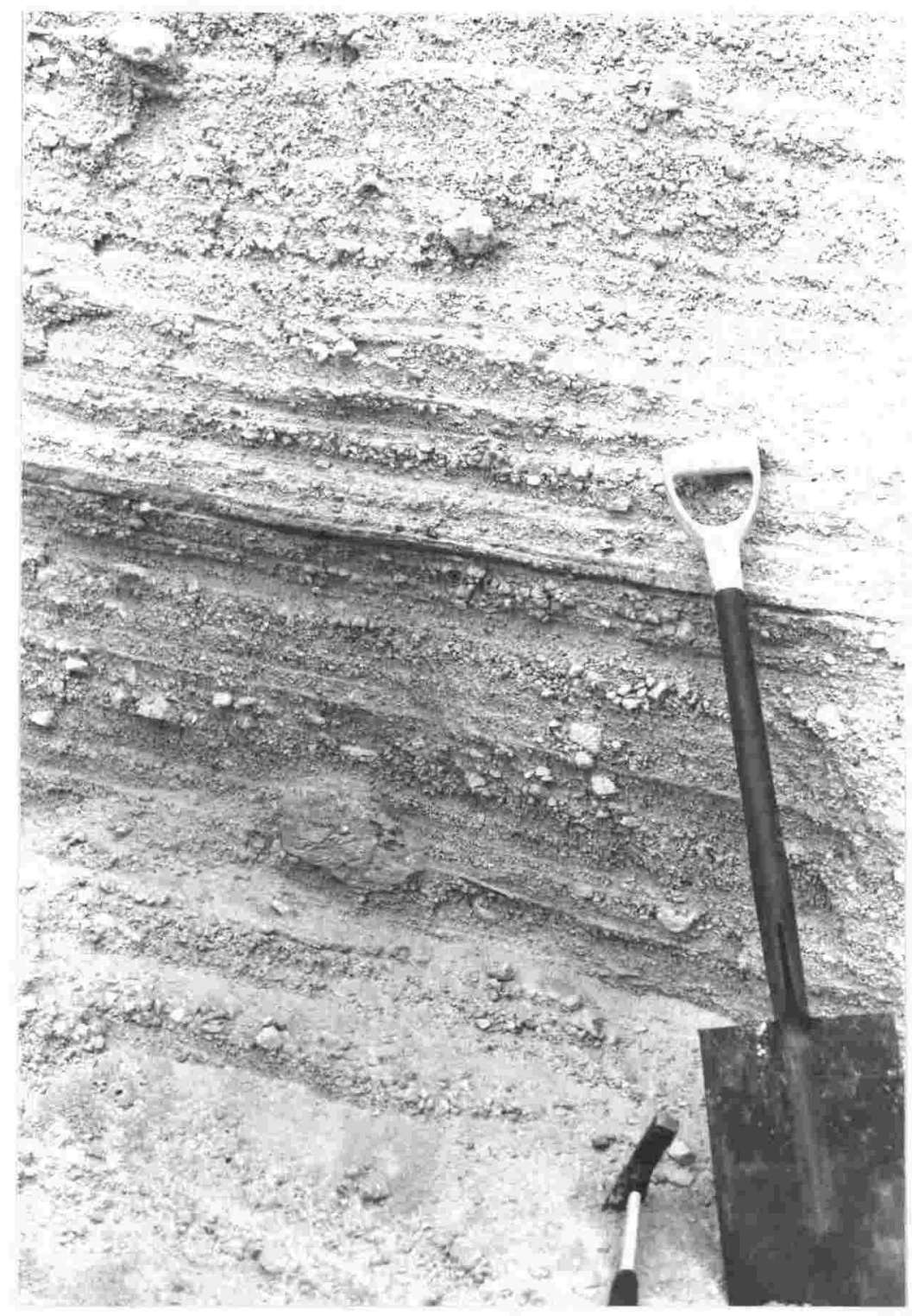

FIG. 24 - Detail of the outward-dipping rhyolite ash and lapilli plane surge beds shown in Fig. 23. Note lack of impact craters associated with larger blocks, and non-mantling bedding. 
incorporation of solidified rhyolite in the basaltic magma. The slightly weathered upper surface of the basic scoria is mantled by the c. 20,000 yrs B.P. Kawakawa Tephra, but the Mangaone Sub-group pyroclastics are missing, indicating an age for the pyroclastic cone of 20-26,000 yrs B.P.

Chemical analyses of the basic eruptives are recorded in Appendix 1 .

Patiti (Banded) Island Rhyolite: A strongly faulted remnant of a rhyolite extrusion within Lake Rotomahana rises $80 \mathrm{~m}$ above the lake floor. Patiti Island is composed of strongly flow-brecciated biotite-bearing lava, and is overlain by the tephra sequence down to and including Rerewhakaaitu Ash but the contact is poorly exposed. The absence of Okareka Ash suggests an age for the extrusion between 15,000 and 17,000 yrs B.P.

\section{Local Explosion Breccias: At least three post-20,000 yr} B.P. local explosion breccias outcrop in poorly exposed sections on the north-east and north-west shores of Lake Rotomahana, adjacent to Banded Island Crater. Hydrothermally altered explosion breccias $4 \mathrm{~m}$ thick, containing angular blocks of rhyolite in a pumiceous matrix, lie above a paleosol on Rotorua Ash at $\mathrm{N} 86 / 918886$ [V16/128206], in the stratigraphic position of Waiohau Ash. Similar altered explosion breccias directly overlie the Waiohau Ash in sections on Patiti (Banded) Island, and on the Rotomahana Tuff and Scoria Cone, where another explosion breccia also outcrops underlying the Rotorua Ash, in the stratigraphic position of Rerewhakaaitu Ash. A third explosion breccia, apparently of magmatic origin, outcrops at the tuff cone. Coarse angular blocks of pumiceous hornblende-hypersthene rhyolite, plus rare basaltic inclusions, occur in a $1.5 \mathrm{~m}$ thick layer beneath Waiohau Ash, and overlying $1 \mathrm{~m}$ of uncorrelated airfall ash and lapilli. A ${ }^{14} \mathrm{C}$ age of $12,300 \pm 200$ yrs B.P. has been obtained from this explosion breccia (see Table 2), which appears to have resulted from a small phreatic eruption between the Rerewhakaaitu and Waiohau Eruptive Episodes.

It is clear that a number of local phreatic and possibly magmatic explosions occurred in the Rotomahana area, both between 
and contemporaneously with the Rerewhakaitu and Waiohau Eruptive Episodes. At least one of these explosion deposits is apparently associated with basaltic intrusion, as was the older eruption of the Rotomahana Tuff Cone.

Pre-Rotoiti Breccia Rhyolites: Hornblende-biotite rhyolite lavas outcrop on the southern shores of Lake Rotomahana, and are overlain by strongly-crossbedded rhyolite lapilli and block beds indicating a local eruptive source. These pyroclastic surge deposits underlie Rotoehu Ash. Similar cross-bedded pyroclastics are interbedded between Matahina Ignimbrite and Rotoehu Ash on the lake shore to east and south of Patiti (Banded) Island and appear to represent an early phase of intra-caldera explosive volcanism at Rotomahana. Airfall basaltic scoria is again interbedded within these rhyolite pyroclastics (Nairn 1979, p. 374; included on p.234 of this thesis). 
Rotoma Volcanic Complex

Structure of Rotoma Caldera(?) is described on p. 55 of this thesis. Geology of the intracaldera(?) rhyolite eruptives is described below.

Rotoma Lava Flow: The western part of Rotoma Caldera(?) is occupied by the young Rotoma Lava Flow (Map 2), erupted from a vent near its western end, and flowing east onto the basin floor. The ridged lava flow surface is subdued by a thick pyroclastic mantle, and has steep flow margins which fall $40 \mathrm{~m}$ onto the floor of Lake Rotoma. Only the upper surface of the lava is exposed, beneath a pyroclastic mantle, in sections on the lake edge (Fig.25).. The exposed lava is autobrecciated into breadcrust expanded, pumiceous blocks. No lava vent is preserved; a small summit tholoid is assumed to mark the vent position (Map 2).

Rotoma Pyroclastics and Tuff Ridge: Rotoma Lava Flow is directly overlain by rhyolite lapilli and ash of the Rotoma Pyroclastics without weathering or erosional break at the contact. In many sections the pyroclastics have been pneumatolytically altered by heat from the underlying lava (Fig. 25). The pyroclastics become markedly thicker (to $>10 \mathrm{~m}$ ) and coarser towards the Matutu Basin eruptive vent, and a lithic block bed appears between the upper, finely-bedded widespread plinian fall deposits of the Rotoma Ash and the underlying brecciated lava flow.

No apparent time breaks occur within the sequence, and the pneumatolytic staining extends up into the finely-bedded plinian deposits. Cross-bedding with development of u-shaped channels becomes apparent in coarse proximal pyroclastics (Fig. 26) south-west of Matutu Basin, where a tuff-ring remnant ridge of Rotoma Pyroclastics forms the shore of Lake Rotoma (Map 1). The tuff-ridge is apparently overridden by the adjacent margin of Rotoma Lava Flow. Stratigraphy also suggests that most of the coarse pyroclastics forming the tuff-ridge were erupted prior to the lava flow. Shallow sections within the tuff ridge expose relatively dense, angular pumiceous lapilli and expanded obsidian blocks in an ash matrix, forming massive pyroclastic flow deposits with interbedded weakly shower-bedded fall deposits. 


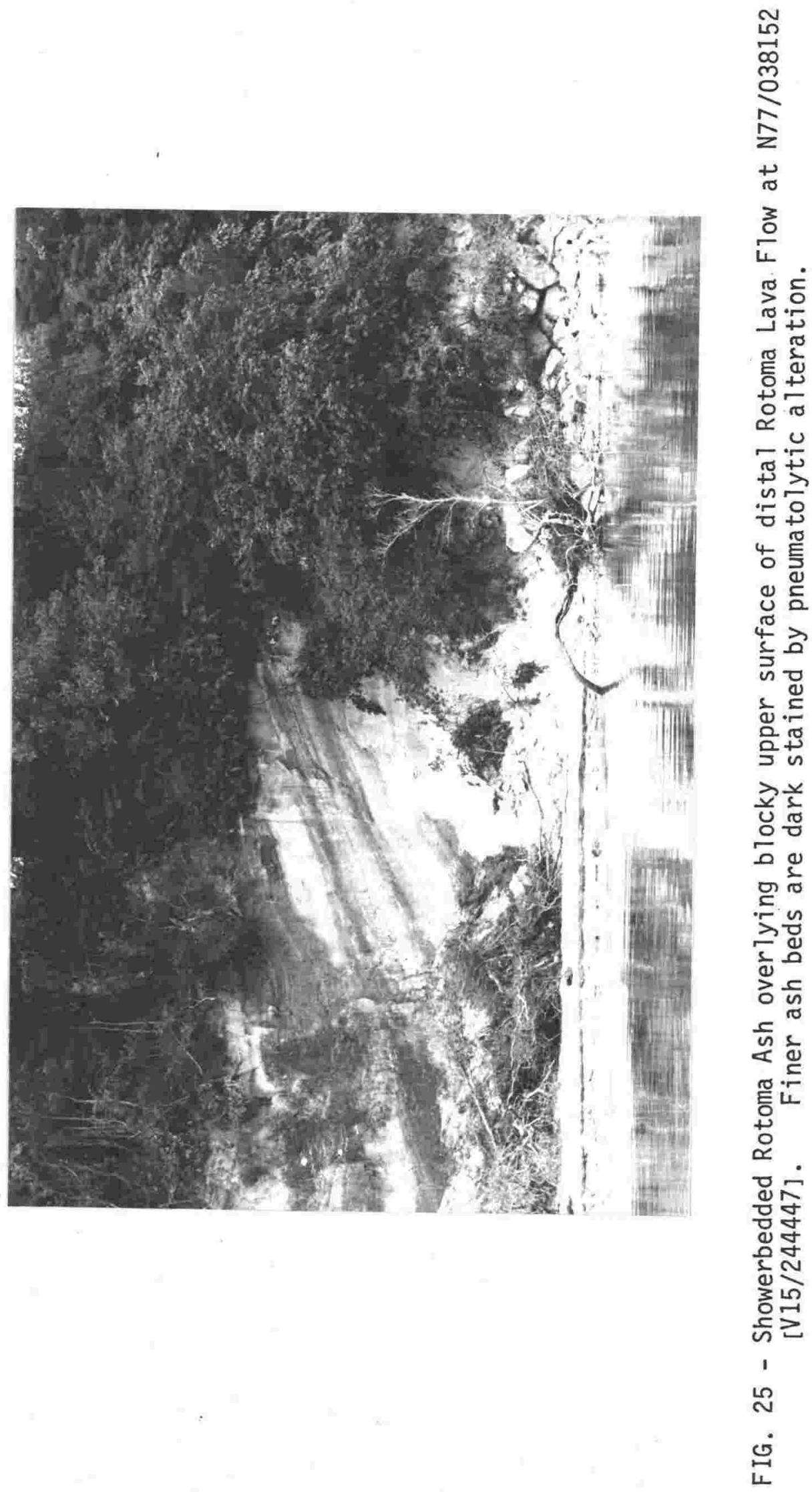




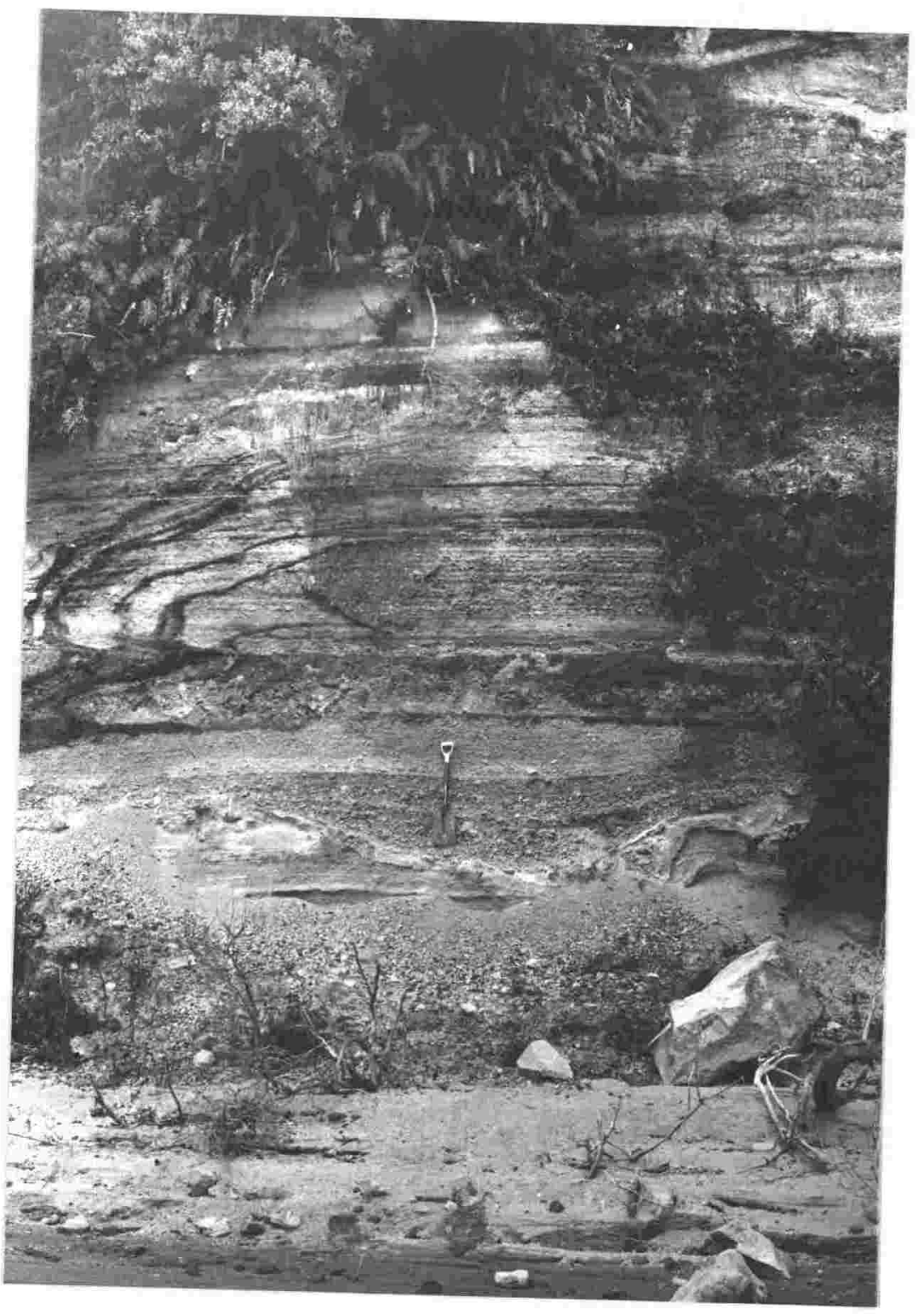

FIG. 26 - Rotoma Pyroclastics in Tuff ridge at N77/024163 [V15/232457], exposed on lake shore $400 \mathrm{~m}$ south of Matutu Basin vent. Note development of u-shaped channel and its infilling by lapilli and blocks passing upward into finer non-mantling planar beds. Base of Rotoma Pyroclastics is not exposed and total thickness is unknown. 
These coarse, angular, block deposits outcrop only within $1.5 \mathrm{~km}$ of Matutu Basin.

Submerged Domes(?): Age of the dome-shaped elevations on the floor of Lake Rotoma (Map 2) is unknown, but they are assumed to be rhyolite domes extruded at the same time as the Rotoma Lava Flow. No pyroclastics are identified as associated with these domes(?), which together with the known vents at Rotoma may delineate a ring structure (Map 2).

Rotoma Hydrothermal Field: Warm springs outcrop adjacent to the north-west and southern margins of the Rotoma Lava Flow, and may be related to a heat source associated with the Rotoma Volcanic Complex. The Rotoma Hydrothermal Field is described in Part III.A.

Tikitapu Rhyolite Complex

The young Okareka eruptives of the Tikitapu Rhyolite Complex (as defined by Ewart 1968) are described elsewhere (Nairn 1980). This paper is included on p.203 of this thesis. 


\section{D: VOLUINES OF OKATAINA ERUPTIVES}

Caldera-Forming Eruptives (pre-20,000 yrs B.P.)

An attempt has been made to estimate volumes of emptives from the O.V.C. (Tables $6 \& 7$ ). Because of burial under younger rocks, stripping by erosion, and loss of much pyroclastic material offshore, volume estimates for the older eruptives are very imprecise. Calculations for the Matahina Ignimbrite illustrate the difficulties involved, although this sheet is the best preserved of the O.V.C. caldera-forming ignimbrites.

Bailey (1965) recorded a present outcrop area for Matahina Ignimbrite of $1200 \mathrm{~km}^{2}$, with exposed and drilled thicknesses between 80 and $130 \mathrm{~m}$ (Ewart 1965) in the sector to east of O.V.C.. Ewart and Healy (1965) record thicknesses up to $37 \mathrm{~m}$ at the Bay of Plenty coast, and c. $100 \mathrm{~m}$ of Matahina Ignimbrite has been drilled in. several Kawerau geothermal wells (Browne 1978). Assuming a conservative average thickness of $70 \mathrm{~m}$, the volume represented by the $1200 \mathrm{~km}^{2}$ present outcrop area is $84 \mathrm{~km}^{3}$. However, isolated remnants of Matahina Ignimbrite not recorded by Bailey occur on the Paeroa Fault Scarp (where it is $50 \mathrm{~m}$ thick) and in the Ngakuru Graben to south-west of the O.V.C. (Nairn 1973), indicating that the sheet was originally more extensive. An unknown area of Matahina Ignimbrite occurs offshore in the Bay of Plenty. A rounded outline drawn through the outlying deposits suggests an original sheet extent of c. $2400 \mathrm{~km}^{2}$ (Fig. 27). If average thickness over this area is $40 \mathrm{~m}$ an ignimbrite volume of c. $100 \mathrm{~km}^{3}$ is obtained (Table 6). This volume does not include the airfall basal and coignimbrite ashes which have not been mapped beyond the margins of the flow deposits. Kohn (1973) has correlated with the Matahina Ignimbrite a rhyolitic ash (Layer $\mathrm{E}$ of Ninkovich 1968) found more than $1000 \mathrm{~km}$ east of the North Island in deep sea cores. The airfall plinian and coignimbrite ashes associated with the Matahina Ignimbrite are probably of comparable volume to the extracaldera pyroclastic flow deposits, a general relationship suggested for large ignimbrites by Sparks and Walker (1977). For example, the airfall Rotoehu Ash is of roughly equivalent volume to the associated Rotoiti Breccia pyroclastic flow 


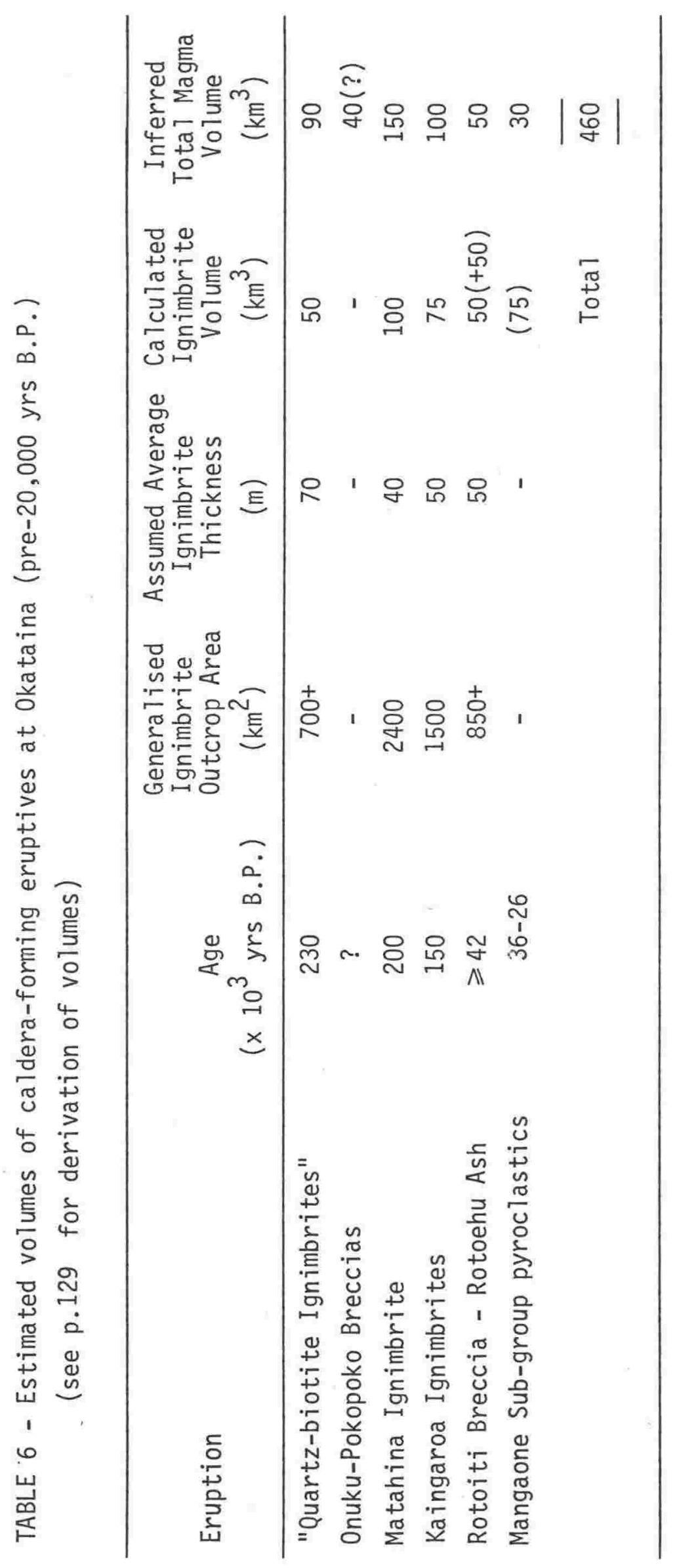




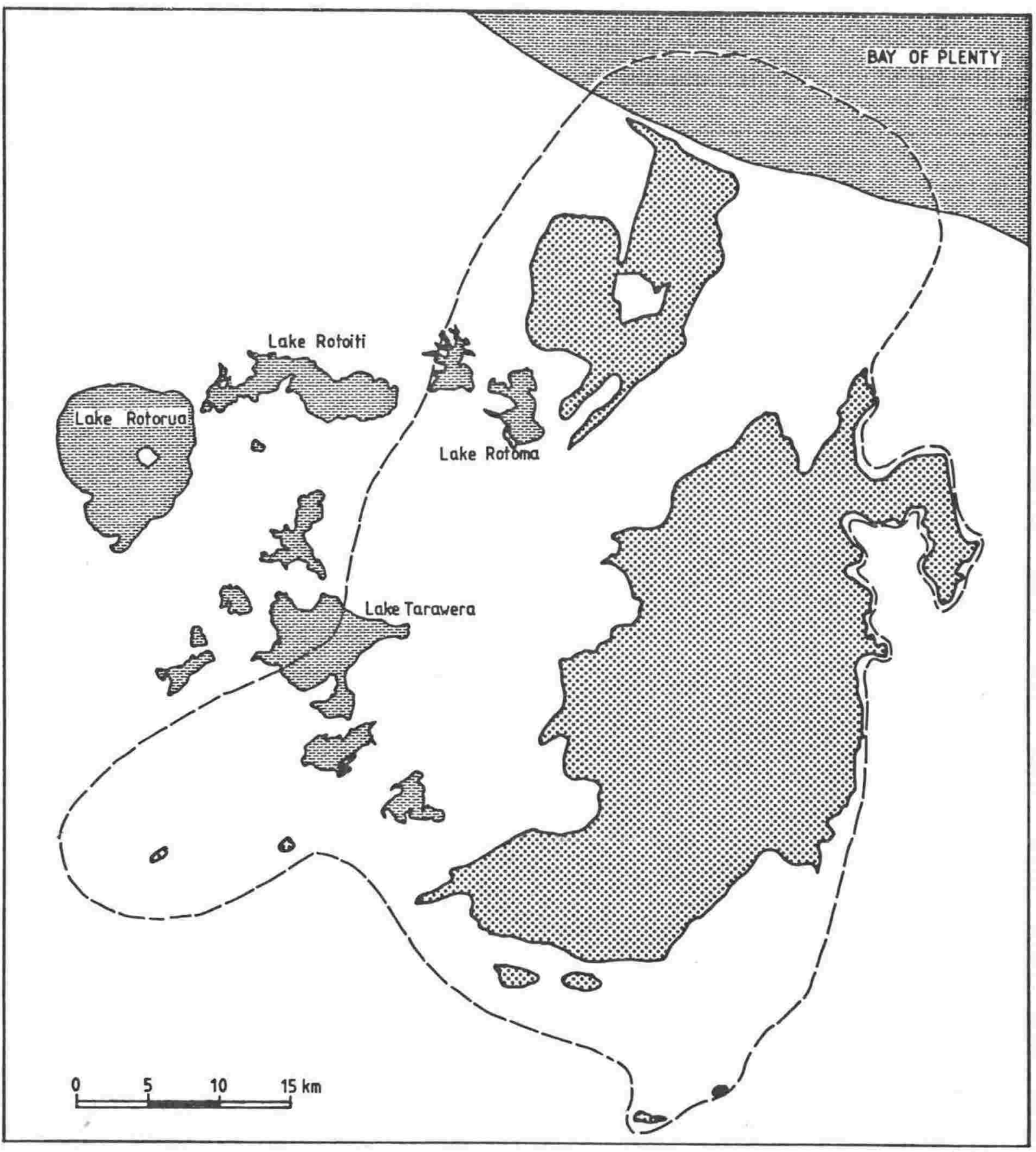

FIG. 27 - Areas of present Matahina Ignimbrite outcrop, shown by dot stipple, with an estimate of original extent shown by dashed line. 
deposits (Nairn 1972), as is the airfall Mazama Ash to the Crater Lake pyroclastic flows (Williams and Goles 1968). Bailey et al (1976) estimated that the extracaldera volumes of airfall Bishop Ash and Bishop Tuff pyroclastic flow deposits were $300 \mathrm{~km}^{3}$ and $140 \mathrm{~km}^{3}$ respectively. A 1:1 ratio of fall to flow deposits would indicate a total pyroclastic volume of c. $200 \mathrm{~km}^{3}$ for the Matahina Ignimbrite. A further unknown factor is the volume of tuff which accumulated within the caldera during the Matahina Ignimbrite eruptions. Bailey et al (1976) consider that two thirds of the Bishop Tuff accumulated in the subsiding Long Valley Caldera. If a similar relationship holds for the Matahina Ignimbrite, the total pyroclastic flow volume would be $300 \mathrm{~km}^{3}$. Thus estimates for the total erupted volume of Matahina Ignimbrite and associated airfall ash range from $>84 \mathrm{~km}^{3}$ to $400 \mathrm{~km}^{3}$. Pyroclastic volumes are converted to equivalent magma volumes as follows. Specific gravities of Matahina Ignimbrite cores (Hole 72 - Matahina Dam Site Ewart 1965) range from 1.66 to $2.22 \mathrm{~g} \mathrm{~cm}^{-3}$ at depths between 23 and $140 \mathrm{~m}$, and average $2 \mathrm{~g} \mathrm{~cm}^{-3}$. Assuming a magma density of $2.3 \mathrm{~g} \mathrm{~cm}^{-3}$ (Bottinga and Weill 1970) the rounded outline pyroclastic flow volume $\left(100 \mathrm{~km}^{3}\right)$ is equivalent to $87 \mathrm{~km}^{3}$ of magma. The inferred equal volume of airfall ash of assumed density $1.0 \mathrm{~g} \mathrm{~cm}^{-3}$ is equivalent to $43 \mathrm{~km}^{3}$ of magma, for a total magma volume of $\mathrm{c} .130 \mathrm{~km}^{3}$. This is probably a minimum as it makes no allowance for intracaldera tuff. An inferred erupted magma volume of order $150 \mathrm{~km}^{3}$ (Table 6) seems reasonable for the Matahina Ignimbrite.

Volume estimates are made on a similar basis for the "quartzbiotite" and Kaingaroa Ignimbrites, although even less dimensional data are available for these deposits.

The "quartz-biotite ignimbrites" are between 30 and $90 \mathrm{~m}$ thick where drilled in Waiotapu Geothermal Field (Martin 1961, Grindley 1963, Briggs 1973); c. $100 \mathrm{~m}$ of an apparent correlative has been drilled in well KA22 at Kawerau Geothermal Field (Nairn, unpublished well log, Browne 1978); $75 \mathrm{~m}+$ is exposed in sections on the Mangaharakeke Stream in northern Kaingaroa Forest (Healy 
1959); and $60 \mathrm{~m}+$ is exposed in the Mangawhio Stream to east of Puhipuhi Basin (see p. 17). A rounded outline drawn to include these outcrop areas encompasses $700 \mathrm{~km}^{2}$, but the ignimbrite clearly covered a much greater area, although it has not been identified elsewhere. Assuming an average thickness of $70 \mathrm{~m}$ the outcrop area is equivalent to a minimum ignimbrite volume of $50 \mathrm{~km}^{3}$. Equating this volume to the $84 \mathrm{~km}^{3}$ estimated under the same conditions for the Matahina Ignimbrite, the inferred erupted magma volume appears likely to be of order 90 $\mathrm{km}^{3}$ (Table 6).

The Kaingaroa Ignimbrites cover a present rounded outline area of $1500 \mathrm{~km}^{2}$. Total thickness on the Kaingaroa Plateau is c. $60 \mathrm{~m}$; the lower "sandy black" member is more than $120 \mathrm{~m}$ thick in Puhipuhi Basin, and exceeds 50 m near Kawerau. Assuming an average thickness of $50 \mathrm{~m}$, the ignimbrite volume is $75 \mathrm{~km}^{3}$. Making the same assumptions regarding associated airfall pyroclastic deposits and intracaldera tuff as for the Matahina Ignimbrite, the Kaingaroa magma volume would approximate $100 \mathrm{~km}^{3}$.

The Onuku and Pokopoko Breccia deposits reach considerable thicknesses on the margins of the O.V.C.; i.e. $120 \mathrm{~m}+$ at Lake Okataina and to north-west of Lake Rotoiti (Thompson 1974); $60 \mathrm{~m}$ at Rerewhakaaitu to south of the O.v.C. (Nairn 1973). However, so little is known about the widespread distribution of these deposits that no realistic volume estimates can be made from areal extent. An arbitrary minimum magma volume of $40 \mathrm{~km}^{3}$ (Table 6) is assigned to the Onuku and Pokopoko Breccias, by comparison with the somewhat similar Mangaone Sub-group pyroclastics, which are thinner near source and have an equivalent magma volume of c. $40 \mathrm{~km}^{3}$.

Erupted volumes of $\geqslant 50 \mathrm{~km}^{3}$ for both the Rotoiti Breccia and Rotoehu Ash have been calculated (Nairn 1972, Pullar 1972). Assuming an average density of 1.25 for the pyroclastic flow deposit and $1.0 \mathrm{~g} \mathrm{~cm}^{-3}$ for the fall deposits, the pyroclastic volumes are equivalent to $c .50 \mathrm{~km}^{3}$ of magma. This estimate 
is probably a minimum as it makes no allowance for intracaldera tuff.

Howorth (1975) estimated a total erupted volume of c. $75 \mathrm{~km}^{3}$ for the Mangaone Sub-group pyroclastics, equivalent to a magma volume of $30 \mathrm{~km}^{3}$ if an average deposit density of $1.0 \mathrm{gm} \mathrm{cm}^{-3}$ is assumed.

Intracaldera Eruptives (post-20,000 yrs B.P.)

Volumes of the post-20,000 yrs B.P. intracaldera lavas and pyroclastics at Okataina are shown in Table 7. The eruptives at Okareka and Rotoma are included within the Haroharo volume estimates. Pyroclastic volumes are modified from Pullar (1972, 1973), with addition of proximal pyroclastic flow and surge deposits. Lava volumes have been estimated from measured areas and averaged thicknesses. Often, only minimum thickness data is available for the lavas.

The volume of magma erupted from the Haroharo vent lineation during the past 20,000 years is about twice that from the Tarawera vent lineation. The total erupted volume from O.V.C. during this period is c. $80 \mathrm{~km}^{3}$ magma.

Eruption Rates

The inferred magma volumes erupted from O.V.C. between c. 230,000 and 26,000 yrs B.P. total $460 \mathrm{~km}^{3}$ (Table 6), equivalent to an average magma eruption rate of $2.3 \mathrm{~km}^{3}$ per 1000 years. The much better controlled estimate of $80 \mathrm{~km}^{3}$ of magma erupted from O.V.C. during the last 20,000 years is equivalent to average emission of $4 \mathrm{~km}^{3}$ per 1000 years. These rates are sufficiently similar to suggest that the estimate of pre-20,000 years B.P. erupted magma volume is of the correct order, despite the gross assumptions made in its calculation. Most of this magma volume probably originated from the central area of Haroharo Caldera, where the overlap of inferred sub-caldera structures ( see p. 331 ) defines a deeply-subsided cauldron with area of $150 \mathrm{~km}^{2}$. Eruption of c. $500 \mathrm{~km}^{3}$ of magma from this area would produce a drawdown of $3.3 \mathrm{~km}$ in an underlying magma body. Such a depth 


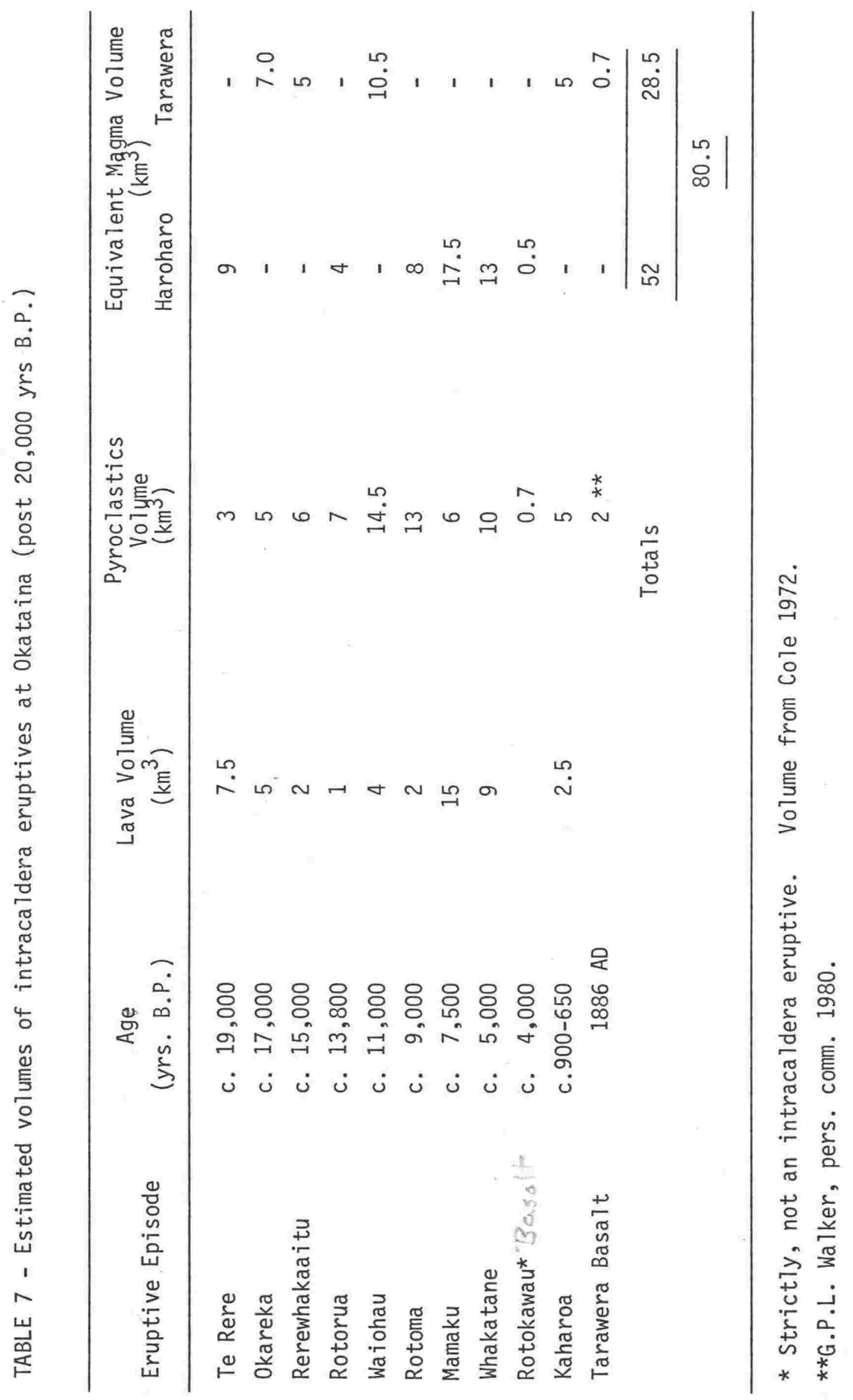


of collapse is consistent with the extent of basement subsidence estimated from geophysical evidence (i.e. Rogan 1980). 
PART II

ERUPTIVE HISTORY OF OKATAINA VOLCANIC CENTRE AND EFFECTS ON REGIONAL DRAINAGE 


\section{A: SYNTHESIS OF ERUPTIVE HISTORY}

Introduction

The history of Okataina Volcanic Centre is considered here under three headings: (1) the early caldera-forming eruptions preceding the Rotoiti Breccia, (2) the Rotoiti Eruptive Episode, and (3) the post-Rotoiti Breccia eruptions. Due to lack of good exposure, relatively little is known about the pre-Rotoiti Breccia eruptions and they have not been investigated in detail.

Haroharo Caldera had largely reached its present size following eruption of the Rotoiti Breccia, although some further modification may have accompanied the Mangaone Subgroup eruptions. Subsequent eruptions at Okareka, Haroharo, and Tarawera have largely infilled the caldera without greatly altering its margins.

\section{Eruptive Episodes}

The synthesis of volcanic history presented here for the Rotoiti Breccia and younger eruptions is based on the concept of the "eruptive episode". This concept is implicit in the earlier stratigraphic studies of Vucetich and Pullar (1964, 1969) and in the Tarawera eruptive history and volcanic formations described by Cole (1970a, b). Kohn (1970, 1973) showed that Tarawera lavas and pyroclastics from the same "eruptive episode" had similar titanomagnetite compositions.

The widespread pyroclastic fall deposits from O.V.C. commonly form separate stratigraphic formations in distal sections, and are delineated by paleosols developed within the upper parts of each deposit. Individual pyroclastic fall formations are inferred to represent the products of "short-lived eruptive episodes" (The Royal Society of New Zealand, 1977), separated by long periods of quiescence during which paleosols are developed within the upper part of each deposit.

In near-vent sections within O.V.C., the pyroclastic fall deposits of each eruptive episode are interbedded with 
local pyroclastic flow and surge deposits, and associated lavas, to form much thicker and more complex multiple-bedded deposits. Lavas commonly form the final eruptive phase of each episode. In each case, no weathering, or major erosional breaks are recognised within the proximal deposits of each eruptive episode, so that episode duration generally appears to have been very short (of order $<100$ years, say), in comparison to the quiescent intervals between eruptive episodes ( $>1000 \mathrm{yrs}$ ), represented by the paleosols.

Very commonly at Okataina the eruptives of each episode originated from multiple vents widely separated along underlying fissures. The eruptives from individual vents are either interfingering, or form conformably sequential deposits, without evidence of significant intervening time intervals. Detailed descriptions of some individual eruptive episodes are contained in later sections of this thesis, but the concept is illustrated by the Mamaku Eruptive Episode. During this episode, lavas and pyroclastics were erupted from at least 5 distinct magmatic vents and one phreatic vent, spread along $14 \mathrm{~km}$ of an underlying eruptive fissure. No major apparent time breaks separate the various eruptives from these vents, and ${ }^{14} \mathrm{C}$ dates available for pyroclastic deposits from two vents are not significantly different (see Table 2). Similarly a lava flow and a pyroclastic surge of the Rotoma Eruptive Episode were erupted from vents $7 \mathrm{~km}$ apart and have given ${ }^{14} \mathrm{C}$ dates of $9080 \pm 100$ and 9120 \pm 130 yrs B.P. respectively. In contrast, stratigraphically consistent ${ }^{14} \mathrm{C}$ ages from beds within the Kaharoa pyroclastics suggest an extended eruptive episode duration approaching 300 years (see p. 219).

Based on this concept, the late Quaternary eruptive deposits from O.V.C. have been separated into 19 distinct eruptive episodes, between and including the Rotoiti Eruptive Episode at $\geqslant 42,000$ yrs B.P., and the 1886 A.D. Tarawera eruption. Durations of each eruptive episode are uncertain, but most appear to be distinguishable by ${ }^{14} \mathrm{C}$ dating. 


\section{Early Volcanism}

The earliest events at O.V.C. were the extrusion of ha1 rhyolite lavas now outcropping on the Okataina Ring Structure in the northern part of the Centre. These lavas were probably extruded from ring dikes marking planes of weakness above magma bodies, both prior to and following eruption of the "quartz-biotite ignimbrites". No trace remains of older lavas which probably lay within the central area of later collapse. The exact age of the ha1 rhyolites has not been established. Matahina Ignimbrite and Onuku Breccia overlie the ha1 rhyolites at Rotoma. Mamaku Ignimbrite and Pokopoko Breccia overlie the western ha1 rhyolites between Okareka and Whakapoungakau. Similar dissection suggests that all these rhyolites are likely to predate the Matahina Ignimbrite and underlying Onuku Breccia, but contacts with the Rangitaiki Ignimbrites are nowhere exposed and the relationship between the "quartz-biotite ignimbrites" and the ha1 rhyolites is uncertain. In Kawerau Geothermal Field, quartz-biotite tuffs (which probably correlate with the "quartz-biotite ignimbrites") are interbedded with rhyolite lavas, and a similar stratigraphic sequence is assumed at O.V.C.

The "quartz-biotite ignimbrites" are the first widespread pyroclastics which can be associated with formation of Haroharo Caldera. The full extent of their distribution is unknown but the mapped outcrops and apparent distal correlatives suggest a source in southern O.V.C. The "quartz-biotite ignimbrites" appear to be interbedded with the Rangitaiki Ignimbrites erupted from Taupo Volcanic Centre, suggesting the possibility of closely spaced or even simultaneous eruptions from these two centres at about 230,000 yrs B.P.

Multiple eruptions of the pyroclastic flow and fall deposits of the Onuku and Pokopoko Breccias followed after a period of erosion and weathering of the upper Rangitaiki Ignimbrites. Thickest known breccia deposits to east and 
south of O.V.C. suggest eruptive sources close to the eastern margin of Haroharo Caldera, near the present Lakes Okareka, Okataina, and Tarawera, and probably on the Haroharo basement fracture. The large (if uncertain) volumes of these breccias suggests that caldera subsidence also accompanied these eruptions.

A further period of quiescence and erosion of the Onuku Breccia followed, prior to eruptions at about 200,000 yrs B.P. of the Matahina Ignimbrite from the eastern margin of O.V.C., possibly from (or close to) Puhipuhi Basin, which subsided as a result. The ignimbrite flowed into the fault angle depression between Kaingaroa Plateau and the greywacke Ikawhenua Range over which it lapped, and north to the Bay of Plenty coast. Small volumes flowed south-west into the Rotorua-Taupo Graben where remnants are still preserved.

A lake occupied Puhipuhi Basin following its collapse. Lacustrine sediments were deposited, and later intruded, altered, and probably uplifted by Puhipuhi Dacite, which also formed a small cone near the centre of the basin.

Eruption of the Kaingaroa Ignimbrites from southern Haroharo Caldera followed at about 150,000 yrs B.P., probably from vents associated with the major basement fracture under Tarawera. The ignimbrite eruptions had been preceded by extrusion of a lowsilica andesite which was incorporated as lithic clasts within the ignimbrite deposits. All the outcropping intermediate-basic volcanics of the O.V.C. occur on the Tarawera vent lineation, so the presence of andesite xenoliths supports a Tarawera source location for the Kaingaroa Ignimbrites. The Kaingaroa Ignimbrite flowed mainly to south of O.V.C., across the Kaingaroa Plateau and into the Reporoa Basin from where large volumes have since been stripped by erosion. Flows to north-east filled eastern Puhipuhi Basin and crossed the ha1 rhyolites to north, to spread into the Kawerau area and to north of Lake Rotoma. Other flows went south-east into the Taupo-Rotorua Graben, to reach the Maroa Volcanic Centre. 
Considerable collapse of the southern half of Haroharo Caldera accompanied the Kaingaroa Ignimbrite eruptions so that the present caldera margins were largely established, with a southern boundary extending from Rerewhakaaitu through Waimangu north-west towards the Tikitapu area. Rhyolites (ha2) of the Hapeotoroa, Tutaeheka and Moerangi massifs were later extruded on or close to the south-western caldera margin before the Mamaku Ignimbrite was erupted at c. 140,000 yrs B.P. from the adjacent Rotorua Caldera. Most of the Mamaku Ignimbrite flowed to north and east of Rotorua, but some passed east over eroded Pokopoko Breccia between older (ha1) rhyolites to cross the eastern margin of Haroharo Caldera. Remnants are preserved on the western and southern shores of Lake Tarawera. Continued growth of the Moerangi rhyolite domes was accompanied by pyroclastic eruptions which flowed over the Mamaku Ignimbrite surface to east of Lake Okareka.

A major quiescent interval, possibly as long as 100,000 yrs B.P. followed the Kaingaroa Ignimbrite eruptions. During this period no major pyroclastic emptions are recognised from the O.V.C. Strongly weathered distal tephras from other volcanic centres accumulated above the Mamaku Ignimbrite, until eruption of the Rotoiti Breccia Formation commenced the major period of caldera activity which continues to the present day.

Rotoiti Eruptive Episode

Some aspects of the Rotoiti Eruptive Episode are discussed in the following manuscript, intended for publication. Submission of the manuscript awaits receipt of further ${ }^{14} \mathrm{C}$ dates (using isotope enrichment techniques) which are required to confirm age of the Rotoiti Breccia. An important part of this manuscript is a discussion of Walker's (1979) interpretation of the origin of the Rotoehu Ash. 
SOURCE, AGE, AND ERUPTIVE MECHANISMS OF THE ROTOEHU ASH, OKATAINA VOLCANIC .CENTRE, NORTH ISLAND, NEW ZEALAND

\section{I.A. Naim}

Geology Dept., Victoria University, Wellington

\section{ABSTRACT}

Rotoehu Ash is a very widespread, prominently showerbedded, generally finely divided and crystal rich pyroclastic fall deposit (>50 $\mathrm{km}^{3}$ volume) which underlies, is interbedded with, and mantles the voluminous $\left(>50 \mathrm{~km}^{3}\right.$ ) unwelded pyroclastic flow (ignimbrite) deposits of the Rotoiti Breccia. Rotoiti Breccia has been ${ }^{14} \mathrm{C}$ dated at $\geqslant c .42,000$ yrs B.P. The Rotoiti Eruptive Episode followed a long period of quiescence at Okataina Volcanic Centre. Distribution of the Rotoehu Ash demonstrates a plinian eruption style, but the grain size of fall units is generally much finer than in most plinian deposits. Although it has been previously suggested that all or part of the Rotoehu Ash was generated by littoral explosions when Rotoiti Breccia pyroclastic flows entered the sea, the dispersal and grain size data available can also be interpreted as indicating eruption of the Rotoehu Ash-Rotoiti Breccia from a common fissure source in Haroharo Caldera. The fine grained nature of much of the Rotoehu Ash demonstrates a high degree of magma fragmentation, perhaps produced initially by intense vesiculation of the upper magma body prior to eruption, followed by interaction between the erupting magma and caldera-lake water. However produced, the crystal-rich ash requires efficient sorting to remove a large part of the fine vitric component of the erupted pyroclastic assemblage, which is probably more closely represented by the pyroclastic flow deposits produced by en masse column collapse. The good sorting and wide distribution of the Rotoehu Ash are consistent with dispersal from a very high eruption column, perhaps with considerable atmospheric turbulence. 


\section{INTRODUCTION}

Rotoehu Ash is a prominently shower bedded rhyolite pyroclastic fall deposit first named by Vucetich and Pullar (1969) who showed it to be closely associated with pyroclastic flow deposits of the late Quaternary Rotoiti Breccia (Healy et al 1964). Nairn (1972) demonstrated that the Rotoehu Ash consists of multiple fall units which underlie, are interbedded within, and mantle the main bulk of the Rotoiti Breccia flow deposits. Rotoehu Ash is of considerable stratigraphic importance as it forms one of the two most widespread late Pleistocene tephra marker beds in New Zealand (see Pullar 1973), with a distribution pattern that indicates original dispersal over at least most of the North Island. The Rotoiti BrecciaRotoehu Ash episode at $\geqslant c .42,000$ yrs B.P. ( ${ }^{14} \mathrm{C}$ date) was also the initial and largest eruption of the present major eruptive sequence from Haroharo Caldera in the Okataina Volcanic Centre (Fig. 1), and followed a long period of relative quiescence. The last previous major eruption from Haroharo Caldera was that of the Kaingaroa Ignimbritesat c. 150,000 yrs B.P. (B.P. Kohn pers. comm.). An erupted volume for Rotoiti Breccia-Rotoehu Ash exceeding $100 \mathrm{~km}^{3}$ has been estimated (Nairn 1972).

Distribution of the Rotoiti Breccia pyroclastic flows (Fig. 1) indicates they were erupted from vents in northern Haroharo Caldera (Ewart and Healy 1965; Ewart 1968; Cole and Nairn 1975), now covered by younger rhyolite lavas of the Haroharo Volcanic Complex. The coeval Rotoehu Ash was presumably erupted from the same source area (Vucetich and Pullar 1969; Nairn and Kohn 1973). Recently, Walker (1979) has suggested that part or all of the Rotoehu Ash originated not at source of the Rotoiti Breccia pyroclastic flow deposits, but from huge steam explosions at littoral sites where the pyroclastic flows entered the sea.

This paper describes detailed stratigraphy and lithology of Rotoehu Ash in the near-source region, e.g. the area including and adjacent to the Rotoiti Breccia deposits (Fig. 1). 


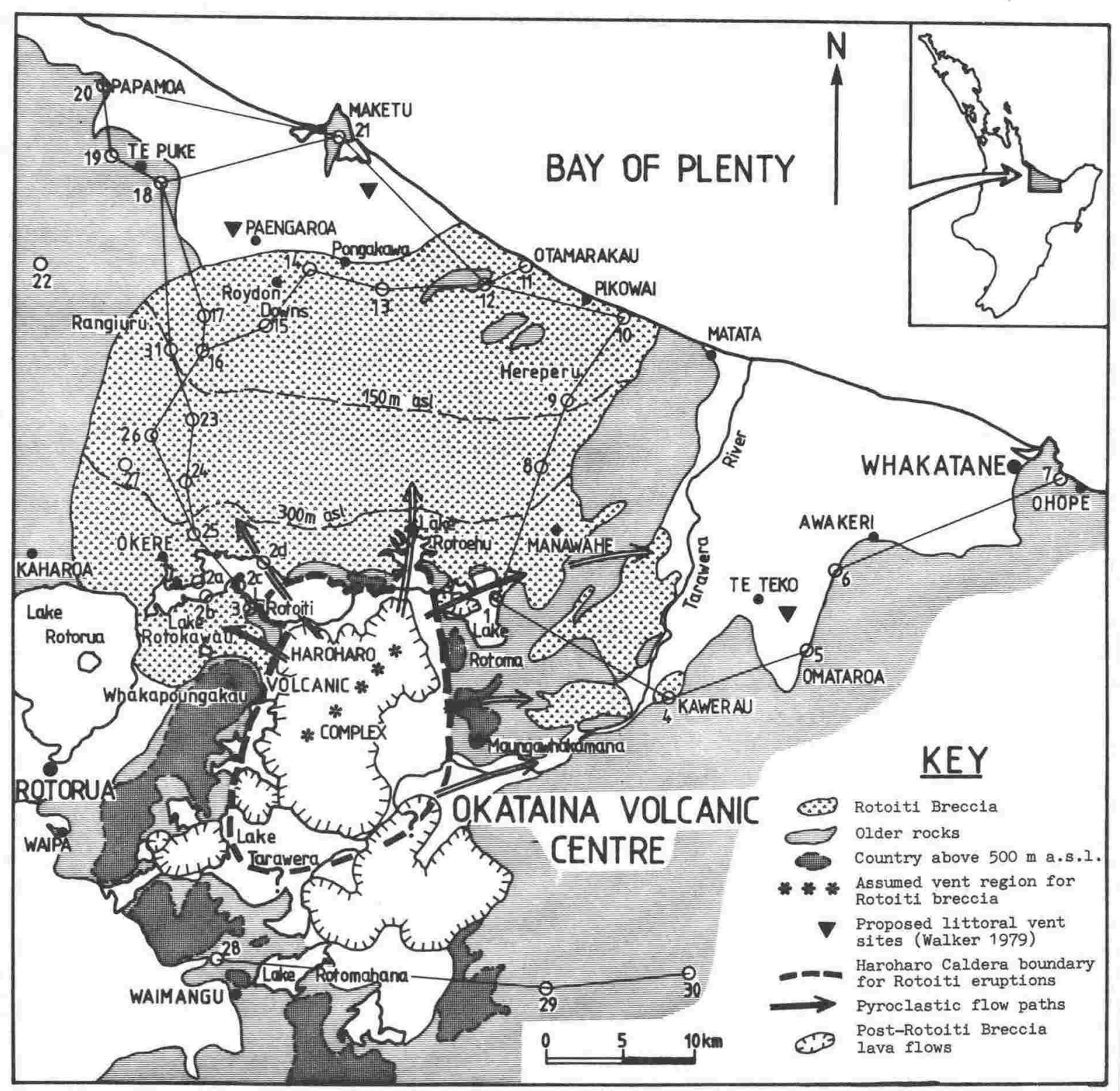

FIG. 1 - Distribution of Rotoiti Breccia pyroclastic flows erupted from vents in northern Haroharo Caldera, and locations of Rotoehu Ash sections described in this paper. Transect lines connect Rotoehu Ash sections. Non-stippled areas indicate rocks younger than Rotoiti Breccia. 
The eruption mechanisms and location of the Rotoehu Ash source are discussed, and an alternative hypothesis to that of Walker (1979) is presented.

\section{ROTOEHU ASH STRATIGRAPHY AND LITHOLOGY}

Rotoehu Ash consists of at least 35 fall units. No single section exposes all units. A sequence shown schematically in Fig. 2 is assembled from the most complete exposures of fall units which underlie and are interbedded with Rotoiti Breccia flow units at Lake Rotoma ( $\mathrm{S} 1$, = section 1 on Fig. 1), together with fall units which overlie the Breccia at Roydon Downs (S15). More distant reference sections sited beyond the Breccia fan at Omataroa (S5) and Ohope (S7) expose apparently complete sequences through the local fall deposits (Figs. 3 \& 4). The only section presently known to the writer of a complete Rotoehu AshRotoiti Breccia sequence occurs $20 \mathrm{~km}$ north of Haroharo at Otamarakau (S12), where the mantling and underlying Rotoehu Ash fall units are separated by up to $20 \mathrm{~m}$ of Rotoiti Breccia (Fig. 5). At distal sections, contacts between all fall units are conformable (Fig. 4), indicating lack of major time breaks during the eruption sequence (see also Naim 1972), but fall units in several near-source sections (e.g. S2c, 8) were strongly eroded by subsequent pyroclastic flows.

In this paper, the Rotoehu Ash fall units underlying, interbedded with, and mantling the Rotoiti Breccia are designated Re1, Re2, and Re3 respectively (see Fig. 2).

Two hundred samples from the coarsest part of fall units at the reference and other sections have been sieved following standard techniques (Folk 1974; Walker 1971) using a one phi $(\phi)$ interval sieve set between $64 \mathrm{~mm}(-6 \phi)$ and $1 / 16 \mathrm{~mm}(+4 \phi)$. Fractions $>4 \mathrm{~mm}$ were hand sieved; split fractions $<4 \mathrm{~mm}$ were screened on an Endecott sieving machine for five minutes. Statistical parameters of Median Ma $\varnothing=\varnothing 50$, Graphic Mean Mz $=$ $(\varnothing 16+\phi 50+\phi 84) / 3$, Graphic Standard Deviation $\sigma \varnothing=(\not 84-\not 16) / 2$ 
FIG. 2 - (Over page). Schematic section through Rotoehu Ash (and Rotoiti Breccia) compiled from sections at Lake Rotoma (S1), Omataroa (S5), Pa Road (S8), and Roydon Downs (S15). Size analysis histograms of pyroclastic fall and flow units are numbered as in the section, and are separated into pumice, crystal and lithic components. $X$ is crystal content. 

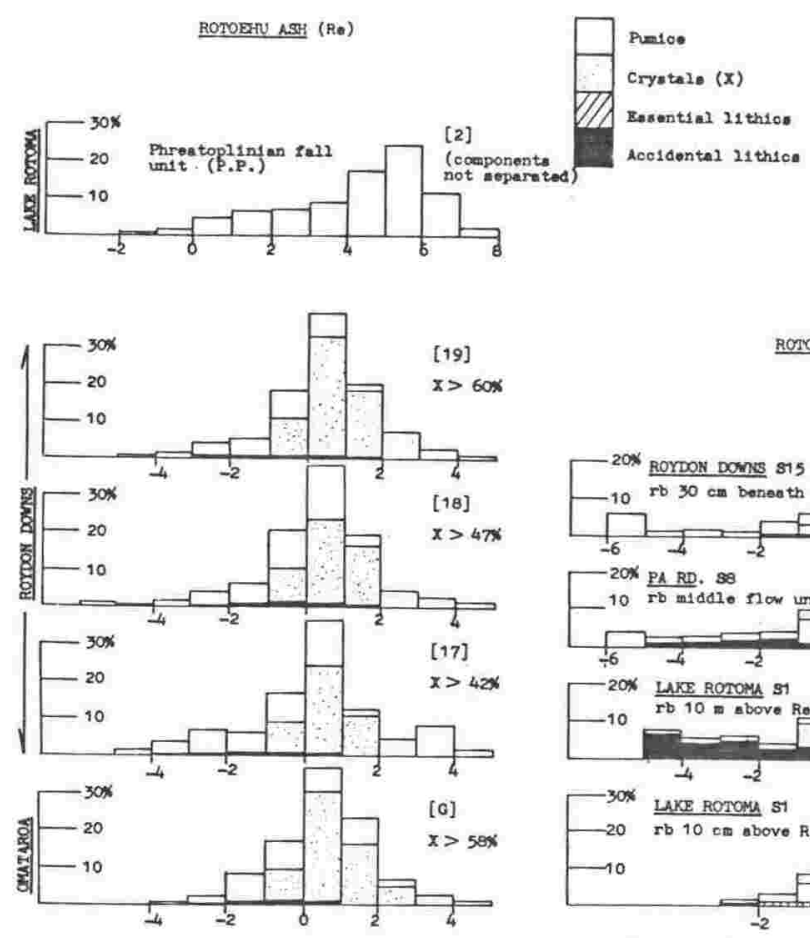

ROTOITI BRPCCIA ( $\mathrm{rb}$ )
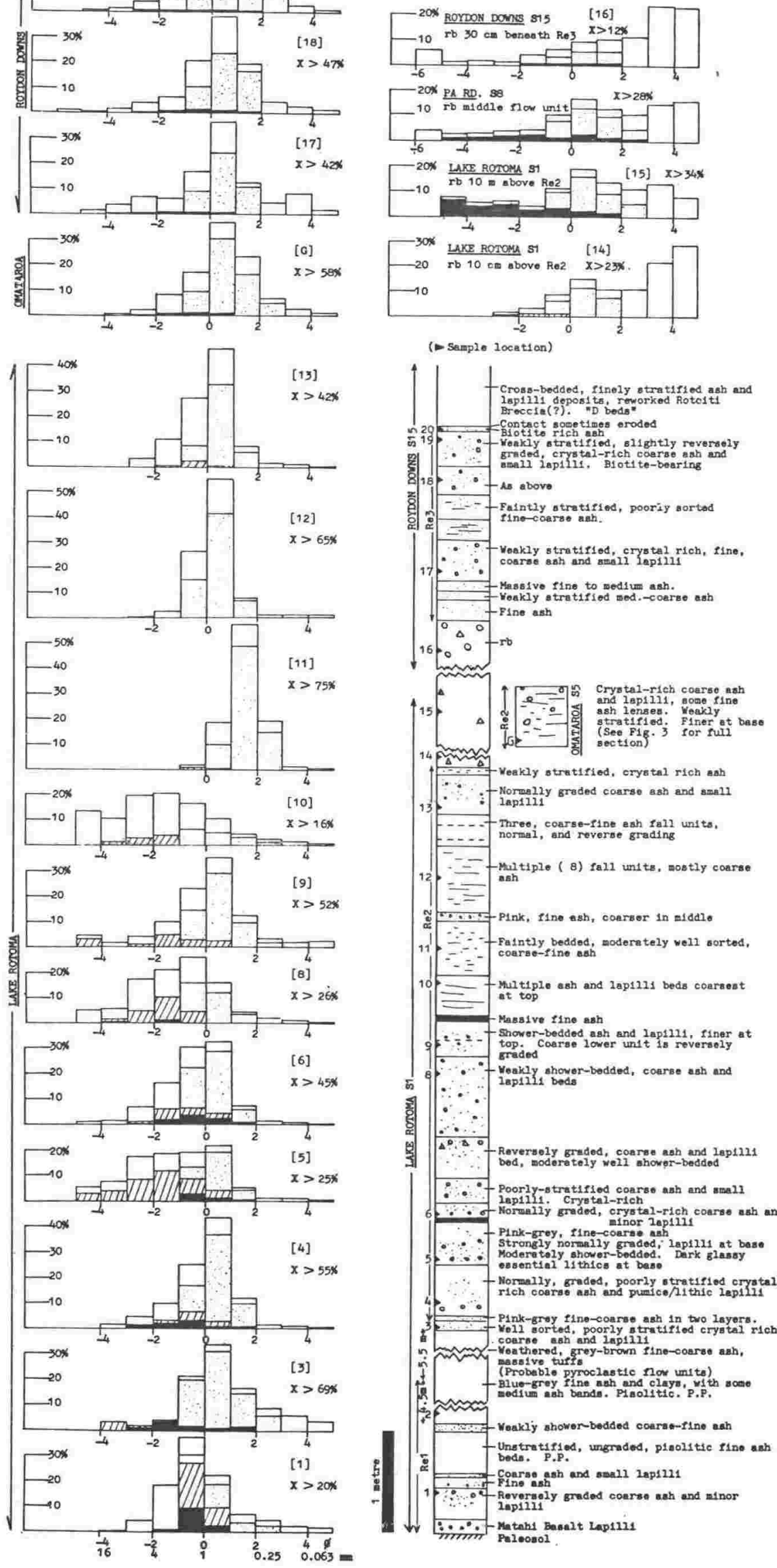

14 㱐的

Veakly stratified, oryatal rich ash

- Norasily graded cosiso ash and $\sin 21$

\begin{tabular}{|lll}
\hline$\ldots-1$ Treo, coarse-fine esh fall units. \\
normal, and reverse grading
\end{tabular}

Multiple (8) fall units, mostly coarse

PInk, Iine ash, coarber in middlo

$11 .-7$ - Fantly bedded, modera tely well sorted,

10 coerse-fine esh

三- Mit tiplo

- Massive fine abh

of-- - Shower-bedded ash and lapill1, finer at

8 …- - Voak1y shover-bodded, coarse ash and

5

혼

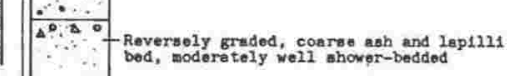

- poorly-stratiriod coarso ash and asse11

$\therefore$ of Normiliy graded, orystal-rich coarse ash and

- Pink-grey, Iine-coaras ash

50 Moderetoly shower-bodded. Dapll11 at bas

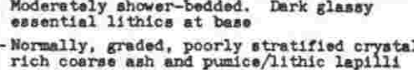

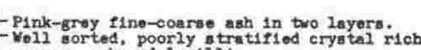

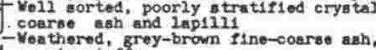

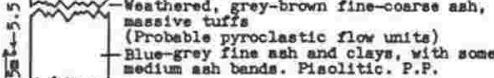

- Weakly shower-bedeed coerat-rine ash

- Ungtratified, ungraded, pioolitic rino sah

Coarso esh and small lapinz1

1 of Reveraily graded coarse wh and alnor

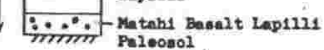



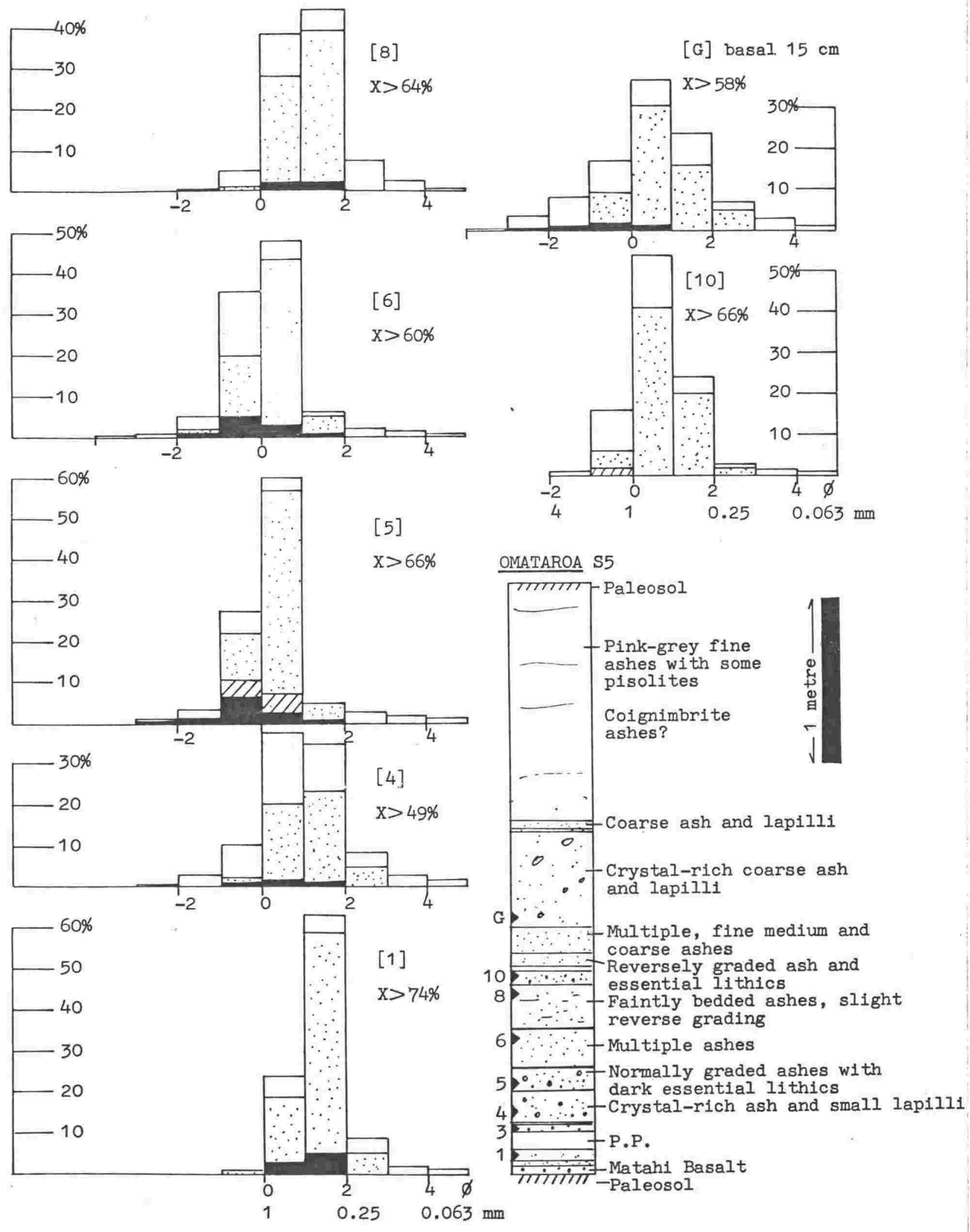

FIG. 3 - Rotoehu Ash at Omataroa (S5), with histograms of individual fall units separated into components as identified in Fig. 2. 

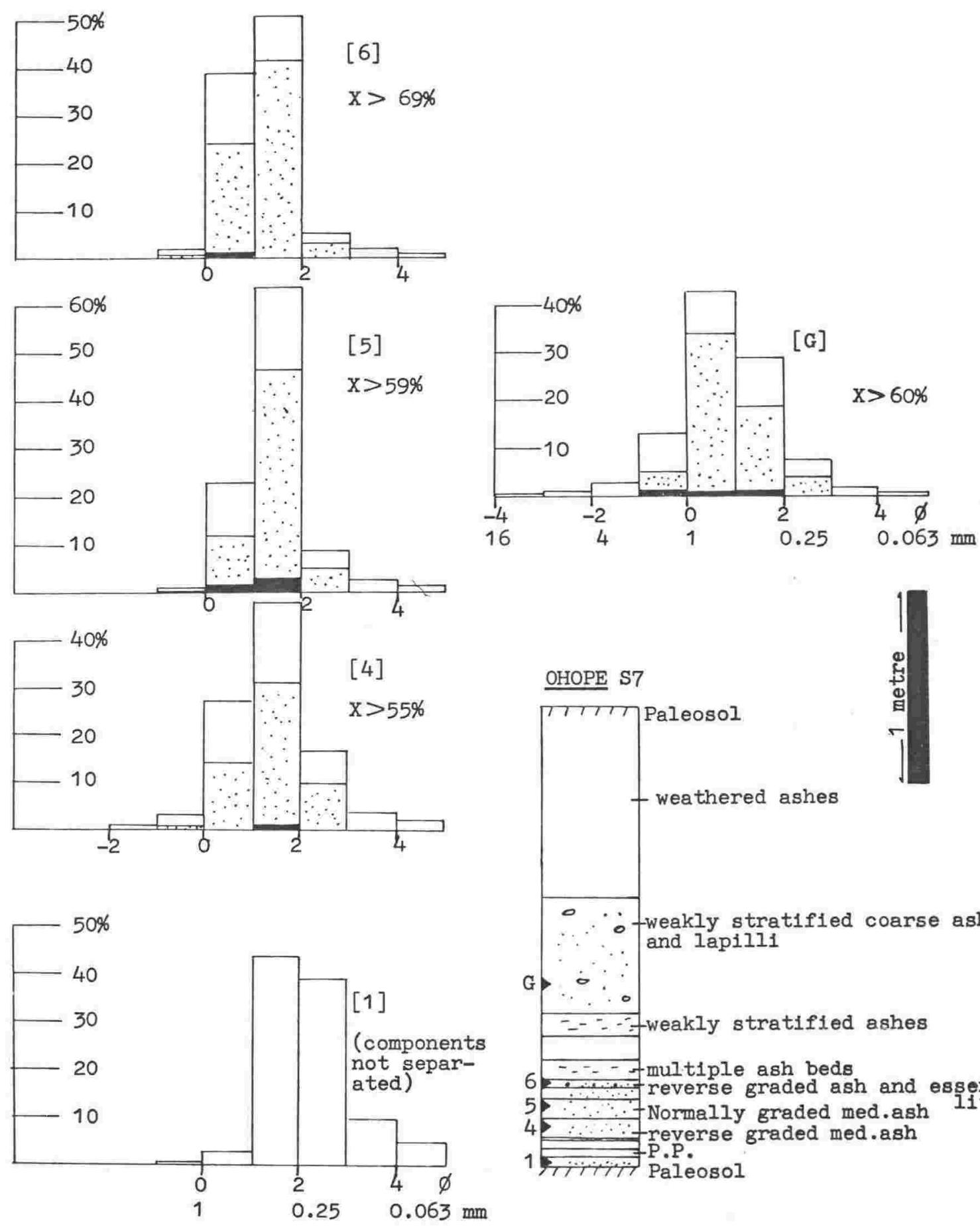

OHOPE S7
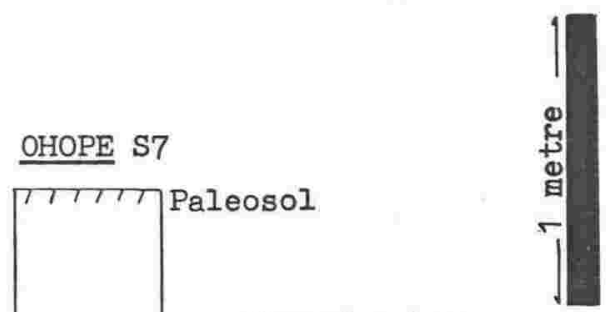

FIG. 4 - Rotoehu Ash at Ohope (S7), with histograms of fall units. 
and Inclusive Graphic Skewness $\mathrm{Sk}_{\mathrm{I}}=\frac{\not 16+\phi 84-2 \phi 50}{2(\varnothing 84-\varnothing 16)}+$ $\frac{\not 5+\varnothing 95-2 \phi 50}{2(\varnothing 95-\varnothing 5)}$ Folk (1974) have been calculated from cumulative curves. Also found useful are parameters of the wt $\%>1 \mathrm{~mm}$, and $\mathrm{C} 5 \%$ (= $\varnothing 5 \mathrm{in} \mathrm{mm}$ ) indicating size of the coarsest fraction of each sample. Size distributions are plotted as histograms in Figs. 2-5, and statistical parameters are presented in Figs. 12 and 13. A complete data list is available from the writer (Appendix 2 in this thesis). The size fraction $<4 \varnothing(<1 / 16 \mathrm{~mm})$ is shown within the $4-5 \varnothing$ interval on each histogram, and thus indicates the sample fraction for which size data are not available. For most Rotoehu Ash samples this fraction is less than $5 \%$ and often about 1-2\%. For Rotoiti Breccia samples the unanalysed fraction can exceed $20 \%$.

Size fractions down to $\frac{1}{4} \mathrm{~mm}$ (or $1 / 8 \mathrm{~mm}$ in some cases) of 50 selected samples have been separated into pumice (including glass shards), free crystals, essential lithics (all of comagmatic eruptive origin), and accidental lithics. Accidental lithics comprise fragments of non-vesiculated, preexisting rocks through which the Rotoehu Ash was erupted. Essential lithics comprise fresh obsidian and glassy to pumiceous lava, here considered to have been erupted as fragments of magma which solidified in the vent. The crystal component consists largely of quartz, plagioclase, amphibole (mainly cummingtonite), orthopyroxene, and magnetite in lower units, with biotite also occurring in upper units. Many fall units are very crystal-rich (see Walker 1979; and Figs. 2-5), containing more than 50 wt $\%$ crystals, although crystal content of the pumice (representing original magma) is about $25 \%$.

The Rotoehu Ash sequence (Fig. 2) commences with Matahi Basalt Lapilli at base (Pullar and Nairn 1972), overlain by Re1 rhyolite ash/lapilli beds and non-stratified, massive "P.P." fine ash beds containing abundant pisolites. The pisolitic beds have widespread distribution as a distinctive, thin, fine ash, but at Lakes Rotoma and Rotoiti they grade up into 
ROTOEHU ASH
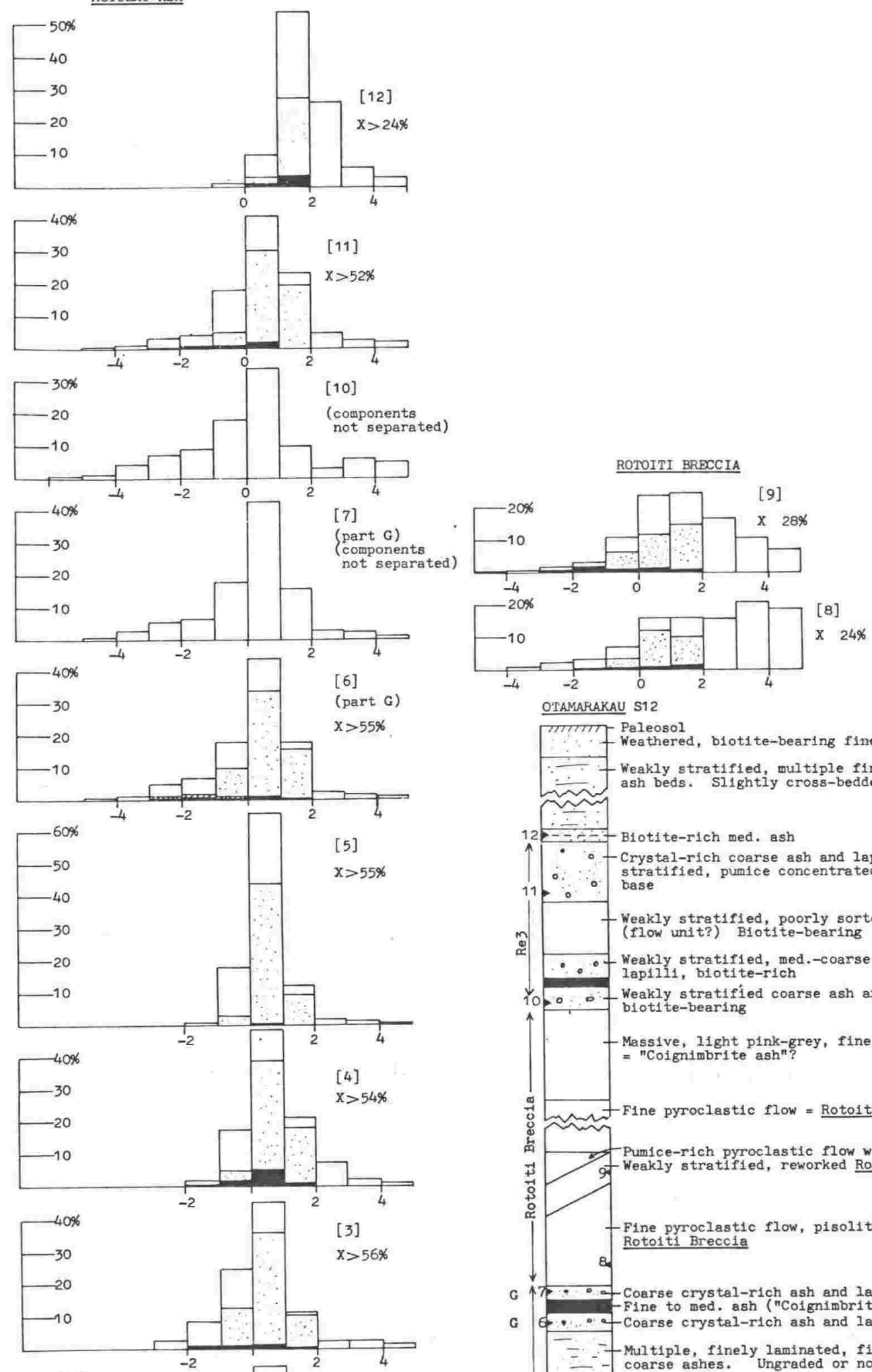

OTAMARAKAU $\$ 12$
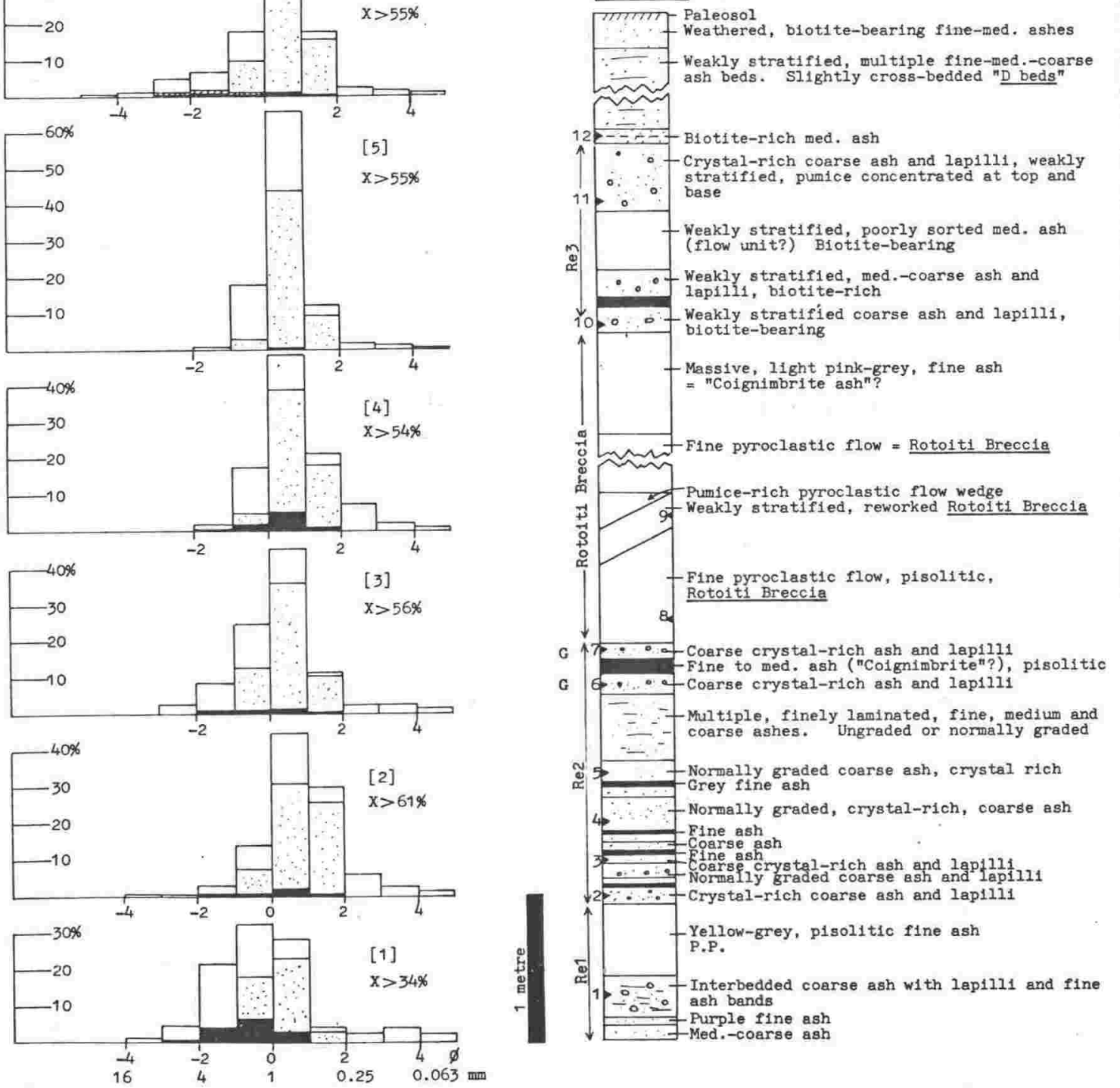

FIG. 5 - Rotoehu Ash and Rotoiti Breccia at Otamarakau (S12) with histograms of fall and flow units. 
fine pyroclastic flow units of relatively limited extent. The airfall P.P. at Paengaroa, $30 \mathrm{~km}$ from source, contains $17 \%$ clay size material $(<0.002 \mathrm{~mm}$ ), with illite, montmorillonite, kaolinite, and allophane identified by XRD and IRA techniques (Nairn 1971). Distinctively shower-bedded Re2 fall units overlie the fine pyroclastic flows, and at Lake Rotoma are c. $5.5 \mathrm{~m}$ thick to base of the main Rotoiti Breccia pyroclastic flows. Many of these Re2 fall units at Rotoma are crystalrich: half of them contain more than 50\% crystals in the $1 / 16 \mathrm{~mm}$ size fractions (Fig. 2). Some fall units are relatively rich in essential lithics, and some lower units in accidental lithics (see Fig. 2).

A particularly coarse, crystal-rich bed of the Re2 sequence is named fall unit "G" by Walker (1979). G is not exposed in sections at Rotoma and Rotoiti, and is also absent from more distant sections to north-west, near okere (S24, 25; Fig. 6), Kaharoa (S27), and Rangiuru (S31; Fig. 6). In all these sections the stratigraphic position of $G$ is occupied by Rotoiti Breccia pyroclastic flows. However G outcrops beneath Rotoiti Breccia in other sections at Kawerau to east (S4; Fig. 7a), Hereperu (S9; Fig. 8), Pikowai (S10; Fig. 8), Otamarakau (S12; Fig. 5), to north-north-east, and Waimangu (S28; Fig. 9) to south. G occurs in nearly all exposures of Rotoehu Ash sited off the Rotoiti Breccia pyroclastic flow fans. In sections to north of Haroharo Caldera, at Maketu (S21; Fig. 6), Otamarakau (S12; Fig. 5), and Hereperu (S9; Fig. 8), G is separated into two parts by a weakly stratified, pisolitic fine ash bed resembling the "co-ignimbrite ash" elutriated from pyroclastic flows (Sparks and Walker 1977). At Woollet Road (S23; Fig. 6) a $70 \mathrm{~mm}$ thick "G-type" crystalrich fall unit is interbedded between Rotoiti Breccia pyroclastic flows, some metres above a similar thin fall unit in the normal stratigraphic position of $G$. These northerm sections suggest that $G$ was deposited in at least two parts, separated by pyroclastic flows. In Fig.2, G is measured and sampled at Omataroa (S5), beyond the pyroclastic flow fan. 


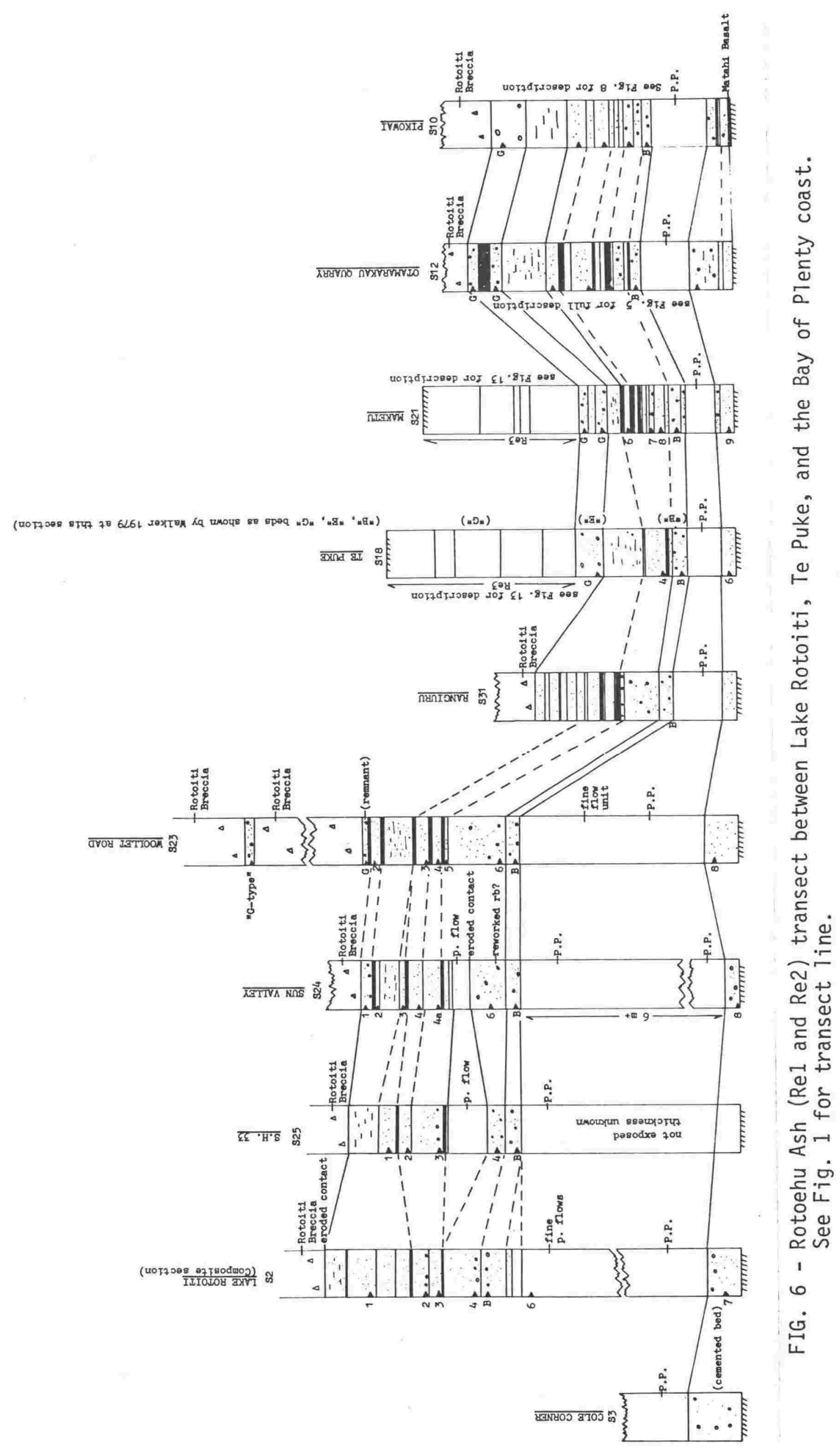


Fall unst 5

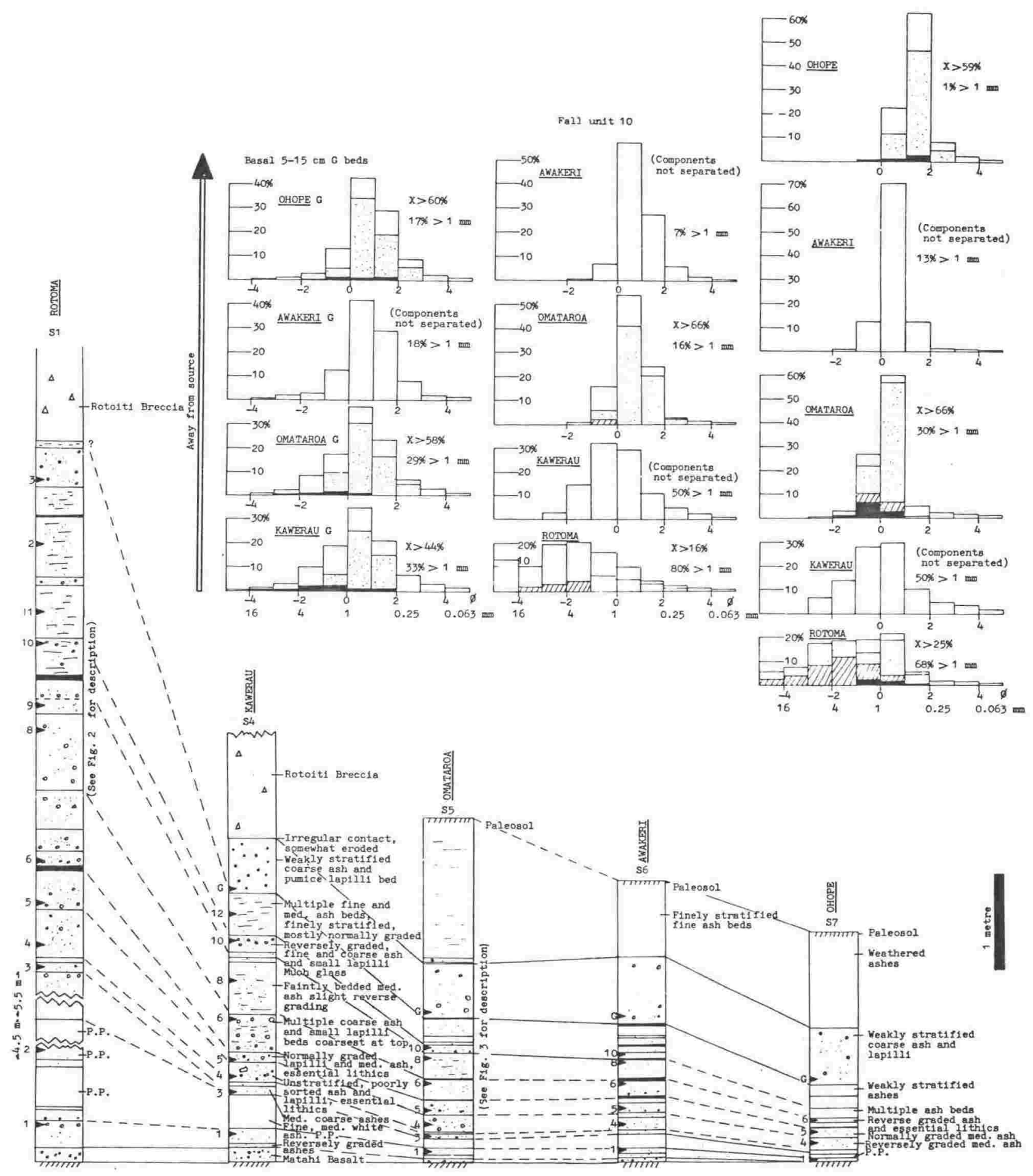

FIG. 7a - Rotoehu Ash transect between Lake Rotoma and Ohope. See Fig. 1 for location of transect line. Also shown are some comparative histograms of individual fall units correlated between the various sections, together with crystal content and \% of total sample larger than $1 \mathrm{~mm}$. 
Fall unit 1

Fall unit 4
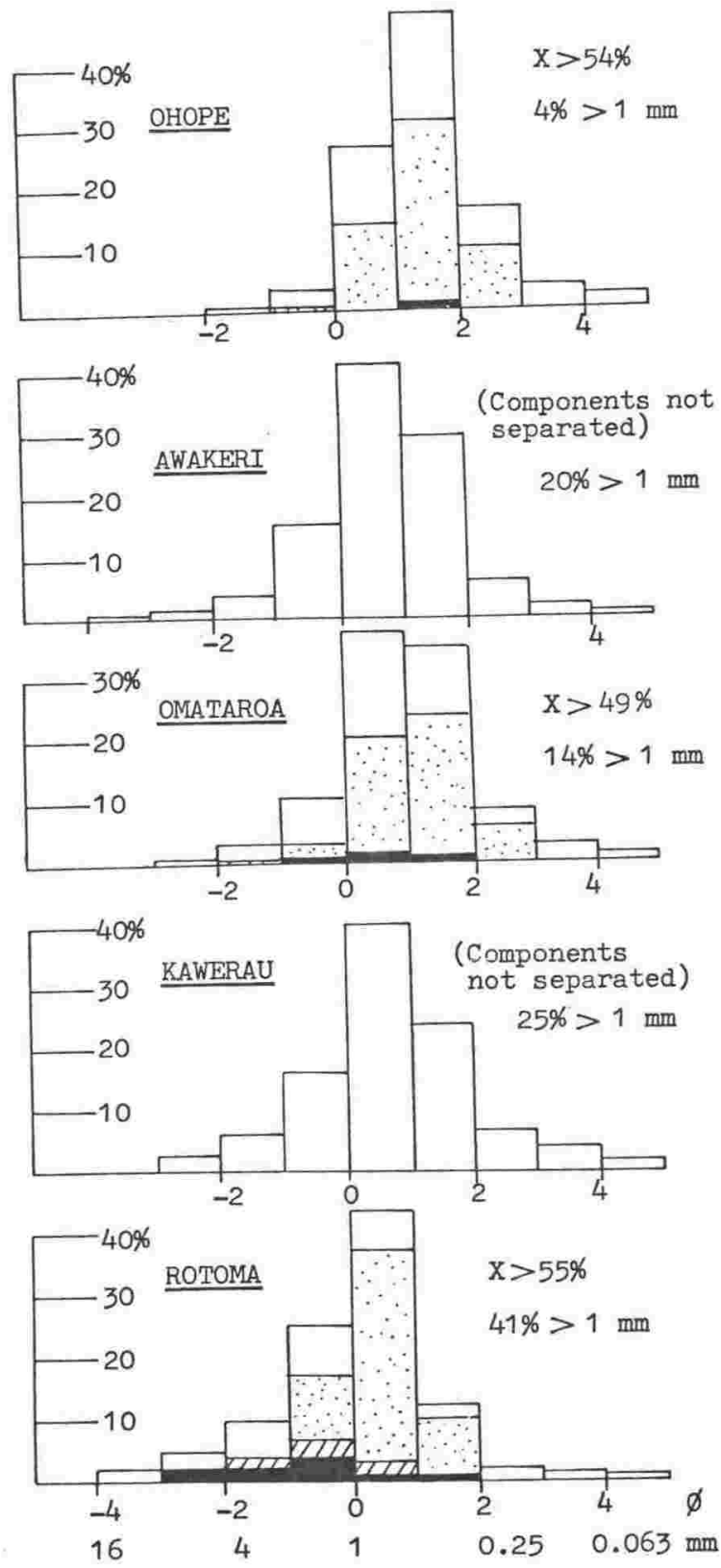
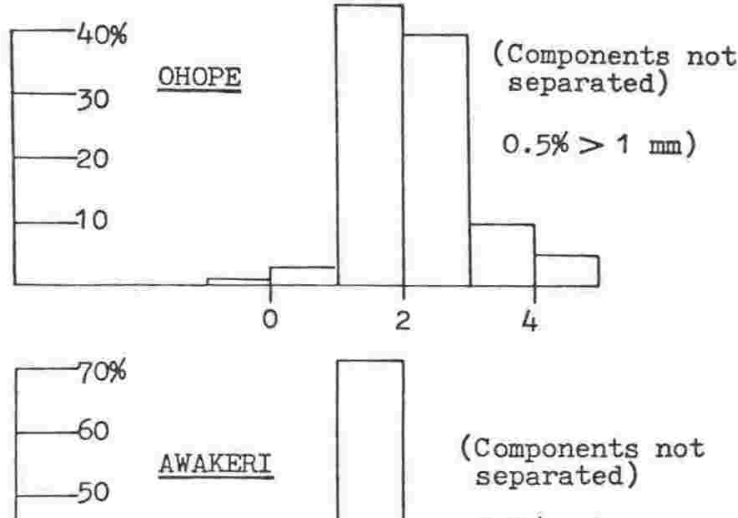

$0.3 \%>1 \mathrm{~mm}$
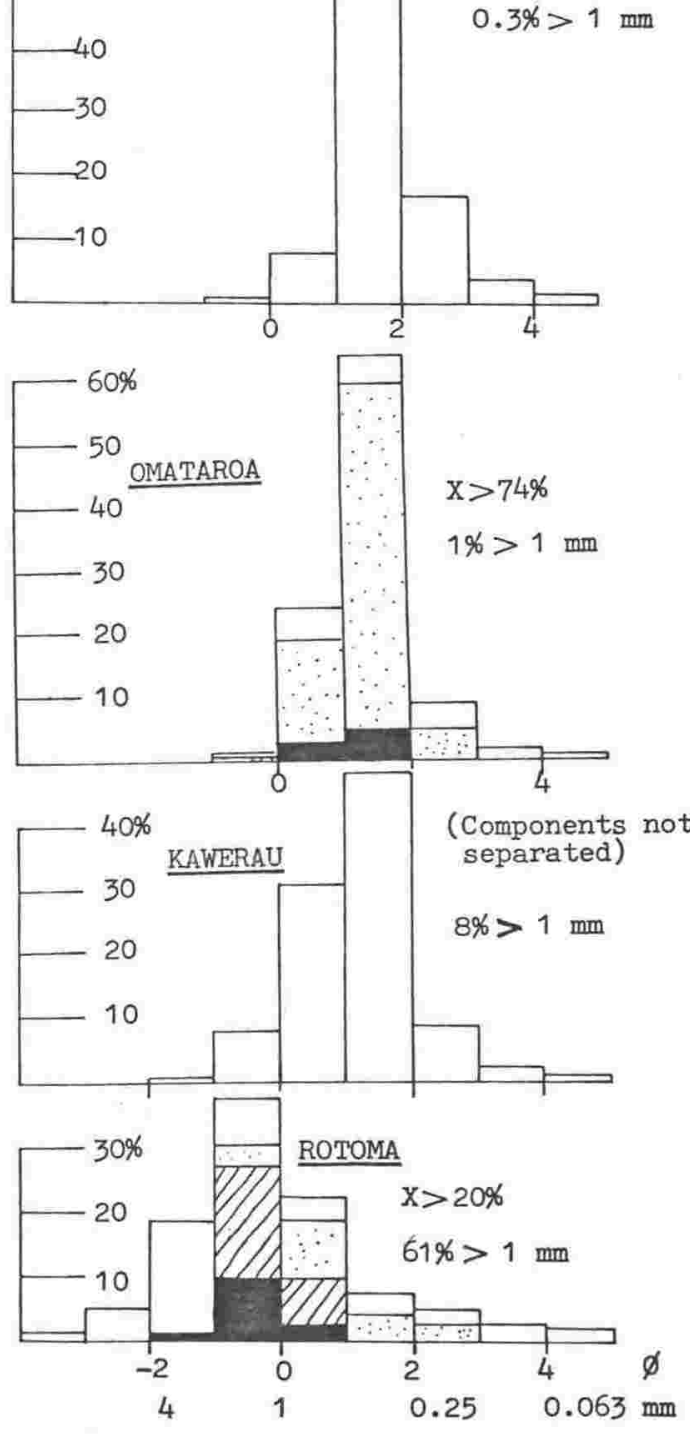

FIG. 7 b - Further comparative histograms of individual fall units correlated between sections between Lake Rotoma and Ohope, as in Fig. 7a. 


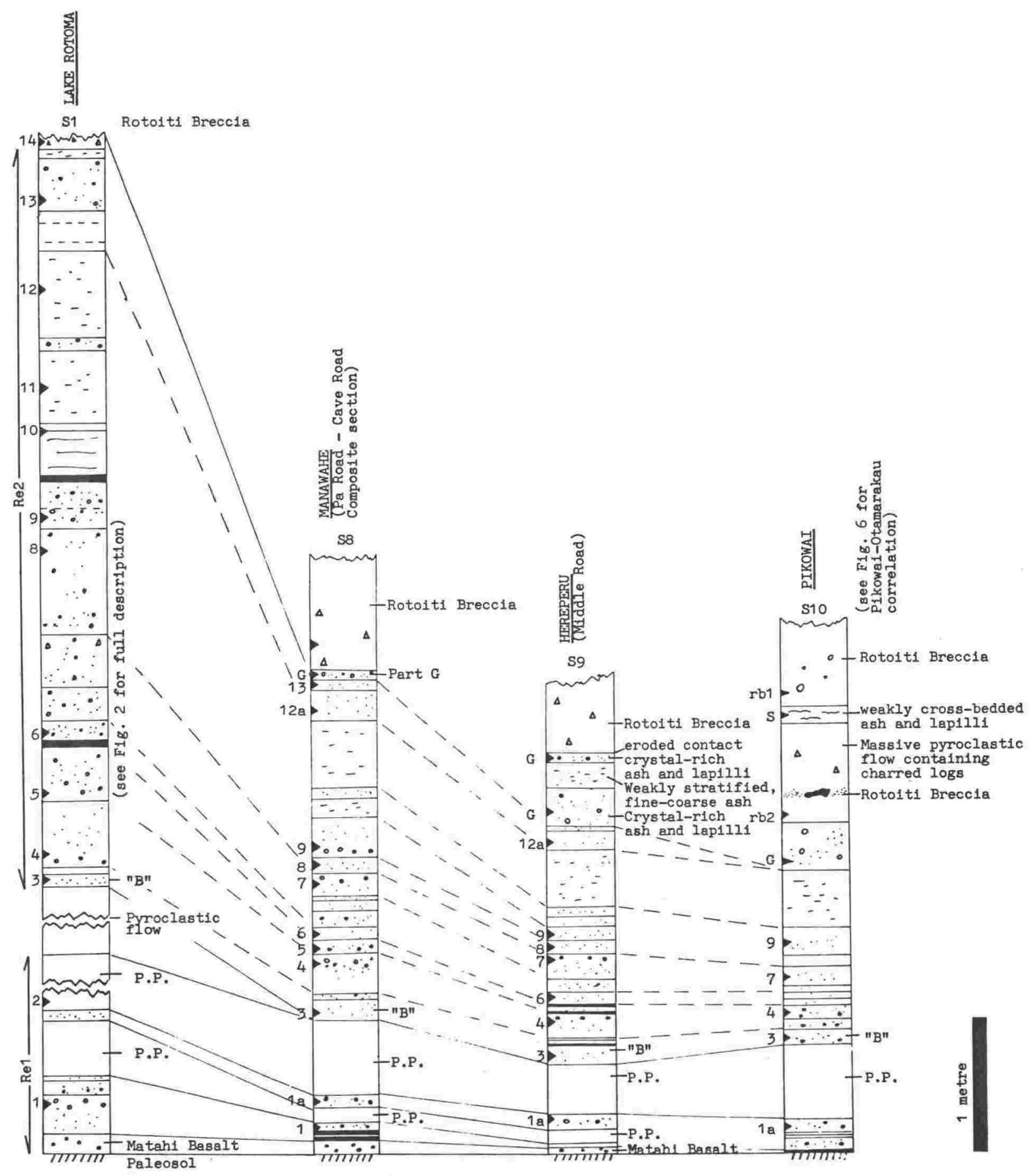

FIG. 8 - Rotoehu Ash (Re1 and Re2) sections on transect line between Lake Rotoma and Pikowai. See Fig. 1 for location of transect line. 


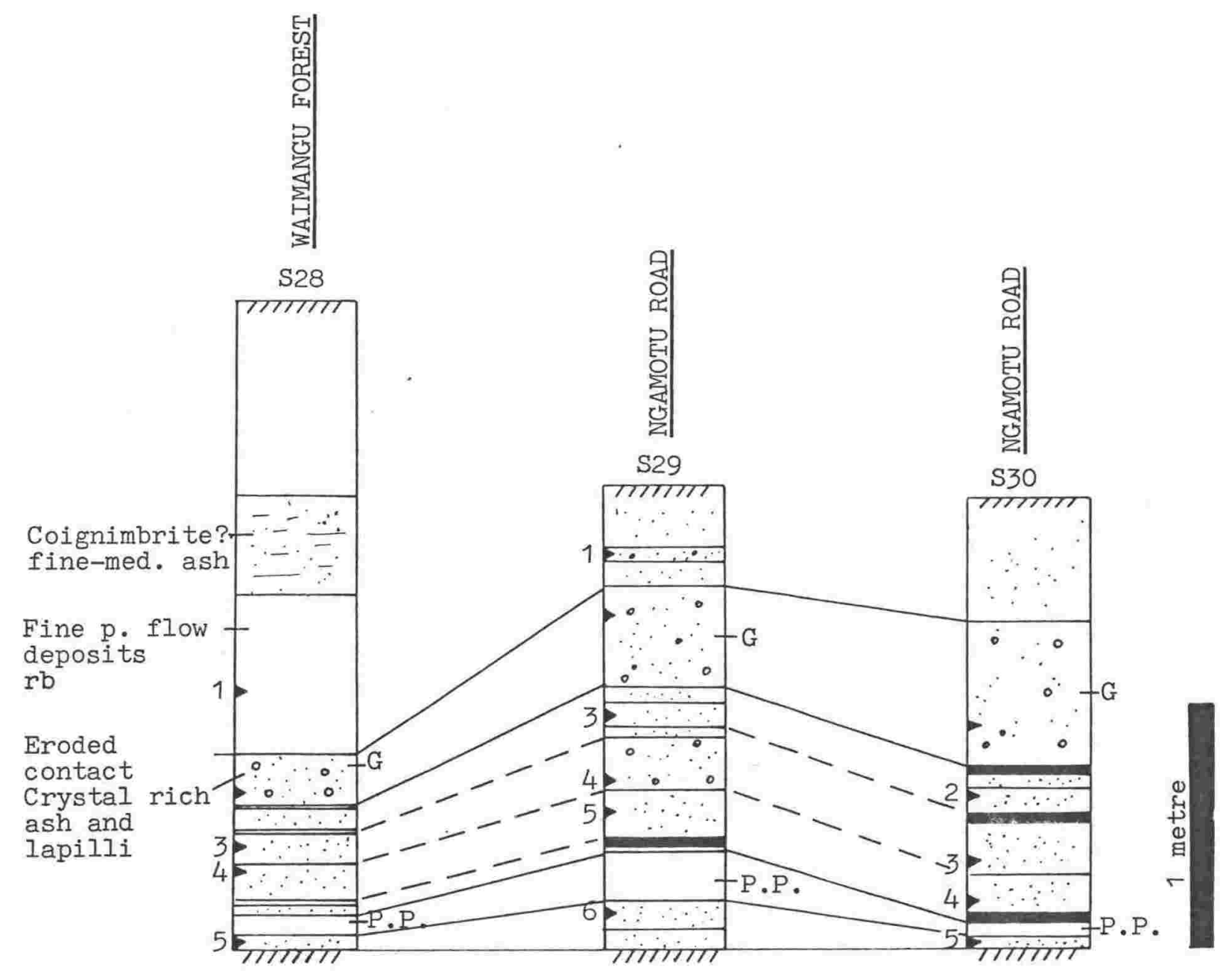

FIG. 9 - Rotoehu Ash sections on transect line between Waimangu Forest and Ngamotu Road. See Fig. 1 for location of transect line. 
Where both $G$ and Rotoiti Breccia are present, $G$ is invariably overlain by bulk of the flow deposits, which exceed $100 \mathrm{~m}$ thickness in the main Breccia fan.

The flow deposits are mantled up by to $2 \mathrm{~m}$ of weakly stratified, crystal-rich Re3 fall units distinguished by the presence of abundant biotite. These Re3 beds are well exposed at Roydon Downs (S15) and are shown from this section in Fig. 2.

At sections located on the Rotoiti Breccia fan, Re3 is commonly conformably overlain by finely stratified, crossbedded ash and lapilli beds, in places strongly gullied, and comprising member "D" of Healy et al (1964). Distribution of these beds is largely restricted to the Breccia fan, and they appear to consist of Rotoiti Breccia redeposited by mass flows, perhaps mobilized by storms immediately following the eruptions.

At Lakes Rotoiti, Rotoehu, and Rotoma, Rotoiti Breccia is overlain by lithic-rich flow units and beds of accidental lithic blocks. The best outcrops occur on the northern shores of Lake Rotoehu (Fig. 10), where beds several metres thick contain sub-angular to sub-rounded accidental blocks with diameters ranging up to $1 \mathrm{~m}$. The coarsest and most block-rich beds appear to be of airfall origin but other beds have a matrix of pumiceous ash and crystals and resemble very lithic-rich pyroclastic flow deposits. These lithic block beds are the coarsest eruptive units found within the Rotoiti Breccia Formation and somewhat resemble the co-ignimbrite lag-fall deposits described by Wright and Walker (1977). The accessory blocks are dominantly rhyolite, with flow-banded lava, glassy lava, brecciated rhyolite, vesiculated rhyolite and spherulitic rhyolite all occurring. Minor components include densely welded lenticulitic ignimbrite, pumiceous tuffs, hydrothermally altered and strongly silicified blocks of pumice tuff and breccia, and some rare greywacke fragments. These dense and coarse block deposits were clearly erupted from a nearby source within Haroharo Caldera. 


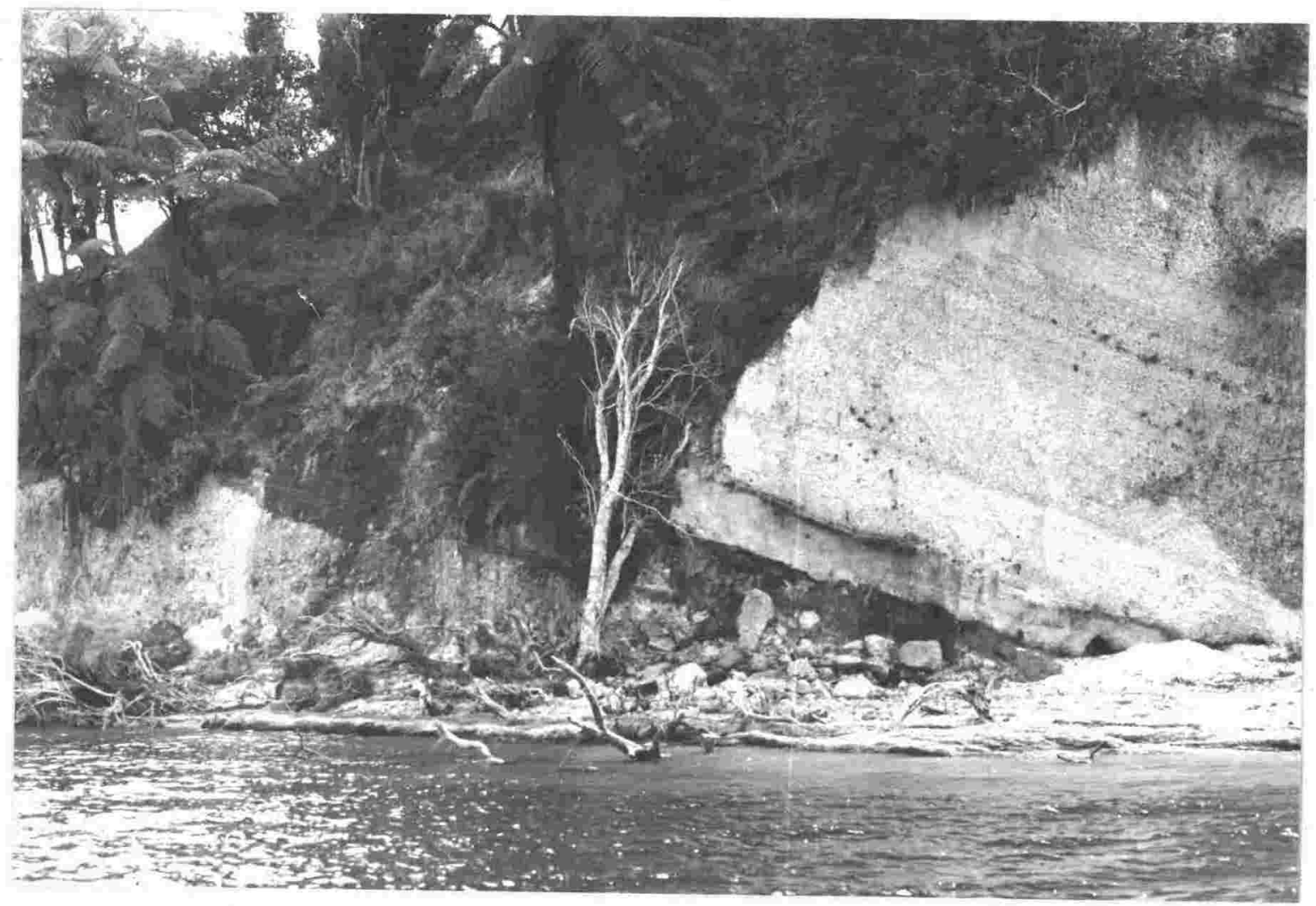

FIG. 10 - Rhyolite block bed which overlies Re3 fall units and Rotoiti Breccia at Lake Rotoehu. Showerbedded mantling pumice beds form part of the younger Mangaone Sub-group pyroclastics. 
Rotoehu Ash isopachs (Pullar 1973; and Fig. 11) demonstrate a somewhat east-south-east extended near-source dispersal pattern, centred on the Lake Rotoma area where the thickest deposits were recorded. Because sections which expose the entire thickness of the interbedded Rotoehu Ash/Rotoiti Breccia deposits are extremely rare, all of the previously recorded Rotoehu Ash thicknesses on the Rotoiti Breccia deposits are minimal (see Nairn 1972). At each section only some units of the Rotoehu Ash (i.e. either Re1 $\pm \operatorname{Re} 2$, or Re3) have been measured. Rotoehu Ash is infrequently exposed near Haroharo Caldera, due to burial beneath younger rhyolite lavas within the caldera, and beneath thick Rotoiti Breccia deposits outside it. Although overall thickness of Rotoehu Ash cannot be measured in most sections on the Rotoiti Breccia fan, individual fall units can be measured and correlated in transects to east, north, and south of Haroharo Caldera (Figs. 6, 7a, 8 and 9). The section at Lake Rotoma contains the most complete lower ash sequence (Re1 and part Re2) close to Haroharo Caldera, and individual fall units present here are generally thicker and/or coarser than in other sections (Figs. 7a, 8). G is not exposed at Rotoma, but occurs (Fig. $7 a$ ) beneath Rotoiti Breccia at Kawerau (S4); and at Omataroa (S5), Awakeri (S6), and Ohope (S7), beyond the breccia fan. Grain size varies upwards through G; samples collected from the finer basal $15 \mathrm{~cm}$ at Kawerau, Omataroa, Awakeri and Ohope show a systematic trend (Fig.12A) with decreasing size parameters ( $\mathrm{Md} \varnothing, \mathrm{Mz}, \mathrm{C} 5 \%, \%$ $>1 \mathrm{~mm}$ ), improved sorting, and slight but steadily finer skewing with distance from Kawerau. Other fall units show similar trends (Fig.12A) with rapid increase in size parameters between Kawerau and Rotoma sections. Thickness of G at Kawerau is somewhat less than in the sections at Omataroa and Awakeri (Fig. 7a), probably due to erosion of the upper part of $G$ at Kawerau by the overlying pyroclastic flow. Such erosion is clearly demonstrated in other sections at Manawahe (S8) and at Waimangu ( $\mathrm{S} 28$ ), where $\mathrm{G}$ is up to $220 \mathrm{~mm}$ thick, but in places has been totally removed beneath a thin over- 


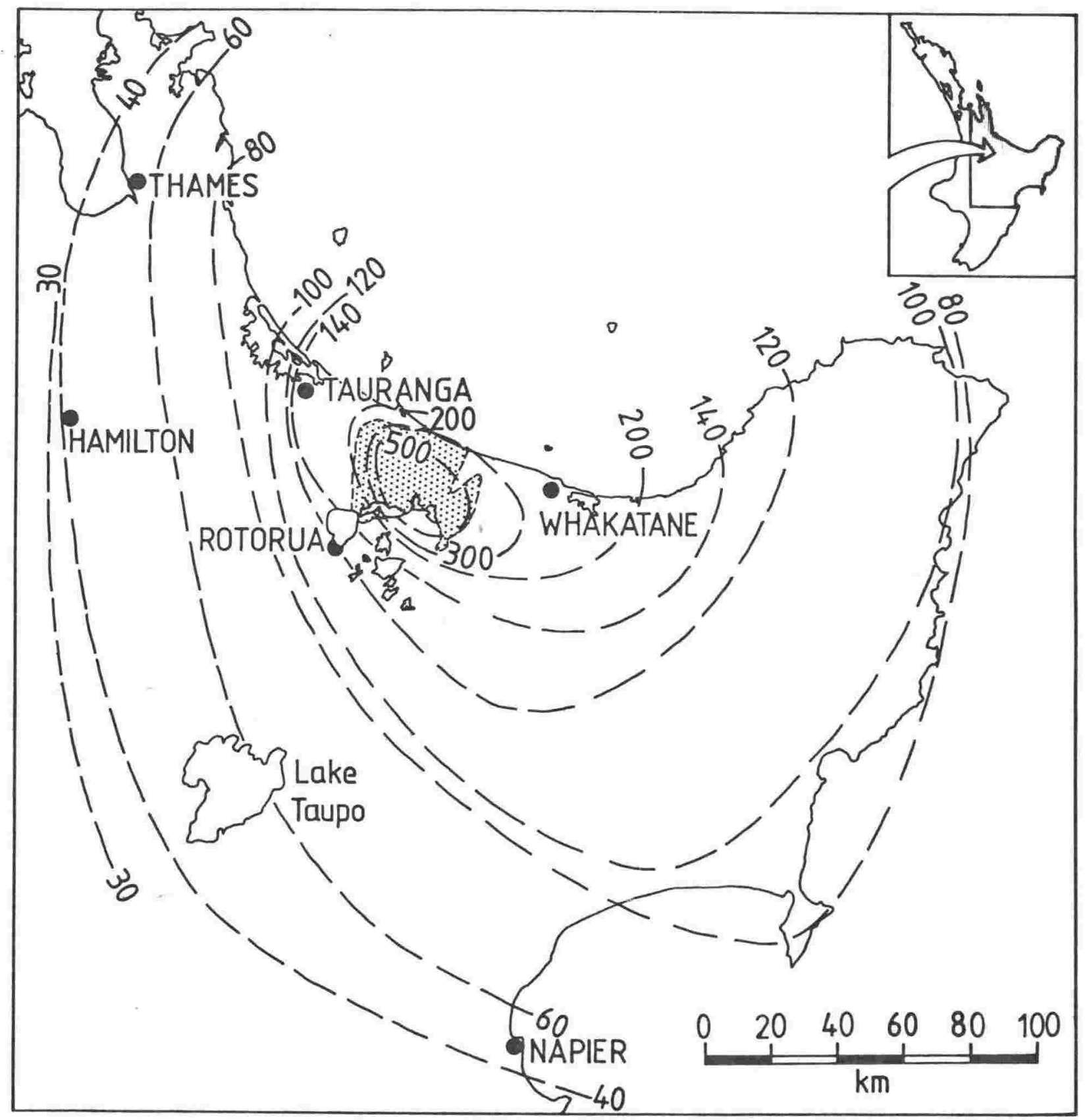

FIG. 11 - Rotoehu Ash isopachs from Pullar (1973). Thicknesses are in centimetres. Main outcrop of Rotoiti Breccia is shown stippled. 
A

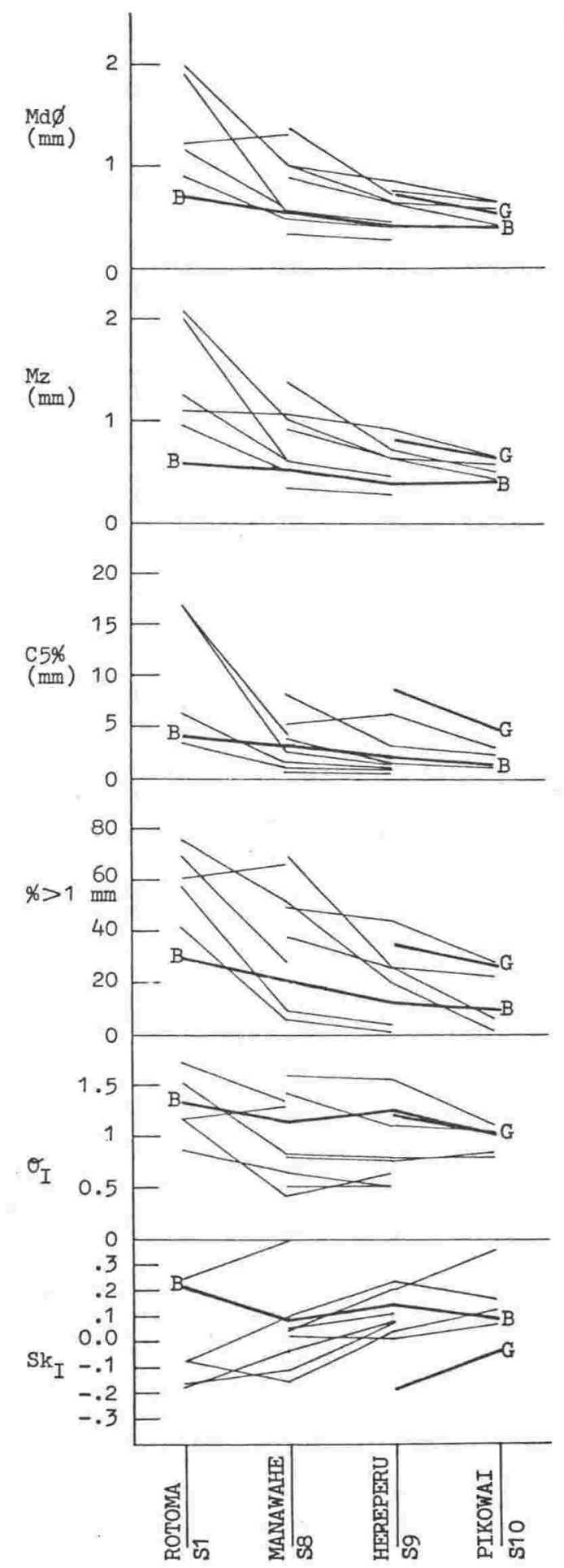

FIG. 12 - Size, sorting, and skewness parameters for correlated fall units on Rotoehu Ash transects between Lake Rotoma and (A) Ohope, (B) Pikowai. Transect lines are as for Figs. 7a and 8. Only fall units $G$ and $B$ are identified; other sample lines illustrat the overall trends of increasing size and poorer sorting towards Rotoma. 
lying pyroclastic flow. Pyroclastic flows did not reach the Omataroa and Awakeri sections. Further, as it seems likely that $G$ is coeval with some pyroclastic flows, upper parts of $\mathrm{G}$ may also lie above the basal exposure at Kawerau, interbedded within, or eroded by, other pyroclastic flows.

The mantling, biotite-bearing Re3 fall units are best exposed in northern near-coastal sections, and can be traced west (Fig. 13) from Otamarakau (S11, 12) through sections at Pongakawa (S13, 14), Roydon Downs (S15), Fail and Farrow Roads (S16, 17), to Te Puke (S18, 19), and Papamoa (S20). These sections show little systematic variation in (a) total thickness of the Re3 fall units between Te Puke and Otamarakau; (b) in thickness of individual beds; or (c) their size and statistical parameters (Fig.14B), so that all these sections appear roughly equidistant from a common source. Re3 fall units are not well exposed near Haroharo, but coarse biotitebearing fall units are found in sections at Kaharoa Road (S26), Cole Corner (S3), and Lake Rotoiti (S2d), where apparently incomplete fall sequences are interbedded with biotite-bearing pyroclastic flow units (Fig. 13). Re3 samples from Cole Corner and Lake Rotoiti have $\mathrm{C} 5 \%$ much coarser than in other sections (Fig.14A), and are considered closest to source. At these sections the fall units locally vary in thickness, some beds being completely eroded in places by overlying pyroclastic flows. Such erosion, plus non-exposure of other interbedded fall units may account for the lesser thickness of the coarse Re3 units near Haroharo Caldera, cf. those at the coastal sites.

\section{AGE OF THE ROTOITI BRECCIA FORMATION}

Radiocarbon ages ( (U15/f1), > 41,000 years B.P. (67\% probability NZ643: Thompson 1968), 44,200 \pm 4300 years B.P. (67\% probability NZ877: Grant-Taylor and Rafter 1971), and 41,700 \pm 3500 years B.P. (NZ1126: Nairn and Kohn 1973) have been obtained on undoubted Rotoiti Breccia deposits. Such ages are on the instrumental limit for New Zealand radiocarbon dating techniques, and 


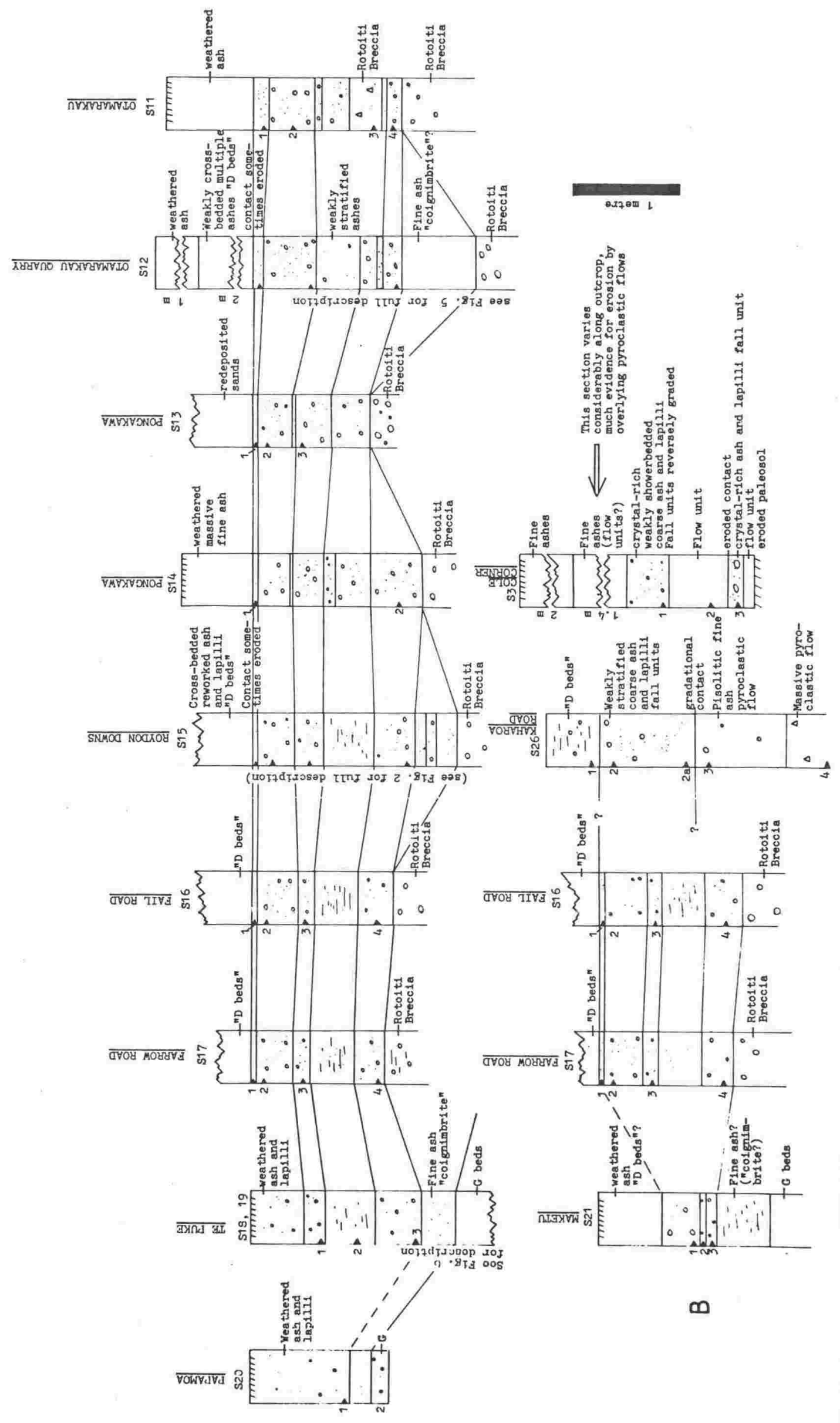

믐

$+$

:

ओे

5

4 N

ते.

$\infty$

등

ธิ ํㅗㅇ

ठ ज

悘

ฮั

ส

पू๊

ว.

준

ปั

臨䍃

2

$\leq$

등

인

世

옹

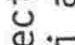

需

등

한응

ले

$\stackrel{\otimes}{\simeq}$

돈

긴

동

뭉

I

$\stackrel{m}{-}$

㟧 


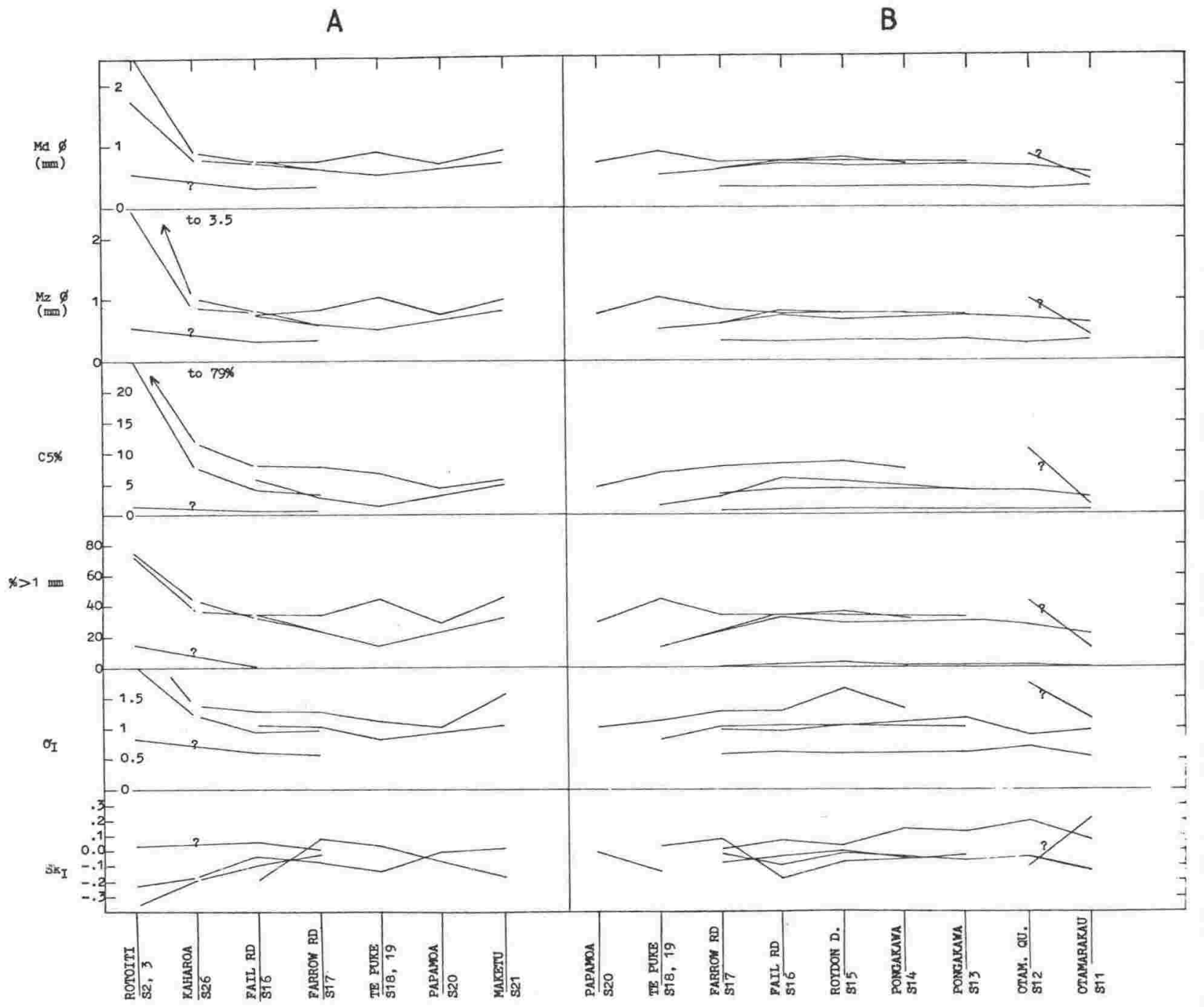

FIG. 14 - Size, sorting, and skewness parameters for correlated Re3 fall units on transects between (A) Lake Rotoiti and Maketu, and

(B) Papamoa and Otamarakau. Transect lines are as for.Fig. 13. 
validity of the absolute dates has been questioned (i.e., Nathan 1975). Two samples of charcoal obtained from new road cuts deep into thick Rotoiti Breccia deposits have recently been submitted to the University of Washington for ${ }^{14} \mathrm{C}$ dating with instrumental range of 60,000 years B.P. for routine counting, and 75,000 years B.P. for isotope enrichment techniques. Results are not yet available. Ages which can be accepted with some confidence are required to estimate position of sea level at time of the Rotoiti Breccia eruptions, as this is a critical point in the littoral explosion hypothesis of Walker (1979).

\section{DISCUSSION}

Littoral Sources for Rotoehu Ash?

Walker (1979) has proposed that part or all of the Rotoehu Ash was generated by immense steam explosions at two or three littoral sites where Rotoiti Breccia pyroclastic flows entered the sea. This conclusion was largely based on his studies of fall unit $G$, although the discussion is complicated by Walker's miscorrelation of beds to east and west of the pyroclastic flow deposits. Walker's crystal rich bed "E" (see fig. 2 in Walker 1979) in sections to west of the flow deposits in fact correlates with his $G$ to east, while Walker's "G" in the western sections comprises the mantling, biotite-bearing Re3 fall units which overlie the Rotoiti Breccia. The following discussion is based on this corrected stratigraphy, as shown in Fig. 6 (see Section S18). Although the miscorrelations lumped together fall units which are separated by a considerable thickness (and very large volumes) of pyroclastic flow material (and therefore some time interval), Walker's basic concept of littoral explosive sources for $G$ to east of the Rotoiti Breccia, and for Re3 (corrected stratigraphy) to west, is not immediately invalidated. However, Walker's conclusions as to the wide dispersal of his "G" bed are affected by the included time interval. "True" $G$ beds are thickest to north-east, east, and south-east of Haroharo. The biotite-bearing Re3 beds are thickest to 
north and north-west of Haroharo. This different dispersal reflects differing wind directions during vertical eruptions separated in time by deposition of the main bulk of the Rotoiti Breccia pyroclastic flows.

Walker considered $G$ to have originated from littoral explosions where Rotoiti pyroclastic flows encountered the sea near Te Teko, and Re3 from similar explosions near Te Puke (see Fig. 1). These sites are $10-20 \mathrm{~km}$ inland from the present coastline so that sea bays projecting to these points at time of the eruption were postulated (Walker 1979). There is no evidence to support this suggestion; instead sea levels during the Otiran glacial stage (80,000-14,000 yr B.P.) were considerably lower (below $-20 \mathrm{~m}$, Chappell 1975) than at present, with Bay of Plenty shorelines generally some kilometres seaward of the present coast (Fleming 1979). Although age of the Rotoiti Breccia is still uncertain, pollen analysis of paleosols and peats above and below the Rotoiti Breccia suggest that it was deposited shortly after the beginning of a cool interstadial (M.S. McGlone pers. comm.). This interpretation is consistent with results from emerged coral reef terraces, Huon Peninsula, New Guinea (Bloom et al 1974) which indicate a sea level maximum of $-38 \mathrm{~m}$ at around 42,000 years B.P. That eustatic sea level can have been little higher than present at time of the Rotoiti eruptions is directly demonstrated by the presence of subaerial Rotoehu Ash $5 \mathrm{~m}$ above sea level at Maketu, an area considered stable by Chappell (1975). Further, the lack of marine deposits in Kawerau geothermal wells which pass through Quaternary volcanics and sediments to reach Mesozoic greywacke basement at c. $1 \mathrm{~km}$ below sea level, (Macdonald and Muffler 1972; Nairn and Solia 1980), together with the provisional results of geodetic level surveys indicating present day subsidence rates of 2-3 mm $\mathrm{yr}^{-1}$ at $\mathrm{Te}$ Teko (P.M. Otway, pers. comm.), combine to demonstrate long continued subsidence of the Whakatane Graben (in which $\mathrm{Te}$ Teko is sited) throughout the late Quaternary. These results suggest that during the Rotoiti eruptions the pre-Rotoiti Breccia ground surface at Te Teko area may have 
been about $100 \mathrm{~m}$ higher above sea level than its present elevation. There is no evidence from present day outcrop that major Rotoiti Breccia flows reached Te Teko, only fine grained vitric (co-ignimbrite?) ash occurring above $G$ at Omataroa, although this reference section lies within $2 \mathrm{~km}$ of the presumed Te Teko explosion site. Thickness and grain size of $G$ at Omataroa are similar to that in nearby sections at Kawerau and Awakeri (Figs. $7 \mathrm{a}, 12 \mathrm{~A}$ ), without the rapid increase in these parameters common in near-vent locations, and without the large ballistic lithic ejecta normally regarded as diagnostic of proximity to source. None of these three sections appear near the source of $G$, although the grainsize parameters for basal G (Fig.12A) suggest that Kawerau may be nearest to source. Such an inference would be consistent with a Haroharo source at c. $18 \mathrm{~km}$ west of Kawerau, and would also account for the lack of ballistic ejecta and other indications of near-vent facies pyroclastics in all presently known G exposures (Kawerau is the nearest G outcrop to Haroharo).

At Kawerau, G underlies Rotoiti Breccia, i.e. G was deposited prior to any pyroclastic flows reaching this location. Te Teko lies beyond Kawerau from the pyroclastic flow source at Haroharo, indicating that here also, G would have fallen prior to any pyroclastic flows reaching the proposed Te Teko littoral explosion site.

Walker also considers that his crystal-rich beds $B$ and $E$ (see S18 - Fig. 6) originated by similar littoral explosions at different points; $E$ at a site near Maketu (see Fig. 1), (position of the vent for $B$ was not specified). The other, finer ashbeds within Rotoehu Ash were thought either normal co-ignimbrite ash falls, or to have originated from weaker littoral explosions. However, $E$ in fact correlates with $G$ at Te Teko while $B$ becomes thicker and coarser towards Lake Rotoiti (Figs. 6, 12), and all other finer ashes appear to thicken/coarsen towards Haroharo. 
The most complete, and therefore thickest, biotite-bearing Re3 mantling fall units occur in near-coastal exposures between Te Puke and Otamarakau. Only thin apparent remnants are present in exposures on Kaharoa Road and near Lake Rotoiti, but individual fall units at these sections are much coarser than in the coastal sections (Figs. 13,14). At least these coarse units appear likely to have been erupted from Haroharo Caldera; the Cole Corner (S3) section is closest to the caldera, but lies c. $10 \mathrm{~km}$ from the presumed source vents under Haroharo Volcanic Complex, i.e. beyond the usual 3-6 km range of ballistic ejecta in large plinian eruptions (Booth et al 1978).

Walker considers the crystal-rich nature of $G$ and similar sandy beds (i.e. B, Re3) within the Rotoehu Ash to be a critical argument for littoral explosive origin of these fall units; crystal-enrichment being produced by elutriation of vitric fines during ignimbrite eruption and flow, followed by aeolian differentiation in the littoral explosion clouds. However, nearly all the sampled fall units which underlie $G$ in the Omataroa and Otamarakau reference sections (and many at Rotoma) are equally or more crystal-rich than G (See Figs. 2, 3, 5), and all are thickest and coarsest at Rotoma or Rotoiti (Figs. $6,7,8,12)$, so that a littoral origin is excluded for these beds.

Fall units $G$ and Re3 do not outcrop in the Rotoma-Rotoiti area, $G$ because it has either been removed by passage of overlying pyroclastic flows, or because it lies above the exposed sections, interbedded within the pyroclastic flows. Re3 is well preserved only where the original planar upper surface of the Rotoiti Breccia pyroclastic flows remains, and such a surface is not well exposed at Rotoma. The lack of $G$ and Re3 beds near Haroharo makes it difficult to decide between littoral or Haroharo sources for these fall units. However the south-west coarsening of basal G towards Kawerau (and thus Haroharo) and the presence of the coarsest individual Re3 fall units at Rotoiti are consistent with a Haroharo source 
for these beds. The lack of ballistic ejecta in all known sections suggests that none is close to the source vents which presumably lie within Haroharo Caldera, some kilometres distant from the nearest exposures on and outside the caldera rim.

In general, the littoral vent concept appears to be an artefact of the much better exposure of Rotoehu Ash in the coastal area, in contrast to its very poor exposure near Haroharo. Walker's isopach and maximum clast size maps contain a large area c. $30 \mathrm{~km}$ in diameter surrounding Haroharo, in which no data are presented. Sections at Rotoiti and Rotoma were not described, the nearest documented section being at Kawerau c. $15 \mathrm{~km}$ from Haroharo Caldera, and Walker presents no evidence which precludes Haroharo Caldera as a source for all or any parts of the Rotoehu Ash.

The littoral vent concept also contains a major internal inconsistency in that vent locations are required beyond the present margins of the Rotoiti Breccia, at sites where presence of the sea at time of the eruption is highiy uncertain. In contrast, no littoral explosions are indicated in the Otamarakau-Matata area (Fig. 1) where the great mass of Rotoiti Breccia pyroclastic flows must have entered the sea. If a littoral explosion mechanism were to operate, it would seem more likely to have occurred in this region, yet the good exposures at Pikowai and Otamarakau exclude this area as a major source of Rotoehu Ash.

Evidence for a Haroharo Source

Inferences as to location of the source of Rotoehu Ash come from two lines of evidence: (a) source of the Rotoiti Breccia pyroclastic flows, assuming Rotoehu Ash was erupted from the same vents, and (b) thickness and grain size studies of Rotoehu Ash fall units.

Distribution of the Rotoiti Breccia pyroclastic flows is concentrated in a major fan to north of Haroharo Caldera, 
with only thin remnants present to south at Waipa and in the vicinity of Rotomahana-Waimangu (Fig. 1). Very little pyroclastic flow material is exposed in the adjacent Rotorua basin, except in the Rotokawau area, where flows passed around the northern foot of the caldera-bounding Whakapoungakau rhyolite. Rotoiti Breccia is not exposed within Haroharo Caldera, although flows passed through the ancestral Tarawera River valley between Maungawhakamana rhyolite dome and the ignimbrite sheets to east, to reach the Kawerau area. Other flows passed through valleys in rhyolite terrain to north of Maungawhakamana, and in the Rotoma area, to reach the Whakatane Graben to east of Manawahe (Fig. 1). This distribution pattern is entirely consistent with a source for the pyroclastic flows in the vicinity of the present Haroharo Volcanic Complex.

While systematic studies have not been made by the writer, the lithic component of Rotoiti Breccia pyroclastic flows appears most coarse and abundant in the Rotokawau-Rotoiti area just outside the caldera margin immediately to west of Haroharo. More significant are the thick accessory block beds and lithicrich flow units at top of the Rotoiti Breccia Formation which outcrop at Lakes Rotoiti, Rotoehu, and Rotoma on, or close to, the caldera rim. Eruption of these block beds at end of the Rotoiti eruption sequence was probably caused by collapse of the oversteepened caldera walls, following major evacuation of the underlying magma chamber during the pyroclastic eruptions (e.g., Lipman 1976). Such collapse produced the strongly scalloped topographic caldera rim in the RotoitiRotoehu area, and provided accessory lithic debris to be ejected in the final explosions of the eruption sequence.

Location of the pyroclastic flow source vents cannot be more precisely defined within Haroharo Caldera. The younger lavas and pyroclastics of the Haroharo Volcanic Complex were erupted from vents which define a north-east striking lineation across Haroharo Caldera (Nairn 1981). This Haroharo vent lineation is considered to mark location of an underlying major basement fracture. The Rotoiti Breccia appears likely to have been erupted from fissures overlying this basement fracture 
in the northern part of the caldera, and was probably the first voluminous ignimbrite eruption from the northern caldera.

More direct evidence as to source of the Rotoehu Ash comes from thickness and grain size of fall units. Matahi Basalt, which commenced the Rotoiti eruption sequence, is thickest and coarsest in the Kawerau-Rotoma area (Pullar and Nairn 1972). The initial rhyolite eruptive - a reverse graded coarse ash/ small lapilli bed - is thickest and coarsest in sections on Motomauri Island in Lake Rotoiti (S2a - Fig. 6), and at Coles Corner (S3 - Fig. 6) on the south shore of Lake Rotoiti (where it is too cemented to sample). The overlying pisolitic, massive fine ash beds are thickest at Lakes Rotoiti and Rotoma (they are not exposed at Lake Rotoehu), although thicknesses at individual sections vary considerably. Overlying fall units up to base of $G$ are thickest and coarsest at the Lake Rotoma sections, and become thinner and finer grained on transects to north and east (Figs. 7a,8). All fall units which outcrop at Lakes Rotoma-Rotoitiare thickest and/or coarsest at these sites, demonstrating a Haroharo source for all beds except the non-outcropping $G$. While source for $G$ cannot be positively located, the available data is at least consistent with an origin within Haroharo Caldera.

Finally, it has long been recognised that no proximal facies Rotoehu Ash beds are exposed. The rapidly-thickening coarse grained deposits containing large ballistic lithic ejecta, which are common wherever the source of large pyroclastic deposits can be closely approached, are absent from all known exposures of Rotoehu Ash. Neither is there evidence of pyroclastic surge deposits, although these occur in the source regions of nearly all the younger Okataina rhyolite pyroclastics (Nairn 1981). The lack of near-source facies Rotoehu Ash requires that the source region be concealed or destroyed. Both these requirements are met by eruptions from a Haroharo source accompanied by catastrophic caldera collapse and followed by deep burial under younger pyroclastics and lavas. All the rocks exposed in northern Haroharo Caldera are younger 
than Rotoehu Ash (Nairn 1981), so that the caldera provides a suitable "hole" in which to hide the proximal deposits of Rotoehu Ash.

Eruption sequence and mechanisms

So little near-source data is available for Rotoehu Ash that attempts at interpretation of the eruption mechanisms must be largely speculative. The following model is suggested, based on the stratigraphic sequence seen at Rotoma-Rotoiti, c. $10 \mathrm{~km}$ from the presumed Haroharo fissure source.

The Rotoiti eruptive sequence commenced with plinian eruption of Matahi Basalt, probably from vents in northern Haroharo Caldera (Pullar and Nairn 1972), and into a southwesterly wind. This basaltic tephra fell onto a strongly weathered soil, ending c. 100,000 yrs of quiescence at Okataina Volcanic Centre. Intrusion of Matahi Basalt into the upper crust may have triggered the following rhyolite eruption, perhaps by injection into the base of the rhyolite magma body, in the mechanism suggested by Sparks et al (1977). A posisible analogy is with the much smaller March 1875 Askja mixed magma plinian eruption in Iceland, which was preceded a few weeks by a nearby basaltic fissure eruption. Although there is little evidence of magma mixing in the Rotoiti pyroclastics, and a basaltic lithic component has not been identified, it is possible that basic magma could have triggered the rhyolite eruptions by induced convection without being itself ejected (Sparks et al 1977).

The Matahi Basalt eruption was followed, without apparent time interval, by the initial rhyolitic plinian eruption of pumiceous ash and lapilli (fall unit 1 at Rotoma - see Fig. 2). This fall unit is relatively crystal-poor at Rotoma, with moderate lithic content, and does not have extremely wide dispersal. Minor ash eruptions were then followed by deposition of massive, pisolitic ash beds which are everywhere dominantly fine grained (unit P.P. - Fig.2, $\mathrm{Mz}=0.02 \mathrm{~mm}$ at Rotoma), both as airfall and pyroclastic flow deposits, with 
some minor interbedded coarse ash. Although thickness of this finely-divided unit initially falls off rapidly from the RotomaRotoiti area, a mantling airfall correlative extends beyond Te Puke and Ohope (Figs. 6, 7a, 8), demonstrating widespread dispersal. The finely-divided P.P. unit is considered to be an example of the "phreatoplinian" eruption class proposed by Self and Sparks (1978) for widely dispersed, fine ash fall deposits.

Phreatoplinian deposits result from the phreatomagmatic interaction of large volumes of silicic magma and water, the resulting explosive steam expansion producing much greater fragmentation than is normal in magmatic eruptions. The deposits are dominantly fine grained even at source, and have wide dispersal due to the high eruption columns produced by the large magma volumes and high mass flux rates involved.

The P.P. fall and flow deposits within Rotoehu Ash thus indicate that large volumes of water became involved in an early stage of the Rotoiti eruptive sequence, presumably derived from a pre-existing caldera lake.

A further mechanism may have contributed to the fine grained nature of the P.P. ash. The high content of crystalline clays in P.P. is similar to that of the phreatic/hydrothermal eruption deposits of the 1886 Rotomahana Mud (N.Z. Soil Bureau 1968; Kirkman 1976). The presence of illite, kaolinite and montmorillonite in Rotomahana Mud is due to the pre-eruption hydrothermal alteration of country rock and lake floor sediments (Nairn 1971; Kirkman 1976; Nairn 1979), in the highly active pre-1886 Rotomahana hydrothermal field. The presence of the same clay minerals in the P.P. unit suggests a similar origin for this component of the Rotoehu Ash, and is supported by a minor content of hydrothermally discoloured pumice in the $>0.063 \mathrm{~mm}$ size fractions. However, most of the coarse fraction (which comprises less than $30 \%$ of the total deposit) consists of completely fresh pumiceous glass and unaltered plagioclase, quartz, amphibole and magnetite phenocrysts, with a rare lithic content, suggesting that the P.P. eruption was dominantly magmatic 
rather than hydrothermal.

The P.P. eruption was followed by multiple plinian ash and lapilli falls, mostly crystal-rich (units 3 to 13 - Fig. 2), and initially containing an increasing proportion of essential lithics, often as conspicuous black glass lapilli. Accidental lithics become less common upwards in the sequence and are absent in upper units with grain sizes also tending to decrease, indicating lack of vent erosion during a less intense stage of the eruption. No pyroclastic flows appear to be associated with these fall units, and their generally crystal-rich nature and dispersal patterns indicate that they are neither co-ignimbrite ashes nor result from littoral explosions, both possibilities suggested by Walker (1979).

An abrupt change occurs above fall unit 13, to pyroclastic flow units at Rotoma, and to fall unit $G$ at most other (more distant) locations. Both $G$ and the sampled basal flow units contain accidental lithics, which become of considerable abundance in overlying flows, indicating either renewed erosion of the vent, or commencement of caldera collapse, with provision of lithic debris by slumping of the vent walls.

The main bulk of Rotoiti Breccia pyroclastic flows was emitted at this stage, presumably by collapse of the previously high eruption column from which $G$ was being widely dispersed. G appears to have been falling in some sections at intermediate distances as early pyroclastic flows passed either through the section (i.e. Woollet Rd, S23) or nearby (i.e. Otamarakau S12, Hereperu S9) so that either flow units or associated co-ignimbrite ash are interbedded within $G$.

Fine-grained, crystal-poor, sometimes pisolitic, coignimbrite ashes associated with the pyroclastic flows occur above G at more distant sections such as Te Puke (S19), where the co-ignimbrite ash is c. $0.3 \mathrm{~m}$ thick (Fig. 13). Similar thin, fine grained vitric ashes occur between some coarse Rotoiti Breccia flow units (e.g. at Roydon Downs, S15), where 
they appear to be derived by fallout from the fine ash clouds elutriated from the underlying pyroclastic flow.

The pyroclastic flow phase was followed by re-establishment of a high eruption column from which the Re3 fall units were carried to the north-west, mantling the pyroclastic flow fan. Small pyroclastic flows appear to have accompanied this stage of the eruption, eroding airfall beds in the near-source area. Major collapse of the northern caldera walls probably occurred at about this time, providing lithic debris to be ejected onto the caldera rim during the closing stages of the eruption.

The problem remains of the crystal-rich nature of $G$ and other fall units, together with the overall generally finegrained nature of the Rotoehu Ash when compared with the coarse lapilli and block component common in the Rotoiti Breccia.

It is clear that effective comminution of the Rotoehu magma occurred to release the moderately high primary phenocryst content, and then very effective sorting separated the crystal and lithic components from the lower density pumice. Walker (1979) has proposed littoral explosions to separate pyroclastic material in which crystals have previously been concentrated by pyroclastic flow. This paper has presented objections to such a mechanism, as it is inconsistent with stratigraphic and dispersal data which indicate that whatever the mechanism occurring, it operated at a Haroharo source. An alternative hypothesis is based on the eruptive environment, both within the magma chamber, and at the overlying ground surface.

Considerable volatile pressures may have accumulated in the crystallizing magma chamber during the long period of quiescence at Haroharo caldera, preceding the Rotoiti eruptions. Ewart et al (1975) have shown that the cummingtonite-bearing rhyolite magmas from Haroharo Caldera equilibrated under conditions of $\mathrm{P}_{\mathrm{H}_{2} \mathrm{O}} \approx \mathrm{P}_{\text {Load }}$ and suggest a magmatic water content around 6 wt \% for Rotoiti Breccia. However, whether magma was erupted as pyroclastics or lava was found to be unrelated to temperature, $\mathrm{P}_{\text {total }}, \mathrm{P}_{\mathrm{H}_{2} \mathrm{O}}$, or crystal content. Instead, 
eruptive behaviour was affected by differences in the kinetic and fluid dynamic behaviour of the magmas, largely controlled by critical size of the magma chamber. Very large pyroclastic deposits, such as the Rotoiti Breccia, were deduced to have been erupted from large magma bodies in which fully turbulent convection was occurring. Intense vesiculation of the upper part of the magma body would have been occurring immediately prior to eruption due to such convection (Ewart et al 1975), and may have been further increased by the injection of basic magma in the mechanism suggested by Sparks et al (1977).

Intense vesiculation would have finely fragmented the erupting magma, reducing much to phenocryst size or smaller vitric particles. Fragmentation may have been further increased by interaction between the erupting magma and external water. The most crystal-rich fall units were deposited following phreatomagmatic eruption of the P.P. unit, apparently erupted through a caldera lake. Further interaction between erupting magma and water during the later eruption sequence would have also contributed to fragmentation of the magma. The much better sorting of the later fall deposits c.f. the P.P. unit, then requires a high eruption column, perhaps produced by very high mass flux rates, so that loss of a considerable proportion of the low density pumice could occur.

\section{CONCLUSIONS}

Rotoehu Ash differs from other pyroclastic fall deposits erupted from Haroharo Caldera during the last 50,000 years. It is characterized by the extremely widespread dispersal of finely divided, crystal-rich, multiple pyroclastic fall beds, which were closely associated with pyroclastic flows of the Rotoiti Breccia. The Rotoiti-Rotoehu Eruptive Episode followed a long period of quiescence at Haroharo Caldera, and was the first voluminous pyroclastic emission from the northern part of the caldera, which collapsed as a result.

Rotoehu Ash is poorly exposed near Haroharo Caldera so that evidence relating to its source location and emption mechanisms 
is lacking. Walker (1979) has suggested that much or all of the Rotoehu Ash originated by littoral explosions where Rotoiti Breccia pyroclastic flows entered the sea. This hypothesis is inconsistent with stratigraphic, thickness variation, and grain size data for all the Rotoehu Ash beds which outcrop in the vicinity of Haroharo Caldera. These beds thicken and/or coarsen towards the caldera. Fall unit $G$ is the only bed which does not outcrop near Haroharo Caldera. However, the data available for dispersal and grain size variation is consistent with a Haroharo source for this bed also. The "littoral explosion" hypothesis is considered to be an artefact of the much better exposure of Rotoehu Ash in the coastal area, when compared with its poor exposure near Haroharo.

The stratigraphic and grain size data presented here are interpreted to indicate that whatever the mechanism responsible for the unusual lithology of the Rotoehu Ash, it operated at Haroharo Caldera rather than at distal locations. Intense vesiculation of the erupting magma, and its possible interaction with external water may have contributed to the fine fragmentation of the Rotoehu Ash.

\section{ACKNOWLEDGEMENTS}

Colleagues at N.Z. Geological Survey, Rotorua, and particularly Dr B.F. Houghton, provided valuable comments on early drafts of this paper. The writer also thanks J.W. Cole, W.A. Pullar, C.G. Vucetich, and S. Self for critically reading the manuscript, and L. Wilson, G.P.L. Walker, and M. McGlone, for valuable discussions. 
REFERENCES

Bloom, A.L.; Broecker, W.S.; Chappell, J.M.A.; Matthews, R.K.; Mesolella, K.J. 1974: Quaternary sea level fluctuations on a tectonic coast: New ${ }^{230} \mathrm{Th} /{ }^{234} \mathrm{U}$ dates from the Huon Peninsular, New Guinea. Quaternary Research 4: 185-205.

Booth, B.; Croasdale, R.; Walker, G.P.L. 1978: A quantitative study of five thousand years of volcanism on Sao Miguel, Azores. Philosophical Transactions of the Royal Society London Series A., 288: 271-319.

Chappell, J.M.A. 1975: Upper Quaternary warping and uplift rates in the Bay of Plenty and west coast, North Island, New Zealand. N.Z. Journal of Geology and Geophysics 18: 129-155.

Cole, J.W.; Nairn, I.A. 1975: "Catalogue of the active volcanoes of the world, including solfatara fields. Part XXII New Zealand". International Association of Volcanology and Chemistry of the Earth's Interior. Rome. $156 \mathrm{p}$.

Ewart, A. 1968: The petrography of the central North Island rhyolitic lavas. Part 2 - Regional petrography including notes on associated ash-flow pumice deposits. N.Z. Joumal of Geology and Geophysics 11: 478-545.

Ewart, A.; Healy, J. 1965: Rotorua volcanic geology. In New Zealand volcanology, Central Volcanic Region. N.Z. D.S.I.R. Information Series 50: 10-26.

Ewart, A.; Hildreth, W.; Carmichael, I.S.E. 1975: Quaternary acid magma in New Zealand. Contribution to Mineralogy and Petrology 51: 1-27.

Fleming, C.A. 1979: "The Geological History of New Zealand and its Life". Auckland University Press. 141 p.

Folk, R.L. 1974: "Petrology of Sedimentary Rocks". Hemphill Publishing Co., Austin, Texas. $182 \mathrm{p}$.

Grant-Taylor, T.L.; Rafter, T.A. 1971: New Zealand radiocarbon age measurements - 6 . N.Z. Journal of Geology and Geophysics 14: 364-402. 
Healy, J.; Schofield, J.C.; Thompson, B.N. 1964: Sheet 5 Rotorua (1st ed.). "Geological Map of New Zealand 1:250,000". Department of Scientific and Industrial Research, Wellington.

Kirkman, J.H. 1976: Clay mineralogy of Rotomahana Sandy Loam soil, North Island, New Zealand. N.Z. Journal of Geology and Geophysics 19: 35-42.

Lipman, P.W. 1976: Caldera-collapse breccias in the western San Juan Mountains, Colorado. Geological Society of America Bulletin 87: 1397-1410.

Macdonald, W.J.P.; Muffler, L.J.P. 1972: Recent geophysical exploration of the Kawerau Geothermal Field, North Island, New Zealand. N.Z. Journal of Geology and Geophysics 15: $303-317$.

Nairn, I.A. 1971: Studies of the Earthquake Flat Breccia Formation and other unwelded pyroclastic flow deposits of the central Volcanic Region, New Zealand. Unpublished M.Sc. thesis lodged in the Library, Victoria University of Wellington.

Nairn, I.A. 1972: Rotoehu Ash and the Rotoiti Breccia Formation, Taupo Volcanic Zone, New Zealand. N.Z. Journal of Geology and Geophysics 15: 251-261.

Nairn, I.A. 1979: Rotomahana-Waimangu eruption, 1886: base surge and basalt magma. N.Z. Journal of Geology and Geophysics 22: 363-378.

Nairn, I.A.; Solia, W. 1980: Late Quaternary hydrothermal explosion breccias at Kawerau Geothermal Field, New Zealand., Bulletin Volcanologique 43: 1-13.

Nairn, I.A. 1981: Some studies of the geology, volcanic history, and geothermal resources of the Okataina Volcanic Centre, Taupo Volcanic Zone, New Zealand. Unpublished Ph.D. thesis, lodged in the Iibrary, Victoria University of Wellington. (this study).

Nairn, I.A.; Kohn, B.P. 1973: Relation of the Earthquake Flat Breccia to the Rotoiti Breccia, Central North Island, New Zealand. N.Z. Journal of Geology and Geophysics 16: 269-279. 
Nathan, S. 1975: Age of the Rotoiti Breccia Formation. Geological Society of New Zealand, Newsletter No. 40: 21-22.

N.Z. Soil Bureau, 1968: Soils of New Zealand. Part 3. N.Z. Soil Bureau Bulletin 26(3): $127 \mathrm{p}$.

Pullar, W.A. 1973: "Isopachs of tephra, Central North Island, New Zealand. Scale 1:1,000,000". N.Z. Soil Bureau Maps 133/8-14 to accompany N.Z. Soil Survey Report 1 .

Pullar, W.A.; Nairn, I.A. 1972: Matahi Basaltic Tephra Member, Rotoiti Breccia Formation. N.Z. Journal of Geology and Geophysics 15: 446-450.

Self, S.; Sparks, R.S.J. 1978: Characteristics of widespread pyroclastic deposits formed by the interaction of silicic magma and water. Bulletin Volcanologique 41: 196-212.

Sparks, R.S.J.; Sigurdsson, H.; Wilson, L. 1977: Magma mixing: a mechanism for triggering acid explosive eruptions. Nature 267(5609): 315-318.

Sparks, R.S.J.; Walker, G.P.L. 1977: The significance of vitric-enriched air-fall ashes associated with crystalenriched ignimbrites. Journal of Volcanology and Geothermal Research 2: 329-341.

Thompson, B.N. 1968: Age of Rotoiti Breccia. N.Z. Journal of Geology and Geophysics 11: 1189-91.

Vucetich, C.G.; Pullar, W.A. 1969: Stratigraphy and chronology of Late Pleistocene volcanic ash beds in Central North Island, New Zealand. N.Z. Journal of Geology and Geophysics 12: 784-837.

Walker, G.P.L. 1971: Grain size characteristics of pyroclastic deposits. Journal of Geology 79: 696-714.

Walker, G.P.L. 1979: A volcanic ash generated by explosions where ignimbrite entered the sea. Nature 281: 642-646.

Wright, J.V.; Walker, G.P.L. 1977: The ignimbrite source problem: Significance of a co-ignimbrite lag-fall deposit. Geology 5: 729-732. 


\section{Later Volcanism}

Mangaone Sub-group Eruptive Sequence: A quiescent interval of about 10,000 years' duration, followed the Rotoiti Eruptive Episode before eruption of the Mangaone Sub-group Pyroclastics commenced. The following summary of the eruption sequence is largely based on the stratigraphic descriptions of Howorth (1975) with additional reconnaissance work by the writer in the O.V.C. region. Locations of Mangaone samples are shown in Fig. 28.

The Mangaone Sub-group eruptions were dominantly of plinian type, and showered well sorted coarse pumice lapilli and ash over much of the eastern North Island [see Isopach maps in Pullar (1973) and Howorth (1975)]. The eruption sequence extended over about 10,000 years, with intervening quiescent intervals during which paleosols were developed on the erupted deposits.

Isopach mapping of the eight Mangaone Sub-group pyroclastic formations led Howorth (1975) to suggest source areas which lay either on or outside the eastern and northern boundaries of the O.V.C. However the isopachs were based on minimal data points, with measurements particularly lacking within the O.V.C. The present writer has considered that all the Mangaone Sub-group Pyroclastics were erupted from vents within Haroharo Caldera (Cole and Nairn 1975). The previously defined source areas were artefacts of both the lack of exposure of the Mangaone plinian fall deposits within the caldera, and the downwind displacement of high eruption columns and the ejecta falling from them. Similar lateral drift has recently been demonstrated for the Taupo plinian pumice (Walker 1980), leading to the thickest accumulation of the deposit some distance downwind of the source. As with the Rotoehu Ash, the lack of large ballistic lithics in all sections exposing Mangaone Sub-group Pyroclastics is consistent with location of eruptive vents now buried beneath younger lavas within Haroharo Caldera.

The initial Ngamotu and Tahuna eruptions of the Mangaone sequence were relatively small, both with total erupted volumes 


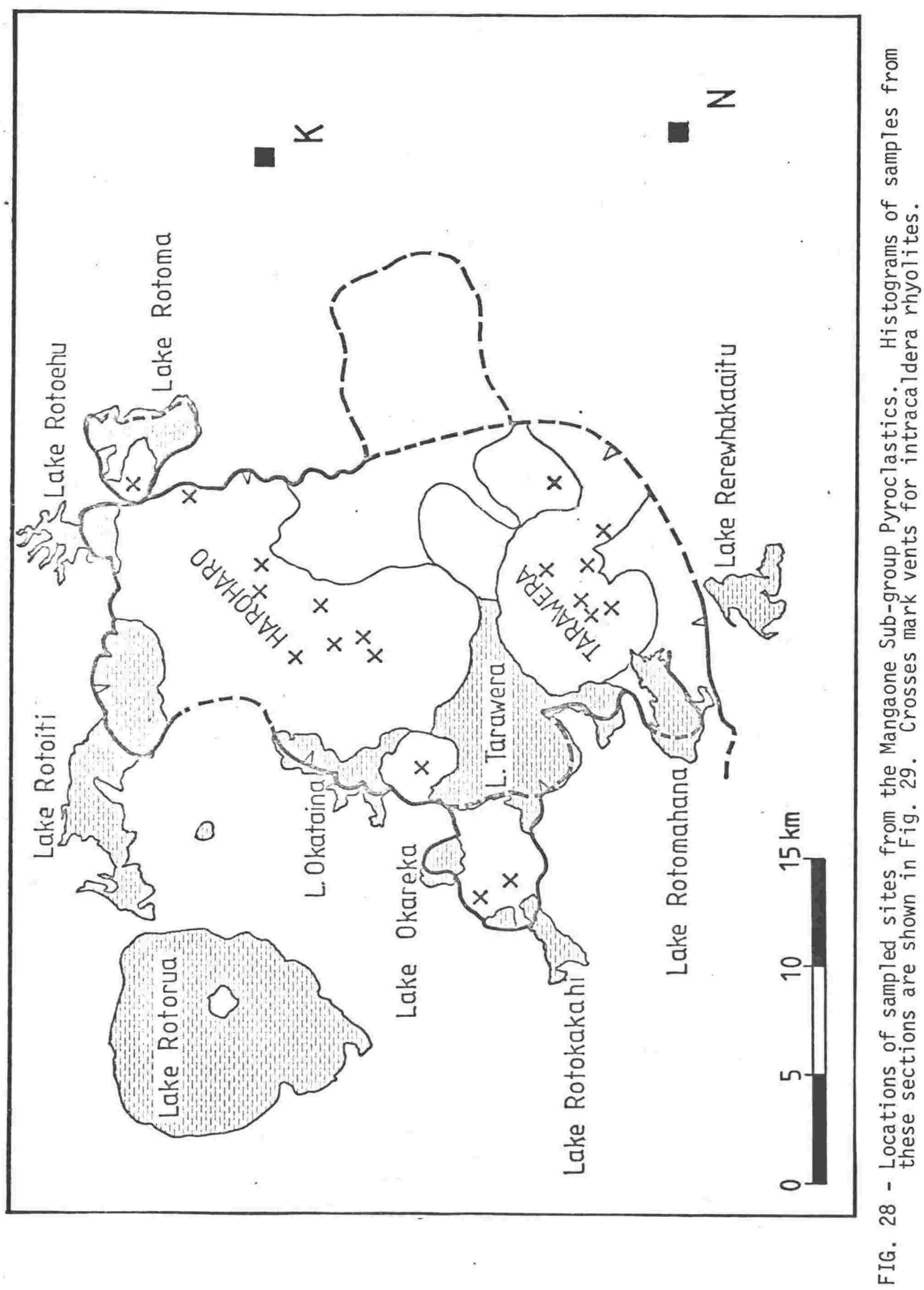


less than $2 \mathrm{~km}^{3}$ (Howorth 1975). The Ngamotu pyroclastics are thickest and coarsest to south-east of O.V.C., and were probably erupted from the Tarawera vent lineation within southern Haroharo Caldera. Fig. 29 includes a histogram of a Ngamotu Tephra sample from the Ngamotu Road area, where the closest outcrops to the presumed vent occur on the dispersal axis. The small erupted volume and low lithic content of the Ngamotu and Tahuna Tephras suggest that little caldera modification would have accompanied these eruptions.

The following Maketu, Hauparu and Mangaone pyroclastic eruptions were of very much larger erupted volume (total c. $50 \mathrm{~km}^{3}$ - Howorth 1975) with wide dispersal of well-sorted, coarse pumice and lithic rhyolite lapilli and block beds (Fig. 30), indicating dispersal from high plinian eruption columns. Eruptive vents appear to have been located in northern Haroharo Caldera, probably on the Haroharo vent lineation. Abundant lithic contents (Fig. 29) indicate considerable vent modification during these eruptions, while an increased essential lithic (obsidian) content which occurs in the plinian fall deposits of the Hauparu and Mangaone Tephra Formations suggests that some lava extrusion may have preceded or accompanied these eruptions. The Mangaone plinian eruptions were immediately followed by very large pyroclastic surges (Fig. 31) which may have been generated by collapse of the plinian eruption columns, or perhaps a change to a phreatomagmatic eruption style if water gained access to the vents. A lower density of pumice in each size fraction of the surge deposits, relative to the fall pumice, is the only evidence of any change in the vent conditions, but could also result from the different depositional mechanisms. The surge deposits are thickest on the northern rim of Haroharo Caldera and in Puhipuhi Basin. Charcoal from the surge deposits at Lake Rotoehu is ${ }^{14} \mathrm{C}$ dated at $34,300 \pm 2000$ yrs B.P. (see Table 2).

The Mangaone Tephra Formation eruptions were succeeded by the relatively small $\left(<2 \mathrm{~km}^{3}\right)$ Awakeri plinian event, and 


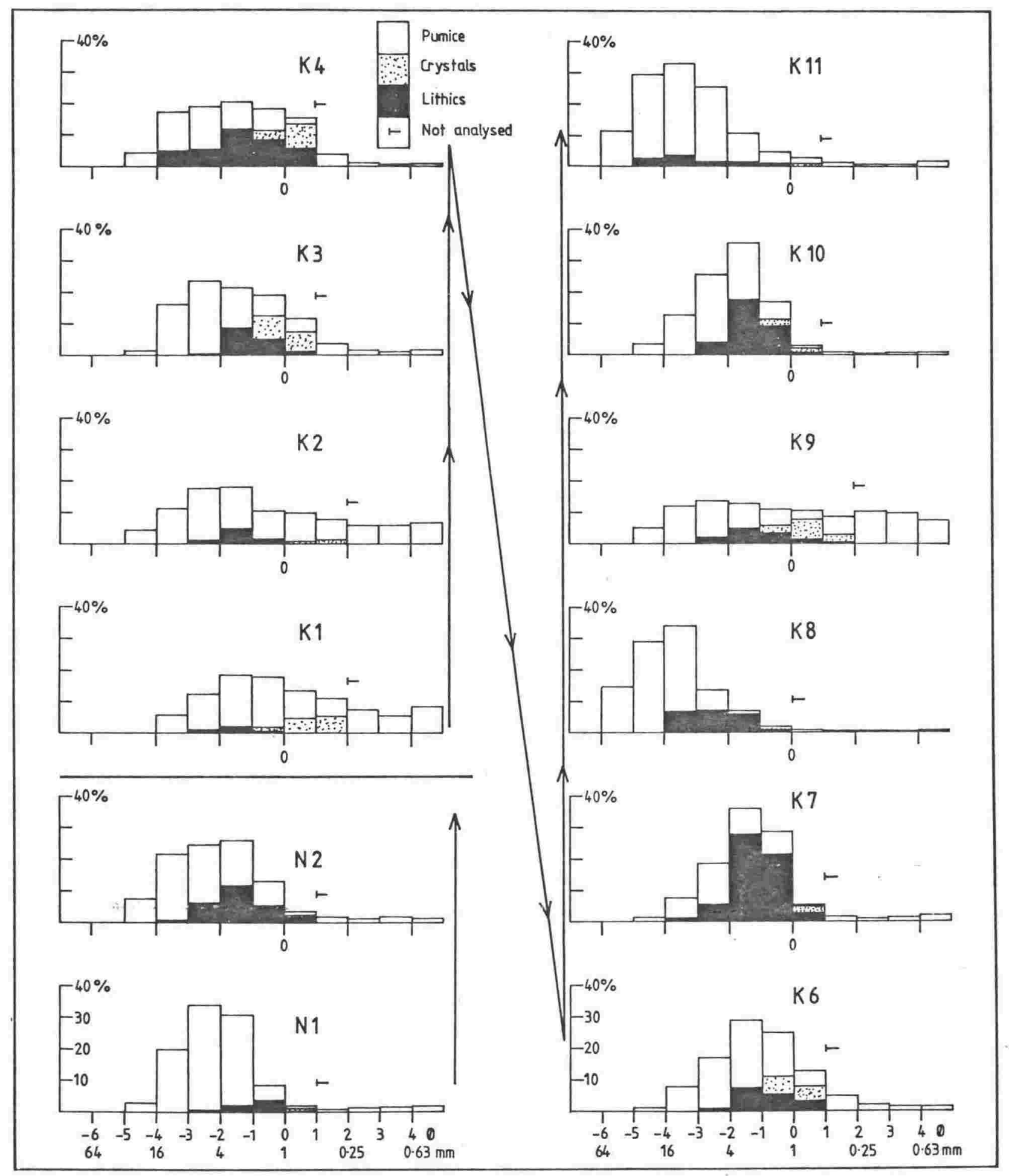

FIG. 29 - Histograms, with component separations, of Mangaone Sub-group Pyroclastics from Ngamotu Rd (N) and Kawerau (K), sites as shown on Fig. 28. Sampled beds at Kawerau are shown on Fig. 30. N1 - Ngamotu Tephra; N2 - Maketu Tephra; K1 - Ngamotu Tephra; K2 - Tahuna Tephra(?); K3 - Maketu Tephra (lower); K4 - Maketu Tephra (upper); K6 - Hauparu Tephra; K7 - Mangaone Tephra (basa 1); K8 - Mangaone Tephra (middle); K9 - Mangaone pyroclastic flow unit; K10 - Awakeri Tephra; K11 - Omataroa Tephra. Arrows indicate upward stratigraphic sequence. 


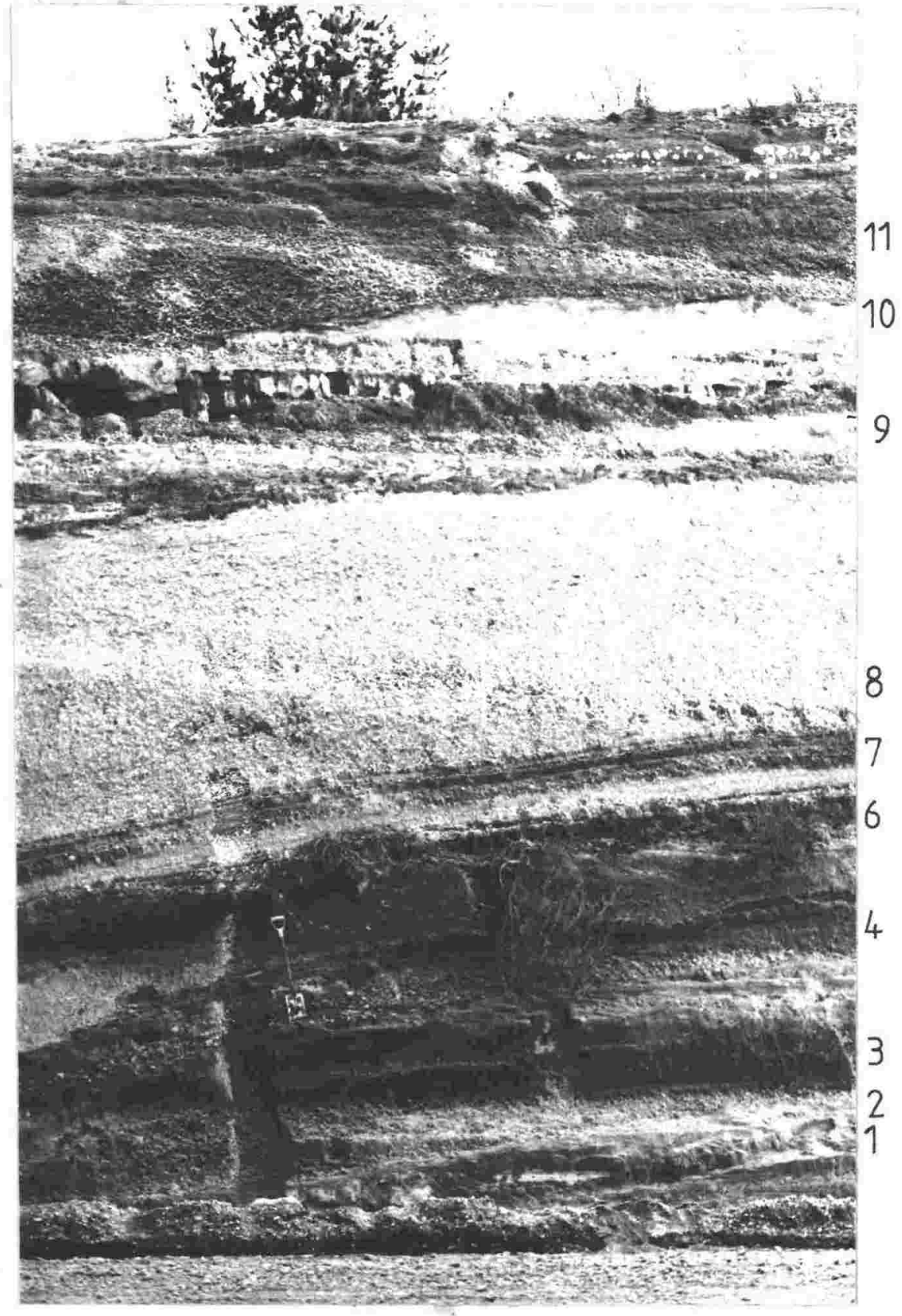

FIG. 30 - Mangaone Pyroclastic Sub-group at Kawerau (site K on Fig. 28) $>20 \mathrm{~km}$ east of inferred vent locations in Haroharo Caldera. Sampled beds are numbered as in Fig. 29. 


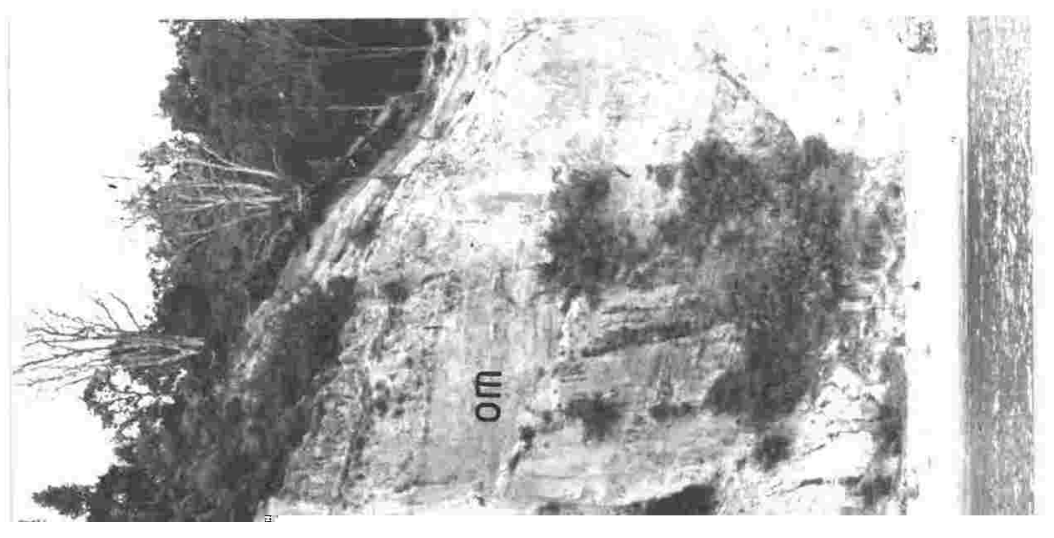

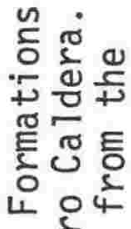

ช

등동드

또

है둥

EE

ब穴弟

ㅎํำ음

믐

它出

묻두

ธ。

틍. 
followed by the Omataroa plinian and pyroclastic surge eruptions $\left(18 \mathrm{~km}^{3}\right)$ which terminated the Mangaone Sub-group eruptive sequence. The Omataroa eruptions were similar to those of the Mangaone Tephra Formation, except that the Omataroa eruption concluded with a small plinian event. Strongly cross-bedded surge deposits interbedded between the Omataroa fall beds on the northern shores of Lake Rotoehu and Rotoiti indicate proximity to source.

Little can be inferred of Haroharo Caldera physiography during and following the Mangaone Sub-group eruptions. All eruptive vents appear to have been situated within the caldera. Pyroclastic exposures on the caldera rim do not contain ballistic lithics suggesting that no exposures are closer than about 5-6 $\mathrm{km}$ from the vents. The high lithic contents and large erupted volumes (of order 15-20 $\mathrm{km}^{3}$ ) for the largest Mangaone Sub-group events indicate that considerable vent modification, and probable local collapse accompanied the eruptions. However, it has not been possible to find evidence of accompanying modification of the presently exposed caldera margins. The obsidian lithic content of the Hauparu and Mangaone Tephra Formations suggest that some extrusion of lava had occurred prior to these pyroclastic eruptions.

Te Rere Eruptive Episode: Te Rere Ash (Vucetich and Pullar 1969) does not outcrop within Haroharo Caldera, and is only rarely exposed on its margins. In previous descriptions, and this discussion, "Te Rere Ash" has been taken as the entire deposit above a paleosol developed on Kawakawa Tephra (or its overlying loess), up to the basal contact of the overlying Okareka Ash. This deposit is now known to include thick tephric loess overlying the basal primary pyroclastic fall deposits of true "Te Rere Ash". Measured thicknesses of Te Rere Ash (Fig. 32) include this tephric loess, so that isopachs provide an unreliable indication of source area. Vucetich and Pullar (1969) considered either Tarawera or Haroharo as an eruptive source for Te Rere Ash. During this study several new exposures of Te Rere Ash have been located around Haroharo Caldera, and 


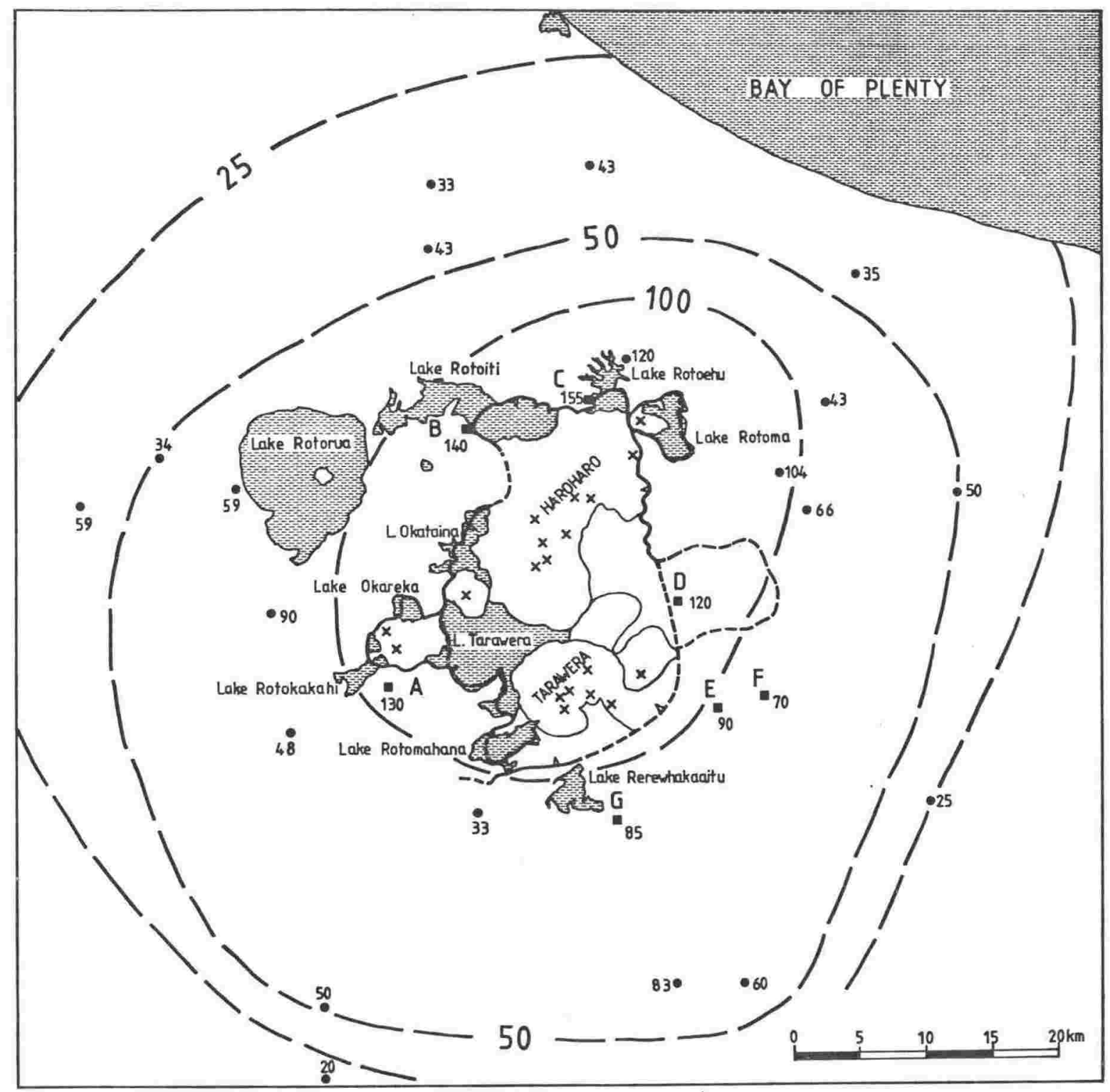

FIG. 32 - Isopach map of Te Rere Ash (and included tephric loess see text) from Vucetich and Pullar (1969), with additional measurements ( made by the writer on margins of Haroharo Caldera. Thicknesses are in centimetres. Sampled sites are lettered as in Figs. 33 and 34 . 
are closest to source area. Variations in lithology, thickness, and grain size show the Te Rere Ash to have a complex eruptive origin from the Haroharo vent lineation. Proximal section locations are shown in Fig. 32, with stratigraphy and size data in Fig. 33. Histograms with some component splits are shown in Fig. 34.

The thickest known deposits of the primary pyroclastic material at base of Te Rere Ash occur in three sections at Lakes Rotoiti and Rotoehu, and Puhipuhi Road (Fig. 35). These sections are sited on the northern and eastern margins of the caldera. The Puhipuhi Road section contains only airfall ash and lapilli, but the two northern (Lake) sections contain an upper ash and lapilli deposit comprising angular fragments of black obsidian and slightly pumiceous glassy rhyolite (Fig. 33). Pumice forms a very minor component. This obsidian deposit is unbedded, contains charcoal ${ }^{14} \mathrm{C}$ dated (old $\mathrm{T} \frac{1}{2}$ ) at $20,700 \pm 450$ yrs B.P.* (Vucetich and Pullar 1969), and is interpreted as resulting from pyroclastic surge, probably produced by a violent explosion through a growing lava dome. The basal fall unit at Rotoehu also contains a high obsidian component, although with a larger pumice fraction (Fig. 34). In contrast, the coarsest fall unit at Puhipuhi Road contains lithic rhyolite (Fig. 34). The ferromagnesian mineralogy of all these deposits is characterized by dominant hypersthene and amphibole (calcic hornblende and cummingtonite - Kohn 1973). Biotite is not present, or rare.

A further section to south of Lake Rotokakahi contains one of the coarsest fall units sampled from the Te Rere Ash (Fig. 33). However, here the deposit dominantly consists of pumiceous to lithic rhyolite with the calcic hornblende-biotite mineralogy

* The dated sample (NZ523) was mistakenly assigned to the Okareka Ash (Vucetich and Pullar 1969, p. 796). Reexamination of stratigraphy at the sample site by this writer has shown the sample to come from Te Rere Ash.

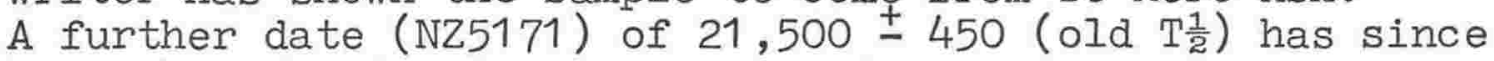
been obtained from the same obsidian horizon at Lake Rotoehu (Fig. 33 and Table 2). 


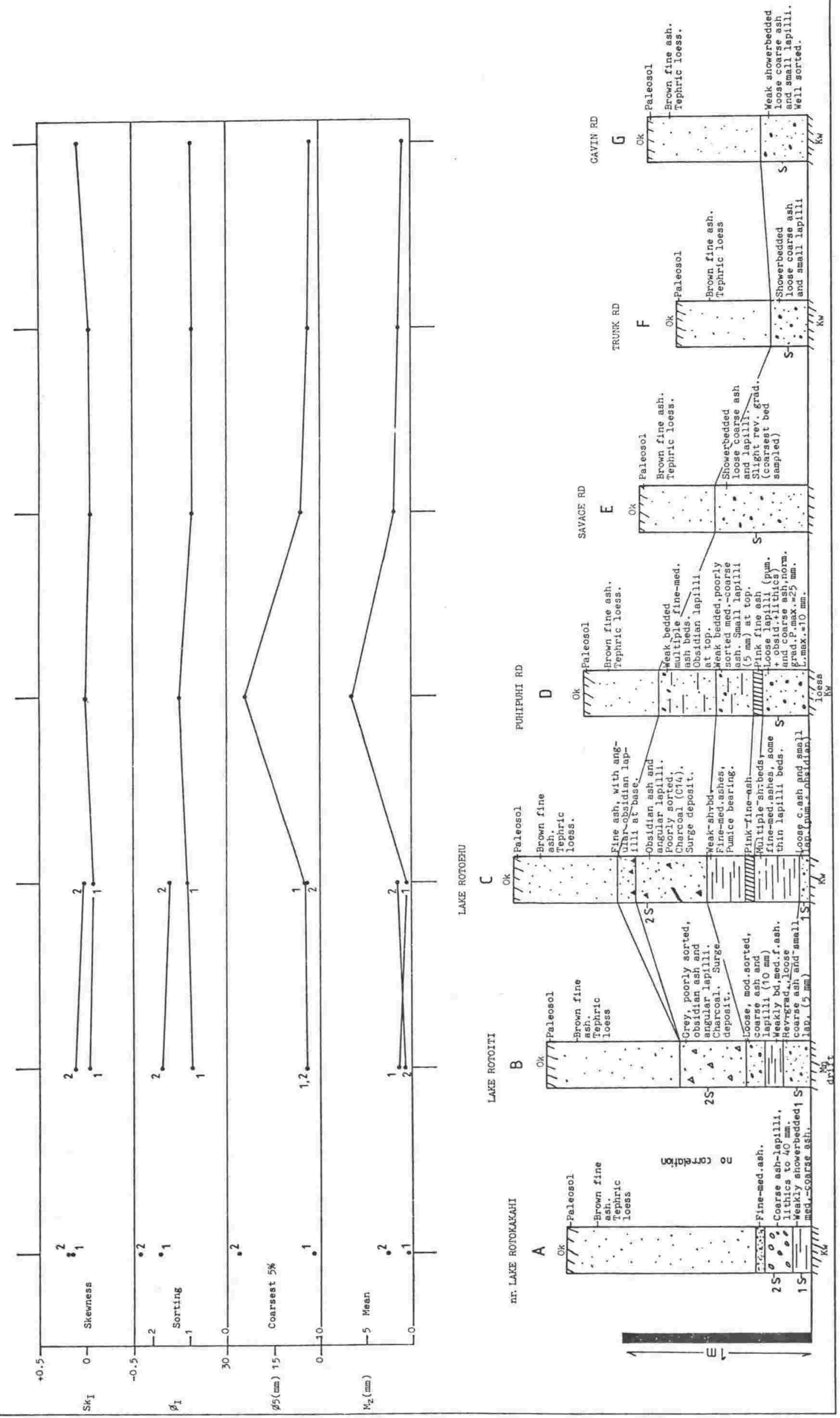

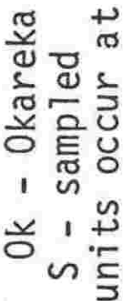

लें:

ติธ

.

는

$=$ के एँ

동

乡엉

的음.

ปै केष

둥

药凶 으

吾

틍 है

4 प

的立点

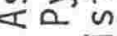

인

के

o 올.

要离

ठ。

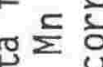

중 ซ을

동

फั

무

实.

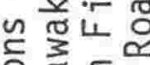

울

品

ป产过

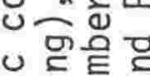

员罂

कृ

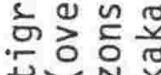

N

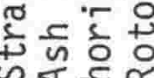

m

ভ্ 

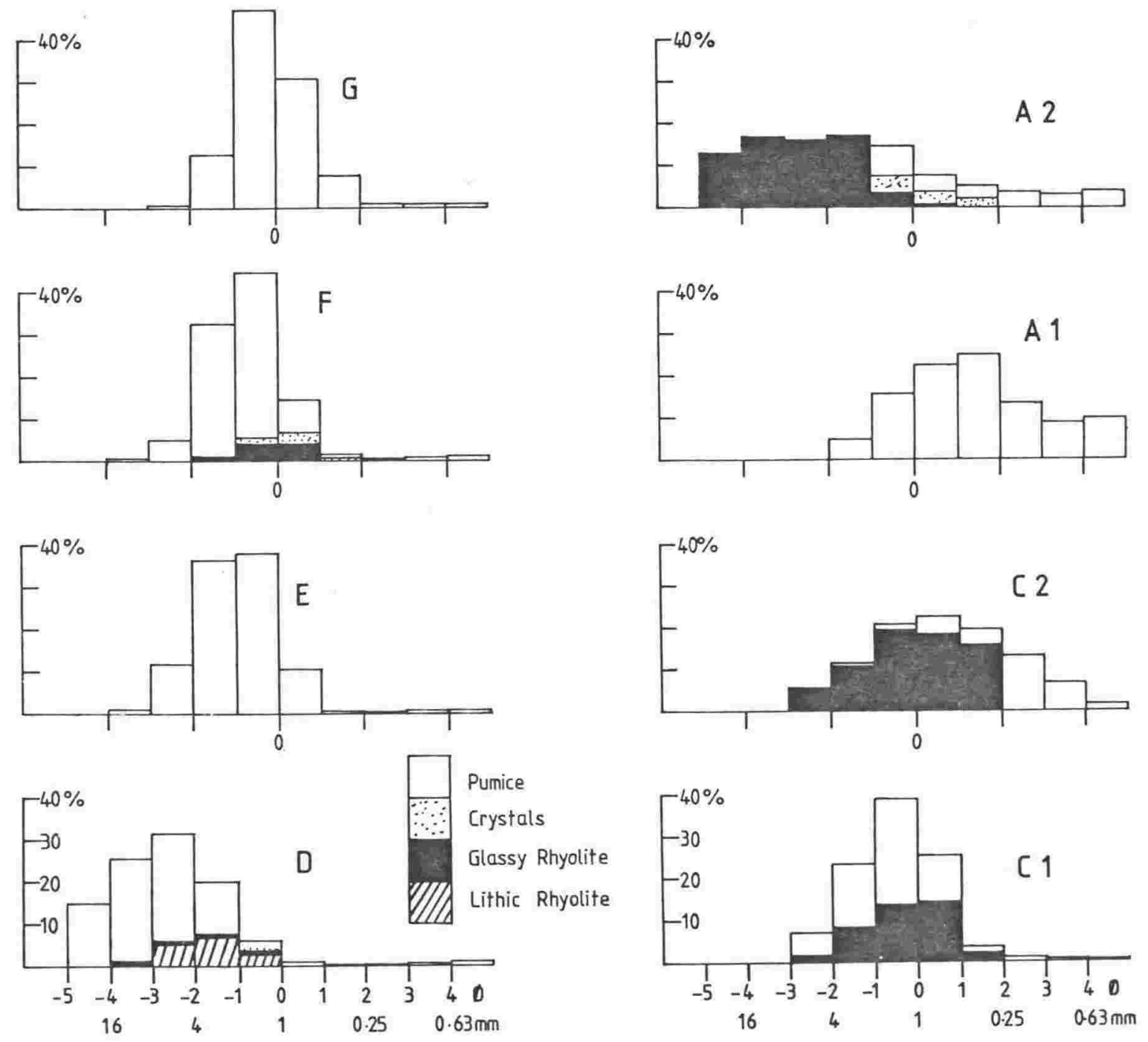

FIG. 34 - Histograms, with component separations, of Te Rere Ash samples located in Fig. 33. Components of samples $E, G$, A1, have not been separated. See text for discussion. 


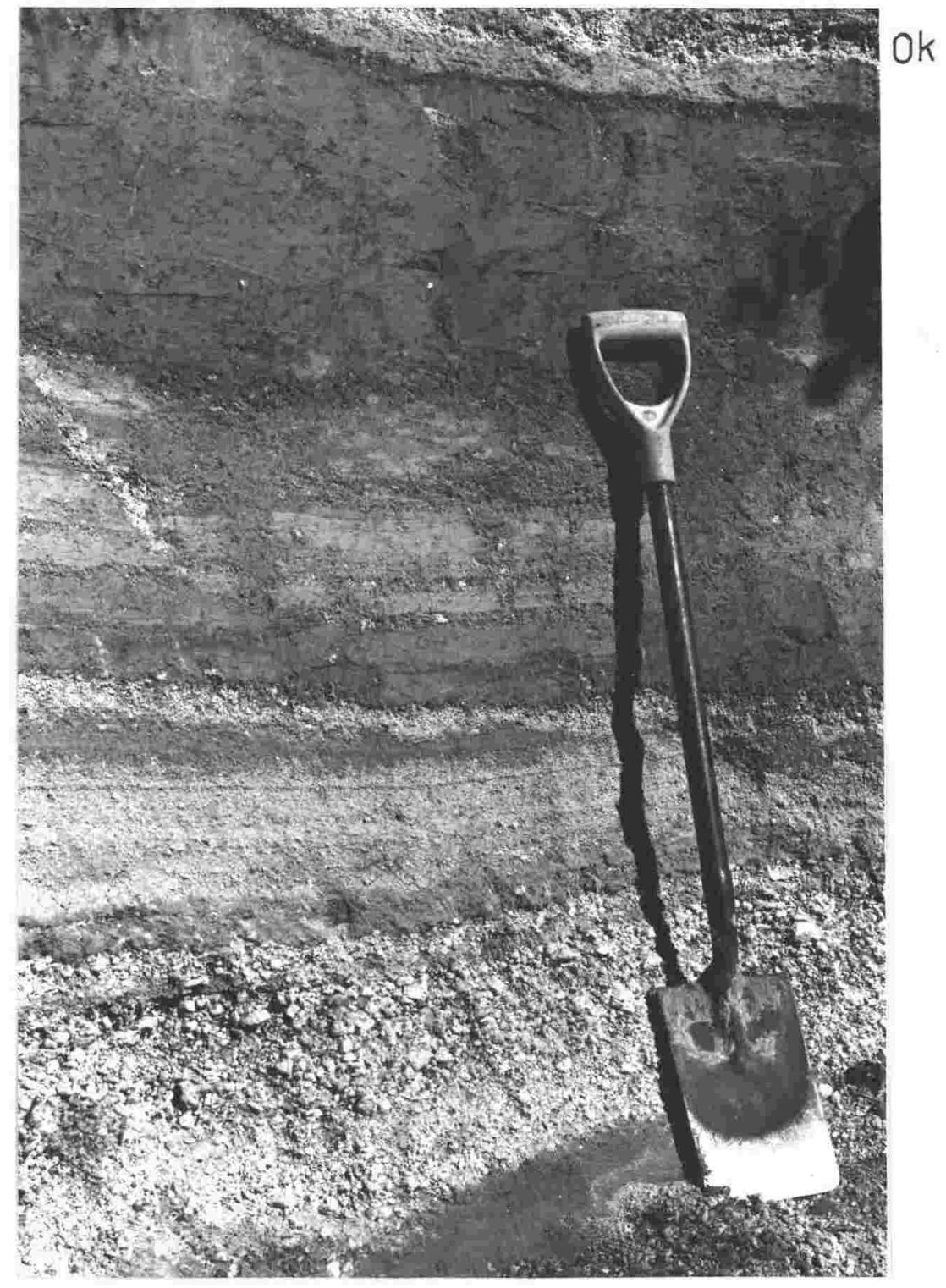

FIG. 35 - Te Rere Ash at Puhipuhi Rd (Site D on Figs. 32, 33) where the basal pumice lapilli bed comprises the coarsest fall unit found in the Te Rere Ash (see Fig 33). The showerbedded fall deposits are overlain by fine-grained tephric loess (at and above spade handle) under basal Okareka Ash (Ok). Spade is $1 \mathrm{~m}$ long. 
found in some flows of the Tikitapu Rhyolite Complex (Ewart 1968).

Data relevant to location of $\mathrm{Te}$ Rere Ash source vents are summarized as follows. The coarsest individual fall units in the Te Rere Ash occur at Rotokakahi and Puhipuhi Road, on opposite sides of southern Haroharo Caldera. The only known surge deposits within Te Rere Ash occur on the northern caldera margin. Other sections at Gavin Road, Trunk Road, and Savage Road, to south and east of Tarawera, contain only a thin, relatively finegrained basal airfall layer, of typical hypersthene-amphibole mineralogy. Abundant biotite occurs only in sections to south of Rotokakahi.

This distribution of sections, and the lithological and mineralogical variations, are explained by eruption of "Te Rere Ash" from multiple vents spread along the Haroharo vent lineation. Such widely separated multiple eruptive vents are demonstrated for the three younger Rotoma, Mamaku, and Whakatane Eruptive Episodes from Haroharo, in later sections of this thesis. At both the Tikitapu and Haroharo Rhyolite Complexes occur lava flows of appropriate age and mineralogy to form part of a $\mathrm{Te}$ Rere Eruptive Episode. The "northern dome" and the oldest exposed flows of the "Trig 7693 rhyolites" (Nairn 1980, see p. 203) within the Okareka Embayment, both underlie Okareka Ash, but are not mantled by Kawakawa Tephra, so were probably extruded at about time of the Te Rere Ash eruption. These lavas do not contain biotite, but adjacent extrusives of apparently similar age are biotite-bearing (Ewart 1968). A pyroclastic source vent in this area would account for the coarse, biotite-rich lapilli present in Te Rere Ash at Rotokakahi, $4 \mathrm{~km}$ to the south, the explosive eruptions being followed by the rhyolite lava extrusions.

The Te Koutu, Haumingi, and Tuarae Lava Flows (Fig. 12) of the Haroharo Volcanic Complex are also of apparent Te Rere Ash age. The source vents for these lavas are buried under younger extrusives, but they appear to have been located on the Haroharo vent lineation, close to Pukerimu Cone (Fig. 12), 
on the western side of Haroharo Caldera. Pyroclastic eruptions from vents in this area would account for the relatively thick and coarse, non-biotite bearing pyroclastic fall deposits at Lakes Rotoehu and Rotoiti, and at Puhipuhi Road. The pyroclastic surge deposits at Lake Rotoehu might also indicate a source for these obsidian-bearing deposits further to north-east along the Haroharo vent lineation, although no Te Rere-age lavas are exposed in this area. The relatively thin and fine grained Te Rere Ash at Gavin Road and Savage Road to south-east and east of Tarawera Volcanic Complex precludes a Tarawera source for the Te Rere Ash.

The thickness, mineralogy, and size distribution patterns suggest that the major source for Te Rere Ash was probably in the Pukerimu Cone area, with a weakly developed south-west dispersal axis indicating that the coarsest ejecta were carried towards Puhipuhi Road. All the explosive events were followed by lava extrusion so that the Te Rere Ash vents are now deeply buried.

Okareka Eruptive Episode: Okareka Ash is exposed only on the oldest lavas within Haroharo Caldera. It overlies weathered surfaces on the earliest exposed extrusives of the Haroharo Volcanic Complex, and some lavas within the Okareka Embayment. No Haroharo or Okareka lavas are stratigraphically associated with the Okareka Ash. Vucetich and Pullar (1969) considered either the Tarawera or Haroharo Volcanic Complexes as possible eruptive sources for the Okareka Ash.

As with the Te Rere Ash, measured thicknesses of Okareka Ash include overlying tephric loess (see Pullar 1973), so that isopachs are an unreliable guide to source area. Section locations around Haroharo Caldera are shown in Fig. 36 with stratigraphy and size data in Fig. 37. Histograms with some component splits are shown in Fig. 38.

Although one of the thickest exposed deposits of Okareka Ash (Fig. 36), occurs on the Haroharo vent lineation at Lake 


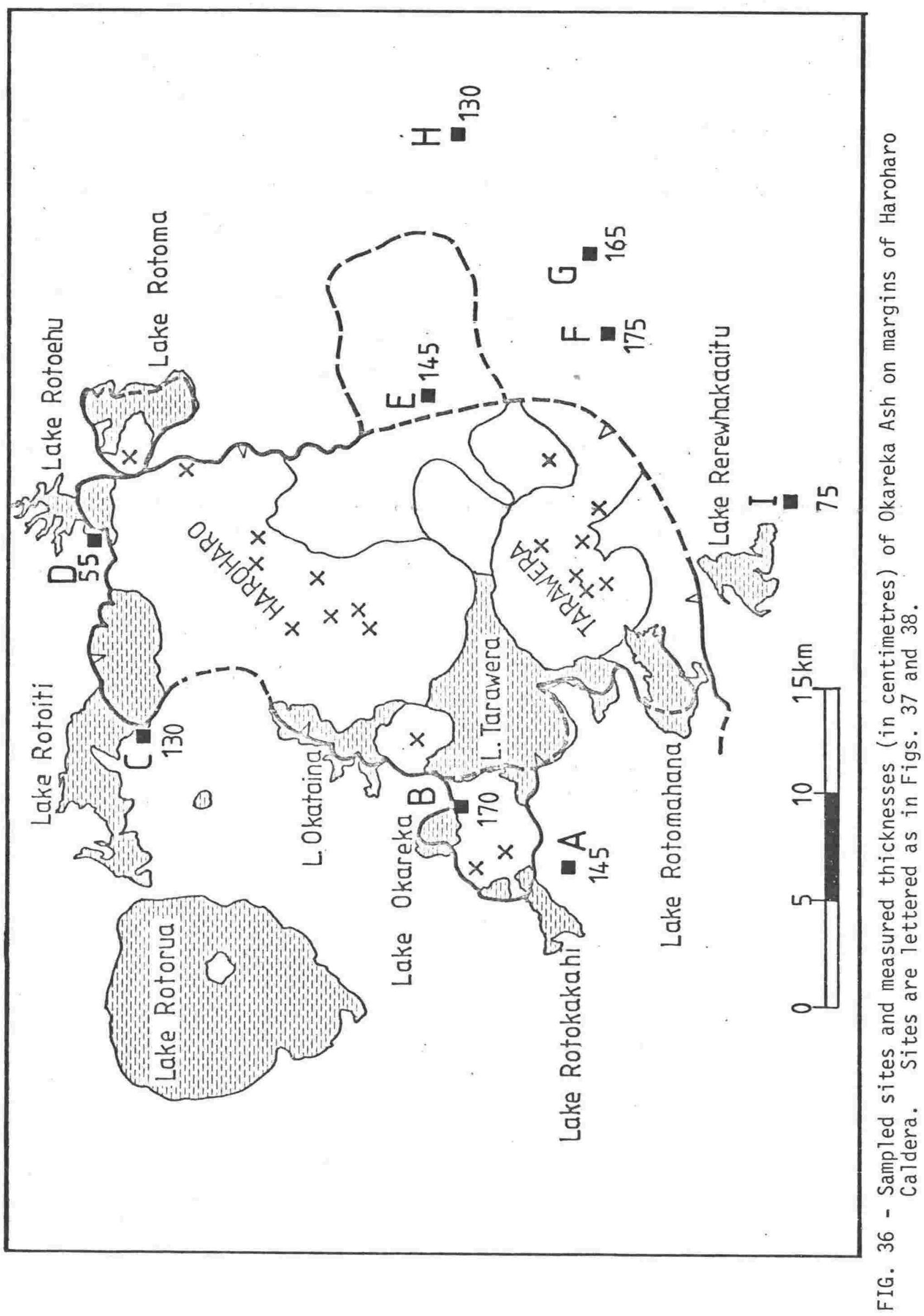




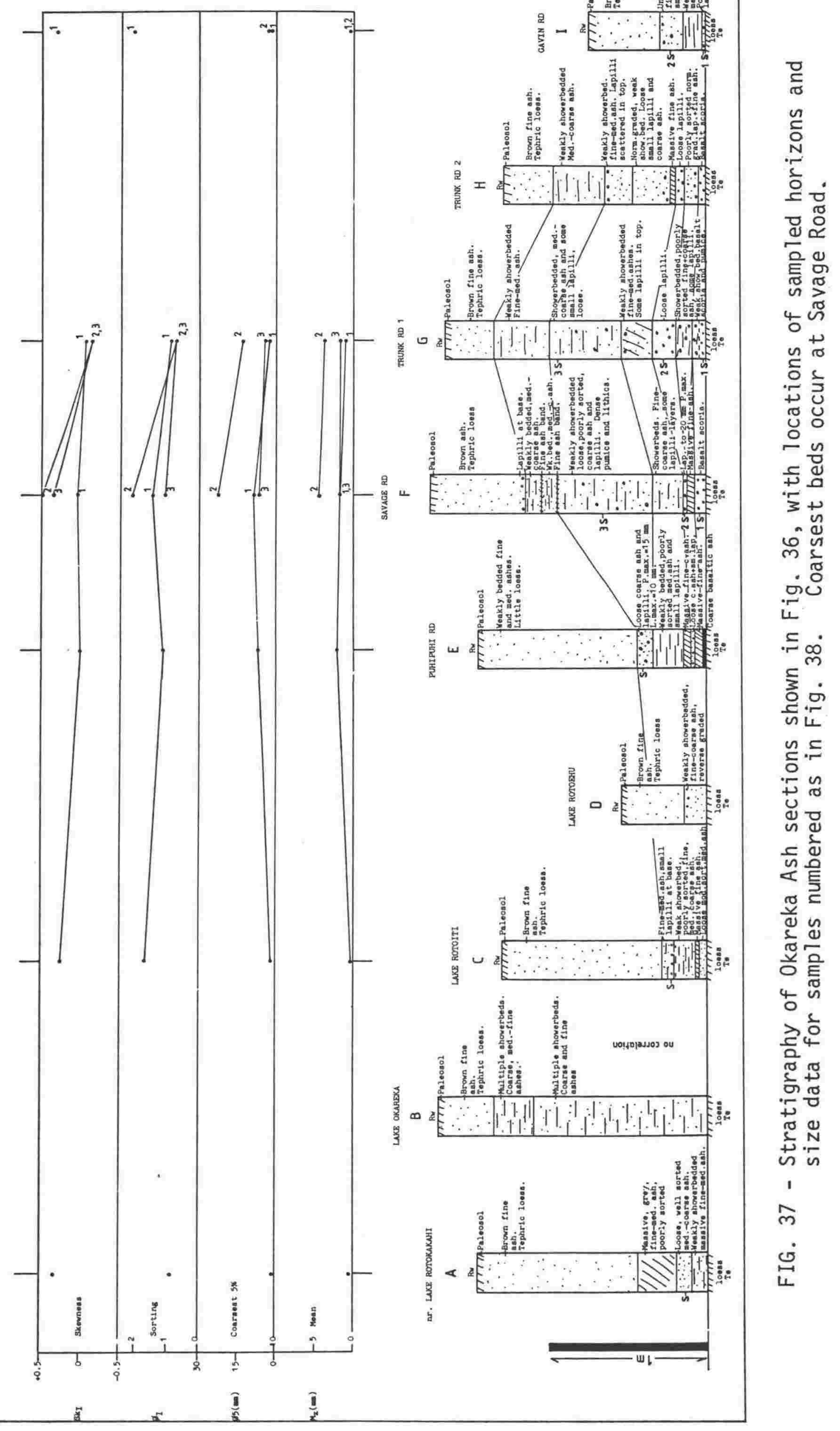




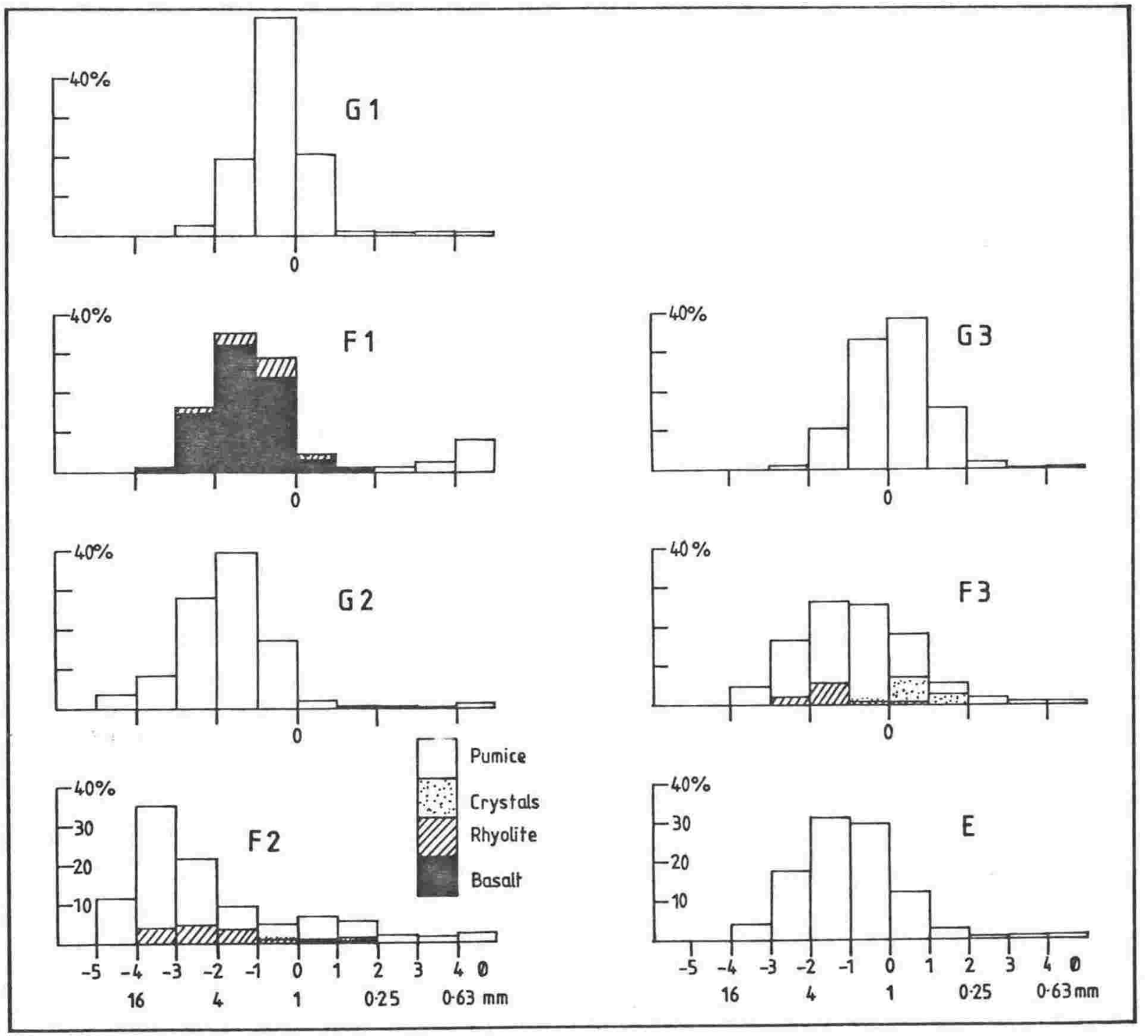

FIG. 38 - Histograms, with component separations, of Okareka Ash samples located in Fig. 37. Samples G1, 2, 3, and E are not separated. See text for discussion. 
Okareka (from which the deposit was named by Vucetich and Pullar, 1969) this section contains largely ash-grade material, and lies in a gully floor where it is probably overthickened by downslope movement. The thickest deposits which include the coarsest lapilli-size clasts occur in new exposures at Savage Road and Trunk Road to east of Tarawera (Fig. 39) and these sections appear both closest to source and on the downwind, eastward axis of dispersal from a plinian eruption column at a Tarawera source vent.

Okareka Ash does not outcrop on any Tarawera lavas. However, the immediately younger Rerewhakaaitu Ash mantles weathered surfaces of lavas or thin tephric loess on the earliest exposed Tarawera extrusives - the Hawea and Ridge lava flows. These lavas are thus coeval with the Okareka Ash eruptions, and are considered to form the final phase of the Okareka Eruptive Episode. The lavas and the Okareka Ash are biotite-bearing. No biotite-bearing lavas occur at Haroharo Volcanic Complex.

The Okareka Ash sections at Savage Road, Trunk Road, and Puhipuhi Road contain a previously unrecorded 10-100 mm thick basal layer (Fig. 39) consisting dominantly of well-sorted basalt lapilli, with minor lithic rhyolite (Fig. 37). Eruption of this sub-plinian basalt appears to have been the initial pyroclastic event of the Okareka Eruptive Episode. The following rhyolite eruptions of the Okareka Ash and associated Hawea and Ridge lavas appear to have been triggered by basalt intrusion and eruption, in the same manner as the plinian Matahi Basalt immediately preceded the Rotoiti Breccia eruptions from northern Haroharo Caldera.

Although the closest exposure of Okareka Ash to Tarawera is more than $8 \mathrm{~km}$ from the assumed vent area, it appears clear that the pyroclastic eruptive source was on the Tarawera Volcanic Complex, probably at the vents for the immediately following Hawea and Ridge Lava Flows. These vents are considered to lie in the vicinity of Eastern Dome, Ridge Dome, and Kanakana Dome, in the north-eastern section of the Tarawera Volcanic Complex. 


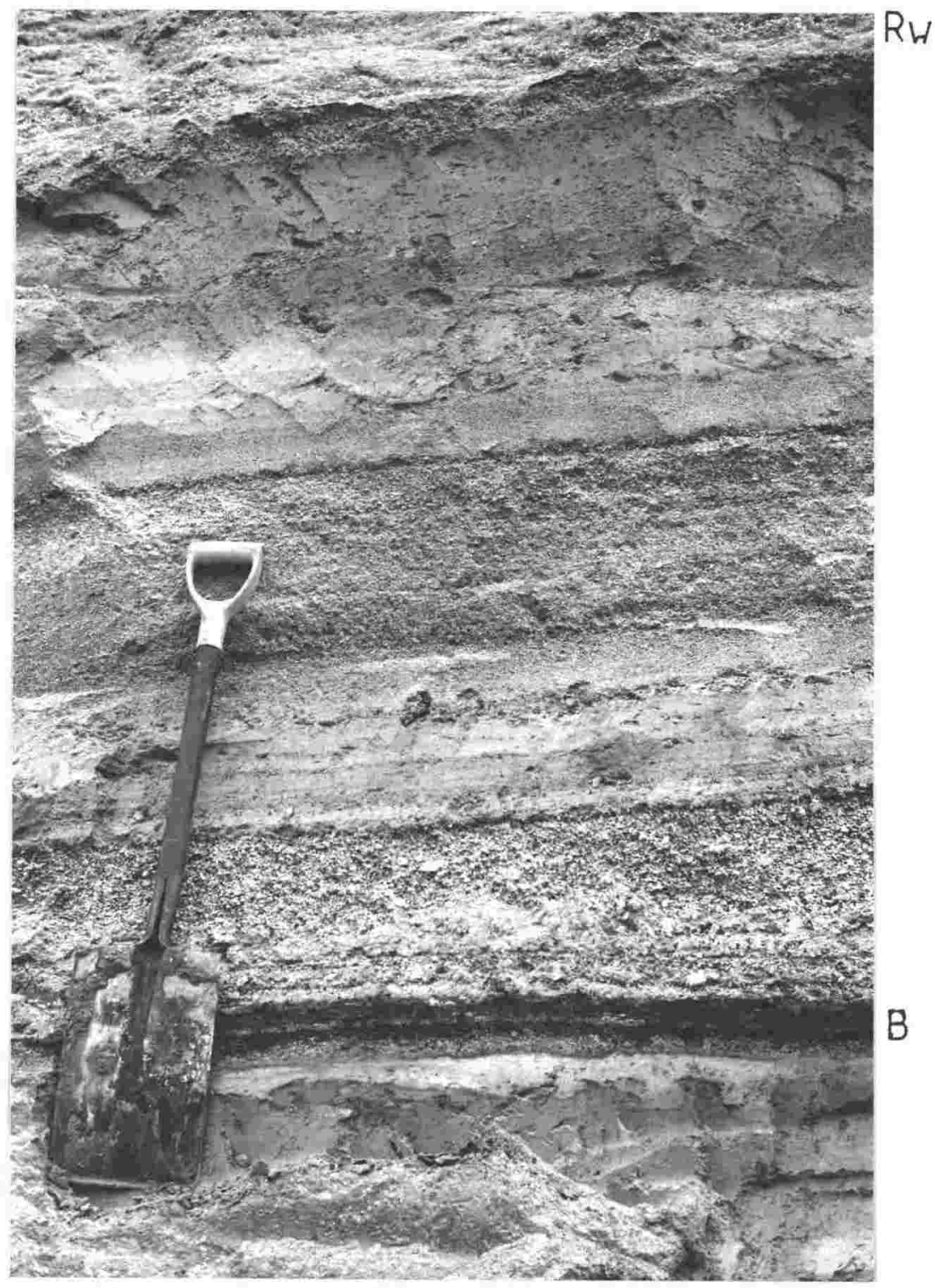

FIG. 39 - Okareka Ash at Trunk Road (site G on Figs. 36 \& 37). Dark basaltic basal layer (B) overlies loess on Te Rere Ash (below spade). Rhyolitic lapilli and ash of the Okareka Ash passes upwards into fine-grained tephric loess beneath Rerewhakaaitu Ash (Rw). 
The Okareka Eruptive Episode apparently marks commencement of construction of the present Tarawera Volcanic Complex, and was initiated by a small sub-plinian basaltic pyroclastic eruption. Pullar (1973) estimated an erupted volume of $4.8 \mathrm{~km}^{3}$ for the Okareka Ash, and an area of $16,000 \mathrm{~km}^{2}$ bounded by the $20 \mathrm{~cm}$ isopach.

Okareka Ash has not been ${ }^{14} \mathrm{C}$ dated.

Rerewhakaaitu Eruptive Episode: Deposits of this very complex eruptive episode are poorly exposed and have yet to be studied in detail, so that only an outline of the eruptive sequence can be described. This summary is based on the stratigraphic data presented on $\mathrm{p} .112$ of this thesis.

A period of c. 2000 yrs quiescence followed the Okareka Eruptive Episode before activity again resumed, this time at the south-western end of Tarawera Volcanic Complex. Rotomahana Dome appears to have been extruded in the earliest phase of the eruptive episode, but as the basal contact of the dome lava is nowhere exposed, the presence of earlier pyroclastics cannot be excluded. Dome extrusion was followed by major pyroclastic fall, flow, and surge emptions which built up the large tuff cone on the eastern margin of the dome and produced the widespread Rerewhakaaitu Ash of plinian origin (see Pullar 1973). The pyroclastics appear to have been erupted from the same vent as Rotomahana Dome and the later Southern Dome, located to south of Koa Trig. The tuff cone pyroclastics are overlain and intruded by lavas of Southern Dome, which was extruded in the tuff cone vent and terminated the emption. The Te Puha Lava Flow was probably also extruded at about this time, possibly slightly preceded by extrusion of Western Dome.

Pullar (1973) estimated a volume of $5.8 \mathrm{~km}^{3}$ for the Rerewhakaaitu Ash, and an area of $9000 \mathrm{~km}^{2}$ bounded by the $20 \mathrm{~cm}$ isopach. 


\title{
Source, age, and eruptive mechanisms of Rotorua Ash
}

\author{
I. A. NAIRN \\ Geology Department, Victoria University of Wellington, Wellington, New Zealand:
}

\begin{abstract}
Rotorua Ash is a widespread $\left(>10000 \mathrm{~km}^{2}\right)$ pyroclastic fall deposit erupted during extrusion of a rhyolite lava complex sited adjacent to the Lake Tikitapu basin, $10 \mathrm{~km}$ south-east of Rotorua City, North Island, New Zealand.

The eruption was plinian in character, with maximum rate of emission occurring early in the eruption sequence to produce a high $(c, 20 \mathrm{~km})$ eruption column. Later explosions accompanied extrusion of lavas. Local, near-vent, pyroclastic flow and surge deposits may have resulted from periods of column collapse. Extrusion of a lava flow from the main pyroclastic vent appears to have terminated the eruption.

A ${ }^{14} \mathrm{C}$ age of $13800 \pm 250$ years B.P. (new $\mathrm{T}_{2}^{\frac{1}{2}}$ ) has been obtained for Rotorua Ash close to the source,

KEYWORDS pyroclastics, lava, eruptions, Rotorua Ash. Rotorua
\end{abstract}

\section{INTRODUCTION}

Rotorua Ash is a widespread rhyolitic pyroclastic fall deposit with thickness exceeding $1 \mathrm{~m}$ over much of the Rotorua district. Near the source it forms a conspicuous pumice block and lapilli bed showing well-developed mantle bedding (Fig. 1). Stratigraphic position (Table 1), thickness, and distribution (Fig. 2) are described by Vucetich \& Pullar (1964) and Pullar (1972).

Rotorua Ash was one of the first New Zealand tephras to be studied. Thomas (1888) described it as a deposit thickening towards an origin in the Lake Tikitapu area (10 km south-east of Rotorua City-Fig. 2); Smith (1886) had earlier suggested that Lake Tikitapu occupied an explosion crater. Grange $(1929 ; 1937)$ considered the Rotorua "shower" had its origin in or near Lake Tikitapu, while Cotton (1952, p. 192) stated that it "came wholly or in part from the explosion-made pit now occupied by the small blue Lake Tikitapu". Vucetich \& Pullar (1964) and Ewart \& Healy (1965) accepted the Tikitapu source.

This paper describes (1) lithology of Rotorua Ash Formation (including near-source pyroclastic flow and surge components) and (2) geology and structure of the source region. The eruption sequence, eruption mechanisms, location of vents, and age of the eruption are discussed, but a detailed study of the widespread distribution of Rotorua Ash has not been attempted.

\section{Rotorua Ash Distribution}

Isopachs (Pullar 1972, and Fig. 2) define a nearsource lobe extending north-west from the Tikitapu region. An apparent less-developed distal lobe (Pullar 1972) extends north-north-east. The coarsest ejecta were distributed along the north-west dispersal axis, indicating a strong south-easterly wind vector during the eruption.
Coeval deposits of unwelded pyroclastic flow and surge origin occupy low-lying areas between Lakes Rotokakahi and Tarawera (Fig. 3) and are interbedded with pyroclastic fall deposits of Rotorua Ash.

\section{Rotorua Ash Lithology}

Accessible exposures through the entire Rotorua Ash eruptive sequence are not available near the source. A type section is chosen at a pumice quarry on Okareka Loop Road (N76/795002) † [U16/018316], 3.5 km from the source along the north-west dispersal axis. Multiple pyroclastic fall units are present (see Fig. 4 for description), but no pyroclastic flows or surges occur at this relatively elevated location. Contacts between all fall units are conformable, indicating lack of major time breaks during the eruption sequence.

Samples from type section fall units (and also from other locations, see Fig. 5) were sieved following standard techniques (Folk 1974; Walker 1971), using a 1-phi $(\phi)$-interval sieve set between $64 \mathrm{~mm}(+6 \phi)$ and $1 / 16 \mathrm{~mm}(+4 \phi)$. Fractions $>4 \mathrm{~mm}$ were hand sieved; split fractions $<4 \mathrm{~mm}$ where screened on an Endecott sieving machine for five minutes. Statistical parameters of Median Diameter, Graphic Mean, Graphic Standard Deviation, and Inclusive Graphic Skewness (see Folk 1974) have been calculated from cumulative curves (Table 2). Because many pyroclastic deposits are strongly bimodal or even polymodal (Visher 1969), only relatively large variations in graphically derived statistics can be considered meaningful (Sparks 1976).

Size fractions down to $\frac{1}{4} \mathrm{~mm}$ of selective samples have been separated into pumice, free crystals, essential lithics (all of comagmatic eruptive origin), and accessory lithics. Accessory lithics comprise somewhat altered

Received 19 July 1979, revised 29 October 1979.

*Present address: N.Z. Geological Survey, P.O. Box 499, Rotorua, New Zealand.

†Grid references are based on the national thousand-yard grid of the 1:63 360 topographical map series (NZMS 1).

These are followed (in square brackets) by the equivalent grid references from the metric 1:50000 map series

(NZMS 260). 


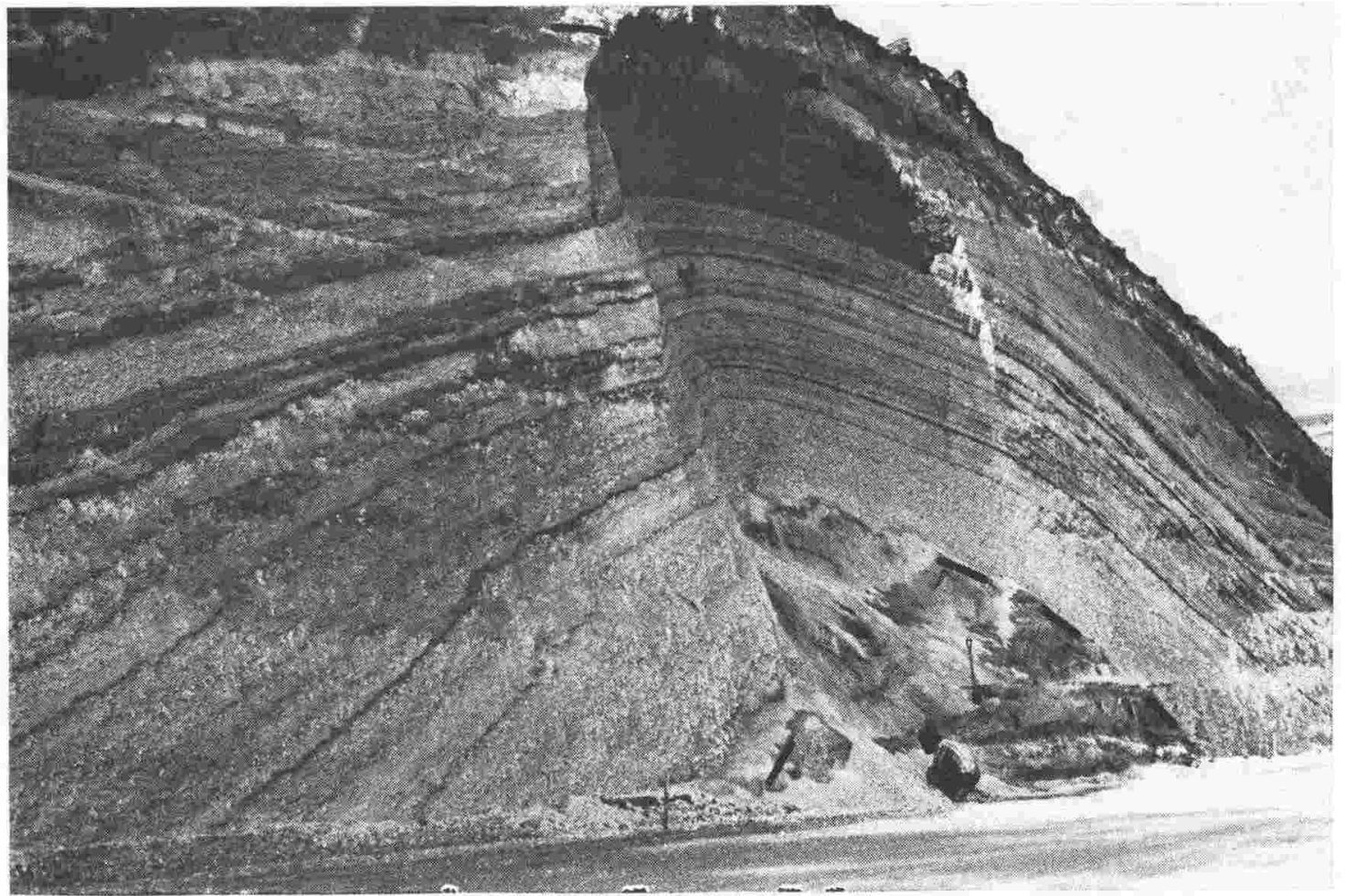

FIG. 1-Showerbedded Rotorua Ash, $6 \mathrm{~m}$ thick (site 2 on Fig. 5), mantling buried ridge (behind geologist) at $6 \mathrm{~km}$ from the source vent.

fragments of non-vesiculated, pre-existing rhyolite lavas (with a devitrified or spherulitic groundmass) through which Rotorua Ash was erupted. Essential lithics comprise fresh obsidian and glassy to pumiceous lava, mineralogically similar to Rotorua Ash pumice, but of greater density*. Complete gradation exists between the strongly vesiculated pumice and the slightly to nonvesiculated pumiceous essential lava. Separation is based on subjective judgment as to likely ballistic performance. Densities of various components of Rotorua Ash are shown in Table 3. The crystal component consists of quartz, plagioclase, hornblende, hypersthene, biotite, and magnetite - all phenocrysts in the erupting magma.

Fall units at the Rotorua Ash type section show a general trend for maximum and mean particle sizes to decrease upwards in the section (overall normal grading), although several individual fall units are reversely graded (Fig. 4). Lithic contents vary. The coarse basal fall unit contains only accessory lithics; the proportion of essential lithics increases in overlying fall units; only essential lithics are found in the uppermost fall unit. Pumice density varies inversely with accessory lithic content. The most inflated pumice is crystal-poor and occurs in lower fall units; upper fall

* It is not always possible to accurately separate accessory and essential lithics, particularly in the finer size fractions, but at least a recognition of occurrence of either or both lithic types usually can be made. units with no accessory lithics contain only lapilli of crystal-rich, relatively dense pumiceous lava.

Histograms and statistical data for Rotorua Ash fall samples from locations progressively downwind on the north-west dispersal axis are shown in Fig. 6. Samples were taken from the coarsest bed at each site, invariably located near the base of the deposit. Little systematic variation of size parameters occurs in the near-source region; mean and median sizes even increase away from the source towards Lake Rotorua, until systematic decrease commences beyond about $6 \mathrm{~km}$. Sorting values, total thicknesses, modal sizes, and maximum sizes of both pumice and lithics, however, show a more general tendency to decrease away from the source area. Three samples from fall units at Ngongotaha show an increasing proportion of essential lithics upward in the formation, together with decreasing mean, median, and modal grain sizes, in a sequence similar to that of the type section. Samples from sections beyond Ngongotaha demonstrate consistently decreasing particle size parameters, improved sorting (decreased Graphic Standard Deviation values), and increasingly fine skewing with distance.

Anomalously coarse and well sorted, but relatively thin block beds crop out in the Whakarewarewa-Hemo Gorge area, 9-10 km west-north-west of the source, near the south edge of the main dispersal axis. Lack of very coarse lithic material and the good sorting (Table 2-sample 7) rule out proximity to a vent, and 
FIG. 2-Rotorua Ash isopachs generalised from Pullar (1972). Thicknesses in centimetres.

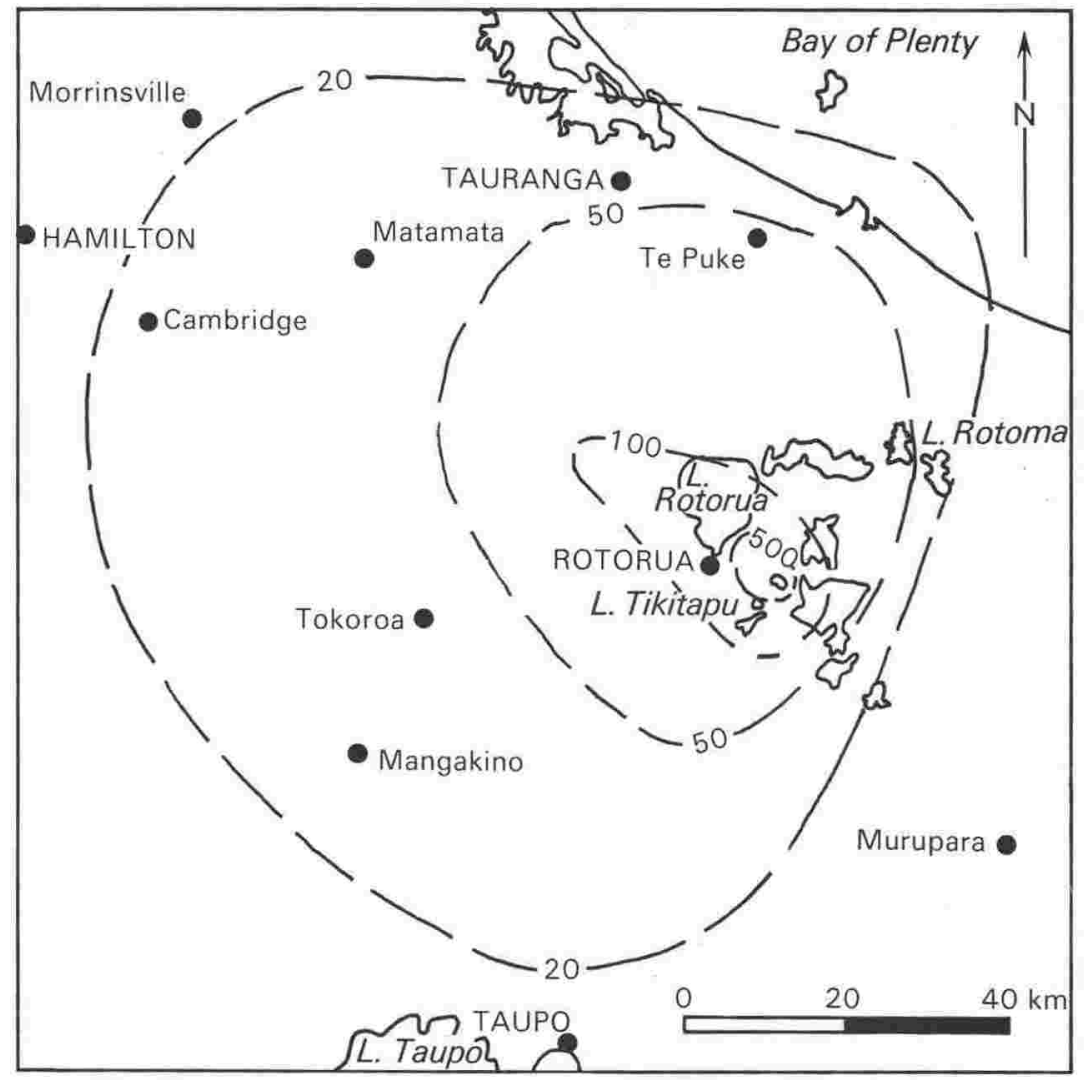

it appears that a restricted lobe of particularly coarse material fell in this area. A form of pinch and swell stratification in block and lapilli beds of the basal Rotorua Ash was briefly exposed in an excavation at Whakarewarewa (E. F. Lloyd pers. comm.), near the Hemo Gorge section, suggesting considerable local atmospheric turbulence during deposition. Such bedding is not present in other sections closer to the source.

Other Rotorua Ash samples from locations upwind of the source and to both sides of the dispersal axis demonstrate a general decrease in grain size parameters (Table 2) and better sorting with distance from the source and the main dispersal axis.

\section{Pyroclastic Flow and Surge Deposits}

Massive, poorly sorted, unwelded block and ash flow deposits, and some faintly crossbedded probable pyroclastic surge deposits, are interbedded within upper Rotorua Ash fall units in a few poorly exposed outcrops between Lakes Rotokakahi and Tarawera (Fig. 3). A composite section at $\mathrm{Te} \mathrm{Mu}$ Road is illustrated in Fig. 7. The coarse basal fall units of Rotorua Ash are not exposed, suggesting that the flow deposits represent late products of the eruptive sequence. Rare impact sags at the base of a surge(?) unit indicate proximity to an eruptive source. The showerbedded upper fall units contain no lithics, although most of the "pumice" is fairly dense pumiceous lava. The underlying surge(?) unit contains no accessory lithics and only a trace of essential lithics, and overlies a pyroclastic flow unit which contains a smal! proportion of accessory lithics (subordinate to essential lithics) - a sequence similar to that of the Rotorua Ash type section. The very coarse block flow deposits at the base of the Te Mu Road section are considered to be derived from adjacent collapse of an advancing comagmatic lava flow front (see Fig. 3). Pyroclastic flow deposits also crop out $3.2 \mathrm{~km}$ east-south-east of the source (at N76/849962 [U16] 067278]), where they contain many angular blocks of spherulitic obsidian and pumiceous rhyolite, plus some charcoal. These flow deposits (sample 19A-Table 2) are also interbedded with showerbedded fall units (sample 19B) of the upper Rotorua Ash (without accessory lithics).

Apparent surge deposits within Rotorua Ash (samples 21A, B, C-Table 2 and Fig. 5) are exposed in forestry road cuts high on the rhyolite lava domes and flows east of Rotokakahi. Weakly crossbedded layers range up to $1 \mathrm{~m}$ thick, contain charcoal, and are typically best developed in channels eroded into underlying airfall Rotorua Ash. No weathering occurs beneath this unconformity which is taken to represent local rainstorm-induced erosion during the eruption (such un- 
TABLE 1-Post-20000 years B.P. pyroclastic sequence in the Rotorua area.

\begin{tabular}{|c|c|c|c|}
\hline Formation & Ase* ${ }^{\text {Agear's before } 1950)}$ & Petrocraphy ${ }^{+}$ & Source \\
\hline $\begin{array}{l}\text { Tarmwera } \\
\text { (Foteminsina iud) }\end{array}$ & $74(10$ June 1886$)$ & $\begin{array}{l}\text { Altered lake floor sediments anci } \\
\text { country rock }\end{array}$ & $\begin{array}{l}\text { I. Rotomahana- } \\
\text { wimangu }\end{array}$ \\
\hline (Tartwera Basalt) & 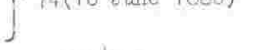 & Afhyrie basalt & Tarawera \\
\hline Kanevon Ach & $930 \pm 70$ & Biotite rinyolite & Trirawera \\
\hline Taupo Funiee & $1850 \pm 100$ & Hypersthene-augite rhyolite & Taupo \\
\hline Waiminia Ash & $3420 \pm 70$ & Hypersthene-augite riyclite & Tanpo \\
\hline Fotokewau Asin & not dated & Aphyric basalt & Okataina \\
\hline Whakatane Ash & $5180 \pm 80$ & Hornblende-bypers thene-rhyolite & Haroharo \\
\hline Namaku Ash & $7050 \pm 77$ & Hyperathene-hornblexde xhyol te & Haroharo \\
\hline Rotoma Ash & 2. $860 \pm 120$ & Hornblende-hyperethene rhyolite & Heroharo - Rotema \\
\hline Waiohau Ash & $11250 \pm 250$ & Hypersthene-hornblende rhyolite & Tarawera \\
\hline Rotonua Asin & $13450 \pm 250$ & $\begin{array}{l}\text { Hyperstiene-homblende-biotite } \\
\text { rhyolite }\end{array}$ & Trig 7693 Done \\
\hline Rerewhakanitu Ash & $14700-200$ & $\begin{array}{l}\text { Biotite-hornblende-hypersthene } \\
\text { rhyolite }\end{array}$ & Tarawera \\
\hline Okareka Ash & not dated & Biotite-hornilende rhyolite & Okataina \\
\hline Te Rere Ash & not dated & Hypersthene-hormblende rhyolite & Okataina \\
\hline Kawakewa Tephra & 19. $850 \pm 310$ & $\begin{array}{l}\text { Hyyers thene-hornblende-augite } \\
\text { rhyalite }\end{array}$ & Taupo \\
\hline
\end{tabular}

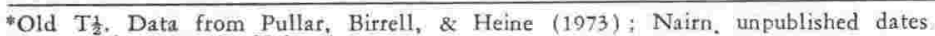

†From Cole (1970a); Kohn (1973).

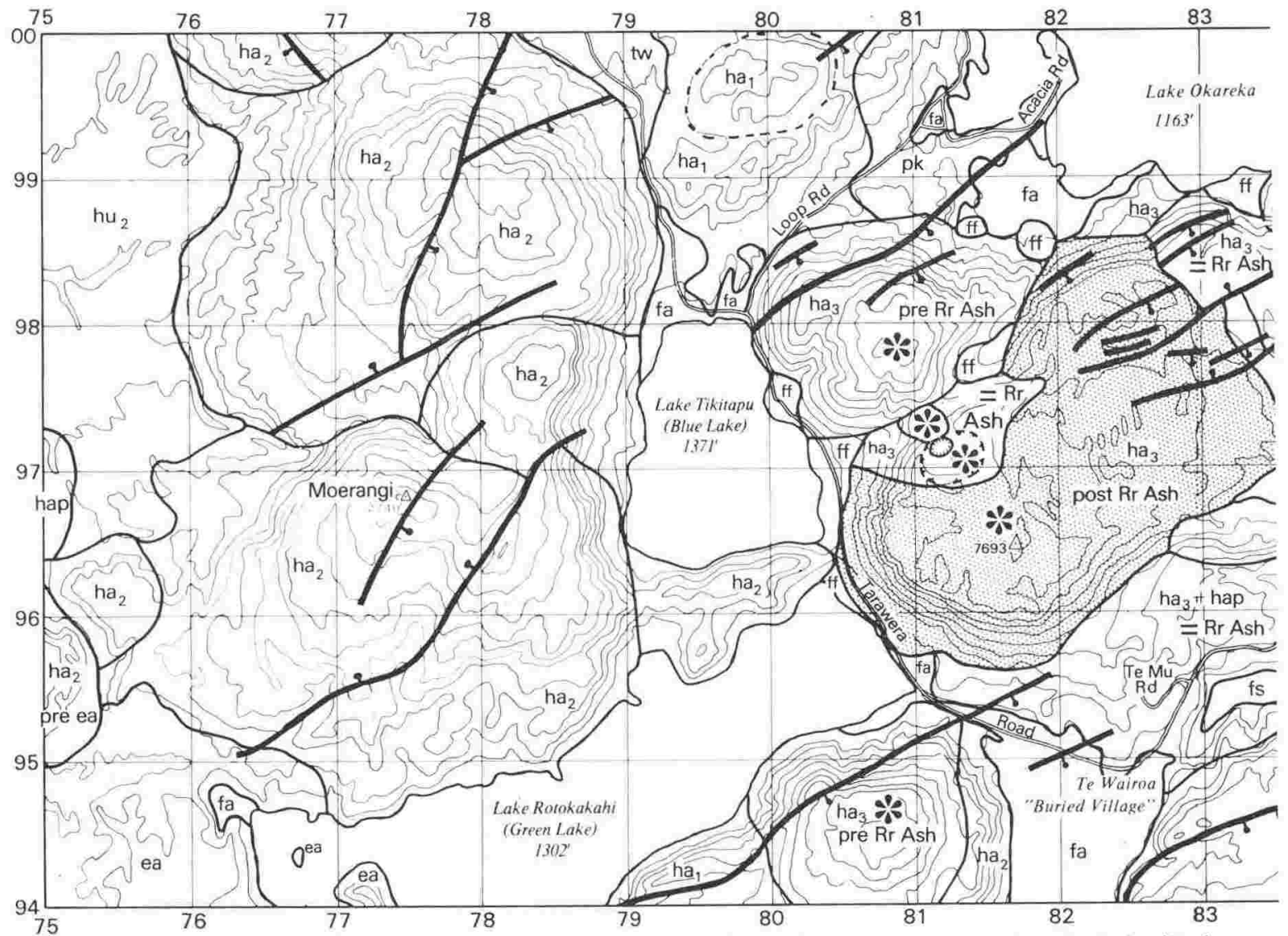

FIG. 3-Geological map of the Tikitapuarea showing inferred eruption sequence for "Trig. 7693" rhyolite lavas (see text), plus sites of eruptive vents. (Youngest lava flow is stippled: "I $\mathrm{Rr}$ Ash" indicites livas coeval with Rotorua Ash: "pre-OK Ash" indicates lavas predating Okareka Ash.) Grid lines are from the national thousand-yard grid, NZMS 1. 
conformities are not observed in Rotorua Ash sections elsewhere). Where erosional channels are absent, the surge beds are not apparent, which might, however, indicate that the channels were eroded by the surges (e.g., Fisher 1977).

Coarse and poorly sorted block and lapilli deposits composed of dense glassy rhyolite overlie the surface of the young rhyolite lavas to east of Lake Tikitapu (N76/835978) [U16/054294]. At this location showerbedded ash and lapilli (upper Rotorua Ash) overlie 1-2 $\mathrm{m}$ of a coarse $(0 \cdot 1-0 \cdot 5-\mathrm{m}$ clast diameter $)$ massive block flow of highly angular glassy rhyolite. Rare impact sags occur at the base of this unit. The block flow overlies $2 \mathrm{~m}$ of faintly crossbedded surge deposits containing a few angular blocks in a matrix of ash and small lapilli. The base of this unit is not exposed. Also exposed in adjacent sections are unstratified ash flow deposits, and coarse, well-sorted airfall block beds. All blocks are relatively dense glassy lava, without pumice or accessory lithics. These deposits are interpreted as a near-vent facies, erupted at a fairly late stage of the Rotorua Ash sequence.

\section{Source Area Geology and Structure}

Lake Tikitapu is surrounded by rhyolite lava domes and flows of late Pleistocene age (Figs 3 and 8). Domes (ha1, ha2) west and north of the lake are moderately eroded, and predate the Earthquake Flat Breccia-Rotoehu Ash marker horizon, radiocarbon dated at $\geqslant c .42000$ years B.P. (Nairn \& Kohn 1973). Younger (ha3) rhyolite extrusions east of the lake post-date this horizon. Lake Tikitapu occupies the ha3 lava-dammed basin between steep flow margins of the rhyolites, probably oversteepened by faulting on the western shore. That the lake basin is not of explosive origin is also indicated by the absence of very large lithic blocks which would have been ejected during any such major crater-forming eruption. The bathymetry (Irwin 1967) supports this view; the lake floor shelves moderately steeply through a $25-\mathrm{m}$ depth, to a near flat bottom at $393 \mathrm{~m}$ a.s.l. This elevation is well above that of the floors of adjacent lakes Rotokakahi ( $370 \mathrm{~m}$ a.s.l.) (Irwin 1970) and Okareka (320 m a.s.l.) (Irwin 1973), through either of which the original Tikitapu valley could have drained to Lake Tarawera with floor at $210 \mathrm{~m}$ a.s.1. (Irwin 1969).

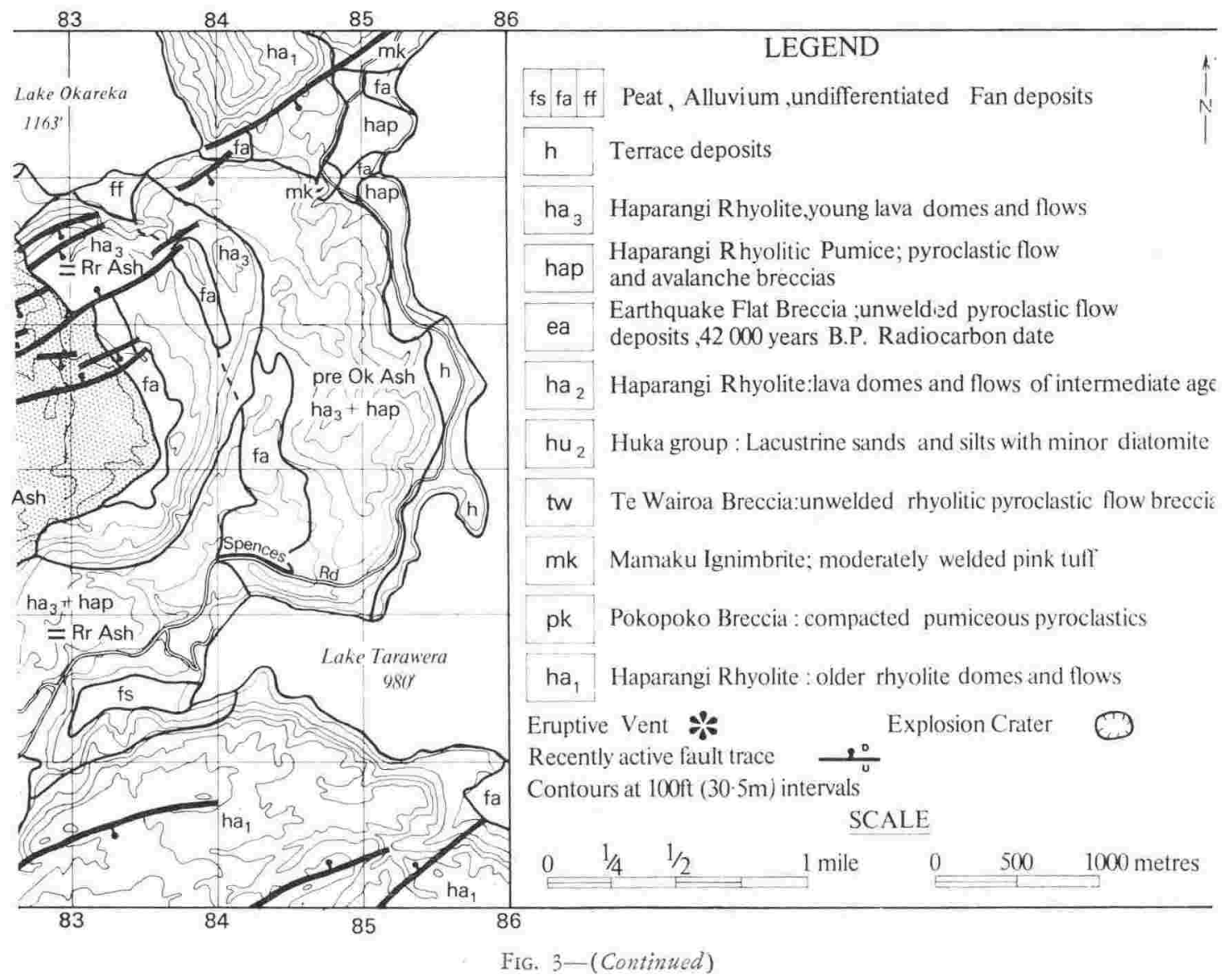




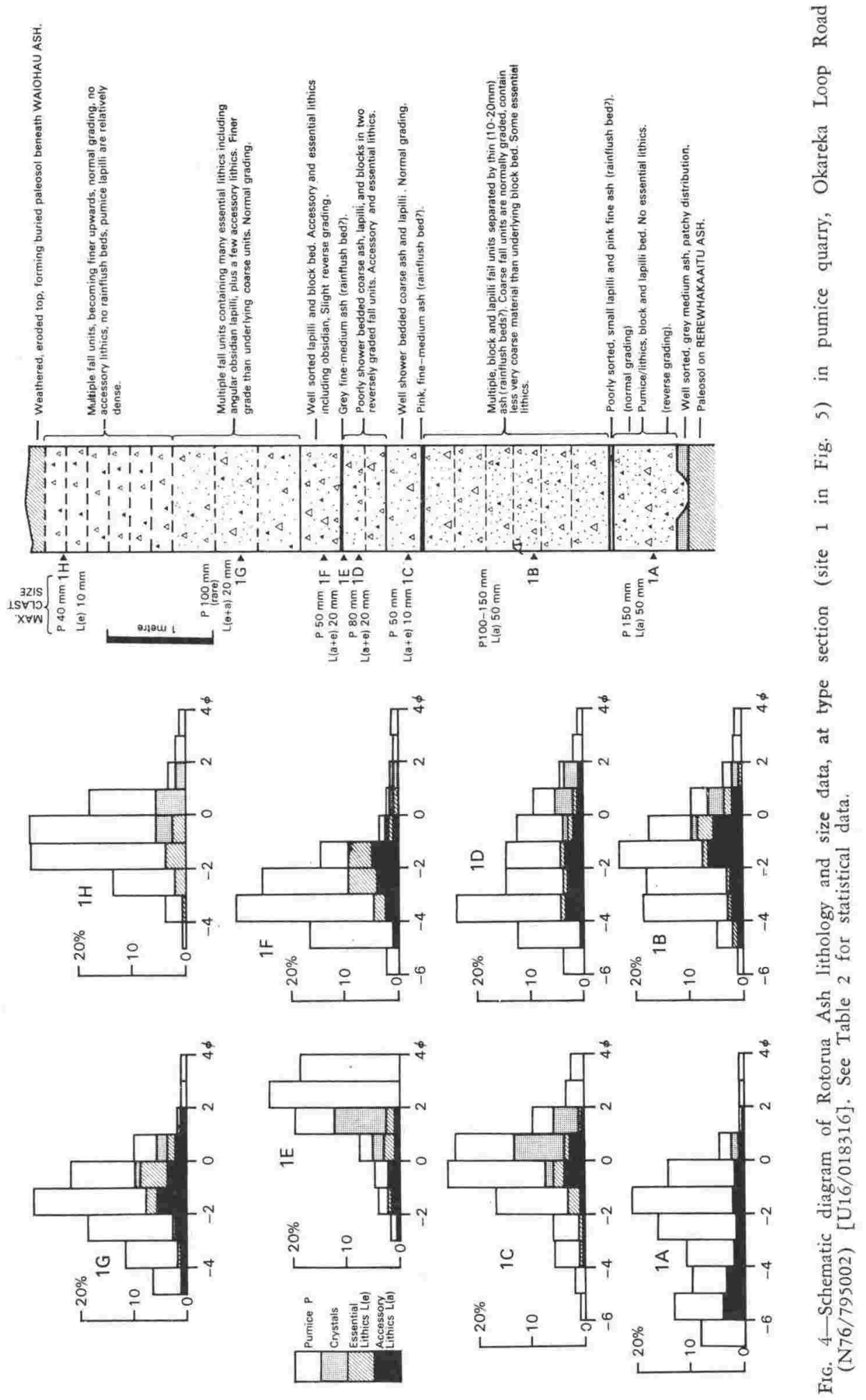




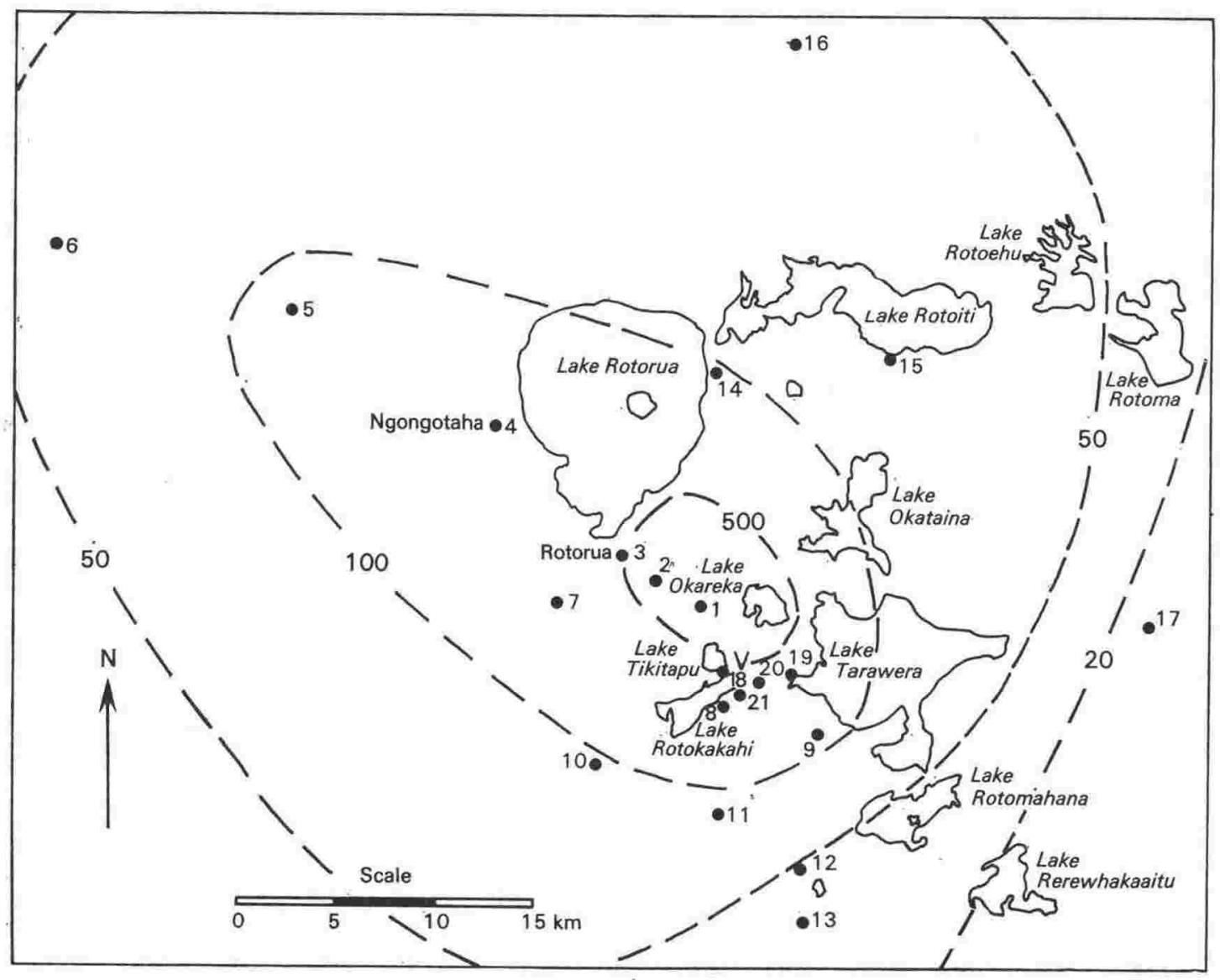

FIg 5-Locations of analysed Rotorua Ash and associated pyroclastic deposits, numbered as in Table 2. "V" marks source area. Isopachs $(\mathrm{cm})$ as in Fig. 2.

The two ha3 rhyolite complexes east of Lake Tikitapu are of different ages (Fig. 3), The northern dome has no crater, rises $190 \mathrm{~m}$ above Tikitapu lake level, and is smoothly mantled by Rotorua Ash which reaches an estimated $20-30 \mathrm{~m}$ thickness in precipitous gully sections. Rotorua Ash overlies a well-developed paleosol on indeterminate reworked ash (probably Okareka Ash) over the northern dome lava. The southern extrusive, here referred to as the "Trig. 7693 rhyolite complex", has a history of multiple eruption, with at least four periods of dome and coulee building interpreted from morphology. The oldest exposed lavas extend $5 \mathrm{~km}$ eastnorth-east from Tikitapu where they block drainage from a pre-existing valley to Lake Tarawera to form the Lake Okareka basin. This flow is overlain by Okareka Ash and younger tephra (see Table 1), over weakly weathered loess mantling the lava. The absence of Kawakawa Tephra suggests that age of the flow is about 18000 years B.P. Younger lavas south of Lake Okareka (Fig. 3) are mantled by components of upper Rotorua Ash, but the very thick and coarse basal fall units are not present, which suggests that these lavas were extruded during the pyroclastic eruptions.

The youngest lava flow of the Trig. 7693 complex was apparently erupted from a vent in the summit area, now marked by a small hill (a tholoid?), and forms an irregular, transverse pressure ribbed surface extending north-east (Fig. 8). No good exposures through the tephra cover on this flow are available, but it is not mantled by thick Rotorua Ash, and therefore post-dates at least most of the tephra. The biotite-rich glassy lava is chemically similar to the upper Rotorua Ash (Table 4). A 300-m-diameter, flat-floored explosion crater lies adjacent to the north-west margin of the lava flow, and a small (approximately $100 \mathrm{~m}$ base diameter) cratered cone has grown immediately to the north-west of this (Fig. 8). The three Trig. 7693 eruptive vents, together with that of the northern dome, are aligned north-west $\left(325^{\circ}\right)$, across the general north-east $\left(50^{\circ}\right)$ strike of recent fault traces which displace all the rhyolite extrusions (Fig. 3). The youngest faults displace Rotorua Ash. 


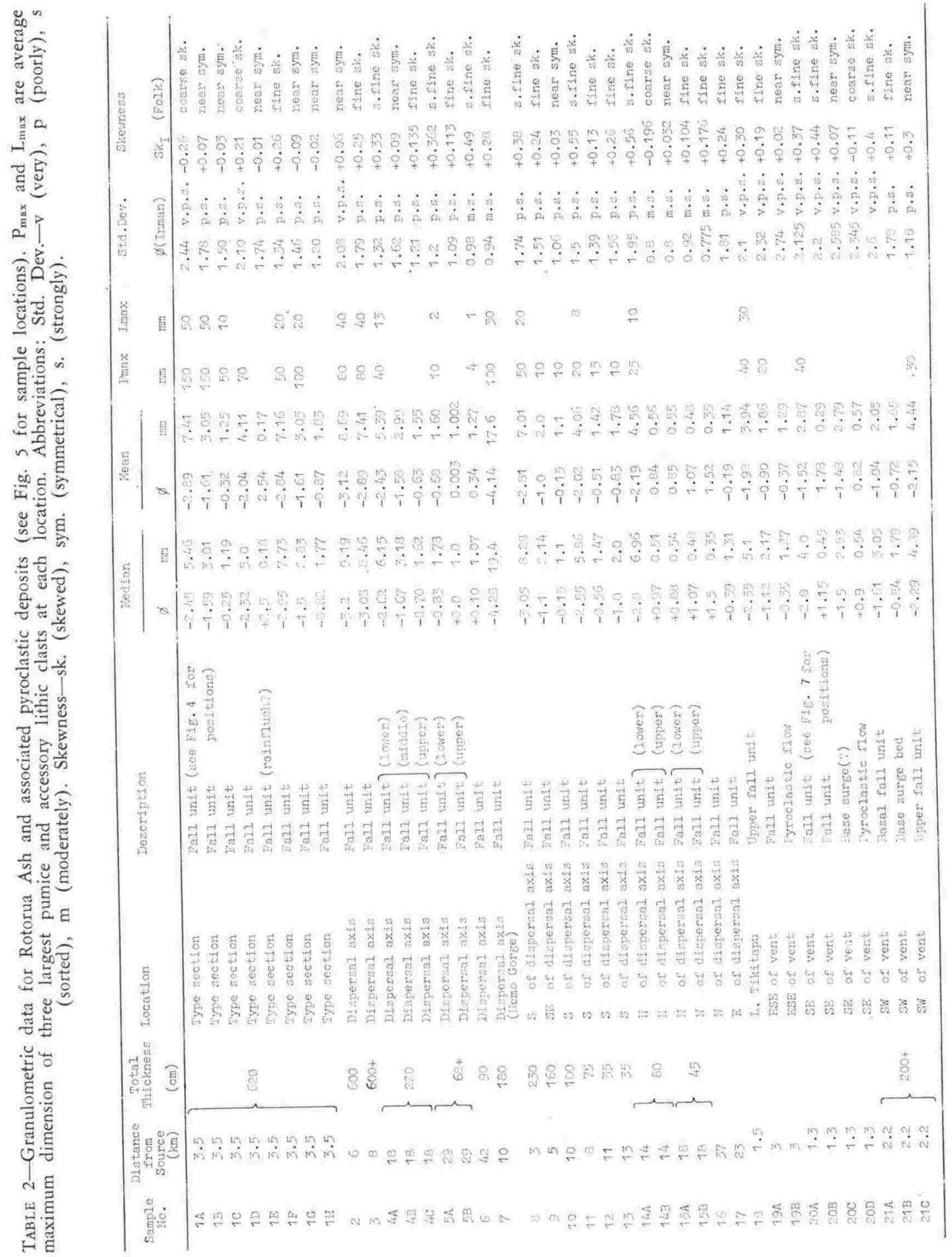


Table 3-Densities of Rotorua Ash pyroclasts.

\begin{tabular}{|c|c|c|c|}
\hline Iithology & $\begin{array}{l}\text { Averabe dry cengity* } \\
\left(\mathrm{s}_{\mathrm{cm}}^{-3}\right)\end{array}$ & $\begin{array}{l}\text { Jianee of values } \\
\left(8 \mathrm{~cm}^{-3}\right)\end{array}$ & Hunber of amples \\
\hline $\begin{array}{l}\text { Punice (Prom loner-ansity blocks } \\
\text { in basal fall units) }\end{array}$ & $0.63 \pm 0.06$ & $0.50-0.68$ & 11 \\
\hline Aceessexy Iithias & $2.32 \pm 0.05$ & $2.27-2.40$ & 6 \\
\hline \multicolumn{4}{|l|}{ Easential Ifthics } \\
\hline eryatal-rich glasey lava & 2.23 & - & 1 \\
\hline spherulitio obalaiun & 2.27 & - & 1 \\
\hline mixed dense and purice ous lava & 2.21 & $\longrightarrow$ & 1 \\
\hline pumiceoue glsasy lava & $1.59 \pm 0.18$ & $1.42-1.77$ & 4 \\
\hline \multicolumn{4}{|l|}{ grystelst } \\
\hline quartz & 2.66 & & \\
\hline platioclase & 2.68 & & \\
\hline norrbilende & $3.0-3.3$ & & \\
\hline hypersthene & $3.5-3.5$ & & \\
\hline viotite & $2.79-3.16$ & & \\
\hline magnetite & $5.1-5.18$ & & \\
\hline
\end{tabular}

†Densities from Milner (1962).

* \pm one standard deviation.

\section{RADIOCARBON DATE}

Carbonised small twigs and branches collected from surge beds within Rotorua Ash on the lava dome east of Rotokakahi (N76/807942 [U16/027262] have been dated $(\mathrm{NZ1615})^{*}$ at $13450 \pm 250$ years B.P. (old $\mathrm{T}_{2}^{\frac{1}{2}}$ ) or $13800 \pm 250$ years B.P. (new $T \frac{1}{2}$ ).

\section{VOLUMES}

An erupted volume of $3.8 \mathrm{~km}^{3}$ was obtained for Rotorua Ash fall deposits by Pullar (1972) using the formula 13ab2 (Cole \& Stephenson 1972). A recalcu. lation based on the areas and averaged thicknesses of Pullar's isopachs gives $4.3 \mathrm{~km}^{3}$ within the $20-\mathrm{cm}$ isopach, while the generalised isopachs shown in Fig. 2 (this paper) give a volume of $6.7 \mathrm{~km}^{3}$ when extrapolated to an inferred $10-\mathrm{cm}$ isopach. Estimates of near-vent pyroclastic flow and surge deposits, and the coeval lava flow volumes, are added to obtain a total equivalent magma volume of $3.3 \mathrm{~km}^{3}$ for the whole eruptive episode (assuming an average bulk density of $0.8 \mathrm{~g} \mathrm{~cm}^{-3}$ for the pyroclastic deposits, and a magma density of $\left.2.3 \mathrm{~g} \mathrm{~cm}^{-3}\right)$.

\section{Discussion}

\section{Eruption Sequence and Rotorua Ash Source Vents}

Although lack of good exposure limits interpretation, a post-20000 years B.P. eruptive sequence can be postulated from pyroclastic lithology and stratigraphy, and the morphology of the young domes east of Lake Tikitapu. The northern dome was probably extruded shortly before the Okareka Ash eruption (c. 18000 years B.P.), when the oldest Trig. 7693 lavas were also erupted.

*New Zealand Radiocarbon Number.
A period of local quiescence followed, ended by commencement of Rotorua Ash pyroclastic eruptions from vent(s) near Trig. 7693. Initial explosions cored out a conduit through pre-existing lava flows, fragments of an advancing lava flow front at about this time. basal pumice fall deposits. Continued pumice eruptions were accompanied by less erosion of the conduit, but by extrusion of some degassed lava, indicated by an increasing proportion of essential lithics in the pyroclastic deposits. Very coarse, angular block flows at Te Mu Road may have been produced by collapse of which comprise the accessory lithic component of the Westward extension of these lava flows blocked the Tikitapu and Rotokakahi valleys to form the present lake basins. Pyroclastic flows and surges passed west into the Tikitapu basin, north-east towards the Lake Okareka outlet, and south into the Te Wairoa area, while pyroclastic fall eruptions continued with decreasing intensity. Lavas extruded from the Trig. 7693 summit vent flowed north-east towards Lakes Okareka and Tarawera to form the ribbed, youngest lava flow and summit tholoid which marks the source vent.

This interpretation suggests that much Rotorua Ash was erupted from the Trig. 7693 lava vent. Because terminal lavas have filled the vent, covering all earlier deposits, no vent facies pyroclastics are exposed. The small explosion crater and cratered cone north-west of Trig. 7693 are also probable sources for part of the upper Rotorua Ash Formation, but were probably not the major vents as they would have been largely infilled by very thick (several tens of metres) pyroclastic deposits if formed early in the eruption. Moreover, none of the eight other major thyolite pyroclastic fall deposits erupted from the Okataina Volcanic Centre during the past 20000 years are associated with preserved explosion craters (with the exception of components of Rotoma Ash). Most source vents are marked by rhyolite lava domes extruded following the pyroclastic eruptions (Cole 1970b; Nairn, unpublished surveys). 

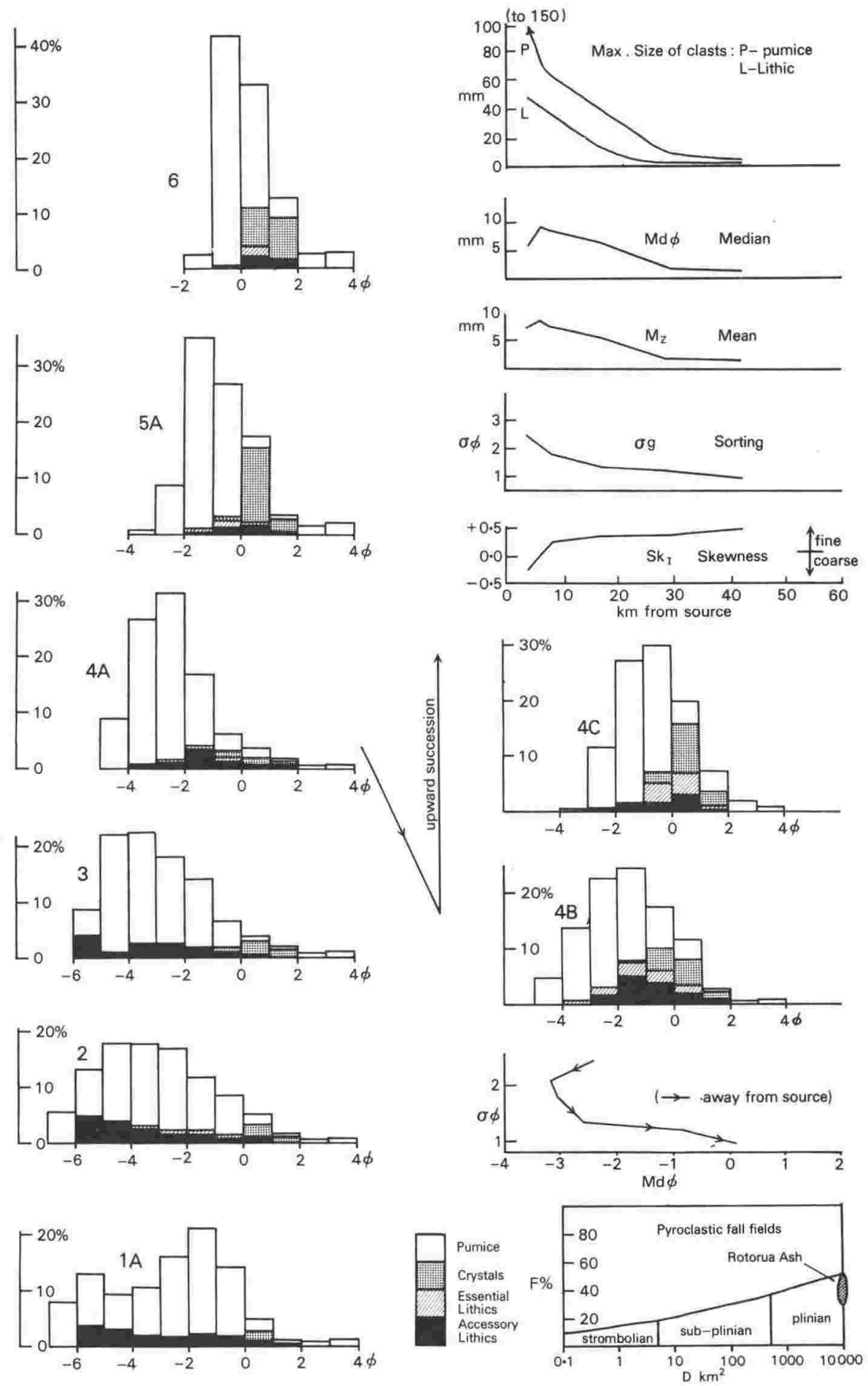

FIG. 6- Histograms and statistical data for Rotorua Ash fall samples from locations progressively downwind on the north-west dispersal axis. Samples numbered as in Table 2 and Fig. 5. Position of Rotorua Ash on the Walker (1973) pyroclastic fall diagram is also shown. 


\section{Pyroclastic Eruption Mechanisms}

Walker (1973) has classified pyroclastic eruptions on parameters of dispersal, D (area enclosed by the $0.01 \mathrm{~T}_{\max }$ isopach), and fragmentation, $\mathrm{F}$ (wt $\%<$ $1 \mathrm{~mm}$ diameter at the $0.1 \mathrm{~T}_{\max }$ isopach on the dispersal axis). $T_{\max }$ is maximum thickness at the source. Dispersal is controlled by wind velocity profile and eruption column height, which in turn is largely determined by mass flux and rate of energy release (largely thermal) to the convecting column (Settle 1978; Wilson et al. 1978). Fragmentation is a measure of the mechanical energy available from gas expansion to disrupt magma (and vent wall rocks) and is roughly equivalent to the "violence" of the eruption. The two indexes are not independent, as heat flux to the column is in part controlled by degree of fragmentation (Sparks \& Wilson 1976), while work available from gas expansion is largely controlled by the initial temperatures and gas pressures. F for Rotorua Ash varies between 29\% for coarse basal ash and $>51 \%$ for finer overlying ash, while $D \geqslant 10000 \mathrm{~km}^{2}$ (from Pullar 1972). The eruption thus falls within the plinian field (see Fig. 6).
Plinian eruptions are characterised by exceptionally high rates of continuous energy release producing eruption columns tens of kilometres high, while $\mathrm{F}$ is low to moderate because little mechanical energy is used to fragment the magma. Relatively coarse grained ejecta is carried to a great height and widely dispersed, producing a coarse deposit spread thinly over a wide area (Walker 1973). Stratification within Rotorua Ash indicates interruptions in the continuous gas blast. Such interruptions probably produced column collapse (Sparks \& Wilson 1976; Sparks et al. 1978) to form the nearsource pyroclastic flows and surges. Reverse grading of several of the near-source fall units may indicate a progressive increase in vigour of the gas blast in individual eruptions as deeper levels of the magma chamber were tapped (Walker 1973), although the overall normal grading demonstrates a decline in eruptive vigour throughout the sequence. Grading could also be affected by more efficient heat transfer and convection in the eruption column, as it becomes established in the atmosphere (Settle 1976; Wilson et al. 1978), and/or erosional widening of the eruptive conduit decreasing frictional drag and allowing increased emis-

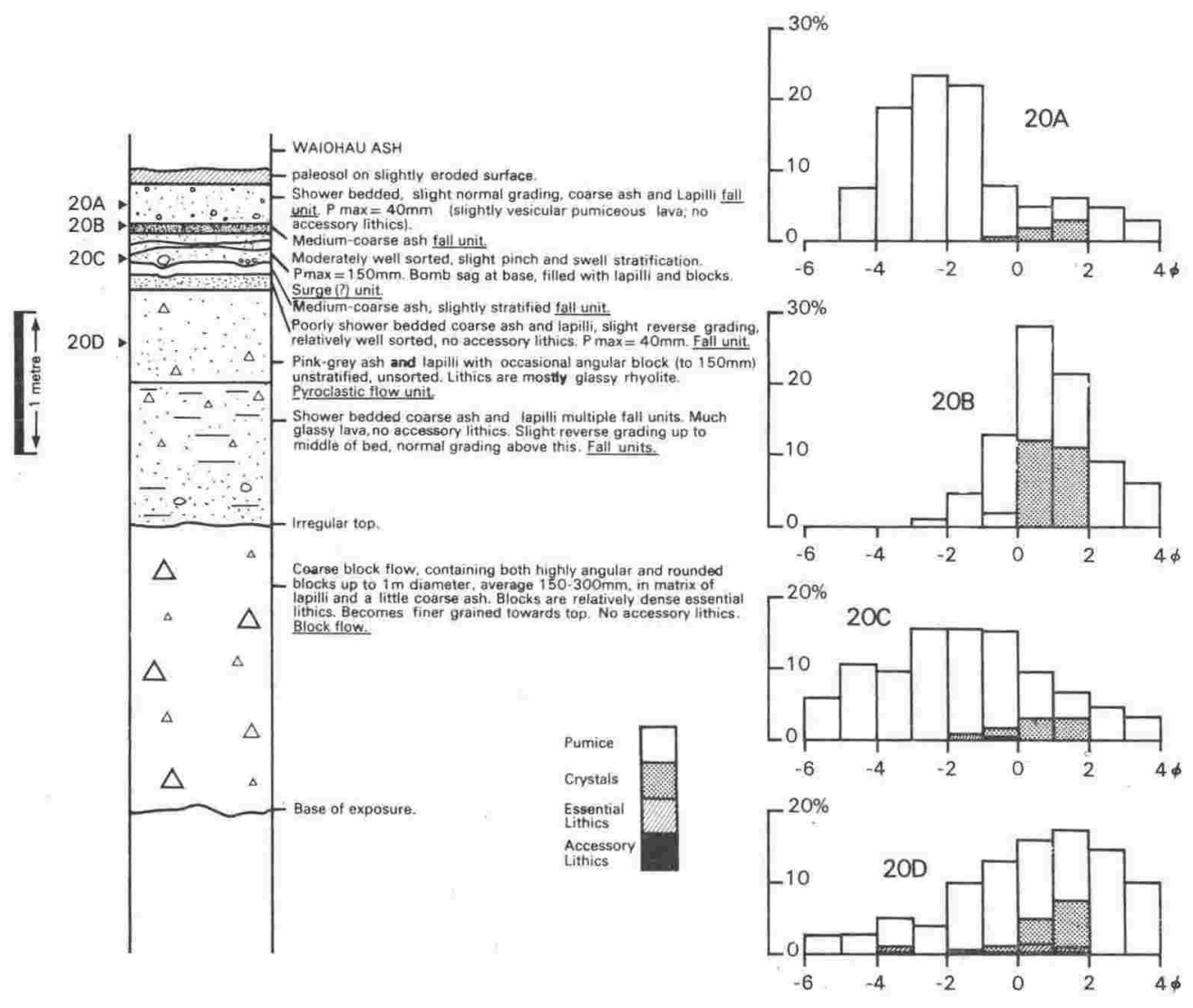

Frg. 7-Composite section and histograms of samples from Rotorua Ash and associated deposits in cuttings near Te Mu Road intersection (N76/828956) [U16/048273], 1.6 km south-east of the vent area. See Table 2 for statistical data. 

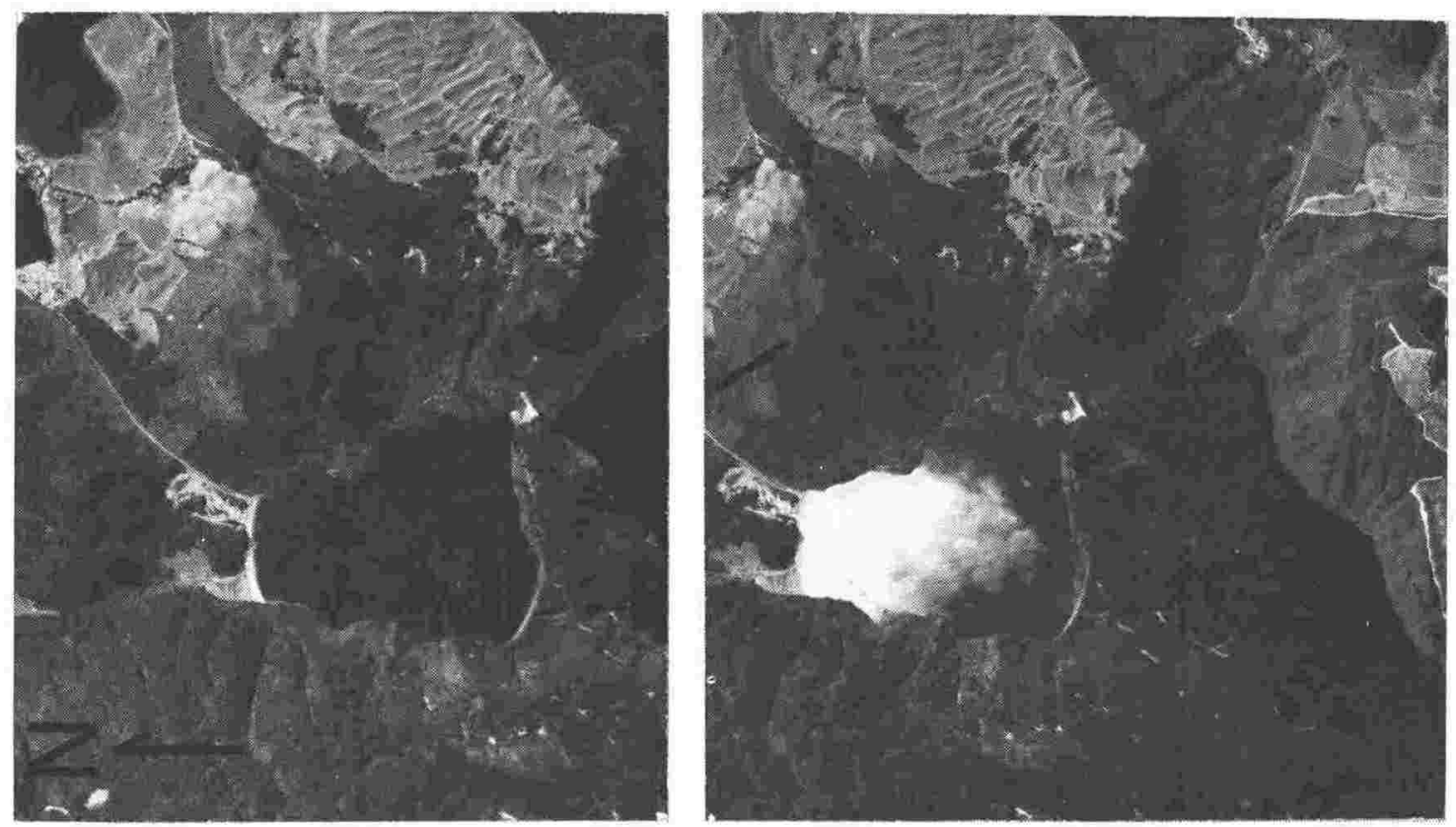

FIG. 8-Stereo-pair aerial photos of Lake Tikitapu-Trig 7693 thyolite complex showing alignment of eruptive vents (summits and craters between the bars) and the pressure-ribbed youngest lava flow. See Fig. 3 for further geological interpretation. Photos SN 3837:K3, K4 reproduced by permission of the Department of Land and Survey, New Zealand.

TABLE 4-Major (\%) and trace element (ppm) analyses of Rotorua Ash and Trig 7693 lava.

\begin{tabular}{|c|c|c|c|c|c|c|c|c|c|c|c|c|}
\hline Samples & $\mathrm{He}_{2} \mathrm{O}_{3}{ }^{\mathrm{F}}$ & in 0 & $T i \theta_{2}$ & Aa 0 & $K_{2} O$ & $E_{2} D_{F}$ & $8 i \mathrm{O}_{2}$ & $\mathrm{Al}_{2}, \mathrm{O}_{3}$ & ME $O$ & $\operatorname{lig}_{2} 0$ & $\pm, 0,1$. & Totral \\
\hline$A$ & 2.06 & 0.05 & 0.28 & 1.78 & 2.93 & 0.04 & 72.05 & 13.12 & 0.34 & $\cdot 4.21$ & 2.62 & 95.48 \\
\hline B & 1.70 & 0.04 & 0.20 & 1.43 & 3.36 & 0.03 & 74.81 & 13.17 & 0.31 & 4.35 & 2.24 & 100.21 \\
\hline & $\mathrm{Cr}$ & V & $\mathrm{zn}$ & $\mathrm{Cu}$ & $m i$ & 35 & $2 x$ & Th & $\mathrm{Fb}$ & $\mathrm{Rb}$ & $y$ & ina \\
\hline A & 0.1 & 10.3 & 36.7 & 4.9 & $4 \cdot 4$ & 140.6 & 171.8 & 8.6 & 12.9 & 91.0 & 21.3 & 746.2 \\
\hline B & 0.0 & -13.4 & 35.0 & 4.1 & 4.9 & 112.2 & 132.2 & 9.7 & 13.2 & 105.6 & 19.3 & 802.7 \\
\hline
\end{tabular}

A-Pumice from upper fall unit of Rotorua Ash at location 18-Fig. 5. V.U.W. Sample No, 13411.

B-Glassy lava from flow front; road cutting immediately east of location 18. 13412.

*Total iron as $\mathrm{Fe}_{2} \mathrm{O}_{3}$.

sion rates. The lack of major erosional breaks within Rotorua Ash would suggest that duration of the main pyroclastic fall eruptions was relatively short, most probably hours or days (as observed for historic plinian eruptions, e.g., Minakami 1942; Lirer et al. 1973; Thorarinsson \& Sigvaldason 1972), rather than weeks or months. The lack of a major eastward dispersal axis is consistent with a short eruption duration, during which prevailing westerly winds did not occur. However, the apparent intercalation of a viscous lava flow which advanced approximately $1 \mathrm{~km}$ towards $\mathrm{Te} \mathrm{Mu}$ Road and $2.5 \mathrm{~km}$ towards Lake Okareka during the pyroclastic eruptions suggests that a longer duration is more likely.
Some estimates of minimum eruption column heights can be made from the distribution and computed terminal fall velocities of clasts at sites along the ejecta dispersal axis, provided that the wind velocity profile is known or assumed (e.g., Minakami 1942). Terminal velocities (T.V.'s) are largely controlled by clast size and density, and have been measured and computed by Walker et al. (1971) for sea-level atmospheric densities. Particle fall times, corrected for variation of ait density with altitude, have been separately derived by Wilson (1972). In the lower atmosphere (up to at least $15 \mathrm{~km}$ ) winds have horizontal speeds of c. 1$15 \mathrm{~m} \mathrm{~s}^{-1}$ with vertical components at least an order of magnitude less (Wilson 1972). Settle (1978) suggests average horizontal wind velocities of c. 5$10 \mathrm{~m} \mathrm{~s}^{-1}$. 
Frg. 9-Vectors for Rotorua Ash accessory lithic clasts sampled at indicated ranges, in a $15 \mathrm{~m} \mathrm{~s}^{-1}$ crosswind, with terminal fall velocities calculated for both maximum and modal size classes (see Table 5 for data). Eruption column release heights are indicated by projected elevations above vent. Vectors for modal sized clasts are indicated by dashed lines.

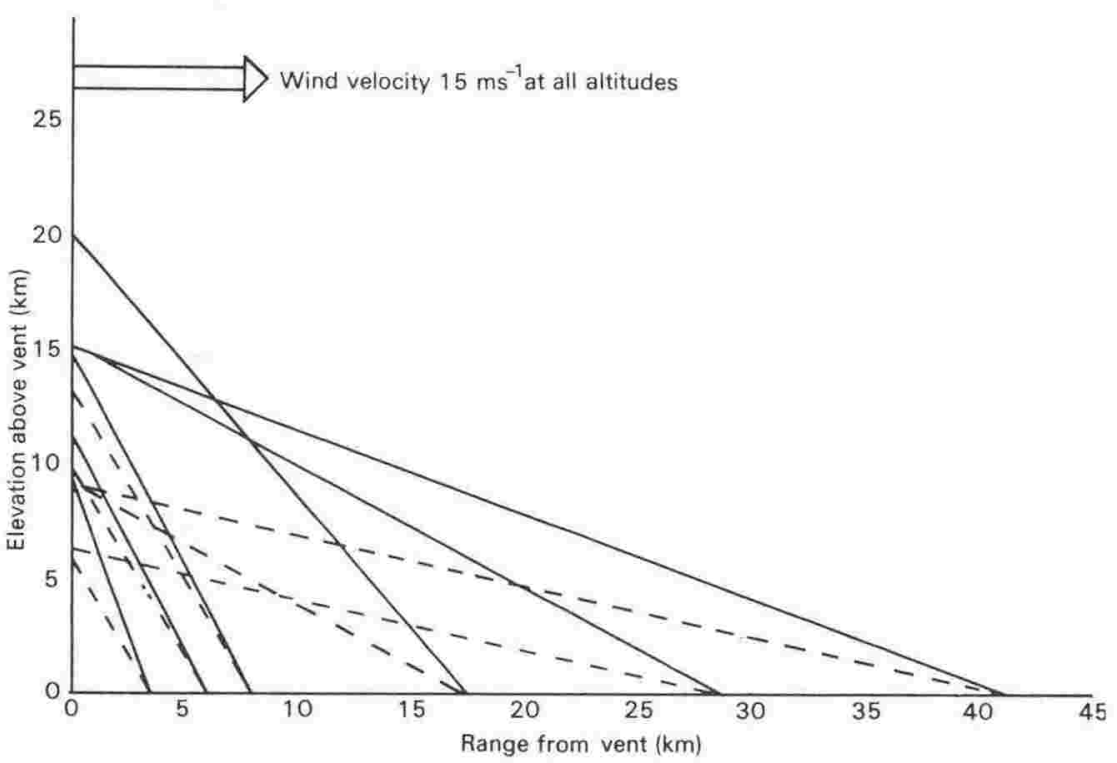

TABIE 5-Size data, terminal fall velocities (T.V.), ranges from vent, and calculated column heights for Rotorua Ash pumice (P) and accessory lithic (L) pyroclasts sampled at locations on the north-west dispersal axis. Column heights are calculated assuming a vertical eruption column and a $15 \mathrm{~m} \mathrm{~s}^{-1}$ average crosswind velocity profile (e.g., Fig. 9) for both (a) maximum and (b) modal sized lithic clasts.

\begin{tabular}{|c|c|c|c|c|c|c|c|c|c|c|c|c|c|}
\hline \multirow{2}{*}{$\begin{array}{l}\text { Sample } \\
\text { ito. }\end{array}$} & \multirow{2}{*}{$\begin{array}{l}\text { Mean } \\
\text { (mm) }\end{array}$} & \multirow{2}{*}{$\begin{array}{c}\text { Nedian } \\
\text { (min) }\end{array}$} & \multicolumn{2}{|c|}{ Modex } & \multirow{2}{*}{$\begin{array}{l}\text { Emex } \\
\text { (mu) }\end{array}$} & \multirow{2}{*}{$\begin{array}{l}\text { Ianizx } \\
(\mathrm{mm})\end{array}$} & \multicolumn{4}{|c|}{ II.V. $\left(x s^{-1}\right)$} & \multirow{2}{*}{$\begin{array}{r}\text { Range } \\
(\mathrm{km})\end{array}$} & \multicolumn{2}{|c|}{$\underset{\text { Column it. }}{(\mathrm{km})}$ it. } \\
\hline & & & $I(\mathrm{~mm})$ & $I(\mathrm{~mm})$ & & & $P \max$ & Imax & Pnode* & Imade* & & & (a) \\
\hline $1 \mathrm{~A}$ & 7.4 & 5.5 & 32 & 32 & 150 & 50 & 36 & 40 & 12 & 25 & 3.5 & 9.35 & 6 \\
\hline 2 & 8.7 & 9.2 & - & 32 & 80 & 40 & 27 & 28 & - & 25 & 6 & 11.2 & 10 \\
\hline 3 & 7.4 & 3,5 & - & 32 & 80 & 40 & 27 & 28 & - & 25. & 8 & 14.9 & 13 \\
\hline $4 \mathrm{~A}$ & 5.4 & 6.2 & 4 & 2 & 40 & 13 & 16 & 17 & 5.5 & 8 & 176 & 20 & 9 \\
\hline $5 \mathrm{~A}$ & 1.6 & 4.8 & 2 & 0.5 & 10 & 2 & 8 & 8 & 4. & 3.3 & 28.8 & 15.4 & 6 \\
\hline 6 & 1.5 & 1.1 & 1 & 0.5 & 4 & 1 & 5.5 & 5.5 & 2.4 & 3.3 & 41.6 & 15.3 & 9 \\
\hline
\end{tabular}

*In polymodal samples, this is mode of greatest diameter. Pumice modes ate not distinct in Samples 2 and 3.

Dispersal of Rotorua Ash indicates strong southeasterly winds at relatively low altitudes, at least during the initial phases of the eruption. A simple model (Fig. 9) assumes a vertical eruption column from which clasts falling at terminal velocities (computed by the method of Walker et al. 1971) are carried downwind at an average horizontal velocity of $15 \mathrm{~m} \mathrm{~s}^{-1}$. Minimum fall times are calculated from ranges on the dispersal axis, and thus estimates are obtained for the column heights reached by both maximum and modal sizes of pyroclasts (Table 5). Maximum lithic (accessory) and pumice clasts at sampled locations have almost identical computed T.V.'s (Table 5), demonstrating a strong control of large particle ranges by this parameter, but there is greater variation in calculated T.V.'s for modal pumice and lithic size components in each sample. The largest clasts at each sample location are also those which reached the greatest heights in the eruption column, while the modal components represent more common size fractions of smaller particles falling from lower elevations. The larger near-source particles appear to have reached minimum heights of $c .10 \mathrm{~km}$, with smaller fragments at distal locations falling from 15 to $20-\mathrm{km}$ heights. The calculated column heights are minima because smaller particles than those considered will rise to greater heights. Lower horizontal wind velocities imply higher eruption columns and vice versa.

The model ignores the effect of crosswinds on the eruption column. There is some dispute as to the sensitivity of eruption columns to crosswind conditions. Settle (1978) calculates eruption column heights for a given pyroclastic mass flux ranging through 8,16 , and $32 \mathrm{~km}$ for crosswind velocities of 20,10 , and $5 \mathrm{~m} \mathrm{~s}^{-1}$ respectively. However, Wilson et al. (1978) suggest that in most large plinian eruptions, the upward velocity of 
the column is commonly much greater than the transverse wind velocity over much of the column height, and that particle-rich plumes should be particularly resistant to bending by wind, due to their greater upward momentum.

Some data are available from observed eruptions. The 1947 Hekla eruption column rose at an average rate of $24 \mathrm{~m} \mathrm{~s}^{-1}$ to a $27-\mathrm{km}$ altitude, when it had also extended c. $23 \mathrm{~km}$ south of the vent (Thorarinsson 1954). The 1970 Hekla eruption column rose at an initial speed estimated at $16 \mathrm{~m} \mathrm{~s}^{-1}$, and at an average $5 \mathrm{~m} \mathrm{~s}^{-1}$ to a maximum height of $16 \mathrm{~km}$ (Thorarinsson \& Sigvaldason 1972). Tephra was carried horizontally at $20 \mathrm{~m} \mathrm{~s}^{-1}$, by a strong wind, to produce a narrow zone of tephra fall. The 1956 (March 30) Bezymianny eruption column rose to $35 \mathrm{~km}$ at an average speed of $20 \mathrm{~m} \mathrm{~s}^{-1}$ (Gorshkov 1959). Crosswind effects are difficult to assess as the explosion was strongly subhorizontally directed. The relatively small 1975 Ngauruhoe eruption column rose at an average rate of $6 \mathrm{~m} \mathrm{~s}^{-1}$ to $10 \mathrm{~km}$ during the phase of mest vigorous emission (Nairn \& Self 1978).

These observations suggest that observed plinian eruption colmns rose at average rates of between 5 and $30 \mathrm{~m} \mathrm{~s}^{-1}$ to altitudes of $c$. $+20 \mathrm{~km}$. Larger prehistoric plinian eruptions, such as that of Rotorua Ash, probably had column rise velocities at or above the upper end of this scale. Attempts to construct more sophisticated models of the wind velocity profile during the Rotorua Ash eruption are not justified by the available data, but both the hypothetical considerations and comparisons with the observed smaller plinian eruptions demonstrate that the Rotorua Ash column rose to a minimum height of $10 \mathrm{~km}$ and probably exceeded $20 \mathrm{~km}$.

\section{Age of Rotorua Ash}

Topping \& Kohn (1973) described from sites in the northern Tongariro Volcanic Centre $(120 \mathrm{~km}$ south-west of Tikitapu) a thin, fine-grained rhyolitic tephra which they considered a correlative of Rotorua Ash. Dates (old $\mathrm{T}^{\frac{1}{2}}$ ) of $12350 \pm 220$ years B.P. (NZ1187) and $13150 \pm 300$ years B.P. (NZ1186) were obtained for over- and underlying andesitic tephra, which led Topping \& Kohn to suggest an intermediate age of about 12500 years for their "?Rotorua Ash". However, three titanomagnetite "finger printing" chemical analyses of "?Rotorua Ash" from the Tongariro region significantly differed from those of three near-source Rotorua Ash samples collected from Rotorua, although it was suggested that this might be due to contamination of the Tongariro samples by andesitic tephra (Topping \& Kohn 1973, p. 388).

The radiocarbon date of $13450 \pm 250$ years B.P. (old $\mathrm{T}^{\frac{1}{2}}$ ) obtained from near-source Rotorua Ash at Rotokakahi overlaps that of the older Tongariro andesitic tephra, but is significantly older than the intermediate age of 12500 years B.P. suggested by Topping \& Kohn (1973). At the present time, the Rotokakahi date is the only one available for undoubted Rotorua Ash, and use of the new $T_{\frac{1}{2}}$ age of $13800 \pm 250$ years B.P. is suggested.

\section{CONCLUSIONS}

Rotorua Ash is typical of rhyolite pyroclastic formations erupted from Okataina Volcanic Centre during the past 20000 years. A $10-20-\mathrm{km}$-high plinian eruption column showered pumice lapilli and ash over more than $10000 \mathrm{~km}^{2}$ of the Bay of Plenty region, accompanied by small near-source pyroclastic flows and surges, and extrusion of lavas. Three eruptive vents are aligned north-west, normal to the regional fault strike, and extend over a distance of $1 \mathrm{~km}$. The eruption appears to have terminated with extrusion of degassed lava from the south-eastern vent.

Near-source dispersal of coarse pyroclastic fall ejecta from initial eruptions was directed into a north-west azimuth, indicating strong lower atmosphere winds from the south-east. The less-directional dispersal of finer deposits suggests varying directions of upper atmosphere winds, either at different elevations during a short eruption period or, more likely, variation of upper wind vectors during the eruption sequence.

\section{ACKNOWLEDGMENTS}

Colleagues at N.Z. Geological Survey, Rotorua, provided valuable comments on early drafts of this paper. The writer also thanks J. W. Cole, W. A. Pullar, and C. G. Vucetich, for critically reading the manuscript, and J. W. D. Hessell for providing meteorological advice.

\section{REFERENCES}

Cole, J. W. 1970a: Description and correlation of Holocene volcanic formations in the TaraweraRerewhakaaitu region. Transactions of the Royal Society of New Zealand, Earth Sciences 8 (7): 93108.

1970b: Structure and eruptive history of the Tarawera Volcanic Complex. N.Z. Journal of Geology and Geopbysics 3 (4): 879-903.

Cole, J. W.; Stephenson, T. H. 1972: Calculation of the volume of a tephra deposit. Appendix in Publication of Geology Department, Victoria University of Wellington 1: 13-14.

Cotton, C. A. 1952: "Volcanoes as Landscape Forms" (2nd ed.). Whitcombe and Tombs Ltd., Wellington. $416 \mathrm{p}$.

EWART, A.; HEALY, J. 1965: Rotorua volcanic geology. In New Zealand volcanology, Central Volcanic Region. N.Z. DSIR Information Series 50: 10-26.

FISHER, R. V. 1977: Erosion by volcanic base-surge density currents: U-shaped channels, Geological Society of America Bulletin 88: 1287-97.

FoLK, R. L. 1974: "Petrology of Sedimentary Rocks". Hemphill Publishing Co., Austin, Texas. 182 p.

Gorshkov, G. S. 1959: Gigantic eruption of Bezymianny volcano. Bulletin Volcanologique 20: 77-109.

Grange, L. I. 1929: A classification of the soils of Rotorua County. N.Z. Journal of Science and Technology 11: 219-28.

1937 The geology of the Rotorua-Taupo Subdivision. N.Z. Geological Survey Bulletin 37.138 p. 
IRwIN, J. 1967: Lake Tikitapu (Blue Lake), Provisional Bathymetry 1:5940. Fisberies Research Division, Lake Series.

1969: Lake Tarawera, Provisional Bathymetry 1:25000. N.Z. Oceanographic Institute Chart, Lake Series.

1970: Lake Rotokakahi (Green Lake), Provisional Bathymetry 1:7920. N.Z. Oceanograpbic Institute Chart, Lake Series.

1973: Lake Okareka, Provisional Bathymetry 1:7920. N.Z. Oceanograpbic Institute Chart, Lake Series.

KoHN, B. P. 1973: Some studies of New Zealand Quaternary pyroclastic rocks. (Unpublished Ph.D. thesis, lodged in the library, Victoria University of Wellington.) $340 \mathrm{p}$.

Lirer, L.; Pescatore, T.; Booth, B.; Walker, G. P. L. 1973: Two plinian pumice-fall deposits from Somma-Vesuvius, Italy. Geological Society of America Bulletin 84: 759-72.

Milner, H. B. 1962: "Sedimentary Petrography". George Allen and Unwin Ltd., London. 715 p.

Minakami, T. 1942: On the distribution of volcanic ejecta (Part II). The distribution of Mt Asama pumice in 1783. Tokyo University Earibquake Research Institute Bulletin 20 (1): 93-106.

NAIRN, I. A.; KoHN, B. P. 1973: Relation of the Earthquake Flat Breccia to the Rotoiti Breccia, Central North Island, New Zealand. N.Z. Journal of Geology and Geophysics 16 (2): 269-79.

NAIRN, I. A.; SelF, S. 1978: Explosive eruptions and pyroclastic avalanches from Ngauruhoe in February 1975. Journal of Volcanology and Geothermal Research 3: 39-60.

Pullar, W. A. 1972: Isopachs of tephra, Central North Island, New Zealand. Scale 1:1000000 N.Z. Soil Bureau Maps 133/8-14. N.Z. Soil Survey Report 1.

Pullar, W. A.; Birrell, K. S.; Heine, J. C. 1973 : Named tephras and tephra formations occurring in the central North Island, with notes on derived soils and buried paleosols. N.Z. Journal of Geology and Geophysics 16 (3): 497-518.

Settle, M. 1976: Rise of volcanic eruption clouds: Relationship between cloud height and eruption intensity. Air Force Geophysics Laboratory Tecbnical Report 76-0127. Hanscome AFB, Massachusetts. $37 \mathrm{p}$.

- 1978: Volcanic eruption clouds and the thermal power output of explosive eruptions. Iournal of Volcanology and Geothermal Research 3: 309-24.

SMITH, S. P. 1886: "The Eruption of Tarawera: A Report to the Surveyor General". Government Printer, Wellington. $\$ 4 \mathrm{p}$.
SPARKS, R. S. J. 1976: Grain size variations in ignimbrites and implications for the transport of pyroclastic flows. Sedimentology 23: 147-88.

SPARKS, R. S. J.; WILSON, L. 1976: A model for the formation of ignimbrite by gravitational column collapse. Joumal of the Geological Society of London 132: 441-51.

Sparks, R. S. J.; WILSON, L.; Hume, G.: 1978: Theoretical modelling of the generation, movement, and emplacement of pyroclastic flows by column collapse. Journal of Geopbysical Research 83: $1727-39$.

Thomas, A. P. W. 1888: "Report on the Eruption of Tarawera and Rotomahana, N.Z." Government Printer, W ellington. $74 \mathrm{p}$.

Thorarinsson, S. 1954: "The Eruption of Hekla 1947-1948". Part II, 3, The tephra-fall from Hekla on March 29th 1947. Societas Scientiarum Islandica, Reykjavik. 68 p.

Thorarinsson, S.; Sigvaiddason, G. E, 1972: The Hekla eruption of 1970. Bulletin Volcanologique 36: $269-88$.

TopPING, W. W.; KoHN, B. P. 1973: Rhyolitic tephra marker beds in the Tongariro area, North Island, New Zealand. N.Z. Journal of Geology and Geo. physics 16 (3): $375-95$.

VISHer, G. S. 1969: Grain size distribution and deposition processes. Journal of Sedimentary Petrology 39: 1074-106.

Vucetich, C. G.; Pullar, W. A. 1964: Stratigraphy and chronology of late Quaternary volcanic ash in Taupo, Rotorua, and Gisborne districts. Part 2. Stratigraphy of Holocene ash in the Rotorua and Gisborne districts. N.Z. Geological Survey Bulletin 73: $43-88$

WALKER, G. P. L. 1971: Grain size characteristics of pyroclastic deposits. Journal of Geology 79: 696714.

- 1973: Explosive volcanic eruptions-a new classification scheme. Geologische Rundscbau 62 (2): $431-46$.

WALKER, G. P. L.; WILSON, L.; BOWELL, E. L. G. 1971 : Explosive volcanic eruptions-I. The rate of fall of pyroclasts. Geopbysics Journal Royal Astronomical Society 22: 377-83.

WILSON, L. 1972: Explosive volcanic eruptions-II. The atmospheric trajectories of pyroclasts. Geopbysics Journal Royal Astronomical Society 30: 381-92.

Wilson, L.; Sparks, R. S. J.; Huang, T. C.; Watkins, N. D. 1978: The control of volcanic column heights by eruption energetics and dynamics. Journal of Geophysical Research 83: 1829-36. 
Rotorua Eruptive Episode: Aspects of this eruptive episode are described in the attached paper. 
Waiohau Eruptive Episode: Lack of good exposure hinders understanding of this complex eruptive episode at Tarawera; Cole (1970b) regarding the sequence of events as unknown. The following interpretation of Waiohau events is based on the stratigraphic data presented on p. 105 of this thesis. Lithology of the pyroclastic deposits has not yet been studied in detail.

Eastern Dome was extruded early in the eruption sequence, preceding and possibly accompanying eruption of the initial flow and fall deposits of the Waiohau Pyroclastics erupted from the Kanakana vent $4 \mathrm{~km}$ to south-west. No explosive eruptions appear to have occurred at the Eastern Dome vent. The Waiohau pyroclastic fall deposits which overlie Eastern Dome are not baked, indicating a dome cooling interval prior to their deposition.

The Waiohau pyroclastic flows spread radially from the Kanakana vent, extending at least $10 \mathrm{~km}$ to north-north-east into the Te Haehaenga Basin. Later pyroclastic eruptions were accompanied by extrusion of the Waikakareao Lavas which flowed to north of the Kanakana vent, and baked the Waiohau Pyroclastics deposited between and over individual lava flows. Eruption of fine-grained pyroclastic surge deposits followed the coarse pyroclastic flows, and reached at least $4 \mathrm{~km}$ from the vent. The main Waiohau Ash plinian pyroclastic fall eruptions then occurred, covering much of the eastern North Island (Pullar 1973) with pumice lapilli and ash. Further small pyroclastic flows and surges interbedded within the fall deposits (Fig. 19) on Tarawera Volcanic Complex may have been generated by column collapse.

The Waiohau pyroclastic eruptions were terminated by extrusion of the Pokohu Lavas from the Kanakana vent. These lavas flowed over the Waikakareao flows, onto the Waiohau Pyroclastics surface and north-east towards the Te Haehaenga Basin. The final event of the Waiohau Eruptive Episode was the extrusion of Kanakana Dome to fill the source vent.

Pullar (1973) estimated a Waiohau Ash erupted volume of $13.8 \mathrm{~km}^{3}$ and an area of $24,000 \mathrm{~km}^{2}$ bounded by the $20 \mathrm{~cm}$ isopach. 
Rotoma Eruptive Episode: A 10,000 year interval followed the Te Rere Eruptive Episode, during which no eruptions occurred from Haroharo Volcanic Complex. This quiescent interval was ended by the Rotoma Eruptive Episode.

Order of the earliest events in the Rotoma Emuptive Episode cannot be precisely defined due to burial of the proximal areas beneath younger lavas and pyroclastics. Extrusion of the Rotoma Lava Flow occurred at an early stage of the episode, but was probably preceded by explosive pyroclastic surge and fall eruptions from the Matutu Basin vent. These explosions built up a tuff ring later overridden by the lava flow. Pyroclastic fall eruptions from the Matutu vent continued after the lava extrusion had ceased. A large plinian emption column must have been formed by these explosive eruptions, showering $12 \mathrm{~km}^{3}$ (erupted volume) of the Rotoma Ash over more than $23,000 \mathrm{~km}^{2}$ of the eastern North Island (Pullar 1973).

Extrusion of the Te Pohue Lavas and associated pyroclastic deposits, from vents now buried under the younger Rotokohu Dome on Haroharo Volcanic Complex, appears to have occurred during the pyroclastic eruptions at Rotoma, as the $\mathrm{Te}$ Pohue eruptives are interbedded with Rotoma Ash. The Otamuri Breccia also appears to have been erupted from the Rotokohu vent, pyroclastic flows passing into the eastern Haroharo Caldera moat.

Eruption of the Pukerimu pyroclastic flow and surge deposits accompanied and followed the main Rotoma Ash emptions from Matutu Basin. The Pukerimu surge deposits were apparently laid down by north-east-directed explosive breaching of the Pukerimu tuff cone. Contacts between the surge deposits and the underlying and interbedded Rotoma Ash fall deposits are everywhere conformable (Fig. 14), so that the Matutu and Pukerimu vents were in simultaneous eruption although $12 \mathrm{~km}$ apart (Fig. 12). No widespread pyroclastic fall deposits have been identified as erupted from the Pukerimu vent as no coarse fall deposits occur in the Pukerimu area. However, a charcoal-bearing massive fine bed in the upper Rotoma Ash in sections at intermediate 


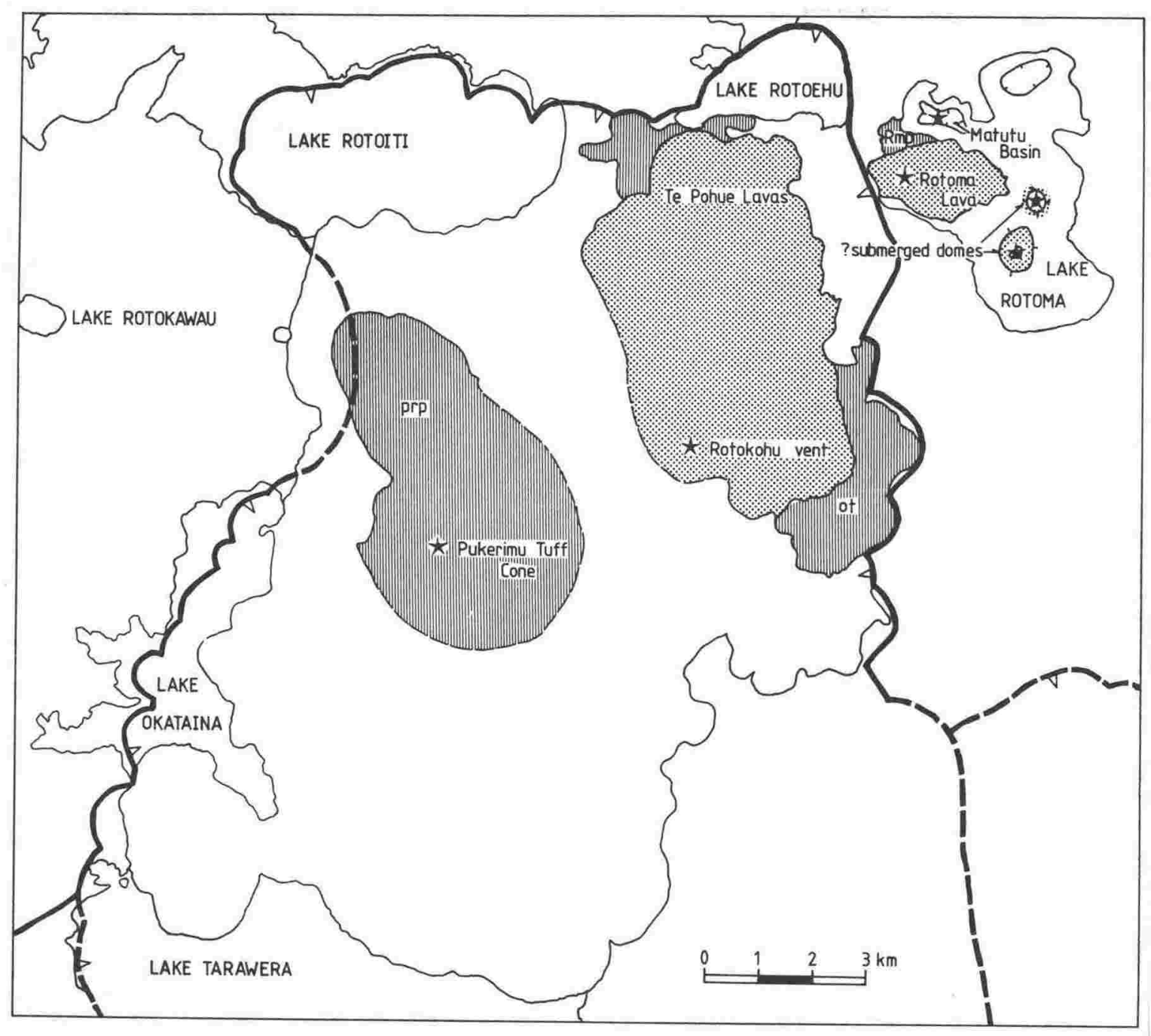

FIG. 40 - Map of Rotoma Eruptive Episode lavas (dot stippled) and pyroclastics (line stippled), with vent locations $(\star t)$, in relation to Haroharo Caldera boundaries.

ot - Otamuri Breccia, prp - Pukerimu Pyroclastics, Rmp - Rotoma Pyroclastics. 
distances from the vents is here interpreted as resulting from wide dispersal of coignimbrite-ash associated with the Pukerimu flow eruptions.

The Rotoma Eruptive Episode provides an excellent example of the complex and fissural nature of eruptions on the Haroharo vent lineation (Fig. 40). At least four vents (Rotoma Lava vent, Matutu Basin, Rotokohu, Pukerimu) were in simultaneous or sequential eruption during the episode, with two other probable vents marked by the submerged domes(?) in Lake Rotoma. Similar ${ }^{14} \mathrm{C}$ dates available for the Pukerimu Pyroclastics and Te Pohue lavas (see Table 2) support the inferred coeval relationship between these two eruptives.

Mamaku Eruptive Episode: As with the Rotoma episode, the Mamaku lava and pyroclastic eruptions occurred from multiple vents spread over at least $14 \mathrm{~km}$ of the Haroharo vent lineation (Fig. 41). All the main vents for the Mamaku pyroclastics are now buried under younger lavas so that little proximal-facies ejecta is exposed, and emption history has to be inferred from relatively distant sections.

Earliest identified events of the Mamaku Eruptive Episode were the sequential extrusion of the Kaipara and Waiti Lavas, flowing northwards from vents which appear to now underlie the younger Haroharo and Rotokohu Domes. The Kaipara and Waiti extrusions preceded the widespread Mamaku pyroclastic eruptions which followed after an interval at least long enough for the Kaipara and Waiti Lavas to have cooled, and possibly to have acquired local patches of colonizing vegetation. Initial phreatomagmatic explosions produced a local fine ash deposit (Fig. 15), followed by plinian eruption of the widespread, showerbedded Mamaku Ash fall deposits, interbedded near source with small pyroclastic flows (Fig. 42) which probably originated by column collapse. Charcoal from these flows is dated at c. 7500 yrs B.P. (see Table2). The pyroclastic flows spread $6 \mathrm{~km}$ north across the Haumingi Lava Flow, passing around Pukerimu Cone and over its strongly dissected pyroclastic apron. Thick Mamaku 


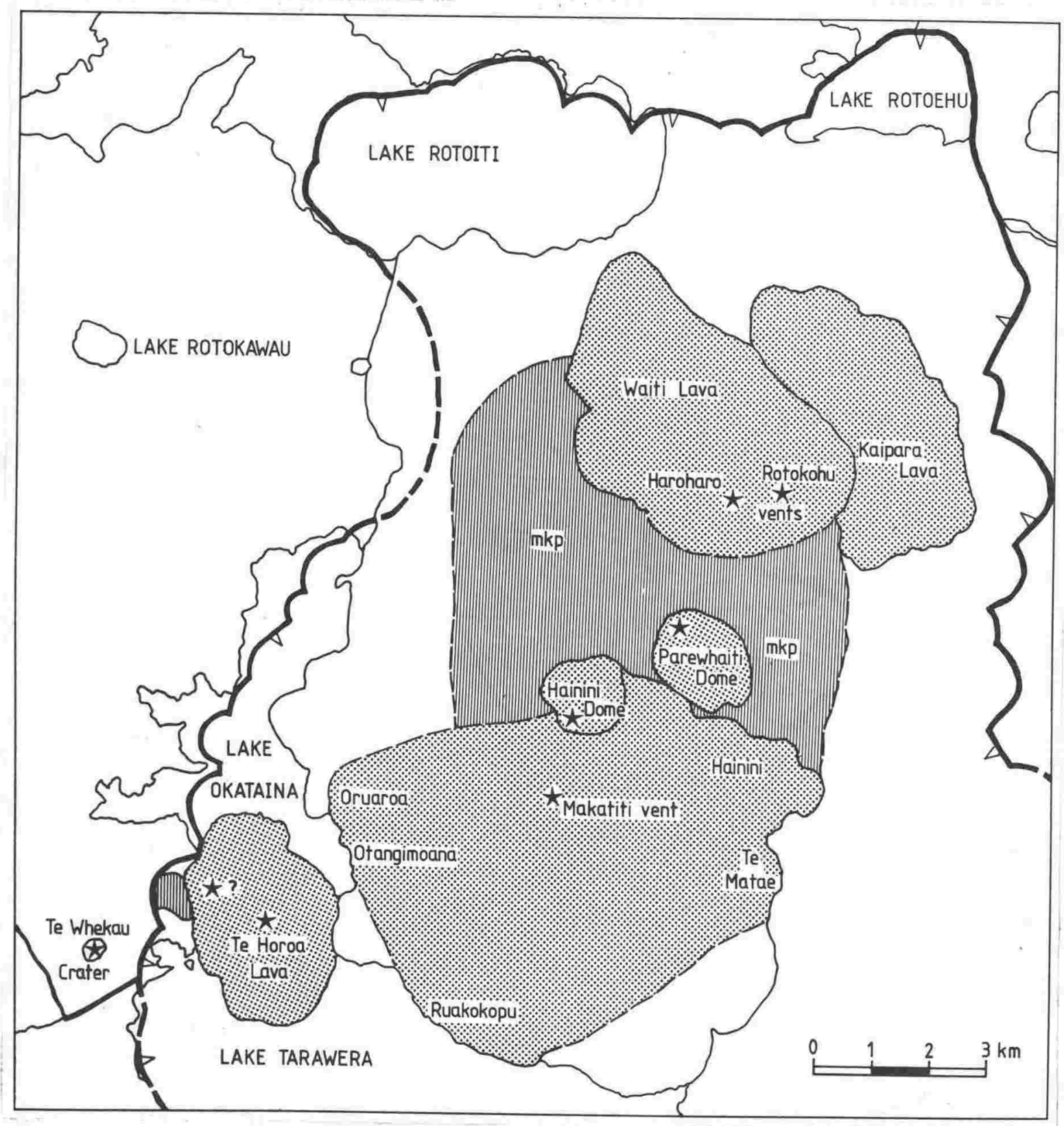

FIG. 41 - Map of Mamaku Eruptive Episode lavas (dot stippled) and pyroclastics (line stippled), with vent locations $(\star)$, in relation to Haroharo Caldera boundaries. mkp - Mamaku Pyroclastics. 


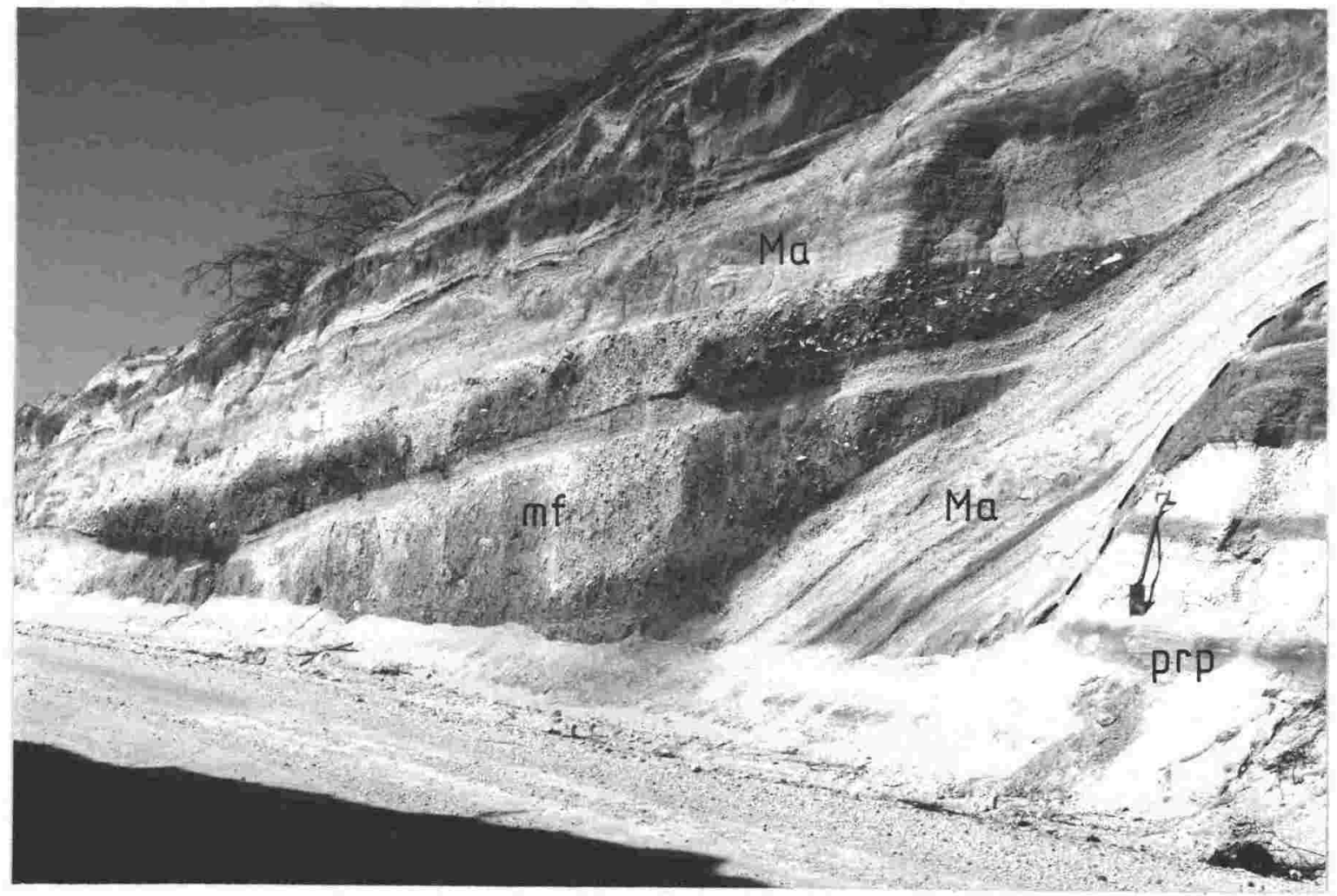

FIG. 42 - Showerbedded pyroclastic fall deposits of Mamaku Ash (Ma) interbedded with two poorly-sorted coeval pyroclastic flow deposits (mf) which wedge out to right. The showerbedded Mamaku Ash mantles the eroded surface of Pukerimu Pyroclastics (prp) on which the spade is resting. Contact between the Pukerimu Pyroclastics and Mamaku Ash is marked by dashed line. Section is located at N77/919106 [V15/134408], $>5 \mathrm{~km}$ north of the presumed Mamaku pyroclastic eruptive vent at Hainini Dome. 
pyroclastic flows are not found on the Waiti and Kaipara Lavas; this restricted distribution is consistent with a pyroclastic source vent located high on the Haroharo Complex to south of Pukerimu Cone, probably in the vicinity of Hainini Dome, or Makatiti Dome. The thickest and coarsest Mamaku pyroclastic fall deposits known are coarse ash and lapilli beds drilled in a $10 \mathrm{~m}$ deep auger hole on the slopes of Pukerimu Cone. The hole did not penetrate the Mamaku pyroclastics. The absence of block size or ballistic ejecta in all Mamaku Ash sections is consistent with the assumed vent position some kilometres to south of the nearest exposures of Mamaku pyroclastics.

A local pyroclastic eruption from a vent later buried under Parewhaiti Dome built up a small tuff cone largely composed of plane surge deposits, which are now exposed in one section on Otamuri Road (N77/960077) [V16/171380]. The surge deposits were strongly eroded (Fig. 43) prior to deposition of the overlying Whakatane Ash, so that relationship of the tuff cone to the Mamaku Ash fall deposits is uncertain. However, Mamaku Ash is not present above the surge deposits, and is assumed to underlie them although the basal contact of the surge deposits is not exposed. Similar explosive eruptions preceded extrusion of Te Horoa Dome, producing the charcoal-bearing pyroclastic flow and surge deposits which mantle the area east of Lake Okareka, and are ${ }^{14} \mathrm{C}$ dated at c. 7500 years B.P. (see Table 2).

All the Mamaku pyroclastic eruptions from at least three vents at $\mathrm{Te}$ Horoa, the Hainini-Makatiti Dome area, and Parewhaiti Dome, were followed by extrusion of the lava domes and associated flows. The Ruakokopu and Otangimoana lava flows were probably also extruded at about this time from vents in the vicinity of Makatiti Dome, but lack of any exposure of the pyroclastic-lava relationship precludes confirmation of this correlation.

The magmatic eruptions of the Mamaku Eruptive Episode were followed by the largely phreatic emption at Te Whekau explosion crater to south-west of the Te Horoa vent. The phreatic explosion appears likely to have been initiated by the rise of magma beneath Te Whekau explosion crater, although this magma did not 


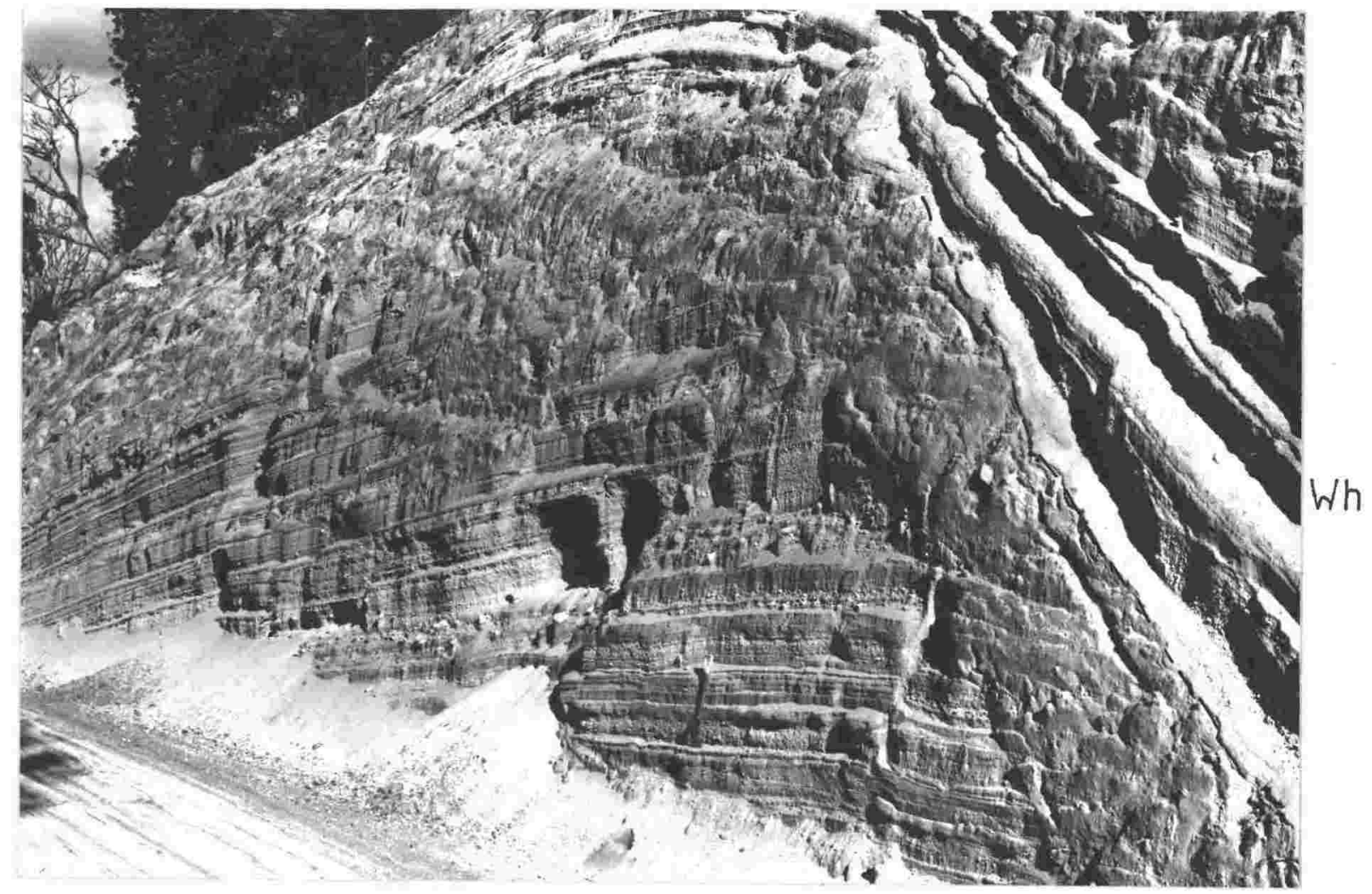

FIG. 43 - Ash, lapilli, and block beds forming plane surge deposits of Mamaku Eruptive Episode age, exposed on Otamuri Road (N77/960077) [V16/171380]. Eroded surface of the surge deposits is mantled by airfall Whakatane Ash (Wh). Contact is marked by dashed line. Spade is $1 \mathrm{~m}$ long. 
itself erupt. Te Whekau explosion crater marks the most southwestern vent of the Mamaku Eruptive Episode.

Whakatane Eruptive Episode: The Whakatane eruptions were the latest to have occurred from Haroharo Volcanic Complex, with rhyolite pyroclastics and lavas erupted from at least 5 vents (Fig. 44) spread over $11 \mathrm{~km}$ of the Haroharo vent lineation.

Initial events of the eruptive episode appear to have been the explosive eruption of pyroclastics from a main vent later buried under Makatiti Dome. Deposits from this source are exposed $1.5 \mathrm{~km}$ to north-east of the vent, in the headwaters of the Te Matae and Mangakotukutuku Streams, overlying the Hainini and Te Matae Lava Flows. In a section at N77/945044 [V16/156350] more than $60 \mathrm{~m}$ of sub-horizontally plane-bedded and long-wavelength, low-amplitude dune-bedded pyroclastic surge deposits (Fig. 45) are exposed, interbedded with minor airfall and pyroclastic flow deposits. Occasional dense blocks range up to $1 \mathrm{~m}$ diameter, but are generally not associated with impact sags, demonstrating transport by surges rather than on ballistic trajectories. Although the deposits are extremely thick, the relatively fine-stratification and lack of large block-size ballistic or fall-back ejecta is consistent with the $1.5 \mathrm{~km}$ distance from the assumed vent. Closer to vent, these initial pyroclastic deposits are buried under younger lavas. Away from the vent, the proximal deposits pass outwards into plinian pyroclastic fall deposits of the Whakatane Ash, which covers more than $16,000 \mathrm{~km}^{2}$ of the eastern North Island with an erupted volume exceeding $10 \mathrm{~km}^{3}$ (Pullar 1973). The plinian fall deposits were dispersed from a high eruption column, which probably generated the near-source pyroclastic surges and flows during periods of partial or complete collapse.

Relatively thin (3-4 m) charcoal-bearing pyroclastic surge and interbedded fall deposits mantle Hainini Dome, showing that surges also travelled north from the Makatiti vent, across the forested top of Hainini Dome. These surges passed down the steep north-east face of Hainini Dome to accumulate as $30 \mathrm{~m}$ of 


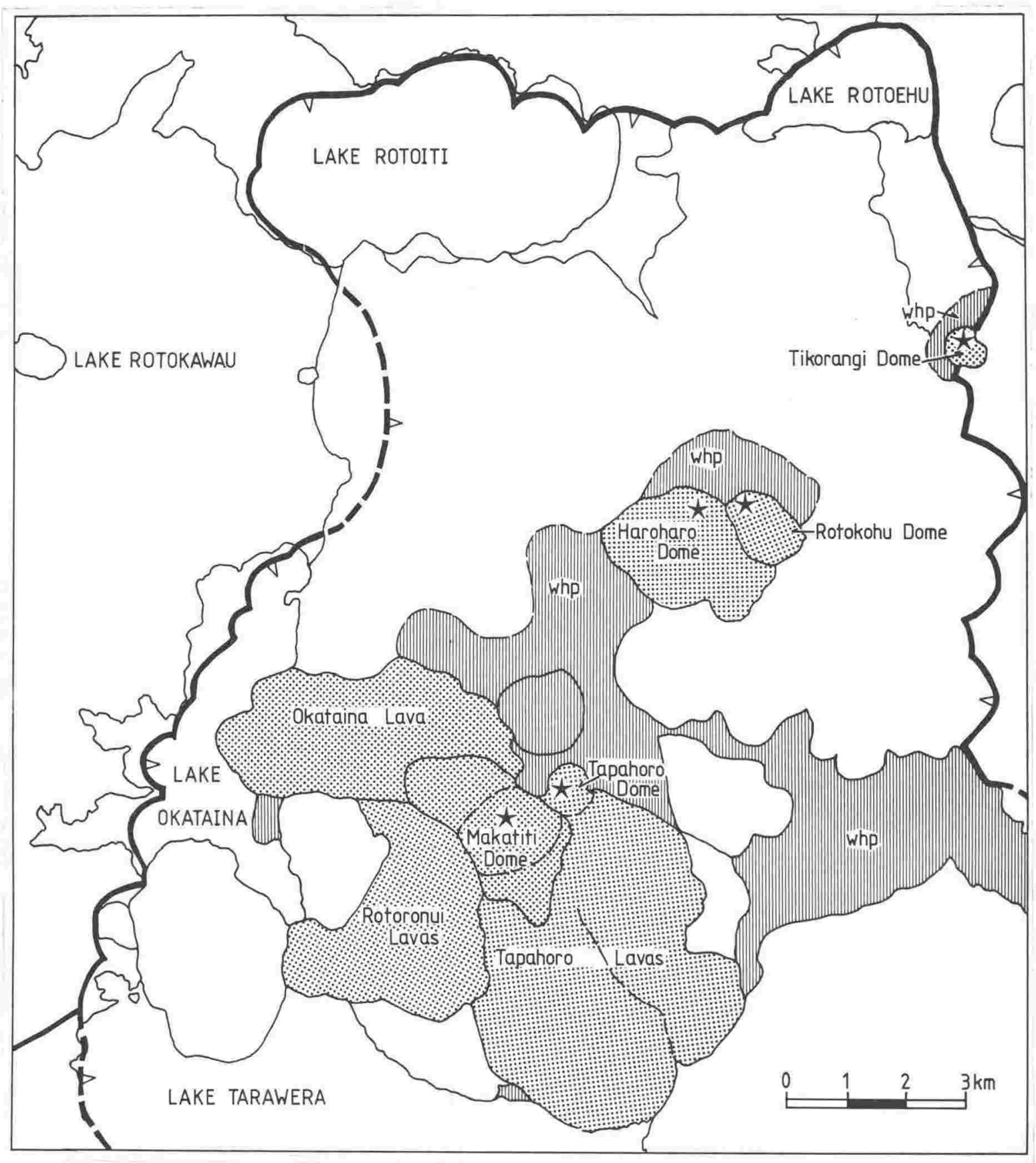

FIG. 44 - Map of Whakatane Eruptive Episode lavas (dot stippled) and pyroclastics (line stippled), with major vent locations $(\star)$, in relation to Haroharo Caldera boundaries. whp - Whakatane Pyroclastics. 


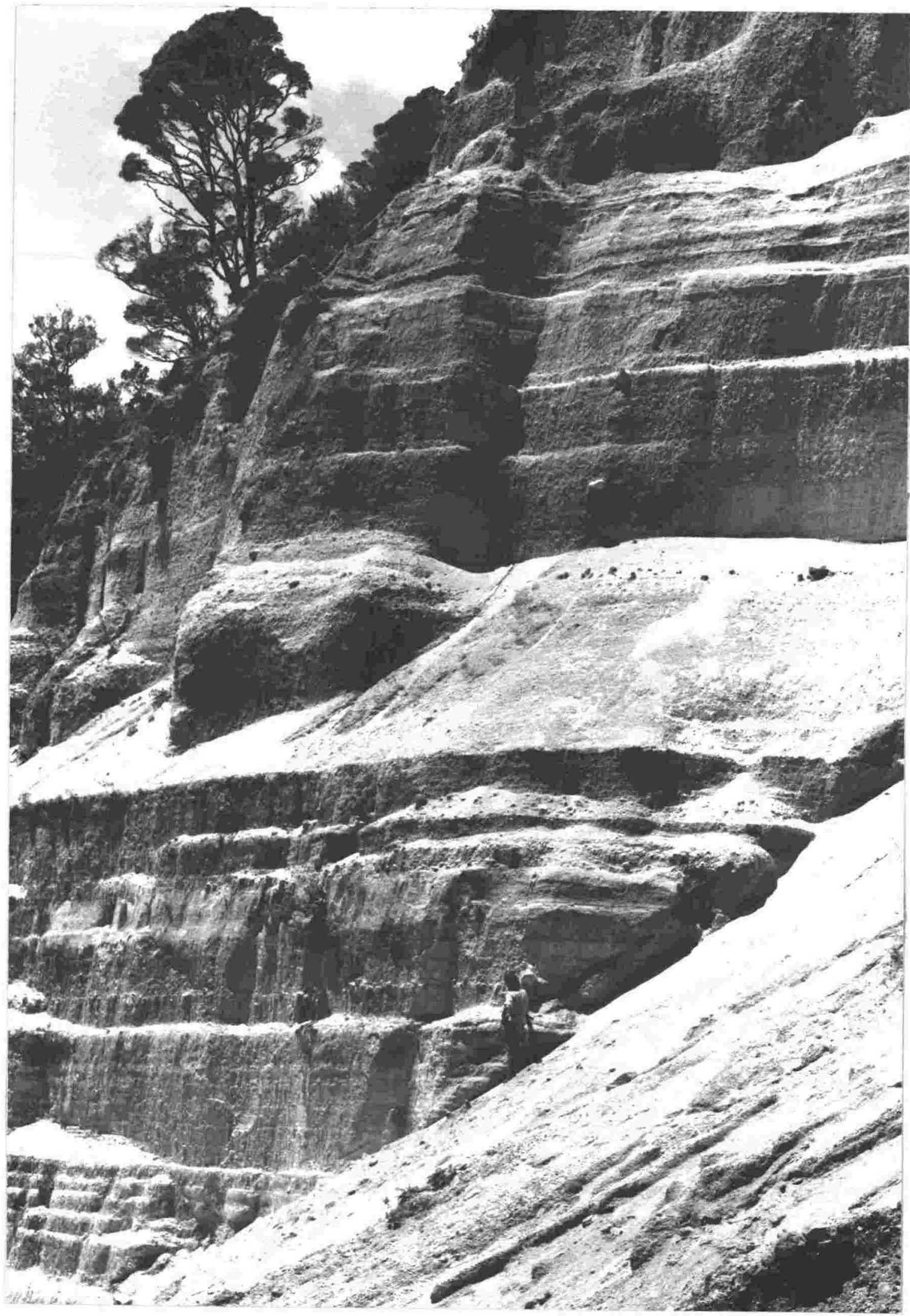

FIG. 45 - Subhorizontally plane-bedded pyroclastic surge and airfall deposits of the Whakatane Pyroclastics exposed on eastern margin of Tapahoro Dome at N77/945 $044 \cdot[\mathrm{V} 16 / 156350]$. This section is c. $1.5 \mathrm{~km}$ from the assumed vent under Makatiti Dome. Note geologist for scale. 
strongly-crossbedded surge deposits, which fill the Mangakotukutuku valley between Hainini and Parewhaiti Domes (see Map 1). Further down valley these surge deposits pass into massive pyroclastic flow deposits which together with the pyroclastic flows which passed over the Hainini Lavas, form a large fan extending to Tarawera River in the Te Haehaenga Basin.

The pyroclastic flow and surge deposits which passed to north-west of Hainini Dome are much thinner and of finer grade in exposures at the southern foot of Pukerimu Cone, suggesting that the main bulk of northward flows was diverted towards Lake Okataina by a valley between the Makatiti vent and Pukerimu Cone. This valley was later filled by the Okataina Lava Flow. Other pyroclastic flows passed south over the Ruakokopu Lavas to Lake Tarawera.

Extrusion of the Rotoroniu and Tapahoro Lavas followed the main plinian eruptions from the Makatiti vent. The Tapahoro Lavas were extruded from the Makatiti vent and two other vents immediately adjacent to north-east (Fig. 44). The multilobate lava flows passed south over the earlier pyroclastics, to reach Lake Tarawera. Explosive eruptions from the Makatiti vent continued after the Tapahoro Lava-extrusion, mantling Tapahoro Dome with up to $10 \mathrm{~m}$ of pyroclastic surge and fall deposits. These pyroclastic eruptions appear to have largely ceased prior to extrusion of the Okataina Lava Flow, also erupted from the Makatiti vent, followed by extrusion of Makatiti Dome. Small explosive eruptions and avalanching of the Makatiti Lava flow front accompanied extrusion of the dome, producing thin (1-2 $\mathrm{m}$ ) pyroclastic flow deposits which overlie the Okataina and Rotoroniu lavas. Final events at Makatiti were small pitforming phreatic explosions which occurred when groundwater encountered the hot lava of the dome.

Eruptions at the vents for Haroharo and Rotokohu Domes also commenced during the Makatiti sequence. Whakatane pyroclastic fall deposits exposed on Otamuri Road to south-west of Haroharo Dome are underlain by thin but coarse surge deposits which 
contain large ballistic blocks of glassy rhyolite, associated with impact sags. These proximal deposits were erupted from the site of Haroharo Dome prior to the main plinian eruptions from the Makatiti vent. Extrusion of the Rotokohu Lavas followed these initial Haroharo explosions, and was also preceded by relatively small explosive eruptions which built up a tuff cone around the Rotokohu vent. Construction of this tuff cone accompanied the Makatiti plinian eruptions. The hot lava of Rotokohu Dome was mantled by further coarse pyroclastic deposits erupted from the Haroharo vent. Extrusion of the Haroharo lavas followed cessation of the Makatiti plinian eruptions, and this dome is mantled only by thin ash of "Bed 1", which probably. originated from the subsequent eruptions at Tikorangi Dome vent.

Extrusion of Tikorangi Dome was aIso preceded by explosive emptions producing pyroclastic flow and surge deposits exposed overlying plinian Whakatane fall deposits at foot of the Dome (Fig. 46). No Whakatane Episode pyroclastics are found on the dome. Radiocarbon ages ( $\mathrm{Table} 2$ ) suggest that the Tikorangi eruptions were the youngest of the Whakatane Episode, consistent with the pyroclastic stratigraphy, although the ${ }^{14} \mathrm{C}$ age difference is not statistically significant. Eruptions at Tikorangi some time after the extrusion of Haroharo Dome would account for development of a weak possible paleosol on the dome lava beneath "Bed 1", which in any case fell after Haroharo Dome had cooled. However, no weathering or erosional break is apparent at the contact between the Whakatane pyroclastic fall deposits and the overlying Tikorangi pyroclastic flow deposits at Tikorangi.

Rotokawau Eruptive Episode: Basaltic pyroclastic eruptions from the Rotokawau-Rotoatua Fissure on the western margin of Haroharo Caldera occurred at about 4000 years B.P. (see p. 67 ). The eruptions have not been ${ }^{14} \mathrm{C}$ dated but the Rotokawau Ash lies between Whakatane Ash and Waimihia Ash (Table 3). The Rotokawau Eruptive Episode has not been studied as part of this thesis. 

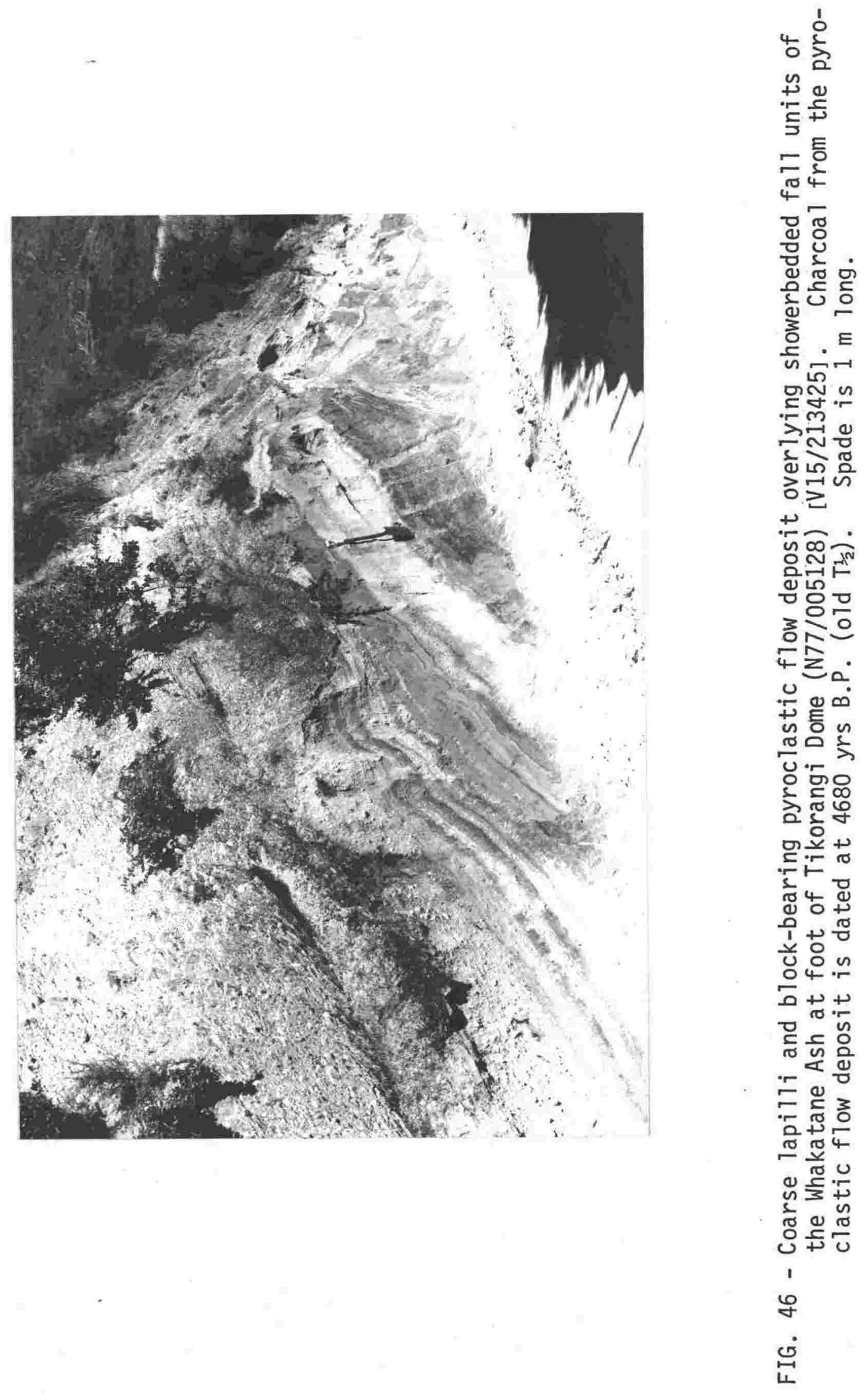
Kaharoa Emuptive Episode: A detailed study of this eruptive episode is in progress (Nairn and Self in prepn.), but does not form part of this thesis. An initial problem has been to determine the age and duration of the eruptive episode. Available age and some stratigraphic data are described in the attached manuscript, intended for publication. 
AGE AND DURATION OF THE KAHAROA ERUPTIVE EPISODE (NOTE)

\author{
I.A. Nairn* \\ Geology Department, Victoria University, Wellington \\ M.S. McGlone \\ Botany Division, \\ Department of Scientific and Industrial Research, \\ Christchurch \\ W.A. Pullar \\ 33 Pegasus Drive, Rotorua
}

\begin{abstract}
The Kaharoa Eruptive Episode of Tarawera Volcanic Complex includes the most recent rhyolitic activity and the largest volcanic eruptions to have occurred in New Zealand during the last 1000 years. Erupted volumes exceed $5 \mathrm{~km}^{3}$ pyroclastics and $2.5 \mathrm{~km}^{3}$ lava. The Kaharoa eruption was previously radiocarbon dated from one dubious wood sample at c. 930 yrs B.P. (NZ1OA). Four well-controlled new radiocarbon dates from middle and upper beds of the Kaharoa pyroclastics range between 780 and 650 years B.P., with three of these dates between 650 and 700 years B.P. A fifth new date of c. 930 years B.P. has been obtained from the areally restricted initial blast bed of the eruptive sequence. The ${ }^{14} \mathrm{C}$ results suggest an extended duration for the Kaharoa Eruptive Episode, although most of the widespread Kaharoa Tephra was erupted between 780 and 650 years B.P. The revised ages are significant for estimates of volcanic risk, and rates of geomorphic processes in New Zealand.
\end{abstract}

\title{
INTRODUCTION
}

The Kaharoa eruption of Tarawera Volcanic Complex in Okataina Volcanic Centre is the youngest rhyolite activity to

\footnotetext{
* Present address: N.Z. Geological Survey, Box 499, Rotorua, New Zealand.
} 
have occurred in New Zealand (Cole and Nairn 1975). The eruption included many types of eruptive mechanisms (Nairn and Self in prepn.), with the widespread Kaharoa Tephra (Kaharoa Ash of many papers) dispersed from plinian eruption columns, to cover much of the northern North Island (Cole 1970a, Pullar 1973, Pullar et al 1977), and offshore Bay of Plenty (Kohn and Glasby 1978). Pyroclastic surges and flows (Fig. 1) are interbedded within fall deposits near the Tarawera vent (Nairn and Self op cit.). The eruption terminated with extrusion of lava domes on the summit of Tarawera (Grange 1937, Cole 1970a,b), and their marginal collapse to form hot debris avalanches. A pyroclastic volume of $5.2 \mathrm{~km}^{3}$ has been estimated for the Kaharoa Tephra (Pullar 1973). The associated lava domes have a volume of $2.5 \mathrm{~km}^{3}$. While smaller than most previous rhyolitic eruptions from Taupo Volcanic Zone, the Kaharoa Eruptive Episode includes the largest volcanic events to have occurred in New Zealand during the last 1000 years.

\section{CHRONOLOGY}

Early Radiocarbon Ages

Radiocarbon ages obtained from Kaharoa pyroclastic deposits and possible correlatives are listed in Table 1. The original ${ }^{14} \mathrm{C}$ date (NZ1OA) was obtained on wood from a $250 \mathrm{~mm}$ diameter $\mathrm{log}$, lying near the base of $1 \mathrm{~m}$ thick airfall Kaharoa Tephra, at $21 \mathrm{~km}$ south-east of Tarawera on Northern Boundary Road (N86/127801) [V16/317124] (Fergusson and Rafter 1955; misquoted in GrantTaylor and Rafter 1963). "No bark was present (on the sample) and the trunk may have been partly decayed ..... it is possible the tree had been destroyed and was still standing when the eruption occurred" (comments on N.Z. Geological Survey Fossil Record Form N86/504, describing the ${ }^{14} \mathrm{C}$ sample). The sample was dated in three runs which gave ages of 840,900 , and 690 years B.P., from which a mean age of $810 \pm 70$ years wàs calculated (Fergusson and Rafter 1955). This mean age was. later corrected for the Suess effect, by addition of 120 years, and a revised age (NZ1OA) of $930 \pm 70$ years B.P. (old T T $\frac{1}{2}$ ), or A.D. 1020 was published (Grant-Taylor and Rafter 1963). 
FIG. 1 - (Over page). Distribution of Kaharoa Tephra, locations of dating sections, stratigraphic correlation between Kohika and Tarawera, and $14 \mathrm{C}$ dates (old $\mathrm{T} \frac{1}{2}$ ). Inset map shows locations of near-vent sections at Wihapi Rd (5A), Ashpit Rd (5B), Tarawera Rd (5C), and Northern Boundary Rd (1). Hatched areas are Kaharoa rhyolite domes on Tarawera Volcanic Complex. 


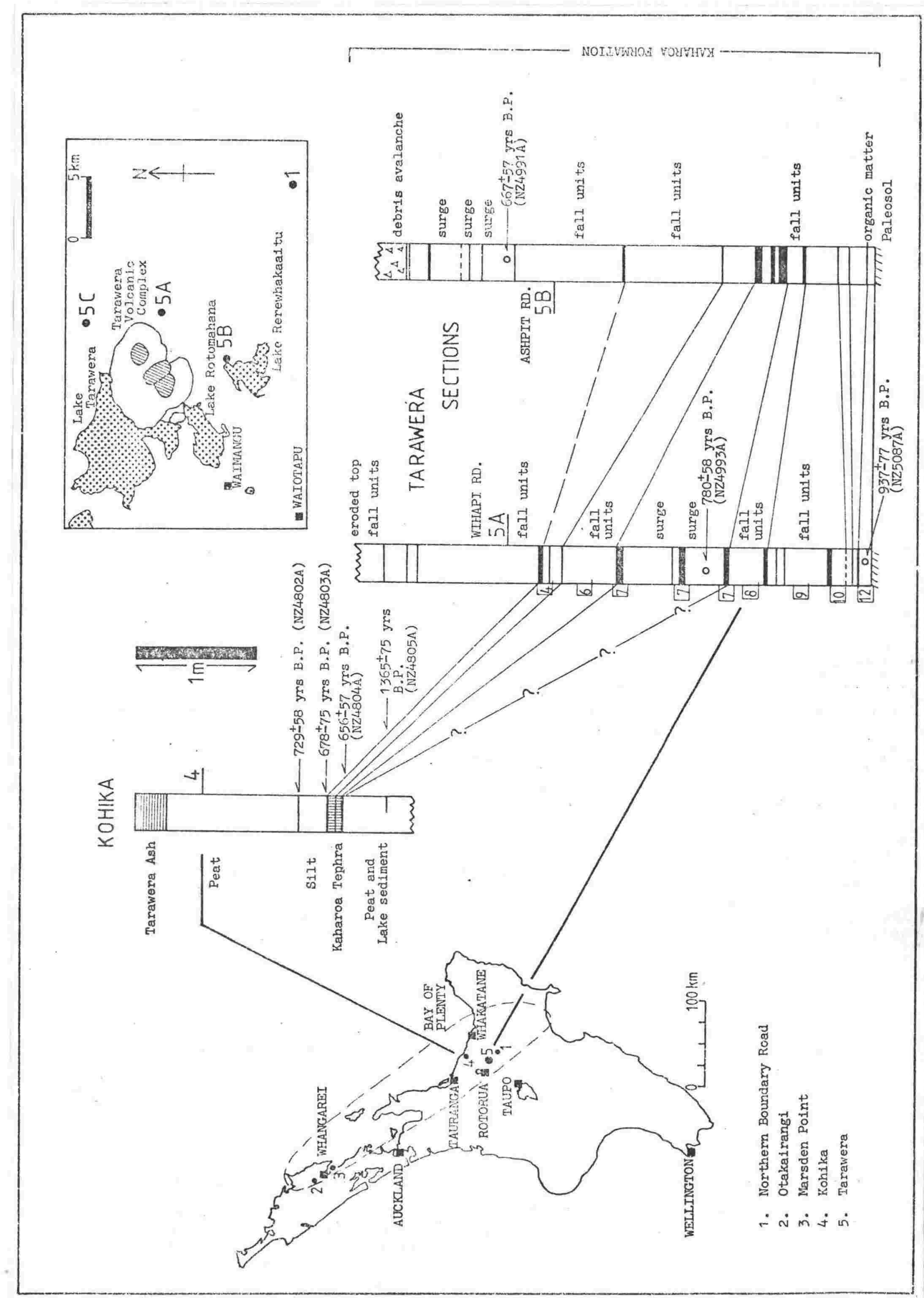




\begin{tabular}{|c|c|c|c|c|c|c|c|c|c|}
\hline $\begin{array}{l}\text { ñ } \\
\text { 苟 } \\
\text { 真 } \\
0\end{array}$ & 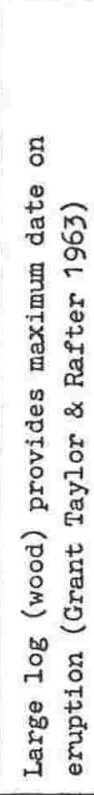 & 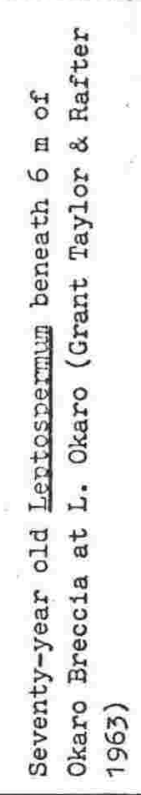 & 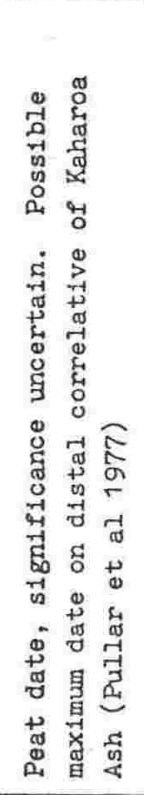 & 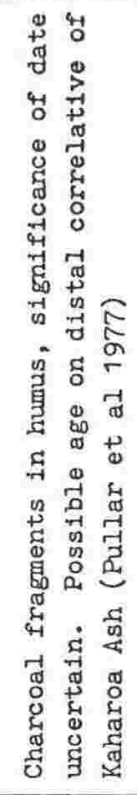 & 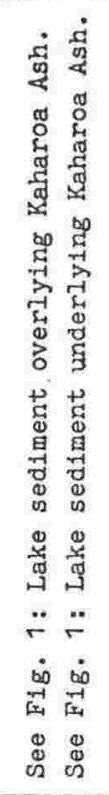 & 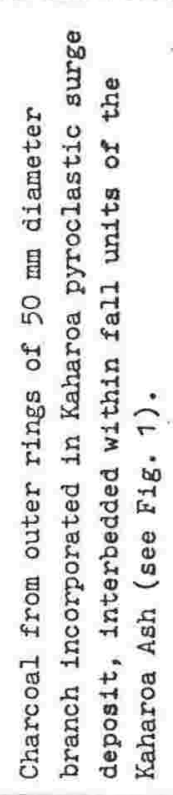 & 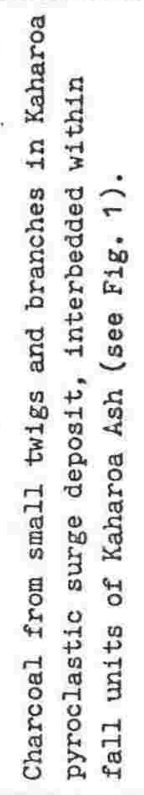 & 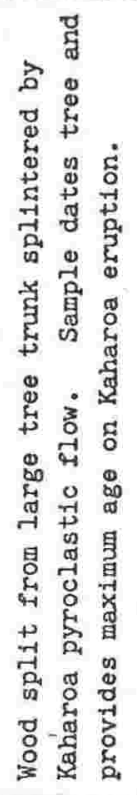 & 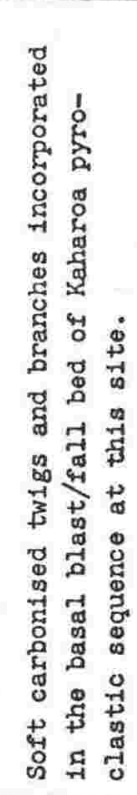 \\
\hline 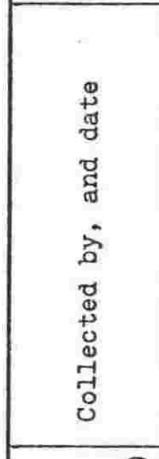 & 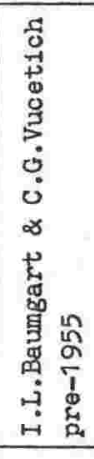 & 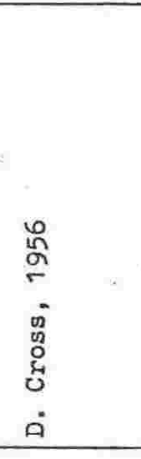 & 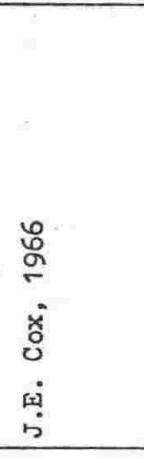 & 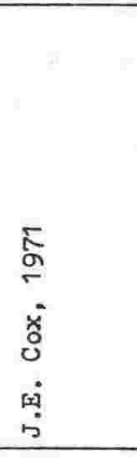 & 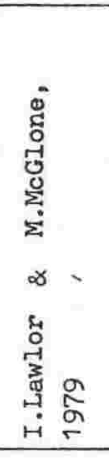 & 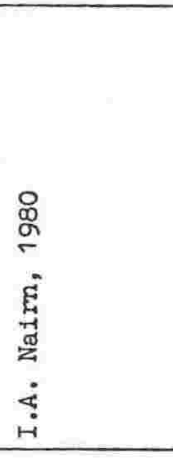 & $\begin{array}{l}= \\
=\end{array}$ & $=$ & 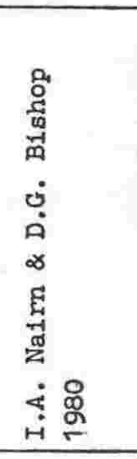 \\
\hline 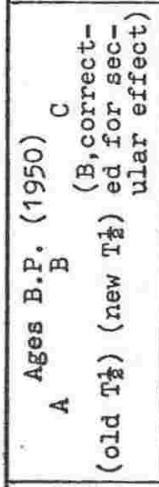 & 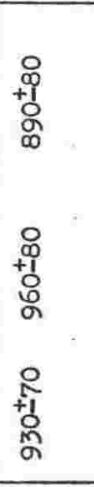 & 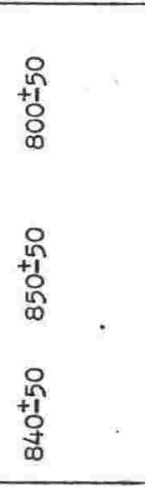 & 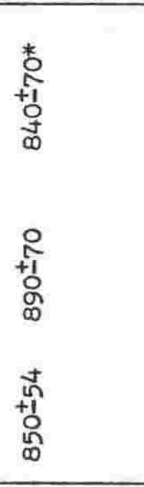 & $\begin{array}{l}\text { on } \\
+1 \\
0 \\
0 \\
0\end{array}$ & 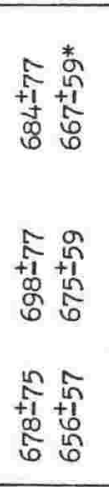 & $\begin{array}{c}\text { o } \\
\substack{+1 \\
+1 \\
0 \\
0 \\
0}\end{array}$ & 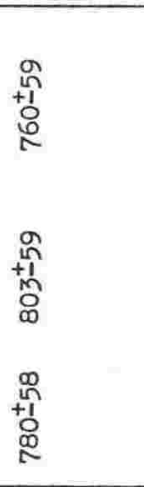 & 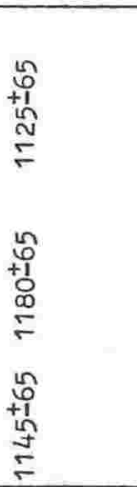 & 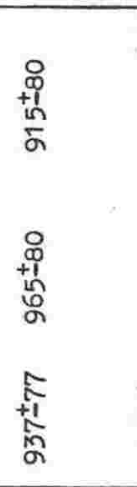 \\
\hline 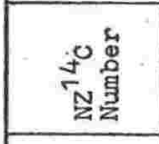 & $\frac{O}{2}$ & 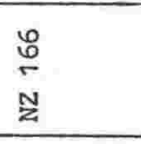 & $\begin{array}{l}\text { N } \\
\infty \\
N \\
N\end{array}$ & 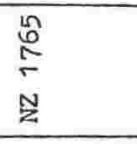 & 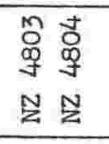 & 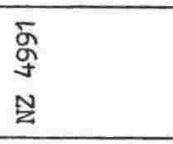 & \begin{tabular}{l} 
No \\
\multirow{\sigma}{*}{} \\
$\mathrm{N}$
\end{tabular} & 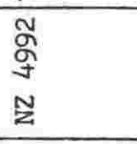 & 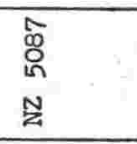 \\
\hline 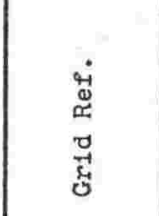 & 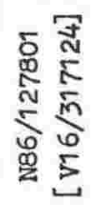 & 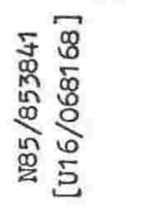 & & & 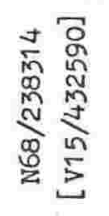 & 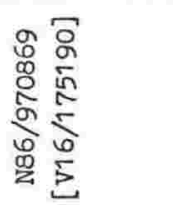 & 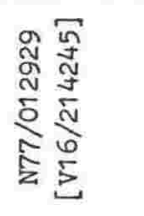 & 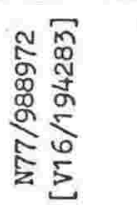 & 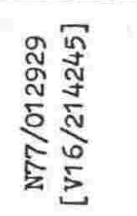 \\
\hline 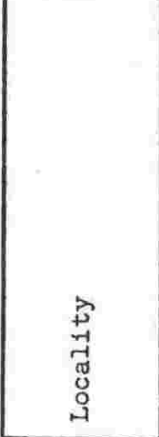 & 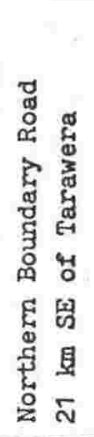 & 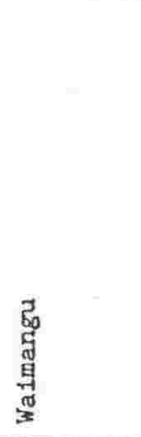 & 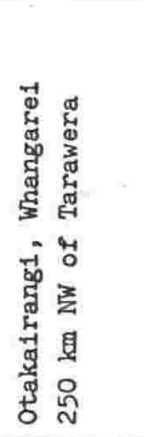 & 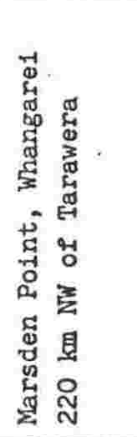 & 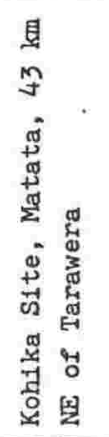 & 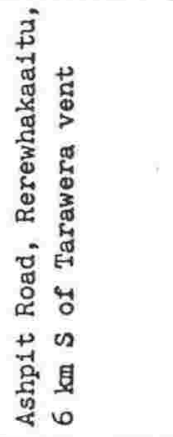 & 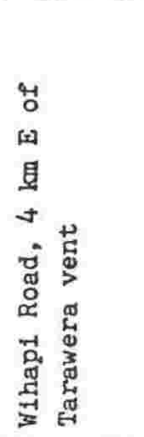 & 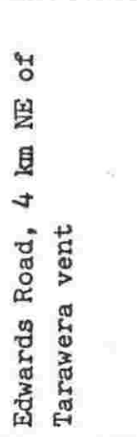 & 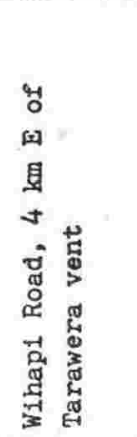 \\
\hline
\end{tabular}


Although described as providing a maximum date for the eruption (Fossil Record Form N86/504; Grant-Taylor and Rafter 1963), the $930 \pm 70$ yrs B.P. NZ1OA age has since been widely quoted as precisely dating the Kaharoa eruption (i.e. Vucetich and Pullar 1964; Cole 1970a, b; Pullar et al 1973; Cole and Nairn 1975; Clark 1977; Pullar et al 1977; Kohn and Glasby 1978).

Some support for the c. 900 yr B.P. date for Kaharoa Tephra came from ${ }^{14} \mathrm{C}$ dates (old T T $\frac{1}{2}$ ) of. $840 \pm 50$ (NZ166A), $900 \pm 40$ (NZ169A) and $960 \pm 75$ (NZ652A) for three hydrothermal explosion breccias at Waiotapu (Fergusson and Rafter 1959; Lloyd 1959; Grant-Taylor and Rafter 1971). These dates approximated NZ1OA for Kaharoa Tephra, leading Lloyd (1959) to suggest that the Waiotapu hydrothermal eruptions were triggered by the Kaharoa volcanism. Cross (1963) reported that small ash lenses, taken to be Kaharoa Tephra, directly underlay the Okaro Breccia (dated by NZ166) at Waiotapu, and the tephra was therefore erupted immediately prior to the breccia. Recent mapping by Nairn has substantiated the existence of patchy remnants of thin $(1-5 \mathrm{~cm}$ ) ash-grade Kaharoa Tephra below the Okaro Breccia at Waimangu. However the Okaro Breccia date (NZ166) was on 70 year-old Leptospermum (Grant-Taylor and Rafter 1963), suggesting a true

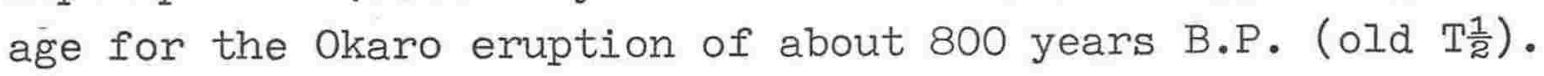

\section{Later Dates}

The first suggestion that Kaharoa Tephra might be younger than c. 900 yrs B.P. was obtained from Bay of Plenty beach accumulation rates above the c. 1800 yrs B.P. Taupo Pumice, which indicated a Kaharoa date at A.D. c. 1350 (Wellman 1962, p. 74), i.e. 600 yrs B.P.

Charcoal fragments from a thin layer of black humus beneath a rhyolitic tephra enclosed in sand dunes at Marsden Point, Whangarei (Fig. 1) gave a ${ }^{14} \mathrm{C}$ date (NZ1765A - old T T $)$ of $607 \pm$ 55 yrs B.P. (Pullar et al 1977). A peat sample (NZ872A) from beneath a similar tephra at Otakairangi Swamp, Whangarei, gave a ${ }^{14} \mathrm{C}$ age of $850 \pm 54$ yrs B.P. (Table 1). Both tephras were 
biotite-bearing, and were correlated with Kaharoa Tephra, but the old $\mathrm{T} \frac{1}{2}{ }^{14} \mathrm{C}$ dates do not overlap at the two standard deviation level, and their significance is somewhat uncertain (see Pullar et al 1977, p. 703). However, although "contamination with younger organic matter was suspected", the NZ1765A date suggested the possibility of a post-900 yr B.P. age for Kaharoa Tephra. No estimate of the relationship of the NZ872A peat age to that of the tephra is presently available to the writers.

Nearer source, $130 \mathrm{~mm}$ thick Kaharoa Tephra is enclosed in swamp deposits at Kohika archeological site (N86/238314) [V15/432590], $45 \mathrm{~km}$ north-east of Tarawera (Fig. 1). Four radiocarbon dates were obtained from this site. Slices of diatomaceous lake sediment 5 and $10 \mathrm{~mm}$ thick, cut from immediateIy above and below the ash (Fig. 1) gave ages of $678 \pm 75$ yrs B.P. (NZ4803A) and $656 \pm 57$ yrs B.P. (NZ4804A) respectively. A $20 \mathrm{~mm}$ thick peat slice at $360 \mathrm{~mm}$ below the ash gave an age of $1365 \pm 75$ yrs B.P. (NZ4805A) and this, taken together with NZ4804A, indicates sediment accumulation rates of $0.4 \mathrm{~mm} / \mathrm{yr}$. The lake sediment sampled to $10 \mathrm{~mm}$ below the Kaharoa Tephra may therefore have accumulated over about 25 years, suggesting an ash date about 10 years younger than the $656 \pm 57$ yrs B.P. date obtained. After deposition of the Kaharoa Tephra, some $60 \mathrm{~mm}$ of diatomaceous lake sediment was laid down, followed by alluvial silt accumulation, which resulted in a layer of slightly organic silt $210 \mathrm{~mm}$ thick. A sample from this alluvial layer 260-220 $\mathrm{mm}$ above the Kaharoa Tephra, gave an age of $729 \pm 58$ yrs B.P. (NZ4802A).

Pollen analysis of this swamp section has shown that destruction of local forest and scrub communities by repeated fires took place in the time interval represented by the postKaharoa alluvium. It is likely, therefore, that the alluvium is the product of erosion of soils in the swamp catchment. Tolonen (1980) has demonstrated that radiocarbon dates obtained from lake sediments in Finland can be up to 1500 years too old 
as a result of contamination by an influx of old organic material following forest clearance. The dates obtained from sediments above the Kaharoa Tephra at Kohika are likely to be too old because of this effect, suggesting that the $656 \pm 57$ NZ4804A age for the sediments immediately below the Kaharoa Tephra gives the closest approximation to the true age.

In order to check on the Kohika dates, three carbon samples (NZ4991, NZ4993, NZ5087), and one wood sample (NZ4992) were obtained from Kaharoa pyroclastic blast and surge deposits in sections at foot of Tarawera Volcanic Complex (Fig. 1). The carbon samples were from small vegetation dismembered and carbonized by an initial blast eruption, and a later series of hot, turbulent, high velocity and directional pyroclastic surges which flowed down the flanks of Tarawera during the major pyroclastic eruptions (Nairn and Self in prepn.). The dated deposits underlie, and are interbedded between pyroclastic fall deposits which comprise the distal Kaharoa Tephra (Fig. 1). Soft, carbonized twigs and small branches incorporated in the initial blast bed are dated (old T $\frac{1}{2}$ ) at $937 \pm 77$ yrs B.P. Hard charcoal from two overlying surge beds has been dated in upward succession at $780 \pm 58$ and $667 \pm 57 \mathrm{yrs}$ B.P. (old T $\frac{1}{2}$ ) respectively (Fig. 1 and Table 1). These near-source ages are in correct stratigraphic sequence. The wood sample was from a large tree broken off and splintered by a pyroclastic surge and gave an age of $1145 \pm 65$ yrs B.P. (Table 1), dating the tree rather than the eruption. The enclosing surge unit lies stratigraphically between the two dated surges described above (Fig. 2), demonstrating an inconsistent date for the wood sample.

\section{DISCUSSION}

Previous studies of the Kaharoa eruptives, including those by the present writers, have implicitly assumed a short duration (say 1-10 years?) for the Kaharoa Eruptive Episode. No significant time breaks, apparent from erosional or weathering hiatuses, have been reported from within the Kaharoa eruptives. 
Detailed stratigraphic correlation (Nairn and Self in prepn.) carried out within the Kaharoa pyroclastics has enabled the various ${ }^{14} \mathrm{C}$ dated pyroclastic beds to be located in the telescoped fall sequence (Fig. 1,2), in sections at intermediate distances from the Tarawera vent. Thin, fine and coarse grained fall units can be traced over considerable distances in these sections without evidence of weathering or erosion between beds. The conformable contacts between dated units provided no evidence of significant time breaks between beds of the Kaharoa Ash sequence, and suggested that all were erupted in a short time interval. The only exception to this relationship has been found at the upper contact between the basal blast bed and the overlying fall unit in sections to north and east of Tarawera. Organic matter (leaf litter?) and slight erosional unconformity has been found at this contact, suggesting the possible existence of a quiescent interval early in the Kaharoa eruptive sequence. The initial blast bed is not widely dispersed.

Where distal Kaharoa Tephra deposits are enclosed in environments of continuous sedimentation, no interbedded sediments occur within the ash. Examples occur in marine sediments cored from water depths up to $510 \mathrm{~m}$ in the Bay of Plenty (i.e. Kohn and Glasby 1978, fig. 4, table 5), and the Kohika peat swamp section (Fig. 1). In both these environ-

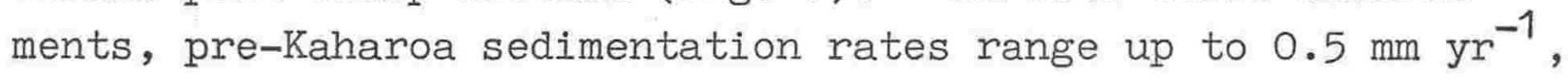
yet no sediments occur within the ash deposit. Similar absence of included sedimentation occurs in all known exposures of Kaharoa Tephra in swamp and lacustrine environments, and also where the ash is enclosed in dune sands at Walker's Access Road (N68/277323) [V15/467597], on the Bay of Plenty coast. These results indicate that no quiescent intervals of long duration (say $>10$ years) can have occurred during deposition of the Kaharoa Tephra which fell at these sites.

The ${ }^{14} \mathrm{C}$ ages for Kaharoa pyroclastics at Tarawera and Kohika are in some conflict with the stratigraphic evidence, as they suggest an eruption episode duration of about 250-300 
FIG. 2 - (Over page). Pyroclastic fall sequence in Kaharoa Tephra at Tarawera Road (Section 5C on Fig. 1). Fall units are numbered as in Fig. 1. Detailed correlation between sections has shown the 780-58 yrs B.P.-dated pyroclastic surge horizon to occur within fall unit 7 (see also Fig. 1). The 656-57 yrs B.P. basal dated fall units at Kohika comprise 3, 4, 6, at least part 7, and possibly components of 8 and 9 at the Tarawera Road section.

No time breaks are apparent in the conformable contacts between fall units 6,7 , and 8 .

The maximum ${ }^{14} \mathrm{C}$ dates of $1145^{+}-65$ yrs B.P. and $937^{+}-77$ yrs B.P. occur in horizons correlated with fall units 4 and 12, respectively. 


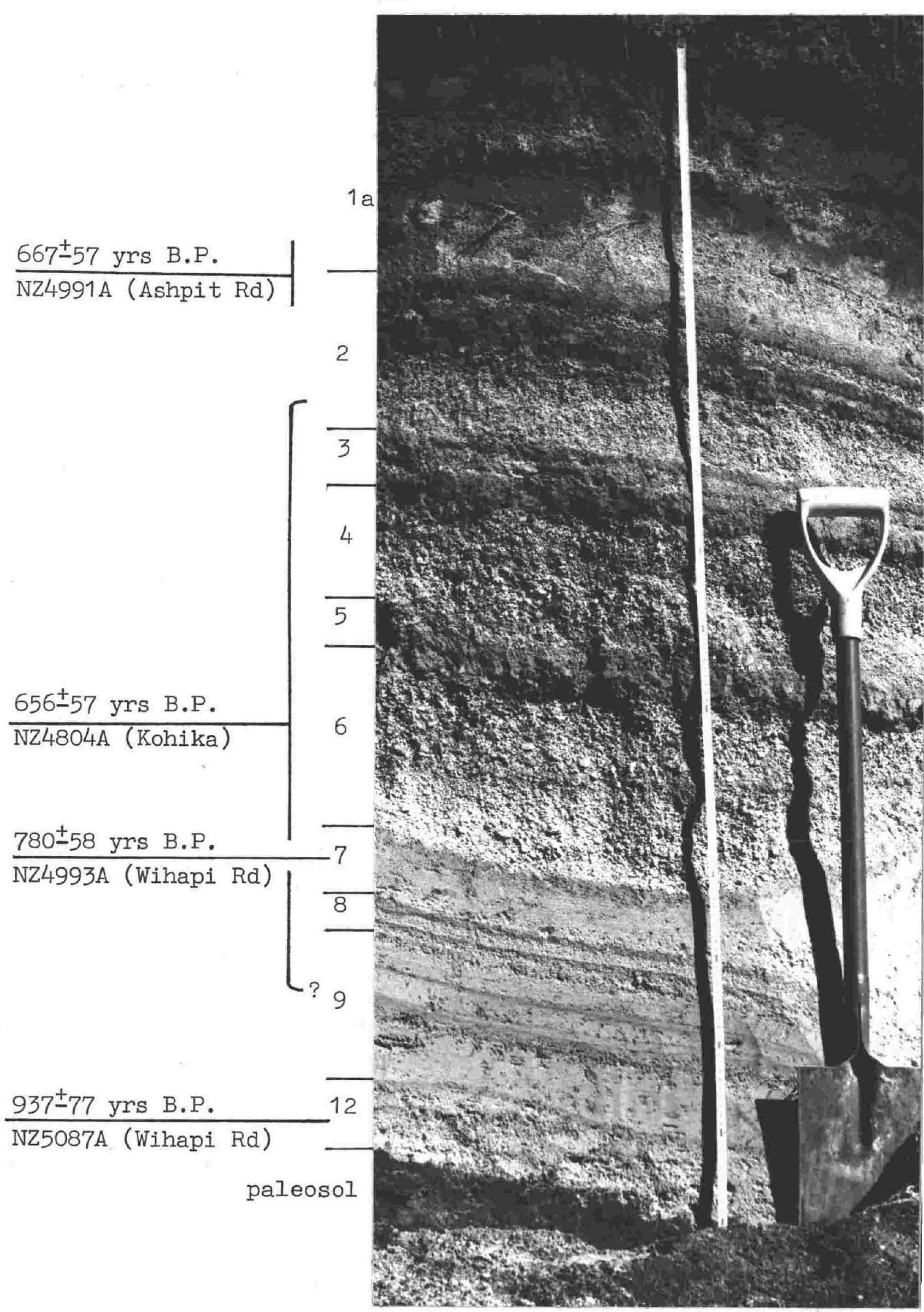


years (Table 1), if taken at face value. The old $T \frac{1}{2}$ dates (NZ5087, NZ4991), for the initial blast bed ( $937 \pm 77$ yrs B.P.) and the youngest overlying dated surge unit (667 \pm 57 yrs B.P.), just avoid overlap at the 95\% confidence level (Fig. 3) suggesting that the age difference is probably real. Fxcluding the NZ5087initial blast bed date, the other Tarawera and Kohika dates (NZ4803, 4804, 4991, 4993) overlap at the 95\% confidence level, and in fact almost overlap at the $67 \%$ confidence level (Fig. 3). These apparent age differences are not statistically significant (H.S. Jansen, pers. comm.).

Detailed correlation between Tarawera and the Kohika site has shown that the $656 \pm 57 \mathrm{yr}$ B.P. dated basal fall unit at Kohika is likely to be interbedded with the surge unit dated at $780 \pm 58$ yrs B.P. at Wihapi Rd (Fig. 1). The apparent age difference is therefore likely to be an artefact of the sampling or dating process, rather than representing included long quiescent interval(s).

We therefore interpret the presently available ${ }^{14} \mathrm{C}$ and stratigraphic data as follows. The Kaharoa Eruptive Episode probably began at about 930 yrs B.P. (old T $\frac{1}{2}$ ), with an initial blast eruption of restricted areal extent. This eruption was followed by a period of pyroclastic quiescence. Date of recommencement of eruption is unknown, but the first pyroclastic surge to east of Tarawera is dated at c. 780 yrs B.P. and had been preceded in this sector by pyroclastic fall deposits (Fig. $1)$, and by earlier undated pyroclastic surges which flowed to north of Tarawera (Nairn and Self in prepn.). Eruption of the most widespread pyroclastic fall units of the Kaharoa Tephra followed. Sedimentation rates at Kohika, Walker's Access Road, and in the Bay of Plenty indicate that the Kaharoa Tephra in at least this northern sector fell over a short period of time, and probably represents the deposits of a single dispersal lobe. Age of the northern tephra deposits appears wellcontrolled at about $650-700$ yrs B.P.

The pyroclastic eruptions were accompanied and followed by extrusion of the summit lava domes at Tarawera. Duration of 


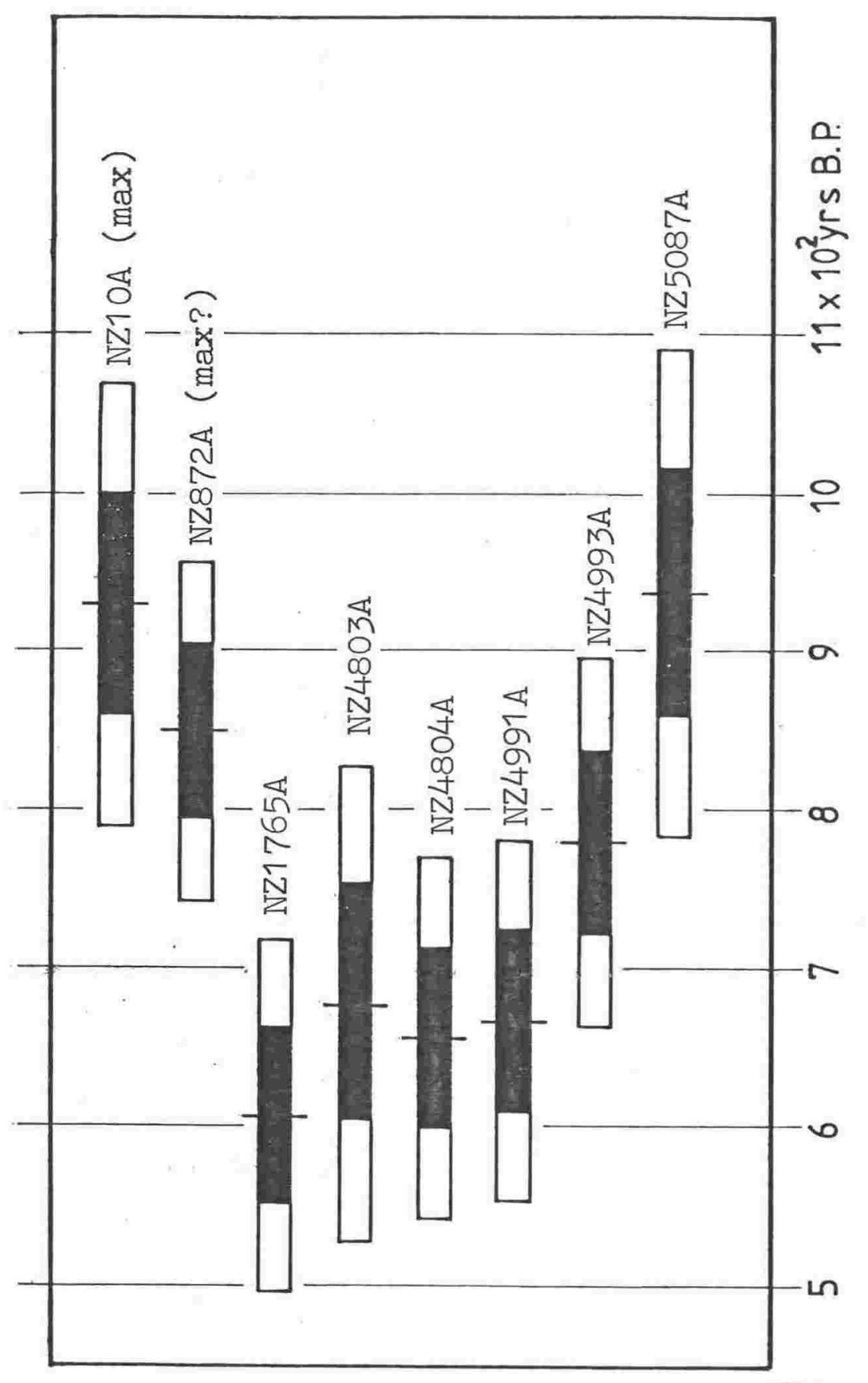

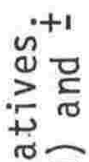

\%

응

응 드

in

음

믇무

ชั $\frac{1}{8}$

U 믈

艼

ज牲

능

$\sum_{1+1}^{1}$

at

ช

흘

吾

등 ํำ

워

足

¿

응

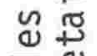

듬임

空 들

능

는

시유

ㄷㅎㅇ

훙

ज $\rightarrow \frac{0}{0}$

(ิ)

들

ㄷำ

芫心界

.

m

密 
this final eruption phase is unknown, but debris avalanche deposits derived from the growing domes overlie the Kaharoa pyroclastic deposits without apparent time break (i.e. section $5 B$ - Fig. 1).

The previously accepted NZ10 age of $930 \pm 70$ yrs B.P. is now considered to have been correctly termed a "maximum" age for the Kaharoa Eruptive Episode. The agreement with the new NZ5087 age obtained for the initial blast bed on Tarawera may be purely coincidental, as the blast bed does not extend close to the NZ10 sample site, where the basal beds are fall units 8 and 9 of Fig. 1. It may be that forest fires associated with the initial eruptions could have caused the death of the NZ10 tree?

The NZ872 and NZ1765 dates from Whangarei (Table 1), have not been considered in this discussion due to the uncertainty regarding their significance. If taken at face value, these dates are also consistent with multiple eruptions of the Kaharoa pyroclastics, separated by a significant time interval.

\section{SUIIVARY}

Four new ${ }^{14} \mathrm{C}$ dates on Kaharoa pyroclastics demonstrate that most of the Kaharoa Tephra was erupted between about 780 and 650 years B.P. Three of these dates are younger than 700 years B.P. and are considerably younger than the $930 \pm 70$ yrs B.P. age previously considered to date the Kaharoa Eruptive Episode. A further new ${ }^{14} \mathrm{C}$ date of $930 \pm 77$ years B.P. for the initial Kaharoa event indicates a probable extended duration for the Kaharoa Eruptive Episode, although there is little stratigraphic support for this interpretation. We conclude that the Kaharoa Eruptive Episode is (a) younger than previously described; (b) probably had an extended duration.

\section{ACKNOWLEDGENENTS}

This paper has benefitted considerably from comments by H.S. Jansen, T.L. Grant Taylor, and C.G. Vucetich, who all provided valuable guidance in our attempts to reconcile the stratigraphic and chronological uncertainties. 
REFERENCES

Clark, R.H. 1977: Volcanic disasters in the Japanese main islands and New Zealand. Journal of the Faculty of Science, Hokkaido University, Series IV, 17: 541-552.

Cole, J.W. 1970a: Description and correlation of Holocene volcanic formations in the Tarawera-Rerewhakaaitu region. Transactions of the Royal Society of New Zealand (Earth Sciences) 8(7): 93-108.

1970b: Structure and eruptive history of the Tarawera Volcanic Complex. N.Z. Journal of Geology and Geophysics 13: 879-902.

Cole, J.W. and Nairn, I.A. 1975: "Catalogue of the active volcanoes of the world including solfatara fields. Part XXII New Zealand". International Association of Volcanology and Chemistry of the Earth Interior. Rome. $156 \mathrm{p}$.

Cross, D. 1963: Soils and geology of some hydrothermal eruptions in the Waiotapu district. N.Z. Journal of Geology and Geophysics 6: 70-87.

Fergusson, G.J. and Rafter, T.A. 1955: New Zealand ${ }^{14} \mathrm{C}$ age measurements - II. N.Z. Journal of Science and Technology B36(4): $371-374$.

1959: New Zealand ${ }^{14} \mathrm{C}$ age measurements - 4. N.Z. Journal of Geology and Geophysics 2: 208-241.

Grant-Taylor, T.L. and Rafter, T.A. 1963: New Zealand natural radiocarbon measurements I-V. Radiocarbon 5: 118-162. 1971: New Zealand radiocarbon age measurements - 6 . N.Z. Journal of Geology and Geophysics 14: 364-402.

Grange, L.I. 1937: The geology of the Rotorua-Taupo subdivision. N.Z. Geological Survey Bulletin 37: $138 \mathrm{p}$.

Kohn, B.P. and Glasby, G.P. 1978: Tephra distribution and sedimentation rates in the Bay of Plenty, New Zealand. N.Z. Journal of Geology and Geophysics 21: 49-70.

Lloyd, E.F. 1959: The hot springs and hydrothermal eruptions of Waiotapu. N.Z. Journal of Geology and Geophysics 2: 141-176. Nairn, I.A. and Self, S. in prepn: The Kaharoa eruption of Tarawera volcano, Taupo Volcanic Zone, New Zealand. (to be submitted to Journal of Volcanology and Geothermal Research). 
Pullar, W.A. 1973: "Isopachs of tephra, Central North Island, New Zealand. Scale 1:1,000,000". N.Z. Soil Bureau Map 133/1-7, to accompany N.Z. Soil Survey Report 31 . Pullar, W.A., Birrell, K.S. and Heine, Janice C. 1973: Named tephras and tephra formations occurring in the central North Island, with notes on derived soils and buried paleosols. N.Z. Journal of Geology and Geophysics 16: 497-518.

Pullar, W.A., Kohn, B.P., Cox, J.E. 1977: Airfall Kaharoa Ash and Taupo Pumice, and sea-rafted Loisels Pumice, Taupo Pumice, and Leigh Pumice in northern and eastern parts of the North Island, New Zealand. N.Z. Journal of Geology and Geophysics 20: 697-717.

Tolonen, K. 1980: Comparison between radiocarbon and varve dating in Lake Lampellonjarvi, South Finland. Boreas 9: 11-19.

Vucetich, C.G., and Pullar, W.A. 1964: Stratigraphy and chronology of Late Quaternary Volcanic Ash in Taupo, Rotorua and Gisborne Districts. Part 2. N.Z. Geological Survey Bulletin 73: 43-82.

Wellman, H.W. 1962: Holocene of the North Island of New Zealand: a coastal reconnaissance. Transactions of the Royal Society of New Zealand, Geology 1(5): 29-99. 
1886 A.D. Tarawera-Rotomahana-Waimangu Eruptive Episode: Aspects of this very short duration (c. 4 hours) eruption are discussed in the attached paper on eruption mechanisms at Lake Rotomahana, and in the following manuscript (submitted for publication) on basalt dikes in the Tarawera Rift. 


\title{
Rotomahana-Waimangu eruption, 1886: base surge and basalt magma
}

\author{
I. A. NAIRN \\ Geology Department, Victoria University of Wellington, Wellington, New Zealand*
}

\begin{abstract}
Steam explosions ejecting country rock and lake-floor sediments from Rotomahana-Waimangu accompanied eruption of basaltic scoria from Tarawera Volcanic Complex during the early morning of 1886 June 10. The near-source Rotomahana ejecta displays wave-like internal bed forms typical of base surge eruption mechanisms. Deposition occurred from high velacity, steam-fluidised density currents, which carried ejecta laterally outwards from the base of a large vertical eruption column. The surges extended at least $6 \mathrm{~km}$ west of the source and passed over steep hills that rise to $350 \mathrm{~m}$ above the eruptive vents,

Controversy has existed as to whether basalt magma was erupted from craters in the previously highly active Rotomahana hydrothermal area. New exposures clearly demonstrate that basalt was erupted from Waimangu in 1886; pre-1886 basic scorias outcrop in the Rotomahana area; much near-source Rotomahana ejecta consists of little or non-altered rock. These data are consistent with the existence of a continuous basaltic dike at depth beneath Rotomahana and suggest that magmatic energy may have contributed to the 1886 Rotomahana explosions.
\end{abstract}

\section{INTRODUCTION}

Steam explosions ejecting country rock and lake-floor sediments from Rotomahana accompanied eruption of basaltic scoria from the adjacent Tarawera Volcanic Complex on 1886 June 10 (Grange 1937; Cole 1970; Cole \& Nairn 1975). The Rotomahana explosions formed a line of large craters up to $180 \mathrm{~m}$ deep, extending $9 \mathrm{~km}$ south-west from Tarawera to Waimangu (Fig. 1). Fine ejecta covered more than $2000 \mathrm{~km}^{2}$ of surrounding country to $>5 \mathrm{~cm}$ depth (see Pullar 1973), forming the "Rotomahana Mud" (Grange 1937). The major explosion craters have since filled with water to form the present Lake Rotomahana.

The near-source Rotomahana ejecta displays sedimentary structures characteristic of base surge deposited pyroclastics (for examples see Moore 1967; Fisher \& Waters 1970; Schmincke et al. 1973), emplaced from steam-fluidised, high velocity, and turbulent density currents. The 1886 Rotomahana activity appears closely analogous to the 1965 phreatomagmatic eruption of Taal (Philippines), where a series of hurricane-velocity steam clouds carried suspended debris radially outwards from the base of the eruption column (Moore 1967). The Taal base surge clouds shattered trees and sandblasted objects up to $6 \mathrm{~km}$ distant, causing extensive damage and loss of life. The surge deposits formed surface dunes with crests tangential to surge direction, and with steeper stoss sides scoured by the blast. The dunes were internally cross-bedded, with low-angle crosslaminations, and undulating wave forms. Dunes were largest adjacent to Taal crater and systematically decreased in wavelength away from the source. Maximum distance of surge travel was $6 \mathrm{~km}$ from the crater, with the surges following the ground contours, passing up, over, and down ridges (Moore 1967).
At Rotomahana, controversy has existed as to the either dominantly phreatomagmatic or hydrothermal nature of the 1886 explosions, i.e., whether or not basalt magma provided a major energy source for the Rotomahana-Waimangu eruptions. This paper presents evidence for base surge eruption mechanisms at Rotomahana in 1886, and discusses the possible tole of basalt magma in generation of the explosions.

\section{Pre-Eruption Geography}

Rotomahana was an intensely active hydrothermal field prior to the 1886 eruption (Hochstetter 1864), with many boiling springs, geysers, and two large siliceous sinter aprons forming the famous Pink and White Terraces. Two small lakes-Rotomahana (hot) and Rotomakariri (cold)-occupied part of the site of the present Lake Rotomahana (see Fig. 1) on a dissected plateau $c .700 \mathrm{~m}$ below the summit of Tarawera. No surface hydrothermal activity was known at Waimangu.

Maori settlements at Te Ariki ( 52 inhabitants), Moura (39), and a camp at Rotomahana (11) were destroyed by the eruption, with a further 14 deaths at Te Wairoa. The Rotomahana area was otherwise uninhabited.

\section{HISTORICAL DATA}

\section{Eruption Sequence}

No observers close to Rotomahana survived the eruption. Distant eye-witness accounts (summarised by Cole 1970) indicate that eruption of basaltic scoria began about 0130 hours from Wahanga Dome on Tarawera (Fig. 1), following an hour-long sequence of earth-

Received 11 July 1978, revised 4 January 1979

*Present address: New Zealand Geological Survey, DSIR, P.O. Box 499, Rotorua. 


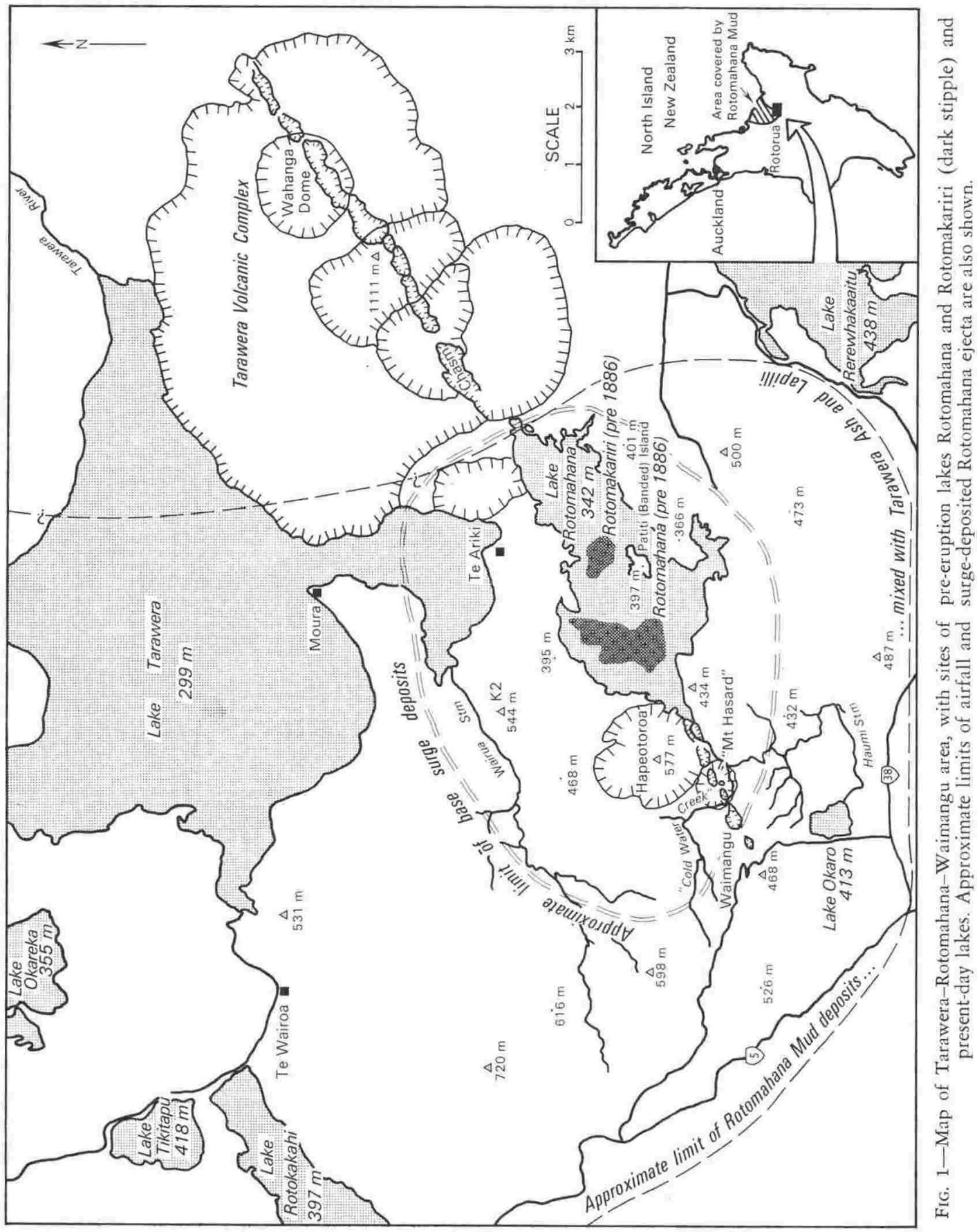


quakes felt at Rotorua. Eruption gradually extended south-west across Tarawera. By 0230 hours, craters along the full $8 \mathrm{~km}$ length of the Tarawera Volcanic Complex were erupting scoria. Steam explosions apparently commenced at Rotomahana about 0320 hours, but had been preceded by an explosion at 0230 hours from a vent at Waimangu, Sharp earthquakes and loud detonations accompanied the major explosions. The latter were heard at Auckland (200 km distant) from 0230 hours, and became particularly loud and frequent from 0330 hours. The Rotomahana eruption column rose to a height variously estimated at $10-13 \mathrm{~km}$, and expanded into a large eruption cloud in which lightning was frequent.

Initial south and south-east winds carried the eruption cloud across Lake Tarawera. Cold wet mud, including large lumps and 2-cm-diameter accretionary lapilli, fell at Te Wairoa (Fig. 1). This was apparently fushed from the cloud by condensation of steam, and further cooled by a cold south-west wind which blew from about 0400 hours. This "mudfall" collapsed many of the buildings at Te Wairoa and coated branches and stripped leaves from vegetation at Tikitapu.

Much incandescent ejecta was observed above Tarawera during the eruption, but not at Rotomahana where the eruption clouds were not lit by glare (Thomas 1888), suggesting that no incandescent lava reached the surface there (however, observers at Rotorua and Te Wairoa could not view Rotomahana directly).

The eruption was largely over by 0530 hours (Cole 1970), although diminishing steam eruptions, particularly from Rotomahana, continued for some months.

\section{Scientific Investigations}

Investigations of eruption effects and deposits were begun almost immediately by a number of workers (Smith 1886a, b; Hector 1886; Hutton 1887; Thomas 1888). At Rotomahana, a series of coalescing explosion craters formed a nearly continuous fissure, extending from the foot of Tarawera $6 \mathrm{~km}$ south-west to the foot of Hapeotoroa rhyolite dome (Fig. 1). From there the fissure was marked by a series of discontinuous craters in the Waimangu area. A thick blanket of ejecta covered the surrounding countryside. Most early investigators agreed that little if any basalt had been erupted from the central Rotomahana craters, although a small amount appeared to have come from Black Crater (and possibly Inferno Crater) at Waimangu (see Fig. 2), during a late stage of the eruption. Conversely, Thomas (1888) thought the basalt near Black Crater had been deposited by directional explosions from the "Chasm" (Fig. 1) on the south-west end of Tarawera, and that the whole of the Rotomahana-Waimangu fissure had a purely hydrothermal eruptive origin. The RotomahanaWaimangu craters were considered to have been formed by explosive flashing of hydrothermal water to steam, as confining pressures were reduced by earthquakeinduced fissuring and the removal of erupted overlying material (Grange 1937), without any direct contribution of extra heat from magmatic sources. However, the fissure at Rotomahana extended well beyond the area of previous surface hydrothermal activity to cut unaltered rock, and the clear independence of crater location from surface topography (craters having formed at the tops of hills as well as in valley floors) showed that location of the fissure was determined at considerable depth. Park (1911) was alone in considering that "a considerable proportion of andesite dust and scoriae" had been erupted from Rotomahana and Black Craters.

Although the mud at Te Wairoa had fallen cold and wet, the deposits near Rotomahana were hot and dry, composed of a mixture of coarse and fine sand mixed with fragments of "trachytic stone" and finely broken sinter (Smith 1886b). Ash at $0.6 \mathrm{~m}$ depth was warm, and at $1.2 \mathrm{~m}$ was "quite hot", six days after the eruption. It appeared to have been deposited in a dry state, although occasional mud patches (presumably from lakefloor sediments) were encountered. In many places, partially buried trees were burning (Hector 1886). The deposit had a very sharply delineated south-west boundary at Okaro and formed a "smooth sheet of grey ash" (Park 1911), although this quickly became deeply furrowed by rain which turned the ash into almost impassable mud.

None of the early investigators described any bedding structures in the Rotomahana ejecta.

The Rotomahana craters quickly filled with water, initially forming two separate lakes which later coalesced and steadily rose to reach $342 \mathrm{~m}$ above sea level in 1972 (Healy 1975). Lake bathymetry (from Irwin in press) is shown in Fig. 2, which also delineates the major explosion craters. The largest is the 125 -m-deep Great Crater Basin, with smaller craters at Rotomakariri and Banded Island Basins. Present crater depths have been lessened by sedimentation within the lake. Small explosion craters on the lake shore, not defined by bathymetry, are also marked.

\section{ROTOMAHANA EJECTA}

\section{Sedimentary Structures}

Good exposures of near-source Rotomahana ejecta are now largely restricted to cliffs around the shore of Lake Rotomahana and to cuts for new forestry roads in the Hapeotoroa area west of the lake. The deposits invariably display internal bed forms characteristic of base surge transport mechanisms. Low-angle cross-bedding, pinch and swell structures, wave-like forms including apparent antidunes and small "chute and pool" structures (e.g., Crowe \& Fisher 1973; Schmincke et al. 1973), and sinusoidal undulations are exposed in ejecta sections up to $20 \mathrm{~m}$ thick on the eastern and southern shores. These features can be traced at least $4 \mathrm{~km}$ west of the lake into the Wairua Stream valley. Because of the compact nature and relatively large silt and clay size fraction in the ejecta, bed forms are not well expressed and are most apparent on cut faces which have weathered for some months.

While many explosions occurred from multiple vents spread over the $9 \mathrm{~km}$ of fissure at RotomahanaWaimangu, most of the flow directions which can be inferred from cross-bedding are consistent with a major base surge source at Great Crater and a lesser source at 


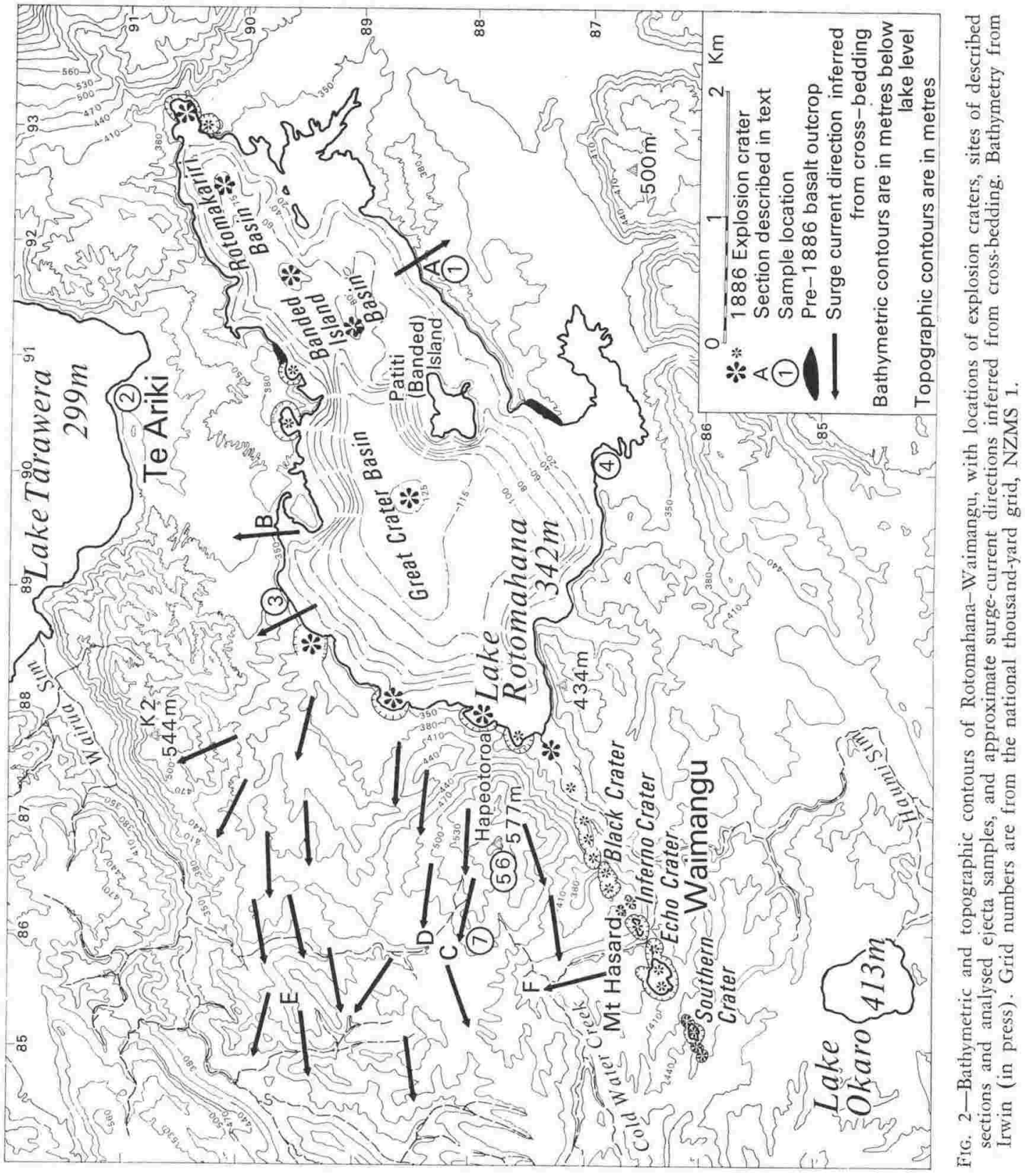


Banded Island Crater (Fig, 2). In some places, the surge currents appear slightly diverted by local topography. Some small surges from the Waimangu craters are also recorded in adjacent exposures.

Cliff sections around Lake Rotomahana are usually oriented tangentially to inferred outward surge current directions. At a section on the south shore of Lake Rotomahana, $0.5 \mathrm{~km}$ south-east of Banded Island Crater (site A, Fig. 2), $10 \mathrm{~m}$ of exposed Rotomahana ejecta comprises multi-layered, moderately compact grey-brown breccia with common low-angle cross-bedding (Fig. 3). The breccia contains scoriaceous basalt lapilli and rare blocks (essential), lapilli and blocks of both altered and fresh accessory rhyolite, ignimbrite, and siltstone, all matrix-supported in poorly sorted fine-coarse ash. (Grain-size data for a bed from this section are reported in Figs 8 and 9, and Table 1, below.) The broad shallow troughs eroded into underlying beds are interpreted as low-angle scour channels cut by current erosion as outward surges passed over previously deposited layers. Such erosional features are common in base surge deposits near crater rims (Fisher \& Waters 1970; Fisher 1977). Rhyolite blocks up to and exceeding $1 \mathrm{~m}$ in diameter are only occasionally exposed in the lake-shore cliffs, but are concentrated on the beaches at the foot of the cliffs. Impact sags in the Rotomahana ejecta are rare, which suggests that most blocks were carried in by surge flows rather than emplaced as ballistic ejecta.

On the north shore of Lake Rotomahana, $1 \mathrm{~km}$ north of Great Crater (site B, Fig. 2), excavation of a lakelevel control outlet channel exposed the upper $5 \mathrm{~m}$ of Rotomahana ejecta as finely bedded, near symmetrically undulating, sinusoidal wave-like bed forms (Fig. 4). Thickness of Rotomahana ejecta at this site is unknown, but probably exceeds $20 \mathrm{~m}$. The undulating bed forms exposed in the uppermost $5 \mathrm{~m}$ are most unlikely to reflect underlying topography, and thus result from depositional processes occurring during the eruption.

Rotomahana ejecta thins rapidly away from the lake into the intensively roaded Hapeotoroa-Wairua area, but base surge bed forms can be traced over a $230 \mathrm{~m}$ altitude range from lake level to the summits of Hapeotoroa and $\mathrm{K} 2$ hills, which reach at least $350 \mathrm{~m}$ above the original floor of Great Crater. Surge-bedded ejecta completely mantles the entire Hapeotoroa dome and extends $4 \mathrm{~km}$ over dissected country to the west; amplitude of bed forms and the grain size of ejecta tend to decrease with distance from source and elevation above lake. The ejecta mantle thickens on the crater-facing sides of low hills and ridges and thins over ridge crests onto lee slopes.

Curving road cuts in the Hapeotoroa area dissect bedding structures at varying orientations. Commonly, the best developed apparent antidune forms (e.g., Figs 5, 6) are exposed on cut faces which parallel radially outward flow directions from Great Crater. Where adjacent road cuts curve from radial to tangential orientation, antidune forms are replaced by undulating pinch and swell crossbeds (e.g., Fig. 7) with internal laminae tangentially approaching upper and lower contacts.

Fig. 6 shows multiple, overriding surge deposits forming a 3-m-thick "climbing antidune" stack deposited on the crater-facing slopes of a small ridge at site C, Fig. 2. The cross-bedded layers overlie a basal, apparent airfall massive layer containing small $(<5 \mathrm{~mm})$ accretionary
FIG. 3-Lake-shore cliff section at site A, Fig. 2. Entire $10 \mathrm{~m}$ exposure comprises 1886 Rotomahana ejecta. Note broad shallow troughs $(1.5 \mathrm{~m}$ above spade) which cut underlying beds, and which are infilled by non-mantling planar beds. Inferred outward flow direction from behind and slightly to right of camera.

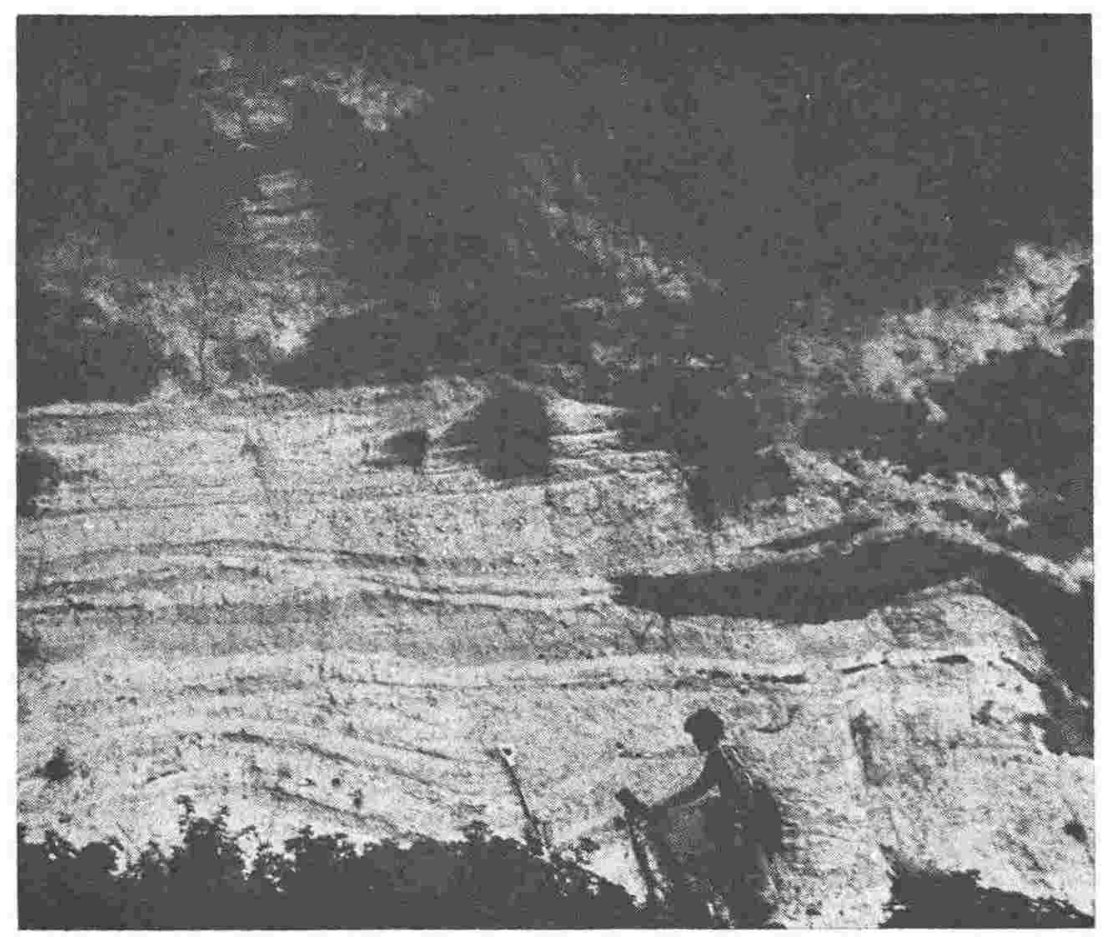



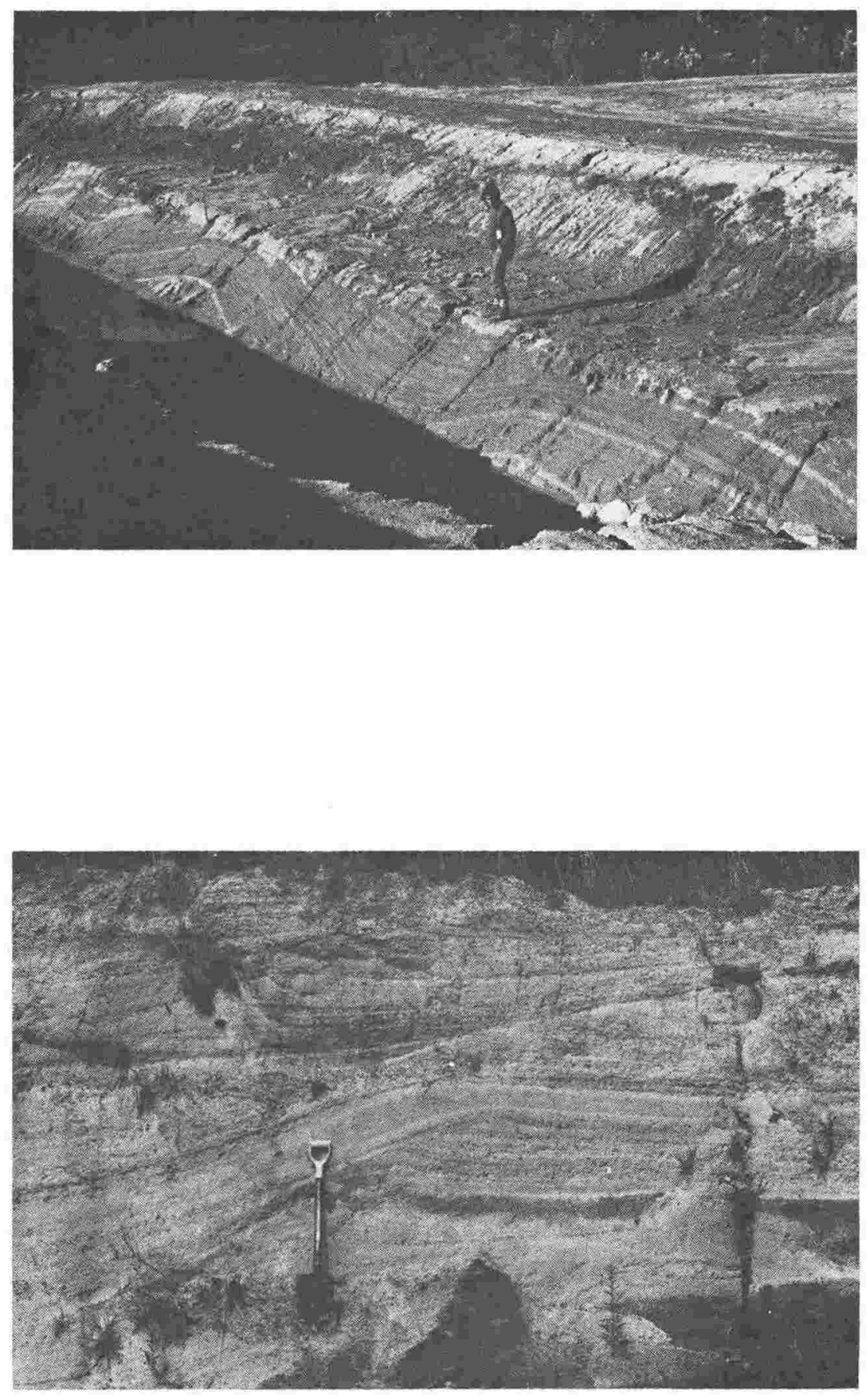

FIG, 4-Sinusoidal wave forms in Rotomahana ejecta, exposed by lakelevel control outlet channel (site B, Fig. 2). Finely laminated waves have amplitudes c. $1 \mathrm{~m}$, wavelengths of $13-15 \mathrm{~m}$. Continuous laminations thin over crests and thicken into troughs. Inferred outward flow direction is sub-parallel to channel, right to left.

Fig. 5-Apparent antidune form in Rotomahana ejecta at $4.7 \mathrm{~km}$ west of Great Crater (site E, Fig. 2) in subradially oriented section. Low-angle lee slopes in core (to right of spade) are mantled by continuous stoss - and - lee - side beds, with up-current advancing wave crest. Flow direction left to right. Basalt scoria and accretionary lapilli, some with scoria nuclei, are incorporated in the beds. 
Fig. 6-Multiple apparent antidune forms in Rotomahana ejecta at site $\mathrm{C}$, Fig. 2, $3.7 \mathrm{~km}$ west and $260 \mathrm{~m}$ above Great Crater. Pre-eruption glound surface is marked by spaded dark (carbonaceous) layer behind the geologist. Thick cross-bedded forms tail out into thinner planar beds which sweep over a buried ridge crest. Inferred flow direction is sub-parallel to section, from left to right.

FIG. 7-Rotomahana ejecta at site D, Fig. 2. Section is oriented roughly perpendicular to that in Fig. 6. Large-scale pinch and swell structures contain internal low angle crossbedding with truncation of upper surfaces. Inferred flow direction shown by anrow.
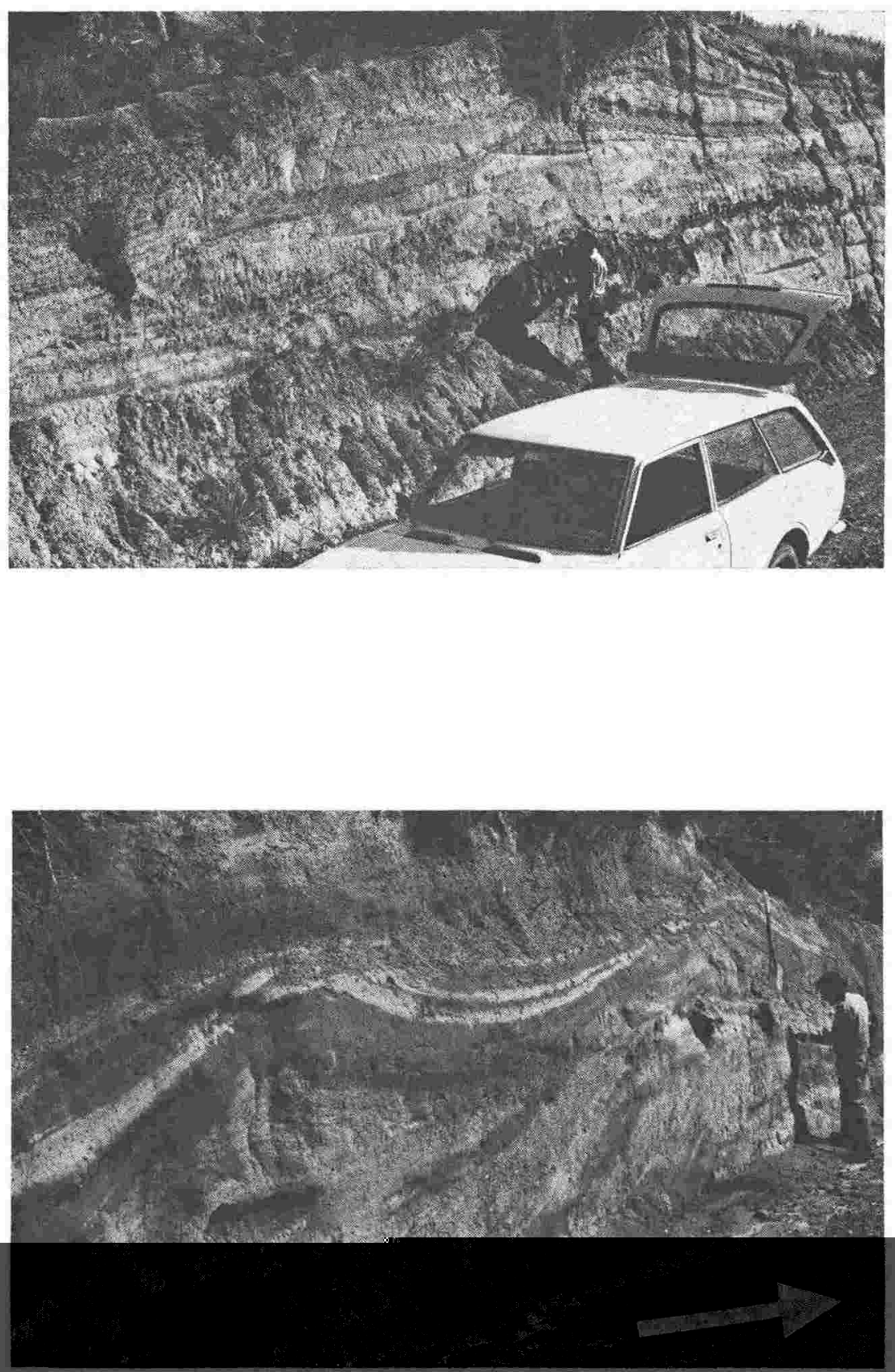
lapilli. To reach this location, the surge currents passed over the summit and flanks of Hapeotoroa, flowed $c$. $1 \mathrm{~km}$ across its western slopes and $100 \mathrm{~m}$ across an alluvial flat, before encountering the low ridge against which the surges piled up. Assuming that each bedding set represents the products of a single base surge (Crowe \& Fisher 1973), at least 7 separate surges are recorded by the strongly cross-bedded antidune forms at this location.

One hundred metres to the north (site D, Fig. 2), a road cut oriented nearly perpendicular to the above section is aligned roughly tangential to surge direction (Fig. 7). Undulating pinch and swell structures are well defined by concentrations of basalt lapilli at upper and lower surfaces; the lapilli is often armoured by compacted fine ash layers.

Although exposure is poor, cross-laminated primary bed forms also occur at the site of Te Ariki Village, $1.5 \mathrm{~km}$ north of the Rotomahana craters. The village was undoubtedly buried under surge flows.

Surface dunes with wave amplitudes of $1 \mathrm{~m}$ and wavelengths of up to $19 \mathrm{~m}$ were formed by the 1965 Taal eruptions (Moore et al. 1966; Moore 1967) and are common in other base surge deposits. Although not described by early Rotomahana investigators, weakly developed apparent surface dunes are recorded on some post-eruption 1886 photographs of the Rotomahana area. Erosion and vegetation now obliterate any cxisting surface dunes, but crude dunes with amplitudes of about $0.5 \mathrm{~m}$ and wavelengths of $5-10 \mathrm{~m}$ are preserved beneath the younger "Black Crater basalt" at Waimangu (site F, Fig. 2). The Rotomahana ejecta here is $1-1.5 \mathrm{~m}$ thick and lies on a fairly regular sub-planar basal contact. The duned surface is formed by internal bedding structuresmostly antidunes-in the Rotomahana ejecta.

\section{Grain Size Distribution}

Size distribution data are shown in Figs 8, 9, and 10, and statistical data in Table 1. (Samples were wet sieved, breaking down any rare accretionary lapilli and other aggregates that may have been present.) Sample 1, from surge beds near source on the south-east shore of Lake Rotomahana (site A, Fig. 2), is the overall coarsest sample analysed, belonging to the "gS" (granular, medium to coarse sand) textural class of Folk (1974). It has a strong mode about $0 \phi(1.00 \mathrm{~mm})$, with two-thirds of the sample between -2 and $2 \phi(4-0.25 \mathrm{~mm})$, and contains almost no clay-size material. Sample 2 from the upper Rotomahana ejecta at Te Ariki, $1.5 \mathrm{~km}$ north of the Rotomahana craters, has a similarly coarse graphic mean, but contains more silt and clay, a minor secondary mode appearing at $7-8 \phi \quad(0.008-0.004 \mathrm{~mm})$. The sample falls into the muddy sandy gravel textural class. Although the two samples cannot be directly compared as they undoubtedly come from different surges, the strongly fine-skewed Te Ariki sample is consistent with the downwind, more distant location. Samples 3 and 4 are also from lake shore sections and have more fines, possibly deposited from lower energy currents. The content of granule-sized and larger material $(>2 \mathrm{~mm})$, representing maximum size of transported ejecta, is thought to be a good indication of surge energy.

Samples 5 and 6 were collected from surge deposits on Hapeotoroa summit (see Fig. 2), and sample 7 from the foot of the dome; respectively 2.8 and $3.5 \mathrm{~km}$ west of Great Crater Basin, and 340 and $270 \mathrm{~m}$ above the crater floor. The nearer source but higher altitude samples contain more fines, suggesting that altitude was a more important control on surge load than distance from source, Both high altitude samples are considerably finer

TABLE 1-Grain size parameters of Rotomahana ejecta (see Fig. 2 for sample locations).

\begin{tabular}{|c|c|c|c|c|c|c|c|c|c|}
\hline $\begin{array}{l}\text { Sample } \\
\text { No. }\end{array}$ & Location & Description & $\begin{array}{l}\text { Median } \\
\text { Nia } \varnothing\end{array}$ & $\mathbb{M}_{z}($ Folk $)$ & $\begin{array}{l}\text { Std. Dev. } \\
\text { OI(Folk) }\end{array}$ & oI (Inman) & $\begin{array}{l}\text { Skewness } \\
\text { SkI (Folk) }\end{array}$ & $\begin{array}{l}\text { Kurtogia } \\
\mathrm{Kg}(\mathrm{Folk})\end{array}$ & $\begin{array}{l}\text { Textural } \\
\text { Class }\end{array}$ \\
\hline 1 & $\begin{array}{l}\text { S.E. Shore } \\
\text { Lake } \\
\text { Rotomahana }\end{array}$ & $\begin{array}{l}\text { near source deposit, } \\
\text { U-shaped channels }\end{array}$ & 0.4 & 0.4 & $\begin{array}{l}2.06 \\
\text { very poorly }\end{array}$ & y sorted & $\begin{array}{l}+0.08 \\
\text { near } \\
\text { symmetrical }\end{array}$ & ${ }^{1.02}$ & $\begin{array}{l}\text { Gravelly } \\
\text { sand }\end{array}$ \\
\hline 2 & Te Ariki & $\begin{array}{l}\text { lowest altitude } \\
\text { sample, weakly } \\
\text { cross-bedded }\end{array}$ & 0.0 & 0.5 & $\begin{array}{l}2,81 \\
\text { very poorly }\end{array}$ & $\begin{array}{r}2.45 \\
\text { y sorted }\end{array}$ & $\begin{array}{l}\quad+0.405 \\
\text { strongly } \\
\text { fine skewed }\end{array}$ & $\begin{array}{c}1.344 \\
\text { 1eptokurtic }\end{array}$ & $\begin{array}{l}\text { Muddy } \\
\text { sandy } \\
\text { gravel. }\end{array}$ \\
\hline 3 & $\begin{array}{l}\text { N.W. shore } \\
\text { Iake } \\
\text { Rotomahana }\end{array}$ & $\begin{array}{l}\text { antidune bed forms } \\
\text { (radial section) }\end{array}$ & 1.0 & 1.87 & $\begin{array}{l}3.72 \\
\text { very poorly }\end{array}$ & $\begin{array}{c}3.5 \\
y \text { sorted }\end{array}$ & $\begin{array}{l}\quad 0.416 \\
\text { strongly } \\
\text { fine skewed }\end{array}$ & $\begin{array}{l}1.522 \\
\text { very } \\
\text { leptokurtic }\end{array}$ & $\begin{array}{l}\text { Grave } 11 y \\
\text { muddy } \\
\text { sand. }\end{array}$ \\
\hline 4 & $\begin{array}{l}\text { S. shore } \\
\text { Iake. } \\
\text { Rotomahana }\end{array}$ & $\begin{array}{l}\text { U-shaped } \\
\text { channels }\end{array}$ & 1.7 & 1.9 & $\begin{array}{l}3.42 \\
\text { very poorly }\end{array}$ & y sorted & $\begin{array}{c}0.188 \\
\text { fine skewed }\end{array}$ & $\begin{array}{l}1.17 \\
\text { leptokurtio }\end{array}$ & $\begin{array}{l}\text { Grave } 11 \mathrm{y} \\
\text { muddy } \\
\text { sand }\end{array}$ \\
\hline 5 & $\begin{array}{l}\text { Summit } \\
\text { area } \\
\text { Hapeotoroa }\end{array}$ & $\begin{array}{l}\text { bed in antidune } \\
\text { form }\end{array}$ & 3.0 & 3.62 & $\begin{array}{l}\quad 4.14 \\
\text { extremely p } \\
\text { sorted }\end{array}$ & $\begin{array}{l}4.1 \\
\text { poorly }\end{array}$ & $\begin{array}{c}0.298 \\
\text { fine skewed }\end{array}$ & $\frac{0.96}{\text { mesokuxtic }}$ & $\begin{array}{l}\text { Gravelly } \\
\text { muddy } \\
\text { sand }\end{array}$ \\
\hline 6 & $\begin{array}{l}\text { Sumit } \\
\text { area } \\
\text { Hapeotoroa }\end{array}$ & $\begin{array}{l}\text { bed in antidune } \\
\text { form }\end{array}$ & 2.8 & 3.41 & $\begin{array}{l}3.76 \\
\text { very poorly }\end{array}$ & $\begin{array}{r}3.73 \\
\text { y sorted }\end{array}$ & $\begin{array}{l}0.306 \\
\text { strongly } \\
\text { fine skewed }\end{array}$ & $\begin{array}{l}0.98 \\
\text { mesokurtic }\end{array}$ & $\begin{array}{l}\text { Grave } 17 \mathrm{y} \\
\text { muday } \\
\text { sand. }\end{array}$ \\
\hline 7 & $\begin{array}{l}\text { Foot of } \\
\text { Hapeotoroa }\end{array}$ & $\begin{array}{l}\text { bed in antidune } \\
\text { form, distal. } \\
\text { section. }\end{array}$ & 1.6 & 2.33 & $\begin{array}{l}3.50 \\
\text { very poorly }\end{array}$ & $\begin{array}{c}3.4 \\
y \text { sorted }\end{array}$ & $\begin{array}{l}0.36 \\
\text { strongly } \\
\text { fine skewed }\end{array}$ & $\begin{array}{c}1.25 \\
\text { Ieptokurtic }\end{array}$ & $\begin{array}{l}\text { Graveliy } \\
\text { muday } \\
\text { sand }\end{array}$ \\
\hline 8 & $\begin{array}{l}\text { Te Wairoa } \\
\text { (see Fig. 1) }\end{array}$ & airfall deposit & 3.8 & 2.65 & $\begin{array}{l}4.81 \\
\text { extremely p } \\
\text { sorted }\end{array}$ & ${ }^{4.93}$ & $\begin{array}{l}-0.22 \\
\text { coarse } \\
\text { skewed }\end{array}$ & $\begin{array}{l}0.98 \\
\text { mesolkurtic }\end{array}$ & $\begin{array}{l}\text { Grave } 11 y \\
\text { mud }\end{array}$ \\
\hline
\end{tabular}


FIG, 8-Size-distribution curves for Rotomahana ejecta. Samples numbered as in Table 1.
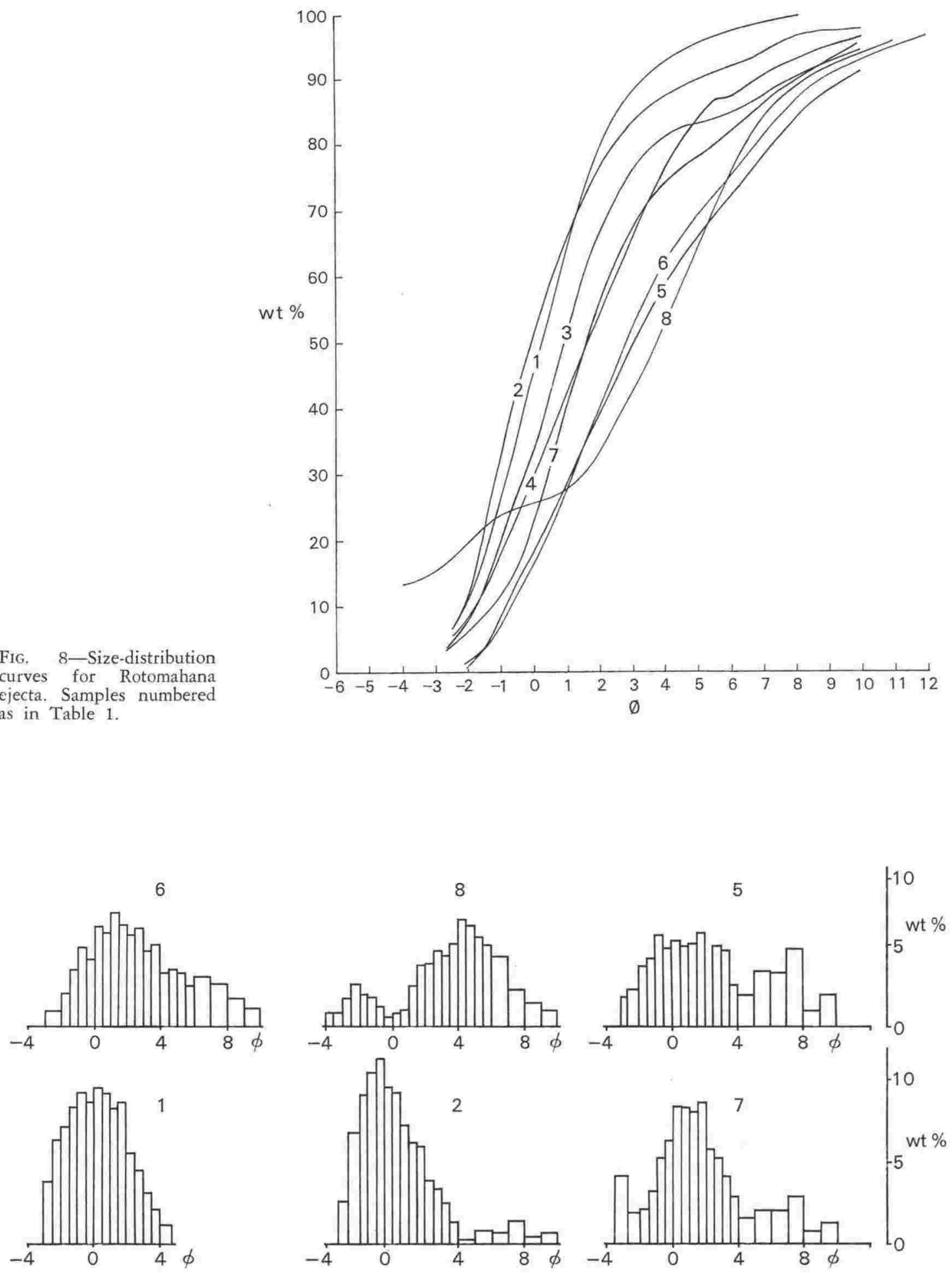

FIG. 9-Histograms of typical Rotomahana ejecta. Samples numbered as in Table 1. 
overall than those from the lake-shore deposits and are more strongly bimodal (Fig. 9).

Al] the surge: samples are very poorly sorted or extremely poorly sorted, reflecting the turbulent flow mechanism transporting all grades of ejecta. All except the near-source sample 1 are fine skewed or strongly fine skewed. This, and the bimodal nature of the more distant samples, reflects the dual origin of the Rotomahana ejecta-the larger particles dominantly from the explosion-fragmented country rock, plus a component of basalt scoria from Tarawera (and Rotomahana?), with fines derived from pre-existing lake-floor silts and hydrothermal clays. However, this initial size distribution must have been strongly modified by sorting processes during eruption, with fines preferentially concentrated into the vertical eruption column and also carried by surges to more distal sections.

The airfall deposit at Te Wairoa (sample 8) is extremely poorly sorted and strongly bimodal with peaks at $4-5 \phi(0.063-0.031 \mathrm{~mm})$, and coarser than $-2 \phi$ $(>4 \mathrm{~mm})$. Both parameters are strongly influenced by a relatively bigh concentration of basalt lapilli, erupted directly from Tarawera and falling at the same time as the mud. The Rotomahana ejecta component at Te Wairoa is of generally finer size grade than the nearersource surge deposits.

Median diameter $(\mathrm{Md} \phi)$ versus Inman sorting $\mathrm{co}$ efficient $\left(\theta_{I}\right)$ for the Rotomahana samples is plotted on Walker's (1971) pyroclastic flow and fallout diagram in Fig. 10. The coarsest Rotomahana sample plots within the overlap between flow and fall deposits, but finer samples plot within or beyond the flow field. The Rotomahana ejecta differs in this respect from other crossbedded surge deposits which are commonly better sorted (i.e., Crowe \& Fisher 1973), but resembles the massive, medium- to fine-grained beds described by Schmincke et al. (1973).

\section{Sand and Gravel Size Fraction}

Gravel fractions of near-source Rotomahana samples typically contain up to $30 \%$ sub-rounded, moderate to poorly vesicular, basaltic scoria. The remainder largely consist of angular to sub-rounded accessory fragments of glassy pumiceous and spheroidal rhyolite and tuff, containing common plagioclase and biotite phenocrysts. Some accessory fragments show incipient hydrotherm 31 alteration in thin section, with minor infilling of vesicles and veins by secondary quartz, and some replacement of biotite, hornblende, and plagioclase by chlorite and illitic clays (P. R. L. Browne pers. comm.). Other fragments are completely fresh without alteration of glass, plagioclase, or ferromagnesian minerals. Rhyolite glass is highly susceptible to hydrothermal alteration (Browne 1973); biotite (and other ferromagnesian minerals) and feldspars alter at progressively higher temperatures. Typically, these minerals are completely replaced in drill cores from hot zones of geothermal fields and in the intensely altered hydrothermal explosion breccias common in New Zealand geothermal fields.

Sand fractions consist of abundant plagioclase and quartz crystals, finely vesicular pumiceous rhyolite fragments, and black basaltic scoria. Minor components include biotite flakes and titanomagnetite grains, with very minor hornblende and hypersthene phenocrysts. Only a small proportion of hydrothermally altered fragments occur as discoloured (originally clear) glass, red-coated pumice fragments, and occasional pyrite cubes. Some biotite and feldspar crystals are replaced by chlorite. However, as with the gravel fraction, most sand fraction particles are not strongly altered, indicating that much source rock cannot have been previously incorporated in the highly active Rotomahana hydrothermal field.

\section{Clay Size Fraction}

"Rotomahana Mud" analyses are reported by N.Z. Soil Bureau (1968) and Kirkman (1976), from a site at

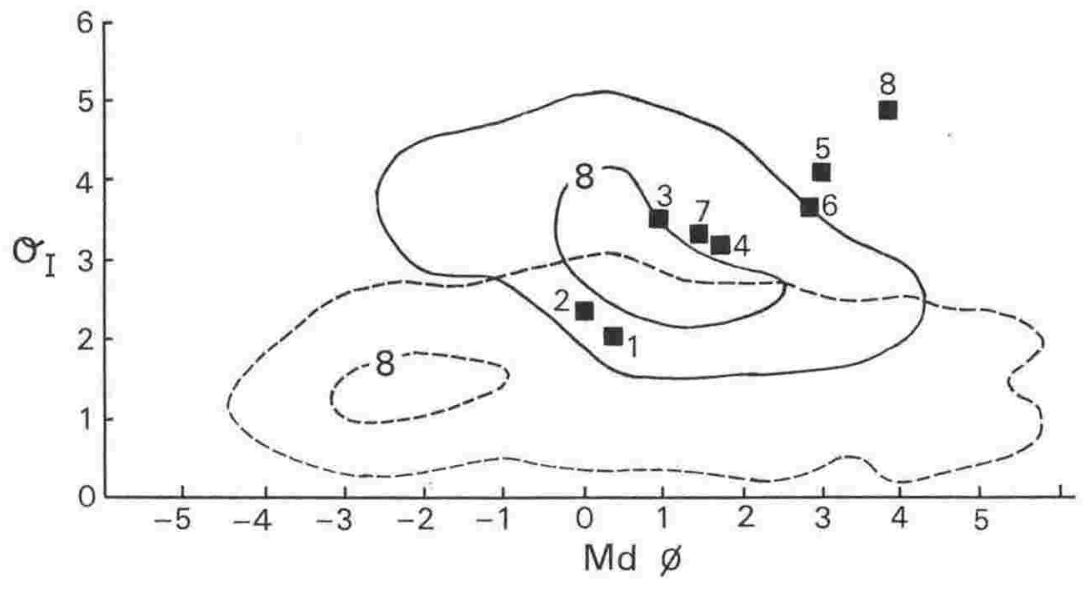

FIG. $\quad 10-$ Kotomahana ejecta samples (numbered as in Table 1) plotted on Walker's (1971) sorting $\left(\theta_{\mathrm{I}}\right.$ versus median diameter $(\mathrm{Md} \phi))$ diagram. Dashed lines enclose Walker's pyroclastic flow field, solid lines the pyroclastic fall field. Contour lines designated with " 8 " enclose greatest density of Walker's flow and fall samples. 
Waimangu Road (N85/845863)* [U16/060188], 5 km west-south-west of Great Crater Basin. Clay made up about $12 \%$ of the $A$ and $C$ soil horizons, with allophane $(56-26 \%)$, kaolin $(10-18 \%)$, illite $(14-24 \%)$, and montmorillonite $(20-32 \%)$ reported by N.Z. Soil Bureau. Kirkman also reported some vermiculite and mordenite. Allophane is the first pedogenic weathering product of rhyolite glass (Fieldes 1955), but mordenite, illite, kaolin, and montmorillonite are formed by hydrothermal alteration of rhyolitic volcanic rocks (Steiner 1968; Browne 1973), and originated from the preeruption hydrothermal activity at Rotomahana, with a possible contribution from weathered lake-floor sediments. It is clear that the hydrothermal field and lake floors provided a major source of silt and clay size ejecta during the eruption, producing the unusual physical properties of the Rotomahana ejecta.

\section{Basalts at Rotomahana-Watmangu}

\section{"Black Crater Basalt"}

Soil surveys have mapped 320 ha of "Haumi hill soils" west of Black Crater (Vucetich \& Wells 1978). The soils are gravelly sands consisting of interbedded basalt lapilli and rhyolitic ash layers, overlying "Rotomahana Mud". The "Haumi lapilli and ash" was considered to have been erupted from Black Crater during the terminating phase of the 1886 eruption, and is equivalent to the informal name "Black Crater basalt", in common usage for this deposit.

New road cuts in the "Cold Water Creek" area north of Waimangu (site F, Fig. 2) now expose "Black Crater basalt" as $1-2 \mathrm{~m}$ of well-stratified block, lapilli, and ash beds, overlying Rotomahana ejecta and passing upward into hydrothermally altered ejecta from the 1917 Frying Pan Flat eruption (Cole \& Nairn 1975). The "Black Crater basalt" here includes many large Rangitaiki Ignimbrite accessory blocks; rare lithic rhyolite blocks form a minor component. The accessory content shows that the basalt at "Cold Water Creek" was largely erupted from Echo Crater, $500 \mathrm{~m}$ to the south. Echo Crater is underlain by Rangitaiki Ignimbrite (Lloyd \& Keam 1974) and is mantled by unwelded pyroclastic flow deposits of the Earthquake Flat Breccia. In contrast, the 1-2-m-thick "Black Crater basalt", which mantles the southern slopes of Hapeotoroa (N85/ 867876) [U16/080199] $1 \mathrm{~km}$ to the north-west of "Cold Water Creek", contains pumiceous glassy quartz-biotite rhyolite accessory blocks, but no ignimbrite. This basalt was clearly erupted from Black Crater and the three unnamed craters to the east which cut rhyolite lavas of "Mt Hasard" dome and the south-eastern flank of Hapeotoroa dome.

\footnotetext{
* Grid references are based on the national thousand-yard grid of the 1:63 360 topographical map series (NZMS 1). These are followed by the equivalent grid references (in square brackets) based on the thousand-metre grid of the 1:50000 series (NZMS 260).
}

Basalt is not present beneath the Rotomahana ejecta at Waimangu, which shows that scoria from the initial eruptions at Tarawera did not fall this far west. Lack of basalt concentrations within the Rotomahana ejecta strongly suggests that major eruption of basalt at Waimangu occurred only late in the eruption after the main explosions at Rotomahana (ejecta from the first Waimangu eruption at 0230 hours has been provisionally identified as silt-rich mud confined to the Waimangu area (C. G. Vucetich pers. comm.)).

"Black Crater basalt" is characterised by common inclusions of silicified fine-grained sediments, apparently derived from hydrothermal areas at Waimangu, and is distinguished from the Tarawera-erupted basalt which contains inclusions of fused glassy rhyolite (Cole 1970). Spectrographic analyses for 18 trace elements in Tarawera Ash and Lapilli (i.e., the 1886 basalt scoria) and "Haumi lapilli and ash" are reported by Vucetich \& Wells (1978). Apart from strontium and cobalt, the trace element contents are generally similar (Table 2 ) and indicate no significant chemical differences between the basalts from Tarawera and Waimangu. Major and trace element analyses (Table 2) also support this conclusion; minor variations in $\mathrm{Cr}, \mathrm{V}$, and $\mathrm{Zr}$ are presumably due to variable contamination by rhyolite and sediment inclusions.

The basalt at Cold Water Creek also displays surge bed forms indicating deposition from laterally moving flows, i.e., lack of impact sags associated with large blocks, imbricate textures, and infilling of troughs in the underlying ground surface.

\section{Basalts at Rotomahana}

Cliffs up to $30 \mathrm{~m}$ high on the northern shore of eastern Lake Rotomahana include more than $50 \%$ discrete basaltic scoria layers up to $0.5 \mathrm{~m}$ thick, containing many fresh rhyolite blocks and occasional charred logs. The scoria is interbedded with grey, fine-grained Rotomahana ejecta, but was clearly erupted from Tarawera, most probably from the "Chasm" and adjacent craters on the south-west end of the mountain. Some large rhyolite blocks occupy asymmetric impact sags, demonstrating a ballistic trajectory from Tarawera. Basalt layers thin west from Tarawera, and basalt blocks and discrete scoria beds become uncommon within the Rotomahana ejecta beyond $1 \mathrm{~km}$ from Tarawera. No discrete basalt lapilli beds are found on the western shore. This distribution confirms that the major basalt eruptive source was Tarawera. However, much basalt lapilli and ash is disseminated through the Rotomahana surge deposits; lapilli is often concentrated at contacts between surge beds and is particularly abundant in upper surge beds between Hapeotoroa and Wairua Stream. The source of this basalt cannot be positively identified, but at least some would have been erupted from Tarawera, to fall into the Rotomahana surges. The higher basalt content of upper surge beds near Wairua may be significant as these were presumably deposited late in the eruption when the wind had changed to south-west, reducing the proportion of Tarawera ejecta reaching the Wairua area. This suggests that some of this basalt may have been erupted from Rotomahana. 
TABLI 2-Major (wt \%) and trace element (ppm) analyses of 1886 Tarawera basalt and "Black Crater basalt".

\begin{tabular}{|c|c|c|c|c|c|c|c|c|c|c|c|c|c|c|c|c|c|c|}
\hline Sample & Name & $\mathrm{SiO}_{2}$ & & $\mathrm{TiO}_{2}$ & & $\mathrm{Al}_{2} \mathrm{O}_{3}$ & \multicolumn{2}{|c|}{$\mathrm{Fe}_{2} \mathrm{O}_{3}$} & Feo & Mino & & $\mathrm{MgO}$ & $\mathrm{CaO}$ & & $\mathrm{Na}_{2} \mathrm{O}$ & \multicolumn{2}{|c|}{$\mathrm{K}_{2} \mathrm{O}$} & $\mathrm{P}_{2} \mathrm{O}_{5}$ \\
\hline 1 & Tarawera basalt & 51.2 & 24 & 0.77 & & 17.28 & \multicolumn{2}{|c|}{5.25} & 4.32 & 0.15 & & 5.82 & \multicolumn{2}{|c|}{11.08} & 2.20 & \multicolumn{2}{|c|}{0.60} & 0.20 \\
\hline 2 & Tarawera basalt & $51: 2$ & 21 & 0.83 & & 17.07 & \multicolumn{3}{|c|}{$9.64 *$} & 0.18 & & 6.27 & 11.4 & & 2.57 & \multicolumn{2}{|c|}{0.55} & 0.14 \\
\hline \multirow[t]{2}{*}{3} & "Black Crater basalt" & 50. & .58 & 0.86 & & 17.18 & & \multicolumn{2}{|c|}{$10.76^{*}$} & 0.17 & & 6.13 & \multicolumn{2}{|c|}{11.59} & 2.23 & \multicolumn{2}{|c|}{0.53} & 0.15 \\
\hline & & & $\mathrm{Cr}$ & $\nabla$ & & $\mathrm{Zn}$ & $\mathrm{Cu}$ & $\mathrm{Ni}$ & $\$ x$ & $\mathrm{Zr}$ & & Th & $\mathrm{Rb}$ & $Y$ & & $\mathrm{Ba}$ & Co & \\
\hline 2 . & Tarawera baialt & & 55 & 256 & & & 25 & 14 & 308 & 82 & & & 18 & & & & 61 & \\
\hline 4 & Tarawera basalt & & & & & & & & 300 & & & 1.5 & 15 & & & & & \\
\hline \multirow[t]{2}{*}{3} & "Black Crater basalt". & & 18 & 189 & & 82 & 21 & 12 & 323 & 50 & & 1.9 & 15 & 1 & 8 & 198 & & \\
\hline & & Iit & $\mathrm{Rb}$ & $\mathrm{Cg}$ & $\mathrm{Cu}$ & $\mathrm{Be}$ & Sr & $\mathrm{Ba}$ & Ti & $2 x$ & $\mathrm{As}$ & $\mathrm{V}$ & $\mathrm{s}$ & $\mathrm{Cr}$ & Mo & $\mathrm{Mn}$ & & Ni. Se \\
\hline 5 & Tarawera Ash and Iapilil & 18 & 28 & $<30$ & 30 & 30 & 2000 & 300 & 10000 & $<100$ & 2 & 400 & 100 & 40 & $<1:$ & 3000 & $<5<$ & 《1 1.5 \\
\hline 6 & Haumi lapilli and ash & 20 & 13 & $<30$ & 30 & $<10$ & 800 & 400 & 10000 & 150 & - & 500 & 130 & 30 & 10 & 2000 & 60 & $2-$ \\
\hline
\end{tabular}

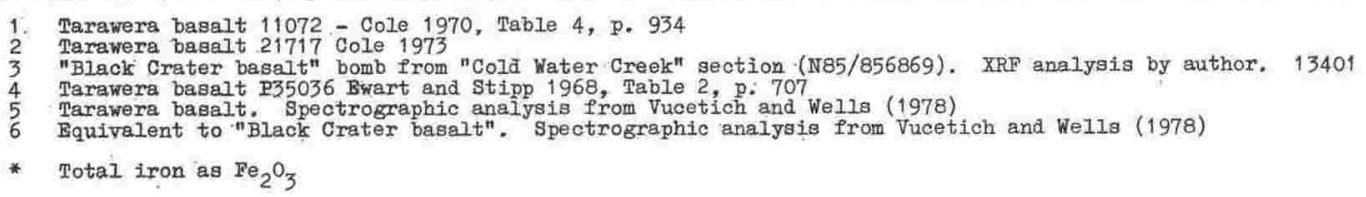

Some comparative scanning electron microscope studies have been made of basaltic scoria in the 100-200 $\mu \mathrm{m}$ size fractions of Rotomahana ejecta at Hapeotoroa and Wairua, and from aiffall Tarawera Ash and Lapilli at Kawerau, $20 \mathrm{~km}$ north-east of Tarawera. While a range of grain morphologies is found, scoria particles in Rotomahana ejecta are commonly irregularly shaped, bounded by relatively smooth, somewhat angular surfaces, and contain a moderate number of $5-20 \mu \mathrm{m}$ diameter vesicles (Fig. 11A). Tarawera Ash particles (Fig. 11B) tend to be more rounded, contain some larger and many finer vesicles, and have hackly surfaces formed of granular material. Although the morphological differences are not great, they are consistent (i.e., Walker \& Croasdale 1971; Heiken 1972) with more rapid chilling and fracturing of the Rotomahana scoria, possibly due to eruptive interaction with groundwater in the Rotomahana basin.

Occasional large blocks of basalt also occur at considerable distances from Tarawera. A $20 \times 15 \times 5 \mathrm{~cm}$ slaggy block found on the southern lake shore (N85/899869) [V16/110192] $5 \mathrm{~km}$ from the Tarawera "Chasm" is unlikely to have come directly from Tarawera and may have been erupted from Rotomahana. Alternatively, large blocks of Tarawera-erupted basalt may have been transported west by repeated eruptions from the Rotomahana craters, although this seems less likely.

\section{Older Scorias at Rotomabana}

Two small Late Pleistocene basic scoria deposits crop out at Rotomahana (see Fig. 2); the younger erupted through a rhyolite tuff cone now cut by the northern lake shore (N86/910897) [V16/121217], the scoria immediately following the rhyolite eruption. Some assimilation of rhyolite inclusions produced olivine "andesite" hybrids containing large corroded quartz xenocrysts, but other vesicular black scoria bombs contain only a few rhyolite inclusions. The scoria underlies a paleosol beneath the 20000 year B.P.-dated Kawakawa Tephra (Vucetich \& Howorth 1976). Older tephras ( $c$. 26-36000 years B.P.) are missing, indicating a scoria eruption age between 20000 and 26000 years B.P.

An older scoria deposit on the southern shore of Lake Rotomahana (N86/904875) [V16/115197] is interbedded with rhyolite pumiceous pyroclastics which underlie Rotoehu Ash and, therefore, predates 42000 years B.P. (Nairn \& Kohn 1973).

\section{Discussion and Conclusions}

\section{Generation of the Rotomabana Explosions}

Basalt was erupted from at least two Waimangu craters during the 1886 eruption. Older scorias erupted at Rotomahana demonstrate the long-continued existence of a major structural connection to a deep basic magma source (e.g., Cole 1973, p. 61-2). A continuous basalt dike appears likely to extend at depth from Tarawera under Rotomahana to Waimangu and to have contributed to the 1886 Rotomahana explosions. Park (1911) inferred that "andesite" ( = basalt) was erupted from the 1886 Rotomahana craters. Though this cannot now be directly confirmed, extension of the craters into areas where surface hydrothermal activity was unknown prior to the eruption, and more significantly, into areas of 

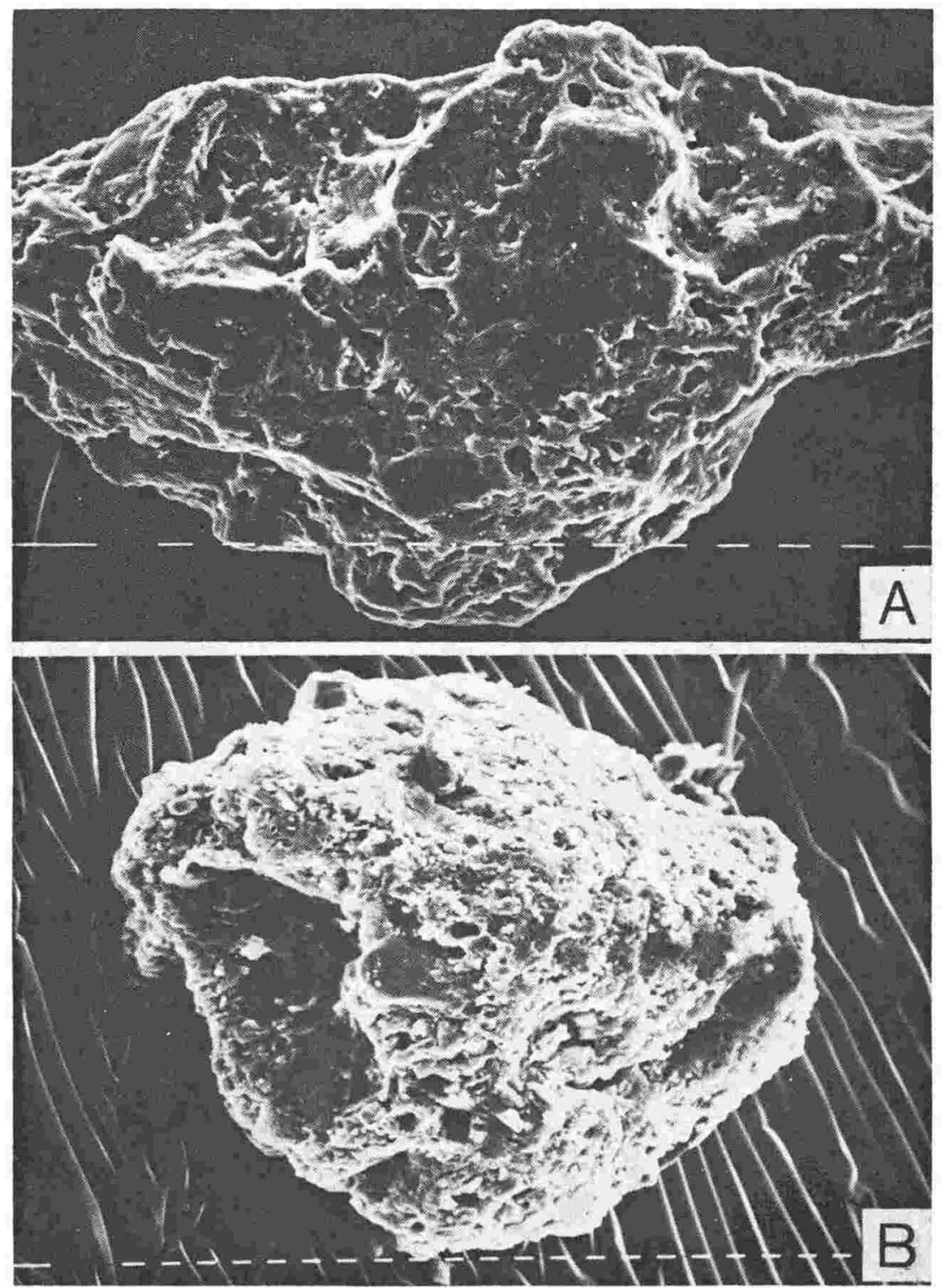

FIG. $\quad 11-A-$ Scanning electron micrograph of typical basaltic scoria fragment from Rotomahana ejecta at Wairua. Note smooth, apparently fractured, angular surfaces. B-Typical basaltic scoria fragment from 1886 Tarawera Ash at Kawerau. Note more rounded shape, wide range of vesicle sizes, and granular exterior surface.

Small white bars are $c$. $10 \mu \mathrm{m}$ in both $\mathrm{A}$ and $\mathrm{B}$. 
unaltered rock, would support a phreatomagmatic rather than purely hydrothermal origin for some of the explosions. At least the initial eruption energy could come from interaction between an intruding basalt dike and groundwaters. The dike need not have reached the surface and become explosive to have formed the craters, as shown by the eruption sequence at Waimangu where basalt was erupted only after the main crater-forming explosions had occurred.

Dike intrusion into water-saturated shallow strata would rapidly raise groundwater temperatures. Drillholes in liquid-dominated hydrothermal fields commonly encounter temperatures near boiling-point-for-depth, i.e., the hydrothermal fluid at depth is at or near boiling, temperatures rising with increasing depth and fluid pressure. This condition undoubtedly applied in the highly active Rotomahana field prior to the 1886 eruption. Rapid temperature rise above boiling at shallow depths would quickly induce steam pressures exceeding lithostatic load (Goguel 1956), and flashing to steam would occur causing large explosions. Removal of overburden by perhaps isolated initial phreatic explosions (as at Waimangu) would locally reduce pressures on the preexisting hydrothermal system, allowing flashing to steam and triggering large purely hydrothermal explosions. Flashing of hot groundwater in rock pores and fissures is an extremely effective comminution mechanism to contribute material to the high proportion of fines in the Rotomahana ejecta. Previously cold groundwater was also raised to flashing temperatures in areas of unaltered rock outside the pre-existing hydrothermal field.

\section{Eruption Mechanisms}

However generated, the steam explosions at Rotomahana formed an $c$. 11-km-high vertical eruption column, that expanded into a huge cloud from which fine ash fell beyond the Bay of Plenty coast, $60 \mathrm{~km}$ distant. The dominantly fine-grained Rotomahana ejecta, with more than $50 \%$ of $<1$-mm-diameter particles in the coarsest sample analysed (and more than $80 \%$ in more distant samples) promoted efficient heat transfer between solids and gases to drive the turbulently convecting column (cf. Wilson et al. 1978). Effective sorting preferentially carried fines upwards into the eruption cloud where condensation of steam promoted growth of accretionary lapilli.

Larger ejecta were transported laterally, either on divergent ballistic trajectories, or by falling back into the vents to be carried outward by base surges. Typical surge bed forms in the near-source Rotomahana ejecta demonstrate that classic base surges formed at the base of the tall eruption column. It is probable that both primary and secondary base surges were formed (Moore 1967). Energy of the larger Rotomahana explosions appears adequate to generate primary base surge by direct subhorizontal outward flow from the vents. Approximate explosion magnitudes are indicated by average eruption rate. The volume of the 1886 Rotomahana-Waimangu explosion craters, estimated from topography and bathymetry, is $5 \times 10^{8} \mathrm{~m}^{3}$, of which over $95 \%$ lies in Lake Rotomahana. The 130-minute eruption duration indicates an average solid volume eruption rate of $6 \times 10^{4} \mathrm{~m}^{3} \mathrm{~s}^{-1}$. The major detonations heard at considerable distances from Rotomahana will have accompanied large discrete explosions, during which instantaneous eruption rates must have considerably exceeded the average, probably by at least an order of magnitude. Hence, instantaneous eruption rates of between $10^{5}$ and $10^{6} \mathrm{~m}^{3} \mathrm{~s}^{-1}$ are indicated for the largest explosions, separated by periods of lesser emission.

Wilson et al. (1978) showed that heat exchange between magma and water in phreatomagmatic eruptions reduces the heat available to drive convecting plumes, unless condensation of steam occurs. Condensation releases latent heat of vapourisation, but also considerably reduces volume of the eruption column and substantially increases its density. The increasingly dense column collapses to form secondary base surges, as bulk subsidence converts to outward flow. At Rotomahana, even less heat was available to drive the plume because of the high proportion of country rock ejecta, at either cold or hydrothermal temperatures (probably $<300^{\circ} \mathrm{C}$, i.e., much less than magmatic). Column collapse is therefore very likely to have occurred at Rotomahana to produce secondary base surges.

Settle (1978) obtained from measurements on six magmatic eruptions the relation

$$
\Delta \mathrm{H}=0.117 \mathrm{M}^{0.22}
$$

where $\mathrm{H}$ is eruption column height $(\mathrm{km})$ and $\mathrm{M}$ is pyroclastic mass flux $\left(\mathrm{gs}^{-1}\right)$. The equation indicates a $30 \mathrm{~km}$ column height for the $c .1 \times 10^{11} \mathrm{gs}^{-1}$ average mass flux at Rotomahana, much greater than the $10-13 \mathrm{~km}$ observed column height. The discrepancy is due to the much lower erupting temperature of the Rotomahana ejecta, plus the removal of much ejecta from the column by collapse. There is much closer agreement between observed column height and effective thermal flux. A column height of (say) $11 \mathrm{~km}$ is equivalent to $c$. $3 \times 10^{13} \mathrm{cals} \mathrm{s}^{-1}$ (Settle 1978). This thermal flux is obtained if the Rotomahana ejecta was erupted at an average temperature of about $300^{\circ} \mathrm{C}$.

By analogy with the similar Taal 1965 eruptions, the Rotomahana surges were multiple, steam-fluidised debris flows, which carried ejecta in hurricane-velocity $\left(>40 \mathrm{~ms}^{-1}\right)$, ground-hugging turbulent clouds. The surges passed over the summit of Hapeotoroa at $200 \mathrm{~m}$ above adjacent country and $360+\mathrm{m}$ above the main crater floor, to travel at least $6 \mathrm{~km}$ west of the largest eruptive source at Great Crater.

The Rotomahana surges were some of the most destructive manifestations of the 1886 Tarawera eruption. With Lake Rotomahana now much enlarged along $7 \mathrm{~km}$ of the Tarawera-Waimangu fissure, recurrence of similar eruption types is likely during future activity of the Tarawera Volcanic Complex.

\section{ACKNOWLEDGMENTS}

The writer thanks W. M. Crafar and B. J. Scott for assistance in the field; C. G. Vucetich, E. F. Lloyd, and R. F. Keam fo: valuable discussions; and J. W. Cole, C. P. Wood, and P. R. L. Browne for critically reading 
the manuscript. The Sedimentation Laboratory of N.Z. Geological Survey carried out some of the size analyses; figures were draughted by P. van der Werff; A. C. Sharp provided instruction in scanning electron microscopy.

\section{REFERENCES}

Browne, P. R. L. 1973: The geology, mineralogy, and geothermometry of the Broadlands Geothermal Field, Taupo Volcanic Zone, New Zealand. (Unpublished Ph.D. Thesis, lodged in the Library, Victoria University of Wellington.) $153 \mathrm{p}$.

Cole, J. W. 1970: Structure and eruptive history of the Tarawera Volcanic Complex. N.Z. Journal of Geo$\log y$ and Geopbysics 13: 879-902.

1973: High-alumina basalts of Taupo Volcanic Zone, New Zealand. Lithos 6: 53-64.

Cole, J. W.; NAIrn, I. A. 1975: "Catalogue of the active volcanoes of the world, including solfatara fields. Part XXII New Zealand." International Association of Volcanology and Chemistry of the Earth's Interior. Rome. $156 \mathrm{p}$.

Crowe, B. M; Fisher, R. V. 1973: Sedimentary structures in base surge deposits with special reference to cross-bedding, Ubehebe Craters, Death Valley, California. Geological Society of America Bulletin 84: 663-82.

EWART, A.; STIPP, J. J. 1968: Petrogenesis of the volcanic rocks of the Central North Island, New Zealand, as indicated by a study of $\mathrm{Sr}^{87} / \mathrm{Sr}^{80}$ ratios, and $\mathrm{Sr}, \mathrm{Rb}, \mathrm{K}, \mathrm{U}$, and $\mathrm{Th}$ abundances. Geochimica et Cosmocbimica Acta 32: 699-736.

Fieldes, M. 1955: Clay mineralogy of New Zealand soils, Part II: Allophane and related mineral colloids. N.Z. Journal of Science and Tecbnology 37 : $336-50$.

FISHER, R. V. 1977: Erosion by volcanic base surge density currents: U-shaped channels. Geological Society of America Bulletin 88: 1287-97.

Fisher, R. V.; Waters, A. C. 1970: Base surge bed forms in maar volcanoes. American Journal of Science 268: 157-80.

FOLK, R. L. 1974: "Petrology of sedimentary rocks." Hemphill Publishing Co., Austin, Texas. 182 p.

Goguel, J. 1956: Le Mécanisme des explosions phréatiques. Bureau Central Seismologique Inter. national Serie A, Travaux Scientifiques-Fascicule 19. (Memoirs presentés a l'assemblée de Rome, 1954).

Grange, L. I. 1937: The geology of the Rotorua-Taupo Subdivision. N.Z. Geological Survey Bulletin 37: $138 \mathrm{p}$.

Healy, J. 1975: Volcanic Lakes. Pp. 70-83 in Jolly, V. H,; Brown, J. M. A. (Eds) : "New Zealand Lakes". Oxford University Press.

Hector, J. 1886: Preliminary report on the recent volcanic eruptions, with appendix by Skey, W.; First report of analyses of dust from volcano at Tarawera. Appendices to the Journal of the House of Representatives (N.Z.), $\mathrm{H}-25$ : 1-6.

Heiken, G. 1972: Morphology and petrography of volcanic ashes. Geological Society of America Bulletin 83: 1961-8.
Hochstetter, F. voN, 1864: "Geologie von Neu Zealand." Vienna. (Translated by C. A. Fleming 1959). Government Printer, Wellington. 320 p.

Hutron, F. W. 1887: The eruption of Mount Tarawera. Quarterly Journal of The Geological Society of London 43: 178-89.

IRwIN, J. in press: Lake Rotomahana Bathymetry 1:11 880. N.Z. Oceanographic Institute Chart, Lake Series.

KiRKMAN, J. H. 1976: Clay mineralogy of Rotomahana sandy loam soil, North Island, New Zealand. N.Z. Journal of Geology and Geopbysics 19: 35-41.

LlOYD, E. F.; KEAM, R. F. 1974: Trinity Terrace hydrothermal eruption, Waimangu, New Zealand, N.Z. Journal of Science 17: 511-28.

MOORE, J. G. 1967: Base surge in recent volcanic eruptions. Bulletin Volcanologique 30: 337-63.

Moore, J. G.; Nakamura, K.; Alcaraz, A. 1966: The 1965 eruption of Taal Volcano. Science 151 (3713): $955-60$.

NAIRN, I. A.; KoHN, B. P. 1973: Relation of the Earthquake Flat Breccia to the Rotoiti Breccia, Central North Island, New Zealand. N.Z. Journal of Geology and Geopbysics 16: 269-79.

N.Z. Soll Bureau 1968: Soils of New Zealand. Part 3. N.Z. Soil Bureau Bulletin 26 (3). 127 p.

PARK, J. 1911: Tafawera eruption and after. Geograpbic Journal 37: 42-9.

Pullar, W. A. 1973: "Isopachs of tephra, Central North Island, New Zealand. Scale 1:1 000 000." N.Z. Soil Bureau Maps $133 / 1-7$, to accompany N.Z Soil Survey Report 31.

SCHMincke, H. U.; Fisher, R. V.; Waters, A. C. 1973: Antidune and chute and pool structures in the base surge deposits of the Laacher See area, Germany. Sedimentology 20: 553-74.

SETTLE, M. 1978: Volcanic eruption clouds and the thermal power output of explosive eruptions. Journal of Volcanology and Geothermal Research 3: 309-24.

Smith, S. P. 1886a: "The eruption of Tarawera: A report to the Surveyor General". Government Printer, Wellington. $84 \mathrm{p}$.

1886b: Preliminary report on the volcanic eruption at Tarawera. Appendix to the Journal of the House of Representatives (N.Z.), H-26: 1-4.

SteINer, A. 1968: Clay minerals in hydrothermally altered rocks at Wairakei, New Zealand. Clays and Clay Minerals 16: 193-213.

Thomas, A. P. W. 1888: "Report on the eruption of Tarawera and Rotomahana, N.Z.". Government Printer, Wellington. $74 \mathrm{p}$.

Vucetich, C. G.; Howorth, R. 1976: Proposed definition of the Kawakawa Tephra, the c. 20000 years B.P. marker horizon in the New Zealand region. N.Z. Journal of Geology and Geopbysics 19: 4350.

VuCETICH, C. G.; Welis, N. 1978: Soils, agriculture, and forestry of Waiotapu region, Central North Island, New Zealand (Guthrie, Waiotapu, Rerewhakaaitu, Atiamuri, and Reporoa districts). New Zealand Soil Bureau Bulletin 31. 100 p. 
WALKER, G. P. L. 1971: Grain-size characteristics of pyroclastic deposits. Journal of Geology 79: 696714.

WALKeR, G. P. L.; Croasdale, R. 1971: Characteristics of some basaltic pyroclastics. Bulletin Volcanologique 35 : 301-17.
WILSON, L.; SPARKS, R. S. J.; WATKINS, N. D.; HuANG, T. C. 1978: The control of volcanic column heights by eruption energetics and dynamics, Journal of Geopbysical Research 83: 1829-36. 
BASALT DIKES IN THE 1886 TARAWERA RIFT

I.A. Nairn* and J.W. Cole

Geology Dept., Victoria University of Wellington

\section{ABSTRACT}

Basalt intruded into Tarawera Rift during the 1886 emption occupies an en-echelon pattern of dike-filled emuptive fissures. The left-stepping pattern of dilation fractures is consistent with dextral/normal movement on an underlying, older, master fault which appears to have influenced location of the earlier rhyolite eruptive vents of Tarawera Volcanic Complex, and controlled the orientation of deep basaltic intrusions. Although the Tarawera Rift was previously regarded as a pure normal fault, the 1886 dike pattern provides further geological evidence for the occurrence of dextral shear in the Taupo Volcanic Zone.

\section{INTRODUCTION}

The 1886 June 10 basaltic scoria eruption of Tarawera (Cole 1970a, Cole and Nairn 1975) was preceded by an hour-long earthquake sequence of increasing felt intensity at Rotorua, $25 \mathrm{~km}$ to north-west. Eruption commenced at Wahanga Dome (Fig. 1) and over the next hour extended $8 \mathrm{~km}$ south-west across the rhyolite domes and flows of the Tarawera Volcanic Complex. Phreatic explosions followed at Waimangu and Rotomahana. Sharp earthquakes accompanied the eruptions, which had a total duration of about 4 hours.

The emution formed a $17 \mathrm{~km}$ long series of separate and coalescing explosion craters - the "Tarawera Rift" (Fig. 1). Basalt was emupted from at least Echo Crater and Black Crater at Waimangu (Nairn 1979), probably also from some Rotomahana craters, and from all Tarawera craters (with the possible

\footnotetext{
*Present address: N.Z. Geological Survey, D.S.I.R., P.0. Box 499, Rotorua
} 


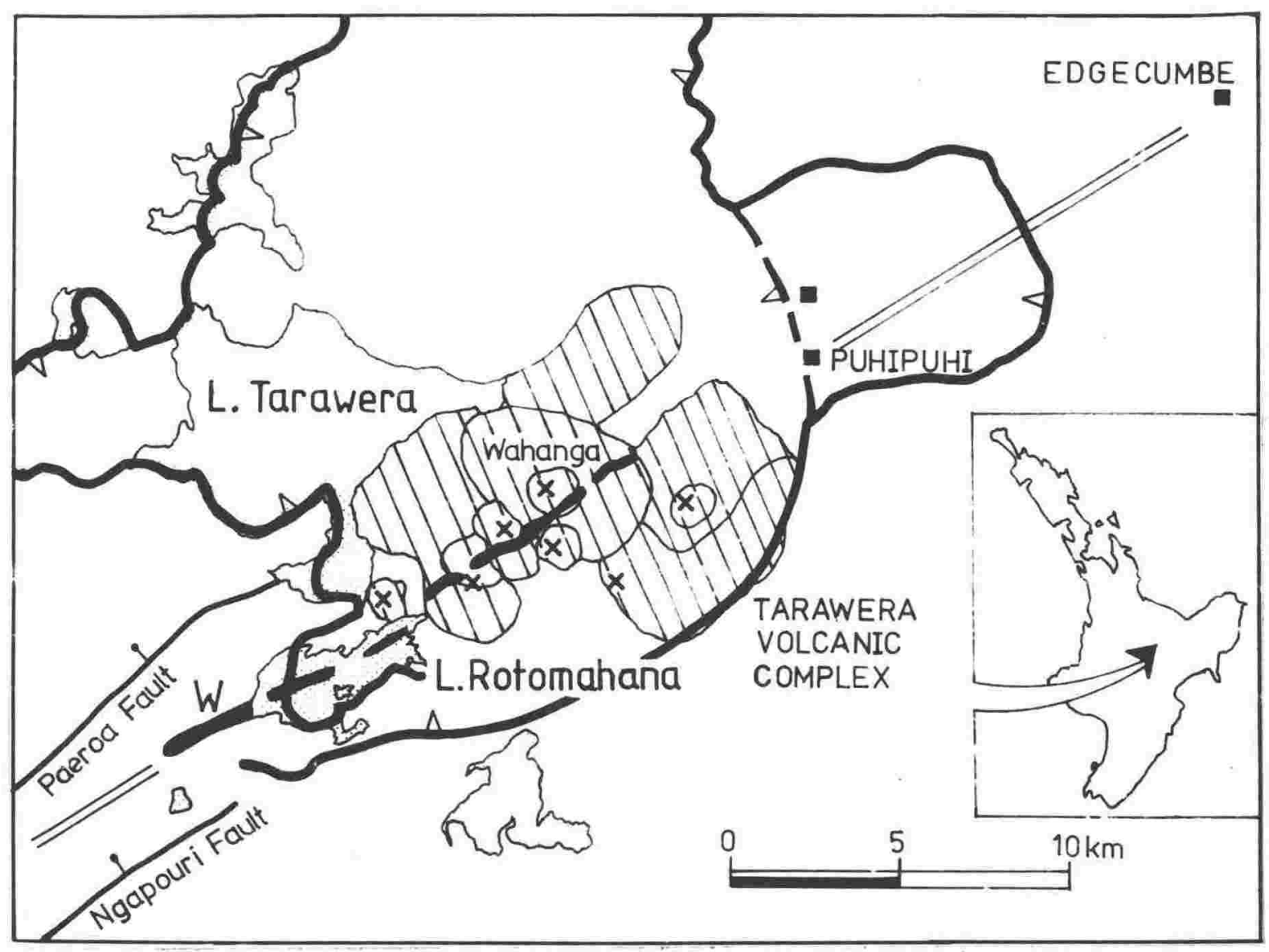

FIG. 1 - Map of Tarawera Volcanic Complex (lavas crosshatched) in southern Haroharo Caldera, showing pre-1886 vent locations $(x)$, Tarawera Rift craters (shaded), and locations of Puhipuhi and Edgecumbe dacite/andesite cones $(-)$. Double line indicates axis of the Tarawera vent lineation. 
exception of the most north-eastern). Total erupted dense basalt magma volume is about $0.7 \mathrm{~km}^{3}$ (Walker in press).

Measurements of vertical magnetic field intensity (WatsonMunro 1938) suggested the existence of basic intrusions in the rhyolitic Tarawera massif. Cole and Hunt (1968) first described basalt dikes at two localities in the Tarawera Rift and considered a basalt dike occupied the Rift within Tarawera Volcanic Complex. They followed Watson-Munro to interpret magnetic measurements as indicating that a sub-parallel second dike was buried about $0.3-0.4 \mathrm{~km}$ to south-east of the Rift. Nairn (1979) considered that a basalt dike was likely to extend at depth from Tarawera under Rotomahana to Waimangu.

Recent detailed mapping (Nairn 1981) has located many further dike exposures in the 1886 explosion craters, including some vertical sections where intrusive relationships can be studied. The exposed dikes, together with buried dike locations inferred from shapes of the 1886 explosion craters, provide evidence for the shallow intrusion of an en echelon series of short, discontinuous dikes, rather than the single continuous linear fissure previously inferred (i.e. Williams and McBirney 1979, p.258). This paper describes the 1886 Tarawera dikes and discusses their implications for 1886 eruptive mechanisms, and regional tectonics of the Taupo Volcanic Zone.

\section{REGIONAL GEOLOGY AND STRUCTURE}

Tarawera Volcanic Complex has been constructed within southern Haroharo Caldera during 4 major rhyolite eruptive episodes between c. 17,000 to 600 yrs B.P. (Cole 1970a, Nairn 1981). Basalt is known to be associated with two of these rhyolite eruptions. A sub-plinian eruption of basalt scoria forms the initial phase of the c. 17,000 yrs B.P. Okareka Eruptive Episode, during which the earliest exposed rhyolitic lavas and pyroclastics (Okareka Ash) were erupted at Tarawera (Nairn 1981). Pyroxene basalt was intruded into the Tarawera 
Volcanic Complex at some time prior to the $900-600$ yr B.P. Kaharoa Eruptive Episode, during which the summit domes (Fig. 2) were extruded and the widespread Kaharoa pyroclastics were erupted. Pyroxene basalt lithics are common in the Kaharoa pyroclastics, often enclosed in rhyolite lava (Cole 1970b) and have also been found in the lava of Tarawera and Wahanga Domes. Pre-20,000 yr B.P. basalts outcrop at Rotomahana (Nairn 1979).

Although the multiple rhyolite vents at Tarawera are scattered over a wide area of the complex (Fig. 1), all vents (acid and basic) lie within a $5 \mathrm{~km}$ wide zone, striking at $057^{\circ} \mathrm{N}$, which probably lies above a deep-seated fundamental crustal fracture (Malahoff 1968). This fracture extends beyond the Haroharo Caldera boundaries, from the basaltic/ phreatic 1886 explosion craters at Waimangu, $38 \mathrm{~km}$ north-east through Rotomahana and Tarawera, to the andesite/dacite cones of Puhipuhi and Edgecumbe (Fig. 1). The active zone appears likely to overlie a basic intrusion (Cole 1973) which provides a source for the basic and hybrid rocks erupted at Waimangu, Rotomahana, Tarawera, Puhipuhi and Edgecumbe. The zone has been termed the "Tarawera vent lineation" (Nairn 1981) and is not a direct continuation of any of the regional faults or structures of the Taupo Volcanic Zone to south-west of Tarawera. These regional structures commonly strike at about $040^{\circ} \mathrm{N}$.

The Tarawera Rift is defined by the 1886 explosion craters and occupies an axial position in the Tarawera vent lineation. Grindley (1959, 1963, 1965) followed Wellman (1954) in considering the Rift to represent a pure normal fault, assumed parallel to a present "principal horizontal stress" (PHS)* oriented at about $060^{\circ} \mathrm{N}$. However, no normal faulting associated with the 1886 eruption is evident within the Rift or extending beyond either end.

\footnotetext{
* Since changed to "principal horizontal shortening" (Lensen and Otway 1971, Lensen 1981): i.e. a component of the strain observed, rather than the stress field inferred to produce it.
} 


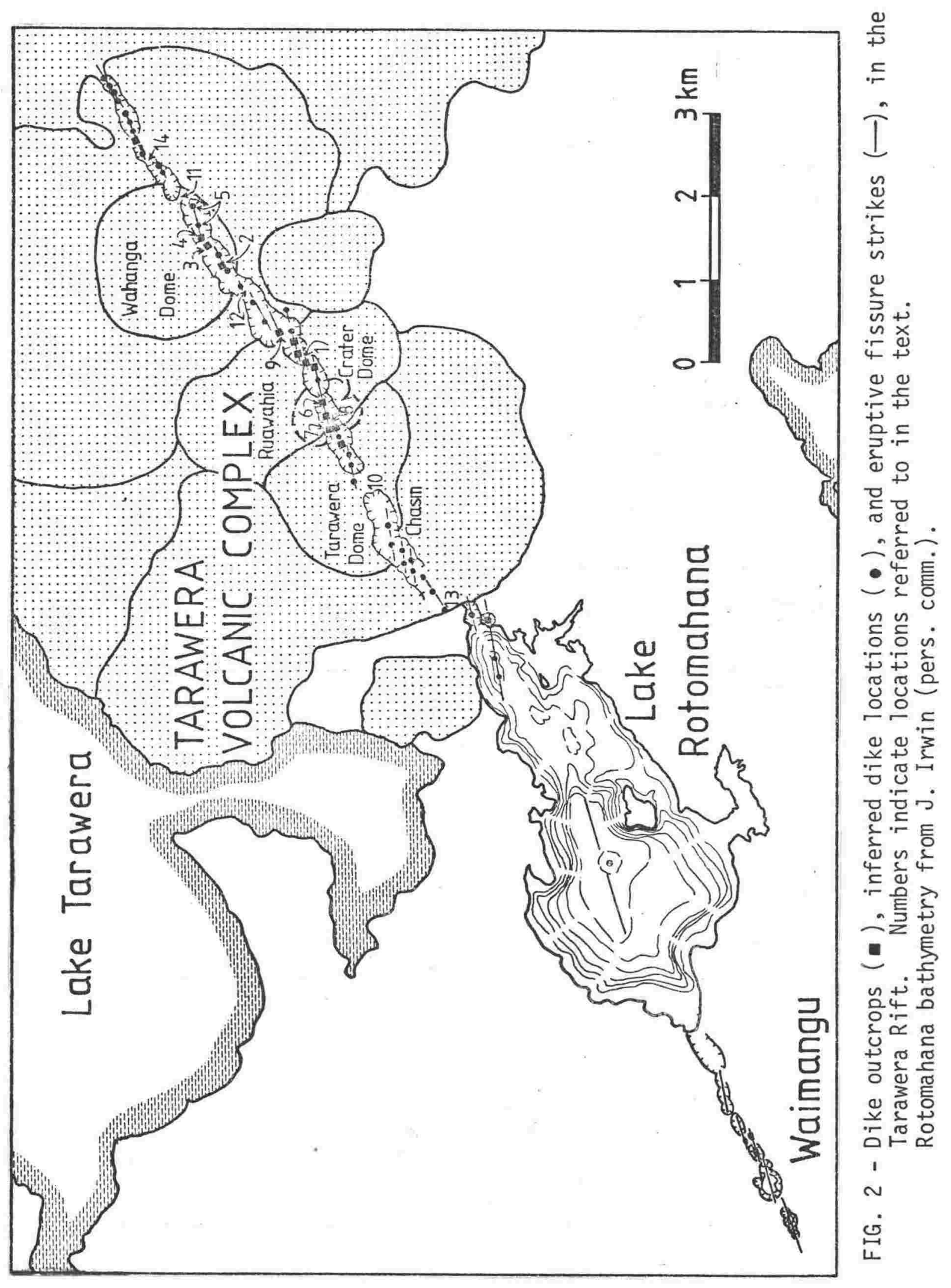




\section{DIKE DISTRIBUTION AND MORPHOLOGY}

\section{Dike Outcrops}

All the 16 known outcrops of 1886 basalt dikes occur within the Rift on Tarawera Volcanic Complex (Fig. 2). The dikes are preserved only where they did not become highly explosive. Most outcrops occur on the narrow end walls of the elongate 1886 explosion craters, where basalt intruded jointed massive lavas of the Kaharoa domes and older flows. At three locations in Wahanga and Crater Domes (Fig. 2), dikes are exposed over $30 \mathrm{~m}$ of vertical section so that intrusive relationships can be studied. Elsewhere, dike remnants outcrop as patches of basalt veneer plastered onto the side walls of craters. Commonly, only a few metres of horizontal exposure is available, providing little control on strike, but partial dike removal (by eruption, magma withdrawal, or erosion), has exposed enclosing fissure walls within Ruawahia and Crater Domes so that local strikes are readily apparent (Fig. 3).

\section{Inferred Dike Locations}

During and since the 1886 eruption, the floors of Tarawera craters have been considerably infilled by avalanching of the crater walls, burying any dike exposures. However, the eruptive fissure (and thus dike locations) probably underlies the deepest parts of crater floors. Position of the fissure is more closely delineated between outcrops of dome lava forming the opposite walls of narrow craters. In many cases buried dike locations inferred from crater morphology lie along strike from dike outcrops, showing that crater shape is an accurate guide to dike position (Fig. 2).

The rhyolite lava of fissure walls adjacent to and in contact with dike outcrops often appears highly polished, and sometimes striated, apparently due to softening and abrasion by basalt magma passing upwards during the eruption. Highly polished crater walls also occur where dikes are not preserved, and are interpreted to mark dike locations during the eruption. 


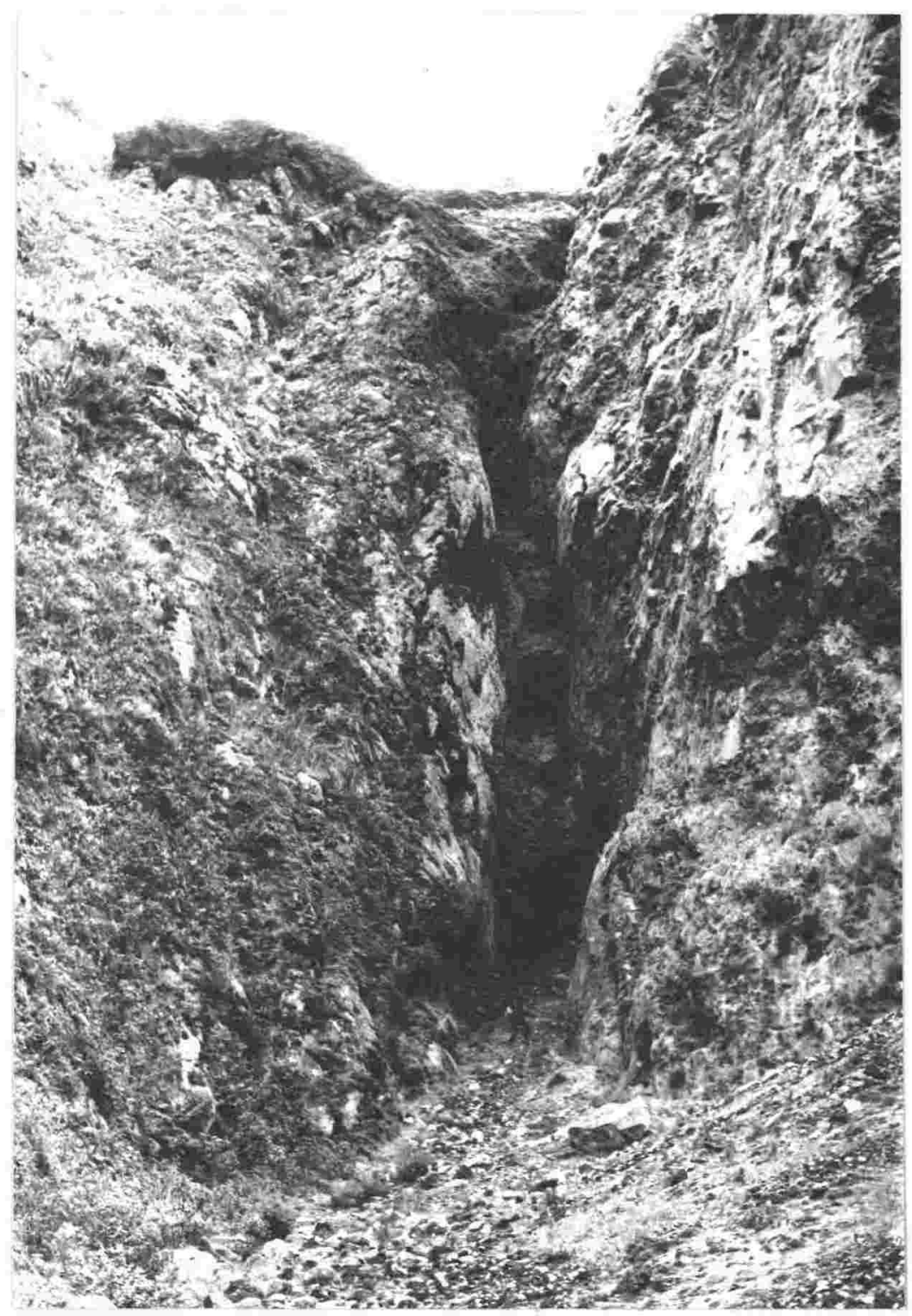

FIG. 3 - Basalt dike intruding Crater Dome rhyolite in north-east end wall of Crater Dome crater. Locality (6) on Fig. 2. Note figure in fissure for scale. 
Elsewhere, the rhyolite of crater walls displays a largescale hackly fracture formed by spalling of lava blocks into the crater during and following the eruption. Dike outcrops do not occur in crater walls displaying such hackly fracture, which is diagnostic of enlargement of the eruptive fissure by both explosion, and gravity-induced, collapse.

\section{Dike Morphology}

The two previously known Tarawera dike exposures have been described by Cole (1970a). A $12 \mathrm{~m}$ wide complex dike occupies the bridge between two 1886 explosion craters on Ruawahia Dome (Locality 1 on Fig. 2). The dike has dense chilled margins fused against polished and striated rhyolite fissure walls.

The other previously described dike occurs on the floor of the south-western crater in Wahanga Dome (Loc. 2 on Fig. 2). Where exposed, the scoriaceous dike is 1-2 m wide, with chilled margins against baked rhyolite fissure walls, and contains many vesiculated and fused rhyolite inclusions. The dike is intruded close to the contact between rhyolite lava of the dome, and its enclosing envelope of flow-brecciated lava blocks and ash. The dike passes up to the lava/breccia contact, being sub-vertical within breccia at base of the exposure, and tilting to north-west at the top where it intrudes jointed lava and bifurcates. The dike outcrops over about $6 \mathrm{~m}$ horizontally within a low bridge between adjacent deeper sections of the explosion crater, and may represent an offshoot from a main crater-forming dike now buried beneath the crater floor. However, the exposed dike is roughly aligned with a previously unmapped dike which outcrops high on the rhyoli.te lava bridge between the southwestern and north-eastern craters in Wahanga Dome (Loc. 3 on Fig. 2). Here the dike is poorly preserved, but appears to be a continuation of a well-exposed dike on the north-eastern side of the crater bridge, within the north-eastern Wahanga crater (Loc. 4 on Fig. 2). This dike dips at $80^{\circ}$ to southeast, intrudes massive rhyolite lava over about $30 \mathrm{~m}$ of near- 
vertical face, and thins both upwards and horizontally into the lava bridge. At base of the exposure, the dike is 1.5$2 \mathrm{~m}$ wide, consisting of dense black basalt with little intermal vesiculation and containing common rhyolite inclusions. The rhyolite surface of the adjacent crater wall to north of the dike is highly polished, indicating a preserved fissure margin. Further north, and to south of the dike, the crater wall rhyolite displays large-scale hackly fracture where the eruptive fissure has been enlarged by gravity collapse of lava blocks. Sub-horizontal open joints adjacent to the dike have not been intruded by the basalt, suggesting a relatively high magma viscosity and lack of excess intrusive pressure, at a depth of $\mathrm{c} .80 \mathrm{~m}$ below the pre-eruption ground surface.

No other dike outcrops occur in the north-eastern Wahanga Crater, but north-eastward strike of the eruptive fissure is well controlled by brecciated rhyolite outcropping in situ on both side walls of the crater (Loc. 5 on Fig. 2). Although somewhat sinuous, the inferred trace of the eruptive fissure is aligned with the exposed dike, and strikes obliquely across the crater (Fig. 2), the shape of which is partly controlled by the lava margin of Wahanga Dome.

Basalt dikes intmuding massive rhyolites along the axis of the rhyolite extrusions are exposed in the end walls of deep craters on Crater and Ruawahia Domes (Fig. 2). At the north-east end of Crater Dome crater (Loc. 6 on Fig. 2) a 2 m-wide dike occupies $30 \mathrm{~m}$ of vertically-exposed fissure between walls of massive rhyolite (Fig. 3). The dike followed vertical fractures in the dome lava. No horizontal or vertical displacements of opposite walls of the fissure could be determined, the fissure apparently having formed by pure dilation. Dense, vertically-banded basalt of the dike margins is fused to spherulitic rhyolite on the polished fissure walls. Slaggy, vesiculated lava within the dike is exposed in a lava tunnel which extends at least $50 \mathrm{~m}$ into the dike, and was apparently formed by withdrawal of magma from the lower part of the dike. 
Along strike to south-west, the same dike outcrops on the north-west (side) wall of the crater, and again in the rift bridge closing the south-west end of the crater (Loc. 7 on Fig. 2), where the fissure is c. $10 \mathrm{~m}$ wide. Fifty metres to the south, a second dike, $0.5 \mathrm{~m}$ wide, also outcrops on the north side of the rift bridge, and is again exposed deep in the crater on the south side of the rift bridge (Loc. 8 on Fig. 2) as a vertical scoriaceous dike $1.2 \mathrm{~m}$ wide with black centre and red margins. The dike cuts well-jointed massive lavas of Crater Dome, but again no basalt has been intruded into the many sub-horizontal joints on either side of the fissure, and the joint patterns provide no evidence for other than simple dilation of the fissure walls. This dike appears to strike south-west to other outcrops on the south-west end wall of the crater (Fig. 2). A bifurcating dike on this wall strikes nearly east-west, and apparently follows a weakness in the rhyolite.

A further exposure of a basalt dike cutting massive dome rhyolite occurs in the north-west face of Ruawahia Dome above the largest 1886 explosion crater. A scoriaceous dike $1 \mathrm{~m}$ wide dips at $60^{\circ}$ to the south-east, and outcrops at the head of a 2-3 $\mathrm{m}$ wide fissure from which a larger dike has been removed. The fissure walls are sub-vertical, horizontally somewhat sinuous, and polished. The average strike of the fissure (Loc. 9 on Fig. 2) is to east of the main crater trend.

\section{Rift Bridges}

Two major non-eruptive areas occur on Tarawera Volcanic Complex. One lies between "The Chasm" and the most southwestern explosion crater on Tarawera Dome summit (Loc. 10 on Fig. 2). No dikes crop out in the north and east walls of the "Chasm" although more than $150 \mathrm{~m}$ of strongly-jointed rhyolite is exposed in a near vertical face. A $15-20 \mathrm{~cm}$ wide, branching, sub-vertical, open fracture cuts rhyolite of the "Chasm" wall where it intersects the axis of the crater, but the fracture has not been intruded by basalt. Basalt was erupted from the floor of the "Chasm" about $300 \mathrm{~m}$ to south-west 
of the wall, and from the Tarawera Dome craters about $400 \mathrm{~m}$ to north-east and $300 \mathrm{~m}$ higher in elevation. The lack of an eruptive dike in the intervening area demonstrates that intrusion was discontinuous at shallow depths.

The second $0.5 \mathrm{~km}$ long non-eruptive zone separates explosion vents in the craters on and to north-east of Wahanga Dome (Loc. 11 on Fig. 2). The crater floors are separated by about $250 \mathrm{~m}$ in elevation.

Smaller bridges also lie across the 1886 Rift between and within explosion craters. Some have not been intruded by dikes. A significant example immediately south.of Wahanga Dome shows stratified Kaharoa pyroclastics lying undisturbed across the Rift (Loc. 12 on Fig. 2), demonstrating that no tensional rifting had occurred at that locality (Cole 1966).

\section{Dike Pattern}

The eruptive fissures defined by dike outcrops and inferred locations on Tarawera commonly form a left-stepping, often slightly overlapping pattern (Fig. 2). Particularly large $(\mathrm{c} .300 \mathrm{~m})$ side steps occur between the crater at the north-eastern end of Lake Rotomahana and the adjacent crater to north on Tarawera Volcanic Complex (Loc. 13 on Fig. 2), and between the "Chasm" and the summit craters on Tarawera Dome (Loc. 10 on Fig. 2).

Waimangu-Rotomahana Craters

Exposures of 1886 basalt dikes have not been found at Waimangu and Rotomahana, but basalt was erupted from at least some of the Waimangu explosion craters and probably also at Rotomahana (Nairn 1979). Waimangu explosion craters are commonly strongly elongate, and/or adjacent craters form leftstepping linear features which strike at between $073^{\circ}$ and $080^{\circ}$ N (Fig. 4). Similar side-stepping of elongated explosion craters is also suggested by the bathymetry of Lake Rotomahana (Fig. 2). The crater axes and lineations at Waimangu and 




FIG. 4 - Aerial photograph of 1886 explosion craters at Waimangu showing en echelon pattern of elongate craters, and alignments of vents. Photo by courtesy of N.Z. Forest Service, Rotorua. 
Rotomahana are inferred to mark the locations of underlying basalt dikes which initiated the largely phreatic, craterforming eruptions (Naim 1979).

\section{DISCUSSION}

Waimangu-Tarawera Dike Pattern

The pattern of dike outcrops and inferred dike locations within the Tarawera Rift defines a series of sub-parallel, leftstepping, en echelon eruptive fissures (Fig. 2). This tectonic pattern is particularly clear at Waimangu (Fig. 4), is largely consistent with Rotomahana bathymetry (Fig. 2), and is evident in most of the Tarawera explosion craters (Fig. 2). The Tarawera Rift has a regional trend averaging about $057^{\circ} \mathrm{N}$, but individual fissures strike at up to $080^{\circ} \mathrm{N}$ (Waimangu) to $070^{\circ} \mathrm{N}$ (Tarawera). Apart from a few craters which parallel the regional trend, the strike of most fissures is rotated to east of the Rift trend (Fig. 2).

The Tarawera Rift was previously considered to represent a pure normal fault, assumed parallel to the "principal horizontal stress" (Grindley 1959, 1963, 1965). However, the en echelon fracture pattern now mapped in the rift is common in situations where trend of a fracture zone is oblique to direction of dilation (Nakamura 1970). Such en echelon fracture patterns in surface rocks often result from a non-perpendicular relation between tension and a master fracture at some relatively shallow depth (Duffield and Nakamura 1973). The structural interpretation shown for the Tarawera Rift in Fig. 2 is most consistent with the fracture pattern which would be produced by dextral/normal movement on an underlying master fault striking at c. $057^{\circ} \mathrm{N}$. The dikes fill tensile fractures propagated normal to the minimum principal stress (Roberts 1970), and therefore reflect the tectonic stress field existing at shallow depths prior to and during the 1886 eruption.

Regional trend of the Tarawera Rift appears to have been controlled by deep magmatic intrusion on the master fault/ 
basement fracture. The eruptive fissure orientations were determined at shallow depths by dilational fracturing controlled by the local PHS which lies between $070-080^{\circ} \mathrm{N}$, and which resulted from dextral movement on the underlying master fault.

\section{Intrusion Mechanisms}

Where best exposed (i.e. in the craters on Crater Dome), the basalt dikes appear to have intruded pure dilational fractures without detectable horizontal or vertical shear displacements of the fissure walls. There is no evidence for high intrusion pressures at the exposed depths, as basalt did not enter adjacent joints and fractures in the rhyolite of the fissure walls. Instead, the deepest-exposed dikes appear to have passively occupied $2 \mathrm{~m}$ wide sub-vertical extensional fissures. (The wider dike exposures, up to $12 \mathrm{~m}$ on Ruawahia and Tarawera Domes, are at shallow depths, immediately underlying erupted basalt, and probably fill eruptive fissures enlarged by early explosion and collapse).

The earthquakes felt at Rotorua for 1 hour prior to the 1886 eruption (and at least some during it) were presumably caused by upward fracturing which allowed magma to rise towards the ground surface. The largest earthquakes occurred prior to the first eruptions at Wahanga Dome, but even these were not reported felt much beyond $100 \mathrm{~km}$ from Tarawera. This, and the lack of widespread associated surface faulting suggests that the earthquakes were not of normal tectonic origin, and that primary cause of the 1886 emption may have been an increase in magmatic pressure at depth, rather than passive intrusion in response to regional extension and/or fault displacement. However, the lack of evidence for large intrusion pressures in the deepest exposed dikes, and the apparent tensional origin of the eruptive fissures is consistent with low magmatic pressures at shallow depths. In fact, both magmatic and tectonic processes may have contributed. Regional lowering of compressive stresses by continuing crustal extension may have reached a stage where magmatic pressure beneath Tarawera (either static or increasing) came 
to exceed the minimum compressive stress plus tensile strength of the rock (Phillips 1972, Williams and McBirney 1979). The presence of magma under pressure reduces the effective principle stresses across fracture tips, so that dilational fracturing only occurred where magma was present. Alternatively, updoming and dilation above a forcefully intruded magma body would also produce extensional cracks to be filled with magma (Koide and Battacharji 1975).

Basaltic Eruption Duration and Repetition

A mechanism which may account for the short duration of the 1886 eruption has been advanced by Weertman (1971). As magma is intruded into a large fracture opened above a magma body, magma pressure decreases as the occupied volume increases. When magma pressure falls below the local confining pressure, the fracture pinches shut behind the intrusion so that the intruded magma is no longer connected to the underlying magma source. A discrete body of magma then cracks its way upwards while its bottom tip is continually squeezed shut. Provided the intruded magma does not freeze during ascent it eventually reaches the surface to solidify as a dike. Its presence can preclude later-rising cracks from reaching the surface, and these are sequentially trapped below the frozen earlier intrusions until solidified magma extends down to the magma source. At this stage the cycle can be repeated and a new fracture rise to the surface. This mechanism is consistent with the periodic occurrence of relatively small basaltic eruptions and intrusions along the Tarawera vent lineation.

Pre-1886 basaltic scoria eruptions are known to have occurred on the vent lineation at $>42,000$ yrs B.P., $>20,000$ yrs B.P. (Nairn 1979), at c. 17,000 yrs B.P. (Nairn 1981), and a basaltic intrusion pre-dates the c. 900 yrs B.P. initiation of the Kaharoa Eruptive Episode (Cole 1970a). The 1886 eruption is the largest of the basaltic eruptions from the Tarawera vent lineation. 
Dike Flow Outputs and Velocities

The emission of $0.7 \mathrm{~km}^{3}$ of dense basalt magma during the $4 \mathrm{hr}$-long eruption is an average effusion rate of $\mathrm{c}$. $5 \times 10^{4} \mathrm{~m}^{3} \mathrm{~s}^{-1}$. Although the Rift extends for $8 \mathrm{~km}$ across Tarawera Volcanic Complex, the total eruptive fissure length measured on the explosion crater floors is about $5.5 \mathrm{~km}$. Assuming an average dike width of $2 \mathrm{~m}$ (as measured at c. 100 $m$ depth), and that most of the erupted basalt came from Tarawera, the relationship of eruption rate and fissure surface area requires an average upward flow velocity through the fissures of about $5 \mathrm{~ms}^{-1}$ for dense magma, and higher velocities for the vesiculating erupting lava.

Regional Implications

The previously assumed pure normal character of the $060^{\circ} \mathrm{N}$-striking Tarawera Rift implied a pronounced dextral transcurrent component for the $040^{\circ} \mathrm{N}$-striking major faults of the Taupo Volcanic Zone (Grindley 1963). The dextral component now recognised in the Tarawera Rift suggests a PHS direction between 070 and $080^{\circ} \mathrm{N}$, and thus a larger dextral component for the main faults of the Taupo Volcanic Zone.

\section{ACKNOWLEDGEMENTS}

This paper has been improved by valuable comments from D.G. Bishop, G.W. Grindley, G.J. Lensen, and H.W. Wellman. S. Msenya and B.J. Scott provided assistance in the field. 
REFERENCES

Cole, J.W. 1966: Tarawera Volcanic Complex. Unpublished Ph.D. thesis, lodged in the Library, Victoria University, Wellington. 229p.

1970a: Structure and eruptive history of the Tarawera Volcanic Complex. N.Z. Journal of Geology and Geophysics 13: 879-902.

1970b: Description and correlation of Holocene volcanic formations in the Tarawera-Rerewhakaaitu region. Transactions of the Royal Society of New Zealand (Earth Sciences) 8(7): 93-108. 1973: High-alumina basalts of Taupo Volcanic Zone, New Zealand. Lithos 6: 53-64.

Cole, J.W.; Hunt, T.M. 1968: Basalt dikes in the Tarawera Volcanic Complex, New Zealand. N.Z. Journal of Geology and Geophysics 11: 1203-6.

Cole, J.W.; Nairn, I.A. 1975: "Catalogue of the active volcanoes of the world, including solfatara fields. Part XXII New Zealand." International Association of Volcanology and Chemistry of the Earth's Interior. Rome. $156 \mathrm{p}$.

Duffield, W.A.; Nakamura, K. 1973: A photogeologic method for determining the direction of horizontal dilation from patterns of en echelon fracturing. Journal of Research, U.S. Geological Survey 1: 283-287.

Grindley, G.W. 1959: Sheet N85, Waiotapu. "Geological Map of New Zealand, 1:63,360." N.Z. Department of Scientific and Industrial Research, Wellington.

1963: Geology and structure of Waiotapu Geothermal Field. N.Z. Department of Scientific and Industrial Research Bulletin 155: 10-25.

1965: The geology, structure and exploitation of the Wairakei Geothermal Field, Taupo, New Zealand. N.Z. Geological Survey, Bulletin n.s. 75.

Lensen, G.J. 1981: Tectonic strain and drift. Tectonophysics (in press)

Lensen, G.J.; Otway, P.M. 1971: Earthshift and post-earthshift deformation associated with the May 1968 Inangahua Earthquake, New Zealand. Royal Society of New Zealand Bulletin 9: 107-116. 
Malahoff, A. 1968: Origin of magnetic anomalies over the Central Volcanic Region of New Zealand. in Knopoff, L. et al, eds., Geophysical Monograph 12, American Geophysical Union, Washington D.C.

Nairn, I.A. 1979: Rotomahana-Waimangu eruption, 1886: base surge and basalt magma. N.Z. Journal of Geology and Geophysics 22: 363-78. 1981: Some studies of the geology, volcanic history, and geothermal resources of the Okataina Volcanic Centre, Taupo Volcanic Zone, New Zealand. Unpublished Ph.D. thesis, lodged in the Library, Victoria University of Wellington (this study).

Nakamura, K. 1970: En echelon features of Icelandic ground fissures. Acta Naturalia Islandica II (8): 3-15.

Phillips, W.J. 1972: Hydraulic fracturing and mineralization. Journal of the Geological Society 128: 337-359.

Roberts, J.L. 1970: The intrusion of magma into brittle rocks. in Newall, G., and Rast, N., eds., Mechanism of igneous intrusion: Gallery Press, London, p.297-338.

Walker, G.P.I. In press: Tarawera 1886, New Zealand ... a basaltic plinian emuption. Nature 1981.

Watson-Munro, C.N. 1938: Reconnaissance survey of the variation of magnetic force in the New Zealand thermal regions. N.Z. Journal of Science and Technology B20: 99-115.

Weertman, J. 1971: Theory of water-filled crevasses in glaciers applied to vertical magma transport beneath oceanic ridges. Journal of Geophysical Research 76: 1171-1183.

Wellman, H.W. 1954: Stress pattern controlling lode formation and faulting at Waihi Mine and notes on the stress pattern in the north-western part of the North Island of New Zealand. N.Z. Journal of Science and Technology, B36: 201-206.

Williams, H.; McBirney, A.R. 1979: Volcanology. Freeman, Cooper and Co., San Francisco. 397p. 
B: EFFECTS OF O.V.C. ERUPTIONS ON REGIONAL DRAINAGE Introduction

The formation of Haroharo Caldera and its subsidiary structures, followed by their partial infilling with the Tarawera, Haroharo, Okareka and Rotoma rhyolite massifs, has greatly affected regional drainage patterns. The catchment area external to the O.V.C. is relatively small (Fig. 47), as much of the adjacent T.V.Z. drains either south-west towards the Waikato River, or north-east into the Whakatane Graben. Country to north and south generally slopes away from the O.V.C. This drainage pattern has been established for at least the last 40,000 years, since the Earthquake Flat Breccia eruptions blocked any possible Haroharo Caldera outlet south-west through the Rotokakahi area into the Ngakuru Graben (see Map 2). Haroharo Caldera has since drained east through Puhipuhi Basin into the Whakatane Graben,

\section{All the larger lakes of the Rotorua area (except Lake Rotorua} in Rotorua Caldera) are situated within or on the periphery of Haroharo Caldera (Fig. 47), and owe their origin dominantly to damming of drainage channels by lavas and pyroclastics erupted from within the caldera. Rotomahana and the smaller Okaro, Rotokawau, and Rototatua lakes occupy recent explosion craters. Catchment and lake data for all these lakes is presented in Table 8 . Although Lake Rotorua does not form part of the present Haroharo catchment, the most extensive hydrological effects of Haroharo volcanism have been on drainage from the Rotorua basin.

\section{Ancient Lakes}

Little is known of the pre-20,000 yr B.P. lacustrine history of Haroharo Caldera, which must be discussed in conjunction with that of the adjacent Puhipuhi Basin. Lakes are presumed to have occupied the caldera floor following the earliest voluminous pyroclastic eruptions of the "quartz-biotite Ignimbrites", and the Pokopoko and Onuku Breccias, but any resulting sediments have been downfaulted by later subsidence. Puhipuhi Basin is considered to have approached its present form following the 


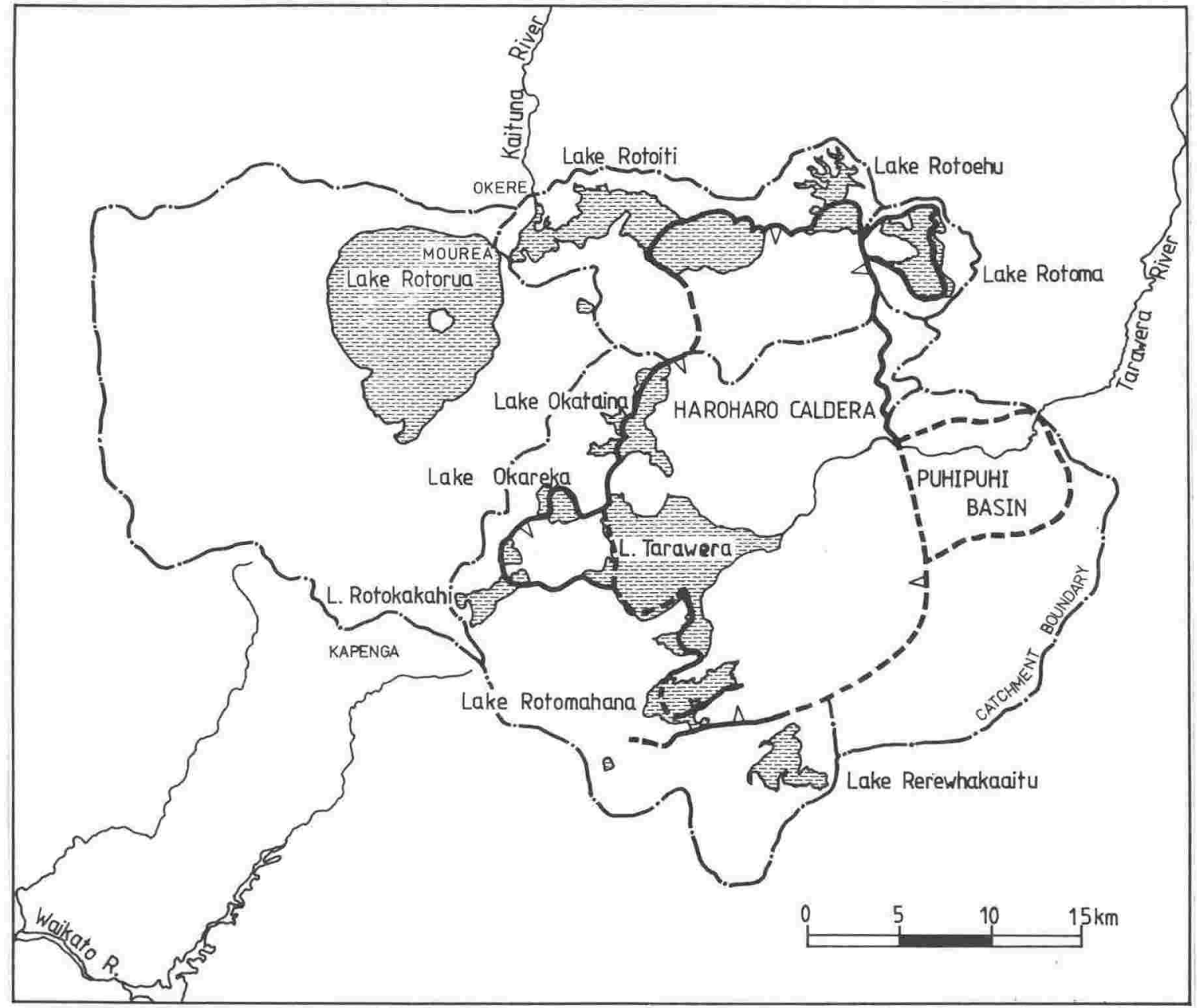

FIG. 47 - Catchment boundaries (--) for Lake Rotorua, Haroharo Caldera and Puhipuhi Basin. Northern sub-catchment within Haroharo Caldera is also shown, now draining to Kaituna River. 
TABLE 8 - Catchment and lake data for lakes associated with Okataina Volcanic Centre. Data compiled in 1973 by H.J. Freestone from M.W.D. records; Fish 1970; McColl 1972; Nairn 1970, 1975; P.R. Stephens, pers. comm.

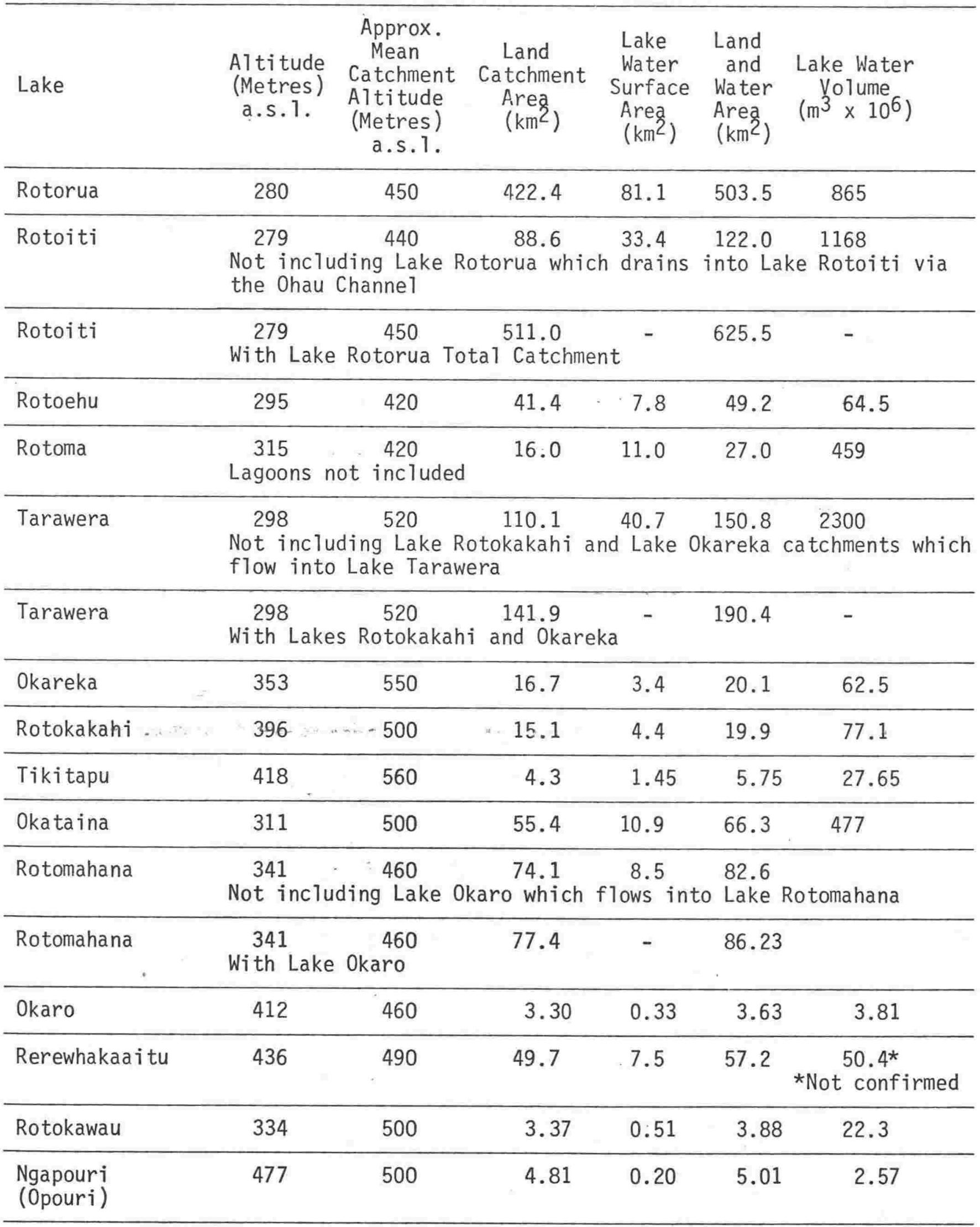


Matahina Ignimbrite eruptions, and contained ancient lakes discussed on p. 59. Once Puhipuhi Basin was formed, its overflow level was controlled below c. $150 \mathrm{~m} \mathrm{a.s.l.} \mathrm{by} \mathrm{the} \mathrm{Matahina}$ Ignimbrite surface on the north-east rim, providing an ultimate control on lake levels within Haroharo Caldera. However, following growth of the Puhipuhi dacite cones in Puhipuhi Basin, caldera drainage into northern Puhipuhi Basin was restricted. The basin was later infilled by the Kaingaroa Ignimbrites, allowing higher possible lake levels (i.e. somewhat above $150 \mathrm{~m}$ a.s.l.), in Haroharo Caldera, before erosion cut down towards previous levels. The same sequence is assumed to have been associated with the Rotoiti Breccia emptions, again temporarily allowing higher lake levels to be contained within Haroharo Caldera. Lacustrine sediments occur beneath Rerewhakaaitu Ash at c. $210 \mathrm{~m}$ a.s.1. In the Mangakotukutuku Stream, and beneath Okareka Ash at about the same elevation in the Waiaute Stream valley. These sediments must have been deposited at a time when the outlet from Haroharo Caldera was raised above its present $130 \mathrm{~m} \mathrm{a.s.l.} \mathrm{elevation,} \mathrm{presumably} \mathrm{by} \mathrm{infilling} \mathrm{of}$ the Puhipuhi Basin outlet by Rotoiti Breccia which has since been largely eroded from the Basin.

\section{Lake Rotorua Drainage}

The catchment area of Lake Rotorua is $505 \mathrm{~km}^{2}$ (Nairn 1975) of which the present lake area (with surface at $280 \mathrm{~m} \mathrm{a.s.1.)}$ is $80 \mathrm{~km}^{2}$, or $16 \%$. The present outlet level for Lake Rotorua basin is ultimately controlled at $277 \mathrm{~m}$ a.s.1. on Mamaku Ignimbrite at Okere (Fig. 47), where the Kaituna River leaves Lake Rotoiti. If lake levels drop below this elevation, no outflow can occur. Downcutting of the outlet channel has occurred during the Holocene, and earlier control levels would have been at higher elevations. Rotorua Caldera probably formed about 140,000 years B.P. when the Mamaku Ignimbrite was erupted. Mamaku Ignimbrite is downfaulted by at least $100 \mathrm{~m}$ in Tikitere Graben (Map 2), to north-east of Rotorua Caldera. The graben controlled outflow to north-east from Rotorua basin prior to eruption of the Rotoiti Breccia at $\geqslant 42,000$ yrs B.P. 
Two wells drilled in Tikitere Geothermal Field near the axis of the graben encountered the upper surface of the ignimbrite beneath Rotoiti Breccia at $240 \mathrm{~m}$ and $140 \mathrm{~m}$ a.s.l. respectively, suggesting that level of Lake Rotorua may have been very low prior to the Rotoiti Breccia eruptions. Rotoiti Breccia pyroclastic flows passed north-west around the Whakapoungakau rhyolite massif to infill Tikitere graben, where they blocked Rotorua drainage and raised lake level to c. $370 \mathrm{~m} \mathrm{a.s.1.;} 90 \mathrm{~m}$ above the present level. Subsidence which accompanied the Rotoiti Breccia eruptions formed or deepened the northern part of Haroharo Caldera, now partly occupied by the eastern half of Lake Rotoiti. Headward erosion from the north-western rim of Haroharo Caldera cut back into the Rotoiti Breccia deposits infilling the graben, and eventually captured the north-eastward drainage from Lake Rotorua (Healy 1975a). The subsequent outflow from Lake Rotoma rapidly cut a deep channel now apparent in the Lake Rotoiti bathymetry (Map 2), as Lake Rotorua drained into Haroharo Caldera, and thence into the Whakatane Graben.

Kennedy et al (1978) have used tephra deposits as marker beds to study lake level changes in the Lake Rotorua basin during the last 50,000 years. Their results are summarized as follows (Fig. 48). Lake Rotorua remained at c. $360 \mathrm{~m} \mathrm{a.s.1.} \mathrm{after} \mathrm{the}$ Rotoiti Breccia eruptions, until after about 22,000 yrs B.P. It then fell to below $290 \mathrm{~m} \mathrm{a.s.l}$. by $20,000 \mathrm{yrs}$ B.P., and to below $280 \mathrm{~m}$ (the present level) at time of the Okareka Ash eruption (c. 17,000 yrs B.P.), was still low at time of the Rotorua Ash eruption (13,800 yrs B.P.), was at or below $277 \mathrm{~m}$ immediately prior to c. 8500 yrs B.P., and rose to c. $290 \mathrm{~m} \mathrm{a.s.l.}$ following the Mamaku Ash eruption at c. 7600 yrs B.P.

This history of lake levels in the Rotorua basin can be compared with that of the major eruptive events in Haroharo Caldera. The following discussion assumes that no undetected major tectonic subsidence or tilting has affected the RotoruaHaroharo area since the Rotoiti Breccia emptions. 

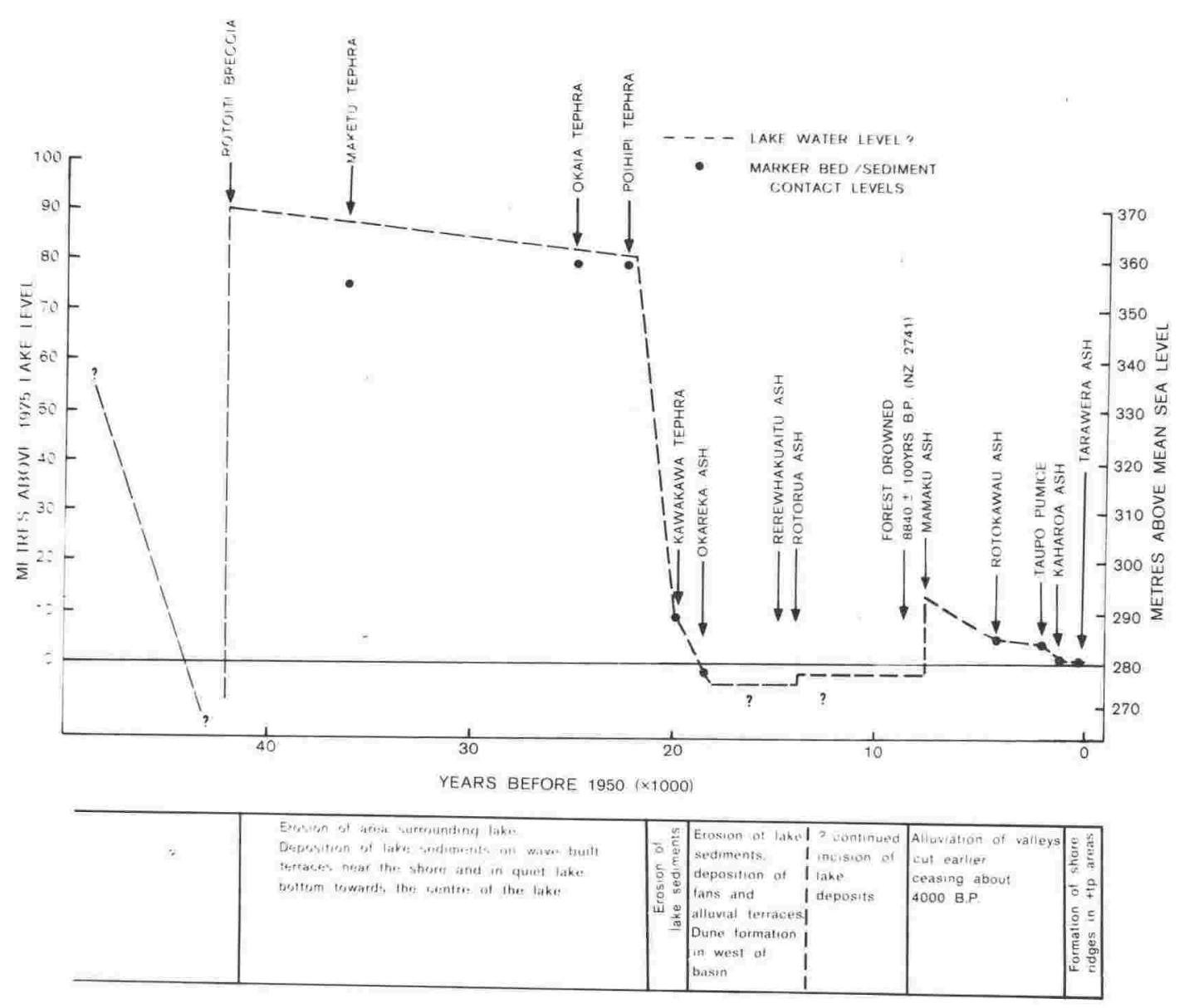

FIG. 48 - Inferred variations in the water level of Lake Rotorua from before 42,000 yrs B.P. to the present. Summary of geomorphic history with each change in level. Figure is fig. 8 of Kennedy et al 1978. 
The high stand of Lake Rotorua between $\geqslant 42,000$ and 22,000 years B.P. occurred during the interval before headward erosion from Haroharo Caldera breached the Rotoiti Breccia fan containing the lake. Prior to this breakthrough, the level of Lake Rotorua (Fig. 49), was probably controlled by overflow north through a shallow channel cut across Mamaku Ignimbrite at $1.5 \mathrm{~km}$ west of Mourea (i.e. Grange 1937, p. 30, 45), and/or by drainage south through the Hemo Gorge into the Kapenga basin and towards the Waikato River system (Grange 1937, p. 45; Nairn 1971, p. 253). In both these outlet areas, present overflow levels are close to 360-370 m a.s.I.

The possible existence of other northward outflows, perhaps through buried channel seepage paths close to the present Okere outfall, is suggested by the considerable dissection of Rotoiti Breccia in the lower Kaituna River area, to south of Paengaroa. This dissection occurred prior to the 36,000-26,000 years B.P. eruptions of the Mangaone Sub-group Pyroclastics, which mantle the eroded Rotoiti Breccia, and suggest that considerable river flows were occurring in the lower Kaituna area, at a time when Lake Rotorua still stood at high level.

The rapid erosion which followed the c. 22,000 yr B.P. breakthrough of Rotorua waters into Haroharo Caldera cut a narrow channel more than $60 \mathrm{~m}$ deep into the Rotoiti Breccia filling Tikitere Graben. Floor of this channel was controlled at or below about $210 \mathrm{~m} \mathrm{a.s.1.} \mathrm{presumably} \mathrm{in} \mathrm{hard} \mathrm{rock} \mathrm{(Mamaku}$ Ignimbrite?) on the Haroharo Caldera rim. Lake Rotorua had fallen below $290 \mathrm{~m}$ a.s.I. by 20,000 yrs B.P. and had reached an unknown depth below c. $280 \mathrm{~m}$ a.s.1. by 17,000 yrs B.P. (Fig. 48). The present $270 \mathrm{~m}$ a.s.1. bathymetric contour in Lake Rotoiti closely approaches the present Ohau Channel (Map 1) connection to Lake Rotorua, so that ancient overflow from Lake Rotorua at about this level seems quite feasible.

Rotorua drainage into Haroharo Caldera during the period 22-20,000 yrs B.P. probably flowed freely across the caldera floor, as the existence of large pre-20,000 yr B.P. intracaldera 
rhyolite extrusions seems unlikely. The earlier Tapuaeharuru Breccia outcropping at the eastern end of Lake Rotoiti formed a topographic high which probably directed the ancient drainage to south-west (Fig. 49). At about 19,000 yrs B.P., the Te Koutu, Tuarae, Haumingi, and older lava flows (now submerged beneath Lake Rotoiti) were extruded during the Te Rere Eruptive Episode to partly fill the north-western Haroharo Caldera, and together with the Tapuaeharuru Breccia to east, effectively dammed nearly all northern Haroharo Caldera to Rotorua drainage (Fig. 49). These lavas were in place prior to deposition of the Okareka Ash, which also fell on the Rotorua lake shore exposed by the low lake level at c. 17,000 yrs B.P. The only possible low level $(<280 \mathrm{~m}$ ) channels remaining in the northern Haroharo Caldera must have then been located in (1) a possible narrow channel between the Tuarae Lava Flow and the Tapuaeharuru deposits (Fig. 49), or (2) through a northern caldera moat into the Rotoehu area. No direct evidence is available to support either of these alternatives, as the Waiti and Te Pohue Lava Flows later buried both areas. However, assuming that level of Lake Rotorua was controlled by overflow rather than climate during this period (i.e. the lake did not fall below overflow), then occurrence of a post-17,000 yr B.P. lake level below $277 \mathrm{~m}$ (the present overflow level at Okere)* requires a lower level outlet into Haroharo Caldera. The post-17,000 yr B.P. low level of Lake Rotorua is strong evidence that a channel through the Haroharo Caldera still existed following the Te Rere Eruptive Episode. The assumption that level of Lake Rotorua was not climatically controlled is further discussed at end of this section.

The next major eruptive event in northern Haroharo Caldera was extrusion of the 9000 yr B.P. Te Pohue Lavas which conclusively blocked any low level drainage passing through the northern

* In fact, as the present Okere control level has been lowered by erosion during the Holocene (see p. 262), this level would be higher, probably above $293 \mathrm{~m}$ - the lake level following the post-Mamaku Ash northward overflow at Okere (Fig. 48 ). 
caldera moat, into the Rotoehu area. The contemporaneouslyerupted Pukerimu Pyroclastics flowed across the Haumingi Lava Flow and into the alternative southward drainage channel (Fig. 49) between the Tuarae Lava Flow and the Tapuaeharuru Breccia. The Pukerimu deposits must have greatly affected any southward drainage channel, if they did not completely block it. Radiocarbon dates (Table 2) for this emptive episode are $8860 \pm 120$ years B.P. for the Pukerimu Pyroclastics and $8830 \pm 90$ years for the Te Pohue Lavas (both old T $\frac{1}{2}$ ). Trees growing at about $277 \mathrm{~m}$ a.s.l. on the shore of Lake Rotorua were drowned by a rising lake level (Kennedy et al 1978) and are ${ }^{14} \mathrm{C}$ dated at $8590 \pm 90$ years B.P. (old $\mathrm{T} \frac{1}{2}$ ). The age differences are not statistically significant, as the dates overlap at two standard deviations. This rise in lake level may have been induced by blockage of Haroharo Caldera channels by the c. 9000 yrs B.P. Rotoma Eruptive Episode.

If Rotorua drainage through Haroharo Caldera was not fully blocked by the 9000 yr B.P. eruptive episode, all channels were conclusively closed by extrusion of the Waiti Lava Flow during the 7500 yrs B.P. Mamaku Eruptive Episode. Northward flow of the Waiti Lava was controlled by the drainage channel between the Haumingi Lava Flow and the Tapuaeharuru deposits, and no southward drainage was possible after its eruption (Fig. 49). Mamaku Ash in the Rotorua Basin is water sorted up to $287 \mathrm{~m} \mathrm{a.s.I.}$ (Grange 1937) and the airfall ash has not been identified below $293 \mathrm{~m}$ a.s.l. (Kennedy et al 1978). This rise of $16 \mathrm{~m}$ in lake level between c. 8500 and c. 7500 years B.P. may have been caused by the Waiti Lava extrusion forcing the final northward overflow of Rotorua drainage into the Kaituna River system. Since the Mamaku Ash emption, the Kaituna outlet has gradually and continuously cut down to the present level of $277 \mathrm{~m}$ (Fig. 48).

Climatic Versus Geological Controls on Lake Rotorua Levels

Whether outflow occurred from Lake Rotorua into Haroharo Caldera during the period c. 17,000-9000 yrs B.P. depends critically on the low lake levels at this time being controlled by geologic factors rather than climate. Some data relating 
to this problem are discussed below.

Global sea level and marine isotope curves place the maximum Wisconsinan (Late Otiran) ice volume (Andrews and Barry 1978) at about 18,000 yrs B.P. From their studies of paleosol development on pyroclastic deposits in the central North Island, Pullar and Birrell (1973b) suggested that the Oruanui, Te Rere and Okareka Ashes were empted during a period of cool climate such as a glacial advance. Vucetich and Pullar (1969) had previously correlated this period with the later Kumara-2 glacial advance recorded in the South Island (Suggate 1965) (Kumara-3 in Fleming 1979). Tephric loess is found interbedded with Okareka Ash in the Lake Rotorua catchment (Nairn 1971, Pullar and Birrell 1973a, Kennedy et al 1978), suggesting cold, arid, climatic conditions at time of the Okareka Eruptive Episode. These results suggest that climate could have been a controlling factor on level of Lake Rotorua at time of the Okareka Ash eruption. Certainly, historic levels of closed lakes in the Rotorua district have fluctuated considerably, and are dominantly controlled by cumulative rainfall (Healy 1975b). However, Rotorua differs from the closed lakes in that it occupies a smaller part (16\%) of a much larger catchment, so that lake inflows are proportionally much larger than seepage and evaporation losses from the lake. Further, the present closed lakes are all much younger than Rotorua so that sealing of their floors by sedimentation should be less effective, and all except Okataina are known to have seepage outflows to adjacent areas of lower elevation (i.e. Taylor et al 1977). No seepage outflows are known for Lake Rotorua.

An approximation of the level to which rainfall would have to diminish before Lake Rotorua falls below overflow may be indicated by present-day water balance studies (R.E. Murray pers. comm.). During the period 1953-78, the mean discharge from Lake Rotorua (at Ohau Channel) was $18.9 \mathrm{~m}^{3} \mathrm{~s}^{-1}$, equivalent

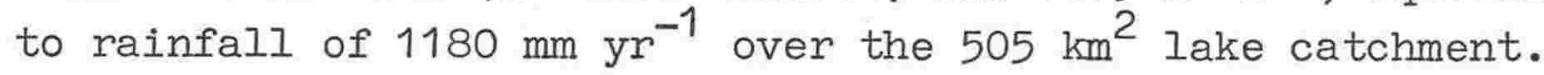
Actual mean rainfall over the catchment during this period was $1800 \mathrm{~mm} \mathrm{yr}^{-1}$, so that evaporation and transpiration losses 


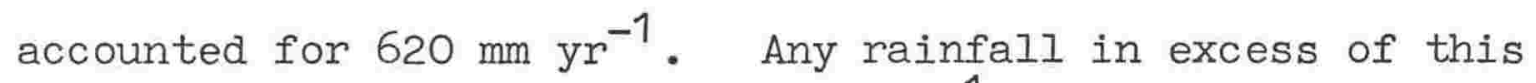
evapotranspiration figure $\left(620 \mathrm{~mm} \mathrm{yr}^{-1}\right)$ would therefore result in lake overflow. During the cold climatic conditions inferred to have existed at time of the Okareka Ash eruption, both evaporation and transpiration would have been below present day values. Overflow of Lake Rotoma would have ceased only if precipitation fell below $620 \mathrm{~mm} \mathrm{yr}^{-1}$, or to less than $34 \%$ of present mean rainfall.

Actual long-term precipitation during the period of low Rotorua lake level is unknown, although it was probably less than present levels during the glacial maxima (i.e. Flint 1971, Gates 1976, M. McGlone 1980, written comm.). It seems unlikely however, that precipitation would have been reduced to less than $34 \%$ of the present day mean. Manley (1951) has derived a theoretical value of $80 \%$ of present day values for precipitation on British highlands during glacial maxima. Heusser et al (1980) have interpreted Quatemary precipitation values for the north-west coast of North America from pollen records. These records indicate that annual precipitation values during the period 20-13,000 yrs B.P. exceeded $50 \%$ of the present day rainfall. If similar values hold for the Lake Rotorua catchment then overflow of Lake Rotorua should have continued through the period of low lake levels. This conclusion is strongly supported by the continuing low levels of Lake Rotorua both at time of the Rotorua Ash eruption, and prior to 8600 yrs B.P. (Fig. 48). By this time, climate in the Rotorua area had considerably improved with temperatures close to present day values after the 15,000 yr B.P. Rerewhakaaitu Ash eruption (Birrell and Pullar 1973). Rainfall should also have been close to present values, yet Lake Rotorua could not have been overflowing at Okere prior to 8600 yrs B.P.

Lake Rotoiti

Western Lake Rotoiti occupies the drowned drainage channel from Lake Rotorua to Haroharo Caldera. To east the lake covers the caldera moat between the Haroharo lava flows and the eastern and northern caldera rim (Fig. 49). Growth of the Haroharo 
Volcanic Complex blocked the initial southward drainage paths, and spilled Rotorua drainage to the north. Lake Rotoiti has thus formed within the last 20,000 years and had reached its present shape at end of the c. $7500 \mathrm{yr}$ B.P. Mamaku Eruptive Episode (Fig. 49). There is no evidence of much higher past lake levels at Rotoiti.

Lake Rotoehu

This shallow lake occupies a closed basin lying across the northern Haroharo Caldera rim. The northern part of the lake is external to the caldera and consists of drowned valleys (Fig. 50) formed by deep erosion of soft Rotoiti Breccia and Mangaone Sub-group Pyroclastics. The southern part of the lake lies within Haroharo Caldera, bounded by ha1 rhyolites to east and west (Map 2). Initial southward drainage across the caldera floor was blocked by Holocene extrusion of the Te Pohue and Kaipara lavas (Fig. 49). The lake has been in existence for at least the last 9000 years and has been largely infilled with pyroclastics associated with the Te Pohue and Kaipara Lavas. There is no evidence for higher past lake levels. Crossbedded "lacustrine sediments" mapped at $330 \mathrm{~m} \mathrm{a.s.l.} \mathrm{to} \mathrm{north} \mathrm{of} \mathrm{Lake}$ Rotoehu (and Rotoiti) by Healy et al (1964) are now recognised as very large pyroclastic surge deposits associated with the Mangaone and Omataroa pyroclastic eruptions, and were not deposited in water. The present lake would overflow to Rotoiti if it rose $10 \mathrm{~m}$ above its present level at $295 \mathrm{~m} \mathrm{a.s.1.,} \mathrm{and} \mathrm{to}$ north at slightly higher lake levels. Major overflow to north has never occurred.

\section{Lake Rotoma}

Lake Rotoma occupies Rotoma Caldera(?) which originally drained west into the adjacent Haroharo Caldera through a channel now occupied by the 9000 yr B.P. Rotoma Lava Flow (Figs.49, 50). The lake formed after the Rotoma Eruptive Episode, and now drains by subterranean flow west to Lake Rotoehu, and east to the Waikanapiti Stream (Taylor et al 1977). 


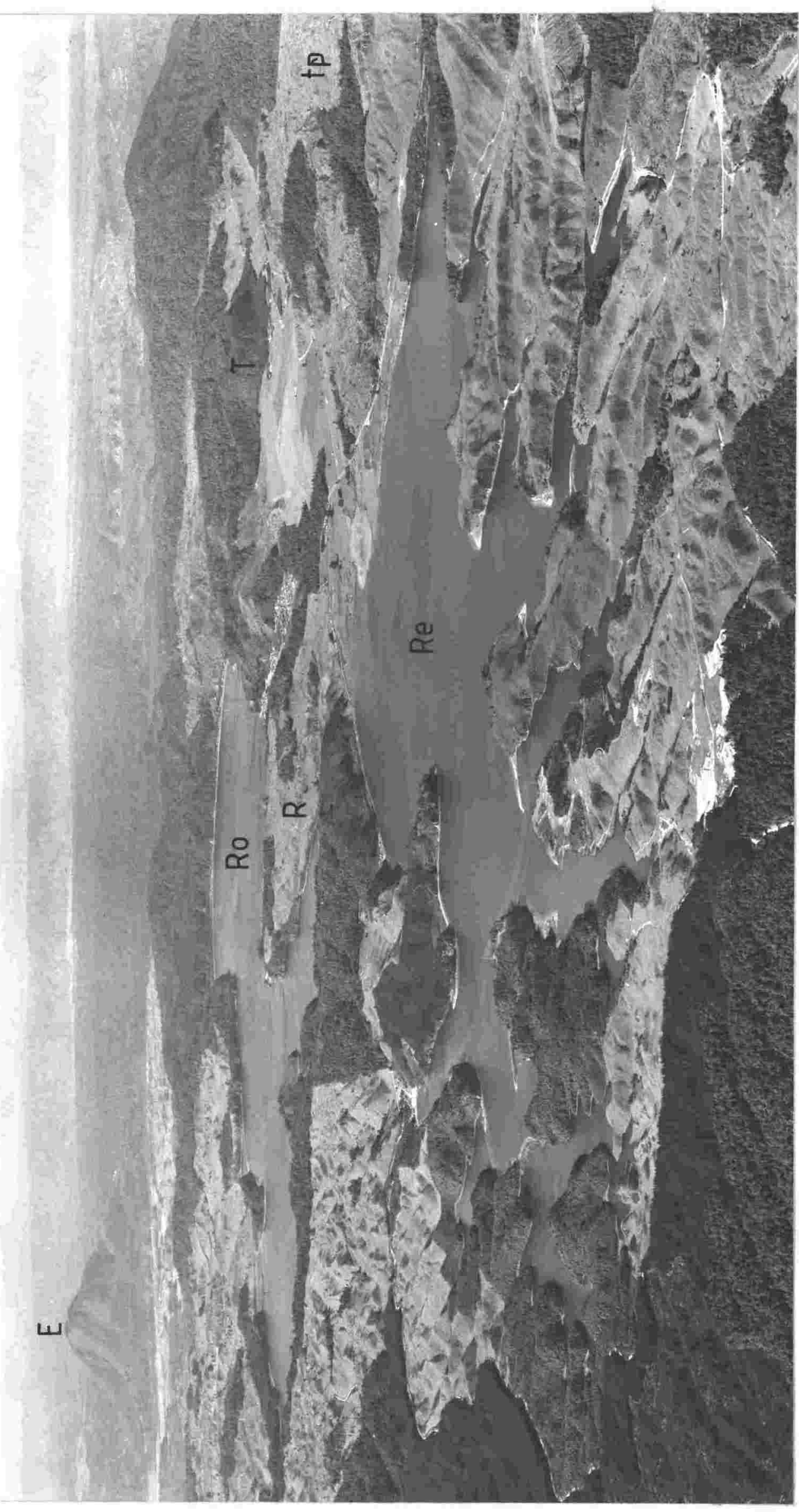

$\infty$

<

万 $\frac{5}{\pi}$

용응

음

है.

可.

$\therefore$

$\checkmark$ 흥

틍.

넝

$\simeq$ 잉

을

엉잉

틍ㅇㅇ응

군

4 .

ए

ro.

암

으나

is 1

- $\frac{1}{1}$

(4) 잉

$\cong 0$ u

곤

롱

단

눙

$x \simeq$

웡

ㄸ.

궁

4 6.

in in

近

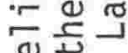

ᄃิ잉

을 응

모

드

응 n

규

넌

뭉

동

등응

융

岕 
Lake Okataina

This lake occupies a deep closed basin in the moat between the western caldera rim and the Te Koutu (c. 19,000 yrs B.P.) and younger Haroharo lava flows. Drainage from the Okataina catchment flowed south into Lake Tarawera basin before extrusion of Te Horoa Dome and the Otangimoana and Rotoroniu Lava Flows blocked this channel. The present lake is thus at least c. 5500 , and probably c. 7500 years old (see Fig. 49). Sediments which outcrop at up to $411 \mathrm{~m} \mathrm{a.s.1.} \mathrm{to} \mathrm{north} \mathrm{of} \mathrm{the} \mathrm{lake} \mathrm{(Map} \mathrm{1),}$ occupy an earlier-formed basin between the Te Koutu/Haumingi lava flows and Whakapoungakau Dome. This early basin lies outside Haroharo Caldera, and the sediments do not indicate a high past level of Lake Okataina, which would overflow past the Te Horoa extrusion at levels less than $350 \mathrm{~m}$ a.s.I. Seepage outflows to Lake Tarawera at $13 \mathrm{~m}$ lower elevation are assumed.

Lakes Okareka, Tikitapu, and Rotokakahi

These lakes occupy drowned valleys between rhyolite domes and ignimbrites, on the margins of the Okareka Embayment to Haroharo Caldera. The valleys previously drained to Lake Tarawera, but were dammed by extrusion of the Trig 7693 rhyolite lavas (Nairn 1980) forming the Lake Okareka basin during the Te Rere Eruptive Episode at c. 19,000 yrs B.P. (Fig. 49), and the Tikitapu and Rotokakahi basins during the Rotorua Eruptive Episode at c. 13,800 yrs B.P. Small terrace remnants around Lake Okareka include reworked Rotorua Ash, indicating that lake level rose to approximately $10 \mathrm{~m}$ above its present level after the Rotorua Eruptive Episode. Lakes Okareka and Tikitapu occupy natural closed basins (at present levels), although an artificial overflow channel has been constructed at Okareka. Rotokakahi overflows naturally into Lake Tarawera.

\section{Lake Rotomahana}

Origin of this lake is discussed in Nairn (1979), see p.234 of this thesis. Prior to the 1886 Tarawera-Rotomahana emption the Rotomahana catchment drained to Lake Tarawera. Since the eruption, Rotomahana has only overflowed at times of maximum lake levels in 1973. 
Lake Rerewhakaaitu

This lake occupies a shallow eroded basin extending south from a small embayment in the southern Haroharo Caldera rim. Awaatua Bay (Fig. 8) is a small explosion crater (c. 10,000 yrs B.P. see p. 65) on the western shore, but the lake was formed by pyroclastic flows from Tarawera (Fig. 17) infilling the northern outlet channel through the caldera rim. Initial blockage was probably caused by the c. 11,000 yr B.P. Waiohau Pyroclastics (Fig. 17), with further damming to present levels by the Kaharoa pyroclastic flows.

Blockage of the northern outlet has forced surface overflow of Lake Rerewhakaitu (at times of high lake level) south-east into the Rangitaiki River system, and away from Haroharo Caldera. A small seepage flow occurs north into the Rotomahana catchment.

Lake Tarawera and the Tarawera River

Lake Tarawera is dammed between the post-20,000 yr B.P. rhyolites extruded at Tarawera, Haroharo and Okareka, and the older (pre-50,000 yr B.P.) Tutaeheka rhyolites and Moura Block ignimbrite on the south-west lake shore (Map 2). The Central Basin of the lake at $210 \mathrm{~m} \mathrm{a.s.1.} \mathrm{may} \mathrm{reflect} \mathrm{the} \mathrm{deeply} \mathrm{sediment-}$ buried caldela floor. The Tarawera River drains between the Haroharo and Tarawera massifs to pass through the Haroharo Caldera rim at an elevation of $130 \mathrm{~m}$ a.s.l. in the Te Haehaenga Basin. This basin occupied the lowest area within Haroharo Caldera and provides a maximum elevation for the post-Rotoiti Breccia caldera floor. These relative elevations suggest a sediment thickness exceeding $90 \mathrm{~m}$ under Central Basin, deposited within the last 20,000 years.

By 17,000 yrs B.P. the caldera floor had become partly infilled by the Hawea and Ridge Lava flows from Tarawera Volcanic Complex on the south-eastern Lake Tarawera margin, the earliest Okareka Lavas on the western lake margin, and the Te Koutu and Haumingi Lavas on the north-western margin (Fig. 49). The 15,000 yr B.P. Rotomahana, Southern, Western, and Te Puha lavas 
then infilled the southern caldera floor, followed by the 11,000 yr B.P. Waiohau Pyroclastics, Waikakareao, and Pokohu Lavas (all from Tarawera Volcanic Complex). These latter eruptives extended north into the Te Haehaenga Basin beneath Maungawhakamana, forcing the Tarawera River to north of its present location (Fig. 49). By this time also, the level of the ancestral Lake Tarawera must have risen considerably from its pre-20,000 yr B.P. level below about $210 \mathrm{~m} \mathrm{a.s.1.} \mathrm{The} \mathrm{northern} \mathrm{lake} \mathrm{shore} \mathrm{was} \mathrm{then} \mathrm{modified}$ by extrusion of the c. $7500 \mathrm{yr}$ B.P. Ruakokopu and Te Matae Lavas, followed by the 5500 yr B.P. Tapahoro Lavas (all from Haroharo) which finally confined the river into the present channel. Extrusion of the Tapahoro Lava Flow caused a rise in lake level exceeding $30 \mathrm{~m}$. A tree found in vertical growth position at $30 \mathrm{~m}$ depth off the western shore of Lake Tarawera has given a ${ }^{14} \mathrm{C}$ age (Table 2) of 5860 190 years B.P. (s.corr.). The age dates a rise in lake level which drowned the tree after the Tapahoro Lava Flow deflected outlet drainage to south, onto the Pokohu Lava Flow (Fig. 49). Previously outflow had been at lower elevation around the northern margin of the 11,000 yr B.P. Pokohu Flow, in a channel between this flow and the margins of the c. 7500 yrs B.P. Ruakokopu and Te Matae Lavas from Haroharo (Fig. 49). Pyroclastics of the Whakatane Eruptive Episode would have further raised lake level above the present lavacontrolled outlet channel so that the lake would have stood at higher than present levels.

Small terraces of Holocene age occur on the western shore of Lake Tarawera at up to $20 \mathrm{~m}$ above present lake level (i.e. at $320 \mathrm{~m} \mathrm{a.s.1.)}$ and record a brief high stand of lake level before a pyroclastic dam was removed. A similar high stand of lake level followed the Kaharoa Emuptive Episode. An extensive alluvial terrace extends down the Tarawera River from below the Tarawera Falls to Kawerau, and was formed by a catastrophic lahar following collapse of a Kaharoa pyroclastic dam.

A similar but smaller lahar followed the 1886 eruption of Mt. Tarawera, when the outlet of Lake Tarawera was blocked by volcanic debris, and the lake rose to about $12.8 \mathrm{~m}$ (Bell 1906) 
above its pre-eruption level. On November 1, 1904, at a time of high rainfall and lake level, the lake overtopped this barrier and flooded down-river. The lake fell $1 \mathrm{~m}$ in one day and on November 3, 1904, the barrier was carried away and a flood of $700 \mathrm{~m}^{3} \mathrm{~s}^{-1}$ went down the river (Maclaren 1906). The peak flood flow at Kawerau has been more recently estimated (Rotorua Ministry of Works files, 1954) as $786 \mathrm{~m}^{3} \mathrm{~s}^{-1}$ at a section near the Pulp Mill water filtering tanks, and the channel capacity of the Tarawera River in the Kawerau area as about $425 \mathrm{~m}^{3} \mathrm{~s}^{-1}$ (H.J. Freestone pers. comm.). The 1904 flood crossed the terrace at the site of Kawerau, as the upper metre of material on the terrace locally consists of pumice mixed with Tarawera Ash and scoria. A total drop in lake level of $3.35 \mathrm{~m}$ was measured in 1906.

Puhipuhi Basin Outflow Channel

During the post-22,000 yr B.P. period when Lake Rotorua was draining into Haroharo Caldera, the catchment above the Tarawera River outlet from Puhipuhi Basin occupied twice its present day area (see Table 9). The present surface catchment area above the outlet to Puhipuhi Basin is $463 \mathrm{~km}^{2}$. To this can be added seepage flows from the closed lake basins - Okataina, Tikitapu, Rotomahana, and Rerewhakaaitu, which are all adjacent and higher to the Tarawera system, to give a total present day surface and subterranean catchment of $\mathrm{c} .700 \mathrm{~km}^{2}$. At 20,000 yrs B.P. all these closed lake catchments drained by free surface flow into Haroharo Caldera and the Puhipuhi Basin, as did the present catchment areas of Lakes Rotorua, Rotoiti, Rotoehu, and Rotoma. At this time the total catchment area above Puhipuhi outlet was c. $1400 \mathrm{~km}^{2}$ (Table 9). Extrusion of the Haroharo lava pile diverted the surface Rotorua discharge from Haroharo Caldera, together with the discharges from the northern subcatchments of the caldera now draining into Lakes Rotoiti, Rotoehu, and Rotoma (see Fig. 47). Rotoma now seeps east into springs feeding the Waikanapiti Stream and west to Lake Rotoehu. Rotoehu seeps north towards the Pongakawa Stream and west to Lake Rotoiti and thence the Kaituna River. The effect has been to divert much of the previous northem Haroharo Caldera surface 
TABLE 9 - Comparison of the catchment area above outlet to Puhipuhi Basin, at present day, and at 20,000 yrs B.P. See text for details.

Present day catchment areas $\quad \mathrm{km}^{2}$

Tarawera River (Lake Tarawera

outlet to Puhipuhi Basin outlet)

Lake Tarawera

Lake Rotokakahi

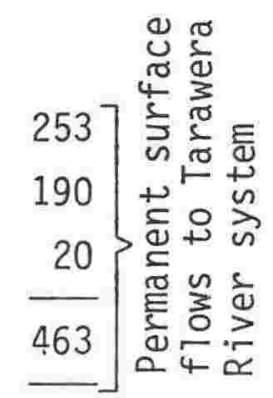

Lake Okareka

Lake Okataina

Lake Tikitapu

Lake Rotomahana

Lake Rerewhakaaitu

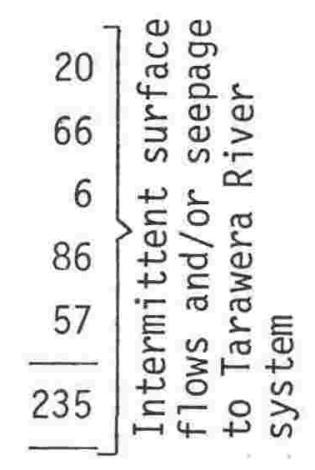

20,000 yr B.P. catchment areas $\mathrm{km}^{2}$

$\underline{\text { Tota } 1}$

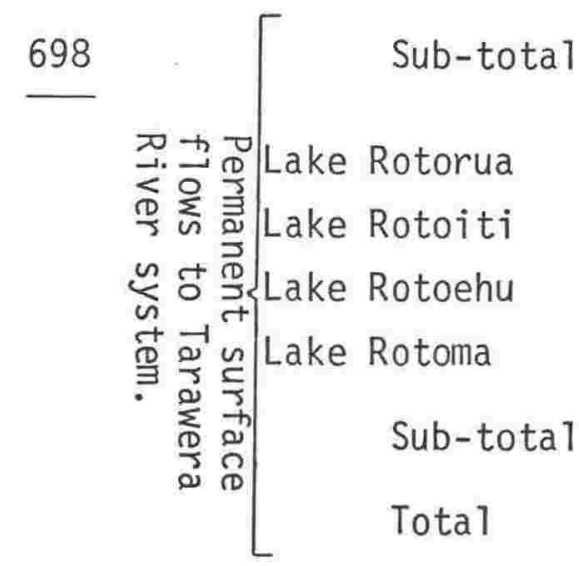

698 
drainage away from the Tarawera River. Since c. 11,000 yrs B.P., the Lake Rerewhakaaitu catchment has overflowed to east (at times of high lake level) to the Rangitaiki River catchment, rather than north into Haroharo Caldera. Although some seepage occurs west into Lake Rotomahana from Rerewhakaaitu, and from Rotomahana into Lake Tarawera, the absence of surface flows must have considerably reduced peak discharges into the Tarawera River catchment. Similarly, although the other closed lakes - Tikitapu, Okareka and Okataina undoubtedly seep into Lake Tarawera, the damming of surface discharge channels and creation of lakes must have considerably increased evaporation losses from the increased water surface areas. Considering the halving of the catchment area, and the reduction in peak flood flows caused by the formation of closed lake basins, the present maximum outflows from Puhipuhi Basin are likely to be about half the maximum flows which occurred sometime between c. 22,000 and 7000 yrs B.P. Such a decrease in river flows would account for the "underfit" appearance of the Tarawera River where it flows through the welldefined channel cut in Matahina Ignimbrite between Puhipuhi Basin outlet and Kawerau. This $0.5 \mathrm{~km}$ wide channel was cut to size during the period of maximum river flow associated with capture of Lake Rotorua drainage. 


\section{A: REGIONAL RESOURCES}

Introduction

The sequential eruption of at least $500 \mathrm{~km}^{3}$ of rhyolite magma from O.V.C. during the last 250,000 years, $160 \mathrm{~km}^{3}$ of which was erupted during the last 50,000 years, $80 \mathrm{~km}^{3}$ during the last 20,000 years, and $5 \mathrm{~km}^{3}$ during the last 1000 years Tables 6,7 ) demonstrates that a large magmatic heat source should continue to underlie Haroharo Caldera. Bodies of silicic magma have been considered the most effective cause of nearsurface thermal anomalies, because they are presumed to reside in shallow and long-lived reservoirs more commonly than do mafic magmas (Smith and Shaw 1975, 1979; Duffield et al 1980). However, relatively little surface hydrothermal activity occurs in Haroharo Caldera, with minor fields at Lake Okataina, Lake Tarawera, Lake Rotoehu, Lake Rotoma, and at Tikorangi (Map 3). Weak fumarolic activity occurs in three localities in the 1886 Rift on Tarawera Volcano, and small areas of warm springs occur in the Waiaute and Mangakotukutuku Stream valleys (Map 3). The largest identified thermal feature within Haroharo Caldera is a major hot spring area recently discovered on the floor of Centre Basin in Lake Rotoiti (Calhaem 1973). Intense thermal activity also occurs on the west shore of Lake Rotomahana, and other activity is submerged under that lake.

The surface hydrothermal manifestations within Haroharo Caldera appear so small that possible connections to the large external fields at Waimangu, Waiotapu, Kawerau, and Tikitere, require investigation. The Rotomahana, Waimangu, and Waiotapu thermal areas are closely associated with the south-west extension of the Tarawera vent lineation and 1886 Rift (Map 3), and might represent an outflow of geothermal fluids from a magmatic heat source associated with the Tarawera Volcanic Complex. Kawerau Geothermal Field lies at the north-east end of the Tarawera vent lineation, and might also represent a deep outflow from Tarawera (or Puhipuhi Basin), although deep drilling has shown Kawerau to overlie an older volcanic complex, which may form a local heat source. Little hydrothermal activity 
appears related to the Haroharo Volcanic Complex vent lineation, unless the Tikitere and Lake Rotoiti fields are related to a Haroharo heat source.

Of the geothermal fields associated with O.V.C., reasonably complete multidisciplinary investigations have been completed only for Kawerau, Tikitere, and Waiotapu areas. These investigations include surveys of geology, the chemical and isotopic analysis of hot spring and well discharge fluids, and geophysical surveys. Electrical resistivity surveys have proved to be the most valuable geophysical technique for delineating hot water geothermal systems in New Zealand (Hatherton et al 1966), the presence of hot mineralized fluids underground being signalled by low resistivity anomalies measured at the surface. Resistivity surveys have been carried out at Kawerau (Macdonald \& Muffler 1972), Tikitere (Macdonald 1974), and on parts of the western and south-western O.V.C. boundaries (G. Dawson, pers. comm. 1980) (Map 3). A single traverse has also been carried out on State Highway 30 between Rotoma and Rotoiti. However, most of O.V.C. has not been covered by resistivity surveys, so that the existence of geothermal systems in unsurveyed areas is presently indicated only by the occurrence of surface hydrothermal features.

Electrical resistivity surveys delineate the extent of a geothermal system; an appreciation of its magnitude can be obtained by measuring the total heat and mass flows from the system to the ground surface. The natural heat flow represents the minimum exploitable energy of the system (Ellis and Mahon 1977). Surface heat flows have been measured by physical techniques (i.e. Dawson and Dickinson 1970), requiring detailed measurements of heat loss by conduction, convection, evaporation, and direct discharge from individual thermal features. Such measurements have been carried out for the Tikitere, Kawerau, and Waiotapu Geothermal Fields, but have not been carried out at the other O.V.C. thermal areas. In areas where heat flow and resistivity surveys have not been carried out, an indication of the existence and minimum size of geothermal fields can be 
obtained from chemical contents and chloride fluxes in lake and river waters.

Hydrothermal Fields Associated with O.V.C.

Lake Okataina hydrothermal activity: Hydrothermal activity is known only on the eastern lake shore (Map 3), to south of Oruaroa where gas bubbles (dominantly $\mathrm{CO}_{2}$ ) rise in the lake, and seepage of warm water at $30-36^{\circ} \mathrm{C}$ occurs through the beach sands at times of low lake level (Thompson 1971; Glover 1974; writer's observations 1978). The surface manifestations are very small, but higher than normal conductive heat flow values were measured offshore in the adjacent Otangimoana arm of the lake (Calhaem 1973).

Lake Tarawera hydrothermal activity: Hydrothermal activity is known in three areas of Lake Tarawera (Map 3).

Calhaem (1973) found an area of higher than normal conductive heat flow through the floor of the lake in the Humphrey ${ }^{\prime} \mathrm{s}$ Bay area, adjacent to the south-eastern shore of Te Horoa lava dome. Healy (1975a) reports that warm water was encountered by a drillhole at head of this bay, and a warm spring exists on the lake shore (Healy pers. comm.). These minor hydrothermal manifestations, plus those at Lake Okataina, are the only known surface activity associated with the south-west to central part of the Haroharo vent lineation. Preliminary surveys have found isolated small areas of moderately low resistivity ( $<50 \mathrm{ohm} \mathrm{m}$ ) on the western shore of Lake Tarawera (see Map 3), suggesting the presence of mineralized water at depth, but no surface activity is known in this area.

Slightly warm springs, with deposition of iron, occur just below lake level on the toe of the Te Puha lavas, on the southeastern shore of Lake Tarawera (Map 3).

The only intense surface thermal activity at Lake Tarawera occurs on the shore at Te Rata, extending over $1.5 \mathrm{~km}$ between the mouth of the Waima Stream and Rapatu Bay where it is 
associated with the two arms of the bifurcating Paeroa Fault (Map 3). Spring temperatures range from $37-90^{\circ} \mathrm{C}$ (Nairn 1974). Most springs discharge within $1 \mathrm{~m}$ above lake level, but high lake temperatures along the shore indicate that considerable seepage probably occurs below the lake surface. A moderately high conductive heat flow value was measured offshore by Calhaem (1973). No measurement of the onshore natural surface heat flow has been made, but it is probably of order 10 MW (Nairn 1974). Preliminary results of chemical analyses show the springs discharge near-neutral $\mathrm{pH}$ water with a moderate chloride content (130-425 $\mathrm{mg} \mathrm{I}^{-1}$, R.B. Glover pers. comm.).

Lake Rotoiti hydrothermal activity: Lake floor heat flow studies by Calhaem (1973) revealed the occurrence of high temperatures and heat flows in the Centre Basin area of Lake Rotoiti (Map 3). Centre Basin lies inside the Haroharo Caldera rim crossing Lake Rotoiti. It also lies close to the inferred north-east extension of a fault which forms the south-eastern boundary of the Tikitere Graben. Depths exceed $70 \mathrm{~m}$ in several parts of Centre Basin, the two southernmost forming $90 \mathrm{~m}$ and $120 \mathrm{~m}$ deep sub-circular depressions (Calhaem 1973) which appear to be craters. As they have not been infilled with sediment the craters must be fairly young, postdating the 22,000-19,000 yr B.P. excavation of the drowned valleys now occupied by the western arm of Lake Rotoiti. The arcuate trend suggested by location of the deeps and areas of highest heat flow are sub-parallel to the inferred caldera rim and the deeps may be located over a caldera ring fault.

The area of very high conductive heat flow is confined to Centre Basin and occupies about $2 \mathrm{~km}^{2}$. The greatest sediment temperature and thermal gradient recorded by Calhaem were $130^{\circ} \mathrm{C}$ and $63^{\circ} \mathrm{C} \mathrm{m}^{-1}$ respectively, suggesting that boiling-point-fordepth temperatures would be reached at a depth of $2.6 \mathrm{~m}$ in the sediment. Temperature inversions were commonly recorded in the bottom water, and the heat flow probe commonly smelt strongly of $\mathrm{H}_{2} \mathrm{~S}$ gas when recovered from the Centre Basin floor. Collected gas bubbles contained $\mathrm{CH}_{4}$ and $\mathrm{H}_{2}$, having lost $\mathrm{CO}_{2}$ 
by passing through $90 \mathrm{~m}$ of lake water. Isotope composition is the same as most gas samples from the Tikitere Geothermal Field (Lyon 1977).

Because the lake water becomes stratified after mixing during winter overturn, the hypolimnion (bottom water layer) acts as a natural calorimeter. Any large increase in hypolimnion temperature during the period of lake stratification is due to geothermal heat flow through the lake floor. From measurements of rate of hypolimnion temperature increase with time and calculation of hypolimnion volume, Calhaem (1973) estimated the mean heat input to the lake as $140 \mathrm{MW}$. This heat input requires a mean conductive heat flow much higher than that measured in the bottom sediments, so that most heat must be entering the lake by convection. A ratio of convective to conductive heat transfer of about 14:1 was calculated, equivalent to $0.3 \mathrm{~m}^{3} \mathrm{~s}^{-1}$ of boiling water flowing into the floor of Centre Basin. The occurrence of convective heat flow at some stations in Centre Basin was verified by measurements of temperatures at depths of $1.8 \mathrm{~m}$ in the sediment which were greater than expected from the temperature gradients (Calhaem 1973). No samples have been obtained of the hot water entering Centre Basin. Because the areas of high heat flow coincide with the deepest parts of the lake, the deeps may be intercepting sub-horizontal flows of hot water.

Resistivity, magnetic, and gravity surveys cover the western Lake Rotoiti area (Macdonald 1974), including some resistivity measurements made on the lake floor. However no resistivity results have been published for the Centre Basin area (Map 3).

Occasional reports of fish kills, water upwellings, and sulphurous gas emissions, have been associated with the area to south of $\mathrm{Te}$ Papatu Pt in eastern Lake Rotoiti, suggesting that some thermal activity may occur in that area also. However Calhaem found no areas of high conductive heat flow in this area, and more recent reconnaissance investigations by B.J. Scott and the writer have not found elevated lake floor 
temperatures.

A number of shallow wells have been drilled on the lake shore at Hauparu Bay, $1 \mathrm{~km}$ to south-west of the Centre Basin thermal area (Map 3), and lying between Centre Basin and the Tikitere Geothermal Field. The deepest well at N76/870151 [U15/092450] reached temperatures of $91^{\circ} \mathrm{C}$ at $330 \mathrm{~m}$ (c. $-20 \mathrm{~m}$ a.s.l.), while the other wells have not exceeded $75^{\circ} \mathrm{C}$ at depths reaching $220 \mathrm{~m}$. The Hauparu wells probably tap ground waters heated by steam which has travelled a considerable distance (Klyen 1970). However the relatively low well temperatures suggest that the much hotter Centre basin waters, which emerge from the lake floor at 160-190 m a.s.I., cannot originate as a subhorizontal shallow outflow from the Tikitere Geothermal Field further to south-west. An alternative source for the hotter waters may lie beneath the Haroharo Volcanic Complex to southeast of Centre Basin.

Other hot springs on the south and north shores of western Lake Rotoiti lie outside Haroharo Caldera, and are described as part of the Tikitere Geothermal Field.

Lake Rotoehu hydrothermal activity: Local residents report warm seepages in sand along the eastern shore of Te Wairoa Bay at Lake Rotoehu (Map 3), at times of low. lake level. This area is located on the Haroharo Caldera rim, as are the adjacent Waitangi springs. These springs are described below as part of the Rotoma Geothermal Field.

Rotoma Geothermal Field: The Rotoma Geothermal Field (Map 3) consists of the Waitangi Springs, solfataric activity at Tikorangi, and a warm spring and drillhole at Lake Rotoma (Nairn 1974). The hydrothermal activity at both Waitangi Spring and Tikorangi was briefly described by Grange (1937). Healy (1969) reported on geology, structure, and hydrothermal activity associated with the Tikorangi sulphur deposits. Five sulphur prospecting holes were drilled in 1969 (Utting 1969). 
The main Waitangi Spring lies only a few metres from the shore of Lake Rotoehu, close to the point of tangential convergence of the eastern margin of Haroharo Caldera with the Rotoma Caldera(?). The spring emerges at the western end of a swamp area where large (cold) springs and seepages rise. Stable isotope data and correlation of spring flows with lake levels shows that most swamp outflow comes by seepage from Lake Rotoma (Taylor et al 1977).

The Haroharo Caldera margin extends south to the $4600 \mathrm{yr}$ B.P. Tikorangi rhyolite dome, extmuded on the caldera rim. A broad valley lies between the ha1 rhyolite of the eastern caldera margin and the Holocene Kaipara and Te Pohue lava flows of the Haroharo Volcanic Complex to west. The Tikorangi solfataras lie at the north-west foot of Tikorangi Dome and about $1.2 \mathrm{~km}$ to south-west of the dome, on the margins of the Haroharo lavas (Map 3 and Fig. 50).

Both the Waitangi Spring and Tikorangi hydrothermal area lie just beyond the flow margins of the Haroharo Volcanic Complex. Few surface streams flow off the complex, due to high permeability of the rhyolite lavas. Most of the precipitation which falls on the complex is inferred to flow radially outwards underground, to rise as springs near the lakes to the north and west, and the Tarawera River to the south.

The Waitangi Spring is a clear, weakly acid pool ( $\mathrm{pH}$ 5.6), with an outflow in 1973 of $0.0531 \mathrm{~m}^{3} \mathrm{~s}^{-1}$ at $49.5^{\circ} \mathrm{C}$ (H.J. Freestone pers. comm.), equivalent to a heat flow of 7 MW relative to $15^{\circ} \mathrm{C}$. The spring discharges chloride-bicarbonate water, containing $365 \mathrm{mg} \mathrm{I}^{-1}$ chloride and $278 \mathrm{mg} \mathrm{I}^{-1}$ bicarbonate. Sulphate is low. A stream which flows past the Waitangi Spring from the south-east has a flow of $0.0372 \mathrm{~m}^{3} \mathrm{~s}^{-1}$ at $25^{\circ} \mathrm{C}$, while a spring on the south edge of the swamp has a flow of $0.0113 \mathrm{~m}^{3}$ $\mathrm{s}^{-1}$ at $27.5^{\circ} \mathrm{C}$. The temperature of the seepages in the swamp also appears to be elevated, perhaps to about $22^{\circ} \mathrm{C}$ (H.J. Freestone pers. comm.). The position of these eastern springs suggests that they may be obtaining heat from beneath the 
adjacent young Rotoma rhyolite extrusion; alternatively, the Waitangi Spring is likely to have a heat source beneath the Haroharo Complex, the hot water rising on the caldera margin.

Solfataric activity at Tikorangi occurs as warm sintersulphur pans to the north-west of Tikorangi Dome, where slight emission of $\mathrm{H}_{2} \mathrm{~S}$ gas is occurring and there are a few small patches of active sulphur deposition with temperatures up to $97^{\circ} \mathrm{C}$ measured in 1969 (Healy 1969). Two similar sinter-sulphur pans occur at the foot of the Haroharo lava flow margin to the south-west (see Map 3), with only slight $\mathrm{H}_{2} \mathrm{~S}$ gas apparent, and no fresh sulphur deposition. The main area of activity is to the south where an extensive bare area of slipped hydrothermally altered ground contains some small fumaroles with temperatures exceeding $90^{\circ} \mathrm{C}$, and patches of steaming ground with active sulphur and alum deposition. The lava cliff above is also hydrothermally altered, and contains steam vents depositing sulphur for some distance up the face. All the hydrothermal activity at Tikorangi is confined solely to the emission of steam and gas and deposition of sulphur.

Small warm springs (Otei Springs) have been reported on the southern shore of Lake Rotoma, but in recent years have been below lake level. Wells at Stillwater Lodge, Rotoma, are pumped to obtain bicarbonate water at $35^{\circ} \mathrm{C}$.

No geothermal investigation holes have been drilled at either Tikorangi or Waitangi Springs; however 5, sulphur prospecting holes were drilled to depths between 30 and $70 \mathrm{~m}$ at Tikorangi in 1969 (Utting 1969). A temperature of $102^{\circ} \mathrm{C}$ at $30 \mathrm{~m}$ depth was encountered by a hole near Tikorangi Dome (Map $3)$, while another hole between the sulphur pans below the Haroharo lava flow margin encountered steadily increasing (but unspecified) temperatures to $30 \mathrm{~m}$ depth. After standing overnight the hole erupted, and steam at $270 \mathrm{kilopascals}$ wellhead pressure precluded further drilling. This pressure indicates a wellhead temperature of $134^{\circ} \mathrm{C}$. No resistivity survey has been made at Rotoma to define the boundaries of the geothermal 
field, but a preliminary single traverse made along S.H. 30 has found some areas of low resistivity at Lakes Rotoehu and Rotoma (H. Rayner pers. comm., 1980).

Tikitere Geothermal Field: Tikitere Field has been the subject of considerable investigation (Klyen 1970, Dickinson 1972, Espanola 1974, Glover et al 1974, Lyon 1977, and Sheppard and Lyon 1979). Data has been previously summarized (Nairn 1974). Investigation drilling may commence at Tikitere in the near future.

Tikitere Field (Map 3) is located to north-west of the O.V.C., within Tikitere Graben trending north-west from Rotorua Caldera. Shallow well drilling during 1980 has shown that Mamaku Ignimbrite is strongly downfaulted by at least $200 \mathrm{~m}$ within the graben. Largely steam heated acid-sulphate surface hydrothermal activity extends from the west shore of Lake Rotokawau north to Lake Rotoiti, where minor, neutral chloride-bicarbonate diluted springs occur at low elevation. Total natural surface heat flow was estimated at $120 \mathrm{MW}$ relative to $12^{\circ} \mathrm{C}$ (Dickinson 1972). Other thermal springs, warm water wells, and patches of altered ground occur on the north shore of Lake Rotoiti. These, and the small Taheke thermal area further to north, are thought likely to be connected to Tikitere Field at depth.

Although the bounding faults of the Tikitere graben are well expressed, no faults have been mapped within the field. However, the shapes of individual areas of hydrothermal activity, alignments of explosion craters, and the elongated low-resistivity anomaly which delineates the field (Macdonald 1974) all parallel the north-east trend of the graben.

The area of Tikitere Geothermal Field has been estimated from resistivity data at c. $10 \mathrm{~km}^{2}$. However, the resistivity anomaly is unclosed north-west into Lake Rotoiti (including the Centre Basin area), and beyond onto the north shore of the lake. The estimated area is thus a minimum, and the north-western boundaries of the field are uncertain. 
Several hydrothermal explosions have occurred at Tikitere during the last 50,000 years. Deposits from two large explosions are interbedded within the pyroclastic fall sequence at Tikitere, where they unconformably overlie paleosols developed on the Rotoiti Breccia, and Rotoma Ash, respectively (Espanola 1974). The explosion breccias do not appear to be directly related to emptive activity at Okataina Volcanic Centre, and they may have been triggered by fluctuating levels of Lake Rotorua following the Rotoiti Breccia eruption (see Part II, B).

Rhyolite domes occupy the north-eastern Tikitere Field. Lithic rhyolite and Mamaku Ignimbrite clasts occur in hydrothermal explosion ejecta from craters in the south-west of the field. Lithic rhyolite ejecta was also erupted from Lake Rotokawau during the c. 4000 yrs B.P. basaltic eruptions. This ejecta composition indicates that much of Tikitere Field is underlain at depth by rhyolite lavas which both pre- and post-date the Mamaku Ignimbrite.

No direct evidence exists as to location of the heat source for Tikitere Geothermal Field. The field is closely associated with both Rotorua and Haroharo calderas, but lies in a separate structure between these two calderas. Further, the field area has been the site of late Quaternary rhyolite extrusion, and could therefore directly overlie a local magmatic heat source. Stable isotope compositions of Tikitere chloride waters fall close to values for local meteoric waters, without evidence of the oxygen isotope exchange commonly observed in other geothermal fields (Sheppard and Lyon 1979). The isotope results provide no evidence as to source of the deep geothermal fluids which have not been sampled at Tikitere.

Tikitere is considered here in some detail because it may be related to an O.V.C. heat source. Confirmation of this hypothesis can come only from drilling in the field to sample the deep fluids, and from deep-penetrating electrical resistivity soundings to examine the area surrounding the surface field. 
Warm Springs: During this study, two previously unrecorded areas of warm springs were located within Haroharo Caldera, both areas associated with large cold water springs. The Mangakotukutuku Springs (Map 3) are located on the eastern margin of the Haroharo Volcanic Complex, where weakly mineralized warm springs occur in the Mangakotukutuku Stream valley (Fig. 51), most on the downthrown side of the Mangakotukutuku Fault. The spring temperatures range from $12^{\circ} \mathrm{C}$ (probably ambient) to $24^{\circ} \mathrm{C}$ in the largest spring. Water analyses are presented in Table 10.

Sample 311 was taken from a cold spring rising in lacustrine sediments overlying the Maungawhakamana (ha1) rhyolite. It represents the regional cold ground water and has a chloride content of $6 \mathrm{mg} \mathrm{l}^{-1}$. Sample 314 is from a cold spring in the Mangakotukutuku group and contains a small increment of hydrothermal water $\left(13 \mathrm{mg} I^{-1} \mathrm{Cl}\right.$ ). The other sampled springs (312, $315,317)$ are all more highly mineralized and indicate an increasing contribution of hydrothermal water mixed with cold shallow groundwater. Chloride contents increase with discharge temperature to $173 \mathrm{mg} I^{-1}$ and $24^{\circ} \mathrm{C}$. The hottest and most highly mineralized spring (317) is sited adjacent to the Mangakotukutuku Fault.

The Waiaute Springs (Map 3) are located on the northern margin of the Tarawera Volcanic Complex, where they outcrop along the north-west toe of the Hawea Lava Flow (Fig. 51). Many cold springs $(405,412,415)$ also outcrop at the toe of this lava flow, and are relatively unmineralized ( $\left.<6 \mathrm{mg} \mathrm{I}^{-1} \mathrm{Cl}-\mathrm{Table} 10\right)$. The warm springs range in temperature from 16 to $23^{\circ} \mathrm{C}$ and in chloride content from 20 to $81 \mathrm{mg} \mathrm{l}^{-1}$. Chloride content again follows discharge temperature. No structural control on location of the Waiaute warm springs is evident.

Both the Maungakotukutuku and Waiaute warm spring areas are associated with very large discharges of cold shallow ground water and the chemistry of the warm spring waters indicates they have undergone considerable dilution (W.A.J. Mahon, pers. comm.). Location of the Mangakotukutuku Springs is controlled 


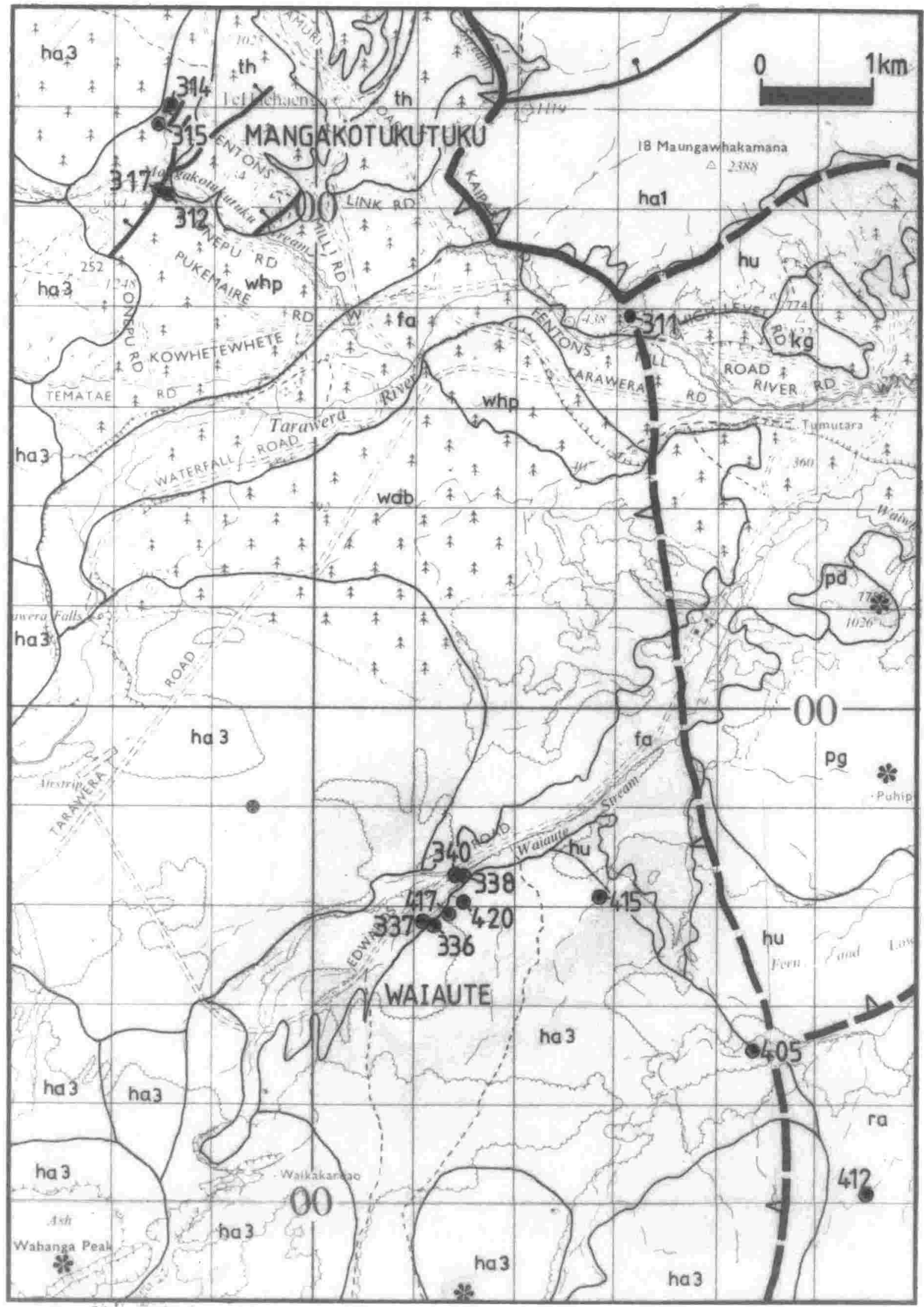

FIG. 51 - Location map for Mangakotukutuku and Waiaute springs on eastern margin of Haroharo Caldera. Geology simplified from Map 1. Note that National Yard Grid appears on this figure - not the metric grid of Maps 1-3. 


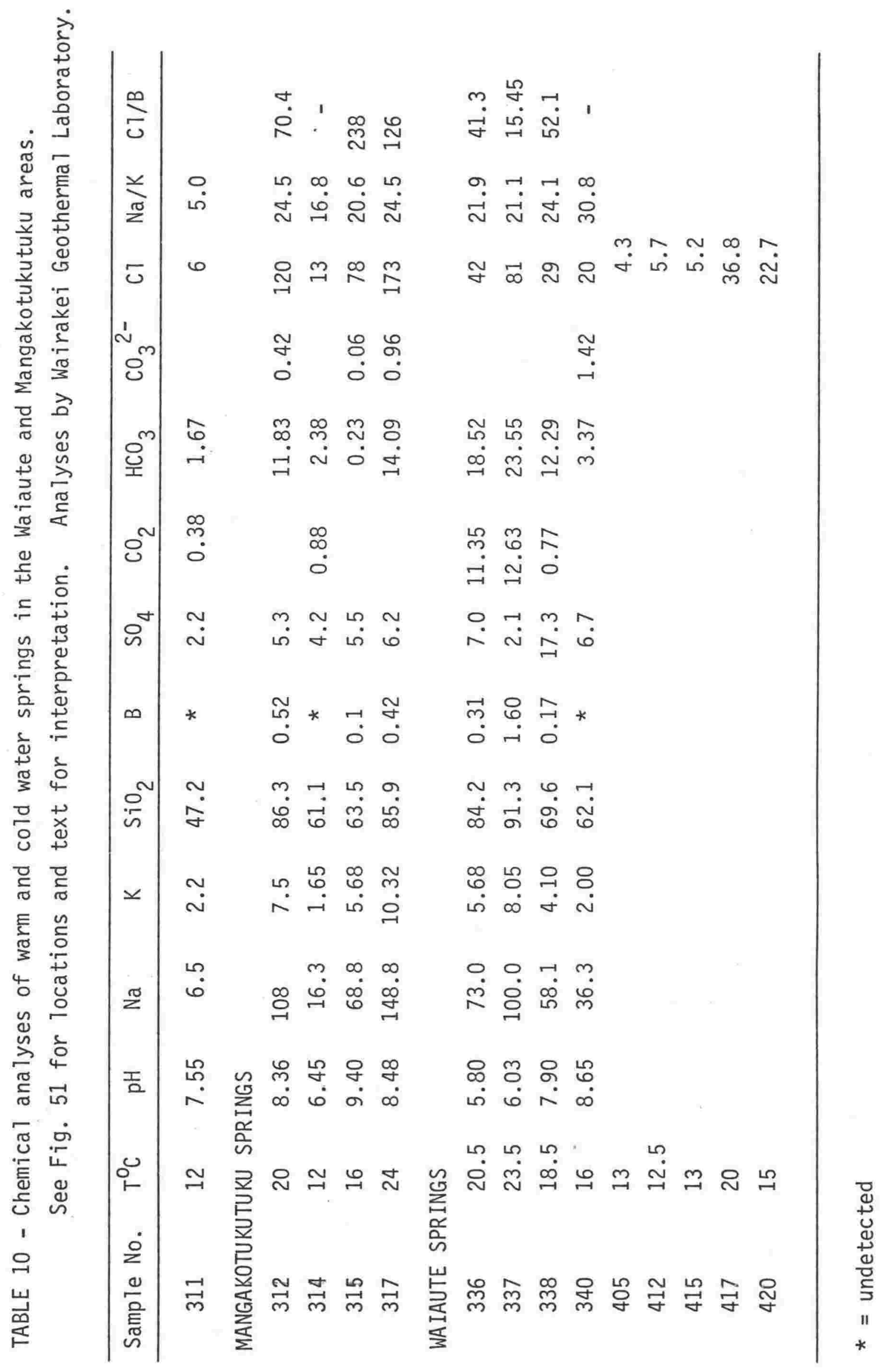


by a recently active fault which provides a path for the upward transfer of fluids from a reservoir of hot chloride waters at depth. The hottest and most highly mineralized springs ( 312 and 317) represent the least diluted deep chloride water, and thus provide the best samples for assessment of deep temperatures from liquid-phase chemical geothermometers (i.e. Ellis and Mahon 1977, Ellis 1979).

Hydrothermal geothermometers are based on chemical equilibria of sufficiently slow reaction rate that surface-discharged waters reflect the equilibrium conditions at depth. Commonly used are the silica concentration and $\mathrm{Na} / \mathrm{K}$ ratio geothermometers (Ellis and Mahon 1977). The ${ }^{\mathrm{T}} \mathrm{SiO}_{2}$ geothermometer is affected by mixing and dilution processes, but the $\mathrm{T}_{\mathrm{Na}} / \mathrm{K}$ alkali geothermometer relies on relative cation concentration ratios which may not be greatly affected by dilution. Using the equation of Truesdell (1975) for concentrations in ppm

$$
t^{O \mathrm{C}}=\frac{855.6}{\log (\mathrm{Na} / \mathrm{K})+0.8573}-273.15
$$

underground temperatures in excess of $150^{\circ} \mathrm{C}$ are indicated at both Mangakotukutuku and Waiaute. (These results must be treated with some reserve due to the inadequacy of the $\mathrm{Na} / \mathrm{K}$ geothermometer when applied to cooler waters - Ellis 1979).

The Mangakotukutuku and Waiaute warm springs represent the highly diluted surface discharge of geothermal waters flowing outwards at depth from the Haroharo and Tarawera volcanic complexes.

Mt. Tarawera Fumaroles: Steam rises from low pressure fumaroles and areas of warm ground in the Tarawera Rift at five adjacent localities in Crater Dome and Tarawera Dome (Map 3). Most thermal features are closely associated with outcrops of the 1886 basalt dikes, and comprise the only solfataric activity remaining in the 1886 craters on Tarawera Volcanic Complex. Fumarole locations and intensities have remained practically constant in recent years, although visible steam emission varies greatly with atmospheric humidity and temperature. Temperatures 
between 55 and $70^{\circ} \mathrm{C}$ were measured in the Crater Dome crater fumaroles in 1973 and 1980. No chemical or isotopic analyses of the Tarawera fumarole emissions have yet been made.

No hydrothermal activity was recorded on Tarawera prior to the 1886 eruption, even though the Kaharoa Eruptive Episode had ended approximately 600 years earlier.

Lake Rotomahana Hydrothermal Field: Prior to 1886, Rotomahana (Map 3) was the most intensely active hydrothermal field in the Rotorua region (Healy 1975a), with many boiling springs, geysers, fumaroles and large sinter terraces (Hochstetter 1864). The Rotomahana area had been the site of many previous small phreatic and magmatic eruptions (see p.120). The hydrothermal field formed the site of the largest craters excavated on the Tarawera Rift during the 1886 eruption and was subsequently the focus of vigorous steam emission before inundation by the present Lake Rotomahana. No survey has been made of present day lake-floor heat flow but the intensity of pre-1886 hydrothermal activity, and the fissuring induced by the eruption suggests that heat flow may be large.

Jolly (1968) found that Lake Rotomahana was up to $3^{\circ} \mathrm{C}$ warmer than Lake Tarawera in winter, both at the surface and at depth. Irwin (1968) considered that a lake bottom temperature $4-5^{\circ} \mathrm{C}$ higher in Rotomahana than in other nearby lakes of similar size and depth was probably caused by local heat input from the lake floor. In February 1966, temperatures of $23.3^{\circ} \mathrm{C}, 23.9^{\circ} \mathrm{C}$, and $37.8^{\circ} \mathrm{C}$ were measured at three points on the lake floor in southwest Lake Rotomahana (Map 3). At each point the temperature of the overlying water was $15.8^{\circ} \mathrm{C}$ from $40 \mathrm{~m}$ depth to within $1 \mathrm{~m}$ of the lake floor. Howercer $6 \Omega$ other temperature measurements 
Present day surface hydrothermal activity occurs mainly along the western shore of Lake Rotomahana (Map 3) where it extends north from the adjacent Waimangu thermal area, as boiling springs, geysers, and fumaroles. This activity fluctuates with lake level, and the most vigorous features are associated with the 1886 explosion craters. Large upwellings of hot water in the lake indicate the locations of major submerged hot springs 10-20 m offshore. Total surface heat flow from this area has not been estimated, but visual comparison with other measured areas suggests it is at least $100 \mathrm{MW}$. The Rotomahana springs are chemically similar to those at Waimangu with up to $750 \mathrm{mg} \mathrm{I}^{-1}$ $\mathrm{Cl}$ and similar Cl/B ratios (R.B. Glover pers. comm.).

Minor hydrothermal activity also occurs as low pressure fumaroles and areas of altered ground associated with small faults on rhyolite lavas to north of Black Terrace Crater and as warm and hot springs $\left(64^{\circ} \mathrm{C}\right)$ close to lake level along the southern shore of Lake Rotomahana. Apart from bubbles of gas rising through the lake off Star Hill Crater on the northern shore, no surface thermal activity is known in the eastern lake.

A detailed heat flow survey of Lake Rotomahana is probably the most pressing requirement for a realistic assessment of Okataina geothermal resources, together with completion of resistivity mapping of the entire Tarawera-Rotomahana area, including the floors of Lakes Rotomahana and Tarawera.

Waimangu Hydrothermal Field: The Waimangu field has been described in detail elsewhere (Lloyd and Keam 1965, Mahon 1965a, Lloyd 1974). Boiling alkaline chloride waters rise to the surface mainly in craters formed on the Tarawera Rift during the 1886 eruption. Surface hydrothermal activity was not known at Waimangu prior to 1886 but fissuring associated with underlying transcurrent fault movement and uprise of basalt magma (see p.235) has allowed access for hot water to the surface. Hydrothermal explosions of diminishing size have followed the 1886 eruption (Lloyd and Keam 1974). A heat flow of 250 MW in Waimangu Valley has been estimated (R.F. Keam pers. comm.) 
made up of a measured 180 MW from Echo and Inferno Craters, and a visually estimated $70 \mathrm{MW}$ from the remaining thermal features. Unpublished incomplete resistivity surveys have partially delineated the hydrothermal field boundaries to west and east of Waimangu (Map 3).

Haumi Springs: These springs (first recorded in Nairn 1973) lie $1 \mathrm{~km}$ to south of Waimangu (Map 3). Small discharges of water at temperatures of $50-80^{\circ} \mathrm{C}$ occur just above the level of the incised Haumi Stream tributary. The main Haumi Springs occur in and associated with small explosion craters on the apparent north-eastward extension of the Ngapouri Fault. The spring area also lies just inside the south-west extension of a major fault which bifurcates from the Haroharo Caldera rim fault, to south of Lake Rotomahana (Map 3). Other hot and warm springs occur on the stream banks to north. The Haumi Springs discharge diluted $\left(200 \mathrm{mg} \mathrm{l}^{-1}\right.$ ) $\mathrm{Cl}$ waters (R.B. Glover pers. comm.), and lie within the large low resistivity anomaly encompassing Waimangu, Waiotapu, Waikite, and Reporoa (Map 3).

Waiotapu and Reporoa Hydrothermal Fields: The Waiotapu hydrothermal area (Map 3) has been described by Grange (1937), Lloyd (1959), numerous authors in DSIR Bulletin 155 (1963), and Healy (1974). Some aspects of the geology were discussed by Nairn (1973). The surface field is situated at the north end of the Reporoa Basin, and extends northwards along the Ngapouri Fault to the northern slopes of Maungakakaramea. The field has a measured surface heat flow of C. 550 MW (D.S.I.R. 1963), with a relatively large evaporative heat loss compared to hot water outflow (Studt 1963). Extent of the field at depth has been defined by incomplete resistivity surveys. Seven exploration wells have been drilled in the field passing through stratified volcanic sediments and ignimbrites to depths of $1100 \mathrm{~m}$. Apart from the Ngakoro Andesite and a rhyolite lava in the southern part of the field, no other near-vent volcanics were drilled at depth. This stratigraphy suggests that, unlike Kawerau, Waiotapu is not underlain by a large rhyolite centre which could 
indicate a local heat source. The adjacent young cones of Maungaongaonga and Maungakakaramea are dacites which were probably erupted from deeper sources (Cole 1979). Lack of associated magnetic anomalies suggests these are superficial cones with narrow roots (Studt 1963) and are therefore unlikely to provide a shallow heat source. A large rhyolite dome $(\triangle 8566)$ which forms the south-eastern margin of the Waiotapu field has an associated magnetic anomaly (suggesting extension to considerable depth) but the dome is intersected by a collapse scarp forming the northern rim of Reporoa Basin and is mapped as ha1 (pre-ignimbrite). It may be associated with the rhyolite lava drilled at the bottom of Well 4 at $760 \mathrm{~m}$ below sea level.

Several early writers (Lloyd 1959; Healy 1963; Studt 1963) suggested that the Waiotapu Field is fed from two basement fault sources - a northern steam(?) feed via the Ngapouri Fault, and a southern water feed giving rise to the highest measured temperatures (to $295^{\circ} \mathrm{C}$ ) in the southernmost drill holes - Waiotapu 6 and 7 , and a considerable flow of high chloride water at Champagne Pool. A southern feed zone, possibly also related to the southward thickening of Ngakoro Andesite in holes 6 and 7 (Grindley 1963 , p. 23), may be related to the semi-circular collapse structure postulated to the south of Hole 7 (Nairn 1973).

Lineations of young explosion craters and hot springs suggest the locations of buried underlying faults (Lloyd 1959; Grindley 1963; Nairn 1973). The Ngapouri Fault strongly controls the location of explosion craters and hydrothermal features which extend north-east from a solfataric area on the fault, lying immediately to the south of Ngapouri Road (N85/774779) [U16/994113]. To north-east along the Ngapouri Fault occur a large explosion crater occupied by Lake Opouri (Ngapouri), a highly active fumarolic area on the flanks of Maungaongaonga, Waiotapu Drill Hole 1, acid weathering pits and explosion craters, Waiotapu Drill Hole 2, steaming ground, warm Lake Rotowhero $\left(32^{\circ} \mathrm{C}\right)$, explosion craters and steaming ground on the western slopes of Maungakakaramea, and explosion craters including warm ground in the low country to the north-east of Maungakakaramea. 
At the north-eastern end of the semi-continuous Ngapouri fault trace lie the Haumi hot springs. Further north-east, along the inferred extension of the Ngapouri Fault into Haroharo Caldera, occur small seepages of hot water on the southern edge of Lake Rotomahana.

The association of four areas of hydrothermal activity and many young explosion craters with the Ngapouri Fault indicates that it is a major structural feature controlling the upflow of hot fluids from depth.

The large explosion craters occupied by Lakes Okaro and Ngahewa lie $0.5 \mathrm{~km}$ to the north-west of the Ngapouri Fault, as do several smaller explosion craters. Some explosion craters also pit Maungakakaramea to the south of the Ngapouri Fault, and may indicate less well expressed faults. Although now cold, the explosion craters indicate the sites of recent (<1000 years B.P.) hydrothermal activity.

A chemical and isotopic survey of the Waiotapu and Reporoa hydrothermal discharges has recently been carried out (Sheppard and Robinson 1980). The results indicate that deep chloride waters (c. $1850 \mathrm{mg} \mathrm{1^{-1 }}$ ) move from north to south under Waiotapu, reaching the surface only in the central area. Elsewhere the deep water interacts with shallow groundwaters to produce diluted mixed waters. Steam from both the deep and mixed waters rises to the surface throughout the field to produce the common steamheated acid-sulphate surface features. Gas compositions and isotope analyses both suggest that the major gas upflow and highest gas temperatures occur in the north of the field (Sheppard and Giggenbach; Lyon and Cox, both in Sheppard and Robinson 1980).

A total surface chloride flux from the Waiotapu area has been estimated at $385 \mathrm{~g} \mathrm{~s}^{-1}$ by Sheppard and Giggenbach (op. cit.).

Two thermal areas at Opaheke and Longview Road, to the south of Waiotapu, possibly represent upflow from hot water moving 
sub-horizontally southwards through the Reporoa Basin from the Waiotapu area, as there is both resistivity and chemical evidence (Macdonald 1967, Mahon 1966) that the Waiotapu and Reporoa fields are connected at depth. A drill hole (Reporoa 1) near the Opaheke thermal area passed through $305 \mathrm{~m}$ of mudstone and sandstone beds, and then through alternating sequences of tuff, rhyolite, and pumice breccia to the bottom of the hole at $1360 \mathrm{~m}$. Temperatures were moderately high, but permeability was low and no production was obtained. The existence of temperature reversals in the hole with maxima at $305 \mathrm{~m}$, and between $855 \mathrm{~m}$ $975 \mathrm{~m}$ where $255^{\circ} \mathrm{C}$ was measured, decreasing to $219^{\circ} \mathrm{C}$ at the hole bottom (Glover 1967) suggested that the hole is fed by subhorizontal aquifer flow from the Waiotapu area (Healy and Hochstein 1973).

Waikite-Paukohurea Field: The Waikite-Paukohurea thermal area lies on and immediately north-west of the Paeroa Fault, and to west of the Waiotapu thermal area (Map 3). The WaikitePaukohurea springs have been described by Healy (1952, 1974), Mahon (1965b, Nairn (1973), and Cole and Nairn (1975). Total heat flow is estimated at 70 MW.

Most thermal activity in the Waikite-Paukohurea area is concentrated in the southern (Waikite) part of the field, sited on or close to the small step fault which parallels the main Paeroa scarp in the Waikite area. Strongly flowing springs up to $97^{\circ} \mathrm{C}$ in temperature rise in a gully (N85/768812) [U16/989143] adjacent to Waikite Valley Road, and are utilised for a bathing pool. Smaller springs (up to $101^{\circ} \mathrm{C}$ ), hot pools, and acid weathering pits are situated $1 \mathrm{~km}$ north-east along the step fault (N85/777820) [U16/997151], at the foot of an area of steaming ground and fumaroles which extends to the top of the main fault scarp.

The Paukohurea Springs are situated a further $0.8 \mathrm{~km}$ to the north-east (N85/783827) [U16/003157], where a north-northwest trending cross fault cuts off the step fault. A small pool on the downthrown side of the cross fault is at $46^{\circ} \mathrm{C}$ despite 
a stream inflow at $32^{\circ} \mathrm{C}$, while small ponds in a hydrothermal explosion crater adjacent to the main scarp are at $33^{\circ}$ and $36^{\circ} \mathrm{C}$. A cold spring rises in altered Waiora sediments (N85/789828) [U16/009158], $0.6 \mathrm{~km}$ to the east of the Paukohurea Springs, with considerable gas discharge including $\mathrm{H}_{2} \mathrm{~S}$, while white sulphur is deposited.

A young hydrothermal explosion crater (post Taupo Pumice) is sited adjacent to Earthquake Flat Road (N85/794847) [U16/ 014175], c. $2 \mathrm{~km}$ north-east of the Paukohurea Springs. The explosion crater is probably about the same age as those at Waiotapu, i.e.700-900 yrs B.P. Slightly steaming ground occurs at the southern end of the explosion crater, and a small area of steaming ground, small hot pools at $80^{\circ}-90^{\circ} \mathrm{C}$, and slight sulphur deposition lies to the south of the crater. A ridge covered by hydrothermally altered clays extends between the explosion crater and the Paukohurea Springs, but the ground is now cold and vegetation is reclothing the area.

Warm springs at $26^{\circ}-34^{\circ} \mathrm{C}$ also emerge from the steep fault scarp (N85/754798) [U16/976131], about $1.5 \mathrm{~km}$ south-west of the Waikite thermal area (Map 3). The springs combine to feed a $30^{\circ} \mathrm{C}$ outflow estimated at $281 \mathrm{~s}^{-1}$ to the Te Waro stream.

The Waikite-Paukohurea Springs fall within the continuous area of low resistivity $(<50 \mathrm{ohm} \mathrm{m}$ ) which encompasses Waimangu, Waiotapu, and Reporoa (Map 3), and discharge diluted neutral sodium chloride-bicarbonate waters, with relatively low $\mathrm{Cl}$ concentrations of $100-200 \mathrm{mg}^{-1}$ (Mahon 1965b).

Kawerau Hydrothermal Field: Kawerau field has been described by Studt (1958), Mahon (1962, 1968), Banwell (1965), Macdonald and Muffler (1972), and Healy (1974). The following summary is updated from Cole and Nairn (1975).

Kawerau hydrothermal field (Map 3), is situated on both banks of the Tarawera River where it skirts the western margin of an alluvial plain within the Whakatane graben. Surface 
geology is dominated by the two young Onepu dacite domes. The late Holocene andesite-dacite cone of Mt. Edgecumbe lies $3 \mathrm{~km}$ south-east of Kawerau and is the youngest volcanic centre in the district. The main area of surface hydrothermal activity (Onepu Springs) lies $2 \mathrm{~km}$ to the north of Kawerau Borough, and comprised hot springs and seepages, some at boiling point, plus steaming ground mainly at higher elevations. Hot water seepages and hot pools were scattered in a broad belt along about $2 \mathrm{~km}$ of the river to the south (Banwell 1965). The surface activity at Onepu covers an area of $\mathrm{c} .1 .3 \mathrm{~km}^{2}$ but warm ground (measured at $1 \mathrm{~m}$ depth) extends over a considerable area west of the river (Thompson, in Banwell 1965), and electrical resistivity surveys and investigation drilling have shown that hot water underlies a much larger area on both sides of the river (Studt 1958). A recent deep resistivity survey has shown the field to have an area of between 6 and $10 \mathrm{~km}^{2}$ (to the $20 \mathrm{ohm} \mathrm{m}$ contour), with near vertical boundaries apparently extending to a depth of at least $2 \mathrm{~km}$ (Macdonald and Muffler 1972). Outcrops of leached and silicified rock suggest that surface hydrothermal activity was formerly more extensive, while considerable historic changes in hot springs discharge appear to have accompanied fluctuations in flow of the Tarawera River (Studt 1958). Another area of minor hydrothermal activity outcrops $3 \mathrm{~km}$ east of the Onepu Springs, where large hydrothermal explosion craters lie in the vicinity of numerous gas escapes and superficial deposits of sulphur. A large patch of steaming ground occurs $2 \mathrm{~km}$ south-west of the Onepu Sprịngs.

Natural surface heat flow from the Onepu Springs area has been variously estimated at 105 MW relative to $12^{\circ} \mathrm{C}$ in 1952 (Studt 1958) and 75 MW in 1962 (Thompson, in Banwell 1965).

The Kawerau hydrothermal field has been partially exploited for steam to drive machinery, generate electricity (10 MW plant) and provide process heat in a large pulp and paper mill complex. Twenty eight geothermal wells have been drilled in the field (to 1980), passing through alluvium and pumice breccias, rhyolite lavas and breccias, andesite, and ignimbrite, to reach greywacke 
basement between $900 \mathrm{~m}$ and $1100 \mathrm{~m}$ below sea level. Temperatures encountered in the field approach $290^{\circ} \mathrm{C}$ in the basement.

Kawerau hot spring waters are of the neutral chloride type, with chloride contents of $400-600 \mathrm{mg} / \mathrm{l}$, although some partially steam-heated springs have low $\mathrm{pH}$ and high sulphate contents (Mahon 1962). The chemistry of the larger chloride springs is similar to that of deep drillhole waters diluted with near surface water, indicating a direct path from depth to the surface (Mahon 1968).

The deep wells discharge water with chloride concentrations of $1200-1300 \mathrm{mg} / \mathrm{l}$ (indicating chloride contents of $800-850 \mathrm{mg} / \mathrm{I}$ in the deep water) all apparently supplied from a common source of hot water, with temperatures of $260-265^{\circ} \mathrm{C}$ indicated by silica and $\mathrm{Na} / \mathrm{K}$ ratio geothermometry (Mahon 1968 ).

Hydrothermal explosion breccias at Kawerau are described in the attached paper which provides some data on history and structure of the geothermal field. 


\section{Late Quaternary Hydrothermal Explosion Breccias at Kawerau Geothermal Field, New Zealand}

\section{I.A. NAIRN *}

SOLIA WIRADIRADJA **
Geology Department, Victoria University, Private Bag, Wellington.

Geothermal Division, Pertamina, JL Perwira no, 6, Jakarta.

\section{ABSTRACT}

Two large $\left(10^{6}-10^{7} \mathrm{~m}^{3}\right.$ erupted volume $)$ hydrothermal explosions occurred from craters on the eastern margin of Kawerau Geothermal Field at c. 14,500 and 9,000 yrs B.P. Explosion products are interbedded within $\mathrm{C} 14$ dated pyroclastic fall deposits and contain clasts of hydrothermally altered ignimbrite, rhyolite and tuff, in a silty hydrothermal clay matrix. No magmatic ejecta are found.

Some ejected blocks record earlier pre-eruption episodes of shallow hydraulic fracturing and silica cementation. Drillhole stratigraphy indicates that explosion extended to about 190 $\mathrm{m}$ below present ground level. The explosion is analysed as a rock/water interaction with eruptive energy provided by flashing of about half the available water.

Although surface heat flow and shallow temperatures are now low at eastern Kawerau, the hydrothermal explosions demonstrate the previous existence of a high temperature shallow geothermal system, probably related to a major fault feeding water up through the basement.

\section{INTRODUCTION}

Kawerau Geothermal Field is drilled for steam utilized in the Tasman Pulp and Paper Company mill (MACDONALD and MUFFLER, 1972; COLE and NAIRN, 1975). Two hydrothermal explosion breccias in-

*Also at N. Z. Geological Survey, P.O. Box 499, Rotorua.

** Now deceased. terbedded between C14-dated pyroclastic fall deposits crop out in deep new road cuts south-east of the mill (Fig. 1). Other recent hydrothermal explosion breccias are unknown at Kawerau, although much older (>200,000 yr B.P.) explosion breccias have been identified in drill cores (BROWNE, in press).

\section{HYDROTHERMAL EXPLOSIONS}

Hydrothermal explosions occur when superheated water at shallow depths flashes to steam, disrupting the confining rocks and ejecting solid debris, water, and steam (MUFFLER et al., 1971). Acc. to these authors, magma is not directly involved in "hydrothermal explosions» whereas it is in "phreatic eruptions». On this distinction, the term "hydrothermal» - well established at least in New Zealand and USA - fits with the origin of the Kawerau explosion breccias.

Magma is not directly involved in the explosion generation, eruptive energy being contained within the hot water and rock of the shallow hydrothermal system. Temperatures in liquid-dominated geothermal fields (such as Kawerau) commonly increase with depth on the boiling point curve, providing conditions suitable for triggering of hydrothermal explosions by flashing. Hydrothermal explosions have occurred in most boiling spring areas 
of New Zealand during the late Quaternary (LLOYD, 1972) including several historic events (COLE and NAIRN, 1975).

\section{KAWERAU GEOLOGY AND STRUCTURE}

Kawerau Geothermal Field lies within a north-east trending graben at foot of the Holocene andesite-dacite volcanic complex of Mt Edgecumbe (DUNCAN, 1970). The graben is partly filled with Quaternary volcanic sediments, lavas, tuffs and breccias (Fig. 1) unconformably overlying $\mathrm{Me}$ sozoic greywacke basement below $900 \mathrm{~m}$ depth. The oldest exposed rock is Matahina Ignimbrite (welded tuff), overlain by numerous pyroclastic formations (Fig. 2). Stratigraphic succession beneath Matahina Ignimbrite is established in 22 geothermal wells (BROWNE, 1978a) and varies

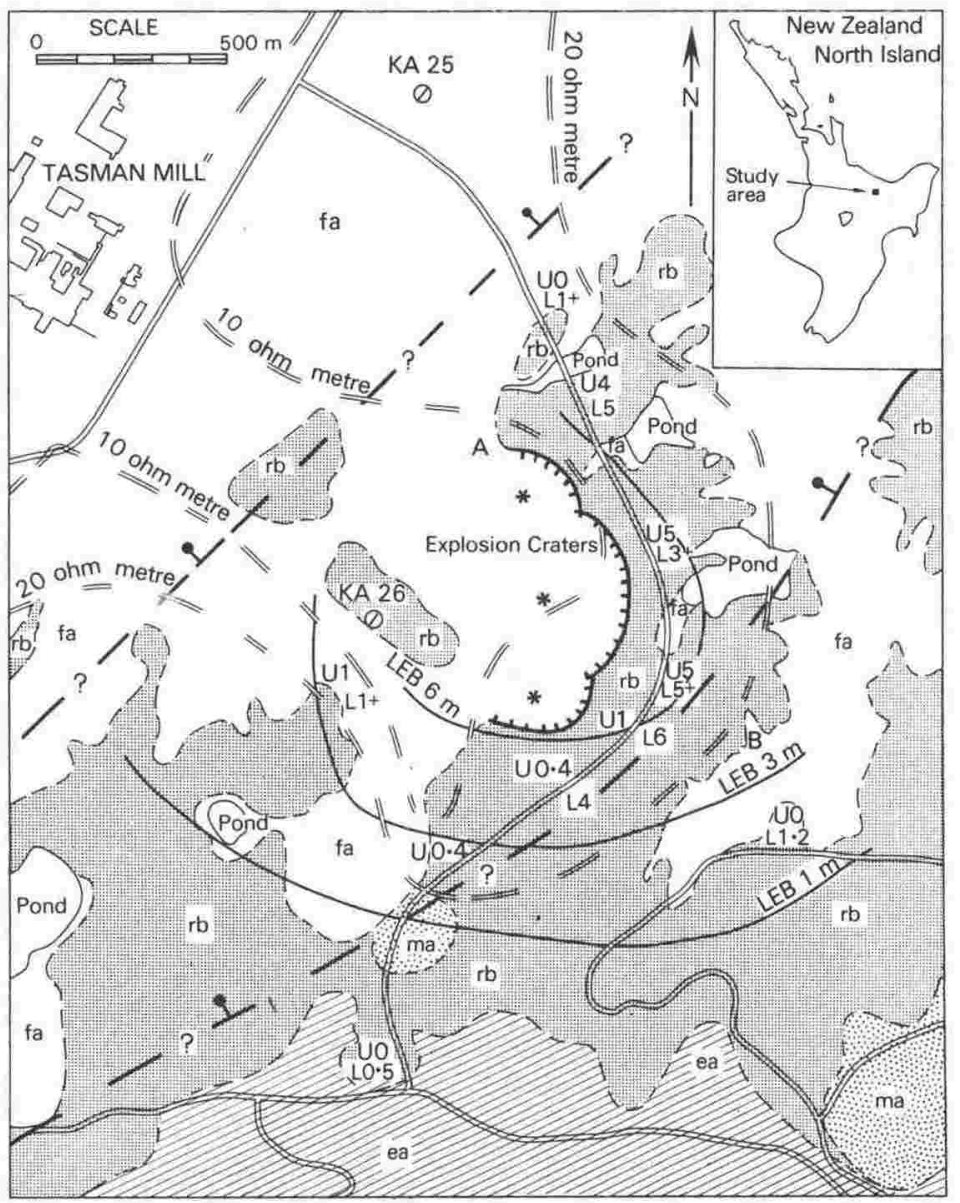

FIG. 1 - Geological map of eastern Kawerau Geothermal Field showing location of explosion vents $(*$ ), drillholes (KA 25, 26), measured thicknesses in metres of upper (U) and lower (L) explosion breccias; lower explosion breccia (LEB) isopachs, inferred buried fault zones, and boundary of field delineated by 10 and $20 \Omega \cdot \mathrm{m}$ resistivity contours (from MACDONALD and MUFFLER, 1972). ma - Matahina Ignimbrite; rb - Rotoiti Breccia and younger pyroclastics; ea - Edgecumbe Lavas (andesite and dacite); fa - alluvium. 
across the field. Stratigraphy of the eastern field is known from wells KA 25 and $\mathrm{KA}$ 26 (Fig. 3), cored at $25-100 \mathrm{~m}$ intervals, with intervening lithologies identified from drill cuttings.

Several basin-shaped depressions occur in the eastern field, with centre of the largest basin at $450 \mathrm{~m} \mathrm{E}$ of KA 26 (Fig. 1). The basin has a well preserved, steeply sloping $\left(40^{\circ}\right)$ eastern rim reaching $50 \mathrm{~m}$ height. Sub-horizontally stratified pyroclastic breccias and tuffs outcrop at its base. Scalloped rim shapes (Fig. 1) suggest coalescence of three $0.3-0.5 \mathrm{~km}$ diameter craters cutting through a pre-existing eroded ridge. The western rim has been eroded and the basin floor filled with alluvium deposited by the meandering Tarawera River, following large pyroclastic eruptions in the adjacent Okataina Volcanic Centre. A hydrothermal explosion origin for this multiple crater is confirmed by outcrop of thick explosion breccias on the basin rim, and in deep road cuts immediately to the south and east (Fig. 1). Trajectories of ballistic ejecta, indicated by asymetric impact sags, are also consistent with this eruptive source. The crater floor is cold, although considerable gas emission and some sulphur deposition occurs in acid altered areas. Several adjacent smaller ponded basins (Fig. 1) lack steep rim slopes and may have formed by backfilling of valleys during deposition of the youngest Kawerau terrace.

At Kawerau, rare surface fault traces strike north-east parallel to the regional trend of the Taupo Volcanic Zone, although some eruptive vents on Mt Edgecumbe are aligned north-west suggesting cross faulting may occur. Structural models consistent with north-east trending buried normal faults can be inferred from drillhole stratigraphy in the field. A major basement fault occurs between KA 25 and KA 26 and other fault displacements are likely between KA 26 and out-cropping Matahina Ignimbrite on the access road to east. A possible structural model assumed in this paper is shown in Figs. 1 and 3, implying that the Kawerau explosion craters lie either on or above a northwest-dipping major fault zone.

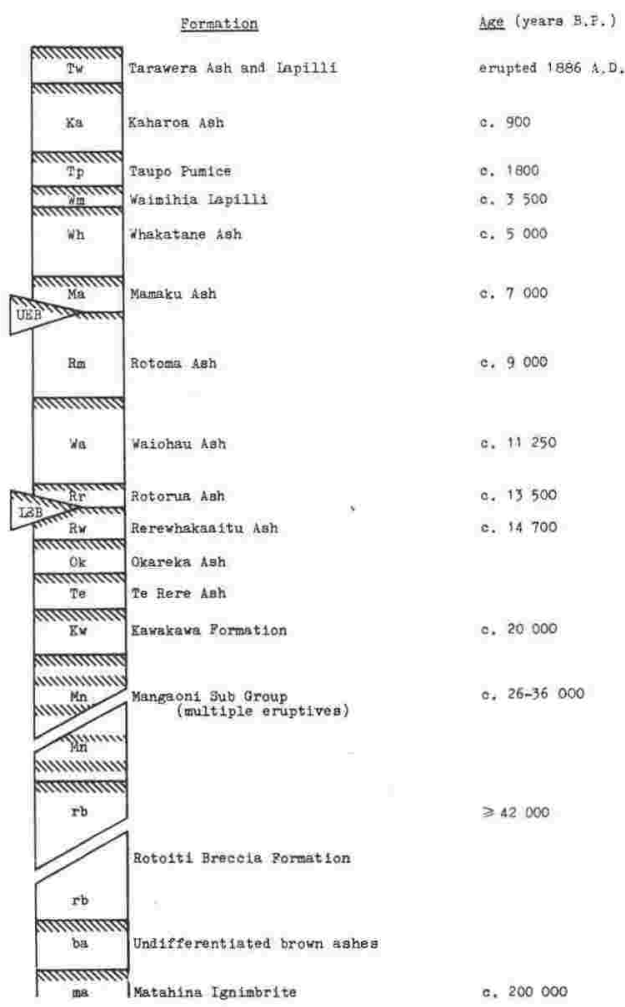

FIG. 2 - Schematic stratigraphic succession and radiometric dates of outcropping pyroclastic formations at Kawerau, with interbedded UEB and LEB. Stippled zones represent paleosols. (Age data from PULLAR et al., 1973; COLE and NAIRN, 1975; HowORTH, 1975; B. P. KoHN pers. comm., and I.A. NAIRN in prepn).

\section{KAWERAU EXPLOSION BRECCIAS}

\section{Lithology and Petrography}

The upper (UEB) and lower (LEB) explosion breccias are best exposed in road cuts within $200 \mathrm{~m}$ of the multiple crater rim (Fig. 1); crater rim sections are obscured by younger tephras and vegetation. Both breccias are very poorly sorted, with large angular blocks up to 2 metre size in 
a gravelly muddy Sand (gmS-Folk 1974) matrix, containing hydrothermal clays. No magmatic component is identified in the ejecta.

The LEB typically consists of multiple, thin-bedded, grey lapilli tuffs (c. $1 \mathrm{~m}$ total thickness) at base; passing up into bluegrey fine tuffs $(2-4 \mathrm{~m})$ containing much hydrothermal clay and abundant $1-2 \mathrm{~m}$ pyrite cubes; overlain by yellow-grey lapilli tuffs (c. $1 \mathrm{~m}$ ) containing common 0.1$1 \mathrm{~m}$ angular blocks. Thickness varies along section from a maximum $8 \mathrm{~m}$ at foot of a buried ridge, thinning to $3 \mathrm{~m}$ over its crest. The sequence also varies, with a basal $0.3-2 \mathrm{~m}$ of grey hydrothermal clay occurring in some sections.

Lapilli and block-size ejecta in the LEB are hydrothermally altered and silicified, consisting of abundant pumiceous and coarse crystal-vitric tuffs; less common Matahina Ignimbrite; with rare rhyolite lava, chalcedony, pumice, and silicified breccias. Initial LEB ejecta to reach road cut exposures are blocks which occupy impact sags within the underlying pre-LEB paleosol. These blocks are dominantly

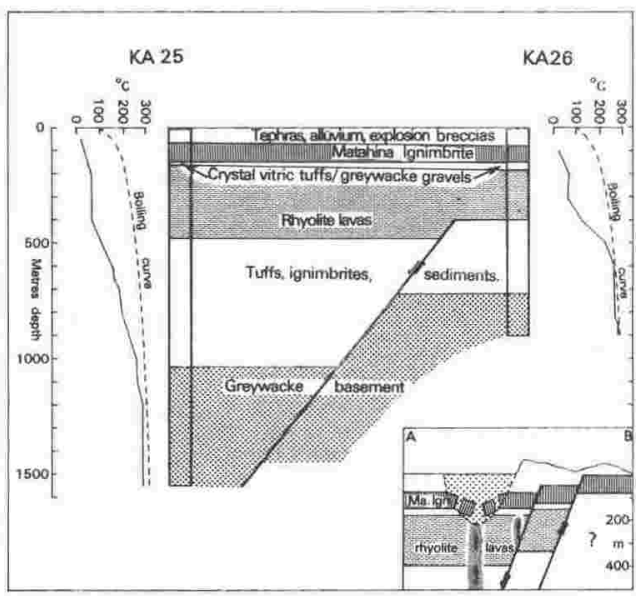

FIG. 3 - Cross section through KA 25, 26 with downhole temperatures compared with boiling curve for pure water. Well depths are in metres below ground level; horizontal and vertical scales are equal. Buried fault is inferred. Inset shows possible stratigraphy and structure assumed on cross section A-B (Fig. 1), through the explosion craters.

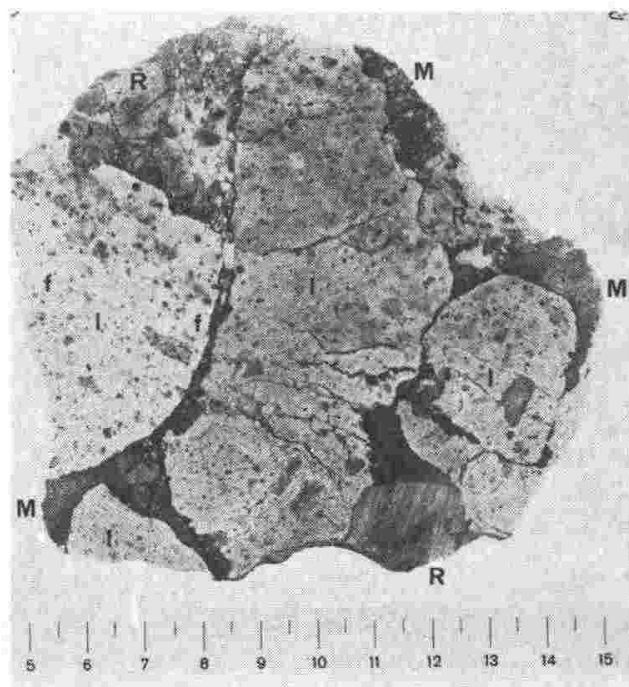

FIG. 4 - LEB block containing subrounded clasts of Matahina Ignimbrite (I) and flowbanded rhyolite (R), intruded and cemented by dark siliceous matrix (M). Note closely fitting contacts betweeen some ignimbrite and rhyolite clasts, and second generation fine fractures (f) cutting clasts and siliceous matrix. Scale is in centimetres.

coarse crystal-vitric and pumiceous tuffs with rare Matahina Ignimbrite. At distal sections (>1 km from vents) all blocks are Matahina Ignimbrite. Impact sags are also present within the LEB, but many blocks are not associated with sag structures and do not appear to have been ballistically transported.

Pre-eruption hydrothermal alteration had commonly leached primary plagioclase phenocrysts, and partly replaced them by quartz and some adularia. Glass was altered to abundant finely crystalline hydrothermal quartz, and patches of clay. Mafic phenocrysts were commonly replaced by illitic clays, and pyrite disseminated throughout. Other hydrothermal minerals include cristobalite, amorphous silica and leucoxene (C. P. WooD, pers. comm.), but bladed calcite does not occur. The clay-size fraction of the LEB, as determined by XRD and Infra red techniques, is dominantly quartz, inter-layered 
illite-montmorillonite, with minor kaolinite and chlorite (C.P. WoOD, pers. comm.). Alteration of explosion breccia clasts and clays at the sampled sites did not continue after eruption, as the enclosing vitric pyroclastic fall beds are unaltered. Hydrothermal alteration of the ejecta is much more intense than that encountered in KA 25 and 26 (BROWNE, 1978a) within the same stratigraphic units.

Some LEB blocks had been fractured and recemented prior to eruption. Fractures range from hairline $(<0.5 \mathrm{~mm})$ to centimetre wide gaps, filled with siliceous matrix. One block (Fig. 4) contains subrounded $5-10 \mathrm{~cm}$ clasts of Matahina Ignimbrite and 1-2 cm clasts of flow-banded rhyolite, with minor fragments of pumice and siltstone plus greywacke pebbles. The clasts are separated, intruded, and cemented by a poorly sorted, structureless matrix composed of finely crystalline quartz plus larger primary phenocrysts (partially replaced by adularia and secondary quartz). Some of the ignimbrite clasts in this block have congruent adjacent walls which match neatly across tensional fractures, demonstrating that only rifting had occur-

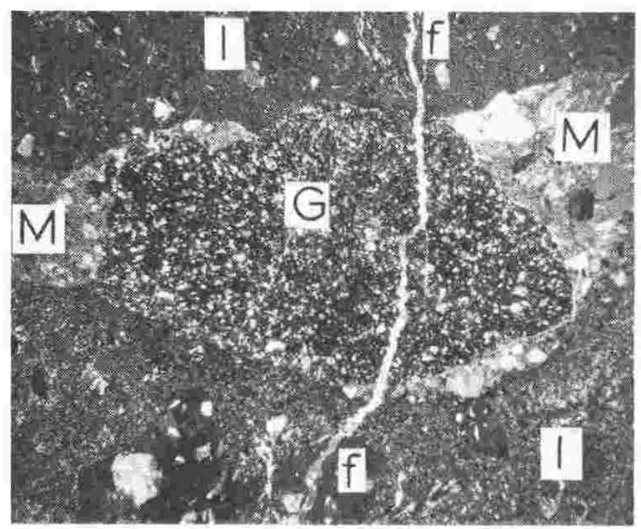

F1G. 5 - Photomicrograph of thin section cut from LEB block shown in Fig. 4. A greywacke pebble (central dark clast-G) is jammed between ignimbrite clasts (I), separated by lightcoloured siliceous matrix (M). Ignimbrite and greywacke clasts are cut by a second-generation fracture (f) filled with interlocking anhedral grains of secondary quartz. Greywacke pebble is $8 \mathrm{~mm}$ long ( $\mathrm{x}$ nicols).

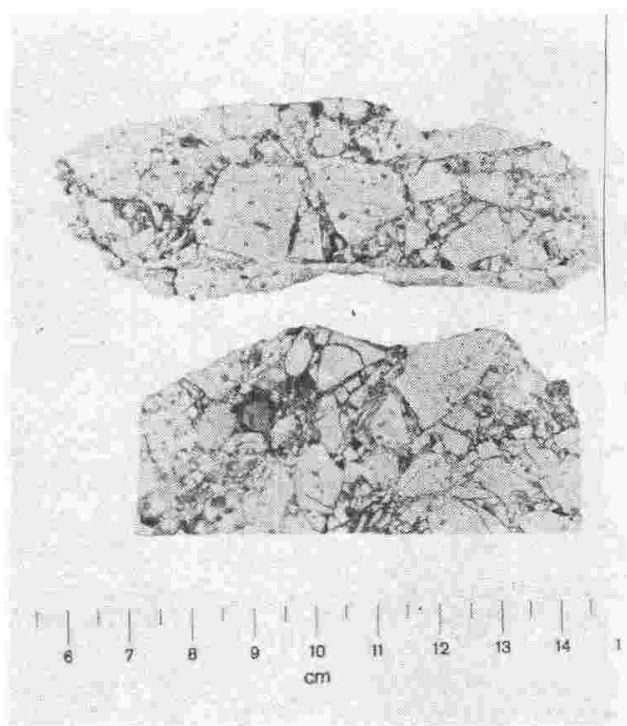

FIG. 6 - Two faces of a LEB block consisting, of highly-angular fragments of brecciated $\mathrm{Ma}$ tahina Ignimbrite, in dark siliceous matrix. Note congruence of many fracture walls.

red. In contrast, some ignimbrite, greywacke, and rhyolite clasts from different stratigraphic levels are pressed tightly together (Fig. 4), indicating considerable compression. A greywacke pebble tightly jammed between two ignimbrite clasts appears to have held open a closing fracture (Fig. 5). A second generation of fractures cuts both rock clasts and intervening siliceous matrix (Figs. 4, 5), having occurred after the initial brecciation, mixing of clasts, and solidification of the matrix had been completed. The second generation fractures are commonly about $0.1-0.3 \mathrm{~mm}$ wide, many cms long, and are partly filled with anhedral interlocking grains of secondary quartz, occasional adularia, and rare pyrite. The fractures break individual primary quartz phenocrysts and rock fragments in ignimbrite and greywacke clasts and in the matrix, demonstrating considerable rock strength at time of the second generation fracturing. 
Another brecciated LEB block (Fig. 6) consists solely of lenticular Matahina Ignimbrite, broken into many highly angular fragments of sub-millimetre to centimetre size, separated by siliceous matrix. The ignimbrite glassy ground-mass is strongly devitrified and recrystallized to small quartz crystals, plus patches of hydrothermal clay. Plagioclase phenocrysts have been totally dissolved leaving cavities, although possibly locally replaced by large "dusty" quartz. Pyrite is disseminated throughout. Fracture walls and cavities are lined with anhedral interlocking secondary quartz. Fractures break a few large primary quartz phenocrysts, but only slightly displace some of the ignimbrite fragments. The original rock has clearly been fractured in place, without abrasion of fragments, and with a significant (c. $20 \%$ ) dilational increase of in situ volume.

Both the LEB brecciated blocks described above appear to be examples of hydraulically fractured rocks (see Discussion), and are included in a detailed investigation of fractured clasts from several hydrothermal explosion deposits (BRow. $\mathrm{NE}$ and NAIRN, in prep.).

Bedding structures are poorly developed within the clay-rich LEB, but wedging, pinch-and-swell structures and wavelike bed forms, as well as more common sub-parallel bedding can be observed when accentuated by differential erosion. The wave-like bed forms, thickness variations, and lack of impact sags associated with many blocks are consistent with deposition of much of the near-source LEB as laterally transported base surges (e.g. MOORE, 1967), common in many steam eruptions.

The upper explosion breccia (UEB) contains proportionally more blocks near source than the LEB, with Matahina Ignimbrite the dominant lithology in basal impact sags and throughout the deposit. Also present are clasts of flow-banded glassy rhyolite, pumice, and crystal-vitric and lithic tuffs. Apart from the predominance of Matahina Ignimbrite, UEB clast content and hydrothermal alteration are similar to that of the LEB, including some strongly fractured and silica cemented breccia blocks with 1-2 mm secondary quartz crystals filling open cavities. Impact sags again indicate an eruptive origin in the large explosion crater complex. However, in bulk the UEB is less heterogeneous than the LEB, consisting of 3 relatively massive, similar lithic tuff units, generally lacking in bedding and stratification and without the pyrite-bearing clay-rich beds of the LEB. Clay grade material in the UEB is dominantly quartz and opaline silica with kaolinite and illite-montmorillonite (C.P. WoOD, pers. comm.). UEB thickness varies considerably along section from c. $4 \mathrm{~m}$ in gully fill sites, to less than $1 \mathrm{~m}$ over buried crests.

\section{Distribution}

The Kawerau explosion breccias are well exposed only in road cuts south and east of the explosion craters (Fig. 1); elsewhere they are buried beneath thick Holocene pyroclastic and alluvial deposits. The LEB has considerably wider distribution than the UEB. Both thin rapidly away from source, although some large dense blocks travelled further than lapilli and ash grade material. At sections near

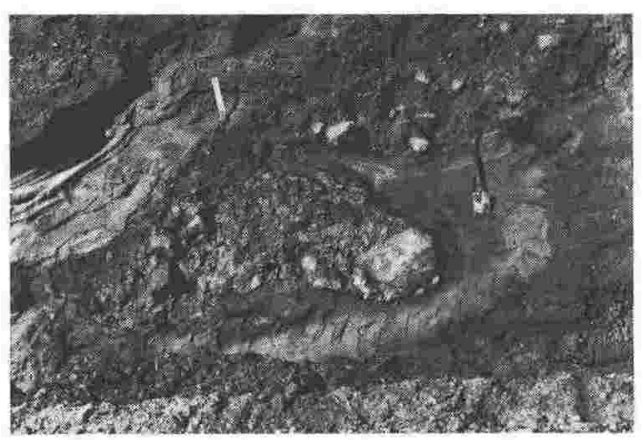

FIG. 7 - Dense ignimbrite block buried in low-angle impact crater penetrating pre-LEB hillslope formed in weathered tuff. Upturned tongue of weathered tuff lies above impact crater which is filled with tightly packed finegrained LEB ejecta. All blocks are LEB clasts, overlain by younger shower-bedded fresh Waiohau Ash (c. 11,250 years B.P.) and other tephras. Spade is $1 \mathrm{~m}$ long. 
Edgecumbe cone, $1.3 \mathrm{~km}$ south-west of the explosion crater centre, the LEB consists of many large (0.5-1.0 m max dimension) angular blocks of Matahina Ignimbrite which densely cratered the ground surface. Only patchy distribution of $0.2 \mathrm{~m}$ of ash and lapilli grade material is present at this site. One $0.5 \mathrm{~m}$ block arrived on a very low $\left(15^{\circ}\right)$ trajectory, excavating a $2 \mathrm{~m}$ long tunnel in tuff of a crater-facing hill slope (Fig. 7). The tunnel mouth is densely packed with smaller LEB blocks, lapilli, and ash, without incorporation of the weathered tuff forming the ridge soil. Because an upturned thin tongue of tuff above the impact crater has not collapsed into the tunnel, it appears that the LEB tunnel-filling closely followed the craterforming block as a comet-like tail.

\section{Ejecta Velocities}

Atmospheric range of ballistic ejecta is a function of ejection velocity, ejection angle, projectile mass, cross-sectional area, and drag coefficient (FUDALI and MELSON, 1972; WILSON, 1972). The $1.3 \mathrm{~km}$ range of $0.5-1 \mathrm{~m}$ sized blocks at Kawerau, indicates minimum initial ejection velocities of about $150-200 \mathrm{~ms}^{-1}$, using Wilson's computations, and assuming optimum $45^{\circ}$ ejection angles.

\section{Volumes}

Due to the limited exposure, estimates of the Kawerau explosion breccia volumes are very approximate. Volumes estimated from thickness data shown in Fig. 1, assuming symmetrical distribution around the vent and exponential thinning with distance (COLE and STEPHENSON, 1972) are LEB: $2 \times 10^{7} \mathrm{~m}^{3}$; UEB, ? $10^{6} \mathrm{~m}^{3}$.

\section{Stratigraphy and Chronology}

The Kawerau explosion breccias are interbedded within C14 dated pyroclastic fall deposits (Fig. 2) which provide radiocarbon ages between c. 14,700 and 13,500 years B.P. for the LEB; and c. 9,000 and
7,000 years B.P. for the UEB. More precise age definition comes from the nature of upper and lower contacts. The upper Rerewhakaaitu Ash, where conformably underlying the LEB, has an apparent weakly developed paleosol - indicating a short weathering interval between deposition of the Ash and eruption of the LEB. The LEB upper contact is moderately weathered and contains some carbonized organic material, suggesting a longer interval prior to deposition of the overlying Rotorua Ash. These relationships suggest an age for the LEB closer to that of the Rerewhakaaitu Ash than to the Rotorua Ash, and a date of c. 14,500 years B.P. is considered reasonable.

The UEB overlies slightly eroded Rotoma Ash, without a paleosol at the contact. In one section, airfall Rotoma Ash mantling a small channel is overlain by water-sorted, redeposited Ash. Both the airfall and redeposited tephra is overlain by UEB, showing that the hydrothermal explosion followed a short interval of erosion and redeposition of Rotoma Ash. The upper contact of the UEB with overlying Mamaku Ash is moderately weathered and contains some organic material, indicating a considerable quiescent interval after the UEB eruption. An age for UEB of c. 9,000 yrs B.P. is indicated.

\section{DISCUSSION}

\section{Depth of Explosive Disruption}

Assuming a pre-LEB eruption stratigraphic sequence similar to that in KA 26 (Fig. 3), the breccia clast lithologies indicate depth of explosive disruption. The LEB is the earliest post-Matahina Ignimbrite explosion breccia known at eastern Kawerau, implying undisturbed vent stratigraphy. The assumption that formation depths were the same as in KA 26 is less certain, as reasonable geological models suggest that upfaulting occurs east of KA 26 . In this discussion the craters are assumed to lie above a normal fault zone, but not intersect it (see Figs. 1 and 3). Only 
further drilling can confirm structure, but the depths quoted here will be accurate if the assumptions are correct, or else maximums if upfaulting exists.

LEB clasts demonstrate that explosion extended down to reach the banded rhyolite lavas (Fig. 3), found at $190 \mathrm{~m}$ depth in KA 26. Much explosion energy was released in the Matahina Ignimbrite and underlying tuffs between 90 and $190 \mathrm{~m}$ depth, producing an abundance of these lithologies in the ejecta, and the maximum ballistic range of ignimbrite blocks. Correlation of explosion depth with clast lithology is less certain for the UEB which would have incorporated much reworked LEB ejecta; however, no extra lithologies were involved in the younger and smaller eruption. The greater proportion of $\mathrm{Ma}$ tahina Ignimbrite blocks strongly suggests that much UEB explosion energy was released in this unit.

Basal clasts in proximal exposures provide some information on explosion sequence (FUNICIELLO et al., 1976). The abundant clasts of silicified tuff and rarer $\mathrm{Ma}$ tahina Ignimbrite which occupy impact craters at base of the LEB suggest that this material was among the initial ejecta, and that at least the largest explosions originated within these lithologies. Aerodynamic drag and the $300 \mathrm{~m}$ distance from crater centre to proximal exposures adds some uncertainty to this concept: if a mixture of large dense clasts, and ash sized material is erupted, the large clasts are less affected by drag, and outdistance the cloud of smaller ejecta, to be first deposited. However, the large blocks in basal impact craters at Kawerau do appear to have been ejected in the initial explosions, which also incorporated large quantities of overlying tuffs and hydrothermal clays.

\section{Previous Fracturing Episodes}

The strongly silicified brecciated and recemented blocks in both LEB and UEB have similarities to brecciated drill cores from Wairakei, Broadlands, and Yellowstone geothermal drill holes (GRINDLEY and BROWNE, 1976; KEITH and MUFFLER,
1978). The drill core textures have been ascribed to hydraulic fracturing. PHLLIPS (1972) suggested that hydrothermal fluids accumulate on normal fault planes, where the difference between lithostatic and hydrostatic pressure gradients drives fluid upwards into fracture tips of blind faults (or against mineral sealed regions of existing faults). The gradually increasing fluid pressures transmitted from depth exceed local hydrostatic pressures, raising pore pressures adjacent to the fissure. Rapid extension of the fault occurs, either by tectonic movement; or induced by hydraulic fracture when fluid pressures exceed the sum of the least principle (normal) compressive stress across the fracture, and tensile strength of the rock. The increased volume available for fault plane fluids causes an abrupt pressure drop in the fracture, and the induced overpressures in adjacent rock pores explode the fissure walls to produce angular breccias. High initial velocities of fault plane fluids rushing to fill the newly created fracture space can carry fragments upward and round them by abrasion, to be redeposited as intrusion breccias. Such hydraulically fractured breccias can occur on the dipping fault plane, or extend vertically above it, as offshoots. The breccias are recemented by silica deposited from hydrothermal solutions.

Examples of both angular (Fig. 6) and abrasion-rounded hydraulic breccias (Fig. 4) occur as blocks in the Kawerau hydrothermal explosion ejecta. The mixing of greywacke pebbles, rhyolite, and ignimbrite clasts in the hydraulic breccias shows that rock fragments were transported vertically over more than $40 \mathrm{~m}$ (see Fig. 3). At least two episodes of hydraulic fracturing occurred, preceding the LEB explosion by a time interval sufficient for recementation to occur. Fracturing took place at shallow depths $(<200 \mathrm{~m})$ in Matahina Ignimbrite and the upper rhyolite lavas. Hydrothermal mineralization of the brecciated blocks is typical of zones of subsurface boiling (BROWNE, 1978b), where upward flowing and cooling waters deposit quartz, adularia and pyrite (BATZLE and SIMMONS, 1976), to form a "self-sealed» cap rock (FACCA and TONANI, 1967), al- 
though the absence of calcite suggests that the ascending Kawerau fluids were low in dissolved $\mathrm{CO}_{2}$.

The Kawerau hydraulic breccias demonstrate fracturing, pressure drops and flashing at depth; and may represent incipient "hydrothermal explosions» which did not reach the surface. Lack of similar fracturing in cores from KA 26 is consistent with strong vertical control of fracture development.

\section{Eruption Mechanisms}

Generation of hydrothermal explosions has been discussed by GoGUEL (1956) and MUFFLER et al (1971). A similar analysis is applied to the Kawerau events.

The present day water table lies at ground level ( $27 \mathrm{~m}$ a.s.1.) within the explosion craters, and is assumed to have been at similar elevation prior to the LEB eruption which occurred through an eroded ridge of c. $30 \mathrm{~m}$ average height above the present crater floor. Boiling point for pure water at depths between 90 and $200 \mathrm{~m}$ (where much of the explosion energy appears to have been released) increases from $\mathrm{T} \approx 180^{\circ}$ to $210^{\circ} \mathrm{C}$. (The $0.5-1 \% \mathrm{CO}_{2}$ concentration in Kawerau geothermal waters (W. A. J. MAHON, pers. comm.) will not significantly affect position of the shal- low boiling curve). Actual temperatures and pressures beneath the Matahina Ignimbrite may have been somewhat higher due to local overpressures beneath a selfsealed cap. Available explosive energy of the rock-water system at an assumed average focal depth of $160 \mathrm{~m}$ (where $T=200^{\circ} \mathrm{C}$, vapour pressure $P=15$ bars) depends on rock porosity controlling the solid/volatile ratio. Porosities of ejected clasts vary from $15 \%$ in welded and silicified ignimbrite to $25-40 \%$ in the coarse tuffs (Table 1). An average value of $20 \%$ porosity is assumed in rock of grain density $2.4 \mathrm{gm} \mathrm{cm}^{-3}$, containing $200^{\circ} \mathrm{C}$ liquid water of density $0.86 \mathrm{gm} \mathrm{cm}^{-3}$ (KENNEDY and HoLsER, 1966).

Each cubic centimetre of the system contains 1.929 rock of specific heat (S. H.) 840 joules $\mathrm{kg}^{-1}$, and $0.17 \mathrm{~g}$ water with $\mathrm{S}$. H. 4186 joules $\mathrm{kg}^{-1}$, i.e. a water mass fraction of $8 \%$. Useful heat energy is available in cooling and expanding the rock/water system from $200^{\circ} \mathrm{C}$ and 15 bar to $100^{\circ} \mathrm{C}$ and 1 bar, when $P \mathrm{~d} V$ work is done by flashing of water, and expansion of steam against atmospheric pressure to about $1700 \mathrm{x}$ the original water volume. The major heat sink in this process is the $1.9-2.3 \times 10^{6}$ joules $\mathrm{kg}^{-1}$ required to vapourize the water between 200 and $100^{\circ} \mathrm{C}$, each unit mass of water at $200^{\circ} \mathrm{C}$ containing only enough heat to vaporize about

TABLE 1 - Densities and porosities of LEB ejecta clasts (determinations by T.C. MUMME). Sample numbers are from N.Z. Geophysics Division Catalogue.

\begin{tabular}{|clllcc|}
\hline Scmple & \multicolumn{3}{c}{ Lithology } & \multicolumn{3}{c|}{$\begin{array}{c}\text { Density } \\
\left(\mathrm{g}^{\circ} \mathrm{cm}^{-3}\right)\end{array}$} & Porosity \\
\hline \multirow{2}{*}{8324} & Tuff & (dry) & $($ wet $)$ & $($ grain) & $\%$ \\
8325 & Tuff & 1.37 & 1.79 & 2.36 & 42 \\
8326 & Tuff & 1.79 & 2.03 & 2.34 & 24 \\
8327 & Matahina Ignimbrite & 2.03 & 2.18 & 2.39 & 31 \\
8328 & Matahina Ignimbrite & 2.01 & 2.17 & 2.41 & 15 \\
8329 & Matahina Ignimbrite & 2.02 & 2.19 & 2.43 & 16 \\
& & & 1.97 & 2.41 & 17 \\
\hline
\end{tabular}


$1 / 5$ th of its mass on cooling to $100^{\circ} \mathrm{C}$. Further heat is supplied by the rock, the original $1 \mathrm{~cm}^{3}$ of the system containing 160 joules in the rock and 70 joules in hot water (above $100^{\circ} \mathrm{C}$ ), totalling slightly more than half the 390 joules required to flash all the water. Thus, about $60 \%$ of the water would be flashed to steam provided that all available heat was transferred from the rock.

Whether heat can be transferred from rock to water quickly enough during explosive interaction depends on degree of rock fragmentation. SPARKS and WILSON (1976) showed that time for a thermal wave to pass from the centre to the edge of a sphere of radius $R$ and thermal diffusivity $k\left(=3 \times 10^{-7} \mathrm{~m}^{2} \mathrm{~s}^{-1}\right.$ for rock) is given by $t=R^{2} / 8 k$. More than $80 \%$ of both Kawerau explosion breccias is less than $2 \mathrm{~mm}$ diameter, for which $t=0.4 \mathrm{~s}$. The time available for thermal equilibration during the explosion largely depends on fluid velocity from explosion focus to ground surface, as settling velocities of the heat-transferring small particles in the uprushing fluid are very low (WILSON, 1976). Theoretical computation of settling velocities (ROHLOF, 1969; WALKER et al., 1971; WILSON, 1976; SPARKS et al., 1978) suggest that the $150-200 \mathrm{~ms}^{-1}$ ejection velocities of $0.5 \mathrm{~m}-1 \mathrm{~m}$ blocks at Kawerau are consistent with fluid velocities ranging up to about $400 \mathrm{~ms}^{-1}$, depending on various assumptions made as to the effective density of the "dusty gas" transporting fluid, and efficiency of block acceleration to maximum velocity. Assuming constant fluid velocity and density of $0.01 \mathrm{gm} \mathrm{cm}^{-3}$, and an injection depth of $150 \mathrm{~m}$, RoHL OF's (1969) curves indicate a fluid velocity of about $400 \mathrm{~ms}^{-1}$ for $0.5 \mathrm{~m}$ blocks ejected at $200 \mathrm{~ms}^{-1}$. From an assumed focal depth of $160 \mathrm{~m}$ such fluid velocities indicate an interaction time of about $0.4 \mathrm{~s}-$ sufficient for considerable heat transfer to occur and suggesting that much Kawerau ejecta was able to thermally equilibrate with the erupting fluid. The comminution energy (0.1-0.5 $\mathrm{cal} \mathrm{cm}^{-3}$ - MUFFLER et al., 1971) required to fragment the solid material appears insignificant in relation to the total energy available.

This analysis produces the maximum available energy because it assumes that all ejecta came from the focal depth, and that all useful heat was transferred from rock to water. However, much Kawerau ejecta came from above focal depth, either by similar auto-explosion from shallower depth at lower temperatures, or by entrainment in the expanding fluid rushing up through the vent. In particular, the kaolinite-bearing clay beds probably came from near-surface acid-altered areas where the pre-explosion hydrothermal system outcropped. Temperatures above a sealed ignimbrite cap may have been below the boiling curve on a conductive rather than convective gradient, as observed at Yellowstone (WHITE et al., 1975). The component of large ejecta also demonstrates that not all rock was fragmented and thus able to transfer its heat. These factors suggest that no more than half the available water would be flashed in the explosion, resulting in a steam mass fraction of about $4 \%$, and indicating that explosive energy of the rock/water system is somewhat buffered against variations in porosity and thus water content. Increased water contents cannot be flashed, while lower total water fractions are compensated by an increasing flashed fraction (all the water being theoretically flashed at $10 \%$ porosity $=4 \%$ water mass fraction) so that available energy remains roughly constant.

Total thermal energy released by the LEB explosion was about $5 \times 10^{15}$ joules, assuming an average temperature increment of $140^{\circ} \mathrm{C}$ in cooling from about $160^{\circ}$ to $20^{\circ} \mathrm{C}$. This represents a dissipation of about one year of the pre-exploitation natural surface heat flow, estimated at about $100 \mathrm{MW}$ (heat) (STUDT, 1958), or about half a year of the $200 \mathrm{MW}$ (heat) 1972 well discharge (M. A. GRANT, pers. comm.).

\section{Kawerau Eruption Model}

The following model is suggested for the Kawerau hydrothermal explosions. Prior to the LEB event, a highly active shallow hydrothermal system underlay eastern Kawerau, related to a major fault 
acting as a feed for hydrothermal fluids from depth. Lack of widespread surface hydrothermal alteration suggests the system may have been localized by sealing of fractures in the initially permeable basal Matahina Ignimbrite, where mixing of rising hot water with cold meteoric water would promote mineral deposition. Over-pressures of a few bars may have built up in the system beneath a sealed ignimbrite cap, but widespread overpressures are not essential to the model. Episodes of hydraulic fracturing and silica cementation occurred in and beneath the ignimbrite, prior to venting of the hydrothermal system to the surface, either by faulting or hydraulic fracturing. Decreasing fluid pressure in the vented fissure allowed superheated water to flash to steam, disrupting the fissure walls and carrying ejecta upward to the ground surface, entraining shallower vent wall strata. Blocks were transported in a three phase (vapour-liquid-solid) fluidized system, which formed a continuous eruption jet above the vent, although individual discrete explosions may have also occurred. Large ejecta rapidly separated from the eruption jet above the vent and travelled on ballistic trajectories.

The release of most explosion energy within the basal Matahina Ignimbrite and underlying crystal-vitric tuffs and sediments excavated a cavity, into which the surface vent enlarged by collapse (e.g. LORENZ, 1973). Crater area/ejecta volume relationships suggest the LEB collapse crater was initially about $100 \mathrm{~m}$ deep.

Eruption of the UEB from the same or adjacent craters 5,000 years after the LEB, suggests that the hydrothermal system was resealed during the intervening period. Rotoma Ash in the Kawerau area is commonly displaced by faulting which seems to have occurred at about the same time as the UEB eruption, and may have triggered it.

It has not been necessary to invoke magmatic intrusion in the Kawerau explosion model, although the adjacent young andesite/dacite cone of Mt Edgecumbe might provide a suitable magma source. There is no evidence of a mag- matic component in the explosion ejecta; Mt Edgecumbe appears to post-date at least the LEB, all exposed lavas being less than 5,000 years old; where intrusive bodies have upthrust ignimbrite «roof domes» at Edgecumbe (DUNCAN, 1970), no steam explosions occurred. However, the possibility of triggering of the explosions by steam generation from nearby magmatic intrusions, perhaps in a manner similar to that suggested by BRADLEY (1965) cannot be entirely ruled out.

\section{History of Hydrothermal Activity and Geothermal Implications}

The Kawerau explosion breccias demonstrate that intense hydrothermal activity was occurring at shallow depths in the eastern field at and prior to 15,000 and 9,000 years B. P. There is no evidence of other hydrothermal explosions occurring during the past 40,000 years - the limit of the well-exposed stratigraphic record - although considerably older, preMatahina Ignimbrite explosion breccias have been recognised in the Kawerau drillcores. There is negligible present day surface hydrothermal activity in the eastern field. KA 25 and KA 26 encountered relatively low temperatures $\left(<200^{\circ} \mathrm{C}\right)$ to 800 and $480 \mathrm{~m}$ depths respectively (Fig. 3 ), although both recorded high temperatures $\left(>280^{\circ} \mathrm{C}\right)$ in impermeable basement (P. F. BIXLEY, pers. comm.). Both wells are non-producers due to low permeability.

The low present day shallow temperatures and lack of permeability, together with the hydrothermal explosion history suggest that fault fissures feeding from depth into the eastern Kawerau geothermal field have been sealed by mineral deposition. Silicification of tuffs and pyroclastics beneath the rhyolite lavas may have also formed a sub-horizontal barrier to upflow of hot water, and could have been promoted if cold surface water gained access to the field through the explosion crater vents.

The geological model presented in this paper suggests a major fault feed zone lies 
under or east of the Kawerau explosion craters, and was open until at least 9,000 yrs B. P. Although the hydrothermal explosions allowed the escape of much shallow stored heat to the surface, and surface temperatures remain low, the postulated fault(s) or others, may still provide permeability within the basement. Such fracture permeability would be a suitable drilling target for wells sited to east of KA 26 in the hope of encountering both the high basement temperatures of KA 26, and fault induced permeability.

\section{ACKNOWLEDGEMENTS}

Solia Wiradiradja was killed in a tragic accident at Dieng Geothermal Field (Central Java) as this paper was being completed in October 1978. Work by Solia at Kawerau was carried out in early 1977 as part of a geothermal training exercise in New Zealand, under a Bilateral Aid Agreement between the Indonesian and New Zealand Governments. Much assistance in geothermal studies was received from P. R. L. Browne and C. P. Wood.

The paper has been improved by valuable discussions with the authors' colleagues at D.S.I.R., Rotorua and Wairakei, and by critical reviews from F. E. Studt, J. W. Cole, G. W. Grindley, B. F. Houghton, C. P. Wood and P. R. L. Browne.

\section{REFERENCES}

Batzle, M. I. and Simmons, G., 1976, Microfractures in Rocks from Two Geothermal Areas. Earth and Planet. Sci. Letters, 30, p. 71-93.

BradLey, J. S., 1965, Intrusion of Major Dolerite Sills. Trans. of the Roy. Soc. of N. Z., Geology 3 (4), p. 27-55.

Browne, P. R. L., 1978 , Petrological Logs of Drillholes: Kawerau Geothermal Field. Report N.Z.G.S. 84, N.Z. Geological Survey, D.S.I.R., New Zealand, 57 pp.

1978b: Hydrothermal Alteration in Active Geothermal. Fields. Annual Rev. Earth and Planet. Science, 6, p. 229-50.

- (in press), Minimum Age of the Kawerau Geothermal Field, North Island, New
Zealand. Jour. of Volcan, and Geoth. Res. Cole, J. W. and NAIRN, I. A., 1975, Catalogue of the Active Volcanoes of the World, Including Solfatara Fields. Part 22, New Zealand. International Association of Volcanology and Chemistry of the Earth's Interior, Rome, 156 pp.

- and Stephenson, T. H., 1972, Calculation of the Volume of a Tephra Deposit. Appendix in Publication of Geology Department, Victoria Univ. of Wellington, 1, p. 13-14.

Duncan, A. R., 1970, Eastern Bay of Plenty Volcanoes. Unpubl. Ph.D. thesis, Victoria Univ. of Wellington Library, 316 pp.

FACCA, G. and TonANI, F., 1967, The Self-sealing Geothermal Field. Bull. Volcanol., 30, p. 271-273.

FOLK, R. L., 1974, Petrology of Sedimentary Rocks. Hemphill Publishing Co., Austin, Texas, $182 \mathrm{pp}$.

Fudali, R. F. and Melson, W. G., 1972, Ejecta Velocities, Magma Chamber Pressure, and Kinetic Energy Associated with the 1968 Eruption of Arenal Volcano. Bull. Volcanol. 35 , p. $383-401$.

Funiciello, R., Locardi, E., Lombardi, G., and PAROTTO, M., 1976, The Sedimentary Ejecta from Phreatomagmatic Activity and Their Use for Location of Possible Geothermal Areas. Proc. Intern. Congr. on Thermal Waters, Geothermal Energy, and Vulcanism of the Mediterranean Area, Athens, 1, Geothermal Energy, p. 227-240. GoGUEL, J., 1956, Le mécanisme des explosions phréatiques. Bureau Central Seismologique International, Série A, Travaux Scientifiques, Fasc. 19 (Memoirs presentes à l'assemblée de Rome).

Grindley, G. W., and Browne, P. R. L., 1976 , Structural and Hydrological Factors Controlling the Permeabilities of Some Hotwater Geothermal Fields. Proc. 2nd U.N. Symp. on Development and Use of Geothermal Resources, San Francisco, 1975, p. 377-386.

HoworTH, R., 1975, New Formations of Late Pleistocene Tephras from the Okataina Volcanic Centre, New Zealand. N.Z. Jour. of Geol. and Geophys., 18, p. 683-712.

KeITH, T. E. C., and Muffler, L. J. P., 1978, Minerals Produced during Cooling and Hydrothermal Alteration of Ash Flow Tuff from Yellowstone Drillhole Y-5. Jour. of Volcan. and Geoth. Res., 3, p. 373-402.

KenNedy, G.C., and Holser, W. T., 1966, Pressure-Volume-Temperature and Phase Relations of Water and Carbon Dioxide. In: Handbook of Physical Constants - Revised Edition, The Geol. Soc. of Am., Mem. 97, p. $371-383$. 
LLOYD, E. F., 1972, Geology and Hot Springs of Orakeikorako. N.Z. Geol. Surv. Bull., 85, D.S.I.R., New Zealand, 164 pp.

Lorenz, V., 1973, On the Formation of Maars. Bull. Volcanol., 37 (2), p. 183-204.

Macdonald, W. J. P., and Muffler, L. J. P., 1972, Recent Geophysical Exploration of the Kawerau Geothermal Field, North Island, New Zealand. N.Z. Jour. of Geol. and Geophys., 15 (3), p. 303-317.

Moore, J. G., 1967, Base Surge in Recent Volcanic Eruptions. Bull. Volcanol., 30, p. 337-363.

Muffler, L.J.P., White, D.E., and TruesDELL, A.H., 1971, Hydrothermal Explosion Craters in Yellowstone National Park. Geol. Soc. of Am. Bull., 82, p. 723-740.

PHILlIPS, W.J., 1972, Hydraulic Fracturing and Mineralization. Jour. of the Geol. Soc., 128, p. 337-359.

Pullar, W.A., BirRell, K.S., and Heine, J. C., 1973, Named Tephras and Tephra Formations Occurring in the Central North Island, with Notes on Derived Soils and Buried Paleosols. N.Z. Jour. of Geol. and Geophys., 16, p. 497-518.

RoHLoF, K.J., 1969, Analysis of the Exterior Ballistics of Block Ejecta at Nanwaksjiak Crater, Nunivak Island, Alaska. M.S. Thesis, Air Force Inst. of Technol., WrightPatterson AFB, Ohio, 118 pp.
Sparks, R.S.J., and WILson, L., 1976, A Model for the Formation of Ignimbrite by Gravitational Column Collapse. Journ. Geol. Soc. London, 132, p. 441-451.

, and Hume, G., 1978, Theoretical Modelling of the Generation, Movement, and Emplacement of Pyroclastic Flows by Column Collapse. Jour. of Geophys. Res., 83, p. 1727-1739.

STUDT, F. E., 1958, Geophysical Reconnaissance at Kawerau, New Zealand. N.Z. Jour. of Geol. and Geophys., 1 (2), p. 219-246.

WALKeR, G. P. L., WILSON, L., and BOWEll, E. L. G., 1971, Explosive Volcanic Eruptions 1. The Rate of Fall of Pyroclasts. Geophys. Jour. of the Roy Astronom. Soc., 22, p. 377-383.

White, D. E., Fournier, R. O., Muffler, L. J. P., Truesdell, A. H., 1975, Physical Results of Research Drilling in Thermal Areas of Yellowstone National Park, Wyoming. U.S. Geol. Surv. Prof. Paper, 892, 70 pp.

WILSON, L., 1972, Explosive Volcanic Eruptions - II. The Atmospheric Trajectories of Pyroclasts. Geophys. Jour. of the Roy. Astronom. Soc., 30, p. 381-392.

- 1976, Explosive Volcanic Eruptions, III, Plinian Eruption Columns. Geophys. Journ. Roy. Astronomical Society 45: 543556.

Ms. received and sent to review Feb. 1979 Revised ms. received Sept. 1979 
Lake Water Chemistry

Partial chemical analyses of lake waters associated with O.V.C. have been published by McColl (1975), and Taylor et al (1977). Results of these analyses (including Lake Rotorua) are reproduced in Tables 11 and 12 , and are significant in indicating the occurrence (or lack of) a hydrothermal contribution to the lake waters.

Catchment and lake data for O.V.C. lakes are summarized in Table 8, (see p. 255).

The lake waters fall into 3 main groups*. Lakes Rotoehu, Tarawera, and Rotomahana all contain more than $100 \mathrm{mg} I^{-1} \mathrm{Cl}$; Lakes Rotoiti, Rotoma (and Rotorua) contain c. 20-35 $\mathrm{mg} \mathrm{I}^{-1} \mathrm{Cl}$; while Lakes Rerewhakaaitu, Rotokakahi, Tikitapu, Okareka, Ngapouri, Okaro, Ngahewa, and Rotokawau all contain less than $6 \mathrm{mg} \mathrm{I}^{-1} \mathrm{Cl}$.

The very low values for chloride and other ions found in Rerewhakaaitu, Rotokakahi, Tikitapu, and Okareka demonstrate that no significant hydrothermal chloride inflows occur to these lakes. Tikitapu water composition is in fact very close to that of local rainwater (McColl 1975). The slightly elevated chloride value for Okataina $\left(11 \mathrm{mg} \mathrm{I}^{-1}\right)$ is consistent with the known small hydrothermal inflow to the lake, and

* Most water analyses reported in Table 11 were carried out at the D.S.I.R. Ecology Division Laboratory by McColl in 1971. Later analyses by the Wairakei Geothermal Laboratory have produced lower chloride values for Lake Tarawera waters (see Table 13-0utlet).Whether the different results represent different Tarawera water compositions at different times, or arise from different analytical practices is uncertain. Chloride analyses by the Wairakei Laboratory on samples collected from Lakes Rotoma, Okareka, and Rerewhakaaitu in September 1972 (Table 12) have given practically identical results to those reported by McColl. In this discussion the relative values for lakes sampled in 1970-71 are considered significant. 


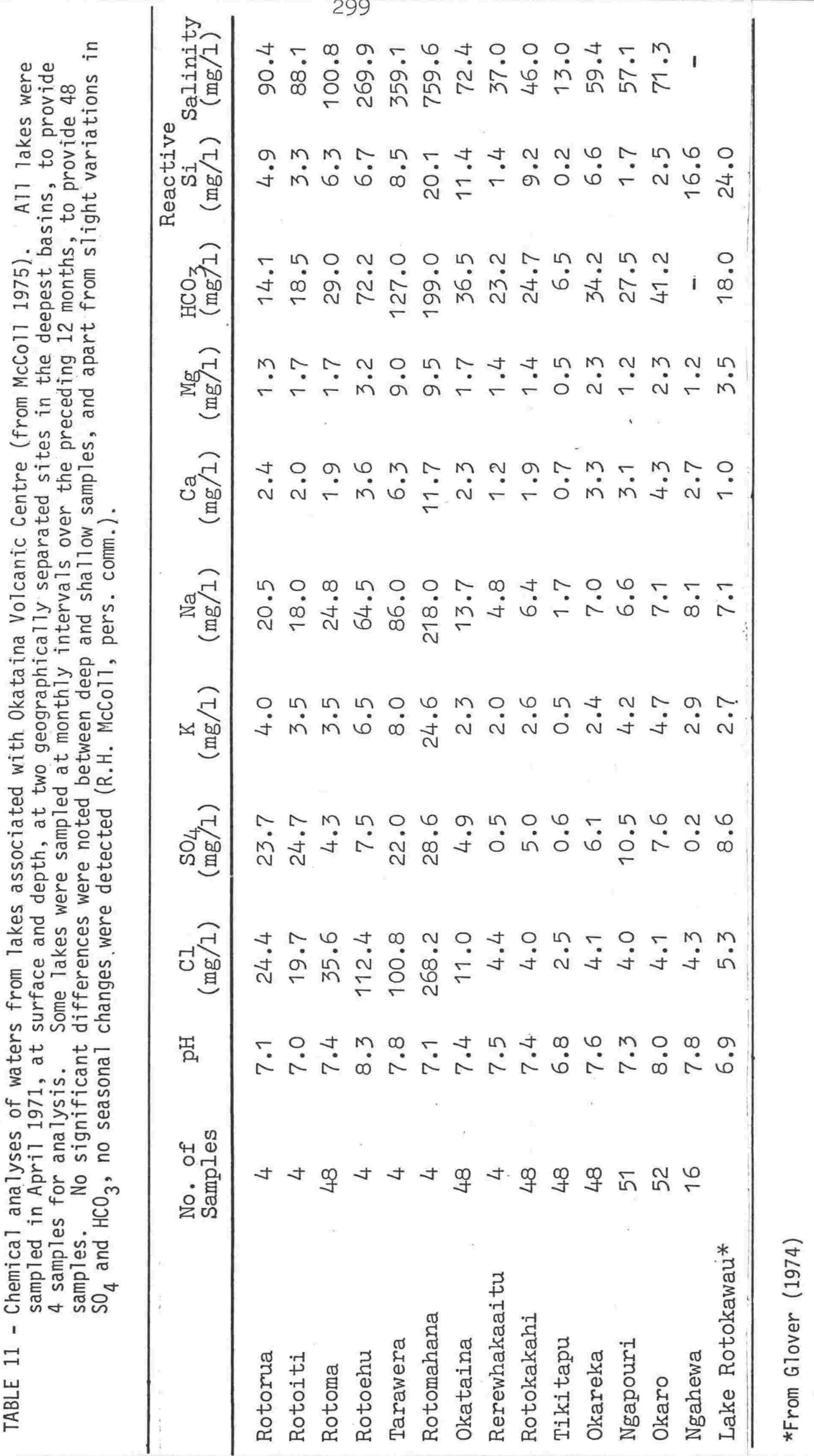


TABLE 12 - Chloride contents of lake waters sampled in September 1972. Analyst R.B. Glover. Analyses are reported in Taylor et a) 1977.

C1 $\mathrm{mg}^{-1}$

Lake Rotoma (surface)

36.3

Lake Rotoma (bottom)

36.3

Lake Okareka (surface)

4.7

Lake Okareka (bottom)

4.6

Lake Rerewhakaaitu (surface)

4.4

Lake Rerewhakaaitu (Crater Basin surface)

3.9

Lake Rerewhakaaitu (Crater Basin bottom)

3.5 
indicates that no other major hydrothermal outflows occur on the lake floor. The low chloride contents of the crater lakes Rotokawau, Ngapouri, Okaro, and Ngahewa show that no significant outflows of chloride waters can occur in the floors or catchments of these lakes, although somewhat elevated $\mathrm{SO}_{4}$ contents may suggest the input of acid sulphate waters or $\mathrm{H}_{2} \mathrm{~S}$ gas to Rotokawau, Okaro, and Ngapouri.

Large surface hydrothermal inflows occur into Rotomahana from Waimangu Valley and the western lake shore. Similar large inflows occur into Lake Rotorua from the Rotorua City Geothermal Field, plus small known contributions from other thermal areas at Mokoia Island, Rotokawa, and the Hell's Gate area of Tikitere (Glover et al 1974). The order-of-magnitude difference between the chloride contents of Rotomahana and Rotorua waters reflects the much greater proportion of fresh water inflow to Lake Rotorua from a total catchment area (Iand and water surface) which is 6 times larger than that for Rotomahana (Table 8). The longterm chloride content of Rotomahana waters may be higher than the $268 \mathrm{mg} \mathrm{I}^{-1}$ measured in 1971, as this was a period of high rainfall when Lake Rotomahana was rising rapidly (Healy 1975b) to reach its maximum recorded level in 1972. The influx of fresh water into storage is likely to have diluted the lessvariable hydrothermal inflow.

Lake Rotoiti has similar chemical composition to Lake Rotorua. However this is not due to passage of Rotorua waters through Rotoiti, as Fish (1975) has shown that Rotorua waters pass directly through the western arm of Lake Rotoiti to the Okere outlet, and do not mix with the main Rotoiti waters in the lake basins to east. The chloride content of Rotoiti waters is therefore due to thermal activity in the Rotoiti catchment and on the lake floor. The small surface discharge (c. $20 \mathrm{ls}^{-1}$ ) of the Tikitere hot springs contains low chloride ( $\max 220 \mathrm{mg} \mathrm{I}^{-1}$ - Glover 1974) and cannot contribute much chloride to the lake outflow $\left(e . g .<5 \mathrm{~g} \mathrm{~s}^{-1}\right)$. The $0.3 \mathrm{~m}^{3} \mathrm{~s}^{-1}$ thermal water thought to enter the lake from the Centre Basin hot springs has not been analysed, but estimates of measured 
heat flow and chloride flux (see p. 304 ) suggest that this water also cannot be high in chloride.

Relatively high chloride values are recorded from Lakes Tarawera, Rotoehu, and Rotoma. The known surface hydrothermal inflows to Lake Tarawera are small, particularly when compared to the very large cold water inflow demonstrated by the $7.4 \mathrm{~m}^{3}$ $\mathrm{s}^{-1}$ 1971-79 mean outflow at Lake Tarawera outlet (R.E. Murray pers. comm.). Lake Tarawera is surrounded by the higher and largely closed lake basins of Okataina, Okareka, Tikitapu, Rotokakahi, and Rotomahana. The closed lake basins are considered to drain underground into Lake Tarawera to produce a total lake catchment area of $c .350 \mathrm{~km}^{2}$. Of the sub-catchment lakes, only Rotomahana waters are significantly mineralized. Assuming the Rotomahana contribution to Lake Tarawera inflows is broadly proportional to the respective catchment areas (Rotomahana = $86 \mathrm{~km}^{2}$; Tarawera land catchment, plus Okataina, Okareka, Tikitapu, and Rotokakahi areas $=220 \mathrm{~km}^{2}-$ Table 8), then Rotomahana water at $268 \mathrm{mg} \mathrm{I}^{-1} \mathrm{Cl}$ would be diluted to less than $80 \mathrm{mg} \mathrm{I}^{-1}$ $\mathrm{Cl}$ in Lake Tarawera*. The remaining $20 \mathrm{mg} \mathrm{I}^{-1} \mathrm{Cl}$ in Tarawera waters would therefore come from local sources within the lake. This concentration appears too large to have come from the known small surface inflows at Te Rata and suggests that other chloride inflows occur beneath the lake surface.

Similarly, the high chloride values for Lakes Rotoma and Rotoehu seem too large to be accounted for by the known surface hydrothermal inflows. The Rotoma value ( $35 \mathrm{mg} \mathrm{l}^{-1}$ ) demonstrates chloride inflows greatly exceeding the known minor Otei hot spring on the lake shore. The Rotoehu chloride content (112.4 $\mathrm{mg} \mathrm{I}^{-1}$ ) is also much higher than could be contributed solely by the Waitangi Spring. This spring has a chloride content of

\footnotetext{
* In common with other lakes in the Rotorua district (Hoare 1980), direct precipitation on the Lake Tarawera surface exceeds lake evaporation by a factor of about 2. Thus no evaporation concentration of chloride occurs in Rotorua district lakes; instead further dilution occurs.
} 
$365 \mathrm{mg} \mathrm{I}^{-1}$, but is considerably diluted by cold water seeping from Lake Rotoma, before it enters Lake Rotoehu. Mixing calculations based on spring and stream flows measured in 1973 (H.J. Freestone pers. comm.) and the cooling of the spring water from $49^{\circ} \mathrm{C}$ to $20^{\circ} \mathrm{C}$ suggest that the Waitangi Spring water would be diluted to about $1 / 6$ th its original concentration. The surface inflow to Lake Rotoehu would therefore be at about 60 $\mathrm{mg} I^{-1} \mathrm{Cl}$, about half the value measured in the lake waters which must receive inflows from other, more highly mineralized sources.

\section{Chloride Fluxes}

Minimum natural heat flows from geothermal fields can be estimated by chemical means if the total amount of chloride discharged from the geothermal field can be determined (EIlis and Wilson 1955, Fournier, White, and Truesdell 1976). The method requires that the approximate chloride content and temperature of the deep reservoir water are known. Where this information is not available, assumption of a maximum chloride concentration and a minimum deep temperature (both indicated from surface spring analyses) will produce a minimum calculated heat flow figure, based on the ratio of heat to chloride in the deep reservoir water (Ellis \& Wilson 1955).

Where lake outflow rates are known, an approximation of chloride flux can be obtained from the water analyses. During the 13 months prior to April 1971 when Lake Tarawera was sampled to contain $100 \mathrm{mg} \mathrm{I}^{-1} \mathrm{Cl}$ (Table 11), the lake had a mean outflow of $9 \mathrm{~m}^{3} \mathrm{~s}^{-1}$ (Ministry of Works Water and Soil Division flow data - R.E. Murray, pers. comm.). Calculated lake residence times for Lake Tarawera are about 10 years, so that lake storage factors are ignored. A calculated chloride flux of $900 \mathrm{~g} \mathrm{~s}^{-1}$ was therefore passing out of Lake Tarawera in 1971. The composition of deep thermal waters in the Lake Tarawera catchment is not known. The most highly mineralized springs at Waimangu contain $780 \mathrm{mg} \mathrm{I}^{-1}$ $\mathrm{Cl}$ (Mahon 1965), and $\mathrm{Na} / \mathrm{K}$ geothermometry indicates minimum deep temperatures of $260^{\circ} \mathrm{C}$ (R.B. Glover, pers. comm.). The most 
highly mineralized springs and wells at Waiotapu contain up to $2000 \mathrm{mg} I^{-1} \mathrm{Cl}$ (Lloyd 1959, Wilson 1963, Sheppard and Giggenbach 1980) although isotopic data indicates that these waters have probably been concentrated by boiling from an initial fluid containing about $1850 \mathrm{mg} \mathrm{I}^{-1} \mathrm{Cl}$ (Stewart 1980). Maximum deep well temperature measured at Waiotapu was $295^{\circ} \mathrm{C}$.

Assuming conservative values of $2000 \mathrm{mg} \mathrm{I}^{-1}$ chloride and a deep water temperature of $260^{\circ} \mathrm{C}$, the calculated chloride flux from Lake Tarawera during April 1971 is equivalent to a minimum heat flow of $490 \mathrm{MW}$. If the chloride and temperature values are assumed at a perhaps more realistic $1500 \mathrm{mg} \mathrm{I}^{-1}$ and $280^{\circ} \mathrm{C}$ respectively, the minimum natural heat flow is 700 NW. Both figures are in excess of the c. 360 MW physically estimated for the surface hydrothermal areas at Waimangu, Rotomahana, and Te Rata, and suggest that considerable other chloride inflows may occur undetected beneath Lakes Rotomahana and/or Tarawera.

The method can be checked empirically. Lake Rotorua has a long term mean outflow of $19 \mathrm{~m}^{3} \mathrm{~s}^{-1}$ (R.E. Murray pers. comm.). The chloride content of $24.4 \mathrm{mg} \mathrm{I}^{-1}$ (Table 11) is equivalent to a chloride flux of $460 \mathrm{~g} \mathrm{~s}^{-1}$. If deep reservoir waters with $1000 \mathrm{mg} \mathrm{I} \mathrm{I}^{-1}$ chloride and $250^{\circ} \mathrm{C}$ (Glover 1974) are assumed, a natural surface heat flow of $480 \mathrm{NW}$ is obtained. Natural surface heat flows for the Rotorua basin have not been physically measured, but estimates of 250 MW have been made. for the Whakarewarewa area (i.e. Lloyd 1979, Allis 1980). Addition of the remainder of the Rotorua City Geothermal Field (c. 100 MW?), Rotokawau, Mokoia Island, and the Hell's Gate area of Tikitere (total c. 50 NW?) to this estimate, indicates that the total heat flow estimated by chloride flux is of the correct order. Similar techniques applied to the Lake Rotoiti mean outflow of $4 \mathrm{~m} \mathrm{~s}^{-1}$ (i.e. minus the Lake Rotorua mean outflow), indicate a Rotoiti chloride flux of $80 \mathrm{~g} \mathrm{~s}^{-1}$ and a heat flow of c. $80 \mathrm{MW}$ (assuming deep waters with 1000 $\mathrm{mg} I^{-1} \mathrm{Cl}$ and at $250^{\circ} \mathrm{C}$ ). This figure is well below the 140 MW heat flow measured in Centre Basin by Calhaem (1973), indicating that the Centre Basin inflows are also low in 
chloride and/or that considerable water is lost from Lake Rotoiti by seepage. The lake is known to be perched on its northern shore (Thompson 1974) and the adjacent Lakes Rotoehu and Rotoma, in similar geological environments, have large seepage outflows (Pittams 1968, 1979).

Chloride fluxes for lakes without surface overflow are harder to estimate, as they require assessment of seepage outflows. Lake Rotoma had measured average seepage losses to three adjacent lower springs of $1.19 \mathrm{~m}^{3} \mathrm{~s}^{-1}$ in 1964 and 1966, at a time when average total seepage losses were calculated at $1.36 \mathrm{~m}^{3} \mathrm{~s}^{-1}$ (Pittams 1968). If this same outflow occurred in 1970-71 when the lake water contained $35.6 \mathrm{mg} \mathrm{I}^{-1} \mathrm{Cl}$ (Table 11) the total chloride flux is $48 \mathrm{~g} \mathrm{~s}^{-1}$. Composition and temperature of deep reservoir fluids are unknown, but assuming $1000 \mathrm{mg} \mathrm{I}^{-1}$ and $250^{\circ} \mathrm{C}$, a heat flow of 50 MW is indicated, greatly in excess of the known hydrothermal inflows to Lake Rotoma.

Seepage west from Rotoma enters Lake Rotoehu at $c_{j} 0.53 \mathrm{~m}^{3}$ $\mathrm{s}^{-1}$ gauged in 1964 and 1966 (Pittams 1968), and $0.48 \mathrm{~m}^{3} \mathrm{~s}^{-1}$ gauged in 1973 (H.J. Freestone, pers. comm.). Assuming an average flow rate of $0.5 \mathrm{~m}^{3} \mathrm{~s}^{-1}$ of $35 \mathrm{mg} \mathrm{l^{-1 }} \mathrm{Cl}$ water from Rotoma, a known chloride flux of $\mathrm{c} .18 \mathrm{~g} \mathrm{~s}^{-1}$ enters Lake Rotoehu from Lake Rotoma. Average seepage outflow from Lake Rotoehu is considered to approximate $1.7 \mathrm{~m}^{3} \mathrm{~s}^{-1}$ (Pittams 1968) of $112.4 \mathrm{mg} \mathrm{I}^{-1} \mathrm{Cl}$ water (Table 11), indicating a chloride flux of $191 \mathrm{~g} \mathrm{~s}^{-1}$. From this must be subtracted the $18 \mathrm{~g} \mathrm{~s}^{-1}$ entering from Lake Rotoma; so that a net chloride flux into Lake Rotoehu of $173 \mathrm{~g} \mathrm{~s}^{-1}$ is indicated. Based on the same reservoir conditions assumed for Rotoma, this chloride flux would be equivalent to $180 \mathrm{MW}$. This heat flow figure is probably grossly inaccurate, as the water balance for Rotoehu is only imperfectly known. However, it is an order of magnitude greater than the estimated heat flow from the only known hydrothermal area in the Lake Rotoehu catchment (Waitangi Spring) and strongly suggests that other undetected inflows of chloride water occur to Lake Rotoehu. 
Tarawera River Chloride Flux: Water samples were collected from multiple sites on the Tarawera River during M.W.D. river gaugings on 25.11.80 and 10.12.80, and analysed for chloride at the Wairakei Geothermal Laboratory (J.B. Finlayson pers. comm.). Results are presented in Table 13, and Fig. 52. The chloride fluxes measured at Lake Tarawera Outlet are considerably less than that calculated from the 1971 flows and lake water analyses. The reason for this discrepancy is unknown, but indicates that a detailed sampling programme for Lakes Rotomahana and Tarawera, and the Tarawera River is required to firmly establish relative chloride contents and flux values. However, the relative chloride flux values of 10.12.80 demonstrate that considerable inflow of chloride ( $311 \mathrm{~g} \mathrm{~s}^{-1}$ ) occurs to the Tarawera River between the lake outlet and Mangate Bridge (Site G on Fig. 52), where the river passes out of Puhipuhi Basin. Most of the additional chloride enters the Tarawera River within Haroharo Caldera, with c. $200 \mathrm{~g}$ $\mathrm{s}^{-1}$ being added between the lake outlet and the Waterfall Road bridge (Site B on Fig. 52). A further $72 \mathrm{~g} \mathrm{~s}^{-1}$ is contributed by the tributary Mangakotukutuku Stream (Site C on Fig. 52). Only a small additional chloride flux enters the river within Puhipuhi Basin, most from the Waiaute Stream (Site F on Fig. 52). Making reservoir assumptions of $1500 \mathrm{mg} I^{-1} \mathrm{Cl}$ and $280^{\circ} \mathrm{C}$ the chloride fluxes are equivalent to a heat flow of 220 MW added to the river within Haroharo Caldera, and 240 MW to the Puhipuhi outlet, where the total chloride flux of $765 \mathrm{~g} \mathrm{~s}^{-1}$ is equivalent to $600 \mathrm{MW}$. These chloride flux results suggest that the most promising area for hidden chloride reservoirs will lie in the region between the Lake Tarawera outlet and Te Haehaenga Basin.

\section{B: DISCUSSION OF OKATAINA GEOTHERMAL RESOURCES}

Assessment of Total Heat Flow at O.V.C.

Measured (M), estimated ( $E)$, and inferred ( $I$ ) heat flows from the hydrothermal fields thought to be associated with O.V.C. are tabulated in Table 14. The inferred heat flows are based on chloride fluxes. The heat flow values can be summed in different ways. For those fields definitely 


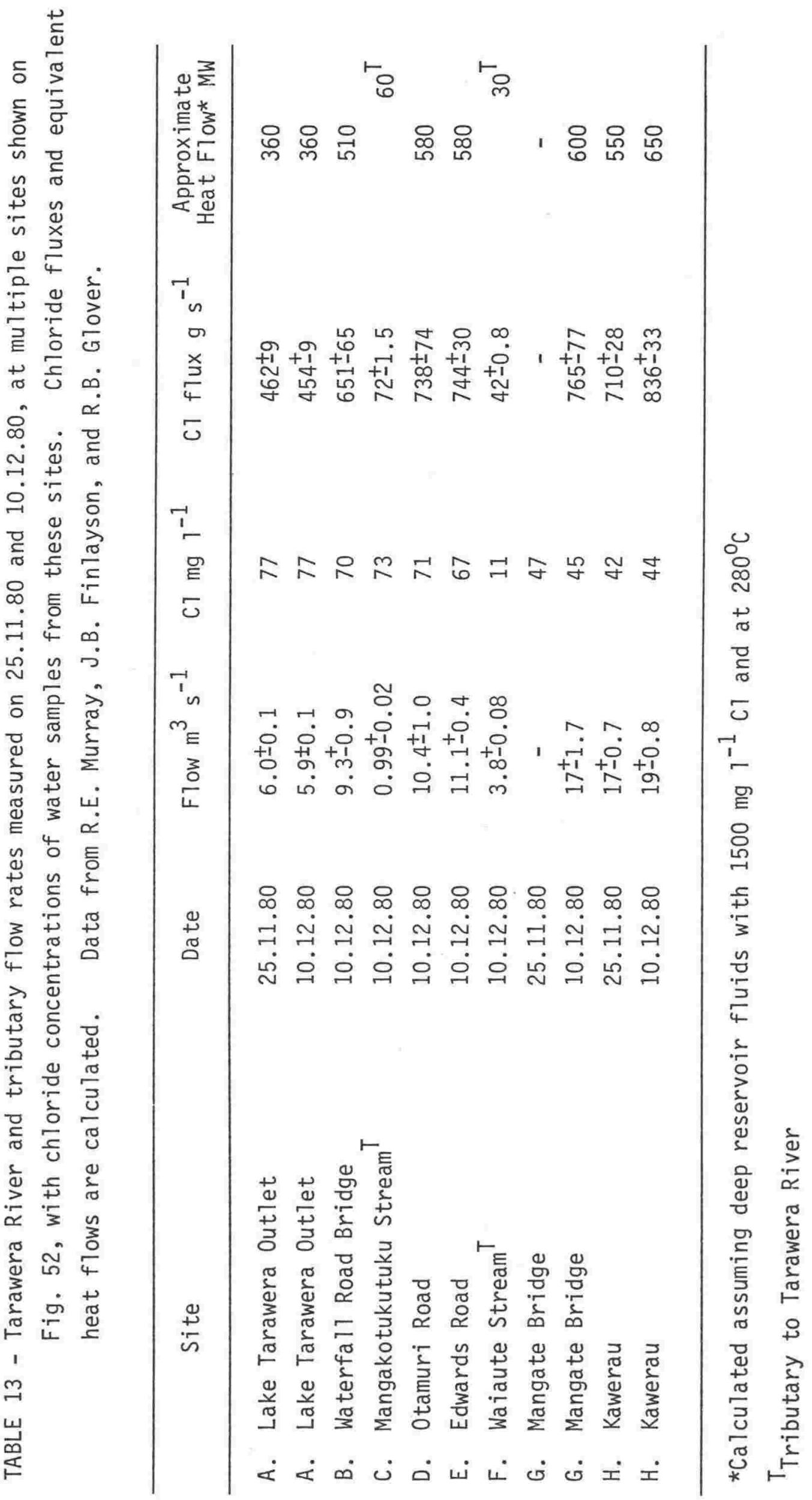




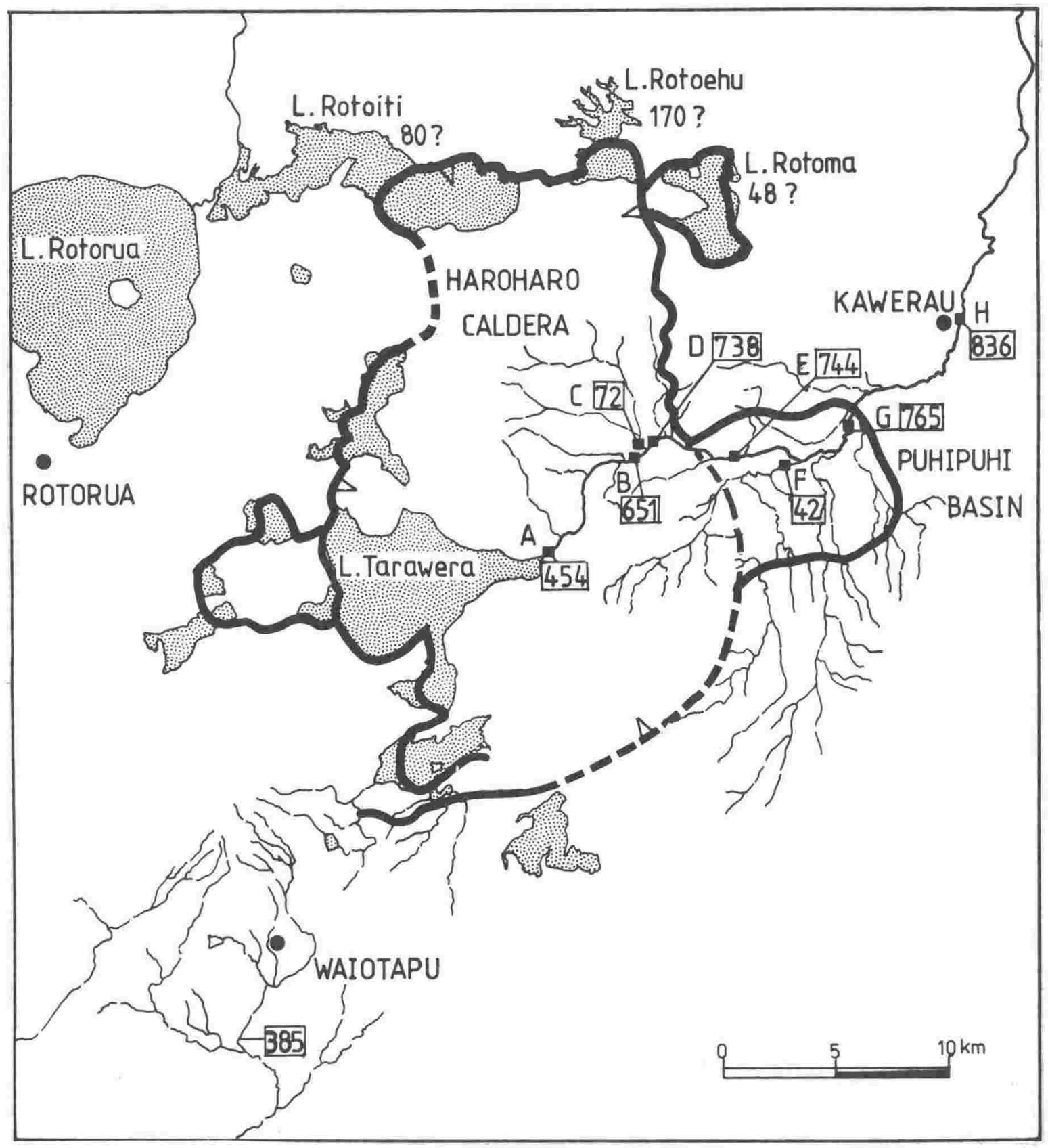

FIG. 52 - Locations of sampling sites ( ) and chloride flux values 72 on Tarawera River and tributaries. Sites lettered as in Table 13. Also shown are the chloride flux measured from Waiotapu Geothermal Field (Sheppard and Robinson 1980) and the chloride fluxes inferred in Lakes Rotoma, Rotoehu, and Rotoiti. 
TABLE 14 - Measured (M), estimated (E), and inferred (I) natural surface heat flows in MW at 0.V.C. Inferred values are not summed as they include repeated estimates of the same chloride flux at different points in the drainage path.

Geothermal Fields definitely associated with 0.V.C.

Wa imangu-Haumi

Rotomahana

(M)

(E)

$(M+E)$

Te Rata

180

80

260

$-\quad 100$

Lake Tarawera at Outlet

Okataina

Waiaute

Mangakotukutuku

Tarawera River catchments (below

-
-

$-\quad 5$

$-5$ lake outlet)

Tarawera River above Kawerau

Centre Basin

Rotoma-Tikorangi-Rotoehu

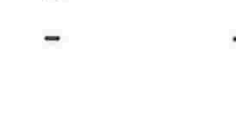

$\begin{array}{rrrr}- & - & - & 600 \\ 140 & - & 140 & 80 \\ 10 & 10 & 20 & 230 \\ \text { Sub-total } & & \overline{545} & \end{array}$

Geothermal Fields probably associated with 0.V.C.

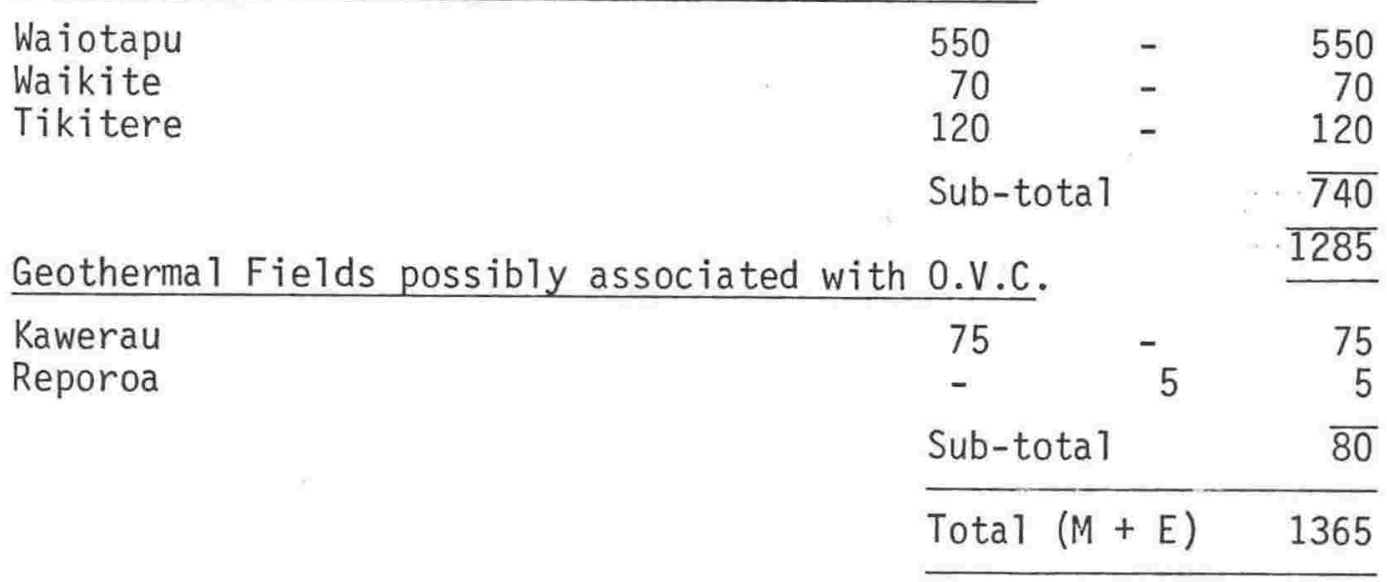

TABLE 15 - Summary of reasonable hydrothermal heat flow estimates from 0.V.C.

Geothermal Fields

Waimangu-Haumi-Rotomahana-Te Rata

Waiotapu-Waikite

Tarawera River (below Lake Outlet)

Centre Basin-Rotoehu-Rotoma

Tikitere
MW

$370(M+E)$

620 (M)

240 (I)

$200(M+I)$

120 (M)

Total 1570 
associated with O.V.C., measured surface heat flows equal 330 MW, and visually estimated surface heat flows $210 \mathrm{MW}$, for a total $(M+E)$ of $540 \mathrm{MW}$. This figure is considered to represent a firmly based, absolute minimum heat flow from the centre. Coincidentally, it nearly equals the heat flow inferred from chloride flux in the Tarawera River at Mangate Bridge near the Puhipuhi Basin outlet (Table 13). However, that both the $(M+E)$ and $(I)$ heat flow values represent minimums is demonstrated by the northward and westward drainage of the Rotoma-Rotoehu-Centre Basin geothermal fields, away from the Tarawera River. Chloride from these fields does not contribute to the Tarawera River flux, and therefore their $(M+E)$ heat flows (c. $160 \mathrm{NW}$ ) could be added to the 550 MW (I) at Puhipuhi Basin outlet to give a total of $710 \mathrm{MW}$.

The 360 NW (I) at Lake Tarawera Outlet calculated for November and December 1980 also closely matches the total (M + E) heat flow for Waimangu-Haumi, Rotomahana, and Te Rata - the known fields which are considered to contribute to the Lake Tarawera chloride flux. However, when chloride flux values can be checked against physically measured heat flows, as at Waiotapu and Centre Basin, the (I) values are much less than the (M). (I) for Centre Basin and Waiotapu is 80 MW and 250 MW respectively, to be compared with (M) values of $140 \mathrm{MW}$ and 550 MW. If this same relationship applies to the Tarawera River (I) value then a doubled heat flow of c. 700 MW might be correct.

To the $(M+E)$ (Table 14) values for the above fields can also be added the (M) values for Waiotapu, Waikite, and Tikitere, all fields which are considered probably associated with O.V.C. [The (I) values are much lower than the (M)]. A total of 1280 MW is obtained, to which could also be added 80 MW (Table 14) if Kawerau and Reporoa are related to an O.V.C. heat source.

In summary, although total heat flow from O.V.C. cannot at present be accurately estimated, it is clearly large, and the O.V.C. must contain major geothermal energy resources. 
The summation given in Table 15 may be a reasonable approximation of hydrothermal heat flows from O.V.C., and suggests a total heat flow exceeding 1500 MW. Further efforts should be directed at accurate heat flow estimates within O.V.C., and the study of deep hydrothermal structures with geophysical techniques.

Comparison with Volcanic Heat Flow

A hydrothermal heat flow of 1500 MW can be compared with the long term volcanic heat flow, manifested by the eruption of c. $500 \mathrm{~km}^{3}$ of rhyolite magma during the last 250,000 yrs. The erupted volume is equivalent to a volcanic heat flow of c. 250 MW averaged over this time interval (Appendix 3); i.e. about $1 / 6$ th of the present day hydrothermal heat flow. If hydrothermal heat flow has been fairly constant over the lifetime of Haroharo Caldera, then fluid convection has played a dominant role in the transfer of heat from depth in the crust to the surface.

Location of the Surface Fields

A basic problem arises in attempting to explain the apparent lack of major surface heat flows within Haroharo Caldera. A possible influence is the comparatively young $(<20,000$ yrs B.P.) age of the caldera-filling surface rocks. The limited available information on the age and duration of major hydrothermal fields shows them to be long lived (Browne 1979). The Wairakei hydrothermal system has been considered to have a minimum age of 500,000 years (Grindley 1965); Broadlands and Kawerau system ages are of similar order: $>400,000$ years and $>200,000$ years B.P. respectively (Browne 1979). The time required to set up a large hydrothermal convective system is unknown. If it is say one-tenth that of the duration of hydrothermal activity, it may be that insufficient time has elapsed since the last major eruptions at Okataina to establish large convective systems which reach the ground surface within the caldera. Ellis and Mahon (1977) suggest that water turnover time in major geothermal systems is very long $\left(10^{4}-10^{5}\right.$ years) 
and that large outflows may be intermittent. The repeated infilling of Haroharo Caldera with voluminous pyroclastic deposits during the period 50,000-20,000 years B.P., and the construction of massive lava piles during the last 20,000 years may have acted to delay the establishment of complete convective systems at Okataina.

The occurrence of surface hydrothermal activity within Haroharo Caldera will also be suppressed by the geohydrological environment. The caldera will act as a major recharge zone to deep hydrological systems. Considerable infiltration of water from the marginal lakes is likely to occur down the caldera ring faults on which these lakes are perched. The rhyolite massifs of Haroharo and Tarawera are areas of relatively high rainfall ( $>2000 \mathrm{~mm} /$ year - De Lisle 1962) and are permeable to infiltrating rain water, with surface flowing streams being rare. The downward infiltration of large volumes of cold meteoric water would tend to overwhelm rising columns of hot fluids, and sweep these away subhorizontally. A conceptual model of the possible heat flow and hydrological systems active at O.V.C. is shown in Fig. 53, which suggests that hot fluids convectively rising above a deep magmatic body are swept outwards by infiltrating denser cold water, to rise external to the caldera. Such a model is consistent with the relative lack of thermal activity above the main magma bodies thought to underlie the major locii of magma emission at Haroharo and Tarawera during the last 50,000 years. Instead, the heat flow from these magmatic bodies is largely appearing in the external hydrothermal fields forming the Tarawera-Rotomahana-WaimanguWaiotapu system, the Centre Basin-Lake Rotoiti and RotoehuTikorangi fields, at Tikitere, and even Kawerau.

Assessment of hydrothermal fields at O.V.C.

O.V.C. geothermal areas are considered here under two groupings - (1) the northern fields which appear likely to be related to a Haroharo heat source, and (2) the southern fields which are 

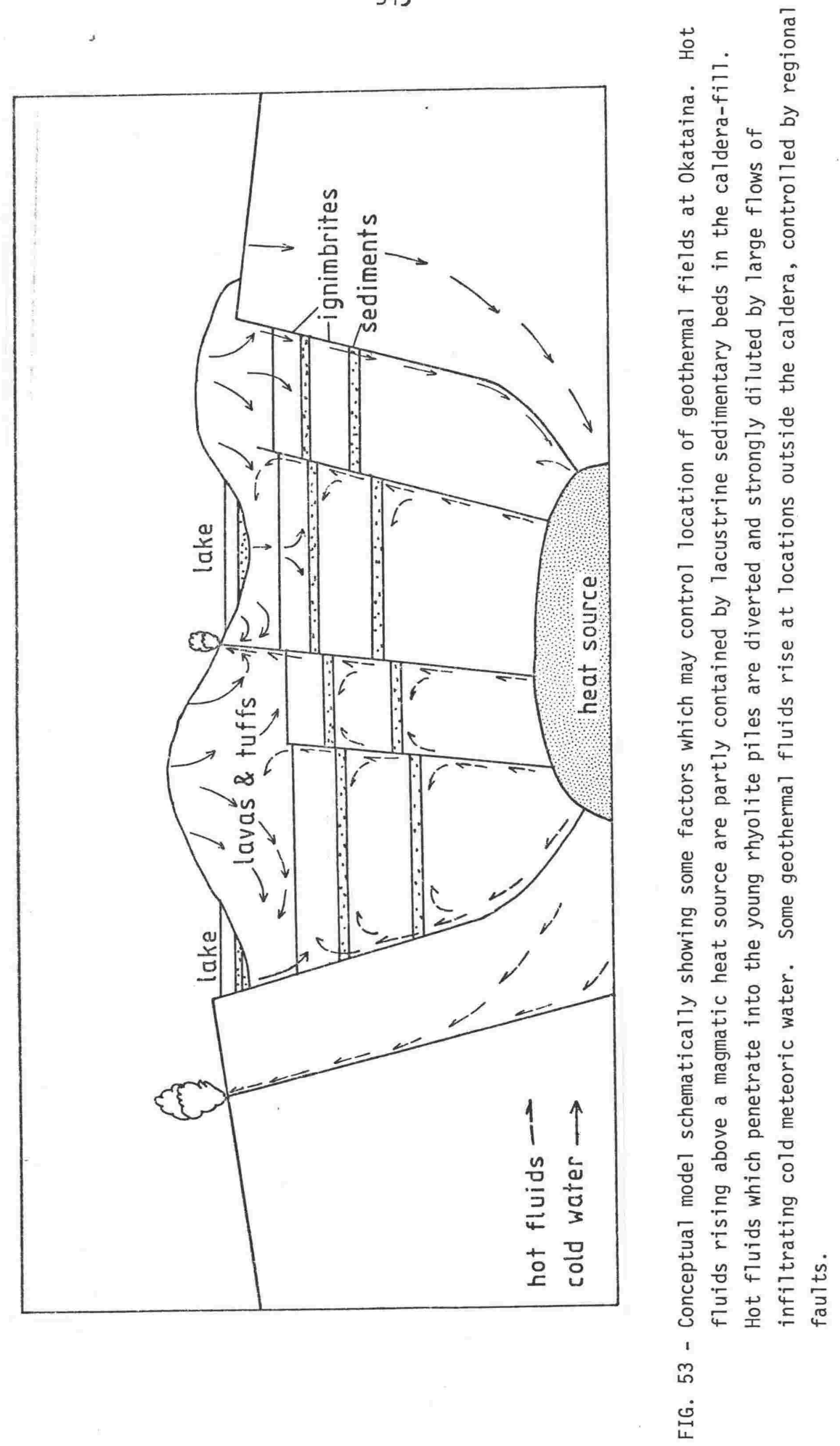
more likely to be related to a Tarawera heat source. Kawerau, although a northern field, is situated close to the Tarawera vent lineation. Insufficient data is available to assess any connection to a Tarawera heat source.

Northern Fields: Sulphur exploration drilling at Tikorangi has revealed the presence of high temperature steam at shallow depths, and low resistivities have been recorded along Highway 30 in the Rotoehu-Rotoma area $2 \mathrm{~km}$ to the north. No other resistivity data is available. The chloride contents of Lakes Rotoma and Rotoehu waters suggest much greater hydrothermal inflows to these lakes than is indicated by the known surface hot springs.

Detailed geophysical surveys of the Tikorangi-Rotoma area are required before a better assessment of the geothermal resource here can be made, but the geological parameters are encouraging. The sequential extrusion of Rotokohu, Haroharo, and Tikorangi Domes at c. 5500 yrs B.P. indicates the existence of a young north-east trending fracture zone which could provide a high-permeability drilling target, as should the north-south trending caldera rim on which Tikorangi Dome is located. A geothermal reservoir is likely to extend at depth south-west from Tikorangi under the Haroharo lavas, possibly related to a major heat source in this direction. Tikorangi should be the target for surveys of gravity to delineate structures, and resistivity to delineate shallow field extent. It will be necessary to employ resistivity techniques which will penetrate the glassy Haroharo lavas of high intrinsic resistivity.

It may be significant that the Tikorangi solfatara area occurs at $260 \mathrm{~m} \mathrm{a.s.1.} \mathrm{in} \mathrm{the} \mathrm{only} \mathrm{area} \mathrm{of} \mathrm{relatively} \mathrm{low}$ elevation on the Haroharo vent lineation which is not occupied by, or close to, a lake. Although surface heat flow is small, the Tikorangi field may have considerable energy potential and should receive much greater scientific attention. 
The recent resistivity traverse carried out along S.H. 30 between Rotoma and Rotoiti indicates areas of hot water at depth, probably forming a sub-horizontal outflow from beneath the Haroharo massif. This hot water finds surface outlet at Lakes Rotoma and Rotoehu, and in the only significant topographic low in the northern Haroharo Caldera, where it forms the Centre Basin thermal area in Lake Rotoiti. Deeper circulating water from Haroharo may also rise in the Tikitere area, with further deep subhorizontal outflow to Taheke. These possibilities can only be further examined by deep resistivity sounding techniques. Isotopic analyses of deep waters at Tikitere, if investigation wells are drilled, should also provide some evidence of water source elevation and locality. Drilling of investigation wells has been proposed at Tikitere and the field is not considered further here.

The areas of warm springs and high conductive heat flow in Lake Okataina and at Humphrey's Bay in Lake Tarawera are the only other surface hydrothermal manifestations to occur on the Haroharo vent lineation. They are probably also fed by deep hot water outflows from beneath the Haroharo massif, with location controlled both by vent lineation structures allowing access of hot water to the surface, and the near-surface hydrological environment adjacent to the lakes. Seepage from the lakes may also account for the complete lack of surface thermal activity further south-west on the vent lineation, in the Okareka, Tikitapu and Rotokakahi areas. Preliminary resistivity traverses in this area have encountered some moderately low values $(30-100 \mathrm{ohm} \mathrm{m}$ ) on the western shore of Lake Tarawera, indicating that some hot water is probably present at depth but it has no known surface expression. Resistivity values in the Okareka, Tikitapu and Rotokakahi areas are all relatively high (100-1000 ohm $\mathrm{m}$ ) indicating the presence of cold water only, as also evidenced by the low chloride contents of water samples from these lakes.

The warm Mangakotukutuku Springs on the eastern flanks of the Haroharo massif demonstrate that hot chloride water is 
flowing eastwards at shallow depth from beneath Haroharo towards a sink formed by the Te Haehaenga Basin on the eastern caldera rim. This basin at $130 \mathrm{~m} \mathrm{a.s.1.} \mathrm{is} \mathrm{the} \mathrm{lowest} \mathrm{surface} \mathrm{within}$ Haroharo Caldera (including the lake floor deeps), and should be an early target for deep resistivity surveys. Resistivity surveys are also required to trace deep flow paths to the Mangakotukutuku Springs, and to investigate the possible existence of a deep geothermal reservoir in this area.

In summary, the Tikorangi-Rotoma, Mangakotukutuku, Okataina, Humphrey's Bay (Lake Tarawera), and Centre Basin (Rotoiti) thermal areas all appear to be directly related to a Haroharo Volcanic Complex heat source.

Southern Fields: Several earlier workers (i.e. Macdonald 1967, Healy 1969, 1974, Mahon 1965a,1966, Healy and Hochstein 1973) have suggested deep connections between the surface hydrothermal fields at Reporoa, Waikite, and Waiotapu forming an extensive geothermal system at depth. Recent resistivity survey results have demonstrated the continuation of low resistivity values north-north-east from Waiotapu to Waimangu and Rotomahana, and support the existence of an extensive system. Mahon (1965a,b) considered that a close chemical relationship existed between the Waiotapu, Waikite, and Waimangu springs. Much work remains to be done to complete understanding of the deep hydrology in this region, but the presently available data is consistent with the existence of a very large geothermal system extending from Lake Tarawera, through Rotomahana, Waimangu, and Waiotapu, to Waikite and Reporoa. As an initial geological model, this geothermal system is considered likely to arise from a magmatic heat source associated with the Tarawera Volcanic Complex and vent lineation. Outflow from a deep chloride water reservoir associated with this heat source is dominantly channelled to south-west along the Tarawera vent lineation, and the Paeroa and Ngapouri and intervening faults, to give rise to the surface activity at Te Rata (Lake Tarawera), Rotomahana, Waimangu, Haumi Stream, Ngapouri Fault, Earthquake Flat Road, and Waikite. To south of the Ngapouri Fault, this deep outflow 
becomes dominantly controlled by the southward regional flow of groundwater moving into the Reporoa Basin towards the hydrological sink represented by the Waikato River (Healy and Hochstein 1973). Deep flow through the Waiotapu field may be controlled by north-north-east trending faults, probably related to and extending from the collapse scarp at the northern end of the Reporoa basin.

The existence of such a large geothermal system can only be confirmed by completion of extensive geophysical and geochemical surveys, to be correlated with the results of drilling to sample the deep fluids and examine geological and hydrological structures. If the concept is correct, the "Tarawera-Waiotapu geothermal system" would form the largest single geothermal resource yet identified in New Zealand, with a total measured and estimated natural surface heat flow exceeding 1000 MW (Table 15). 
PART IV

COMPARISON OF OKATAINA VOLCANIC CENTRE WITH OTHER CALDERA STRUCTURES 


\section{COMPARISON OF OKATAINA VOLCANIC CENTRE WITH OTHER CALDERA STRUCTURES}

The understanding of caldera-forming mechanisms, their associated eruptions, and the relationships of geothermal systems to magmatic heat sources underlying young calderas has been greatly advanced by recent intensive studies of calderas in the western United States. These calderas are all somewhat older than Haroharo Caldera, and have reached more advanced stages of development. Although many Cenozoic calderas have been described from the western United States, comparisons are drawn here between Haroharo Caldera and the Valles, Long Valley, and Yellowstone Calderas, all of Quaternary age. Similar concepts are illustrated by older calderas (i.e. Steven and Lipman 1976, Christiansen et al 1977).

Williams and McBirney (1979) divided calderas into 7 groups, of which the "Valles type" had formed by foundering along arcuate fractures independent of pre-existing volcanoes, and accompanying eruption of large volumes of siliceous magma from underlying magma chambers. All the calderas considered here, including Haroharo, are of "Valles-type", and many of the mechanistic concepts are based on studies of Valles Caldera.

\section{Valles Caldera}

Valles Caldera has areal dimensions of $19 \times 24 \mathrm{~km}$, between scalloped topographic walls rising $600 \mathrm{~m}$ above the caldera floor. An upthrust structural dome in centre of the caldera is $13-16 \mathrm{~km}$ in diameter, with $1000 \mathrm{~m}$ relief. The moat between the central dome and the topographic walls is partly filled by a discontinuous ring of 10 large rhyolite domes. Valles Caldera was formed at c. $1 \mathrm{~m}$ yrs B.P. during emption of $\mathrm{c}$. $200 \mathrm{~km}^{3}$ of the upper Bandelier Tuff (Smith and Bailey 1966), consisting of a basal pyroclastic fall deposit overlain by ash flows. It truncates the adjacent Toledo Caldera which had been formed c. $0.4 \mathrm{~m}$ yrs earlier, by similar eruption of the lower Bandelier Tuff. The Toledo and Valles Calderas represent overlapping caldera collapses in the same general source area, formed within a time span of a few hundred thousand 
years or less (Christiansen 1979).

Smith and Bailey (1968) used the Valles Caldera as a model to define the concept of "resurgent cauldrons". Seven stages were recognised in the development of the Valles resurgent cauldron.

(1) Regional doming, with the formation of a ring-fracture system over the Valles magma chamber. Pre-caldera lava eruptions on radial and ring fractures. Duration $<4 \mathrm{x}$ $10^{5}$ years.

(2) Eruption of c. $200 \mathrm{~km}^{2}$ of the upper Bandelier Tuff from the ring fracture system. Duration $<10$ yrs (est.).

(3) Collapse of roof of the magma chamber, at Valles probably following stage (2). A central cauldron block, 13-16 $\mathrm{km}$ across, bounded by the inner ring fracture, subsided to $1 \mathrm{~km}$ almost intact. Around it, a ring fracture zone 2-5 $\mathrm{km}$ wide subsided in discontinuous arcuate steps, with progressively lesser displacements outwards. The caldera floor is composed mainly of Bandelier Tuff. Avalanches and collapse of the caldera walls occurred. Duration $<10$ yrs (est.).

(4) Formation of a caldera lake, and emption and deposition of "early" rhyolite lavas and pyroclastics on the caldera floor, and conformable on the Bandelier Tuff. During this stage the central cauldron block was completely buried by talus and landslides from the caldera walls, alluvial and lake deposits, and pyroclastics. Duration of this stage plus (5) below, is estimated at $<10^{5}$ years.

(5) Uplift and doming of the oval central cauldron block accompanied by radial and longitudinal fracturing to form an apical graben. Contemporaneous "middle" rhyolite volcanism from the structural dome during this uplift. Sedimentation in the caldera-moat lake. Duration, plus (4) $<10^{5}$ years. 
(6) Eruption of the "late" rhyolite domes, after cessation of the central uplift, from a ring dike occupying the inner ring fracture zone, during a time span much longer than that for the previous events. No further deformation occurred during this period. Duration c. $8 \times 10^{5} \mathrm{yrs}$.

(7) Hydrothermal and solfataric activity. This stage extends to the present day. Duration $>10^{5}$ yrs since last eruption, although it probably extended through all the other stages.

Subsidence of the caldera block may accompany or follow the caldera-forming eruptions. Within Valles Caldera, the last erupted units of the Bandelier Tuff are no thicker than outside the caldera, indicating that emptions had virtually ended before major fault-bounded subsidence occurred. At other calderas (i.e. Long Valley), tuff within the calderas is much thicker than outside, indicating that caldera collapse was concurrent with eruption.

\section{Long Valley Caldera}

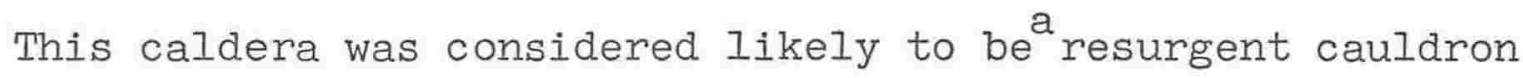
by Smith and Bailey (1968), although little data was then available to support the interpretation. Long Valley is now considered to be a single resurgent ring fracture caldera (Christiansen 1979). The caldera has been the subject of detailed geological, geochemical and geophysical investigations (Muffler and Williams 1976) as part of a multidisciplinary geothermal research programme. A comprehensive summary of geological data was presented by Bailey et al (1976).

Long Valley is a $17 \times 32 \mathrm{~km}$ elliptical depression on the east front of the Sierra Nevada, formed at c. $0.7 \mathrm{~m}$ yr B.P., during eruption of the Bishop Tuff. The caldera area is $450 \mathrm{~km}^{2}$ between the topographic walls, or $350 \mathrm{~km}^{2}$ within the subsided central block. No great pre-caldera edifice occupied the caldera site, although a large rhyolite pile (Glass Mountain), represents pre-caldera leakage from an incipient ring fracture 
over the Long Valley magma chamber. Glass Mountain was later cut by the caldera-bounding fault. Bailey et al estimate a total volume of $800 \mathrm{~km}^{3}$ for the basal airfall Bishop Ash and overlying Bishop Tuff, 2/3 of which accumulated within the caldera. Correction for porosity indicated a total erupted magma volume of $600 \mathrm{~km}^{3}$. Mineralogical and geochemical studies indicate that roof of the magma chamber was at about $6 \mathrm{~km}$ depth prior to the eruption, and the final ash flows came from c. $10 \mathrm{~km}$ depth. The caldera roof collapsed into the partially evacuated magma chamber, on arcuate faults now buried beneath caldera fill on the main caldera floor. The present area of the caldera is enlarged by slumping of the initially unstable cauldron walls. Caldera subsidence is estimated at 2-3 km from gravity (Kane et al 1976) and seismic refraction (Hill 1976) data, with a tilted floor. Eighty percent of the subsidence volume of $800 \mathrm{~km}^{3}$ can be accounted for by the Bishop pyroclastics and associated intracaldera volcanic rocks.

The caldera collapse was almost immediately followed by eruption of early (largely aphyric) rhyolites from 12 known vents aligned on north-west trending faults in the central part of the caldera. Eruption of the early rhyolites continued for between 40,000 and 100,000 years after the caldera collapse. Contemporaneously, the west central caldera floor was uplifted into a structural dome $10 \mathrm{~km}$ in diameter and $500 \mathrm{~m}$ above the surrounding moat. The dome is transected by a $5 \mathrm{~km}$ wide keystone graben of north-west trend, with most rhyolite eruptive centres situated on the graben-bounding faults. Orientation of the graben was controlled by the dominant northwest trending pre-caldera regional structures. Location of the resurgent dome was also thought to be controlled by lines of structural weakness within the caldera roof. The doming began shortly after collapse, and continued for c. 100,000 years. After resurgence, porphyritic rhyolites were erupted from 3 groups of vents in the caldera moat, at about $0.5,0.3$, and $0.1 \mathrm{~m}$ yr B.P. These domes are analogous to the "late" 
domes of the Valles Caldera, with their distribution controlled by ring fractures that bound the Long Valley resurgent dome, and intersection with major north-west trending pre-caldera faults within the cauldron block. Rhyodacites were erupted on or close to the caldera rim between 200,000 and 50,000 yrs B.P.

The west caldera moat is occupied by basalts that form part of an extensive regional chain of mafic volcanic rocks. The basaltic volcanism is contemporaneous (i.e. less than $0.1 \mathrm{~m}$ yr B.P.) with the younger moat rhyolites, and the rim rhyodacites. Basalt could not have penetrated a liquid rhyolitic magma chamber, so the distribution of the intracaldera basalts indicates that solidification of the Long Valley magma chamber had extended inward $4 \mathrm{~km}$ from the caldera walls.

Holocene rhyolitic volcanism on a north trending linear fracture is apparently related to the Mono Craters to north of the caldera. Rhyolite dome and phreatic explosion craters are ${ }^{14} \mathrm{C}$ dated at between 1200 and 450 years B.P. (Wood 1977), and indicate that residual rhyodacite magma was present in the western Long Valley chamber as recently as 450 yrs B.P.

Present surface hydrothermal activity within Long Valley caldera is dominantly controlled at depth by the ring fractures, with surface activity concentrated mainly on or near recently rejuvenated segments of the regional Sierra Nevada faults that have extended across the caldera, and muptured the selfsealed cap rock. These faults are acting as conduits for hot water from deeper reservoirs. Fossil hydrothermal alteration on the flanks of the resurgent dome demonstrates that past hydrothermal activity was more intense than at present - the decline may be due to self-sealing by mineral deposition. Magnetic surveys indicate that the Bishop Tuff beneath the resurgent dome is intensely hydrothermally altered (Williams et al 1977). Extensive hydrothermal alteration in $0.3 \mathrm{~m}$ yr B.P. lacustrine sediments indicates the geothermal system may have reached maximum development at about $0.4 \mathrm{~m}$ yr after caldera 
collapse. There is a paucity of evidence for hydrothermal activity associated with the $0.73-0.63 \mathrm{~m}$ yr B.P. early rhyolites, i.e. during the first 100,000 yrs after the caldera collapse. This implies that the geothermal system is not related to the individual post-caldera eruptive groups, but to the main magma chamber which is a deeper and larger heat source. It also suggests that development of the geothermal circulatory system may have required considerable time, and have been completed only during the latter part of the caldera history.

Regional faults show large and abrupt decreases in displacement at the caldera margins, and their intracaldera continuations have apparently been active only in very recent times. With increased crystallization of the magma chamber, and consequent thickening and strengthening of the roof, tectonic stresses have begun to be transmitted through the cauldron block, as indicated by the recent development of faults crossing the caldera floor on strike with the regional faults.

A recent very detailed study (Hildreth 1979) of the Bishop Tuff mineralogy and chemistry has greatly added to understanding of the pre-eruption Long Valley magma chamber, and has shown the eruption of the Bishop Tuff to have been an essentially continuous event. Eruption was from a single coherent volume of magma rather than from discrete cupolas or apophyses not in mutual equilibrium. The Bishop Tuff eruption tapped only a small fraction (probably 5-20\%) of the magma stored in the chamber, from a differentiated, stagnating, high silica roof zone, above convecting subjacent magma. The unerupted magma is thus greater in volume, and probably less silicic than the erupted part.

Gravity studies have shown Long Valley Caldera to coincide with a $-50 \mathrm{mGal}$ amplitude low, interpreted as a steep sided depression filled with low density material to about $4 \mathrm{~km}$ depth, and deepening to the east (Kane et al 1976). A low density mass located beneath the caldera fill may be related 
to the magma source. Steeples and Iyer (1976) and Iyer and Stewart (1977) reported relative $\mathrm{P}$ wave delays at Long Valley, which indicated the presence of low velocity material beneath the caldera at depths between 7 and $40 \mathrm{~km}$. [The seismic refraction survey (Hill 1976) had shown that the low velocity zone does not occur above $7 \mathrm{~km}$ in the crust]. The low velocities were considered to indicate anomalously hot rocks at depth, the low velocity zone being most pronounced under the resurgent part of the caldera. A well developed magnetic low over the western half of the caldera contrasted with an equally well developed high over the eastern half, indicating the presence of a strong contrast in magnetisation within the caldera fill (Williams et al 1977). This was interpreted as indicating that the Bishop Tuff beneath the resurgent dome had been intensively hydrothermally altered as a result of postcaldera volcanism. Elsewhere in the caldera the Tuff is not altered and retains strong magnetisation. This interpretation is consistent with the heat conduction model of Lachenbruch et al (1976), who considered that Long Valley Caldera was the surface expression of a deep magmatic system, resupplied with heat from deep crustal or sub-crustal magmatic sources. The near-normal heat flow at the east rim of the caldera suggested that magma in this area was exhausted during eruption of the Bishop Tuff. High heat flow measured near the western rim indicated that the resurgent dome may mark the location of a shallow residual magma chamber, more circular in plan, and possibly at about $10 \mathrm{~km}$ depth.

Natural convective heat flow from the hydrothermal features in Long Valley Caldera has been hydrochemically estimated at between about 180 MW (Sorey and Lewis 1976) and 290 MW (White 1965).

\section{Yellowstone Caldera}

The Yellowstone Plateau volcanic field has evolved over the last $2.2 \mathrm{~m}$ yrs, with eruption of three voluminous ignimbrite sheets from a caldera complex (Christiansen 1979; Smith and Christiansen 1980). The third and most recent emption cycle, 
which formed the Yellowstone Caldera, began at c. $1.2 \mathrm{~m}$ yrs B.P. with eruption of rhyolite lavas from a developing pair of distinct and almost overlapping ring fracture zones, generated by two magma cupolas rising above a common magma chamber of batholithic dimensions (Christiansen 1979). The cycle climaxed with emuption of more than $1000 \mathrm{~km}^{3}$ of the Lava Creek Tuff at 600,000 yrs B.P. (Christiansen and Blank 1972). The Lava Creek Tuff consists of two members which were sequentially emupted from the western and eastern ring fracture zones. The second outburst was probably triggered by the first, so that the Lava Creek Tuff forms a compound cooling unit. Collapse of the magma chamber roofs coalesced to form the compound Yellowstone Caldera with areal dimensions of $45 \mathrm{x} 65 \mathrm{~km}$.

Two resurgent domes have developed in the central, unfractured parts of each ring fracture zone. The dome in the east section of the caldera developed almost immediately after collapse. Formation of the dome was followed by eruption of "early" rhyolitic lavas and tuffs from vents on both ring fracture zones. Post-collapse rhyolites continued to erupt from the western ring fracture zone until 250,000 yrs B.P. (Eaton et al 1975). The resurgent dome in the west section of the caldera appears to have formed later, as a result of renewed magmatic activity beginning at 150,000 yrs B.P. (Pelton and Smith 1979). Rhyolite tuffs and lava flows with a youngest age of 70,000 yrs B.P. are associated with this most recent intrusion. The present widespread and intense hydrothermal activity associated with Yellowstone Caldera probably dates from this youngest magmatic insurgence (Eaton et al 1975).

Vent locations for the intracaldera rhyolites are related to fissures which extend across the caldera from faults outside it. Most fissures have erupted rhyolite only where they intersect the caldera ring fractures, suggesting that the magma at the top of the Yellowstone chamber has been crystallizing and solidifying over the past 150,000 yrs. As the solidified crust becomes rigid enough to fracture, faults break it, 
allowing deeper magma to rise to the surface and erupt (Smith and Christiansen 1980). Basalt has not yet been erupted within Yellowstone Caldera, although extensive basalts are present external to the caldera. The presence of silicic magma has prevented the rise of basaltic magma to the surface, although it has been erupted through the older calderas at Yellowstone.

The volcanic history of Yellowstone Caldera, together with the associated intense hydrothermal activity, has attracted detailed investigation of Yellowstone in recent years, partly as a model for evaluating the characteristics of geothermal resources (Smith 1977). Numerous geophysical studies have produced the best evidence yet found for the continued existence of a rhyolitic magma chamber beneath a large caldera (Eaton et al 1975). The geophysical data (as summarized by Morgan et al 1977) include the following:- a large Bouguer gravity low of amplitude $-50 \mathrm{mGal}$ over the rhyolite plateau, with a steep gradient approximately following the mapped caldera boundary; a marked decrease in seismic activity within the caldera boundary (events are about 90\% less frequent than outside the caldera), associated with an abrupt change in the maximum hypocentral depth from c. $20 \mathrm{~km}$ outside the caldera to $\mathrm{c} .5 \mathrm{~km}$ inside it; attenuation and local delay of $\mathrm{P}$ phase and shadowing of $\mathrm{S}$ phase seismic waves crossing the caldera. An area of low magnetic intensity also occurs inside the caldera, surrounded by a belt of generally higher intensity (Eaton et al 1975). The magnetic results are interpreted as reflecting hydrothermal alteration and possibly the presence of material above its Curie temperature $\left(560^{\circ}-580^{\circ} \mathrm{C}\right)$, in the central caldera area, at shallow depths variously estimated at between 5 and $13 \mathrm{~km}$ (Bhattacharyya and Leu 1975, Smith et al 1977), cf. a normal Curie depth of 15-20 km. The marginal highs may indicate a deep-seated ring intrusion (Smith et al 1974). The geophysical results are considered consistent with the existence of a shallow magma chamber beneath the caldera. On energy balance alone, the extensive convective heat flow from the hydrothermal areas, plus the long history of voluminous rhyolitic volcanism would require the presence of a 
large volume of still partially molten or recently solidified silicic rock. The seismic evidence indicates that below depths of $5-10 \mathrm{~km}$ the crustal material is so hot it cannot fracture.

Recent relevelling has shown the caldera area to have risen up to $700 \mathrm{~mm}$ between 1923 and the mid 1970s. Maximum measured uplift occurs between the two resurgent domes, where the peak rate is $14 \mathrm{~mm} \mathrm{yr}^{-1}$, possibly indicating the recent influx of magma beneath Yellowstone (Pelton and Smith 1979). Recent seismic studies (Iyer 1975, Iyer and Stewart 1977) have shown that Yellowstone is underlain to a depth of 150-250 km by a low density, low velocity body - consistent with a voluminous shallow magma chamber containing at least partly silicic magma underlain by dispersed pockets of more basic magma. Eaton et al (1975) concluded that a large body of silicic magma, in part still molten, lies a few kilometres below the Yellowstone surface. The body has large areal dimensions ( $85 \times 55 \mathrm{~km}$ ), but is probably only a few $\mathrm{km}$ thick.

A minimum total convective heat flow discharged by the hydrothermal features in Yellowstone National Park (and presumably originating in Yellowstone Caldera), was estimated from chloride flux as $5.3 \times 10^{3}$ NW by Fournier et al (1976). This heat flow could be supplied by the crystallization and cooling of about $0.1 \mathrm{~km}^{3}$ of rhyolite magma per year, during cooling from 900 to $500^{\circ} \mathrm{C}$. Over a 150,000 year period (apparently assuming the hydrothermal system was set up following the western magma resurgence) Fournier et al calculated that a cooled and crystallized layer about $6.5 \mathrm{~km}$ thick would have been formed just under the caldera. However, this simple cooling history does not allow for the sporadic intrusion of new magma into the upper crust, suggested by the recent uplift at Yellowstone (Pelton and Smith 1979). 
Calderas of Okataina Volcanic Centre

In the classification of Christiansen (1979), the O.V.C. consists of a complex of overlapping calderas resulting from successive voluminous pyroclastic eruptions from the same general source area. At Okataina, at least 4 main and possibly 2 minor caldera-forming eruptions have occurred over a 200,000 year period. Poor exposure of the older caldera boundaries and the associated proximal eruptive products, means that attempts to interpret the structural history are highly speculative. This particularly applies to the southern O.V.C., where much of the older structure has been buried under intracaldera lavas, and modified by regional faulting. Because of the lack of exposure and the complexity of eruptive history at Okataina, the following interpretations of structural history rely heavily on analogy with the better understood Valles and other calderas described above.

Caldera structures: Four main sub-caldera structures are interpreted to have formed at Okataina (Fig. 54), related to the main pyroclastic emuptions of (1) the "quartz-biotite ignimbrites", (2) Matahina Ignimbrite, (3) Kaingaroa Ignimbrites, and (4) the Rotoiti Breccia. The "quartz-biotite" and Kaingaroa Ignimbrites are inferred to have been erupted from the southern part of Haroharo Caldera (see p. 45 and 140). Collapse of the southern sub-caldera probably occurred during eruption of the "quartzbiotite ignimbrites" forming sub-caldera (1), with position of the present southern rim in part controlled by regional faulting. Matahina Ignimbrite overlying Onuku Breccia outcrops within sub-caldera 1, on a back-tilted block forming the south-east shore of Lake Rotomahana (Map 1). Subsidence and tilting of this block was probably related to later collapse associated with eruption of the Kaingaroa Ignimbrites from a smaller subcaldera (3) largely nested within sub-caldera (1). Analogy with Valles and Long Valley calderas suggests that the arcuate ring fault indicated by location of vents for Eastern Dome, Ridge Dome, Southern Dome, and Western Dome of the Tarawera Volcanic Complex may mark the southern structural boundary of sub-caldera (3) (Fig. 54). The northern structural boundary of this sub-caldera has been drawn through the vent locations 


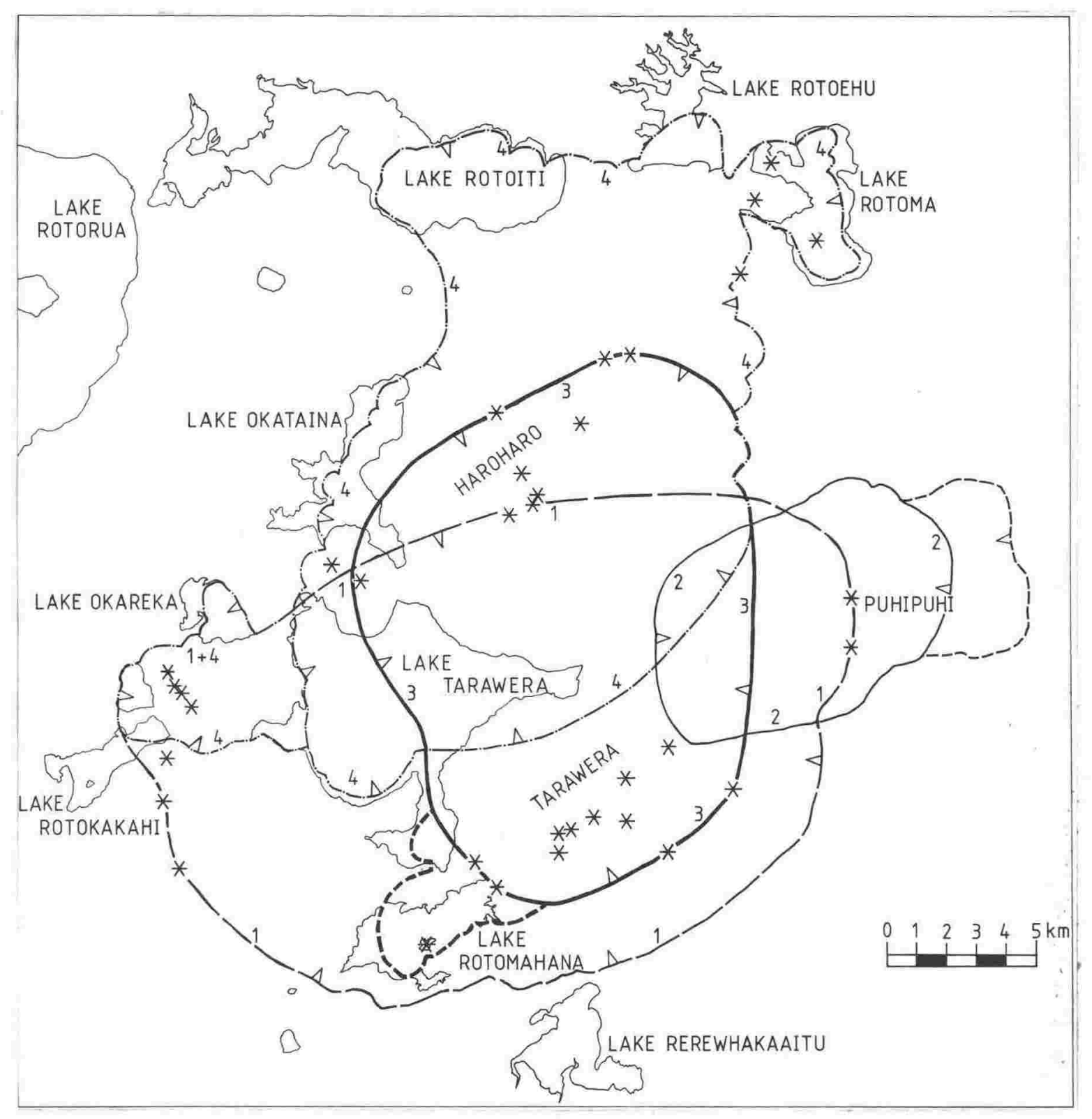

FIG. 54 - Interpretation of sub-caldera structures developed at 0.V.C. Sub-caldera 1 associated with eruption of "quartz-biotite ignimbrites"; 2 - Matahina Ignimbrite; 3 - Kaingaroa Ignimbrites; 4 - Rotoiti Breccia. Crosses mark post-collapse rhyolite-dacite vents. 
for Te Horoa, Pukerimu Cone, and Haroharo Dome, although there is no firm evidence of the actual location.

Sub-caldera (2) is drawn extending west from the margins of Puhipuhi Basin into Haroharo Caldera. No positive evidence is available for location of the western boundary which is buried under younger lavas from Tarawera. The boundary is drawn through a linear collapse gully above a presumed NNE trending fault on the Pokohu Lava Flow, and to pass through the abrupt north-eastward termination of the Tarawera Rift 1886 explosion craters.

Sub-caldera (4), associated with the Rotoiti Breccia eruptions, is the youngest and best preserved subsidence structure in the O.V.C. Strongly scalloped northern, eastern and western boundaries clearly mark the topographic rim to north of Lake Tarawera and the Tarawera River, with a probable embayment into Rotoma Caldera(?). Location of the southern boundary is not evident from the surface geology. Volume considerations suggest that the caldera should not be drawn too large, and an inferred southern boundary is placed symmetrically around the younger vent locations on the Haroharo Volcanic Complex.

The largely speculative structural pattern shown in Fig.54 is consistent with the available gravity data which centres the negative anomaly in the Lake Tarawera Outlet area, where most of the sub-caldera structures overlap.

Eruption Cycles: History of the Haroharo sub-calderas can be considered in light of the seven stage development of resurgent cauldrons proposed by Smith and Bailey (1968). A summary of the application of this cycle to the O.V.C. appears in Table 16. A major question is whether Haroharo is a true "resurgent cauldron" in the definition of Smith and Bailey. Certainly "resurgence" of magma beneath Haroharo Caldera is demonstrated by the post-collapse extrusion of voluminous rhyolites and associated pyroclastics, but little 
TABLE 16 - Summary of the resurgent-cauldron cycle at Okataina Volcanic Centre as compared to Valles Caldera.

(See p. 320 for description of stages)

Stage 1: Regional tumescence and extrusion of hal rhyolites from the external "Ring Structure" occurred at O.V.C., at some time prior to the Pokopoko-Onuku Breccia eruptions. No earlier time-stratigraphic control is available.

Stage 2: Multiple, voluminous pyroclastic eruptions from sub-calderas within O.V.C., over a 200,000 yr period.

Stage 3: Collapse of sub-caldera roofs at 0.V.C. during and following each eruption. Little data available except for the early collapse of andesite terrain in the Kaingaroa eruptions, and major wall collapse during and following the Rotoiti Breccia eruptions to produce deep scalloping of the caldera rim.

Stage 4: Lakes formed in each sub-caldera, but sediments are exposed only in Puhipuhi Basin and on the eastern margin of Haroharo Caldera. "Early" rhyolites were probably extruded on the sub-caldera floors, but were buried or destroyed by the subsequent eruptions. Alternatively, the present Haroharo and Tarawera rhyolite massifs may comprise the "early" rhyolites?

Stage 5: No evidence available to demonstrate structural updoming within Haroharo Caldera. If earlier structural domes existed, they may be buried under the Haroharo and Tarawera volcanic piles, but the post-20,000 year lavas exposed in these complexes appear undeformed. Uplift may have occurred under the hal Maungawhakamana massif adjacent to the caldera.

Stage 6: Some eruptive vents at Haroharo and Tarawera are inferred to lie on a ring fault, but many vents are also controlled by the vent lineations inherited from regional structures. One vent is located on the caldera rim.

Stage 7: Hydrothermal activity is continuing at 0.V.C. 
evidence exists for the structural updoming required by the original definition.

Pre-caldera tumescence of the area occupied by the O.V.C. (and adjacent Rotorua Caldera) is evident from the continued elevation of early ha1 rhyolites above the downfaulted younger ignimbrites occupying the Ngakuru and Whakatane Grabens. The stripped surface of the Rangitaiki Ignimbrites to south of Lake Rotomahana has a gentle dip away from the caldera. Extrusion of the pre-caldera rhyolites from external ring fractures developed as a result of this Stage 1 tumescence, but occurred only in the northern O.V.C. These rhyolites are assumed to pre-date the "quartz-biotite ignimbrites" but this relationship cannot be confirmed by stratigraphic superposition.

Little can be discerned of the subsequent history of subcaldera (1), except that the Onuku and Pokopoko Breccias were probably erupted from it, following the earlier collapse. Caldera development is therefore discussed in relation to subcalderas 2,3 , and 4 .

Eruption of the Matahina Ignimbrite from sub-caldera 2 probably occurred from vents now underlying and to west of the Puhipuhi Complex, in an area where the gravity contours steepen (see Fig. 3). Although poorly-controlled, the gravity pattern in eastern Puhipuhi Basin indicates that no major basement subsidence can have occurred in this region, and the eastern basin shape may have developed largely by rim slumping and later erosion. The Puhipuhi Complex may represent a resurgent dome. Lacustrine sediments intruded and interbedded with the Puhipuhi Dacite lavas are altered and deformed, so that no consistent dips can be measured. However, the sediments outcrop up to elevations well above the present. overflow level of Puhipuhi Basin, suggesting that uplift has occurred.

Eruption of the Kaingaroa Ignimbrites probably occurred from within the cauldron ring fracture defined by the later rhyolite vents (Fig.54). Embayments from this structural 
boundary extended outwards into the Rotomahana area, and possibly between the Wairua Stream and Lake Okareka, apparently controlled by pre-existing regional faults. After a period of time marked by eruption of the Mamaku Ignimbrite from Rotorua Caldera, the Tutaeheka ha2 rhyolites were extruded on the rim fracture, to flow north-east towards the caldera centre.

Rotoiti Breccia was erupted from the northern sub-caldera, probably from a fissure source marked by the Haroharo vent lineation. Large-scale slumping of the caldera walls occurred during and following this eruption. The existence of a deep caldera depression (remaining from the Kaingaroa Ignimbrite eruptions) to south of the Rotoiti eruptive vents, may partly explain the lack of Rotoiti Breccia pyroclastic flows to south of Haroharo Caldera.

These repeated eruption-collapse events comprise stages 2 and 3 of the resurgent cauldron cycle.

Following the Rotoiti Breccia eruptions, the volcanic piles of Haroharo and Tarawera have been extruded from vents partly located on ring faults, together with other vents controlled by their respective vent lineations. There is little exposure within Haroharo Caldera of sedimentary deposits representing stage 4 of the resurgent cauldron cycle. Shallow dips measured in the few outcropping sediments are inconsistent with updoming of either Haroharo or Tarawera massifs (Map 1). [Instead, the dips suggest uplift centred beneath the ha1 Maungawhakamana massif, consistent also with the elevation of lacustrine sediments on Maungawhakamana above any possible present day lake level. With its "apical graben" (Map 2), Maungawhakamana is the only structure within the O.V.C. suggestive of updoming. Perhaps resurgence of magma is occurring beneath this area?].

Any structural dome formed within Haroharo Caldera following eruptions of the Kaingaroa Ignimbrites would probably have been destroyed by subsidence associated with the Rotoiti Breccia eruptions. Whether structural resurgence followed the Rotoiti 
Breccia eruptions is uncertain. The exposed lavas of the Haroharo Complex are undeformed and very largely unfaulted, so that little updoming appears to have occurred during the last 20,000 years. The strong positive magnetic anomaly over the northern Haroharo Complex suggested that the exposed lavas mantled a considerable thickness of older lavas (Malahoff 1968), perhaps extruded following the Rotoiti Breccia events or associated with the Mangaone Sub-group pyroclastic eruptions. If so, little room remains available in which to fit a structural dome. However, Rogan (1980) considers that the anomaly can be produced by a much smaller magnetic body, probably only 1-2 km thick.

The writer's preferred hypothesis is that magmatic resurgence has occurred beneath Haroharo Caldera. However, the welldeveloped Haroharo and Tarawera vent lineations indicate that the caldera roof is strongly fractured along lines of weakness inherited from the pre-caldera regional structures. These fracture systems have allowed resurging magma to erupt freely to the surface to form the voluminous (c. $100 \mathrm{~km} 3$ ) post-collapse rhyolite lavas and pyroclastics. This relatively free escape of magma has prevented the build up of pressure necessary to cause structural updoming of the caldera roof. Haroharo caldera may still be in Stage 4 of the resurgent cauldron cycle, with structural updoming yet to occur when sufficient impedance to magma emission is built up by magma solidification both at top of the chamber and as lava erupted onto the overlying ground surface. If this is correct, then all the present rhyolites belong to the "early" post-collapse stage which continued at Long Valley for 40,000-100,000 years after caldera collapse. Although resurgent doming almost immediately followed collapse at Valles and Long Valley calderas, it did not occur in the western Yellowstone caldera until 450,000 years after caldera collapse.

Evidence for magma at Okataina

At Long Valley and Yellowstone Calderas, seismological evidence best indicates the existence of underlying acidic magma 
bodies. At Okataina, these investigations have yet to be carried out. Perhaps the strongest evidence for the presence of magma still underlying Haroharo Caldera comes from the long continued eruption history extending almost to the present day. Rhyolite magma was clearly present beneath the Haroharo Volcanic Complex at 5000 yrs B.P. and beneath Tarawera Volcanic Complex at 900-600 yrs B.P. Smith and Shaw (1973, 1975) and Smith (1979) have suggested that not more than $10 \%$ of the magma present within a chamber is erupted in any one large pyroclastic eruption. Residual magma bodies of these ages at O.V.C. would not yet have had time to cool. Quiescent intervals much longer than the present periods have occurred at both Haroharo and Tarawera eruptive centres during the last 20,000 years. The available geophysical evidence does not preclude the continued presence of acidic magma bodies beneath Haroharo Caldera.

The eruption of basalt from Tarawera in 1886 may be interpreted as indicating the solidification of underlying rhyolitic magma allowing uprise of basaltic magma to the surface, and possibly marking a "closing phase(?)" of the eruptive cycle (Healy 1963). However, these studies have shown the Okareka Eruptive Episode (the earliest of the Tarawera Volcanic Complex) to have been preceded by the eruption of a basaltic scoria fall, and the Kaharoa Eruptive Episode to have been preceded by shallow basaltic intrusions. Similarly, at Haroharo the Rotoiti Breccia was preceded by eruption of the Matahi Basalt, and the Pukerimu pyroclastics by intrusion of basalt. These relationships suggest either that basalt may sometimes be able to penetrate rhyolite magma chambers (i.e. Walker 1974), or that the preceding basalts were intruded or erupted at sites immediately adjacent to the rhyolitic magma bodies. The heat flow represented by unerupted intrusions associated with the erupted basalt precursors could reinvigorate cooling rhyolitic magma masses, and cause them to erupt, carrying fragments of the intruded mafic magma. In either case, basaltic eruptions have occurred only close to the structural boundary of the Haroharo cauldron, and they cannot be considered to indicate the end of the cycle of silicic caldera volcanism at Okataina. 
The large hydrothermal heat flows measured and inferred from Haroharo Caldera are much greater than that at Long Valley, and also comprise a significant fraction (c. 25\%) of that from the much larger Yellowstone system. The large Haroharo heat flow provides strong evidence for a major heat source at depth.

The lack of faulting within Haroharo Caldera when compared with the high density of faults external to the caldera, indicates that the intracaldera area is isolated from the regional stress pattern, presumably by an underlying plastic body through which shear stresses cannot be transmitted. The failure of the Rotokawau-Rotoatua basalts to extend into Haroharo Caldera may also be significant in indicating that here basalts could not penetrate the caldera structure. 
ALLIS, R.G. 1980: Taupo Volcanic Zone - Heat Flow. in Guide to geophysics of the volcanic and geothermal areas of the North Island, New Zealand. Royal Society of New Zealand, Miscellaneous Series 3: 47-48.

ANDREWS, J.T.; BARRY, R.G. 1978: Glacial inception and

- disintegration during the last Glaciation. Annual Reviews of Earth and Planetary Sciences 6: 205-228.

BAILEY, R.A. 1965: Field and petrographic notes on the Matahina Ignimbrite. in New Zealand Volcanology, Central Volcanic Region, Department of Scientific and Industrial Research Information Series 50: 125-128.

BAILEY, R.A.; DALRYMPLE, G.B.; LANPHERE, M.A. 1976: Volcanism, structure, and geochronology of Long Valley Caldera, Mono County, California. Journal of Geophysical Research 81: 725-744.

BANWELL, C.J. 1965: Kawerau. Geophysics. in New Zealand Volcanology, Central Volcanic Region. Department of Scientific and Industrial Research Information Series 50: 199-208.

BELL, J.M. 1906: The Great Tarawera Volcanic Rift, New Zealand. Geographic Journal 27: 369-382.

BHATTACHARYYA, B.K.; LEU, LEI-KUANG, 1975: Analysis of magnetic anomalies over Yellowstone National Park: Mapping of Curie Point isothermal surface for geothermal reconnaissance. Journal of Geophysical Research 80: 4461-4465.

BIRRELI, K.S.; PULLAR, W.A. 1973: Weathering of paleosols in Holocene and late Pleistocene tephras in central North Island, New Zealand. N.Z. Journal of Geology and Geophysics 16: 687-702.

BOTTINGA, Y.; WEILL, D.F. 1970: Densities of liquid silicate systems calculated from partial molar volumes of oxide components. American Journal of Science 269: 169-182. 
BRIGGS, N.D. 1973: Investigations of New Zealand pyroclastic flow deposits. (Unpublished Ph.D. thesis, lodged in the library, Victoria University of Wellington). $438 \mathrm{p}$. BROWNE, P.R.L. 1978: Petrological logs of drillholes, Kawerau Geothermal Field. New Zealand Geological Survey Report, N.Z.G.S. 84. $57 \mathrm{p}$. 1979: Minimum age of the Kawerau Geothermal Field, North Island, New Zealand. Joumal of Volcanology and Geothermal Research 6: 213-215. CALHAEM, I.M. 1973: Heat flow measurements under some lakes in North Island, New Zealand. (Unpublished Ph.D. thesis, lodged in the library, Victoria University of Wellington.) $191 \mathrm{p}$.

CHRISTIANSEN, R.L. 1979: Cooling units and composite sheets in relation to caldera structure. Geological Society of America Special Paper 180: 29- 42.

CHRISTIANSEN, R.L.; BLANK, H.R. 1972: Volcanic stratigraphy of the Quaternary rhyolite plateau in Yellowstone National Park. Geological Survey Professional Paper 729-B. U.S. Govt. Printing Office. $18 \mathrm{p}$. CHRISTIANSEN, R.L.; LIPMAN, P.W.; CARR, W.J.; BYERS, F.M.; ORKILD, P.P.; SARGENT, K.A. 1977: Timber Mountain - Oasis Valley caldera complex of southern Nevada. Geological Society of America Bulletin 88: 943-959. COLE, J.W. 1966: Tarawera Volcanic Complex. (Unpublished Ph.D. thesis, lodged in the Library, Victoria University, Wellington.) $229 \mathrm{p}$. 1970a: Description and correlation of Holocene volcanic formations in the Tarawera-Rerewhakaaitu region. Transactions of the Royal Society of New Zealand (Earth Sciences) 8(7): 93-108. 1970b: Structure and eruptive history of the Tarawera Volcanic Complex. N.Z. Journal of Geology and Geophysics 13: 879-902. 

D.S.I.R. 1963: Waiotapu Geothermal Field. Department of Scientific and Industrial Research Bulletin 155: $141 \mathrm{p}$. DUFFIELD, W.A.; BACON, C.R.; DALRYMPLE, G.B. 1980: Late Cenozoic volcanism, geochronology, and structure of the Coso Range, Inyo County, California. Journal of Geophysical Research 85: 2381-2404.

DUNCAN, A.R. 1970: Eastern Bay of Plenty volcanoes. (Unpublished Ph.D. thesis, lodged in the Library, Victoria University of Wellington.) $316 \mathrm{p}$.

EATON, G.P. (and seven others), 1975: Magma beneath Yellowstone National Park. Science 188: 787-796.

ELLIS, A.J. 1979: Chemical geothermometry in geothermal systems. Chemical Geology 25: 219-226.

ELLIS, A.J.; WILSON, S.H. 1955: The heat output from the Wairakei-Taupo thermal region calculated from the chloride output. N.Z. Journal of Science and Technology 36: 622-631. ELLIS, A.J.; MAHON, W.A.J. 1977: Chemistry and geothermal systems. Academic Press, New York N.Y. 392 p. ESPANOLA, 0.S. 1974: Geology and hot springs of Tikitere and Taheke hydrothermal fields, Rotorua, New Zealand. N.Z. Geological Survey Report, N.Z.G.S. 68: 76 p.

EWART, A. 1965: Supplementary petrographic notes on the Matahina Ignimbrite. in New Zealand Volcanology, Central Volcanic Region, Department of Scientific and Industrial Research Information Series 50: 129-132.

1966: Review of mineralogy and chemistry of the acidic volcanic rocks of Taupo Volcanic Zone, New Zealand. Bulletin Volcanologique 29: 147-172.

1967: The petrology of the central North Island rhyolitic lavas. Part I - Correlations between the phenocrysts assemblages. N.Z. Journal of Geology and Geophysics 10: 182-97.

1968: The petrography of the central North Island rhyolitic lavas. Part 2 - Regional petrography including notes on associated ash-flow pumice deposits. N.Z. Journal of Geology and Geophysics 11: 478-545. 
EWART, A. 1969: Petrochemistry and feldspar crystallisation in the silicic volcanic rocks, central North Island, New Zealand. Lithos 2: 371-88.

1971: Notes on the chemistry of ferromagnesian phenocrysts from selected volcanic rocks, Central Volcanic Region. N.Z. Journal of Geology and Geophysics 14(2): 322-40.

EWART, A.; HEALY, J. 1965: Rotorua - volcanic geology. In Thompson, B.N.; Kermode, L.O.; Ewart, A. (Eds): "New Zealand Volcanology: Central Volcanic Region". N.Z. Department of Scientific and Industrial Research Information Series 50: 10-26.

EWART, A.; COLE, J.W. 1967: Textural and mineralogical significance of the granitic xenoliths from the Central Volcanic Region, North Island, New Zealand. N.Z. Journal of Geology and Geophysics 10(1): 31-54.

EWART, A.; STIPP, J.J. 1968: Petrogenesis of the volcanic rocks of the Central North Island, New Zealand, as indicated by a study of $\mathrm{Sr}^{87} / \mathrm{Sr}^{86}$ ratios, and $\mathrm{Sr}, \mathrm{Rb}, \mathrm{K}, \mathrm{U}$, and $\mathrm{Th}$ abundances. Geochimica et Cosmochimica Acta 32(7): 699-735. EWART, A.; TAYLOR, S.R.; CAPP, A.C. 1968: Trace and minor element geochemistry of rhyolitic volcanic rocks, Central North Island, New Zealand - total rock and residual liquid data. Contributions to Mineralogy and Petrology 18: 76-104.

EWART, A; TAYLOR, S.R. 1969: Trace element geochemistry of the rhyolitic volcanic rocks, Central North Island, New Zealand. Phenocryst data. Contributions to Mineralogy and Petrology 22: $127-46$.

EWART, A.; GREEN, D.C.; CARMICHAEL, I.S.E.; BROWN, F.H. 1971: Voluminous low temperature rhyolitic magmas in New Zealand. Contributions to Mineralogy and Petrology 33: 128-44. EWART, A.; HILDRETH, W.; CARMICHAEL, I.S.E. 1975: Quaternary acid magma in New Zealand. Contributions to Mineralogy and Petrology 51: 1-27. 
FISH, G.R. 1970: A limnological study of four lakes near Rotorua. N.Z. Journal of Marine and Freshwater Research 4: 165-194.

1975: Lakes Rotorua and Rotoiti; North Island, New Zealand: Their trophic status and studies for a nutrient budget. Fisheries Research Bulletin 8. N.Z. Ministry of Agriculture and Fisheries. $70 \mathrm{p}$.

FINK, J. 1980: Surface folding and viscosity of rhyolite flows. Geology 8: 250-254.

FLEMING, C.A. 1979: "The Geological History of New Zealand and its Life". Auckland University Press. 141 p.

FLINT, R.F. 1971: Glacial and Quaternary Geology. John Wiley, New York. 892 p.

FOURNIER, R.D.; WHITE, D.E.; TRUESDELL, A.H. 1976: Convective heat flow in Yellowstone National Park. in Proceedings of the Second U.N. Symposium on Development and Use of Geothermal Resources Vol. 1: 731-740. U.S. Govt. Printing Office, Washington D.C.

GATES, W.L. 1976: Modeling the Ice-Age climate. Science 191: $1138-1144$.

GLOVER, R.B. 1974: Geochemistry of the Rotorua Geothermal District. in Geothermal Resources Survey, Rotorua Geothermal District. D.S.I.R. Geothermal Report No. 6. Department of Scientific and Industrial Research, New Zealand.

1967: Chemistry of Hole 1, Reporoa. CD118/12 - RBG, AJE/17. Unpublished report, Chemistry Division, D.S.I.R. New Zealand.

GLOVER, R.B.; and 5 others. 1974: Geothermal Resources Survey, Rotorua Geothermal District. D.S.I.R. Geothermal Report No. 6. Department of Scientific and Industrial Research, New Zealand.

GRANGE, L.I. 1937: The geology of the Rotorua-Taupo Subdivision. N.Z. Geological Survey Bulletin n.s.37. 
GRINDLEY, G.W. 1959: Sheet N85, Waiotapu "Geological Map of New Zealand 1:63 360". N.Z. Department of Scientific and Industrial Research, Wellington.

1960: Sheet 8 Taupo. "Geological map of New Zealand, 1:250 000". N.Z. Department of Scientific and Industrial Research, Wellington.

1963: Geology and structure of Waiotapu Geothermal

Field. In Waiotapu Geothermal Field. N.Z. Department of Scientific and Industrial Research Bulletin 155: 10-26. 1965a: Waiotapu. Geology. in New Zealand Volcanology,

Central Volcanic Region. Department of Scientific and Industrial Research Information Series 50: 185-186.

1965b: The geology, structure, and exploitation of the

Wairakei geothermal field, Taupo, New Zealand. N.Z.

Geological Survey Bulletin n.s. 75.

HATHERTON, T.E.; MacDONALD, W.J.P.; THOMPSON, G.E.K. 1966:

Geophysical methods in geothermal prospecting in New

Zealand. Bulletin Volcanologique 29: 485-98.

HEALY, J. 1952: Waikite hot springs. Unpublished report on

files of the N.Z. Geological Survey Office, Rotorua.

1959: Ignimbrites of the Kaingaroa area. Unpublished

report on files of the N.Z. Geological Survey Office,

Rotorua.

1962: Structure and volcanism in the Taupo Volcanic

Zone, New Zealand. In "Crust of the Pacific Basin".

Geophysical Monograph 6: 151-157.

1963a: The broad approach to volcanic prediction.

Bulletin Volcanologique 26: 141-151.

1963b: Factors in geothermal investigations at

Waiotapu. In Waiotapu Geothermal Field. Department of

Scientific and Industrial Research Bulletin 155: 133-135.

1964: Volcanic mechanisms in the Taupo Volcanic Zone,

New Zealand. N.Z. Journal of Geology and Geophysics 7(1):

$6-23$. 
HEALY, J. 1969: Rotoma sulphur deposits. Unpublished report, on files of the N.Z. Geological Survey Office, Rotorua. 1974: Kawerau, Waiotapu, Waikite, Reporoa Geothermal Fields. In Minerals of New Zealand (Part D: Geothermal) by staff of N.Z. Geological Survey. Report N.Z.G.S. 38D. 1975a: Volcanic lakes. In New Zealand Lakes. eds V.H. Jolly and J.M.A. Brown. Auckland University Press: 70-83.

1975b: The gross effect of rainfall on lake levels in the Rotorua District. Journal of the Royal Society of New Zealand, 5: 77-100.

HEALY, J.; SCHOFIELD, J.C.; THOMPSON, B.N. 1964: Sheet 5 Rotorua. "Geological Map of New Zealand 1:250 000". N.Z. Department of Scientific and Industrial Research, Wellington.

HEALY, J.; HOCHSTEIN, M.P. 1973: Horizontal flow in hydrothermal

systems. Journal of Hydrology (N.Z.) 12: 71-82. HEUSSER, C.J.; HEUSSER, L.E.; STREETER, S.S. 1980: Quaternary temperatures and precipitation for the north-west coast of North America. Nature 286: 702-704.

HILDRETH, W. 1979: The Bishop Tuff: Evidence for the origin of compositional zonation in silicic magma chambers. Geological Society of America Special Paper 180: 43-72. HILI, D.P. 1976: Structure of Long Valley, California, from a seismic refraction experiment. Journal of Geophysical Research 81: 745-753.

HOARE, R.A. 1980: Inflows to Lake Rotorua. Journal of Hydrology (N.Z.) 19: 49-59.

HOCHSTETTER, F. Von., 1864: Geologie von Neu-Seeland. Beitrage zur Geologie der Provinzen Auckland und Nelson. In "Reise der Osterreichischen Frigatte Novara un die Erde". Novara - Expedition, Geological Part 1(1). 274 pp. (English trans. C.A. Fleming, 1959).

HODGES, C.A. 1978: Basaltic ring structures of the Columbia Plateau. Geological Society of America Bulletin 89: $1281-1289$. 
HOWORTH, R. 1975: New formations of Late Pleistocene tephras from the Okataina Volcanic Centre, New Zealand. N.Z. Journal of Geology and Geophysics 18: 683-712. HUNT, T.M.; WHITEFORD, C.M. 1979: Sheet 5, Rotorua (1st Ed.). Magnetic Map of New Zealand, 1:250 000, Total Force Anomalies. Department of Scientific and Industrial Research, Wellington, New Zealand.

IRWIN, J. 1966: Lake Okataina, Provisional Bathymetry. Fisheries Research Division Lake Series, 1:15 840. 1967a: Lake Rotoma, Provisional Bathymetry, Fisheries Research Division Lake Series, 1:15 840. 1967b: Lake Tikitapu (Blue Lake), Provisional Bathymetry. Fisheries Research Division Lake Series, 1:5940. 1968: Observations of temperatures in some Rotorua

District Lakes. N.Z. Journal of Marine and Freshwater Research 2: 591-605. 1969a: Lake Tarawera, Provisional Bathymetry 1:25,000. N.Z. Oceanographic Institute Chart, Lake Series. 1969b: Lake Rotoiti, Provisional Bathymetry, 1:25,000.

Fisheries Research Division, Lake Series. 1970a: Lake Rotokakahi (Green Lake) Provisional

Bathymetry, 1:7920, N.Z. Oceanographic Institute Chart, Lake Series.

1970b: Lake Rerewhakaaitu. Provisional Bathymetry, 1:7920. N.Z. Oceanographic Institute Chart, Lake Series. 1972: New Zealand lakes bathymetric surveys 1965-1970. N.Z. Oceanographic Institute Records 1(6): 107-126. 1973a: Lake Okareka. Provisional Bathymetry, 1:7920. N.Z. Oceanographic Institute Chart, Lake Series. 1973b: Lake Ngahewa 1:1980, Lake Rotokawau 1:3168, Provisional Bathymetry, N.Z. Oceanographic Institute Chart, Lake Series. 
IRWIN, J. 1974: Lake Rotoehu, Provisional Bathymetry 1:11,880. N.Z. Oceanographic Institute Chart, Lake Series.

1975: Morphology and classification. In New Zealand Lakes. eds. V.H. Jolly and J.M.A. Brown. Auckland University Press: 25-57.

in press: Lake Rotomahana. N.Z. Oceanographic Institute Chart, Lake series.

IYER, H.M. 1975: Anomalous delays of teleseismic P-waves in Yellowstone National Park. Nature 253: 425-427.

IYER, H.M.; STEWART, R.M. 1977: Teleseismic technique to locate magma in the crust and upper mantle. In Magma Genesis 1977. Proceedings of American Geophysical Union Chapman Conference on Partial Melting in the earth's upper crust. Oregon Department of Geology and Mineral Industries Bulletin 96: 281-299.

JOLLY, V.H. 1968: The comparative limnology of some New Zealand lakes. 1. Physical and chemical. N.Z. Journal of Marine and Freshwater Research 2: 214-259.

KANE, M.F.; MABEY, D.R.; BRACE, R.L. 1976: A gravity and magnetic investigation of the Long Valley caldera, Mono County, California. Journal of Geophysical Research 81: 754-762. KENNEDY, N.M.; PULLAR, W.A.; PAIN, C.F. 1978: Late Quaternary land surfaces and geomorphic changes in the Rotorua Basin, North Island, New Zealand. N.Z. Journal of Science 21: 249-264.

KLYEN, L.E. 1970: The chemistry of the Tikitere Geothermal Area. Unpublished Chemistry Division report CD118/12 LEK 28 April 1970. Department of Scientific and Industrial Research, Wellington.

KOHN, B.P. 1970: Identification of New Zealand tephra layers by emission spectrographic analysis of their titanomagnetites. Lithos 3(4): 361-368.

1973: Some studies of New Zealand Quaternary pyroclastic rocks. Unpublished $\mathrm{Ph} . \mathrm{D}$. thesis, lodged in the Library, Victoria University of Wellington. $340 \mathrm{p}$. 
LACHENBRUCH, A.H.; SASS, J.H.; MUNROE, R.J.; MOSES, T.H. 1976: Geothermal setting and simple heat conduction models for the Long Valley caldera. Journal of Geophysical Research 81: 769-784.

LATTER, J.H.; MUIR, M.G.; NAIRN, I.A. 1974: Tarawera Earthquakes, 4-5 April 1972. In N.Z. Volcanological Record No. 2:

44-53. Compiled by N.Z. Geological Survey.

LIPMAN, P.W. 1976: Caldera collapse breccias in the western San Juan Mountains, Colorado. Geological Society of America Bulletin 87: 1397-1410.

LLOYD, E.F. 1959: The hot springs and hydrothermal emptions of Waiotapu. N.Z. Journal of Geology and Geophysics 2: 141-176. 1974: Waimangu-Rotomahana Geothermal Field. In Minerals of New Zealand (Part D: Geothermal) by staff of N.Z. Geological Survey. Report N.Z.G.S. 38D.

1979: Report on probable effects of exploitation of Rotorua Geothermal Field on the natural activity. Department of Scientific and Industrial Research Geothermal Circular EFL 6.

LLOYD, E.F.; KEAM, R.F. 1965: Waimangu. In N.Z. Volcanology, Central Volcanic Region, Department of Scientific and Industrial Research Information Series 50: 40-46. 1974: Trinity Terrace hydrothermal eruption, Waimangu, New Zealand. N.Z. Journal of Science 17: 511-528. LOCKE, K.R. 1978: Programme PLEV. Earth deformation vertical control surveys in the Taupo Volcanic Zone. In Proceedings of the 90th Annual Conference N.Z. Institute of Surveyors: 20-39.

LYON, G.L. 1977: Stable isotopes at Tikitere. Institute of Nuclear Sciences, N.Z. DSIR INS - 50/121/- GLL. MacCLAREN, J.M. 1906: The source of the waters of geysers. Geological Magazine III: 511-514. McCOLL, R.H.S. 1972: Chemistry and trophic status of seven New Zealand Lakes. N.Z. Journal of Marine and Freshwater Research 6: 399-447. 
McCOLL, R.H.S. 1975: Chemical and biological conditions in lakes of the volcanic plateau In New Zealand Lakes. eds. V.H. Jolly and J.M.A. Brown. Auckland University Press: 123-141. MacDONALD, W.J.P. 1967: A resistivity survey of the TaupoWaiotapu area at a fixed spacing (1800 ft.). Geophysics Division Report No. 46, Department of Scientific and Industrial Research, Wellington.

1974: Geophysical investigation of the Rotorua Geothermal District. In Geothermal Resources Survey, Rotorua Geothermal District. D.S.I.R. Geothermal Report No. 6. Department of Scientific and Industrial Research, New Zealand. MacDONALD, W.J.P.; MUFFLER, L.J.P. 1972: Recent geophysical exploration of the Kawerau Geothermal Field, North Island, New Zealand. N.Z. Journal of Geology and Geophysics 15: 303-317.

McDOUGALL, I. 1979: The present status of the geomagnetic polarity time scale, in The Earth: Its origin, Structure, and

Evolution. Ed. McElhinny, M.W. Academic Press. MAHON, W.A.J. 1962: A chemical survey of the steam and water discharged from drillholes and hot springs at Kawerau. N.Z. Journal of Science 5: 417-433.

1965a: Geochemistry, Waimangu, Waiotapu. In New Zealand

Volcanology, Central Volcanic Region. Department of

Scientific and Industrial Research Information Series 50: $46-48 ; 187$.

1965b: A chemical survey of the Waikite, Paukohurea

and Te Kopia thermal springs. Chemistry Division Report

CD 118/12 - WAJM 25. Department of Scientific and Industrial Research, Wellington.

1966: A chemical survey of the Opaheke hot springs. Chemistry Division Report CD 118/12 - WAJM 32. Department of Scientific and Industrial Research, Wellington.

1968: Recent chemical results from drillholes at Kawerau. Unpublished Chemistry Division Report CD 118/22 - WAJM 48. Department of Scientific and Industrial Research, Wellington. 
MALAHOFF, A. 1968: Origin of magnetic anomalies over the Central Volcanic Region of New Zealand. Geophysical Monograph 12: 218-240. Ed by L. Knopoff et al. American Geophysical Union, Washington D.C.

MANLEY, G. 1951: The range of variation of the British climate. Geographical Journal 117: 43-68.

MARTIN, R.C. 1961: Stratigraphy and structural outline of the Taupo Volcanic Zone. N.Z. Journal of Geology and Geophysics 4. $449-478$.

MINISTRY OF WORKS, 1965: Kaituna Investigations Report. Unpublished.

MODRINIAK, N.; STUDT, F.E. 1959: Geological structure and

volcanism of the Taupo-Tarawera district. N.Z. Journal of Geology and Geophysics 2(4): 654-684.

MORGAN, P.; BLACKWELL, D.D.; SPAFFORD, R.E. 1977: Heat flow measurements in Yellowstone Lake and the thermal structure of Yellowstone Caldera. Journal of Geophysical Research 82: 3719-3732.

MUFFLER, L.J.P.; WILLIAMS, D.L. 1976: Geothermal Investigations of the U.S. Geological Survey in Long Valley, California, 1972-1973. Journal of Geophysical Research 81: 721-724. MURPHY, R.P.; SEWARD, D. in press: Fission track and palaeomagnetic ages of ignimbrite formations in the Rotorua District, New Zealand. N.Z. Journal of Geology and Geophysics.

NAIRN, I.A. 1970: Land Inventory and Capability Survey of lake catchments in the Rotorua area. Unpublished report, Water and Soil Division, Ministry of Works, Rotorua. 38 p. 1971: Studies of the Earthquake Flat Breccia Formation and other unwelded pyroclastic flow deposits of the Central Volcanic Region, New Zealand. (Unpublished M.Sc. thesis lodged in the Library, Victoria University of Wellington.) 1972: Rotoehu Ash and the Rotoiti Breccia Formation, Taupo Volcanic Zone, New Zealand. N.Z. Journal of Geology and Geophysics 15(2): 251-61. 
NAIRN, I.A. 1973: Geology of the Waimangu Geothermal Mapping Project Area, Central Volcanic Region, New Zealand. Unpublished report, N.Z. Geological Survey, Rotorua. 1974: Rotoma, Lake Rotoiti, Tikitere, Taheke, Tarawera Geothermal Fields in Minerals of New Zealand (Part D: Geothermal) by staff of N.Z. Geological Survey. Report N.Z.G.S. 38D.

1975: Land use capability assessment of the Kaituna River catchment. I.U.C.S. Bulletin 2. National Water and Soil Conservation Organization, New Zealand. 32 p. 1976: Late Quaternary faulting in the Taupo Volcanic Zone. In Excursion Guide No. 55A and 55C, 25th International Geological Congress, compiled by S. Nathan: 26-30.

1979: Rotomahana-Waimangu eruption, 1886: base surge and basalt magma. N.Z. Journal of Geology and Geophysics 22: 363-378. (on p. 234 of this thesis).

1980: Source, age, and emuptive mechanisms of Rotorua Ash. N.Z. Journal of Geology and Geophysics 23: 193-207. (on p. 203 of this thesis).

NAIRN, I.A.; KOHN, B.P. 1973: Relation of the Earthquake Flat Breccia to the Rotoiti Breccia, Central North Island, New Zealand. N.Z. Journal of Geology and Geophysics 16: $269-279$.

NAIRN, I.A.; SELF, S. in prepn: The Kaharoa eruption of Tarawera volcano, Taupo Volcanic Zone, New Zealand. NAIRN, I.A.; SOLIA, W. 1980: Late Quaternary hydrothermal explosion breccias at Kawerau Geothermal Field, New Zealand. Bulletin Volcanologique 43: 1-13. (on p. 297 of this thesis).

NATHAN, S. 1975: Age of the Rotoiti Breccia Formation. Geological Society of New Zealand, Newsletter No. 40: 21-22. N.Z. GEOLOGICAL SURVEY, 1928: Rotorua-Taupo Subdivision (by I.I. Grange), In Extract from the Annual Report of the Department of Scientific and Industrial Research 1927-28: p. 11 . 
NICHOLLS, J.; CARMICHAEL, I.S.E.; STORMER, J.C. 1971: Silica activity and $\mathrm{P}_{\text {total }}$ in Igneous Rocks. Contributions to Mineralogy and Petrology 33: 1-20.

NINKOVICH, D. 1968: Pleistocene volcanic eruptions in New

Zealand recorded in deep-sea sediments. Earth and Planetary Science Letters 4: 89-102.

OTWAY, P.M. 1979: Tilt-level monitoring in the Taupo Volcanic Zone. In N.Z. Volcanological Record No. 8: 28. Compiled by N.Z. Geological Survey.

PELTON, J.R.; SMITH, R.B. 1979: Recent crustal uplift in Yellowstone National Park. Science 206: 1179-1182. PITTAMS, R.J. 1968: Preliminary water balance studies of the Rotorua lakes. N.Z. Journal of Hydrology 7: 24-37. 1979: The relationships between rainfall and the levels of four lakes in the Rotorua area. Unpublished manuscript. PULLAR, W.A. 1973: "Isopachs of tephra, Central North Island, New Zealand. Scale 1:1,000,000". N.Z. Soil Bureau Maps 133/1-14, to accompany N.Z. Soil Survey Report 31 . PULLAR, W.A.; NAIRN, I.A. 1972: Matahi basaltic tephra member, Rotoiti Breccia Formation. N.Z. Journal of Geology and Geophysics 15: 446-50.

PULLAR, W.A.; BIRRELL, K.S. 1973a: Parent materials of Tirau Silt Loam. N.Z. Journal of Geology and Geophysics 16: 677-686.

1973b: Age and distribution of Late Quaternary pyroclastic and associated cover deposits of the central North Island, New Zealand. N.Z. Soil Survey Report 2.

PULLAR, W.A.; BIRRELL, K.S.; HEINE, J.C. 1973: Named tephras and tephra formations occurring in the central North Island, with notes on derived soils and buried paleosols. N.Z. Journal of Geology and Geophysics 16: 497-518. ROGAN, A.M. 1980: Geophysical studies of the Okataina Volcanic Centre. (Unpublished Ph.D. thesis, lodged in the Library, University of Auckland). 
SAMESHIMA, T. 1975: Silica indices of volcanoes in and around New Zealand with reference to volcanic zones in the North Island. N.Z. Journal of Geology and Geophysics 18(4): 523-539.

SCOTT, B.J. 1978: Okataina Volcanic Centre tilt recordings, 1977. In N.Z. Volcanological Record No. 7: 20. Compiled by N.Z. Geological Survey.

1979: Okataina Volcanic Centre tilt recordings, 1978. In N.Z. Volcanological Record No. 8: 29. Compiled by N.Z. Geological Survey.

SEWARD, D. 1979: Comparison of zircon and glass fission-track ages from tephra horizons. Geology 7: 479-482. SHEPPARD, D.S.; LYON, G.L. 1979: The chemical and isotopic composition of water and gas discharges from the Tikitere and Taheke Geothermal Fields, New Zealand. Report to the Geothermal Coordinator, Geothermal Circular CD30/555/4-DSS5. SHEPPARD, D.S.; ROBINSON, B.W. 1980: A chemical and isotopic survey of the Waiotapu, Reporoa, and Waikite hydrothermal discharges. Geothermal Circular 30/555/6 DSS-4. INS BWR-1. SISSONS, B.A. 1979: The horizontal kinematics of the North Island (Unpublished Ph.D. thesis, lodged in the Library, Victoria University of Wellington.)

SMITH, R.B. 1977: Yellowstone Symposium. Journal of Geophysical Research 82: [3663].

SMITH, R.B.; SHUEY, R.T., FREIDLINE, R.O.; OTIS, R.M.; ALLEY, L.B. 1974: Yellowstone hot spot. New magnetic and seismic evidence. Geology 2: 451-455. SMITH, R.B.; SHUEY, R.T.; PELTON, J.R.; BAILEY, J.P..1977: Yellowstone hot spot. Contemporary tectonics and crustal properties from earthquake and aeromagnetic data. Journal of Geophysical Research 82: 3665-3676.

SMITH, R.B.; CHRISTIANSEN, R.L. 1980: Yellowstone Park as a window on the Earth's interior. Scientific American 242: $104-117$. 
SMITH, R.L. 1979: Ash flow magmatism. In Geological Society of America Special Paper 180: 5-27.

SMITH, R.L.; BAILEY, R.A. 1966: The Bandelier Tuff: A study of ash-flow eruption cycles from zoned magma chambers. Bulletin Volcanologique 29: 83-104.

1968: Resurgent cauldrons. In Studies in Volcanology

(Williams Volume), eds. Coats R.R. and others. Geological Society of America Memoir 116: 613-662.

SMITH, R.L.; SHAW, H.R. 1973: Volcanic rocks as geologic guides to geothermal exploration and evaluation. EOS. American Geophysical Union Transactions 54: 1213.

1975: Igneous-related geothermal systems, In White D.E. and Williams, D.L. eds., Assessment of geothermal resources of the United States - 1975: U.S. Geological Survey Circular 726: 58-83.

1979: Igneous-related geothermal systems. U.S. Geological Survey Circular 790: 12-17.

SOREY, M.L.; LEWIS, R.E. 1976: Convective heat flow from hot springs in the Long Valley caldera, Mono County, California. Journal Geophysical Research 81: 785-791.

SPARKS, R.S.J.; WALKER, G.P.L. 1977: The significance of vitricenriched air-fall ashes associated with crystal-enriched ignimbrites. Journal of Volcanology and Geothermal Research 2: 329-342.

STEEPLES, D.W.; IYER, H.M. 1976: Low velocity zone under Long Valley as determined from teleseismic events. Journal of Geophysical Research 81: 849-860.

STEINER, A. 1963: The rocks penetrated by drillholes in the Waiotapu Thermal Area, and their hydrothermal alteration. In Waiotapu Geothermal Field. Department of Scientific and Industrial Research Bulletin 155: 26-34. STEVEN, T.A.; LIPMAN, P.W. 1976: Calderas of the San Juan Volcanic Field, South-western Colorado. Geological Survey Professional Paper 958: $35 \mathrm{p}$. 
STIPP, J.J. 1968: The geochronology and petrogenesis of the Cenozoic Volcanics of the North Island, New Zealand. (Unpublished Ph.D. thesis, Australian National University, Canberra. Lodged in Australian Capital Territory Library, Canberra.)

STUDT, F.E. 1958: Geophysical reconnaissance at Kawerau, New Zealand. N.Z. Journal of Geology and Geophysics 1: 219-246.

1963: Geophysics of the Waiotapu Area; Waiotapu Hydrology

In Waiotapu Geothermal Field. Department of Scientific and Industrial Research Bulletin 155: 35-41; 127-132.

SUGGATE, R.P. 1965: Late Pleistocene geology of the northern part

of the South Island, New Zealand. N.Z. Geological Survey Bulletin n.s. 77 .

TAYLOR, C.B.; FREESTONE, H.J.; NAIRN, I.A. 1977: Preliminary measurements of tritium, deuterium and oxygen-18 in lakes and groundwater of volcanic Rotorua region, New Zealand. Institute of Nuclear Sciences Report INSR-227. Department of Scientific and Industrial Research, Lower Hutt. TAYLOR, S.R. 1969: Trace element chemistry of andesites and associated calc-alkaline rocks. In McBirney, A.R. (Ed.): "Proceedings of the Andesite Conference". Oregon Department of Geology and Mineral Resources Bulletin 65: 43-63. THE ROYAL SOCIETY OF NEW ZEALAND, 1977: Stratigraphic nomenclature in the New Zealand Quaternary. Report of a Sub-committee, National Committee for Quaternary Research. ed. M. Gage. THOMPSON, B.N. 1974: Geology of the Rotorua Geothermal District. In Geothermal Resources Survey, Rotorua Geothermal District. D.S.I.R. Geothermal Report No. 6. Department of Scientific and Industrial Research, New Zealand. THOMPSON, G.E.K. 1971: Near-surface ground temperatures in the North Island volcanic belt. Geophysics Division, Report No. 68. Department of Scientific and Industrial Research, Wellington. 
TRUESDELL, A.H. 1975: Summary of Section III. Geochemical techniques in exploration. In Proceedings of the 2nd U.N. Symposium on the development and use of geothermal resources. Vol. 1: liii-lxxix.

UTTING, B.S. 1969: Report on exploratory drilling for sulphur at Rotoma, New Zealand. [Unpublished report, referred to in Nairn 1974 (Rotoma Geothermal Field)]. VUCETICH, C.G.; HOWORTH, R. 1976: Proposed definition of the Kawakawa Tephra, the c. 20,000 years B.P. marker horizon in the New Zealand region. N.Z. Journal of Geology and Geophysics 19: 43-50.

VUCETICH, C.G.; PULLAR, W.A. 1964: Stratigraphy and chronology of late Quaternary volcanic ash in Taupo, Rotorua, and Gisborne districts. Part 2. Stratigraphy of Holocene ash in the Rotorua and Gisborne districts. N.Z. Geological Survey Bulletin n.s. 73: 43-88.

VUCETICH, C.G.; PULLAR, W.A. 1969: Stratigraphy and chronology of Late Pleistocene volcanic ash beds in central North Island, New Zealand. N.Z. Journal of Geology and Geophysics 12: $784-837$.

WALKER, G.P.L. 1974: Eruptive mechanisms in Iceland. In Kristjansson (ed.), Geodynamics of Iceland and the North Atlantic Area: 189-201.

1979: A volcanic ash generated by explosions where ignimbrite entered the sea. Nature 281: 642-646. 1980: The Taupo Pumice: product of the most powerful known (ultraplinian) eruption? Journal of Volcanology and Geothermal Research 8: 69-94.

WHITE, D.E. 1965: Geothermal Energy. Geological Survey Circular 519. U.S. Geological Survey, Washington D.C. WILLIAMS, D.L.; BERKMAN, F.; MANKINEN, E.A. 1977: Implications of a magnetic model of the Long Valley caldera, California. Journal of Geophysical Research 82: 3030-3038. 
WILLIAMS, H., GOLES, G. 1968: Volume of the Mazama ash-fall and the origin of Crater Lake Caldera. Oregon Department of Geology and Mineral Industries Bulletin 62: 37-41.

WILLIAMS, H.; McBIRNEY, A.R. 1979: Volcanology. Freeman, Cooper \& Co., San Fransisco. 397 p.

WILSON, S.H. 1963: Chemical investigations at Waiotapu In Waiotapu Geothermal Field. Department of Scientific and Industrial Research Bulletin 155: 87-118.

WOOD, S.H. 1977: Distribution, correlation and radiocarbon dating of late Holocene Tephra, Mono and Inyo craters, eastern California. Geological Society of America Bulletin 88: 89-95.

WOOD, B.J., CARMICHAEL, I.S.E. 1973: $\mathrm{P}_{\text {total }}, \mathrm{P}_{\mathrm{H}_{2} \mathrm{O}}$ and the occurrence of cummingtonite in volcanic rocks. Contributions to Mineralogy and Petrology 40: 149-158.

WOODWARD, D.J.; FERRY, L.M. 1973: Sheet 5, Rotorua (1st Ed.) "Gravity Map of New Zealand, 1:250,000, Bouguer Anomalies". Department of Scientific and Industrial Research, Wellington. 
APPENDIX 1

New Chemical Analyses of Okataina Eruptives

\begin{tabular}{|c|c|c|c|c|c|c|c|c|c|c|}
\hline & 1 & 2 & 3 & 4 & 5 & 6 & 7 & 8 & 9 & 10 \\
\hline $\mathrm{SiO}_{2}$ & 74.91 & 75.79 & 74.32 & 72.98 & 72.60 & 74.28 & 73.85 & 74.55 & 75.34 & 75.52 \\
\hline $\mathrm{TiO}_{2}$ & 0.24 & 0.21 & 0.23 & 0.25 & 0.23 & 0.17 & 0.18 & 0.20 & 0.19 & 0.19 \\
\hline $\mathrm{Al}_{2} \mathrm{O}_{3}$ & 12.94 & 13.12 & 12.85 & 13.03 & 13.16 & 12.36 & 12.60 & 12.97 & 12.35 & 12.42 \\
\hline $\mathrm{Fe}_{2} \mathrm{O}_{3}$ * & 1.67 & 1.47 & 1.64 & 1.79 & 1.76 & 1.30 & 1.37 & 1.41 & 1.49 & 1.49 \\
\hline $\mathrm{MnO}$ & 0.07 & 0.05 & 0.04 & 0.05 & 0.05 & 0.04 & 0.04 & 0.04 & 0.04 & 0.04 \\
\hline $\mathrm{MgO}$ & 0.11 & 0.27 & 0.26 & 0.37 & 0.27 & 0.12 & 0.04 & 0.26 & 0.13 & 0.17 \\
\hline $\mathrm{CaO}$ & 1.37 & 1.29 & 1.36 & 1.56 & 1.52 & 1.24 & 1.19 & 1.24 & 1.27 & 1.24 \\
\hline $\mathrm{Na}_{2} \mathrm{O}$ & 4.44 & 4.59 & 4.16 & 4.12 & 4.12 & 4.32 & 3.97 & 4.33 & 4.20 & 4.07 \\
\hline $\mathrm{K}_{2} \mathrm{O}$ & 2.89 & 2.92 & 2.89 & 2.89 & 2.74 & 2.94 & 2.91 & 2.95 & 3.12 & 3.14 \\
\hline $\mathrm{P}_{2} \mathrm{O}_{5}$ & 0.02 & 0.03 & 0.03 & 0.04 & 0.02 & 0.02 & 0.02 & 0.02 & 0.02 & 0.02 \\
\hline L.O.I. & 0.34 & 0.20 & 2.31 & 2.76 & 2.75 & 2.36 & 3.45 & 2.24 & 0.10 & 0.52 \\
\hline Total & 98.99 & 99.94 & 100.10 & 99.83 & 99.21 & 99.14 & 99.62 & 100.21 & 98.27 & 98.83 \\
\hline \multicolumn{11}{|c|}{ *Total $\mathrm{Fe} 0+\mathrm{Fe}_{2} \mathrm{O}_{3}$ expressed as $\mathrm{Fe}_{2} \mathrm{O}_{3}$} \\
\hline $\mathrm{Rb}$ & 88 & 82 & 88 & 86 & 77 & 84 & 76 & 91 & 92 & 101 \\
\hline Sr & 130 & 126 & 125 & 137 & 135 & 110 & 106 & 111 & 105 & 103 \\
\hline $\mathrm{Ba}$ & 780 & 800 & 776 & 788 & 793 & 830 & 791 & 847 & 800 & 830 \\
\hline $\mathrm{Zr}$ & 180 & 160 & 158 & 168 & 155 & 117 & 130 & 134 & 131 & 133 \\
\hline $\mathrm{Cu}$ & 5 & 2 & 2 & 3 & 5 & 3 & 4 & 3 & 1 & 3 \\
\hline $\mathrm{Ni}$ & 6 & 4 & 6 & 5 & 6 & 5 & 4 & 4 & 4 & 5 \\
\hline V & 5 & 4 & 8.5 & 9 & 6 & 2.6 & 3 & 9 & 4.5 & 8 \\
\hline $\mathrm{Cr}$ & 3 & 1.5 & 1 & - & 2 & - & - & 1 & 1 & 2 \\
\hline $\mathrm{Zn}$ & 50 & 44 & 39 & 49 & 40 & 36 & 35 & 42 & 31 & 37 \\
\hline Th & 9 & 9 & 9 & 10 & 7 & 9 & 4 & 8 & 6 & 8 \\
\hline $\mathrm{Pb}$ & 18 & 17 & 13 & 13 & 10 & 13.4 & 6 & 14 & 10 & 16 \\
\hline$Y$ & 31 & 29 & 22 & 23 & 23 & 24 & 22 & 23 & 22 & 23 \\
\hline
\end{tabular}

1. 13501* Glassy, slightly spherulitic, hypersthene hornblende rhyolite. Haumingi Lava Flow. V15/112421

2. 13502 Spherulitic, hypersthene hornblende rhyolite. Haumingi Lava Flow. v15/112422

3. 13503 Pumiceous, hornblende rhyolite. Rotoma Lava Flow. V15/235456

4. 13504 Pumiceous, hornblende rhyolite. Rotoma Lava Flow. V15/245447

5. 13505 Pumice lapilli. Rotoma Ash (upper fall beds). V15/117438

6. 13506 Pumice lapilli. Rotoma Ash (basal fall beds). V15/117438

7. 13507 Pumice lapilli. Rotoma Ash. V15/131423

8. 13508 Pumice lapilli. Rotoma Ash (basal fall beds). V15/218458

9. 13509 Spherulitic, plagioclase rhyolite. Hainini Lava Flow. V16/167360

10. 13510 Pumiceous, plagioclase hornblende rhyolite. Hainini Dome. v16/152368 


\begin{tabular}{|c|c|c|c|c|c|c|c|c|c|c|}
\hline & 11 & 12 & 13 & 14 & 15 & 16 & 17 & 18 & 19 & 20 \\
\hline $\mathrm{SiO}_{2}$ & 75.66 & 75.63 & 75.36 & 74.56 & 73.25 & 73.93 & 75.24 & 75.02 & 75.28 & 74.82 \\
\hline $\mathrm{TiO}_{2}$ & 0.19 & 0.16 & 0.22 & 0.25 & 0.25 & 0.20 & 0.24 & 0.24 & 0.24 & 0.19 \\
\hline $\mathrm{Al}_{2} \mathrm{O}_{3}$ & 12.61 & 12.47 & 12.55 & 12.70 & 12.91 & 12.65 & 12.65 & 12.81 & 12.86 & 12.31 \\
\hline $\mathrm{Fe}_{2} \mathrm{O}_{3}$ * & 1.49 & 1.28 & 1.61 & 1.85 & 1.86 & 1.59 & 1.74 & 1.76 & 1.76 & 1.52 \\
\hline MnO & 0.04 & 0.03 & 0.05 & 0.05 & 0.05 & 0.03 & 0.04 & 0.05 & 0.05 & 0.05 \\
\hline $\mathrm{MgO}$ & 0.04 & 0.21 & 0.24 & 0.27 & 0.40 & 0.17 & 0.25 & 0.24 & 0.26 & 0.14 \\
\hline $\mathrm{CaO}$ & 1.24 & 1.10 & 1.37 & 1.48 & 1.57 & 1.27 & 1.46 & 1.46 & 1.47 & 1.22 \\
\hline $\mathrm{Na}_{2} \mathrm{O}$ & 4.36 & 4.15 & 4.35 & 4.33 & 4.23 & 4.16 & 4.36 & 4.32 & 4.63 & 4.12 \\
\hline $\mathrm{K}_{2} \mathrm{O}$ & 3.15 & 3.26 & 2.97 & 2.96 & 2.90 & 3.08 & 2.99 & 2.98 & 2.99 & 3.08 \\
\hline $\mathrm{P}_{2} \mathrm{O}_{5}$ & 0.02 & 0.02 & 0.01 & 0.02 & 0.05 & 0.03 & 0.03 & 0.02 & 0.02 & 0.01 \\
\hline L.0.I. & 0.51 & 1.46 & 0.60 & 0.52 & 0.74 & 2.33 & 0.44 & 0.74 & 0.74 & 1.35 \\
\hline Total & 99.31 & 99.77 & 99.33 & 98.99 & 99.22 & 99.45 & 99.93 & 99.64 & 100.29 & 98.82 \\
\hline $\mathrm{Rb}$ & 96 & 103 & 89 & 90 & 91 & 92 & 93 & 91 & & 90 \\
\hline Sr & 103 & 93 & 120 & 130 & 137 & 109 & 123 & 131 & & 106 \\
\hline $\mathrm{Ba}$ & 822 & 839 & 791 & 790 & 790 & 800 & 773 & 790 & & 819 \\
\hline $\mathrm{Zr}$ & 126 & 113 & 153 & 173 & 177 & 139 & 158 & 170 & & 138 \\
\hline Cu & 5 & 0.6 & 5 & 4 & 1 & 4 & 3 & 5 & & 4 \\
\hline $\mathrm{Ni}$ & 5 & 4 & 5 & 6 & 4 & 4 & 5 & 5 & & 5 \\
\hline V & 6 & 5 & 7 & 8 & 11 & 6 & 8 & 7 & & 5 \\
\hline $\mathrm{Cr}$ & 0.1 & 0.3 & - & 1 & 0.3 & - & 5 & 7 & & 3 \\
\hline $\mathrm{Zn}$ & 35 & 36 & 40 & 42 & 42 & 37 & 37 & 38 & & 37 \\
\hline Th & 9 & 10 & 7 & 9 & 9 & 9 & 10 & 9 & & 9 \\
\hline $\mathrm{Pb}$ & 12 & 14 & 12 & 11 & 12 & 12 & 13 & 12 & & 13 \\
\hline Y & 23 & 23 & 23 & 23 & 22 & 23 & 23 & 23 & & 22 \\
\hline
\end{tabular}

\footnotetext{
11. 13511 Glassy, hypersthene hornblende rhyolite. Parewhaiti Dome. V16/170376

12. 13512 Glassy, hypersthene hornblende rhyolite. Hainini Lava Flow. V16/168360

13. 13513 Glassy, hypersthene hornblende rhyolite. Waiti Lava Flow. V16/156397

14. 13514 Glassy, hypersthene hornblende rhyolite. Waiti Lava Flow. V16/152400

15. 13515 Spherulitic, plagioclase rhyolite. Waiti Lava Flow. V15/172427

16. 13516 Pumice lapilli. Mamaku Ash (basal fall beds). V15/117438

17. 13517 Glassy, plagioclase hornblende rhyolite. Tikorangi Dome. V15/220427

18. 13518 Pumiceous, plagioclase hornblende rhyolite. Tikorangi Dome. V15/222421

19. 13519 Duplicate sample to 13518

20. 13520 Glassy, plagioclase rhyolite. Haroharo Dome. V16/184391
} 


\begin{tabular}{|c|c|c|c|c|c|c|c|c|c|c|}
\hline & 21 & 22 & 23 & 24 & 25 & 26 & 27 & 28 & 29 & 30 \\
\hline $\mathrm{SiO}_{2}$ & 75.62 & 75.52 & 76.33 & 75.29 & 74.42 & 73.97 & 74.62 & 75.04 & 75.69 & 74.86 \\
\hline $\mathrm{TiO}_{2}$ & 0.15 & 0.16 & 0.16 & 0.16 & 0.19 & 0.23 & 0.14 & 0.25 & 0.25 & 0.26 \\
\hline $\mathrm{Al}_{2} \mathrm{O}_{3}$ & 12.38 & 12.19 & 12.09 & 12.59 & 12.33 & 12.81 & 11.95 & 12.86 & 13.01 & 12.54 \\
\hline $\mathrm{Fe}_{2} \mathrm{O}_{3}$ * & 1.23 & 1.29 & 1.32 & 1.29 & 1.46 & 1.79 & 1.19 & 1.74 & 1.78 & 1.92 \\
\hline $\mathrm{MnO}$ & 0.04 & 0.05 & 0.03 & 0.03 & 0.04 & 0.04 & 0.03 & 0.03 & 0.04 & 0.04 \\
\hline Mg0 & 0.18 & 0.13 & 0.13 & 0.22 & 0.12 & 0.18 & 0.05 & 0.26 & 0.25 & 0.27 \\
\hline $\mathrm{CaO}$ & 1.02 & 1.10 & 1.06 & 1.01 & 1.17 & 1.50 & 0.97 & 1.54 & 1.53 & 1.50 \\
\hline $\mathrm{Na}_{2} \mathrm{O}$ & 4.12 & 4.13 & 4.09 & 4.11 & 4.07 & 4.16 & 3.85 & 4.26 & 4.34 & 4.12 \\
\hline $\mathrm{K}_{2} \mathrm{O}$ & 3.31 & 3.20 & 3.28 & 3.29 & 3.09 & 2.83 & 3.28 & 3.09 & 3.17 & 3.13 \\
\hline $\mathrm{P}_{2} \mathrm{O}_{5}$ & 0.02 & 0.01 & 0.01 & 0.02 & 0.03 & 0.02 & 0.01 & 0.04 & 0.04 & 0.03 \\
\hline L.O.I. & 0.82 & 1.28 & 0.52 & 1.95 & 3.44 & 2.11 & 3.20 & 0.56 & 0.12 & 0.33 \\
\hline Total & 98.90 & 99.06 & 99.01 & 99.97 & 100.36 & 99.65 & 99.30 & 99.68 & 100.21 & 99.00 \\
\hline $\mathrm{Rb}$ & 101 & 100 & 100 & 102 & 88 & 98 & 98 & 94 & 97 & 98 \\
\hline $\mathrm{Sr}$ & 86 & 93 & 85 & 87 & 95 & 104 & 79 & 123 & 124 & 121 \\
\hline $\mathrm{Ba}$ & 820 & 821 & 820 & 785 & 829 & 785 & 826 & 792 & 799 & 790 \\
\hline $\mathrm{Zr}$ & 104 & 114 & 106 & 115 & 120 & 130 & 99 & 155 & 155 & 168 \\
\hline $\mathrm{Cu}$ & 4 & 5 & 5 & 6 & 4 & 3 & 2 & 3 & 4 & 3 \\
\hline $\mathrm{Ni}$ & 4 & 6 & 5 & 5 & 3 & 5 & 4 & 5 & 6 & 5 \\
\hline V & 4 & 4 & 3 & 7 & 4 & 5 & 4 & 10 & 9 & 9 \\
\hline $\mathrm{Cr}$ & 3 & 1 & 0.3 & 5 & - & 1 & 6 & 4 & 6 & - \\
\hline $\mathrm{Zn}$ & 31 & 34 & 32 & 36 & 34 & 35 & 32 & 36 & 37 & 38 \\
\hline Th & 10 & 10 & 9 & 10 & 9 & 10 & 8 & 9 & 10 & 10 \\
\hline $\mathrm{Pb}$ & 13 & 14 & 13 & 13 & 10 & 14 & 12 & 16 & 14 & 14 \\
\hline$Y$ & 23 & 23 & 22 & 22 & 23 & 23 & 23 & 22 & 23 & 24 \\
\hline
\end{tabular}

21. 13521

22. 13522

23. 13523

24. 13524

25. 13525

26. 13526

27. $\quad 13527$

28. 13528

29. 13529

30. 13530
Makatiti Dome. V16/132347

Glassy, plagioclase hornblende rhyolite. Okataina Lava Flow. V16/132368

Glassy, plagioclase hornblende rhyolite. Okataina Lava Flow. v16/144356

Glassy, plagioclase hornblende rhyolite. Okataina Lava Flow. V16/110358

Punice lapilli. Whakatane Pyroclastics (upper) V16/152368

Pumice lapilli. Whakatane Pyroclastics (basal) v16/152368

Pumice lapilli. Whakatane Pyroclastics v16/161377

Glassy, hypersthene hornblende rhyolite. Hawea Lava Flow. V16/237270

Glassy, hypersthene hornblende rhyolite. Hawea Lava Flow. V16/240276

Glassy, hypersthene hornblende rhyolite. Ridge Lava Flow. v16/223246 


\begin{tabular}{|c|c|c|c|c|c|c|c|c|c|c|}
\hline & 31 & 32 & 33 & 34 & 35 & 36 & 37 & 38 & 39 & 40 \\
\hline $\mathrm{SiO}_{2}$ & 75.00 & 72.85 & 75.99 & 76.29 & 75.28 & 70.42 & 72.06 & 74.81 & 62.41 & 62.18 \\
\hline $\mathrm{TiO}_{2}$ & 0.25 & 0.21 & 0.17 & 0.18 & 0.17 & 0.34 & 0.28 & 0.20 & 0.77 & 0.77 \\
\hline $\mathrm{A}_{2} \mathrm{O}_{3}$ & 12.92 & 12.74 & 12.36 & 12.56 & 12.19 & 13.80 & 13.12 & 13.17 & 16.84 & 16.44 \\
\hline $\mathrm{Fe}_{2} \mathrm{O}_{3}$ * & 1.76 & 1.74 & 1.37 & 1.35 & 1.22 & 2.61 & 2.06 & 1.70 & 5.70 & 5.72 \\
\hline MnO & 0.04 & 0.03 & 0.05 & 0.03 & 0.04 & 0.05 & 0.05 & 0.04 & 0.11 & 0.11 \\
\hline $\mathrm{MgO}$ & 0.34 & 0.14 & 0.14 & 0.04 & 0.13 & 0.66 & 0.34 & 0.31 & 1.89 & 1.74 \\
\hline $\mathrm{CaO}$ & 1.56 & 1.44 & 1.18 & 1.18 & 1.16 & 2.50 & 1.78 & 1.43 & 5.08 & 5.10 \\
\hline $\mathrm{Na}_{2} \mathrm{O}$ & 4.17 & 3.68 & 4.08 & 4.37 & 3.92 & 3.75 & 4.21 & 4.33 & 4.56 & 4.55 \\
\hline $\mathrm{K}_{2} \mathrm{O}$ & 3.09 & 3.18 & 3.14 & 3.07 & 3.20 & 2.83 & 2.93 & 3.36 & 1.20 & 1.20 \\
\hline $\mathrm{P}_{2} \mathrm{O}_{5}$ & 0.06 & 0.01 & 0.01 & 0.02 & 0.01 & 0.08 & 0.04 & 0.03 & 0.34 & 0.35 \\
\hline L.O.I. & 0.20 & 3.26 & 0.95 & 0.35 & 2.69 & 2.72 & 2.62 & 2.24 & 0.90 & 0.90 \\
\hline Total & 99.39 & 99.27 & 99.44 & 99.43 & 100.02 & 99.77 & 99.48 & 100.21 & 99.80 & 99.07 \\
\hline $\mathrm{Rb}$ & 92 & 99 & 92 & 92 & 92 & 92 & 90 & 106 & & 32 \\
\hline $\mathrm{Sr}$ & 129 & 115 & 103 & 105 & 100 & 174 & 141 & 112 & & 323 \\
\hline $\mathrm{Ba}$ & 754 & 789 & 817 & 829 & 785 & 705 & 746 & 803 & & 438 \\
\hline $\mathrm{Zr}$ & 154 & 127 & 131 & 132 & 126 & 149 & 172 & 132 & & 165 \\
\hline $\mathrm{Cu}$ & 6 & 4 & 3 & 4 & 2 & 6 & 5 & 4 & & 12 \\
\hline $\mathrm{Ni}$ & 5 & 6 & 5 & 6 & 5 & 4 & 4 & 5 & & 8 \\
\hline V & 10 & 10 & 5 & 4 & 5 & 29 & 10 & 13 & & 79 \\
\hline $\mathrm{Cr}$ & 3 & 1 & 3 & - & 6 & 5 & 0.1 & - & & 6 \\
\hline $\mathrm{Zn}$ & 34 & 35 & 38 & 37 & 34 & 37 & 37 & 35 & & 61 \\
\hline Th & 8 & 10 & 9 & 9 & 10 & 8 & 9 & 10 & & 1 \\
\hline $\mathrm{Pb}$ & 13 & 12 & 14 & 13 & 15 & 13 & 13 & 13 & & 2 \\
\hline$Y$ & $24^{\circ}$ & 22 & 24 & 24 & 24 & 18 & 21 & 19 & & 34 \\
\hline
\end{tabular}

31. 13531 Spherulitic, hypersthene hornblende rhyolite. Hawea Lava Flow. V16/250275

32. 13532 Pumice ash. Okareka Ash (at type section) U16/059306

33. 13533 Spherulitic, plagioclase hornblende rhyolite. Pokoku Lava Flow (lower). V16/216300

34. 13534 Spherulitic plagioclase rhyolite. Pokohu Lava Flow (lower). v16/211112

35. 13535 Pumice lapil1i. Waiohau Pyroclastics. V16/212280

36. 13536 Glassy, hypersthene hornblende rhyolite. Banded Island Lava. v16/117203

37. 13537 Pumice lapil1i, hornblende, hypersthene. Rotorua Ash. U16/025281

38. 13538 Glassy, hornblende biotite rhyolite. Trig 7693 Lava. U16/027281

39. 13539 Plagioclase, hornblende quartz dacite xenolith in Whakatane Pyroclastics. V16/173379

40. 13540 Duplicate analysis to 13539 


\begin{tabular}{|c|c|c|c|c|c|c|c|c|c|c|}
\hline & 41 & 42 & 43 & 44 & 45 & 46 & 47 & 48 & 49 & 50 \\
\hline $\mathrm{SiO}_{2}$ & 63.38 & 62.74 & 59.00 & 77.27 & 76.58 & 75.17 & 76.76 & 77.29 & 73.86 & 72.44 \\
\hline $\mathrm{TiO}_{2}$ & 0.78 & 0.84 & 0.91 & 0.11 & 0.12 & 0.21 & 0.11 & 0.12 & 0.26 & 0.28 \\
\hline $\mathrm{Al}_{2} \mathrm{O}_{3}$ & 16.60 & 16.21 & 17.28 & 12.50 & 12.27 & 12.82 & 12.36 & 12.51 & 14.57 & 13.68 \\
\hline $\mathrm{Fe}_{2} \mathrm{O}_{3}$ * & 4.27 & 5.54 & 7.09 & 1.29 & 1.26 & 1.76 & 1.29 & 0.97 & 2.39 & 2.22 \\
\hline MnO & 0.10 & 0.12 & 0.15 & 0.02 & 0.02 & 0.02 & 0.02 & 0.01 & 0.05 & 0.05 \\
\hline MgO & 1.71 & 1.77 & 2.35 & 0.13 & 0.09 & 0.29 & 0.09 & 0.15 & 0.35 & 0.41 \\
\hline $\mathrm{CaO}$ & 4.91 & 5.44 & 6.32 & 0.89 & 0.90 & 1.42 & 0.83 & 0.93 & 2.49 & 2.09 \\
\hline $\mathrm{Na}_{2} \mathrm{O}$ & 4.45 & 4.78 & 4.07 & 3.98 & 3.94 & 3.96 & 3.84 & 3.93 & 3.55 & 4.22 \\
\hline $\mathrm{K}_{2} \mathrm{O}$ & 1.53 & 1.42 & 1.04 & 3.57 & 3.68 & 3.19 & 3.66 & 3.70 & 2.53 & 3.03 \\
\hline $\mathrm{P}_{2} \mathrm{O}_{5}$ & 0.23 & 0.16 & 0.53 & 0.02 & - & 0.03 & 0.05 & - & 0.01 & 0.06 \\
\hline L.0.I. & 1.34 & 1.46 & 0.84 & 0.51 & 0.43 & 0.42 & 0.58 & 0.32 & 0.83 & 1.58 \\
\hline Total & 100.58 & 99.26 & 99.57 & 100.28 & 99.29 & 99.29 & 99.58 & 99.92 & 100.88 & 100.07 \\
\hline $\mathrm{Rb}$ & & 50 & 28 & 107 & 116 & 90 & 116 & 126 & 76 & 99 \\
\hline Sr & . & 320 & 369 & 73 & 73 & 120 & 73 & 73 & 163 & 151 \\
\hline $\mathrm{Ba}$ & & 470 & 328 & 840 & 888 & 790 & 889 & 893 & 860 & 776 \\
\hline $\mathrm{Zr}$ & & 205 & 137 & 96 & 105 & 167 & 102 & 98 & 98 & 133 \\
\hline $\mathrm{Cu}$ & & 20 & 9 & 3 & 5 & 4 & 4 & 4 & 7 & 6 \\
\hline $\mathrm{Ni}$ & & 11 & 9 & 4 & 6 & 5 & 4 & 5 & 6 & 4 \\
\hline V & & 83 & 80 & 5 & 3 & 11 & 8 & 6 & 26 & 18 \\
\hline $\mathrm{Cr}$ & & 11 & 8 & 3 & 3 & 2 & 2 & 3 & 3 & 3 \\
\hline $\mathrm{Zn}$ & & 53 & 67 & 30 & 29 & 34 & 27 & 31 & 30 & 32 \\
\hline Th & & - & - & 10 & 13 & 10 & 11 & 10 & 5 & 8 \\
\hline $\mathrm{Pb}$ & & 1 & 2 & 13 & 16 & 12 & 13 & 15 & 11 & 12 \\
\hline$Y$ & & 29 & 33 & 20 & 21 & 17 & 10 & 22 & 17 & 19 \\
\hline
\end{tabular}

\footnotetext{
41. 13541 Hornblende quartz dacite xenolith in Rerewhakaaitu Pyroclastics (Analysis from Cole 1966*)

42. 13542 XRF analysis of 13541

43. 13543 Plagioclase, hornblende quartz dacite, similar to 13539 , xenolith in whakatane Ash. V16/165348

44. 13544 Spherulitic hornblende biotite rhyolite. hal. Rere. v15/222410

45. 13545 Spherulitic plagioclase rhyolite. hal. Maungawhakamana. v16/229394

46. 13546 Spherulitic hornblende biotite rhyolite. hal. Rere. v15/232439

47. 13547 Spherulitic plagioclase rhyolite, rare biotite. hal. Waitangi. v15/216461

48. 13548 Spherulitic, silicified, plagioclase rhyolite. hal. Maungawhakamana rhyolite. v16/276351

49. 13549 Hydrothermally altered, porphyritic (quartz and plagioclase) lava. Onepu Dacite (?). V15/363418

50. 13550 Pumiceous, hornblende biotite rhyolite. Earthquake Flat Breccia. U16/021194
} 


\begin{tabular}{|c|c|c|c|c|c|c|c|c|c|c|}
\hline & 51 & 52 & 53 & 54 & 55 & 56 & 57 & 58 & 59 & 60 \\
\hline $\mathrm{SiO}_{2}$ & 71.76 & 73.43 & 73.57 & 63.18 & 64.16 & 56.14 & 55.68 & 52.43 & 50.66 & 55.22 \\
\hline $\mathrm{TiO}_{2}$ & 0.31 & 0.23 & 0.27 & 0.72 & 0.83 & 0.72 & 1.02 & 1.05 & 0.86 & 1.00 \\
\hline $\mathrm{A}_{2} \mathrm{O}_{3}$ & 14.10 & 13.06 & 13.20 & 16.89 & 15.71 & 17.70 & 17.02 & 16.79 & 17.33 & 16.99 \\
\hline $\mathrm{Fe}_{2} \mathrm{O}_{3}$ * & 2.44 & 1.60 & 1.78 & 6.15 & 6.18 & 8.58 & 8.83 & 10.17 & 11.03 & 9.95 \\
\hline $\mathrm{MnO}$ & 0.05 & 0.06 & 0.07 & 0.07 & 0.08 & 0.09 & 0.14 & 0.13 & 0.14 & 0.14 \\
\hline $\mathrm{MgO}$ & 0.33 & 0.13 & 0.17 & 2.13 & 1.50 & 4.64 & 4.06 & 4.40 & 6.19 & 3.93 \\
\hline $\mathrm{CaO}$ & 2.16 & 1.36 & 1.54 & 4.35 & 4.71 & 7.47 & 7.92 & 8.82 & 11.58 & 8.33 \\
\hline $\mathrm{Na}_{2} \mathrm{O}$ & 3.73 & 4.44 & 4.58 & 3.28 & 3.85 & 2.39 & 3.13 & 2.86 & 2.18 & 2.67 \\
\hline $\mathrm{K}_{2} \mathrm{O}$ & 2.81 & 2.86 & 2.74 & 2.14 & 1.80 & 1.06 & 1.10 & 0.96 & 0.54 & 0.96 \\
\hline $\mathrm{P}_{2} \mathrm{O}_{5}$ & 0.01 & 0.04 & 0.04 & 0.14 & 0.22 & 0.09 & 0.26 & 0.22 & 0.14 & 0.15 \\
\hline L.O.I. & 1.78 & 3.49 & 3.03 & 1.01 & 0.49 & 1.40 & 0.34 & 1.01 & 0.38 & 0.42 \\
\hline Total & 99.49 & 100.79 & 100.99 & 100.06 & 99.53 & 100.28 & 99.50 & 98.84 & 101.03 & 99.76 \\
\hline $\mathrm{Rb}$ & 95 & 76 & & 74 & 60 & 37 & 38 & 31 & 15 & 35 \\
\hline Sr & 173 & 125 & & 274 & 286 & 204 & 310 & 290 & 323 & 272 \\
\hline $\mathrm{Ba}$ & 704 & 770 & & 582 & 481 & 386 & 332 & 268 & 198 & 253 \\
\hline $\mathrm{Zr}$ & 151 & 191 & & 207 & 148 & 73 & 130 & 82 & 50 & 80 \\
\hline $\mathrm{Cu}$ & 7 & 4 & & 21 & 9 & 23 & 22 & 14 & 21 & 22 \\
\hline $\mathrm{Ni}$ & 6 & 5 & & 12 & 6 & 17 & 15 & 6 & 12 & 7 \\
\hline V & 22 & 3 & & 124 & 60 & 216 & 232 & 280 & 189 & 289 \\
\hline $\mathrm{Cr}$ & 3 & 4 & & 29 & 2 & 66 & 52 & 17 & 18 & 16 \\
\hline $\mathrm{Zn}$ & 28 & 46 & & 80 & 83 & 79 & 91 & 87 & 82 & 93 \\
\hline Th & 9 & 6 & & 3 & 3 & 1 & 8 & 4 & 2 & 5 \\
\hline $\mathrm{Pb}$ & 7 & 9 & & 8 & 9 & 13 & 10 & 12 & - & 9 \\
\hline Y & 15 & 32 & & 20 & 31 & 31 & 31 & 30 & 18 & 25 \\
\hline
\end{tabular}

51. 13551 Vitroclastic matrix, devitrified, abundant quartz and plagioclase phenocrysts, biotite, hornblende, hypersthene. "quartz biotite ignimbrite" v16/283264

52. 13552 Crystal-poor pumice, no quartz. kgl. Kaingaroa Ignimbrites. v16/290333

53. 13553 Whole rock analysis. kgl. Kaingaroa Ignimbrites. V16/290333

54. 13554 Slightly altered, plagioclase pyroxene dacite. Puhiptuhi Dacite. V16/261316

55. 13555 Pyroxene plagioclase dacite. Waikokomuku Dacite. U16/086151

56. 13556 Pyroxene plagioclase, low - Si andesite. Xenoliths in Kgl. Kaingaroa Ignimbrites. Ul7/073076

57. 13557 Pyroxene plagioclase porphyritic lava with some resorbed quartz. Basic bomb in Rotomahana Tuff and scoria cone. v16/121217

58. 13558 Plagioclase hornblende (plus pyroxene and rare quartz) xenolith found at Earthquake Flat U16/021194

59. 13559 Aphyric basalt, with sinter inclusions. Black Crater basalt, Waimangu.

60. 13560 Aphyric pyroxene olivine lava with quartz xenocrysts. Basic bomb in Rotomahana Tuff and Scoria Cone. v16/121217 


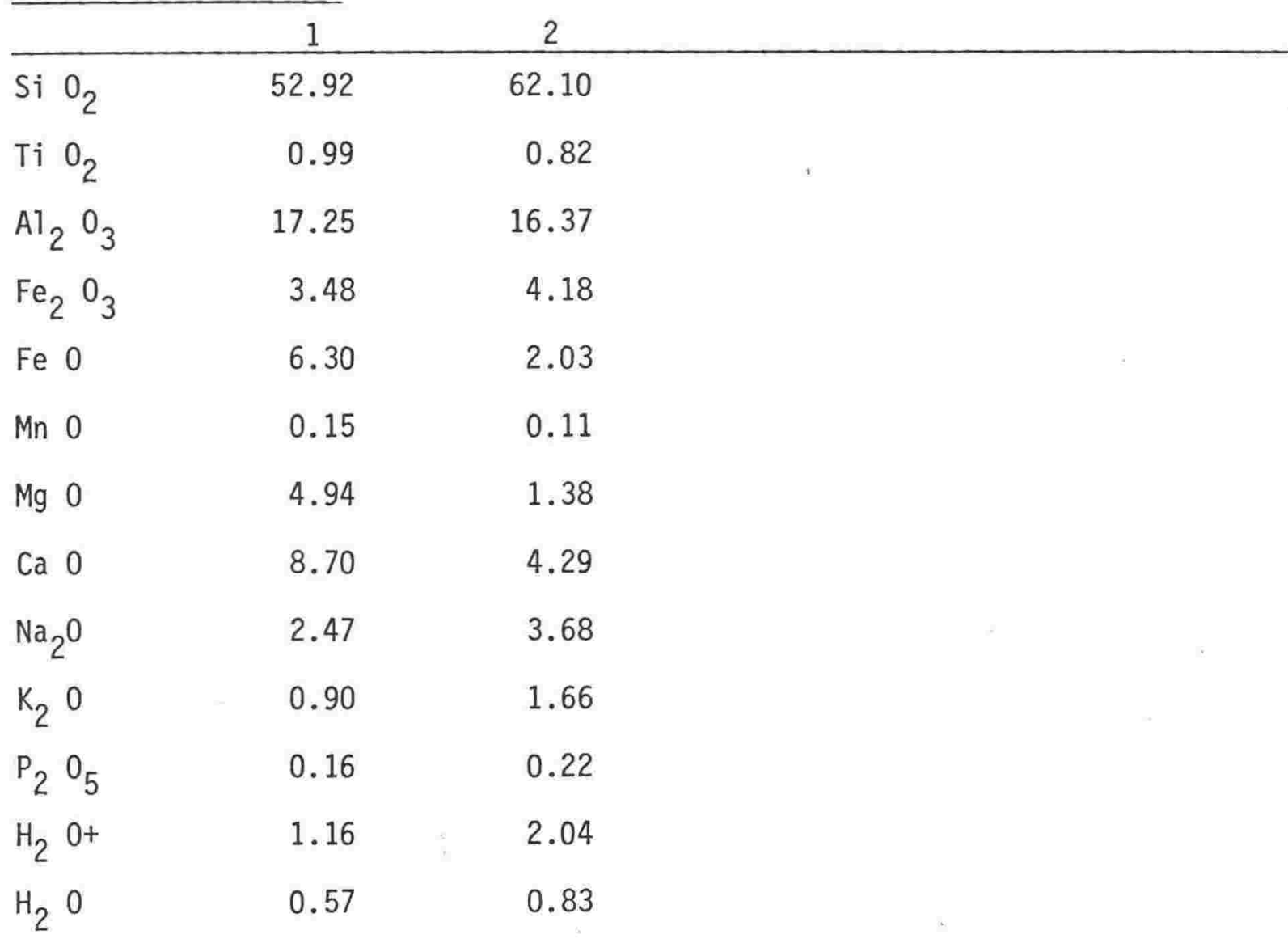

TOTAL

99.99

99.71

1. 24109 Basaltic andesite (pyroxene, olivine, xenocrystic quartz). Terrace Road, Waiotapu Forest. U16/087115. "Terrace Road Basalt."

2. 24111 "Waikokomuku Andesite." Waiotapu Forest (see 13555).

* Analyst: N D Briggs

Footnote: All major (and trace) elements were determined by $\mathrm{x}$-ray fluorescence spectrography on a Siemens SRS-l X-ray spectrometer, using the methods of Norrish and Hutton (1969)* . Concentrations were determined relative to an artificial standard FSL4A, and compared with values obtained for international rock standards AGV, BCR.

* Geochimica and Cosmochimica Acta 33: 431-453. 


\section{APPENDIX 2}

Size data for Rotoehu Ash and Rotoiti Breccia samples. Section numbers are as on Fig. 1 of the Rotoehu Ash manuscript (p. 145) and sample numbers as on Figs. 2-9, 12-14 of that manuscript.

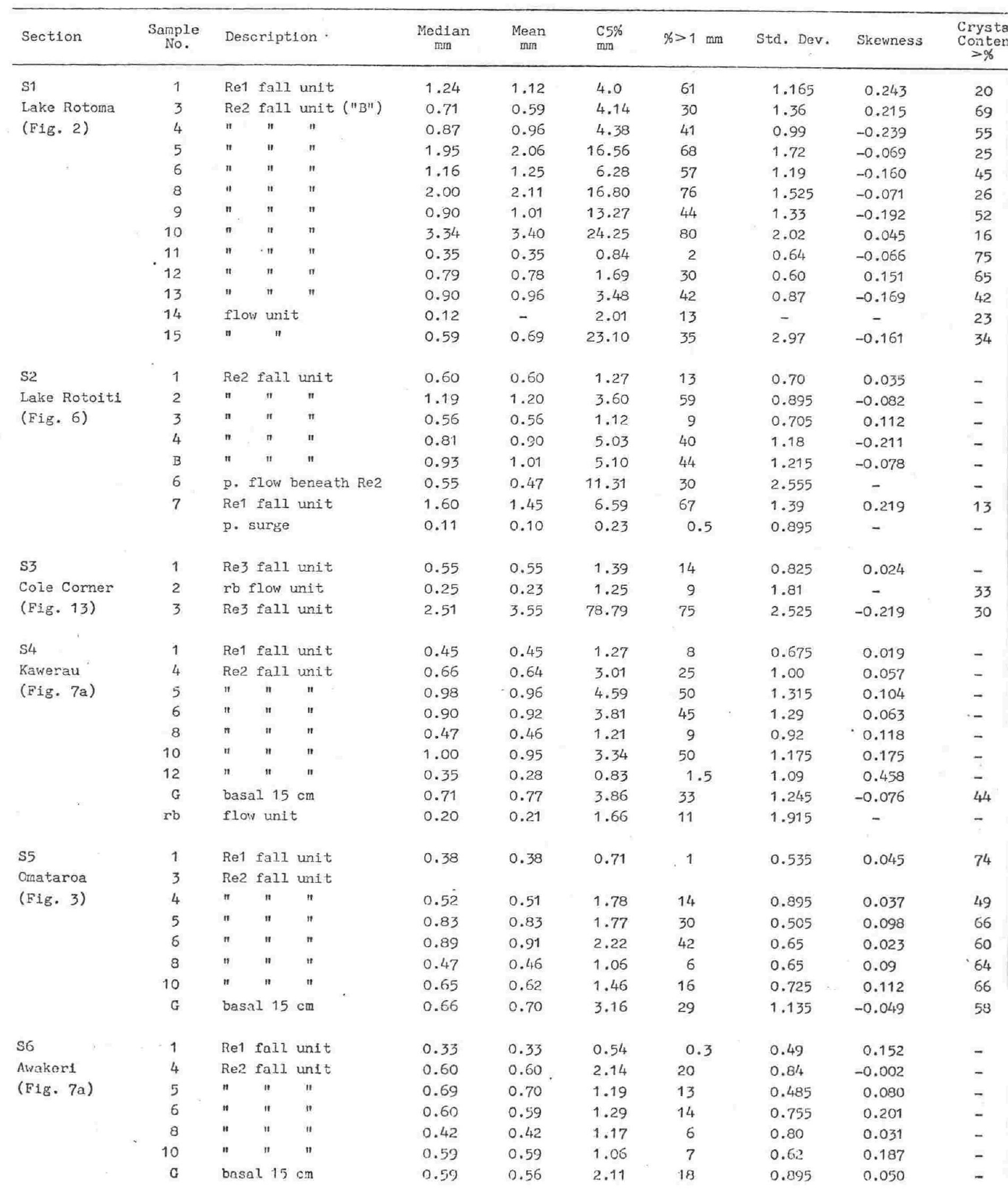




\begin{tabular}{|c|c|c|c|c|c|c|c|c|c|c|c|}
\hline Section & $\begin{array}{l}\text { Sample } \\
\text { No. }\end{array}$ & Descript1 & on & & $\underset{\mathrm{mm}}{\text { Median }}$ & $\underset{\mathrm{mm}}{\text { Mean }}$ & $\begin{array}{l}\mathrm{C} 5 \% \\
\mathrm{~mm}\end{array}$ & $\%>1 \mathrm{~mm}$ & Std. Dev. & Skewness & $\begin{array}{l}\text { Crysta } \\
\text { Conten } \\
>\%\end{array}$ \\
\hline s7 & 1 & Re1 fall & unit & & 0.24 & 0.23 & 0.45 & 0.5 & 0.75 & 0.210 & - \\
\hline Ohope & 4 & $\operatorname{Re} 2$ fall & untt & & 0.38 & 0.37 & 0.87 & 4 & 0.74 & 0.111 & 54 \\
\hline \multirow[t]{2}{*}{ (Fig. 4) } & 5 & $" \quad "$ & " & & 0.38 & 0.38 & 0.73 & 1 & 0.52 & 0.083 & 59 \\
\hline & 6 & $"$ & $"$ & & 0.44 & 0.45 & 0.82 & 2 & 0.59 & 0.070 & 69 \\
\hline . & G & $"$ & $"$ & & 0.57 & 0.55 & 2.08 & 17 & 0.905 & 0.019 & 60 \\
\hline S8 & 1 & Re1 fall & unit & & 1.32 & 1.09 & 3.25 & 66 & 1.28 & 0.389 & - \\
\hline Manawahe & $1 \mathrm{a}$ & $n \quad n$ & $"$ & & 1.01 & 1.06 & 5.35 & 50 & 1.58 & 0.029 & - \\
\hline \multirow[t]{3}{*}{ (Fig. 8) } & 3 & Re2 fall & unit & ("B") & 0.57 & 0.54 & 3.14 & 21 & 1.15 & 0.091 & - \\
\hline & 4 & $" \quad "$ & $"$ & & 0.80 & 0.93 & 8.28 & 38 & 1.435 & -0.180 & - \\
\hline & 5 & " & $"$ & & 0.55 & 0.62 & 4.23 & 27 & 1.35 & -0.159 & - \\
\hline & 6 & ." & $"$ & & 0.57 & 0.59 & 1.30 & 9 & 0.405 & -0.112 & - \\
\hline & 7 & $n$ & $"$ & & 1.38 & 1.38 & 3.86 & 70 & 0.795 & 0.050 & - \\
\hline & 8 & $"$ & $"$ & & 0.34 & 0.34 & 0.68 & 0.5 & 0.525 & 0.050 & - \\
\hline & 9 & $"$ & $"$ & & 1.04 & 1.01 & 2.51 & 52 & 0.825 & 0.105 & - \\
\hline & $12 a$ & $n$ & $"$ & & 0.51 & 0.51 & 1.04 & 5 & 0.64 & -0.031 & - \\
\hline & 13 & $"$ & $n$ & & 0.34 & 0.34 & 0.66 & 0.5 & 0.51 & 0.020 & - \\
\hline & G & $n \quad n$ & $n$ & & 0.57 & 0.57 & 2.99 & 21 & 1.025 & 0.043 & - \\
\hline & $\mathrm{rb}$ & flow unit & & & 0.40 & 0.39 & 24.59 & 28 & 2.68 & -0.126 & - \\
\hline s9 & $1 \mathrm{a}$ & Re1 fall & unit & & 0.87 & 0.91 & 6.28 & 44 & 1.56 & 0.016 & - \\
\hline Hereperu & 3 & Re2 fall & unit & $(" B ")$ & 0.44 & 0.40 & 1.82 & 13 & 1.26 & 0.156 & - \\
\hline \multirow[t]{5}{*}{ (Fig. 8) } & 4 & $n \quad "$ & n & & 0.66 & 0.65 & 3.41 & 26 & 1.125 & 0.039 & - \\
\hline & 6 & $"$ & $n$ & & 0.45 & 0.45 & 0.90 & 3.5 & 0.63 & 0.88 & - \\
\hline & 7 & $n$ & $"$ & & 0.74 & 0.72 & 1.69 & 27 & 0.75 & 0.199 & - \\
\hline & 8 & $"$ & $n$ & & 0.28 & 0.28 & 0.49 & 0 & 0.505 & 0.104 & - \\
\hline & 9 & $n$ & n & & 0.66 & 0.63 & 1.36 & 20 & 0.775 & 0.237 & - \\
\hline \multirow{3}{*}{ - } & $12 \mathrm{a}$ & " & $"$ & & 0.41 & 0.41 & 0.77 & 1 & 0.50 & 0.083 & - \\
\hline & $G(1)$ & " & $"$ & & 0.76 & 0.82 & 8.57 & 35 & 1.22 & -0.176 & - \\
\hline & $G(u)$ & " & $n$ & & 0.74 & 0.75 & 4.26 & 30 & 0.915 & -0.057 & - \\
\hline S10 & $1 \mathrm{a}$ & Re1 fall & unit & & 0.67 & 0.65 & 3.18 & 27.5 & 1.115 & 0.069 & - \\
\hline Pikowai & 3 & Re2 fall & unit & ("B") & 0.44 & 0.44 & 1.27 & 10 & 1.03 & 0.099 & - \\
\hline \multirow[t]{7}{*}{ (Fig. 8) } & 4 & $" \quad "$ & " & & 0.60 & 0.57 & 2.46 & 22 & 1.045 & 0.119 & - \\
\hline & 7 & $n$ & $"$ & & 0.56 & 0.51 & 1.05 & 6.5 & 0.83 & .0 .355 & - \\
\hline & 9 & $"$ & $"$ & & 0.43 & 0.42 & 0.87 & 1.5 & 0.80 & 0.173 & - \\
\hline & G & " $"$ & " & & 0.69 & 0.71 & 4.92 & 29.5 & 1.125 & -0.075 & - \\
\hline & $\mathrm{rb} 2$ & flow unit & & & 0.062 & - & 2.14 & 9.5 & - & - & - \\
\hline & $S$ & p. surge & & & 0.55 & 0.43 & 2.17 & 22.5 & 1.655 & 0.295 & - \\
\hline & rb1 & flow unit & & & 0.21 & 0.21 & 1.52 & 11 & 1.865 & - & - \\
\hline S11 & 1 & Re3 fall & unit & & 0.34 & 0.34 & 0.61 & 0.5 & 0.535 & 0.077 & - \\
\hline Otamarakau & 2 & " $\quad "$ & $"$ & & 0.56 & 0.61 & 2.53 & 21 & 0.96 & -0.134 & - \\
\hline \multirow[t]{2}{*}{ (Fig, 13) } & 3 & rb flow $u$ & enit & & 0.14 & 0.17 & 1.18 & 7 & 1.555 & -0.302 & - \\
\hline & 4 & Re3 fall. & unit & & 0.48 & 0.43 & 1.60 & 14 & 1.20 & 0.207 & - \\
\hline $\mathrm{S} 12$ & 1 & Re1 fall & unit & & 1.21 & 1.21 & 4.11 & 59 & 1.07 & 0.166 & 34 \\
\hline Otamarakau & 2 & Re2 fall & unit & ("B") & 0.60 & 0.59 & 1.84 & 18 & 0.80 & 0.031 & 61 \\
\hline Quarry & 3 & $" \quad "$ & $"$ & & 0.81 & 0.78 & 3.14 & 36 & 0.98 & 0.087 & 56 \\
\hline \multirow[t]{9}{*}{ (Figs. 5, 6, 13) } & 4 & $"$ & $"$ & & 0.64 & 0.61 & 1.38 & 19 & 0.835 & 0.227 & 54 \\
\hline & 5 & $" \quad "$ & $n$ & & 0.73 & 0.72 & 1.46 & 19 & 0.54 & 0.084 & 55 \\
\hline & 6 & G lower & & & 0.75 & 0.80 & 4.92 & 32 & 1.025 & -0.183 & 55 \\
\hline & 7 & G upper & & & 0.77 & 0.85 & 6.68 & 34 & 1.10 & -0.195 & - \\
\hline & 8 & ro flow u & inst & & 0.19 & 0.20 & 2.22 & 12 & 1.91 & - & 24 \\
\hline & 9 & rb (rewor & (ked?) & & 0.39 & 0.35 & 2.1 & 30 & 1.60 & 0.121 & 28 \\
\hline & 10 & $\operatorname{Re} 3$ fall & unit & & 0.85 & 1.004 & 10.55 & 43 & 1.725 & -0.104 & - \\
\hline & 11 & $" \quad "$ & $"$ & & 0.67 & 0.68 & 3.66 & 27 & 0.885 & -0.047 & 52 \\
\hline & 12 & $"$ & $"$ & & 0.30 & 0.29 & 0.62 & 1 & 0.70 & 0.193 & $2 / k$ \\
\hline
\end{tabular}




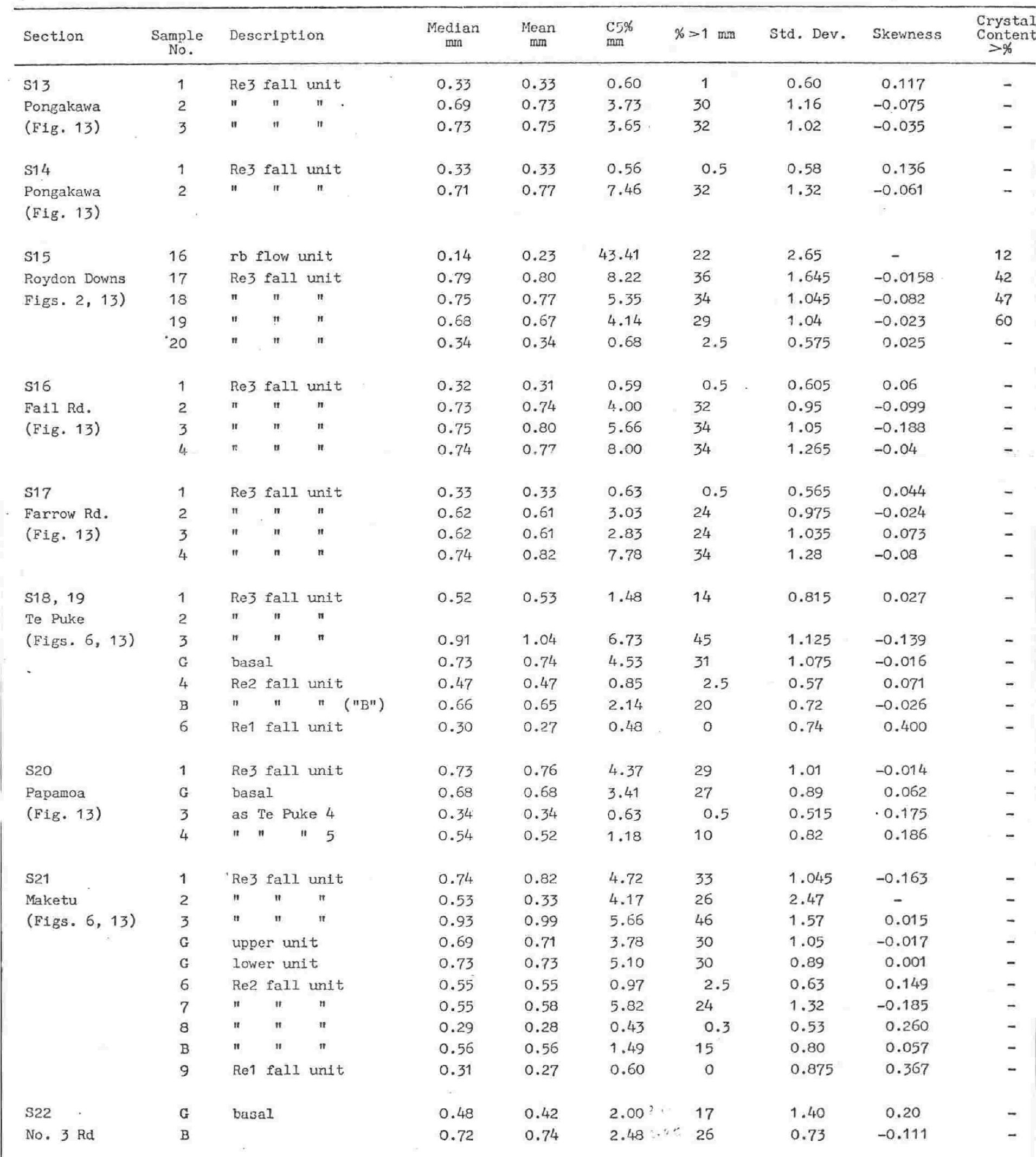




\begin{tabular}{|c|c|c|c|c|c|c|c|c|c|}
\hline Section & $\begin{array}{c}\text { Sample } \\
\text { No. }\end{array}$ & Description & $\underset{\text { mra }}{\text { Median }}$ & $\begin{array}{c}\text { Mean } \\
\mathrm{mm}\end{array}$ & $\begin{array}{l}\mathrm{C} 5 \% \\
\mathrm{~mm}\end{array}$ & $\%>1 \mathrm{~mm}$ & Std. Dev. & Skewness & $\begin{array}{l}\text { Cryst: } \\
\text { Contel } \\
>\%\end{array}$ \\
\hline $\mathrm{S} 23$ & G-type & between flow units & 0.76 & 0.74 & 5.86 & 37 & 1.355 & -0.004 & - \\
\hline Woollet Rd & G & beneath flow units & 0.73 & 0.75 & 4.66 & 31 & 0.90 & -0.053 & - \\
\hline \multirow[t]{4}{*}{$(F 1 g .6)$} & 2 & Re2 fall unit & 0.63 & 0.63 & 1.27 & 14 & 0.63 & 0.045 & - \\
\hline & 3 & " " ". & 0.56 & 0.55 & 1.04 & 6 & 0.63 & 0.163 & - \\
\hline & 4 & $n \quad " \quad "$ & 0.33 & 0.33 & 0.59 & 0.5 & 0.53 & 0.084 & - \\
\hline & 5 & " $\quad "$ & 0.79 & 0.88 & 5.66 & 37 & 1.29 & -0.141 & - \\
\hline & 6 & $" \quad "$ & 0.84 & 0.86 & 3.43 & 40 & 1.18 & 0.069 & - \\
\hline & B & " $" \quad$ " & 0.76 & 0.85 & 8.81 & 34 & 1.21 & -0.209 & - \\
\hline & 8 & Re1 fall unit & 0.71 & 0.69 & 1.88 & 27 & 0.815 & 0.172 & - \\
\hline \multirow{8}{*}{$\begin{array}{l}\mathrm{S} 24 \\
\text { Sun Valley } \\
\text { (Fig. 6) }\end{array}$} & 1 & Re2 fall unit & 0.80 & 0.80 & 1.58 & 30 & 0.53 & 0.076 & - \\
\hline & 2 & " " " " & 0.71 & 0.70 & 1.45 & 21 & 0.625 & 0.145 & - \\
\hline & 3 & ." & 0.32 & 0.32 & 0.49 & 0 & 0.46 & 0.086 & - \\
\hline & $\cdot 4$ & " " & 0.68 & 0.67 & 1.39 & 16 & 0.605 & 0.071 & - \\
\hline & $4 a$ & " $\quad " \quad \pi$ & 0.43 & 0.43 & 0.96 & 4 & 0.805 & $a \cdot v^{\prime} 6$ & - \\
\hline & 6 & " $\quad " \quad$ & 0.81 & 0.82 & 4.00 & 37 & 0.965 & 0.035 & - \\
\hline & B & " $" \quad$ " & 0.74 & 0.76 & 4.29 & 31 & 0.86 & -0.106 & - \\
\hline & 8 & Re1 fall unit & 0.86 & 0.85 & 3.32 & 44 & 1.29 & 0.089 & - \\
\hline \multirow{5}{*}{$\begin{array}{l}\text { S25 } \\
\text { S.H. } 33 \\
\text { (Fig. 6) }\end{array}$} & 1 & Re2 fall unit & 0.38 & 0.40 & 0.81 & 0.3 & 0.61 & -0.056 & - \\
\hline & 2 & " $\quad$ " & 0.81 & 0.82 & 2.22 & 33 & 0.615 & -0.138 & - \\
\hline & 3 & $n$ & 0.59 & 0.53 & 2.30 & 20 & 1.055 & 0.181 & - \\
\hline & 4 & $\pi \quad " \quad$ & 1.37 & 1.23 & 8.75 & 58 & 2.03 & 0.162 & - \\
\hline & B & $\pi \quad n$ & 0.74 & 0.61 & 5.28 & 33 & 1.55 & 0.179 & - \\
\hline \multirow{3}{*}{$\begin{array}{l}\text { S26 } \\
\text { Kaharoa Rd } \\
\text { (Fig. 13) }\end{array}$} & 1 & Re3 fall unit & 0.37 & 0.37 & 0.74 & 2.5 & 0.645 & 0.097 & - \\
\hline & 2 & $n \quad n \quad n$ & 0.91 & 1.03 & 7.57 & 44 & 1.205 & -0.193 & - \\
\hline & $2 a$ & " $\quad " \quad$ " & 0.77 & 0.87 & 11.79 & 37 & 1.38 & -0.176 & - \\
\hline \multirow{2}{*}{ 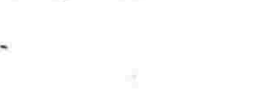 } & 3 & rb p. flow & 0.09 & - & 0.81 & 3.5 & - & - & - \\
\hline & 4 & " $" \quad "$ & 0.24 & 0.28 & 4.28 & 18 & 2.51 & - & - \\
\hline S27 & 1 & rb p. flow & 0.17 & 0.19 & 1.26 & 8 & 1.69 & - & - \\
\hline Kaharoa Rd & 2 & Re2 fall unit & 0.45 & 0.45 & 0.84 & 2.5 & 0.56 & 0.027 & - \\
\hline \multirow[t]{5}{*}{ South } & 3 & " " " " & 0.34 & 0.34 & 0.66 & 1 & 0.625 & 0.089 & - \\
\hline & 4 & " $\quad "$ & 0.62 & 0.60 & 3.61 & 25 & 1.195 & 0.038 & - \\
\hline & 5 & $"$ & 0.87 & 0.80 & 2.95 & 39 & 0.895 & $\cdot 0.250$ & - \\
\hline & B & $n \quad n \quad n$ & 0.64 & 0.61 & 5.03 & 24 & 1.135 & 0.014 & - \\
\hline & 8 & Re1 fall unit & 0.63 & 0.62 & 1.49 & 21 & 0.78 & 0.127 & - \\
\hline $\mathrm{s} 28$ & 1 & rb p. flow & 0.22 & 0.23 & 2.14 & 11 & 1.595 & -0.134 & - \\
\hline Waimangu Forest & G & basal & 0.79 & 0.86 & 3.84 & 37 & 1.01 & -0.165 & - \\
\hline \multirow[t]{3}{*}{ (Fig. 9) } & 3 & Re2 fall unit & 0.30 & 0.30 & 0.53 & 0.5 & 0.605 & 0.108 & - \\
\hline & 4 & $n \quad n \quad n$ & 0.66 & 0.66 & 1.66 & 17 & 0.64 & -0.028 & - \\
\hline & 5 & Re1 fall unit & 0.32 & 0.31 & 0.52 & 0.5 & 0.605 & 0.296 & - \\
\hline S29 & 1 & coignimbrite? & 0.53 & 0.51 & 2.08 & 19 & 1.12 & 0.100 & - \\
\hline Ngamotu Rd & G & & 0.70 & 0.73 & 4.50 & 30 & 1.11 & -0.13 & - \\
\hline (west) & 3 & Re2 fall unit & 0.59 & 0.59 & 0.97 & 3.5 & 0.535 & 0.087 & - \\
\hline \multirow[t]{3}{*}{ (Fig. 9) } & 4 & " " " " & 0.88 & 0.84 & 3.56 & 42 & 1.08 & 0.201 & - \\
\hline & 5 & " " " " & 0.46 & 0.46 & 0.76 & 2.5 & 0.405 & 0.016 & - \\
\hline & 6 & Re1 fall unit & 0.55 & 0.55 & 1.13 & 9 & 0.705 & 0.144 & - \\
\hline
\end{tabular}




\begin{tabular}{|c|c|c|c|c|c|c|c|c|c|c|}
\hline Section & $\begin{array}{c}\text { Sample } \\
\text { No. }\end{array}$ & Description & & $\underset{\mathrm{mm}}{\text { Nedian }}$ & $\begin{array}{l}\text { Mean } \\
\text { mnn }\end{array}$ & $\begin{array}{l}\mathrm{C} 5 \% \\
\mathrm{~mm}\end{array}$ & $\%>1 \mathrm{mrn}$ & Std, Dev. & Skewness & $\begin{array}{l}\text { Crysta } \\
\text { Conten } \\
=\%\end{array}$ \\
\hline$S 30$ & G & & & 0.62 & 0.60 & 3.36 & 22 & 0.94 & -0.087 & - \\
\hline Ngamotu Rd & 2 & Re2 fall unit & & 0.48 & 0.48 & 0.93 & 2 & 0.72 & 0.079 & - \\
\hline (east) & 3 & " $" \quad "$ & & 0.70 & 0.68 & 1.67 & 23 & 0.70 & 0.187 & - \\
\hline \multirow[t]{2}{*}{ (Fig. 9) } & 4 & " $"$ " & & 0.34 & 0.34 & 0.65 & 1 & 0.54 & 0.035 & - \\
\hline & 5 & Re1 fall unit & & 0.45 & 0.41 & 1.09 & 7 & 1.09 & 0.265 & - \\
\hline \multirow[t]{2}{*}{ Murupara } & G & & & 0.61 & 0.60 & 2.69 & 21 & 0.89 & -0.002 & - \\
\hline & 2 & Re2 fall unit & & 0.47 & 0.46 & 0.90 & 3.5 & 0.555 & 0.193 & - \\
\hline
\end{tabular}


An estimate of averaged volcanic heat flow at Okataina Volcanic Centre.

1.) Magma volumes and eruption rates (see Tables 6 and 7)

$540 \mathrm{~km}^{3}$ erupted in 250000 years $=2 \times 10^{-3} \mathrm{~km}^{3} \mathrm{yr}^{-1}$

$160 \mathrm{~km}^{3}$ erupted in 50000 years $=3 \times 10^{-3} \mathrm{~km}^{3} \mathrm{yr}^{-1}$

$80 \mathrm{~km}^{3}$ erupted in 20000 years $=4 \times 10^{-3} \mathrm{~km}^{3} \mathrm{yr}^{-1}$

$5 \mathrm{~km}^{3}$ erupted in 1000 years $=5 \times 10^{-3} \mathrm{~km}^{3} \mathrm{yr}^{-1}$

2.) Assuming a long term averaged eruption rate

of: $2.5 \times 10^{-3} \mathrm{~km}^{3} \mathrm{yr}^{-1}$

$=0.08 \mathrm{~m}^{3} \mathrm{~s}^{-1}$

3.) Further assuming (most7y after Smith and Shaw 1975*).

Initial magma temperature

Latent heat of crystallization

Heat capacity

Mean density of magma $=850^{\circ} \mathrm{C}$

$=65 \mathrm{calgm}^{-1}\left(2.72 \times 10^{5} \mathrm{Jkg}^{-1}\right)$

$=0.3 \mathrm{cal} \mathrm{gm}^{-1}\left(1.26 \times 10^{3} \mathrm{Jkg}^{-1}\right.$

$\left.{ }^{0} \mathrm{C}-1\right)$

$=2.3 \mathrm{gmcm}^{-3}\left(2.3 \times 10^{3} \mathrm{~kg} \mathrm{~m}^{-3}\right)$

4.) Calculated heat loss on cooling erupted magma to $20^{\circ} \mathrm{C}$. Mass flux $=184 \mathrm{kgs}^{-1}$

Sensible heat flux $=184 \mathrm{kgs}^{-1} \times 1.26 \times 10^{3} \mathrm{~J} \mathrm{~kg}^{-10} \mathrm{C}^{-1} \times 830^{\circ} \mathrm{C}$

$=1.92 \times 10^{8} \mathrm{Js}^{-1}$

$=192 \mathrm{MW}$

Latent heat flux $=184 \mathrm{kgs}^{-1} \times 2.27 \times 10^{5} \mathrm{~J} \mathrm{~kg}^{-1}$

$=5 \times 10^{7} \mathrm{Js}^{-1}$

$=50 \mathrm{MW}$

Total Volcanic Heat Flux $=242 \mathrm{MW}$ 